\title{
The Right to Leave and Return and Chinese Migration Law
}

By

Guofu Liu

LLB, LLM

Submitted for the Degree of Doctor of Philosophy

University of Technology, Sydney

July 2005 


\section{Certificate of Authorship/Originality}

I certify that the work in this thesis has not previously been submitted for a degree nor has it been submitted as part of requirements for a degree except as fully acknowledged within the text.

I also certify that the thesis has been written by me. Any help that I have received in my research work and the preparation of the thesis itself has been acknowledged. In addition, I certify that all information sources and literature used are indicated in the thesis.

Guofu Liu

Date 


\section{Acknowledgements}

I am deeply indebted to my principal supervisor, Professor Sam Blay, Faculty of Law, for his very helpful advice, guidance, constructive criticisms and encouragement which were instrumental in bringing this thesis to fruition; to my co-supervisor, Senior Lecturer Ms. Jennifer Burn for her valuable advice and guidance particularly during the initial stages of this thesis.

I acknowledge the generous contribution from my wife, Carol You for her critical comments on research proposal and draft thesis. To my colleague, Ms. Beatriz Carrullo Garcia, a $\mathrm{PhD}$ candidate in the Institute for International Studies, I wish to acknowledge, with gratitude, for her contribution in giving up many hours of her leisure time to read the earlier draft of this thesis and in providing valuable comments. I would like to also thank my colleague, Ms. Thanh Phanthi, a SJD candidate in the Faculty of Law for her valuable comments on part 4.1 of this thesis (the RLR in Vietnam).

Thanks must be expressed to Mr. Liu Qingcai, the acting director of the Centre of Materials Providence, the National Library of China for the use and copy of resources for my research. I also wish to express my gratitude to Ms. Gillian Barker and Mr. Linden Hyatt for their editorial assistance. 


\section{Table of Contents}

\section{The Right to Leave and Return (RLR) and Chinese Migration Law}

Certificate of Authorship/Originality .......................................................

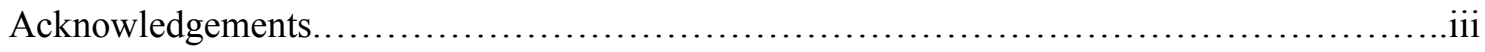

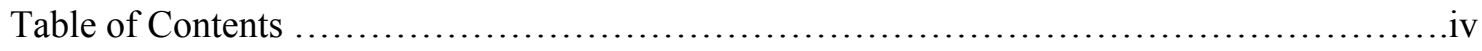

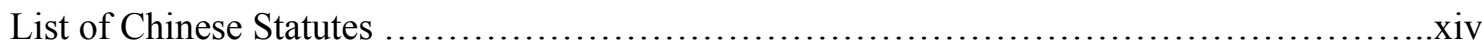

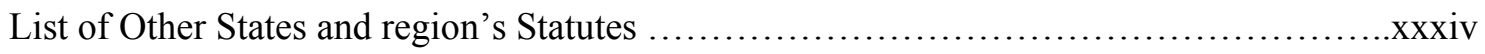

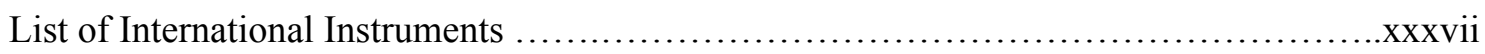

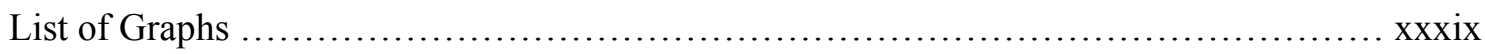

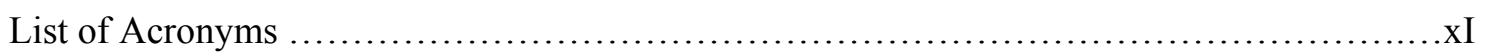

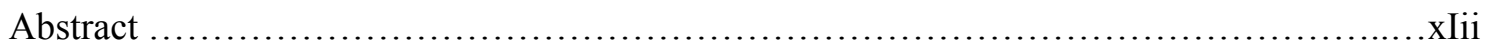

Chapter One Introduction $\ldots \ldots \ldots \ldots \ldots \ldots \ldots \ldots \ldots \ldots \ldots \ldots \ldots \ldots \ldots . . . . \ldots 1$

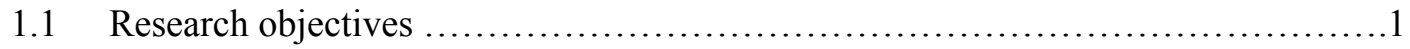

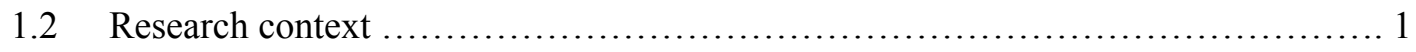

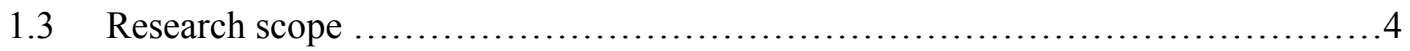

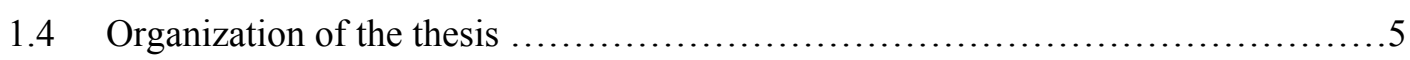

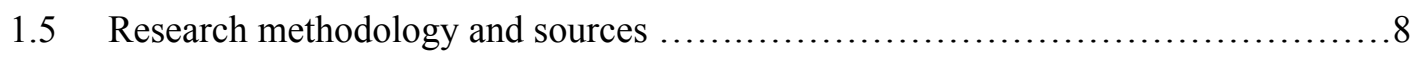

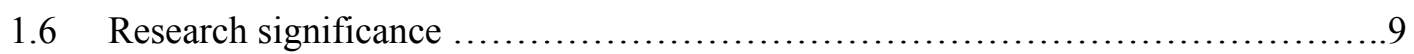

Chapter Two Foundations of RLR...........................13

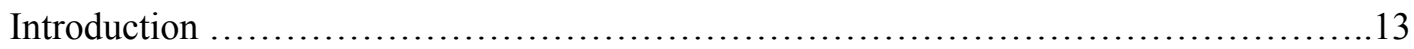

$2.1 \quad$ Philosophical foundations..................................................

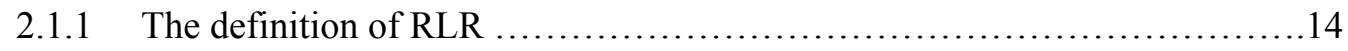

2.1.2 The nature of migration .............................................

2.1.3 RLR is a natural right rooted in natural law ...........................17

2.1.4 RLR translation from natural right to positive right .......................22

2.1.5 Consequences of violating RLR .....................................25

2.1.6 Justification of the limits on RLR ..................................26

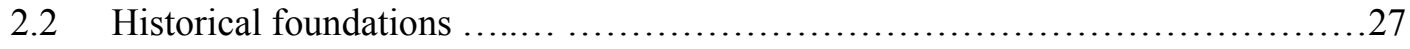

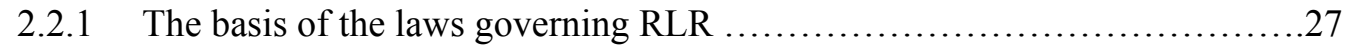

2.2.2 The historical development of the laws governing RLR ..................29 
2.2.3 The factors driving the historical development of the laws governing RLR .................................................. 43

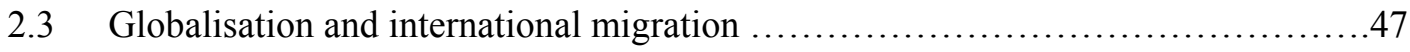

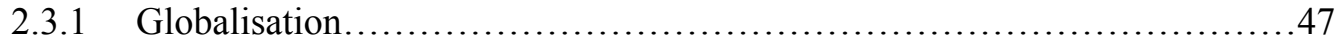

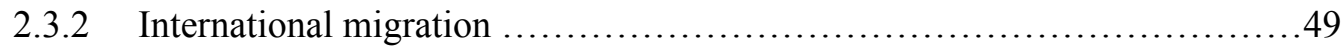

2.3.3 International migration policy .............................................

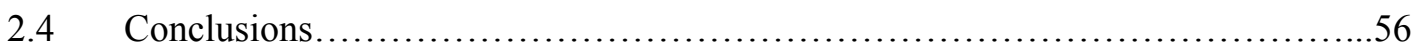

\section{Chapter Three RLR in International Migration Law ..........58}

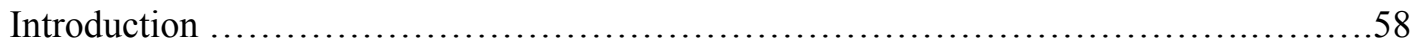

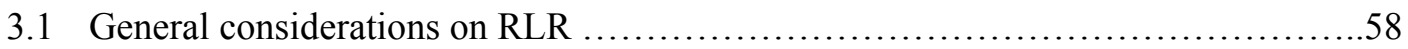

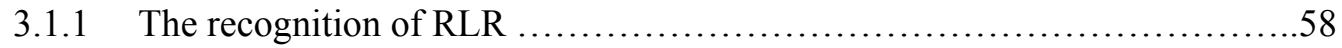

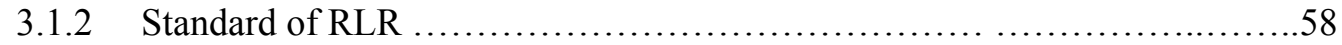

3.1.3 Sources of evolving jurisprudence of RLR ............................62

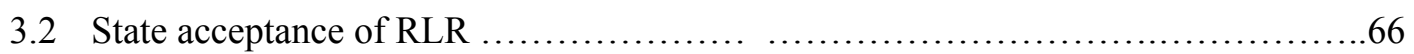

3.2.1 The right to obtain the necessary travel documents, particularly a passport .........................................................67

3.2.2 Passport administration ...............................................68

3.2.3 The effect on RLR of not having a passport ............................69

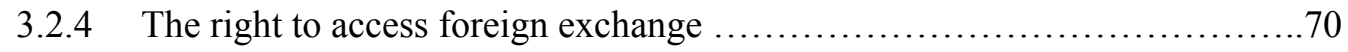

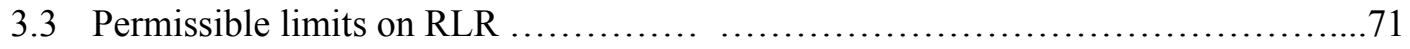

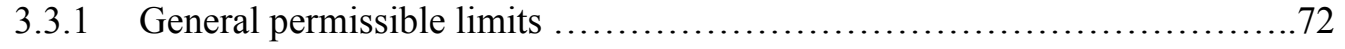

3.3.2 State practice .......................................................

3.3.3 Interpretation of permissible limits .................................... 75

3.3.4 The meaning of the terms used in the limit clauses ....................... 77

3.3.5 The principle of proportionality ........................................... 87

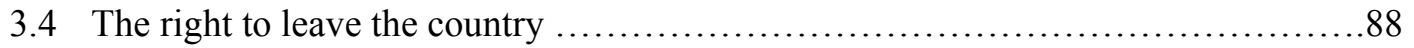

3.4.1 Who may exercise the right to leave ................................... 89

3.4.2 Recognized grounds for limiting the right to leave .......................90

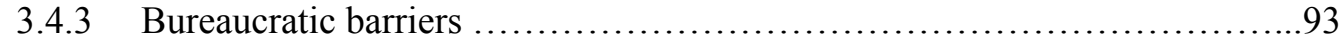

3.4.4 Loss of technical expertise from the State through emigration: the "brain rain"...........................................................94

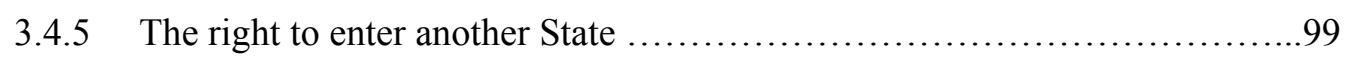

3.4.6 Procedural right against expulsion ................................ 100

3.5 The right to return to one's own country .......................................104

3.5.1 The general considerations of the right to return to one's country ..........104 
3.5.2 "One's own country" ............................................. 106

3.5.3 "Arbitrarily" ...................................................... 112

3.5.4 The duty not to expel nationals and to accept expelled nationals ...........115

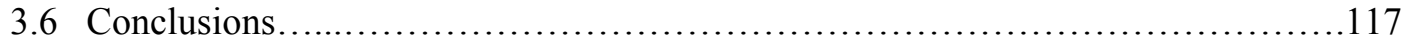

\section{Chapter Four RLR in Selected States and Regions' \\ Practice..........................................118}

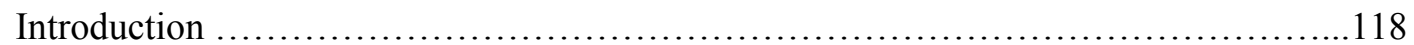

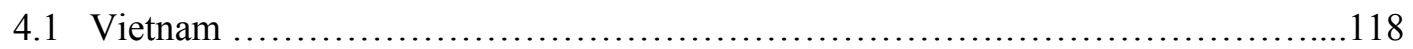

4.1.1 Context in which RLR exists ........................................118

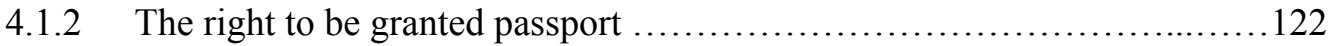

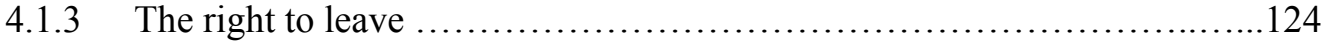

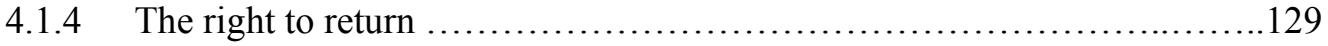

4.1.5 Administration of overseas recruitment services ...........................131

4.1.6 The exit and entry administrative system ................................133

4.2 Taiwan (Republic of China) ............................................... 134

4.2.1 Historical development of regulatory framework governing RLR in Taiwan

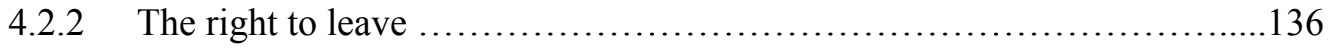

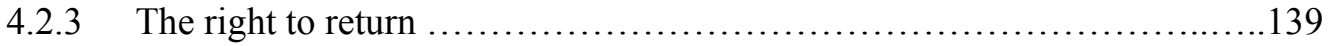

4.2.4 Exit and entry between Taiwan and Mainland China.........................141

4.2.5 Administration of migration services organization.......................143

4.2.6 The exit and entry administrative system ...............................145

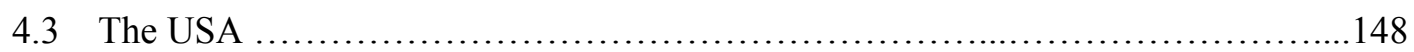

4.3.1 Legal status of RLR ..................................................... 149

4.3.2 Sole departmental authority for passport administration....................150

4.3.3 Limits on the right to be granted a passport ...........................151

4.3.4 Extent of restrictions placed on international travel ......................153

4.3.5 Foreign RLR policy ............................................. 154

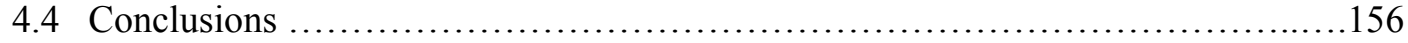

\section{Chapter five Driving Factors of RLR in China..................159}

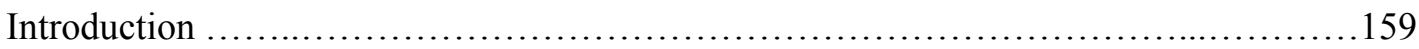

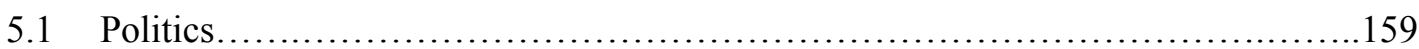

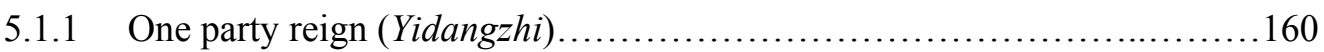

5.1.2 China as a member of the former communist bloc ........................164 
5.2.1 Basic economic factors ............................................... 167

5.2.2 Socialist public ownership of the means of production and a transitional economy.

5.2.3 Interaction between economic development and laws governing exit and entry

5.2.4 Impacts of the limits of the movement within the territory on RLR 173

5.3 Culture 175

5.3.1 The community orientated culture 175

5.3.2 Loyalty (Zhong) and filial piety (Xiao)............................... 177

5.3.3 The duty orientated culture ....................................... 178

5.3.4 Sublating $($ Yangqi) ............................................. 180

5.3.5 Agrarian civilisation and geographical isolation .......................... 182

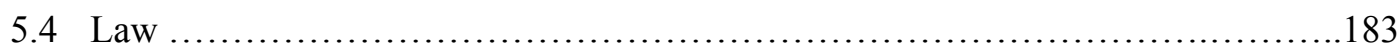

5.4.1 Absence of the Constitutional foundation to protect RLR 183

5.4.2 The nature of law governing exit and netry as the 'ruling tool' (Tongzhi Gongju) to control the exit and entry

5.4.3 The aim of law governing exit and entry: to control the exit and entry ......186

5.4.4 The conflict of laws regarding the exit and entry .......................187

5.4.5 Legal research on RLR in China ..................................... 196

5.5 Conclusions

\section{Chapter Six Historical Development of Chinese Regulatory Framework Governing RLR ..................201}

Introduction 201

6.1 The Qing dynasty: from complete prohibition to practical relaxation ..............202

6.21912 to 1949: limits and encouragement ......................................204

6.31949 to 1978: the return of prohibition policy of the Qing dynasty ................206

6.3.1 1949 to 1958: the establishment of restrictive framework governing RLR..207

6.3.2 1958 to 1978: the development of restrictive framework governing RLR.. 211

6.4 1979 to 1985: the start of the reform of the restrictive framework governing RLR

6.5 1985 to 2001: the development of the reform of the restrictive framework governing RLR

6.6 Conclusions .224 


\section{Chapter Seven Planned Reform Strategy and Measures for the}

Exit and Entry Administration ...............226

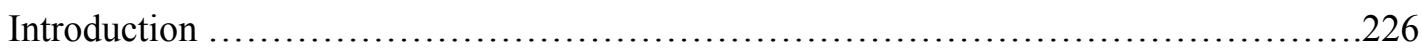

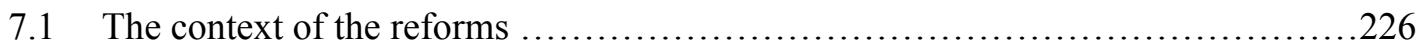

7.2 The Content of the reforms and its implementation ............................227

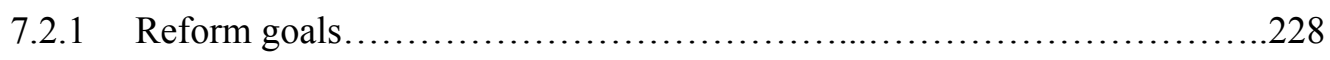

7.2.2 Three rounds of reform measures in 2002, 2003 and 2004 ...............229

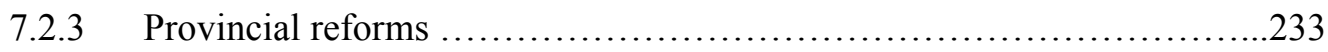

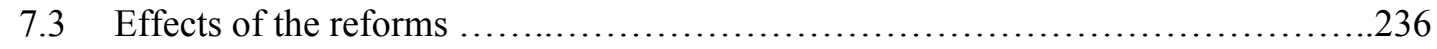

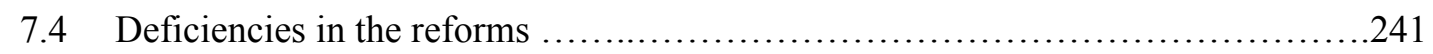

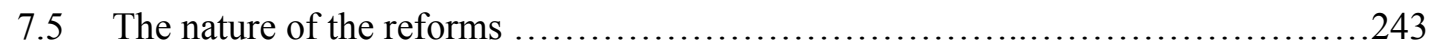

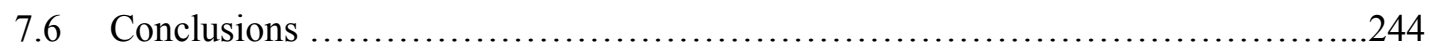

\section{Chapter Eight The Right to be Granted a Passport in China}

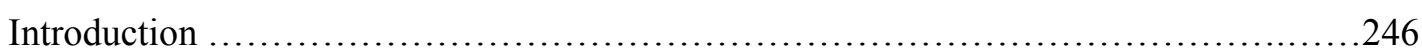

8.1 General considerations of the passport ....................................... 246

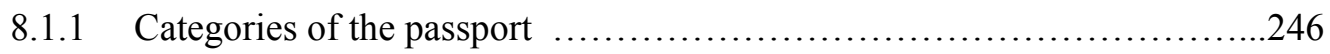

8.1.2 Scope of various kinds of passports ...................................247

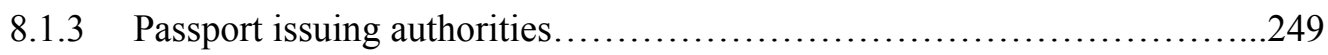

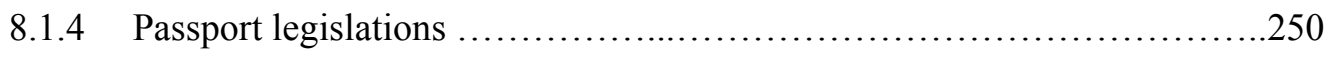

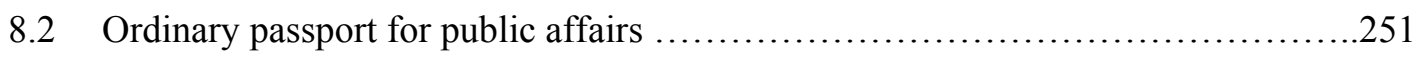

8.2.1 Scope of public affairs passport ..................................251

8.2.2 Application procedures and examination criteria .........................254

8.2.3 Management of public affairs passport ..............................255

8.2.4 Causes of the issues related to public affairs passport ....................256

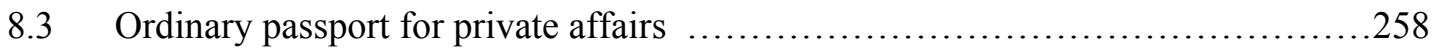

8.3.1 Prohibition of the application lodged in non-registered resident area.......258

8.3.2 Overly elaborate formalities for residents in small cities and rural areas....259

8.3.3 Retention of passports by designed departments .......................261

8.3.4 Revocation of a passport or declaring passport invalid ...................263

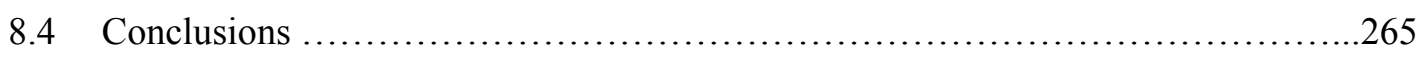

\section{Chapter Nine Limits on the Right to Leave of Chinese}


Introduction

9.1 General limits on the right to leave of Chinese Citizens

9.1.1 Contents of general limits on the right to leave of Chinese Citizens... .....267

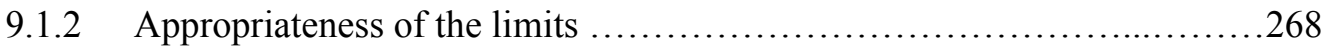

9.1.3 Legal validity of relevant interpretative provisions .......................269

9.2 Special limits on the right to leave of Chinese Citizens...........................2270

9.2.1 Overseas employment: skilled emigration .............................270

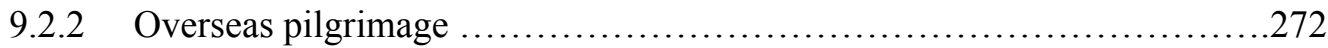

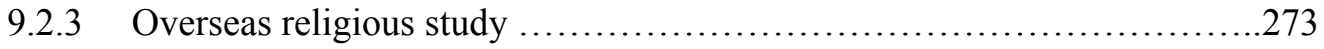

9.2.4 Limits on the right to leave based on the applicants' special status

9.3 Prerequisite certificates from the department in which the applicants are employed (Gongzuo Danwei Yijian Qianzhi) ...................................2276

9.3.1 Scope of the prerequisite comments .................................277

9.3.2 Questions on the prerequisite comments ..............................279

9.4 Household deregistration prior to leaving China ..............................280

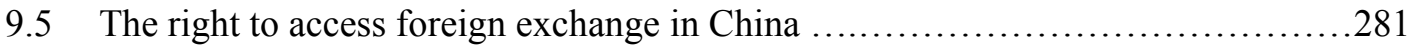

9.5.1 Limits on the right to purchase foreign exchange ........................282

9.5.2 Limits on the right to remit outward foreign exchange ......................283

9.5.3 Limits on the right to carry outward foreign currencies ..................284

9.5.4 Legislations governing foreign exchange ............................286

9.6 The administration of individuals prohibited from leaving China

(Xianzhi Chujing Zhidu) ..................................................286

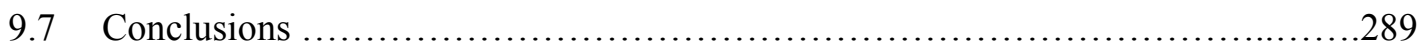

\section{Chapter Ten Limits on the Right to Return to China .........291}

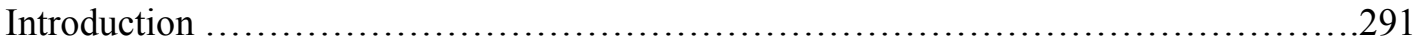

10.1 Limits on the right to return of Chinese citizens, especially dissidents..............291

10.1.1 The scope of limiting Chinese citizens, especially dissidents to return .....291

10.1.2 Practices of limiting Chinese citizens, especially dissidents to return ........294

10.1.3 Effects of limiting Chinese citizens, especially dissidents to return .........297

10.2 Limits on the right to return of Chinese citizens residing abroad

(overseas Chinese or Huaqiao).

10.2.1 Conditions of returning to China for permanent residence or employment. 
10.2.2 Formalities of returning to China for permanent residence or employment 302

10.2.3 Household registration after returning to China .........................304

10.2.4 Reasons for the limits imposed on the return of overseas Chinese ...........306

10.2.5 Effects of the limits on the return of overseas Chinese .....................308

10.3 Limits on the right to return of Chinese irregular migrants ...........................309

10.3.1 Conditions of passport re-issue, replacement and extension of irregular migrants

10.3.2 Formalities of passport re-issue, replacement and extension of irregular migrants 313

10.4 The abuse of the right of Chinese nationals not to be exiled ......................315

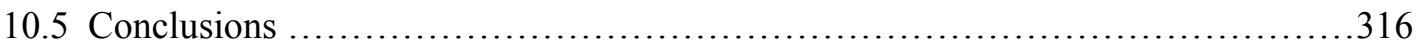

\section{Chapter Eleven Limits on the Right of Travelling to or from} the HKSAR, MSAR and Taiwan ..............319

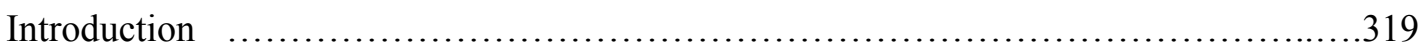

11.1 Limits on Mainland Chinese travelling to or from the HKSAR or MSAR ...........319

11.1.1 Unilateral examination and approval of the Mainland government...........319

11.1.2 Examination and approval of the fixed-quotas...........................322

11.1.3 Strict conditions of applying for travel to the HKSAR or MSAR ..............324

11.1.4 Different treatment of inland Chinese as opposed to the HKSAR and MSAR Chinese

11.2 Limits on Mainland Chinese travelling to or from Taiwan, and Taiwan Chinese travelling to Mainland China

11.2.1 The limits on travel to or from Taiwan of Mainland Chinese and the limits on travel to or from Mainland China of Taiwan Chinese.

11.2.2 The contents and effects of the limits, including the requirements of prerequisite certificates, invitation letters, and approval from Taiwanese authorities

11.2.3 Pre-eminently political nature of the limits 335

11.3 Conclusions .338

\section{Chapter Twelve Chinese Emigration Intermediary \\ Agency Laws}


12.1 Why the Chinese government regulates emigration intermediary agencies

12.2 The development of Chinese emigration intermediary agency laws

12.2.1 Laws governing overseas study intermediary agencies.

12.2.2 Laws governing exit and entry intermediary agencies for private affairs ...345

12.2.3 Laws governing overseas employment intermediary agencies ................347

12.2.4 Laws governing foreign labour trade and cooperation company..............348

12.2.5 Laws governing international travel agencies ...

12.2.6 Laws governing overseas training at government expense intermediary agencies

12.2.7 Laws governing Sino-foreign joint venture skilled personnel intermediary agencies

12.3 Issues arising from Chinese emigration intermediary agency laws 353

12.3.1 Excessive demands of licenses and certificates 354

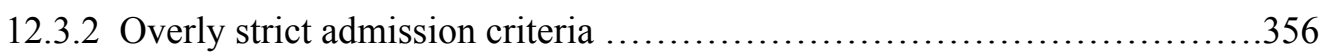

12.3.3 Irregular examination and approval .357

12.3.4 Non-recognition of Chinese emigration intermediary agencies by foreign Countries 358

12.3.5 Joint liabilities of intermediary agencies .360

12.3.6 Inadequate supervision of the operations of emigration intermediary agencies 360

12.3.7 Administrative system of emigration intermediary agencies ...............360

12.4 Conclusions 361

\section{Chapter Thirteen Chinese Exit and Entry Administrative system}

Introduction 363

13.1 Functions of Chinese exit and entry administrative authorities. 363

13.1.1 Divisions of the functions of exit and entry administrative authorities

13.1.2 Issues and implications of the functions of exit and entry administrative authorities 367

13.2 Discretions of Chinese exit and entry administrative authorities 368

13.2.1 The scope of discretion 368

13.2.2 Issues and implications of discretionary scope 370

13.3 Merits review of administrative decisions regrading exit and entry .373

13.3.1 The mechanism for merits review of administrative decisions 373 
13.3.2 Treatment to applicants of the Mainland, HKSAR, MSAR and Taiwan Chinese 374

13.3.3 Relationship between the merits review and external remedies. 374

13.4 Conclusions 375

\section{Chapter Fourteen The need to protect RLR in China, the factors in favour, and resolving practical concerns against it} .377

Introduction .377

14.1 The needs to protect RLR in China 377

14.1.1 Protecting human rights of Chinese citizens

14.1.2 Meeting the demands of a socialist market economy and further opening

China to the world community ..................................... 380

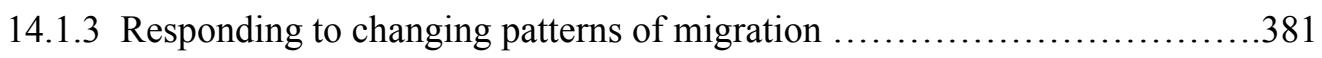

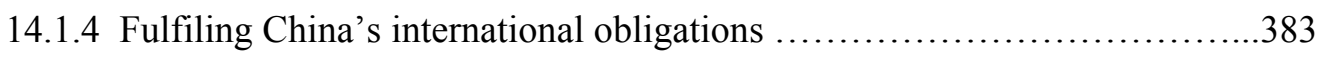

14.2 Factors favouring protection of RLR in China .................................386

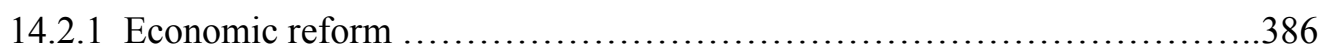

14.2.2 Democratisation and Constitutional reform ..............................387

14.2.3 Growing awareness of RLR and growing Chinese communities abroad .....388

14.2.4 International environment favouring protection of RLR in China ...........390

14.3 Practical concerns about protecting RLR in China ..............................392

14.3.1 It would make no practical difference to many Chinese people..............393

14.3.2 It would not benefit Chinese personal development when used for a

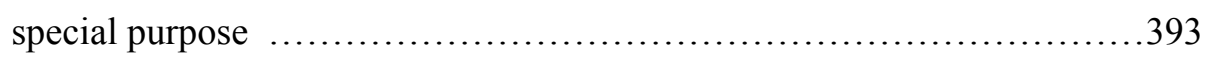

14.3.3 It would cause the loss of talented Chinese and internal instability ..........393

14.3.4 It would encourage people to illegally exit China and settle overseas .........394

14.3.5 It would damage other States' interests ....................................397

14.3.6 It would be irrelevant to other countries .................................398

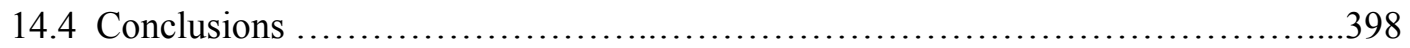

\section{Chapter Fifteen Recommendations and Conclusions ...........401}

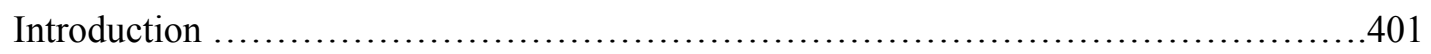

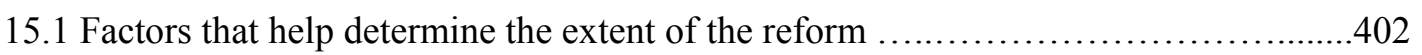

15.2 Recommendations for improving the regulatory framework governing RLR .........404

15.2.1 Incorporating RLR into the Constitution ...............................404 
15.2.2 The Enactment of a uniform Chinese migration law 405

15.2.3 The establishment of an effective exit and entry administrative system.....412

15.2.4 The reform of related laws and regulations ............................414

15.2.5 The enhancement of public awareness of RLR ........................416

15.2.6 The acceleration of the use of information technology in exit and entry administration ........................................................... 417

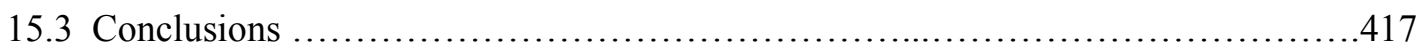

\section{Appendices}

1. The Structure of Chinese State Organizations. .1

2. Merits Review of Administrative Decisions under Chinese Administrative Laws and Administrative Procedure Laws...................................... 2

3. Admission Criteria of Chinese Emigration Intermediary Agencies .................. 4

4. Functions of Public Security Departments in Relation to Exit and Entry Administration

5. Functions of Foreign Affairs Departments in Relation to Exit and Entry Administration 12

6. Functions of Border Security Check and Administration

7. Functions of Hong Kong and Macao Affairs Offices, Taiwan Affairs Offices and Overseas Chinese Affairs Offices in Relation to Exit and Entry Administration 15

8. Functions of Departments Responsible for Emigration Intermediary Agencies .....16

9. Functions of Other Responsible Governmental Departments in Relation to Exit and Entry Administration.....

10. Functions of Other Departments and Units in Relation to Exit and Entry Administration

11. Merits Review of Administrative Decisions Concerned the Imposition of Penalties..21

12. Merits Review of Administrative Decisions Concerned the Processing of Applications for Exit and Entry

\section{Bibliographies}

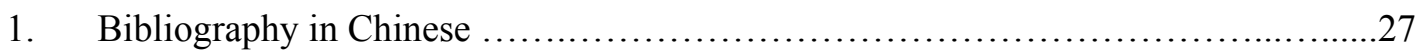

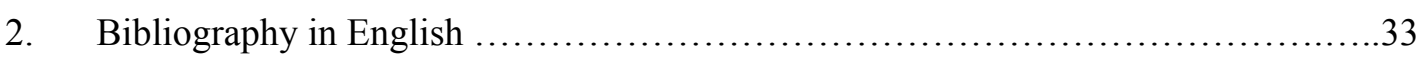




\section{List of Chinese Statutes ${ }^{1}$}

1. Amendment of Article 6 of Regulations on Passport and Visa 1984 (PRC) (Zhonghua Renmin Gongheguo Huzhao Qianzheng Tiaoli Diliutiao Xiuding), promulgated by the State Council on 27 March 1984

2. Application Procedure and Some Notable Matters of Travelling for Public Affairs to the Regions of Taiwan 1994 (PRC) (Yingong Futai Shenbao Chenxu He Ruogan Zhuyi Shixiang), promulgated by Taiwan Affairs Office under the Ministry of Agriculture on 16 March 1994, Nongtaiban [1994] 1

3. Basic Law of Hong Kong Special Administrative Region 1990 (PRC) (Xianggang Tebie Xingzhengqu Jibenfa), promulgated by the National People's Congress on 4 April 1990

4. Circular for Exit-Entry Procedures for Deputies of the National People's Congress and Commissaries of the National People's Political Consultative Conference Who Reside in the Regions of Hong Kong or Macao and Other Relevant Matters When They Return to the Inland 1982 (PRC) (Guanyu Xianggang Aomen Diqu Renda He Zhengxie Daibiao Churujing Chengxu He Fanhui Neidi Qita Shiyi De Tonghzi), promulgated by the State Council

5. Circular for Extending and Re-issuance of Passport of Illegal Migrants 1992 (PRC) (Guanyu Wei Feifa Yimin Bu Huanfa Huzhao De Tongzhi), promulgated by the Ministry of Foreign Affairs and the Ministry of Public Security

6. Circular of Application for Passport and Visa for Individuals Exiting Abroad Temporarily for Public Affairs 1983 (PRC) (Linshi Yingong Chuguo Renyuan Shenban Huzhao Qianzheng Xuzhi), promulgated by the Consular Affairs Division under the Ministry of Foreign Affairs on 19 July 1983

7. Circular of Establishment of Exit and Entry Intermediary Agencies for Private Affairs 2001 (Beijing) (Sheli Yinsi Churujing Zhongjie Jigou De Tongzhi), promulgated by Beijing Municipality Public Security Bureau and Beijing Municipality Administration of Industry and Commerce on 19 December 2001

8. Circular of Formalities Concerning Ratification and Approval of International Treaties and Agreements 1992 (PRC) (Guanyu Canjia He Pizhu Guoji Tiaoyue He Xieding Chengxu De Tongzhi), promulgated by the General Office of the State Council

9. Circular of Handling with Aliens Who Illegally Entering China and Illegally Residing In China in Accordance with the Laws 1992 (PRC) (Guanyu Yifa Chuli Feifa Rujing He Feifa Juliu Waiguoren De Tongzhi), promulgated by the Ministry of Public Security on 6 April 1992

10. Circular of the Ministries of Education, Public Security and Foreign Affairs on Some Affairs Regarding Fulltime Students Exit Abroad Short-term with Ordinary Passport for Private Affairs 2002 (PRC) (Jiaoyubu, Gonganbu, Waijiaobu Guanyu Zaixiao Xuesheng Duanqi Chuguo Chiyong Yinsi Huzhao Youguan Shixiang De Tongzhi), promulgated by the Ministry of Education, the Ministry of Public Security and the Ministry of Foreign Affairs on 25 January 2002

11. Circular of the Ministry of Education, the Ministry of Public Security on Delegating Examination and Approval Power of Primary School and Secondary School Students Exit Abroad for Summer or Winter Study Tour 1999 (PRC) (Jiaoyubu Gonganbu Guanyu Xiafang Zhongxiao Xuesheng Fu Jingwai Xia (Dong) Lingying Deng Huodong Shenpi Quanxian De Tongzhi), Jiaowaizhong No. [1999] 31

\footnotetext{
${ }^{1}$ The promulgation date and effective date of statutes in this appendix are the same day unless the effective date is specially noted.
} 
12. Circular of the Ministry of Finance on Strengthening Administration of Purchasing Foreign Exchange with Renminbi under Non-trading and Non-operation Activities 1999 (PRC), (Guanyu Jinyibu Jiaqiang Feimaoyi Feijingying Xing Gouhui Renminbi Xian”e Guanli De Tongzhi), Caiwaizi [1999] No. 439, 8 August 1999

13. Circular of the Ministry of Foreign Affairs and the Ministry of Public Security on Passport Re-issue, Replacement and Extension of Irregular Migrants 1992 (PRC) (Waijiaobu Gonganbu Guanyu Wei Feifa Yimin Bu Huan Fa Huzhao De Tongzhi), jointly promulgated by the Ministry of Foreign Affairs and the Ministry of Public Security on 30 October 1992

14. Circular of the Ministry of Labour on Prohibition of Illegal Acts of Overseas Employment 1995 (PRC) (Laodongbu Guanyu Jingzhi Feifa Chuguo Laowu Huodong De Tongzhi), promulgated by the Ministry of Labour on 28 April 1995

15. Circular of the Ministry of Public Security on Delivery Measures of Examination, Approval and Circulation of a Circular of the Lists of Individuals Prohibited from Entering China 1992 (PRC) (Gonganbu Guanyu Yingfa Buzhun Rujing Mindan Shenpi Tongbao Banfa De Tongzhi), promulgated by the Ministry of Public Security on 17 February 1992

16. Circular of the Ministry of Public Security on Handling Means of Some Issues on the Implementation of Checking, Monitoring and Prevention of Exit and Entry in Regulation of Inspection of Exit and Entry Borders 1995 (PRC) (Gonganbu Guanyu Shishi Chujing Rujing Bianfang Jiancha Tiaoli Zhong Jiancha Jianhu He Zuzhi Churujing Deng Wenti Chuli Banfa De Tongzhi), promulgated by the Ministry of Public Security on 13 October 1995

17. Circular of the Ministry of Public Security on Printing and Delivery Internal Regulations and Explanations of Implementation of Two Detailed Rules of Implementation of Law on the Control of Exit and Entry of Citizens and Citizens 1987 (PRC) (Gonganbu Yinfa Guanyu Zhixing Liangge Churujing Guanlifa Shishi Xize De Neibu Guiding Shuoming De Tongzhi), promulgated by the Ministry of Public Security on 19 February 1987

18. Circular of the Ministry of Public Security on Repealing Some Regulative Documentation 2001 (PRC) (Gonganbu Guanyu Feizhi Bufeng Guifanxing Wenjian De Tongzhi), promulgated by the Ministry of Public Security on 5 April 2001, Gongtongzi [2001] 16

19. Circular of the Ministry of Public Security on Simplifying the Formality of Citizens Exiting Abroad again for Private Affairs 1992 (PRC) (Gonganbu Guanyu Jianhua Woguo Gongmin Yinsishi Chujing Zaichujing Shouxu De Tongzhi), Promulgated by the Sixth Bureau of the Ministry of Public Security on 10 June 1992

20. Circular of the Ministry of Public Security on Simplifying the Formalities of Mainlanders Short-term Exiting and Entry the Areas of Hong Kong or Macao 2002 (PRC) (Gonganbu Guanyu Jianhua Neidi Jumin Duanqi Wanglai Gangao Diqu De Tongzhi), promulgated by the Ministry of Public Security in June 2002

21. Circular of the Ministry of Public Security on Simplifying the Formality of Intermediate and Senior Science and Technology Personals Exiting Abroad for Private Affairs 1992 (PRC) (Gonganbu Guanyu Jianhua Zhongji Gaoji Keji Renyuan Yinsi Chujing Shouxu De Tongzhi), promulgated by the Ministry of Public Security on 27 August 1992

22. Circular of the Ministry of Public Security on Some Issues of the Application for Traveling to and from Mainland of Mainland Residents who was Granted Permanent Residence of Taiwan Regions 1995 (PRC) (Gonganbu Guanyu Dalu Jumin Huozhun Dingju Taiwan Hou Shenqing Laiwang Dalu Youguan Wenti De Tongzhi), promulgated by the Ministry of Public Security on 8 May 1995

23. Circular of the Ministry of Public Security on Strictly Prohibiting From Illegally Undertaking Activities of Soliciting Clients to Permanently Emigrate 1995 (PRC) (Gonganbu Guanyu Jianjue 
Zhizhi Feifa Congshi Zhaolai Yimin Huodong De Tongzhi), promulgated by the Ministry of Public Security on 9 August 1995

24. Circular of the MPS on Temporally not Grant Permission to the Application for Exit China of Domestic Family Members of Wanted Suspects and Traitors 1991 (PRC) (Gonganbu Guanyu Zhanshi Bu Pizhun Tongji Xianyifa He Panguo Zuifan Guonei Jiasu Chuguo Shenqing De Tongzhi), promulgated by the Ministry of Public Security in 1991 Gongtongzi No. (1991) 13

25. Circular of Organization Department of the Central Committee of Chinese Communist Party on Strengthening Examination and Management on Individuals Exit Abroad for Public Affairs (Extract) 1989 (PRC) (Zhonggong Zhongyang Zuzhibu Guanyu Jiaqiang Dui Yingong Chuguo Renyuan Shencha He Guanli Gongzuo De Tongzhi (Zhailu))

26. Circular of Recognition of 108 Exit and Entry Intermediary Agencies for Private Affairs 2002 (Beijing) (Guanyu Rending 108 Jia Yinsi Churujing Zhongjie Jigou De Tongzhi), promulgated by Beijing Municipality Public Security Bureau on 10 April 2002

27. Circular of Regulating the Administration of the Passport and Visa Application and Exiting Abroad of Seamen Sending Abroad 1995 (PRC) (Guanyu Waipai Haiyuan Banzheng Chujing Guanli Gongzuo De Tonghzi), jointly promulgated by the Ministry of Foreign Trade and Economic Cooperation, the Ministry of Public Security and the Ministry of Communication on 30 March 1995

28. Circular of Some Matters on Implementation of Measures on the Control over Chinese Citizens Travelling to or from the Region of Taiwan 1992 (PRC) (Guanyu Zhixing Zhongguo Gongmin Wanglai Taiwan Diqu Guanli Banfa Ruogan Wenti De Tongzhi), promulgated by the Ministry of Public Security on 9 May 1992

29. Circular of State Administration of Foreign Exchange and General Administration of Customs on Relevant Issues Regarding the Introduction of New Version of "Certificate for Carrying Outward Foreign Exchange Across the Border1999 (PRC) (Guojia Waihui Guanli Ju Haiguan Zongshu Guanyu Faxing Xinban Xiedai Waihui Chujing Xukezheng De Tongzhi)

30. Circular of State Administration of Foreign Exchange on Issues on Regulating Policies of Sales and Payment of Foreign exchange to Domestic Chinese Citizens for Studying Abroad or in Hong Kong, Macao and Taiwan at their Own Expenses 2001 (Guojia Waihui Guanli Ju Guanyu Xiang Jingnei Jumin Chuguo Huozhe Zai Xianggang Aomen He Taiwai Zifei Liuxue Xiaoshou Waihui Guanli Zhengce De Ruogan Wenti De Tongzhi), promulgated by the State Administration of Foreign Exchange on 5 November 201 and effective on 1 December 2001

31. Circular of State Administration of Foreign Exchange on Prepayment of Cash Deposits in RMB to Purchase and Pay Foreign Exchange by Personnel Who Study Abroad or in Hong Kong, Macao, and Taiwan at Their Own Expenses 2000 (Guanyu Zifei Chujing Liuxue Renyuan Yujiao Renminbi Baozhengjin Goufuhui De Tongzhi), Hui Fa [2000] No.82

32. Circular of State Administration of Foreign Exchange on Some Matters of Improving the Administration of Selling Foreign Exchange for Public Affairs 2002 (PRC) (Guojia Waihui Guanli Ju Guanyu Zuohao Yingong Chuguo Shouhui Guanli Gongzuo Youguan Wenti De Tongzhi), promulgated by State Administration of Foreign Exchange on $20^{\text {st }}$ November 2002, Huifa [2002] 118

33. Circular of State Administration of Industry and Commerce on Strengthening the Control of Advertisement of Intermediary Agencies for Self-funded Overseas Study 1999 (PRC) (Guojia Gongshang Xingzheng Guali Ju Guanyu Jiaqiang Zifei Chuguo Liuxue Zhongjie Fuwu Guanggao Guanli De Tongzhi), promulgated by State Administration of Industry and Commerce on 17 July 1999

34. Circular of State Administration of Industry and Commerce on the Control of Advertisement of Intermediary Agencies for Exit and Entry for Private Affairs 2001 (PRC) (Guojia Gongshang 
Xingzheng Guanli Ju Guanyu Yishi Churujing Zhongjie Jigou Guanggao Guanli De Tongzhi), promulgated by the State Administration of Industry and Commerce in September 2001

35. Circular of State Administration of Industry and Commerce on the Prohibition of Release of Emigration Advertisement 1995 (PRC), promulgated by State Administration of Industry and Commerce in 1995, Gongshang Guangzi [1995] No.184.

36. Circular of State Council Bureau for Religion Affairs, State Administration of Foreign Exchange, the Ministry of Foreign Affairs, the Ministry of Public Security, the Bank of China, Customs General Administration and Civil Aviation Administration of China on Several Rules of Self-support Pilgrimage Abroad Administration (Amendment) 1995 (PRC) (Guowuyuan Zongjiao Shiwu Ju Guojia Waihui Guanli Ju Waijiaobu Gonganbu Zhongguo Yinghang Haiguan Zongshu Minyong Hangkong Zongju Guanyu Zifei Chaojing Ruogan Guiding De Tongzhi), jointly promulgated according to Some Rules on Self-funded Pilgrimage Abroad 1990 (PRC) on 28 January 1995

37. Circular of State Education Commission and the Ministry of Public Security on Prohibiting Foreign and Domestic Organs and Individuals from Recruiting Students Studying Abroad Self-funded in China without Allowance 1987 (PRC) (Guojia Jiaowei Gonganbu Guanyu Guoneiwai Zuzhi He Geren Bude Shanzi Zai Woguo Zaoshou Zifei Chuguo Liuxue Renyuan De Tongzhi), jointly promulgated by the State Education Commission and the Ministry of Public Security on 21 August 1987

38. Circular of the State Education Commission, the Ministry of Public Security and the Ministry of Foreign Affairs on Holding Ordinary Passport for Private Passport of Citizens Studying Abroad 1993 (PRC) (Guojia Jiaoyu Weiyuanhui Gonganbu Waijiaobu Guanyu Gongmin Chuguo Liuxue Chiyong Yinsi Putong Huzhao De Tongzhi), Promulgated by the State Education Commission, the Ministry of Public Security and the Ministry of Foreign Affairs on 8 July 1993

39. Circular of the State Education Commission, State Council Bureau for Religions Affairs, the Ministry of Public Affairs and the Ministry of Foreign Affairs on Dealing with Some Issues of Recruiting Students Studying Abroad in China without Permission by Certain Departments and Individuals in China of Foreign Countries and International Organizations 1990 (PRC) (Guojia Jiaowei Guowuyuan Zongjiaoju Gonganbu Waijiaobu Guanyu Chuli Mouxie Guojia He Guoji Zuzhi De Zhuhua Jigou Ji Geren Shanzi Zaihua Zaoshou Liuxuesheng Wenti De Tongzhi), promulgated by the State Education Commission, State Council Bureau for Religions Affairs, the Ministry of Public Affairs and the Ministry of Foreign Affairs on 26 December 1990

40. Circular of the Application for Passport and Visa for Individuals Temporally Exiting Abroad in the Cause of their Duties 1983 (PRC) (Linshi Yingong Chuguo Renyuan Shenban Huzhao Qianzheng Xuzhi), promulgated by the Department of Consular Affairs under the Ministry of Foreign Affairs on 19 July 1983

41. Circular of the Beijing Musicality People's Government on the Implementation of the Law On Administrative License 2003 (PRC) (Beijingshi Renmin Zhengfu Guanyu Shishi Xingzheng Xukefa De Tongzhi), promulgated by the State Council in 2003, Jingzhengfa [2003] 28

42. Circular of the General Office of the Central Committee of Chinese Communist Party and the General Office of the State Council on Transmission of the Measures on the Assigning Administration of National Foreign Culture Exchange Affairs to the Ministry of Culture 1993 (PRC) (Zhonggong Zhongyang Bangongting Guowuyuan Bangongting Guanyu Zhuanfa Wenhuabu Guanyu Quanguo Duiwai Wenhua Jiaoliu Guikou Guanli Guanli Banfa De Tongzhi), Tingzi No. [1993] 30

43. Circular of the General Office of the Central Committee of Chinese Communist Party and the General Office of the State Council on Refraining of Excessively Sending Group, Team and Individuals Exit Abroad 1986 (PRC) (Zhonggong Zhongyang Bangongting Guowuyuan Bangongting Guanyu Zhizhi Lanpai Tuanzu He Renyuan Chuguo De Tongzhi), promulgated on 23 January 1986 
44. Circular of the General Office of the State Council of Some Issues of Overseas Students 1992 (Guowuyuan Bangongting Guanyu Zaiwai Liuxue Renyuan Youguan Wenti De Tongzhi), promulgated by the General Office under the State Council on 12 August 1992

45. Circular of the General Office of the State Council on the Approval and Transmission of a Report Submitted by the National Tourism Administration Concerning the Strengthening of Tourist Work 1988 (PRC) (Guowuyuan Bangongting Guanyu Pizhun He Zhuanfa Guojia Lvyou Guanli Ju Guanyu Jiaqiang Lvyou Gongzuo De Baogao De Tongzhi), promulgated by the General Office of the State Council on 21 December 1988

46. Circular of the General Office of the State Council on the Measures for Receiving Compatriots from Taiwan Coming to the Mainland to Visit their Relatives or as Tourists 1987 (PRC) (Guowuyuan Bangongting Guanyu Taiwan Tongbao Lai Zuguo Dalu Tiaqing Lvyou Jiedai Banfa De Tongzhi), promulgated by the General Office of the State Council on 16 October 1987

47. Circular of the General Office of the State Council on Transmission of the Ministry of Foreign Affairs and the Ministry of Public Security on Some Issues of Timely Collection and Uniquely Keeping Passport of Individuals Exiting Abroad in the Course of Their Duties and Strengthening Issuance Formality of the Certificate of Exiting Abroad 1990 (PRC) (Guowuyuan Bangongting Zhuanfa Waijiaobu Gonganbu Guanyu Jishi Shoujiao Bing Jizhong Baoguan Yingong Chuguo Renyuan Huzhao He Jinyibu Yange Chuguo (Jing) Zhengmin Hefa Shouxu Wenti De Tonghzi), promulgated by the Ministry of Foreign Affairs and the Ministry of Public Security on 19 July 1990

48. Circular of the Ministry of Public Security on Seriously Carrying out the File of Gongfa(Jing) [84] 59 and Further Relaxing Exiting Abroad for Private Affairs (Abstract) 1984 (PRC) (Gonganbu Guanyu Renzhen Guance Zhixing Gongfa (Jing) 59 Hao Wenjian Jinyibu Fangkuang Yisi Chuguo De Tongzhi (Zaiyao)), promulgated by the Ministry of Public Security on 22 November 1984

49. Circular of the Ministry of Public Security, the Ministry of Education, the Ministry of Labour and Social Insurance, the State Administration of Industry and Commerce for Rectifying and Regulating Exit and Entry Intermediary Agencie 2000 (PRC) (Gonganbu Jiaoyubu Laodong He Shehui Baozhangbu Guojia Gongshang Xingzheng Guanli Ju Guanyu Qingli Zhengdun Churujing Zhongjie Jigou De Tongzhi), promulgated and as effective as 27 November 2000

50. Circular of the Organization Department under the Central Committee of Communist Party of China on Issues of Examination and Approval of Exiting Abroad for Private Affairs of Senior Cadres 1992 (PRC) (Zhonggong Zhongyang Zuzhibu Guanyu Shenpi Gaoji Ganbu Yisi Chuguo (Chujing) Wenti De Tongzhi), promulgated by the Organization Department under the Central Committee of Communist Party of China on 20 August 1992

51. Circular of the People's Bank of China on Issuing the Regulation on the Administration of Domestic Foreign Exchange Account 1997 (PRC) (Zhongguo Renmin Yihang Guanyu Xiafa Guanli Jingnei Waihui Zhanghu Guiding De Tongzhi), Yinfa [1997] No.416

52. Circular of the Political Department of the Ministry of Public Security on Some Detailed Issues of Polices Exiting China for Private Affairs and Marrying Aliens 1992 (PRC) (Gonganbu Zhengzhibu Guanyu Gongan Ganjing Yinsi Chuguo(jing) He Tong Waiguoren Jiehun Deng Youguan Jige Juti Wenti De Tongzhi), promulgated on 11 May 1992

53. Circular of the State Administration of Foreign Exchange and the General Administration of Customs on Printing and Distributing the Provisional Measures for the Administration of Carrying Foreign Currency Cash for Persons Entering or Exiting the Territory 2003 (PRC) (Guuojia Waihui Guanli Ju Haiguan Zongshu Guanyu Ying Fa Xiedai Waibi Xianchao Chujing Zanxing Banfa De Tongzhi), Huifa [2003] No.102

54. Circular of the State Administration of Foreign Exchange on Adjusting the Policies for Domestic Resident Individuals to Purchase Foreign Exchange under Current Accounts 2003 (PRC), (Guojia 
Waihui Guanli Ju Guanyu Tiaozheng Jingnei Jumin Jingchang Xiangmu Xia Gouhui Zhengce De Tongzhi), HuiFa [2003] No.104, 1 September 2003

55. Circular of the State Administration of Foreign Exchange on Adjusting Policies on Chinese Citizens' Purchase of Foreign Exchange for Tour Abroad 2002 (PRC) (Guojia Waihui Guanli Ju Guanyu Tiaozheng Zhongguo Gongmin Chuguo Lvyou Gouhui Zhengce De Tongzhi), Hui Fa [2002] No.55

56. Circular of the State Administration of Foreign Exchange on Relevant Issues Regarding Well Selling Foreign Exchange to Persons who Exit from the Territory for Public Affairs 2002 (PRC) (Guojia Waihui Guanli Ju Guanyu Zuohao Yingong Chuguo Shouhui Gongzuo Youguan Wenti De Tongzhi), Huifa [2002] No. 118. 20 October 2003

57. Circular of the State Administration of Foreign Exchange on Relevant Issues Regarding Further Deepen the Reform of Foreign Exchange Administration on Overseas Investment 2003 (PRC) (Guojia Waihui Guanli Ju Guanyu Jinyibu Shenhua Jingwai Touzi Waihui Guanli Youguan Wenti De Tongzhi), Huifa No. [2003] 120

58. Circular of the State Council of Overseas Chinese Affairs Office, the Ministry of Foreign Affairs, the Ministry of Public Security, the Ministry of Labour and the Ministry of Finance on the Arrangement Measures for Returned Korean and Mogonian Chinese for Permanent Residence 1989 (PRC) (Guowuyuan Qiaowu Bangongshi Waijiaobu Gonganbu Laodongbu Caizhengbu Guanyu Chaoxian Menggu Huaqiao Guiguo Anzhi Banfa De Tongzhi), promulgated by of the State Council of Overseas Chinese Affairs Office, the Ministry of Foreign Affairs, the Ministry of Public Security, the Ministry of Labour and the Ministry of Finance on 9 November 1989, [89] Qiaoneihui Zi No. 019

59. Circular of the State Council on Amending Article 6 of Regulations on Passport and Visa (PRC) 1984 (Guowuyuan Guanyu Xiuding Zhonghua Renmin Gongheguo Huzhao Qianzheng Tiaoli Diliutiao De Tonghzi), promulgated by the State Council on 27 March 1984

60. Circular of the State Council on Strengthening the Management of Activities of Intermediary Agencies of Exit and Entry for Private Affairs 2000 (PRC) (Guowuyuan Guanyu Jiaqiang Yinsi Churujign Zhongjie Huodong Guanli De Tongzhi), promulgated by the State Council in 2000, Guofa [2000] No. 25

61. Circular of the State Council on the Implementation of the Law on Administrative Sanctions 1994 (PRC) (Guowuyuan Guanyu Shishi Xingzheng Chufa Fa De Tongzhi), promulgated by the State Council on 9 October 1994

62. Circular of the State Council on the Unified Responsibility of the Ministry of Public Security Regarding the Administration of the Exit and Entry for Private Purpose of Citizens 1956 (PRC) (Guowuyuan Guanyu Woguo Gongmin Yinsi Chuguo De Guanli Gongzuo You Gonganbu Tongyi Zhangwo De Tongzhi), promulgated by the State Council on 14 November 1956

63. Circular of the State Council on Transmitting the Opinions of the Ministry of Public Security Concerning Expediting Small Town Registered Residence Management System Reform 2001 (PRC) (Guowuyuan Guanyu Zhuanfa Gonganbu Jiashu Xiachengzhen Huji Guanli Tizhi Gaige De Tongzhi), promulgated by the State Council in March 2001

64. Circular on 2002 Annual Examination for Exit and Entry Intermediary Agencies for Private Affair 2002 (Beijing) (Guanyu 2002 Yinsi Churujing Zhongjie Jigou Nianjian De Tongzhi), issued by Exit and Entry Administration under Beijing Municipality Public Security Bureau on 17 December 2002

65. Circular on Encouraging Returned Personnel to Establish Business in Beijing 2001 (Beijing) (Guanyu Guli Huiguo Renyuan Zai Jing Chuangli Qiye De Tongzi), made pursuant to Measure for the Implementation of Encouraging Returned Personnel to Establish Business In Beijing 2001 (Beijing), promulgated by Personnel Bureau of Beijing Municipality 
66. Circular on Further Regulating Market Order of Self-funded Overseas Studying Intermediary Service 2002 (PRC) (Guanyu Jinyibu Guifa Zifei Chuguo Liuxue Zhongjie Jigou De Tongzhi), promulgated by the Ministry of Education in November 2002

67. Circular on Relevant Issues on Regularizing Banks' Settlement of Massive Foreign Exchange Holdings of Individual Residents 2004 (PRC) (Guanyu Guifan Jumin Geren Waihui Jiehui Guanli Youguan Wenti De Tongzhi), promulgated by State Administration of Foreign Exchange, take into effect on 1 April 2004

68. Circular on Simplifying the Approval of Sending Abroad Personnel Managing Overseas Enterprises of Processing and Assembling with Materials 2002 (PRC) (Jianhua Waipai Renyuan Guanli Haiwai Chuli Wuzi Qiye De Tongzhi), promulgated by the Ministry of Foreign Trade and Economic Cooperation and the Ministry of Foreign Affairs

69. Circular on Simplifying the Formality of Undergoing Temporary Residence Registration in the Mainland of Taiwan Residents 1992 (PRC) (Guanyu Jianhua Banli Taiwan Jumin Zai Dalu Zanzhu Shouxu De Tongzhi), promulgated by the Ministry of Public Security on 17 June 1992

70. Circular on Some Matters of Examination and Management of Individuals Exiting and Entering for Private Affairs 1999 (PRC) (Guanyu Yinsi Chujing Renyuan Shencha Guanli Youguan Wenti De Tongzhi), promulgated by the Branch of the Ministry of Agriculture of Communist Party of China of on 24 March 1999, Nongdangzufa [1999] 10

71. Circular on Some Matters of Implementation and Carrying Out Regulations on the Administration for Overseas Employment Intermediary Agencies (Amendment) 2002 (Guanyu Guance Shishi Jingwai Jiuye Zhongjie Guanli Guiding Youguan Wenti De Tonghzi (Xiuding)), promulgated by the Ministry of Labour and Social Security on 24 June 2002

72. Circular on Some Noteworthy Issues of Moslem Foreign Affairs 1990 (PRC) (Guanyu Yishilanjiao Shewai Gongzuo Zhong Ying Zhuyi De Jige Wenti De Tongzhi), promulgated by the State Council Bureau for Religious Affairs in 1990

73. Circular on the Amendment of Provisional Regulations of Trial Implementation Establishment of Sino-Foreign Joint Equity Travel Agencies 1999 (PRC) (Guanyu Xiuding Shiban Zhongwai Hezi Lvxingshe Zanxing Banfa De Tongzhi), promulgated by China National Tourism Administration and the Ministry of Foreign Trade and Economic Cooperation on 19 April 1999

74. Circular on the Prohibition on Handling with Notarial Certificate of Permanent Residence Certificate for Taiwan Compatriots 1993 (PRC) (Guanyu Bude Banli Taibao Dingjuzheng Gongzheng De Tongzhi), promulgated by the Ministry of Justice on 20 October 1993, Sifatong [1993] 113

75. Circular on the Prohibition on Issuance of Notarial Certificate of Permanent Residence Certificate for Taiwan Compatriots 1993 (PRC) (Guanyu Bude Chuju Taibao Dingjuzheng Gongzheng De Tongzhi), jointly promulgated by the Department of Unified Front under the Central Committee of CPC, the Ministry of Public Security and the Ministry of Justice in 1993, Tongfa [1993] 14

76. Circular on the Recognition of Qualification of Overseas Training of Dispatching Personals to Other Countries for Training of China Communication Center of Science and Technology and other 19 Institutions and the Mass Organs 2000 (PRC) (Guanyu Rending Zhongguo Kexue Jishu Jiaoliu Zhongxin Deng Shijue Jia Shiye Danwei He Shehui Tuanti Juyou Zuzhi Panqian Tuanzu He Renyuan Chuguo (Jing) Peixun Gongzuo Zige De Tongzhi), promulgated by the State Administration of Foreign Experts Affairs on 1 December 2000

77. Constitution of the PRC 1999 (Zhonghua Renmin Gongheguo Xianfa), as amended by Constitution of the PRC 1982 promulgated by the National People's Congress on 15 March 1999 
78. Decision of the State Council Relating to Regulating and Regularizing the Order of Market Economy 2001 (PRC) (Guowuyuan Guanyu Zhengdun He Guifan Shichang Jingji Zhixu De Jueding), promulgated by the State Council on 8 May 2001

79. Decision on Encouraging Students Overseas to Serve the Motherland in Various Forms 2001 (PRC) (Guanyu Guli Haiwai Liuxue Renyuan Yi Duozhong Xingshi Weiguo Fuwu De Ruogan Yijian), promulgated by Ministries of Personnel, Education, Science and Technology, Public Security and Finance

80. Detailed Rules for Implementing of the Law on the Control of Exit and Entry of Citizens (Amendment) 1994 (PRC) (Gongmin Churujing Guanli Fa Shishi Xize Xiuding), made pursuant to the Law on the Control of Exit and Entry of Citizens 1985 (PRC), promulgated by the Ministry of Public Security, the Ministry of Foreign Affairs and the Ministry of Communications, and approved by the State Council on 15 July 1994.

81. Detailed Rules for the Implementation of Law of National Security 1994 (PRC) (Guojia Anquan Fa Shishi Xize), promulgated by the State Council on 4 June 1994

82. Detailed Rules for the Implementation of Measures for the Administration on Agency Services for Self-funded Studying Abroad (for Trial Implementation) 1999 (Beijing) (Beijingshi Zifei Chuguo Liuxue Zhongjie Fuwu Guanli Banfa (Shixing)) made pursuant to Measures for the Administration on Agency Services for Self-funded Studying Abroad 1999 (PRC), promulgated by the Bureau of Education (Beijng), the Bureau of Public Security (Beijing) and the Administration of Industry and Commerce (Beijing)

83. Detailed Rules for the Implementation of National Security 1994 (PRC) (Guojia Anquanfa Shishi Xize), made pursuant to National Security Law 1993 (PRC), promulgated by the State Council

84. Detailed Rules for the Implementation of Provisional Regulations of Quality Guarantee Deposit for Travel Agencies 1995 (PRC) (Lvxingshe Zhiliang Baozhengjin Zanxing Guiding Shishi Xize), promulgated by China National Tourism Administration on 1 January 1995

85. Detailed Rules for the Implementation of Rules on the Control of Intermediary Agencies for Selffunded Overseas Study (for Trial Implementation) 1999 (PRC) (Zifei Chuguo Liuxue Zhongjie Fuwu Guanli Guiding Shishi Xize (Shxing)), promulgated by the Ministry of Education, the Ministry of Public Security and State Administration of Industry and Commerce on 24 August 1999

86. Detailed Rules for the Implementation of the Law on the Control of Entry and Exit of Aliens 1986 (PRC) (Waiguoren Rujing Chujing Guanlifa Shishi Xize), made pursuant to the Law on the Control of Exit and Entry of Aliens 1985 (PRC), promulgated by the Ministry of Public Security and the Ministry of Foreign Affairs, and approved by the State Council on 27 December 1994

87. Detailed Rules for the Implementation of the Law on the Control of Entry and Exit of Aliens (Amendment) 1994 (PRC) (Waiguoren Rujing Chujing Guanlifa Shishi Xize Xiuding), made pursuant to the Law on the Control of Exit and Entry of Aliens 1985 (PRC) promulgated by the Ministry of Public Security and the Ministry of Foreign Affairs on 15 July 1994, and approved by the State Council on 13 July 1994

88. Detailed Rules for the Implementation of the Law on the Control of Entry and Exit of Citizens (Amendment) 1994 (PRC) (Gongmin Chujing Rujing Guanlifa Shishi Xize), made pursuant to Law on the Control of Exit and Entry of Citizens 1986 (PRC), promulgated by the Ministry of Public Security and the Ministry of Foreign Affairs on 15 July 1994, and approved by the State Council on 13 July 1994

89. Detailed Rules for the Implementation of the Laws on the Administration of Tax Collection 1993 (PRC) (Suishou Zhengguan Fa Shishi Xize), promulgated by the State Council on 4 August 1993 
90. Detailed Rules of the Implementation of the Ministry of Foreign Affairs on Carrying out Some Rules of the General Office of the Central Committee of Chinese Communist Party and the General Office of the State Council on Serious Restriction Cadres in the Organs of Party Committees and Governments Exit China 1987 (PRC) (Waijiaobu Guanche Zhixing Zhonggong Zhongyang Bangongting Guowuyuan Bangongting Guanyu Yange Kongzhi Dangzheng Jiguan Ganbu Chuguo Wenti De Ruogan Guiding De Shishi Xize), promulgated on 7 October 1987

91. Detailed Rules of the Implementation of Regulations on the Administration of Travel Agencies 2003 (PRC) (Lvxingshe Guanli Tiaoli Shishi Xize), promulgated by China National Tourism Administration on 10 June 2003

92. Detailed Rules of the Implementation on Protection of the Rights and Interests of Chinese and Family Members of Overseas Chinese 1993 (PRC) (Guiqiao Qiaojuan Quanyi Baohufa Shishi Xize), made pursuant to Law on Protection of the Rights and Interests of Returned Overseas Chinese and Family Members of Overseas Chinese Law 1990 (PRC), promulgated by the State Council on 19 July 1993

93. Detailed Rules of the Implementation on the Administration of Domestic Resident Individuals to Purchase Foreign Exchange for Private Purpose 2002 (PRC) (Jingnei Jumin Geren Yinsi Gouhui Guanli Shishi Xize)

94. Directive of the State Council on Establishing Regular Household Registration System 1955 (Guowuyuan Guanyu Jianli Jingchang Hukou Dengji Zhidu De Zhishi), promulgated by the State Council of the PRC on 22 June 1955

95. Explanation of the Ministry of Public Security on Some Issues on Implementation of Law on the Control of Exit and Entry of Citizens and Its Detailed Rules for the Implementation 1987 (PRC) (Gonganbu Guanyu Zhixing Zhongguo Gongmin Chujing Rujing Guanli Fa Ji Shishi Xize Ruogan Wenti De Shuoming), promulgated by the Ministry of Public Security on 19 February 1987

96. Explanation of Some Matters on the Implementation of Chapter Six of Measures on the Control over Chinese Citizens Travelling to or from the Region of Taiwan 1992 (PRC) (Guanyu Zhixing Zhongguo Gongmin Wanglai Taiwan Diqu Guanli Banfa Diliuzhang Youguan Wenti De Tongzhi), promulgated by the Ministry of Public Security on 20 June 1992

97. Explanation of Some Matters on Implementation of Measures on the Control over Chinese Citizens Travelling to or from the Region of Taiwan 1992 (PRC) (Guanyu Zhixing Zhongguo Gongmin Wanglai Taiwan Diqu Guanli Banfa Ruogan Wenti De Tongzhi), promulgated by the Ministry of Public Security on 9 May 1992

98. Explanation of Some Matters on Implementation of Provisional Measures on the Control over Chinese Citizens Travelling for Private Affairs to or from the Regions of Hong Kong or Macao 1986 (PRC) (Guanyu Zhixing Zhongguo Gongmin Wanglai Gangao Diqu Zanxing Guanli Banfa Ruogan Wenti De Shuoming), promulgated by the Ministry of Public Security on 19 February 1987

99. Explanation of the Enforcement of the Amendment of Two Detailed Rules of the Implementation 1995 (PRC) (Zhixing Liangge Shishi Xize Xiuding Neirong De Shuoming), promulgated by the Ministry of Public Security on 13 February 1995

100.Explanation of the Law on Administrative License (Draft) 2003 (PRC) (Guanyu Xingzheng Xukefa (Caoan) De Shuoming), promulgated by the Standing Committee of the National People's Congress on 23 August 2003

101.Explanations of the Sixth Bureau of the Ministry of Public Security on Issues of Providing Comments of Employed The organization Where the Applicant is Services of Citizens Exiting Abroad 1989 (PRC) (Gonganbu Liuju Guanyu Gongmin Shenqing Chuguo Tijiao Suozai Gongzuo Danwei Yijian Wenti De Shuomin), promulgated by the Sixth Bureau of the Ministry of Public Security on 11 March 1989 
102.General Principles of the Civil Law 1986 (PRC) (Minfa Tongze), promulgated by the National People's Congress on 12 April 1986 and effective on 1 January 1987

103.Implementation Opinion of Shanghai Municipality on Provisional Regulations of the Establishment and Administration of Sino-Foreign Equity or Cooperative Joint Venture Employment Agencies 2002 (Shanghai) (Shanghaishi Guanyu Jianli He Guanli Zhongwai Hezi Hezuo Rencai Zhongjie Jigou Guanli Zanxing Guiding De Shishi Yijian), promulgated pursuant to Provisional Regulations of the Establishment and Administration of Sino-Foreign Equity or Cooperative Joint Venture Employment Agencies 2002 (PRC) on 23 April 2002

104.Implementing Measures on Protection of the Rights and Interests of Returned Overseas Chinese and Family Members of Overseas Chinese 2002 (Guangdong) (Guangdongsheng Guanyu Guiqiao Qiaojuan Quanyi Baohufa Shishi Banfa), made pursuant to Law on Protection of the Rights and Interests of Returned Overseas Chinese and Members of Overseas Chinese 2000 (PRC), promulgated by the People's Congress of Guangdong Province

105.Instruction to Application for the License for a Overseas Employment Intermediary Agencies 2003 (Beijing) (Beijingshi Guanyu Shenqing Jingwai Jiuye Zhongjie Jigou Xukezheng De Shuoming), issued by Beijing Municipality Labour and Social Security Bureau in 2003

106.Interpretation by the Standing Committee of the National People's Congress Regarding Clause 4 Article 22 and Category (3) of Clause 2 Article 24 of the Basic Law of the Hong Kong Special Administrative Region of the People's Republic of China 1999 (PRC) (Quanguo Renda Changweihui Guanyu Xianggang Tebie Xingzheng Qu Jiben Fa Di 22 Tiao Di 4 Kuan He Di 24 Tiao Di 2 Kuan Di 3 Xiang De Jieshi), promulgated by the Standing Committee of the National People's Congress on 26 June 1999

107.Law of Administration Penalty 1996 (PRC) (Xingzheng Chufa Fa), made pursuant to the Constitution of the PRC 1993, promulgated by the Standing Committee of the National People's Congress

108.Law of Civil Procedure 1991 (PRC) (Minshi Shusong Fa), promulgated by the National People's Congress on 9 April 1991

109.Law of Criminal (Amendment) 1997 (PRC) (Xing Fa (Xiuding)), promulgated by the National People Congress on 14 March 1997

110.Law of Criminal Procedure (Amendment) 1996 (PRC) (Xingshi Shusong Fa (Xiuding)), promulgated by the National People's Congress in accordance with the Law of Criminal Procedure 1979 on 17 March 1996

111.Law of National Security 1993 (PRC) (Guojia Anquan Fa), promulgated by the Standing Committee of the National People's Congress on 22 February 1993

112.Law of Nationality 1980 (PRC) promulgated by the National People's Congress on 10 September 1980

113.Law of the Legislation 2000 (PRC) (Lifa Fa), promulgated by the National People's Congress on 15 March 2000 and effective on 1 July 2000

114.Law of the Organ of the State Council 1982 (PRC) (Guowuyuan Zuzhi Fa), promulgated by National People's Congress on 10 December 1982

115.Law on Administrative License 2003 (PRC) (Xingzheng Xuke Fa), promulgated by the Standing Committee of the National People's Congress on 27 August 2003 and effective on 1 July 2004

116.Law on Administrative Procedure 1989 (PRC) (Xingzheng Shusong Fa), promulgated by the Standing Committee of the National People's Congress on 4 April 1989 and effective on 1 October 1990

117.Law on Administrative Review 1999 (PRC) (Xingzheng Fuyi Fa), promulgated by the Standing Committee of the National People's Congress on 29 April 1999 and effective on 1 October 1999 
118.Law on Administrative Supervision 1997 (PRC) (Xingzheng Jiancha Fa), promulgated by the Standing Committee of the National People's Congress on 9 May 1997

119.Law on Protection of the Rights and Interests of Returned Overseas Chinese and Family Members of Overseas Chinese 1990 (PRC) (Guiqiao Qiaojuan Quanyi Baohu Fa), promulgated by the Standing Committee of the National People's Congress on 7 September 1990

120.Law on Protection of the Rights and Interests of Returned Overseas Chinese and the Family Members of Overseas Chinese (Amendment) 2000 (PRC) (Guiqiao Qiaojuan Quanyi Baohu Fa (Xiuding)), promulgated by the Standing Committee of the National People's Congress according to Law on the Protection of the Rights and Interests of Returned Overseas Chinese and the Family Members of Overseas Chinese 1990 (PRC) on 31 October 2000

121.Law on State Compensation 1994 (PRC) (Guojia Peichang Fa), promulgated by the Standing Committee of the National People's Congress on 12 May 1994 and effective on 1 January 1995

122.Law on the Administration of Tax Collection (Amendment) 2001 (PRC) (Suishou Zhengguan Fa (Xiuding)), promulgated by the Standing Committee of National People's Congress on 28 April 2001 pursuant to the Law on the Administration of Tax Collection 1992 (PRC)

123.Law on the Control of the Entry and Exit of Aliens 1985 (PRC) (Waiguoren Rujing Chujing Guanli Fa), promulgated by the Standing Committee of National People's Congress on 22 November 1985 and effective on 1 February 1986

124.Law on the Control of Exit and Entry of Citizens 1985 (PRC) (Gongmin Chujing Rujing Guanli $\mathrm{Fa}$ ), promulgated by the Standing Committee of National People's Congress on 22 November 1985 and effective on 1 February 1986

125.Legal Rights and Interests of Overseas Labours 2002 (PRC) (Haiwai Laogong Hefa Quanyi De Tongzhi), promulgated by the Ministry of Foreign Trade and Economy Cooperation in January 2002

126.Measures for the Administration on Exit and Entry Agency Service for Private Affairs (for Trial Implementation) 2001 (PRC) (Yinsi Churujing Zhongjie Huodong Gunali Banfa Ruogan Guiding (Shixing)), promulgated by the Ministry of Public Security and the State Administration of Industry and Commerce

127. Measures for the Administration of the Use of Foreign Exchange on Temporally Exiting the Territory for Public Affairs 2002 (PRC) (Yingong Linshi Chuguo Yonghui Guanli Banfa), No. [2003] 314, the Ministry of Finance

128. Measures for the Control of Exit and Entry Taiwai Regions of Chinese Citizens 1992 (PRC) (Zhongguo Gongmin Wanglai Taiwan Diqu Guanli Banfa), jointly promulgated by the Ministry of Public Security, the Ministry of Foreign Affairs and the Ministry of Communication on 1 May 1992

129.Measures for the Control of Intermediary Agencies for Self-funded Overseas Study (for Trial Implementation) 1999 (Beijing) (Beijingshi Zifei Chuguo Liuxue Zhongjie Fuwu Guanli Banfa (Shixing)), promulgated by Beijing Municipality Committee of Education, Beijing Municipality Public Security Bureau and Beijing Municipality Administration of Industry and Commerce on 2 November 1999

130.Measures for the Implementation on Examination and Approval of Exit Abroad (Including Hong Kong or Macao) and Invitation Aliens to China of Employees of National Pilot Enterprises Group (for Trial Implementation Implementation) 1992 (PRC) (Guangyu Guojia Shidian Qiye Jituan Renyuan Chuguo (Han Gangao) He Yaoqing Laihua Shixiang Shenpi De Shishi Banfa (Shixing)), Promulgated by the State Council Foreign Affairs Office, State Planning Committee, State Commission for Restructuring the Economy System, State Council Production Office on 31 March 1992

131. Measures for the Implementation on Examination and Approval of Sending Employees to Temporally Exiting Abroad (Including Hong Kong or Macao) and Inviting Aliens to China by Industry 
Enterprises of the Ownership by the Whole People (For Trial Implementation) 1993 (PRC) (Quanmin Suoyouzhi Gongye Qiye Panqian Linshi Chuguo (jing) Renyuan He Yaoqing Waiguo Jingmao Renyuan Laihua Shenpi De Shishi Banfa (Shixing)), Promulgated by State Council Foreign Affairs Office, State Council Hong Kong or Macao Affairs Office, State Commission of Economy and Trade and State Commission for Restructuring the Economy System on 29 June 1993

132.Measures for the Implementation on Preventing Defaulting Taxpayer from Exiting Abroad 1997 (PRC) (Jingzhi Weifushuizhe Chujing Shishi Banfa), promulgated by the Ministry of Public Security and State Tax Administration on 20 February 1997

133.Measures of Administration on Citizens Tours Abroad 2002 (PRC) (Zhongguo Gongmin Chuguo Lvyou Guanli Banfa), promulgated by the State Council

134.Measures of Beijing Municipal People's Government on Formulation of Rules and Regulations 2002 (Beijing) (Beijingshi Renmin Zhengfu Guizhang Zhiding Banfa), promulgated by Beijing Municipal People's Government on 21 May 2002 and effective on 1 June 2002

135.Measures of Examination and Approval of Intermediary Agencies of Introducing Foreign Professional Talents to Work in China 1996 (PRC) (Waiguo Zhuanye Rencai Laihua Gongzuo Zhongjie Jigou Shenpi Banfa), promulgated by the State Administration of Foreign Experts Affairs on 30 May 1996

136. Measures of Examination and Approval of Sending Individuals to be Employed in Hong Kong and Macao for a Long Term 1991 (PRC) (Guanyu Paiwang Gangao Diqu Changzhu Renyuan De Shenpi Baifa), promulgated by the State Council Hong Kong and Macao Office on 10 August 1991

137. Measures of Examination and Approval of Traveling to Hong Kong or Macao for Permanent Residence of Inland Residents 2004 (PRC) (2004 Nian Neidi Jumin Fu Gangao Diqu Dingju Shenpi Banfa), promulgated by the Ministry of Public Security in December 2003

138. Measures of Examination, Approval and Circulation of a Circular of the Lists of Individuals Prohibited from Entering China 1992 (PRC) (Buzhun Rujing Mindan Shenpi Tongbao Banfa De Tongzhi), promulgated by the Ministry of Public Security on 17 February 1992

139. Measures of Purchasing Travel Agencies Responsibility Insurance of Travel Agencies 2001 (PRC) (Lvxingshe Toubao Lvxingshe Zeren Baoxian Guiding), promulgated by State National Administration of Tourism on 15 May 2001

140.Measures of Taiyuan Municipal Peopls's Government on Legislation 2002 (Taiyuan) (Taiyuanshi Lifa Tiaoli), promulgated by Taiyuan Munipal People's Congress on 24 May 2002

141.Measures of the General Office of the Central Committee of Chinese Communist Party and the General Office of the State Council on Adjusting Examination and Approval Power of Sending Individuals Exit Abroad Temporarily and Inviting Aliens to Visit China 1993 (PRC) (Zhonggong Zhongyang Bangongting Guowuyuan Bangongting Guanyu Tiaozheng Paiqian Linshi Chuguo Renyuan He Yaoqing Waiguo Renyuan Laihua Shenpi Quanxian De Banfa)

142. Measures on Administration of Passport and Other Travel Abroad Documents of Officials Employed by the CPC, governments, Courts, Procuratorial Courts, Justice Departments and Public Security Departments 2003 (PRC) (Dangzheng Sifa Gongan Anquan Ganbu Huzhao Ji Qita Chuguo Zhengjian Guanli Banfa), promulgated by the Central Committee of Communist Party of China in August 2003

143. Measures on Encouraging Personnel Who Study Abroad to Service Sichun Province 2003 (Sichun) (Sichuanshen Guli Haiwai Liuxue Renyuan Laichuan Fuwu Banfa), promulgated by Sichun People's Government of China in 2003

144. Measures on Procedures for Contract Workers Sent Abroad Leaving the Country (Amendment) 2002 (PRC) (Waipai Laowu Renyuan Chengxu Banfa), amended pursuant to Provisional Measures on 
Procedures for Contract Workers Sent Abroad Leaving the Country 1996 (PRC), promulgated by the Ministry of Foreign Trade and Economy Cooperation on 1 April 2002

145.Measures on Prohibition of Exit and Entry of National Currency 1951 (PRC) (Jingzhi Guojia Huobi Churu Guojing Banfa), promulgated by the Government Administration Council, Central People's Government

146.Measures on the Administration of Chinese Citizens' Tours Abroad at Their Own Expense (Amendment) 2002 (PRC) (Zhongguo Gongmin Zifei Chuguo Lvyou Guanli Banfa), promulgated by the State Council on 1 July 2002

147. Measures on the Administration of Exit and Entry Intermediary Agencies for Private Affairs 2001 (PRC) (Yinsi Churujing Zhongjie Huodong Guanli Banfa Ruogan Guiding), jointly promulgated by the Ministry of Public Security and State Administration of Industry and Commerce on 17 July 2001 and effective 17 July 2002

148.Measures on the Administration of Opening Employment Cooperation with Hong Kong Region 1996 (PRC) (Dui Xianggang Diqu Kanzhan Laowu Hezuo Guanli Banfa), promulgated by the Ministry of Foreign Trade and Economic Cooperation on 5 September 1996, Waijingmao Hefa [1996] 605

149. Measures on the Administration of Opening Normal Employment Cooperation with Macao Region 1998 (PRC) (Dui Aomen Diqu Kanzhan Putong Laowu Hezuo Guanli Banfa), jointly promulgated by the Ministry of Foreign Trade and Economic Cooperation and the State Council Hong Kong and Macao Affairs Office, Waijingmao Hefa [1998] 430

150.Operational Manual of the Processing of Aliens Visas 1995 (PRC) (Shenli Waiguoren Qianzheng Chaozuo Shouce), promulgated by the Ministry of Public Security in 1995

151.Operational Norms of Application, Examination and Approval of Exiting Abroad and Passport For Private Affairs of Citizens 1996 (PRC) (Gongmin Yinsishi Chuguo Huzhao Shenqing Shenpi Guanli Gongzuo Guifan), promulgated by the Ministry of Public Security on $3^{\text {rd }}$ December 1996

152.Operational Norms on the Control of Examination and Approval of Traveling to Hong Kong or Macao for Permanent Residence of Inland Residents 1997 (PRC) (Neidi Gongmin Fu Gangao Diqu Dingju Shenpi Guanli Gongzuo Guifan), promulgated by the Ministry of Public Security in May 1997

153.Opinions for Encouraging Enterprises to Develop Business Overseas 1999 (PRC) (Guli Qiye Fazhan Haiwai Yewu De Jianyi), promulgated by the General Office of the State Council

154.Opinions of the State Council Overseas Chinese Affairs Office, Exit and Entry Administration under the Ministry of Public Security and Department of Consular Affairs under the Ministry of Foreign Affairs on Returning to China for Permanent Residence of Overseas Chinese 1991 (PRC) (Guowuyuan Qiaoban Gonganbu Liuju Waijiaobu Lingshisi Guanyu Lvju Guowai Zhongguo Gongmin Shenqing Huiguo Dingju De Yijian), jointly promulgated by State Council Overseas Chinese Affairs Office, the Bureau of Exit and Entry Administration under the Ministry of Public Security and Department of Consular Affairs under the Ministry of Foreign Affairs on 27 February 1991

155.Opinions on Well Handling with the Work of Taiwan Compatriots Traveling to Motherland to Visit the Relatives 1987 (PRC) (Guanyu Zuohao Taibao Lai Zuguo Dalu Tanqin Gongzuo De Yijian), promulgated by the Leading Panel of Taiwan Affairs under the Central Committee of Communist Party of China in 1987, Zhongbanfa [1987] 14

156. Part Seven of Overseas Talents of Outline of Program of National Talents Forster from 2002 to 2005 (2002-2005 Nian Quanguo Rencai Duiwu Jianshe Guihua Gangyao), promulgated by the General Office of the Central Committee of the CPC and the General Office of the State Council in 2002 
157.Proclamation of the Ministry of Public Security, the Central People's Government on the Control over Passengers Traveling to and from the Regions of Hong Kong or Macao 1951 (PRC) (Zhongyang Renmin Zhengfu Gonganbu Guanyu Wanglai Xianggang Aomen Lvke Guanli De Bugao), promulgated by the Ministry of Public Security on 2 August 1951 and effective on 1 September 1951

158.Provisional Detailed Rules of the Implementation of the Stipulations on Sending Term, Group and Individuals to be Trained Abroad 1990 (PRC) (Guanyu Paiqian Tuanzu He Renyuan Fu Guowai Peixun De Guanding De Zanxing Shishi Xize), promulgated by the State Council Introduction of Foreign Intellectuality Leading Panel Office on 15 April 1990

159.Provisional Measures for Citizens Travelling on Private Affairs to or from the Regions of Hong Kong or Macao 1986 (PRC) (Zhongguo Gongmin Yin Sishi Wanglai Xianggang Diqu Huozhe Aomeng Diqu De Zanxing Guanli Banfa), promulgated by the Ministry of Public Security and Approved by the State Council on 25 December 1986

160.Provisional Measures for the Administration of Carrying Foreign Exchange Cash for Persons Entering or Exiting the Territory 2003 (PRC) (Xiedai Waibi Xiaoshao Churujing Guanli Zanxing Banfa) No. [2003] 102 of the State Administration of Foreign Currency

161.Provisional Measures for the Administration of China National Tourism Administration on Organization of Tour to Thailand, Singapore and Malaysia 1990 (PRC) (Guojia Lvyouju Guanyu Zuzhi Woguo Gongmin Fu Dongnanya Sanguo Lvyou De Zaoxing Guanli Banfa), promulgated by China National Tourism Administration on 5 December 1990

162.Provisional Measures for the Procedures of Exiting Abroad Examination and Approval and Handling with Passport of Labours Sending Abroad 1990 (PRC) (Guanyu Waipai Laowu Renyuan Chuguo Shenpi Shouxu He Banli Huzhao De Zanxing Banfa), Promulgated by the Ministry of Foreign Economic Cooperation and Trade, the Ministry of Labour, the Ministry of Foreign Affairs and the Ministry of Public Security on 14 December 1990

163.Provisional Measures of the Administration of Intermediary Agencies of Introducing Foreign Professional Talents to Work in China 1995 (PRC) (Waiguo Zhuanye Rencai Laihua Gongzuo Zhongjie Jigou Zanxing Guanli Banfa), jointly promulgated by State Administration of Foreign Experts Affairs and State Administration of Industry and Commerce on 25 August 1995

164.Provisional Measures of the Beijing Municipality for Promotion the Establishment of Sino-Foreign Joint Venture Skilled Personnel Intermediary Agencies 2002 (Beijing) (Beijingshi Guli Sheli Zhongwai Heying Rencai Zhongjie Fuwu Jigou Zanxing Banfa), jointly promulgated by Beijing Municipal Bureau of Personnel, Beijing Administration of Industry and Commerce, Beijing Committee of Foreign Trade and Economic Cooperation on 14 June 2002

165.Provisional Measures of the Reserve Funds of Foreign Labour Cooperation 2001 (PRC) (Duiwai Laowu Hezuo Beiyongjing Zanxing Banfa), promulgated by the Ministry of Foreign Trade and Economic Cooperation on 27 November 2001

166.Provisional Measures of the Reserve Funds of Foreign Labour Cooperation (Amendment) 2003

(PRC) (Duiwai Laowu Hezuo Beiyongjing Zanxing Banfa) (Xiuding), promulgated by the Ministry of Commerce on 21 August 2003

167.Provisional Measures on Administration of State Dispatched Sports Technicians Exiting Abroad 1992 (PRC) (Guanyu Gongpai Chuguo (jing) Tiyu Jishu Renyuan De Guanli Zanxing Banfa), promulgated by the State Sport Commission on 12 March 1990

168.Provisional Measures on Exit of Aliens in China 1954 (PRC) (Waiguo Qiaomin Chujing Zanxing Banfa), promulgated by the Ministry of Public Security on 10 August 1954

169.Provisional Measures on Procedures for Contract Workers Sent Abroad Leaving the Country and Undergoing Passport Application 1990 (PRC) (Guanyu Paiqian Laowu Chujing He Banli Huzhao 
Chengxu De Zanxing Banfa), jointly promulgated by the Ministry of Foreign Trade and Economic Cooperation, the Ministry of Labour, the Ministry of Foreign Affairs and the Ministry of Public Security, approved by the State Council on 14 December 1990

170.Provisional Measures on Procedures for Contract Workers Sent Abroad Leaving the Country 1996 (PRC) (Guanyu Banli Waipai Laowu Renyuan Chuguo Shouxu De Zanxing Guiding), jointly promulgated by the Ministry of Foreign Trade and Economy Cooperation, the Ministry of Foreign Affairs and the Ministry of Public Security approved by the State Council on 20 December 1996

171.Provisional Measures on Residence Registration and the Issuance of Residence Certificate of Aliens in China 1954 (PRC) (Waiguo Qiaomin Juliu Dengji Ji Juliuzheng Qianfa Zanxing Banfa), promulgated by the Ministry of Public Security on 10 August 1954

172.Provisional Measures on the Administration of Chinese Citizens' Tours Abroad at Their Own Expense 1997 (PRC) (Zhongguo Gongmin Zifei Chugu Lvyou Guanli Zanxing Banfa), promulgated by China National Tourism Administration and the Ministry of Public Security and approved by the State Council on 1 July 1997

173.Provisional Measures on the Administration of Dispatching Groups and Personals to Other Countries for Training 1993 (PRC) (Guanyu Panqian Tuanzu He Renyuan Fu Guo(Jing)Wai Peixun De Zanxing Guanli Banfa), jointly promulgated by the State Administration of Foreign Experts Affairs and the Ministry of Foreign Affairs on 20 October 1993

174.Provisional Measures on the Administration of Domestic Resident Individuals Foreign Exchange (Amendment) 2003 (PRC) (Jingnei Jumin Geren Waihui Guanli Zanxing Banfa), Huifa [1999] No. 305

175.Provisional Measures on the Administration of Foreign Currency Exchange Agencies 2003 (PRC) (Waibi Duihuai Jigou Guanli Zhaixing Banfa), The People's Bank of China No. [2003] 6

176.Provisional Measures on the Administration of Foreign Exchange of Individual Residents in Inland 1998 (PRC) (Jingnei Jumin Geren Waihui Guanli Zanxing Banfa), promulgated by State Administration of Foreign Exchange on 1 September 1998, Huifa [1998]11

177.Provisional Measures on the Administration of Foreign labour and cooperation 1993 (PRC) (Duiwai Laowu Hezuo Guanli Zanxing Banfa), promulgated by the Ministry of Foreign Trade and Economic Cooperation on 5 November 1993

178.Provisional Measures on the Administration of Foreign Organs and Domestic Intermediary Agencies of Introducing Foreign Experts Culture and Education 1993 (PRC) (Guanyu Dui Jieshao Waiguo Wenjiao Zhuanjia Laihua Gongzuo De Jingwai Zuzhi He Jingnei Zhongjie Jigou Guanli De Zanxing Banfa), promulgated by State Administration of Foreign Experts Affairs on 15 June 1993

179.Provisional Measures on the Administration of the Ministry of Agriculture on Agricultural Interchange and Communication with the Regions of Taiwan 1998 (PRC) (Nongyebu Duitai Nongye Jiaoliu Huodong Guanli Zanxing Banfa), promulgated by the Ministry of Agriculture on 9 September 1998, Nongbanfa [1998] 14

180.Provisional Measures on the Administration of Opening Senior Employment Cooperation with Hong Kong Special Administration Regions 2000 (PRC) (Dui Xianggang Tebie Xingzhengqu Kanzhan Gaoji Laowu Hezuo Guanli Zanxing Banfa), jointly promulgated by the Ministry of Foreign Trade and Economic Cooperation on 25 December 2000, Waijingmao Hefa [2000] 660

181.Provisional Measures on the Control over Inland Residents Traveling for Such Business, Training, Employment as Non-Public Affairs to or from Hong Kong Special Administration Regions 1998 (PRC) (Neidi Jumin Congshi Shangwu Peixun Jiuye Deng Feigongwu Huodong Wanglai Xianggang Tebie Xingzhengqu De Zanxing Guanli Banfa), promulgated by the Ministry of Public Security on 19 March 1998 and effective on 30 March 1998 
182.Provisional Measures on the Exit and Entry National Border of Overseas Chinese, 1951 (PRC) (Huaqiao Churu Guojing Zanxing Banfa), promulgated by the Ministry of Public Security on 2 August 1951

183.Provisional Measures on the Experiments of China-foreign Equity Joint Venture Travel Agencies 1998 (PRC) (Shiban Zhongwai Hezi Lvxingshe Zanxing Banfa), jointly promulgated by China National Tourism Administration and the Ministry of Foreign Trade and Economic Cooperation on 2 December 1998

184.Provisional Measures on Travel of Aliens in China 1954 (PRC) (Waiguo Qiaomin Lvxing Zanxing Banfa), promulgated by the Ministry of Public Security on 10 August 1954

185.Provisional Provisions of the Special Economic Zones in Guangdong Province for the Control of Personnel Entering and Leaving China 1981 (Guangdong) (Guangdong Sheng Jingji Tequ Renyuan Churujing Zanxing Banfa), adopted by the $13^{\text {th }}$ Session of the Standing Committee of the Fifth People's Congress of Guangdong Province on November 17, 1981 and promulgated on 24 December 1981

186.Provisional Regulations of Administration of Foreign Holding and Foreign Self-funded Travel Agencies 2003 (PRC) (Waiguo Konggu Waishang Duzi Lvxingshe Zanxing Guiding), jointly promulgated by China National Tourism Administration and the Ministry of Commerce on 12 June 2003 and effective on 11 July 2003

187.Provisional Regulations of Quality Guarantee Deposit 1995 (PRC) (Lvxingshe Zhiliang Baozhengjin Zanxing Guiding), promulgated by China National Tourism Administration on 1 January 1995

188.Provisional Regulations of the Establishment and Administration of Sino-Foreign Equity or Cooperative Joint Venture Employment Agencies 2001 (PRC) (Sheli He Guanli Zhongwai Hezi Hezuo Jingwai Jiuye Zhongjie Jigou Zanxing Guiding), promulgated by the Ministry of Labour and Social Security and the State Administration for Industry and Commerce on 9 October and effective on 1 December 2001

189.Provisional Regulations on the Administration of Ordinary Passport for Public Affairs 1993 (PRC) (Guanyu Yingong Huzhao Guanli De Zanxing Guiding), promulgated by the Ministry of Public Affairs in December 1993

190.Provisional Regulations on the Administration of Sino-Foreign Joint Venture Personnel Intermediary Agencies 2003 (PRC) (Zhongwai Hezi Rencai Zhongjie Jigou Guanli Zanxing Guiding), jointly promulgated by the Ministry of Personnel, the Ministry of Commerce and State Administration of Industry and Commerce on 4 September 2003

191.Provisional Regulations on the Administration of Travel Agencies 1985 (PRC) (Lvxingshe Guanli Zanxing Tiaoli), promulgated by the State Council on 11 May 1985

192.Provisional Regulations on the Administration of Urban Household 1951 (PRC) (Chengshi Hukou Guanli Zanxing Tiaoli), promulgated by the Ministry of Public of Security on 16 July 1951

193.Provisional Rules on Attendance of Games or Competitions Abroad by Employment of Athletes 1989 (PRC) (Yundongyuan Shoupin Dao Guo(Jing)wai Cansai De Ruogan Guiding), promulgated by State Commission for Physical Culture and Sports on 31 May 1989

194.Provisional Rules on Some Issues of State Dispatched Coaches Aid for Foreign Countries 1990 (PRC) (Guanyu Gongpai Yuanwai Jiaolian Renyuan Ruogan Wenti De Zanxing Guiding), promulgated by State Sport Commission on 16 November 1990

195.Provisional Rules on the Administration of the Establishment of Sino-Foreign Equity Joint and SinoForeign Cooperation Job Intermediary Institutions 2001 (PRC) (Zhongwai Hezi Zhongwai Hezuo Zhiye Jieshao Jigou Sheli Guanli Zanxing Guiding), jointly promulgated by the Ministry of Labour and Social Security and State Administration of Industry and Commerce on 9 October 2001 
196.Provisional Rules on the Exit, Entry and Stay of Aliens in China 1951 (PRC) (Waiguo Qiaomin Churu Ji Juliu Zanxing Guize), promulgated by Government Administration Council on 28 November 1951

197.Provisional Rules on the Recognition of Overseas Training Qualification of Dispatching Groups and Personals to Other Countries for Training of the Institutions and the Mass Organs 1993 (PRC) (Guanyu Shiye Danwei Shehui Tuanti Zuzhi Panqian Tuanzu He Renyuan Fu Guo (Jing) Wai Peixun Gongzuo Zige Rending De Zanxing Guiding), promulgated by State Administration of Foreign Experts Affairs in June 1993, Waizhuanfa [1993] 204

198.Provisions on Registration of Marriages Between Chinese Citizens and Foreigners 1983 (PRC) (Zhongguo Gongmin Yu Waiguoren Hunyin Dengji Banfa), promulgated by the Ministry of Civil Affairs and approved by the State Council

199.Provisions on the Introduction of High Quality Talents Abroad 1997(Shanghai) (Yinjin Guowai Gaokeji Rencai Banfa), promulgated by Shanghai People's Government on 10 April 1997

200.Public Circular on Issues Concerning Compatriots in the Region of Hong Kong or Macao Traveling to and from with Compatriots in the Region of Hong Kong or Macao Returning Certificate 1979 (Guangdong) (Guangdongshen Guanyu Qianfa Gangao Tongbao Huixiangzheng Ruogan Wenti De Gonggao), promulgated by the Guangdong Bureau of Public Security in 1979

201.Regulation of Inspection of Exit and Entry Borders 1995 (PRC) (Chujing Rujing Bianfang Jiancha Tiaoli), promulgated by the State Council on 1 September 1995

202.Regulations for Encouragement of Investment by Overseas Chinese and Compatriots from Hong Kong or Macao 1990 (PRC) (Guli Huaqiao Gangao Tongbao Touzi De Guiding), promulgated by the State Council

203.Regulations for Labour Cooperation with Hong Kong Region 1996 (PRC) (Yu Xianggang Diqu Laowu Hezuo De Guanding), promulgated by the State Council on 5 September 1996

204.Regulations for the Administration on Agency Services for Self-funded Studying Abroad 1999 (PRC) (Zifei Chuguo Liuxue Zhongjie Fuwu Guanli Guiding), promulgated by the Ministry of Education and the Ministry of Public Security, and the State Administration of Industry and Commerce on 24 August 1999

205.Regulations of Overseas Chinese Contributions or Donations 1997 (Shanghai) (Shanghaishi Huaqiao Juanzheng Tiaoli), promulgated by Shanghai Municipality People's Government

206.Regulations on Border Inspection 1965 (PRC) (Bianfang Jiancha Tiaoli), promulgated by the State Council on 30 April 1965

207.Regulations on Examination and Approval of Permanent Residence of Aliens in China 2004 (Waiguoren Zai Zhongguo Yongjiu Juliu Shenpi Guanli Banfa), promulgated by the Ministry of Public Security, and effective as of 15 August 2004.

208.Regulations on Passport and Visa 1980 (PRC) (Zhonghua Renmin Gongheguo Huzhao Qianzheng Tiaoli), promulgated by the State Council 13 May 1980

209.Regulations on the Record-keeping for Regulations and Rules 2001 (PRC) (Fagui Guizhang Beian Tiaoli), promulgated by the State Council on 14 December 2001 and effective on 1 January 2002

210.Regulations on Simplifying the Procedure of Examination and Approval of the Chinese Staff Employed in Foreign Investment Enterprises Going Abroad (or to Hong Kong or Macao) 1993 (PRC) (Jianhua Waishang Touzi Qiye Zhong Fang Renyuan Chuguo (Huozhe Gangao) Shouxu De Guiding), promulgated by the Special Economic Zones Office of the State Council, and approved by the State Council

211.Regulations on the Administration for Overseas Employment Intermediary Agencies (Amendment) 2002 (PRC) (Jingwai Jiueye Zhongjie Guanli Guiding (Xiuding)), jointly promulgated by the 
Ministry of Labour and Social Security, the Ministry of Public Security and the State Administration of Industry and Commerce on 14 May 2002 and effective on 1 July 2002

212.Regulations on the Administration for Overseas Employment Intermediary Agencies 1992 (PRC) (Jingwai Jiuye Zhongjie Guanli Guiding), promulagted by the Ministry of Labour.

213. Regulations on the Administration of Entry, Exit, Transit, Residence and Travel of Aliens in China 1964 (PRC) (Waiguoren Rujing Chujing Guojing Juliu Lvxing Guanli Tiaoli), promulgated by the State Council on 13 April 1964

214.Regulations on the Administration of Labour Market 2000 (PRC) (Laodong Shichang Guanli Guiding), effective on 8 December 2000

215.Regulations on the Administration of Skilled Personnel Market 2001 (PRC) (Rencai Shichang Guanli Guiding), effective on 1 October 2001

216.Regulations on the Administration of Travel Agencies (Amendment) 1996 (PRC) (Lvxingshe Guanli Tiaoli), promulgated by the State Council on 15 October 1996

217.Regulations on the Administrative Legislation Procedure 1989 (PRC), promulgated by the Standing Committee of the National People's Congress on 4 April 1989, and effective as of 1 October 1990

218.Regulations on the Administrative of Travel Agencies (Amendment) 2001 (PRC) (Lvxingshe Guanli Tiaoli), amended pursuant to Travel Agencies Administrative Measures 1996 (PRC), promulgated by the State Council on 11 December 2001 and effective on 1 January 2002

219.Regulations on the Procedure for Formulation of Rules 2001 (PRC) (Guizhang Zhiding Chengxu Tiaoli), promulgated by the State Council on 16 November 2001 and effective on 1 January 2002.

220.Regulations on the Procedure for the Formulation of Administative Regulations 2001 (PRC) (Xingzheng Fagui Zhiding Chengxu Tiaoli), promulgated by the State Council on 16 Novermber 2001 and effective on 1 Juanuary 2002

221. Reiteration of Strictly Forbidding of Sending Young Women to Abroad to Do Erotic Service by the Name of Working 1997 (PRC) (Guanyu Congshen Yanjing Yi Waipai Laowu Deng Minyi Xiang Jingwai Paiqian Nv Qingnian Congshi Seqing Fuwu De Tongzhi), promulgated by the Ministry of Foreign Trade and Economy Cooperation. No. [1997] 803

222.Related rules on Strengthening Examination and Approval of Exit China for Public Affairs (Extract) (PRC) 1993 (Guanyu Jiaqian Yingong Lingshi Chuguo(jing) Shenpi He Guanli Gongzuo De Youguan Guiding (Zhaibian)), promulgated by the General Office of the Central Committee of Communist Party of China and the General Office of the State Council

223.Reply of the Department of Consular under the Ministry of Foreign Affairs to Some Questions on Passport Affairs (Excepts) 1993 (PRC) (Waijiaobu Lingshisi Guanyu Huzhao Gongzuo De Jige Wenti De Dafu (Jiexuan)), promulgated by the Department of Consular Affairs under the Ministry Foreign Affairs

224.Rules Governing the Implementation of the Measures for the Administration on Agency Services for Exit and Entry for Private Affairs 2002 (Beijing) (Beijingshi Guanyu Shishi Yinsi Churujing Zhongjie Huodong Guanli Banfa Ruogan Guiding (Shixing)), made pursuant to the Measures for the Administration on Agency Services for Exit and Entry for Private Affairs 2001 (PRC), promulgated by the Bureau of Public Security (Beijing) and the Administration of Industry and Commerce (Beijing) on 1 January 2002

225.Rules of Providing Convenience of Enter and Residence with Senior Talents and Investors of Foreign Nationalities 2003 (PRC) (Guanyu Wei Waiguoji Gaochenci Rencai He Touzizhe Tigong Rujing Ji Bianli De Guiding), jointly promulgated by the Ministry of Public Security, the Ministry of Foreign Affairs, the Ministry of Education, the Ministry of Technology and Science, the Ministry of Personnel, the Ministry of Labour and Social Insurance, the Ministry of Foreign Economic Relations and Trade, State Council Overseas Affairs Office and State Bureau for Foreign Experts in April 2003 
226.Rules of Some Matters of the Application of Inland Residents Traveling to Taiwan for Visiting Relatives 1988 (PRC) (Guanyu Neidi Gongmin Shenqing Qu Taiwan Diqu Tanqing Deng Wenti De Guiding), promulgated by the Ministry of Public Security on 16 November 1988

227.Rules of the Supreme People's Court, the Supreme People's Procuratorate, the Ministry of Public Security, the Ministry of Foreign Affairs, the Ministry of Justice and the Ministry of Finance on Implementation Measures of Forced Expelling Aliens 1992 (PRC) (Zuigao Renmin Fayuan Zuigao Renmin Jianchayuan Gonganbu Waijiaobu Sifabu Caizhengbu Guanyu Qiangzhi Waiguoren Chujing De Zhixing Banfa De Guiding), promulgated by Supreme People's Court, Supreme People's Procuratorate, the Ministry of Public Security, the Ministry of Foreign Affairs, the Ministry of Justice and the Ministry of Finance on 31 July 1992

228. Rules of the Organization Department under the Central Committee of Communist Party of China on Some Issues of Exiting Abroad or to Hong Kong or Macao of Party Member 1981 (PRC) (Zhonggong Zhongyang Zuzhibu Guanyu Gongchandangyuan Yinsishi Chuguo Huo Qu Gangao Diqu De Ruogang Wenti De Guiding), promulgated by the The Organization Department under the Central Committee of Communist Party of China on 11 September 1981

229.Rules of the Organization Department under the Central Committee of Communist Youth League of China on Some Issues of Exiting Abroad or to Hong Kong or Macao of League Member 1981 (PRC) (Gongqingtuan Zhongyang Zuzhibu Guanyu Gongqingtuanyuan Yinsishi Chuguo Huo Qu Gangao Diqu De Ruogang Wenti De Guiding), promulgated by the the Organization Department under the Central Committee of Communist Youth League of China on 21 September 1981

230.Rules on Complaint Reporting 1995 (PRC) (Xingfa Tiaoli), promulgated by the State Council on 28 October 1995 and effective on 1 January 1996

231.Rules on Examination and Appraisal of Public Security Organs' Law Enforcement Quality 2001 (PRC) (Gongan Jiguan Zhifa Zhiliang Kaohe Pingyi Banfa), promulgated by the Ministry of Public Security on 10 October 2001

232.Rules on the Control of Intermediary Agencies for Self-funded Overseas Study 1999 (PRC) (Zifei Chuguo Liuxue Zhongjie Fuwu Guanli Guiding), promulgated by the Ministry of Education, the Ministry of Public Security and State Administration of Industry and Commerce on 17 June 1999

233.Rules on the Procedure of Handling with Administrative Cases of Public Security Organs 2003 (PRC) (Gongan Jiguan Banli Xingzheng Anjian Chengxu Guiding), promulgated by the Ministry of Public Security on 26 August 2003 and effective on 1 January 2004

234.Some Regulations on the Reform of Current Administration of Exit and Entry 1984 (PRC) (Guanyu Gaige Xianxing Ruchujing Guanli Banfa De Ruogan Guiding), promulgated by the Ministry of Public Security on 28 November 1984, Gongfa(Jing) [84] 189

235. Some Rules of the General Office of the Central Committee of Chinese Communist Party and the General Office of the State Council on Serious Restriction Cadres in the Departments of Party Committees and Governments Exit China 1987 (PRC) (Zhonggong Zhongyang Bangongting Guowuyuan Bangongting Guanyu Yange Kongzhi Dangzheng Jiguan Ganbu Chuguo Wenti De Ruogan Guiding)

236. Some Rules on the Implementation of Measures on the Administration of Exit and Entry Intermediary Agencies for Private Affairs (for Trial Implementation) 2002 (Beijing) (Guanyu Shishi Yinsi Churujing Zhongjie Huodong Guanli Banfa Ruogan Guiding (Shixing)), promulgated by Beijing Municipality Public Security Bureau and Beijing Municipality Administration of Industry and Commerce on 1 January 2002 and effective on 1 January 2002

237.Some Rules on the Issues of Prohibiting Aliens and Chinese Citizens from Exiting China 1987 (PRC) (Guanyu Yifa Xianzhi Waiguoren He Zhongguo Gongmin Chujing Wenti De Ruogan Jiuding), 
promulgated by the Supreme People's Court, the People's Procuratorates, the Ministry of Public Security and the Ministry of National Security on 10 March 1987

238. Suggestions of the Ministry of Public Security on Some Issues Concerning the Execution of Law on the Control of Exit and Entry of Citizens 1985 (PRC) and its Detailed Rules of the Implementation 1987 (PRC) (Gonganbu Guanyu Zhixing Zhongguo Gongmin Churujing Guanlifa Ji Shishi Xize Ruogan Wenti De Shuoming), promulgated by the Ministry of Public Security on 19 February 1997

239.Suggestions of National Tourism Administration Concerning the Further Checking-up and Rectification of Tourist Agencies 1990 (PRC) (Guojia Lvyou Guanli Ju Guanyu Jinyibu Zhengdun He Guifan Lvxingshe De Jianyi), promulgated by China National Tourism Administration in 1990

240.Suggestions of the Ministry of Public Security on Relaxing the Conditions of Examination and Approval of Exiting Abroad for Private Affairs 1984 (PRC) (Gonganbu Guanyu Fangkuang Yinsi Chuguo Shenpi Tiaojian De Qingshi), promulgated by the Ministry of Public Security on 11 April 1984

241.Supplementary Circular of the State Administration of Foreign Exchange on Relevant Matters about Investing in the B Stocks by the Domestic Residents 2001 (PRC) (Guojia Waihui Guanli Ju Guanyu Jingnei Jumin Touzi B Gu Youguan Wenti De Bucong Tongzhi), Huifa [2001] No.31, 23 February 2001

242.Supplementary Opinions of State Education Commission, the Ministry of Foreign Affairs and the Ministry of Public Security on Issuing Ordinary Passport for Private Passport for Citizens Studying Abroad Sent by the State 1993 (PRC) (Guojia Jiaoyu Weiyuanhui Waijiaobu Gonganbu Guanyu Wei Gongpai Liuxue Renyuan Huanling Yinsi Putong Huzhao De Buchong Yijian), promulgated by State Education Commission, the Ministry of Foreign Affairs and the Ministry of Public Security in March 1993

243.Urgent Announcement of Several Conspicuous Problems About Labour Export to Gulf Countries 2002 (PRC) (Guanyu Xiang Haiwan Guojia Paiqian Laowu Ying Zhuyi De Jige Wenti De Jinji Tongzhi), promulgated by the Ministry of Foreign Trade and Economy Cooperation in January 2002 


\title{
List of Other States and Region's Statutes
}

\author{
Australia \\ 1. Australian Citizenship Act 1948 (Cth) \\ 2. Australian Migration Act 1958 (Cth) \\ 3. Australian Migration Series Instruction
}

\section{Taiwan, China}

4. Enforcement Regulations of the Immigration Law 1999 (ROC) (Ruchuguo Ji Yimin Fa Shixing Xize)

5. Enforcement Regulations of the Nationality Law 2001 (ROC) (Guoji Fa Shixing Xize)

6. Enforcement Rules of the Implementation of Regulations on Passport Abroad 1952 (ROC) (Chuguo Huzhao Tiaoli Shixing Xize)

7. Enforcement Rules of the Implementation of Regulations on Passport (Amendment) 2002 (ROC) (Huzhao Tiaoli Shixing Xize)

8. Immigration Law 1999 (ROC) (Ruchuguo Ji Yimin Fa)

9. Key Points of Establishment of Review Committee of Non-permission and Banning from Exit and Entry, the Ministry of Interior (Amendment) 2000 (ROC) (Neizhengbu Buyu Xuke Ji Jingzhi Ruchuguo Anjian Shencha Weiyuanhui Shezhi Yaodian)

10. Law of Nationality 2000 (ROC) (Guoji fa)

11. Martial Act of 1934 (ROC) (Jieyan Fa)

12. Measures of Ministry of Education of Sending Overseas Students 1943 (ROC) (Jiaoyubu Xuanpai Liuxuesheng Banfa)

13. Measures of Visas of Foreign Passport 1951 (ROC) (Waiguo Huzhao Qianzheng Banfa)

14. Measures on the Administration of Exit of Military Service Person and Reservists in the Region of Taiwan 1957 (ROC) (Taiwan Diqu Yinan Ji Houbei Junren Chujing Chuli Banfa)

15. Measures on the Administration of Seafarers in the Period of Suppression 1954 (ROC) (Kanluan Shiqi Haiyuan Guanli Banfa)

16. Operation Points of Circular of Population of Nationals Who Exited Two Years Ago and Reentry 2000 (ROC) (Guoren Chujing Man Liangnian Weirujing Ji Zairujing Renkou Tongbao Zuoye Yaodian)

17. Provisional Measures of Issuing Passport Exiting Abroad 1929 (ROC) (Chuguo Huzhao Zanxing Banfa)

18. Regulations Governing Visiting, Residence and Permanent Residence of Aliens (ROC) 1999 (Waiguoren Tingliu Juliu Ji Yongjiu Juliu Banfa)

19. Regulations of the Taiwan Province on the Registration of the Exit of the Servicemen, Government Employees, Teachers and Travelers of the Taiwan Province 1949 (ROC) (Taiwan Sheng Chujing Jun Gong Jiao Renyuan Ji Lvke Dengji Banfa)

20. Regulations on Guidance and Management on Migration Service Organizations and Their Employees 1999 (ROC) (Yimin Yewu Jigou Jiqi Congye Renyuan Fudao Guanli Banfa)

21. Regulations on Passport 2002 (ROC) (Huzhao Tiaoli)

22. Regulations on Permission of Exit and Entry of Nationals (Amendment) 2003 (ROC) (Guomin Ruchuguo Xuke Banfa (Xiuding))

23. Regulations on Permission of Hong Kong Permanent Residents Enter into and Permanently Resident in Taiwan Areas (Amendment) 2002 (ROC) (Xianggang Aomen Jumin Jinru Taiwan Diqu Ji Juliu Dingju Xuke Banfa (Xiuding)) 
24. Regulations on the Certificate of Overseas Chinese Identity 2002 (ROC) (Huaqiao Shenfen Zhengmin Tiaoli)

25. Regulations on the Entry and Exit in Taiwan during the Rebellion Suppression Period 1957 (ROC) (Kanluan Shiqi Taiwan Diqu Rujing Chujing Guanli Banfa)

26. Regulations on the Entry Permission of Mainland Permanent Residents to Taiwan Areas (Amendment) 2002 (ROC) (Dalu Diqu Renmin Jinru Taiwan Diqu Xuke Banfa (Xiuding))

27. Regulations on the Entry Permission of Taiwan Permanent Residents to Mainland Areas 1993 (ROC) (Taiwan Diqu Renmin Jinru Dalu Diqu Xuke Banfa)

28. Regulations on the Entry Permission of Taiwan Permanent Residents to Mainland Areas (Amendment) 2002 (ROC) (Taiwan Diqu Renmin Jinru Dalu Diqu Xuke Banfa (Xiuding))

29. Regulations on the Exit and Entry Means of Nationals with Registered Permanent Residence and Hong Kong or Macau Permanent Residence 2001 (ROC) (Jianjuyou Huji Guomin Ji Xianggang Huo Aomen Jumin Shenfenzhe Ruchu Guo Fangshi)

30. Regulations on the Relationship between Residents in Taiwan Areas and Mainland Areas 1992 (ROC) (Taiwan Diqu Yu Dalu Diqu Renmin Guanxi Tiaoli)

31. Regulations on the Relationship between Residents in Taiwan Areas and Mainland Areas (Amendment) 1995 (ROC) (Taiwan Diqu Yu Dalu Diqu Renmin Guanxi Tiaoli (Xiuding))

32. Regulations on the Relationship between Residents in Taiwan Areas and Mainland Areas (Amendment) 2002 (ROC) (Taiwan Diqu Yu Dalu Diqu Renmin Guanxi Tiaoli (Xiuding))

\section{The USA}

33. Act of Cuban Liberal and Democratic Solidarity 1996 (USA)

34. Passport Act of 1926 (USA)

35. U.S. Code of Federal Regulations Title 22 - Foreign Relations

\section{Vietnam}

36. Circular of the Ministry of Interior Providing Guidance on the Implementation of Government Decree No. 24/CP dated March 23, 1995 on Entry and Exit Proceedings 1995 (Vietnam)

37. Circular of the Ministry of Labour, War Invalids and Social Affairs Providing Guidance on the Implementation of Decree No.07/CP dated 20 January 1995 of the Government, on Sending Vietnamese Labourers Abroad to Work for a Limited Period of Time 1995 (Vietnam)

38. Circular of the State Bank of Vietnam Guiding the Implementation of the Prime Minister's Decision No.61/2001/QD-TTg of April 25, 2001 on the Organization-Resident's Obligation to Sell and Right to Buy Foreign Currencies 2001 (Vietnam)

39. Circular of the State Bank of Vietnam Providing Guidelines on the Implementation of Governmental Decree No.63/ND-CP Dated August 17, 1998, on Foreign Exchange Management 1999 (Vietnam)

40. Circular on Entry, Exit, Residence and Travel Providing Guidelines on the Implementation of Decree No. 04/CP of the Government dated 18 January 1993 Stipulating in Detail the Implementation of the Ordinance on Entry, Exit, Residence and Travel of Foreigners in Vietnam 1993 and Circular on Entry, Exit, Residence and Travel of Foreigners in Vietnam 1993 (Vietnam)

41. Circular on Guiding the Granting of Non-Vietnamese Nationality Certificates 1999

42. Circular on Prescribing the Regime of Collection, Remittance and Use Management of Fees for Granting Passports, Visas and Papers on Entry, Exit, Transit and Residence in Vietnam 2003 (Vietnam)

43. Civil Code of Socialist Republic of Vietnam 1995

44. Constitution of Socialist Republic of Vietnam 1992 
45. Decision No. 210/QD-TTg of 27 October 1999 on the Policy Towards Vietnamese Living Abroad (Vietnam)

46. Decision of the Government of Vietnam on Encouraging Money Transfer of Overseas Vietnamese 1999 (Vietnam)

47. Decision on Carrying Cash in Foreign Exchanges and Vietnamese Dong Through Border Gates 1999 (Vietnam)

48. Decree of the Government of Vietnam Guiding the Execution of Expulsion Penalty 2001 (Vietnam)

49. Decree of the Government of Vietnam on Exit and Entry of Vietnamese Citizens 2000 (Vietnam)

50. Decree of the Government of Vietnam on Foreign Exchange Management 1998 (Vietnam)

51. Decree of the Government of Vietnam on the People's Identity Card 1999 (Vietnam)

52. Decree of the Government of Vietnam Prescribing the Functions, Tasks, Powers and Organizational Structure of Vietnam National Administration of Tourism 2003(Vietnam)

53. Joint Circular Guiding the Granting of General Passports and Laissez-Passers to Vietnamese Nationals Overseas According to the Government's Decree No. 05/2000ND-CP of March 3, 2000 on Exit and Entry of Vietnamese Citizens 2002 (Vietnam)

54. Joint Circular of the Ministry of Finance and the Ministry of Labour, War Invalids and Social Affairs Guiding the Amendments and Supplements to Joint Circular No. 16/2000/ttlt-btc-bldtbxh of February 28, 2000 on Financial Regime for Vietnamese Labourers and Specialists Sent Abroad to Work for Definite Periods of Time 2001 (Vietnam)

55. Joint Circular of the Ministry of Finance, the Ministry of Justice and the Ministry of Foreign Affairs Guiding the Collection, Payment, Management and Use of Fees for Granting, Restoration or Relinquishment of Vietnamese Nationality and for Granting of Vietnamese Nationality Certificates or Vietnamese Nationality Loss Certificates 1998 (Vietnam)

56. Key Points of Establishment of Review Committee of Non-permission and Banning from Exit and Entry, the Ministry of Interior (Amendment) 2000 (Vietnam)

57. Law of Nationality 1988 (Vietnam)

58. Ordinance of Standing Committee of National Assembly on Entry, Exit and Residence of Foreigners in Vietnam 2000 (Vietnam)

59. Ordinance on Entry, Exit, Residence and Travel of Foreigners in Vietnam 1992 (Vietnam)

60. Regulation of the Ministry of Education and Training on Administration of Overseas Students in Vietnam 1999 (Vietnam)

61. Vietnam Provisionally Stipulating a Number of Measures to Prevent and Handle Violations in the Field of Sending Labourers and Experts to Work Abroad 1999 (Vietnam) 


\section{List of International Instruments}

1. African Charter on Human and Peoples' Rights 1981, enter into force on 21 October 1986, 1520 UNTS No.26, 363 OAU doc. CAB/LEG/67/3/rev.5; 21 ILM 58 (1982), AFR

2. American Convention on Human Rights 1969, enter into force on 18 July 1978, OAS Treaty Series, No.36 (1969), AMR

3. American Declaration of the Rights and Duties of Man 1948, AMDRM

4. Arab Charter on Human Rights 1994, 2 month after 7 ratification or accession, 8 Human Rights Law Journal 151 (1997)

5. Charter of United Nations, entered into force on 24 October 1945, Charter of UN

6. Concluding Document of the Vienna Meeting of January 15, 1989 CSCE

7. Convention on the Reduction of Stateless 1961, enter into force on 13/12/1975, 989 UNTS 175, CRS

8. Convention on the Rights of the Child 1989, enter into force on 02 September 1990, 1577 UNTS 3, $\mathrm{CRC}$

9. Convention Relating to the Status Refugees 1951, 28 July 1951, enter into force on 22 April 1954,189 UNTS 137, CSR

10. Declaration on the Right to Leave and the Right to Return, adopted by the Uppsala Colloquium, Uppsala, Sweden, on 21 June 1972, 1972 Uppsala Declaration on RLR

11. Draft Declaration on Freedom and Non-Discrimination in respect of the Rights of Everyone to Leave Any Country, including His Own, and to Return to His Country, by Mubanga-Chipoya, E/CN.4/Sub.2/1987/10, $10 \mathrm{ff}$

12. Draft Principles on Freedom and Non-Discrimination in Respect of the Rights of Everyone to Leave Any Country, including His Own, and to Return to His Country, prepared by Judge Jose Ingles, UN Sales No. 64. XIV.2, UN Doc. E/CN.4/Sub.2/220/Rev.1 (1963), 1963 Ingles Draft Principles on RLR

13. Draft Principles on Freedom and Non-Discrimination in respect of the Rights of Everyone to Leave Any Country, including His Own, and to Return to His Country, adopted by the UN Sub-Commission on the Prevention of Discrimination and Protection of Minorities, Res. 2B (XV), UN Doc. E/CN. 41846 (1963), 1963 UN Draft Principles on RLR

14. European Convention for the Protection of Human Rights and Fundamental Freedoms 1950, enter into force on 03 September 1953, ETS No. 5, EHR

15. European Convention on the Legal Status of Migrant Workers 1977, enter into force on 01 May 1993, ETS No. 93

16. European Social Charter (Revised) 1996, enter into force on 01 July 1999, ETS No.163

17. European Social Charter 1961, enter into force on 26 Febuary 1965, ETS No.35

18. Final Act of the Helsinki Conference on Security and Cooperation in Europe 1975, adopted on 1 August 1975

19. General Comment No. 27 of the HRC on Freedom of movement (Art.12): 02/11/99., adopted on 2 November 1999 by Human Rights Committee, CCPR/C/21/Rev.1/Add.9, General Comment No.27 of HRC on Freedom of Movement (Article 12)

20. General Comment No.31 [80] of HRC: the Nature of the General Legal Obligation Imposed on States parties to the Covenant, adopted on 29 March 2004 (2187 meeting) by Human Rights Committee, CCPR/C/21/Rev.1/Add.13, General Comment No.31 of HRC on Freedom of Movement (Article 12)

21. General Conclusions No. 15 (XXX) "Refugees without an Asylum Country" in Conclusions on the International Protection of Refugees adopted by the Executive Committee of the UNHCR Programme (Geneva: Office of UNHCR, 1990), General Comment No. 15 of the HRC on Position of Aliens 
21. International Convention on the Elimination of All Forms of Racial Discrimination 1966, enter into force on 04 January 1969, 660 UNTS 195, CERD

22. International Convention on the Protection of the Rights of All Migrant Workers and Their Families 1990, 3 month after 20 ratification, UNGA Res. 45/158

23. International Covenant on Civil and Political Rights 1966, 16 December 1966, enter into force on 23 March 1976, 999 UNTS 171, ICCPR

24. International Covenant on Economic, Social and Cultural Rights 1966, enter into force on 3 January 1976, 993 UNTS 3, ICESCR

25. Protocol No. 4 of European Convention for the Protection of Human Rights and Fundamental Freedom, ETS No. 46, EHR P4

26. Protocol Relating to Status of Refugees 1967, 31 January 1967, enter into force on 04 October 1967, 660 UNTS 267, Protocol relating to the CSR

27. Statute of the International Court of Justice, ICJ

28. Strasbourg Declaration on the Right to Leave and Return 1986, adopted by Experts on the Right to Leave and Return on 26 November 1986, 1986 Strasbourg Declaration on RLR

29. The Bangkok Declaration 1993, adopted by the Asian Preparations Conference of the Second Conference on Human Rights

30. Universal Declaration of Human Rights 1948, UDHR, G.A. res.217 A(III), UN Doc.A/810, UDHR

31. Vienna Convention on the Law of Treaties 1960, adopted 22 May 1960, entered into force 27 January 1980, UN Doc. A/CONF. 39/27 


\section{List of Graphs}

Graph 1 Average National Annual Exits in Three Migration Legislative Stages .222

Graph 2 Registered Exit and Entry Numbers Per One Million Chinese Citizens in 1978, 1988, 1996, and 2003

Graph 3 Comparison of international migration stock rates .239 


\title{
Lists of Acronyms
}

\author{
Chinese institutions \\ BBSCA Bureau of Border Security Check and Administration \\ BEEA Bureau of Exit and Entry Administration \\ CCTV China Central Television \\ Central Bank The People's Bank of China \\ CEPA The Closer Economic Partnership Arrangement \\ CNTA Chinese National Tourism Administration \\ CPC Communist Party of China \\ HKSAR Hong Kong Special Administration Region \\ MFA Ministry of Foreign Affairs, China \\ MFERT Ministry of Foreign Economic Relations amd Trade \\ MLSS Ministry of Labour and Social Security, China \\ MOC Ministry of Commerce, China \\ MOE Ministry of Education, China \\ MOP Ministry of Personnel, China \\ MPS Ministry of Public Security, China \\ MSAR Macao Special Administration Region \\ NPC National People's Congress, China \\ SAFE State Administration of Foreign Exchange \\ SAFEA State Administration of Foreign Experts Affairs, China \\ SAIC State Administration of Industry and Commerce, China \\ SBS State Bureau of the Statistics, China \\ SHMO State Council Hong Kong and Macao Affairs Office, China \\ SOCO State Council for Overseas Chinese Affairs Office, China \\ STO State Council Taiwan Affairs Office, China
}

\section{International institutions}

CPDPM UN Sub-Commission on Prevention of Discrimination and Protection of Minorities

HRC UN Human Rights Committee

ICHR International Court of Human Rights

ICJ International Court of Justice

IMF The International Monetary Fund

IOM The International Organization for Migration

NGO Non-Governmental Organizations

OECD Organization of Economic and Cooperation Development 


\section{Regional and other countries' institutions}

$\begin{array}{ll}\text { AFCM } & \text { African Commission on Human and People's Rights } \\ \text { AMCM } & \text { Inter-American Human Rights Commissions } \\ \text { AMCT } & \text { Inter-American Court of Human Rights } \\ \text { CPV } & \text { Communist Party of Vietnam } \\ \text { ECJ } & \text { European Court of Justice } \\ \text { EU } & \text { European Union } \\ \text { EUCM } & \text { European Human Rights Commissions } \\ \text { EUCT } & \text { European Court of Human Rights } \\ \text { MLWS } & \text { Ministry of Labour, War invalids and Social Affairs } \\ \text { OAS } & \text { The Organization of American States } \\ \text { SBV } & \text { State Bank of Vietnam } \\ \text { USCR } & \text { US Committee for Refugees }\end{array}$

\section{Others}

1963 Ingles' Study

on RLR Study of Discrimination in Respect of the Right of Everyone to Leave any country, including His Own, and to Return to His Country: Special Repporteur of the Subcommission on Prevention of Discrimination and Protection of Minorities

OAED Oxford Advanced Learner's English-Chinese Dictionary

PRC The People's Republic of China

RLR The right to leave and return

ROC The Republic of China

SARS Severe Acute Respiratory Syndrome

USVISIT USA Visitor and Immigration Status Indication Technology System 


\begin{abstract}
The Right to leave and return (RLR) has been affirmed as a fundamental human right in several international instruments. While being a fundamental human right, each State has the sovereign right to regulate RLR in accordance with its own laws. The regulation of RLR, however, is not only an attribute of sovereignty but an issue with important political, economic and security implications for the State. Given its significance, it is understandable and desirable that States regulate RLR. The regulation must however take account of both the interests of the State and the human rights dimension of the right. This is an issue of balance.
\end{abstract}

In the case of China, the country's communist political system has significantly affected the development of RLR and the country's approach to it. As a rule China's approach is restrictive. As part of its reform and 'opening up' policies, China has embarked on a range of reforms to liberalise RLR, but the reforms lack cohesion and focus, and remain restrictive. Given its peculiar past and complex social and economic conditions, China may have some justifications for its approach, but on balance, has more to gain from adopting a more liberal approach. The issue of RLR in China is crucial both for the future of China, and for development of RLR in the world.

China's current policy's on RLR still reflects a closed culture. A more open policy is not only consistent with international human rights norms, but also a useful infrastructure for the country's place in the global economy. Great achievements over the last 25 years and encouraging developmental trends demand acceleration of reforms to protect RLR in China. A careful and well-coordinated migration strategy with a well-defined RLR focus could enhance China's economic progress as well as its international human rights image. When designing the reform strategy, the balance of the Western experience and Chinese realities needs to be finely kept.

This thesis will explore the Chinese regulatory regime governing RLR to determine its consistency with international standards. The thesis is divided into 15 chapters. It investigates RLR in international migration law and practice; analyses RLR in the context of China, and identifies its driving factors; investigates the conditions and practical concerns relevant to the protection of RLR; and concludes with recommendations on how the Chinese regulatory regime governing RLR can be improved. 


\section{Chapter one Introduction}

\subsection{Research objectives}

The aim of this thesis is to explore the Chinese regulatory framework governing the right to leave and return (the RLR), to determine its consistency by reference to international human rights ethics. In more specific terms, the thesis focuses on four main objectives: (i) an investigation of the RLR in international migration law; (ii) an analysis of the RLR in the context of China and an identification of the factors that drive it; (iii) an investigation of the favourable conditions and practical concerns relevant to the protection of the RLR in China; and (iv) identification of the policy implications for the protection of the RLR in China.

\subsection{Research context}

The inevitable trend of globalisation ${ }^{1}$ cannot be divorced from orderly international migration, which is, in turn, founded on the RLR. ${ }^{2}$ According to the International Organisation of Migration (IOM), “At the start of the 21st century, one out of every 35 persons worldwide was an international migrant. Over the last 35 years, the number of international migrants has more than doubled." ${ }^{3}$ The late 20th century has been described as both "the age of migration"4 and

\footnotetext{
${ }^{1}$ In this regard Peter Van Ness has said: "Many analysts have concluded that, like it or not, we live in an era of globalisation, and humanity increasingly shares a common fate. ... The peoples of the world are linked more closely through a greater participation by virtually all States in the global market, and thanks to the evolution of modern communications technology." Ness, Peter Van, Human Rights and Democracy in China: Four Theories on Why the World Should Care, working paper No.167, Peace Research Centre, Research School of Pacific Studies, The Australian National University, 1996, pages 13-14.

2 Ingles, Jose D. "The United Nations Study of Discrimination in Respect of the Right of Everyone to Leave any country, including His Own, and to Return to His Country”, in Vasak, Karel and Liskofsky, Sidney, (ed), The Right to Leave and Return: Papers and Recommendations of the International Colloquium Held in Uppsala, Sweden, 19-21 June 1972, The American Jewish Committee, Arbour, the USA, 1976, pages 475-485.

3 The total number of international migrants is estimated 175 millions persons in 2002, 2.9 percent of the world population, in Facts and Figures on International Migration, International Organization of Migration, Migrations Policy Issues, No.2, March 2003, page 1.

${ }^{4}$ Castles, S. and Miller, M., The Age of Migration, Basingstoke, Macmillan, the USA, 1998.
} 
"the age of rights". 5 In 1948, the Universal Declaration of Human Rights (UDHR) was proclaimed, followed by the International Covenant on Civil and Political Rights (ICCPR) in 1966, in which the RLR was affirmed as a fundamental human right that entitles everyone to freely leave any country, including one's own, and to freely return to one's country. Without doubt, the RLR has an important role in human rights because one of the most essential and general forms of human freedom can only be realised through it - namely that people are free to choose where to go, where to stay, and where to live. ${ }^{6}$ From a legal perspective, current debate regarding the RLR is mainly concentrated on the precise interpretation of the RLR and its practical enforcement.

In 2000, 513,000 people, 0.04 percent of the Chinese population, or one out of every 2,500 Chinese people was an international migrant. Chinese international migration has increased exponentially, especially since the reforms of exit and entry administration at the end of 2001. ${ }^{7}$ Yet Chinese international migration is a level of migration considerably lower than the rest of the world. ${ }^{8}$ With further integration into the world, China presents a huge potential for human resources with significant implications for international migration and for the protection of the RLR. ${ }^{9}$

\footnotetext{
5 Bobbio, N. The Age of Rights, Political Press, Cambridge, the UK, 1995.

${ }^{6}$ Foldesi, Tamas, “The Right to Move and Its Achilles' Hell, The Right to Asylum”, Connecticut Journal of International Law, Spring 1993, page 289.

7 According to 2001-2002 Exit and Entry Data published by the Bureau of Entry and Exit Administration, China, Beijing, 2003; in 2002, 121,330,000 Chinese citizens travelled to 240 foreign countries and areas, an increase of 11.485 percent from the same figure in 2001. 118,000 Chinese citizens were approved to permanently immigrate to other countries, 4017000 Chinese were approved to go abroad firstly. In 2002, 112,263,000 aliens entered China from 239 countries and areas, an increase of 10.49 percent from the same figure in 2001.

8 According to International Migration 2002, Department of Economic and Social Affairs, Population Division, the United Nations, October 2002, different countries and regions migration stock rates have been calculated by the author as following: Egypt (0.29 percent), India (0.62 percent), Indonesia (0.19 percent), Romania (1.4.19 percent), Russian Federation ( 9.11 percent), Hungary (2.97 percent), Cuba (0.73 percent), Brazil (0.32 percent), Japan (1.27 percent), Republic of Korea (1.27 percent), Singapore (33.65 percent), United Kingdom (6.78 percent), France (10.59 percent), the USA (12.35 percent), Australia (21.4.58 percent) and New Zealand (22.50 percent). Migration stock rate in China is just a little higher than that in Vietnam (0.028 percent). 0.04 percent is also significantly lower than the average rate in more developed regions, less developed regions and least developed countries, which are 8.739 percent, 1.452 percent and 1.566 percent correspondingly.

${ }^{9}$ China is basically closed society. For more information, please see Chapter five.
} 
The relatively slow pace in the development of international migration in China is mainly due to strict control policies over the RLR. The strict visa policy of destination countries, such as the USA, is the main obstacle for the entrance into other countries of Chinese people. However, it is beyond the research scope of this thesis. With the ratification of the ICCPR by 152 countries in June $2004,{ }^{10}$ concern over the RLR has now passed its global peak, but it is still a problem for China. China is actually one of the few countries worldwide that exercises restrictive policies in relation to the RLR of its nationals. ${ }^{11}$ Nevertheless, the protection of the RLR in China is no longer as hopeless as it was before 1978. The most important cause for this change of attitude is the relaxation of strict control policies over the RLR in China, which began in 1978 alongside economic reforms. Reforms aimed at the simplification of exit and entry procedures began in December 2001. ${ }^{12}$ However, the discrepancy between the RLR protection in China and the rest of the world remains significant.

The universality of the RLR conditions in 21 st century cannot be divorced from the experience of China's 1.3 billion people that make up 21 percent of the human population. ${ }^{13}$ Increasing the RLR protection is desperately needed to stop restrictions that are inconsistent with international norms and which encumber effective interchange and cooperation between China and the rest of the world. The issue of the RLR in China is crucial both for the future of China, and the

\footnotetext{
10 International Services for Human Rights, "The Ratification Status of the Main Human Rights Treaties", ishr-06-2004, http://ww.ishr.ch/About\%20UN/Ratification/Ratification\%20-\%20Human\%20Rights\%20treaties.htm $(18 / 05 / 2003)$

11 Vietnamese and North Korean RLR policies are also restrictive.

12 "State to Simplify Entry-exit Rule", The China Daily, 11/22/2002, at http://www1.chinadaily.com.cn/news/2001-11-22/44711.html (18/04/2003); Ling, Han, "Passport Easier to Get in Shanghai", China Central Television 09:08:21 30-08-2002, at English Channel, http://www.cctv.com/english/news/Tvnews/MorningNews/20020830/100017.html (20/05/2003); Wu, Inner, "Passport Gain Wider Currency in China”, China Central Television, 15:10:23 17-10-2002, English Channel, http://www.cctv.com/news/China/FinanceABusiness/20021017/100400/html (18-04-2003); Zhu, Daqiang, "Chinese Reform Strategy of Exit and Entry Control after Entrance into the WTO” (Zhongguo Mingque Rushihou Churujing Guanli Fangxiang), China News Agency, 23-11-2001, http://review.jcrb.com.cn/ournews/asp/readNews.asp?id=63921 (18/04/2003).

13 According to "Population and Development Indicators for Asia and the Pacific", 2002, http://www.unescap.org/pop/data_sheet/2002/tab1.htm (23/05/2003), Chinese population was 1,299,656,000 in 2002.
} China projected population in 2050 will be $1,460,500,000$. 
development of the RLR in the world. ${ }^{14}$

the RLR theory is the cornerstone of Chinese migration law. It forms the basis of entry and exit control, passport administration, and other key mechanisms or systems in Chinese migration law. Chinese migration law is the central safeguard and reflection of the RLR in China. Based on the above considerations, accelerating Chinese migration law reform may improve the protection of the RLR in China.

\subsection{Research scope}

The Chinese regulatory framework governing the RLR includes Chinese migration law (Zhongguo Yimin Fa), the Constitution, administrative law, and administrative procedural law and foreign exchange law. The Chinese government has not yet promulgated statutes that use the terms 'migration', 'immigration' or 'emigration'. The contents of migration laws are contained in laws governing exit and entry. Chinese migration law here means Chinese existing laws governing exit and entry, which is also called Chinese exit and entry administration law (Zhongguo Churujing Guanli Fa).

Chinese migration law is confined to migration laws on the Mainland of the People's Republic of China (PRC). The regulations of Hong Kong Special Administrative Region (HKSAR), Macao Special Administrative Region (MSAR) and Taiwan, concerning the control over Chinese citizens including residents in Hong Kong, Macao or Taiwan travelling between those regions and the Mainland, will not be included in Chinese migration law. This is due to the particular administrative status of special administrative regions, as in the cases of Hong Kong and Macao, or as an independent region, in the case of Taiwan. In view of the aim of endeavouring to provide some legal reform recommendations based on the

\footnotetext{
${ }^{14}$ Michael, Franz and Wu, Yuanli have asserted that, "The size of China adds to the dimension of the Chinese experience; so does the fact that Chinese culture has been one of the most influential in human development. That Chinese communism has tried desperately to undermine this culture implies the importance of the Chinese story." See, "Introduction: An Overview" in Wu, Yuanli et al, Human Rights in the People's Republic of China, Westview Press, Boulder, Colorado, the USA, 1988.
} 
RLR, apart from migration laws, other pertinent regulations ${ }^{15}$ will be scrutinised from the perspective of the RLR.

Given the explicit distinctions between the RLR and the right to freedom of movement within the territory, the latter will not be discussed in this study. the RLR for public affairs or official duties constitutes one part of the RLR. Unless noted otherwise, the RLR in China in this thesis merely implies the RLR for private affairs in China. If there are statistical contradictions between international organisations and the Chinese authorities regarding the same fact, this research will favour the former. As a consequence of the lack of freedom of information legislation, or an effective monitoring system in China, Chinese data is less reliable than that from international organisations. ${ }^{16}$

\subsection{Organisation of the thesis}

The first four chapters of this thesis will explore the RLR in international migration law and among comparable States. The remaining chapters identify factors driving the RLR in China, analyse the historical development, present status and issues of the RLR in China, then argue as to the favourable conditions and practical concerns for protection of the RLR, to then identify the policy implications for its protection.

The introductory chapter briefly sets out the research objectives, context and scope, organisation of the thesis, research methodology, sources and research significance. It gives a general picture of this thesis. In developing the analytical rationale, it is necessary to decide at the outset what the foundations of the RLR are, and what States' responsibility for the protection of the RLR

\footnotetext{
15 The Constitution of People's Republic of China (Amendment) 2004, the Law of Nationality 1980 (PRC), the Regulations of Inspection of Exit and Entry Borders 1995 (PRC), the Law of Administration Procedure 1989 (PRC), the Regulations of Administrative Review 1999 (PRC) and the Law of Administrative License 2003 (PRC).

16 American international professor, economic professors, Korean economic expert and Chinese economic experts questioned the trueness in their papers or works based on systematic analysis. For details see "international community continually question the falseness of Chinese economic data" (Guoji Shixu Zhiyi Zhongguo Jingji Zhaojia) www.epochtimes.com/gb/2/3/22/n178563.htm (08/07/2005)
} 
might entail. In other words, it is necessary to benchmark the measurement of the RLR in China. Chapter two is concerned with identifying the foundations of the RLR from three angles: philosophy, history, globalisation and international migration.

Critical research of the RLR in China and Chinese migration law requires knowledge of the rules and practice in international migration law, of the legal experiences, precedents, lessons from comparable States, and of the present and past situation in relation to future trends. Chapter three summaries and describes the RLR in international migration law. It aims to provide an objective criterion to which China could make reference and comparison from five perspectives, namely general considerations on the RLR, State acceptance of the RLR, permissible limits on the RLR, the right to leave the country, and the right to return to one's own country. Chapter four contains the descriptive cases studies of Vietnam, Taiwan and the USA. ${ }^{17}$ These three selected States and regions' practices protecting the RLR provide practical experiences and lessons from which China could learn.

Chapter five identifies the factors that drive the RLR in China from the perspectives of the politics, economics, culture and law. The political and legal factors are the foremost and most direct factors affecting the RLR in China. The analysis of above factors argues that the development of the RLR in China and the emergence of the issues of the RLR, explored from chapters six to thirteen, is a corollary of these driving factors. In order to better appreciate the issues associated with the RLR in China, it is necessary to trace the historical development of the Chinese regulatory framework governing the RLR. A brief historical sketch starting from the Qing dynasty, yet focused on the period from 1979 to 2001, is included in Chapter six. Chapter seven explores planned reform strategies and measures of exit and entry administration from 2001 to 2005, to predict which issues of the RLR in China could be solved with their

\footnotetext{
17 Vietnam is experiencing great political and economic reforms, of a similar nature to that of current Chinese political and economic reform. The Taiwanese legal system shares a cultural background with that of Mainland China, and interacts with Chinese legislation governing exit and entry administration. As one of traditional immigration States and typical developed States, the regimes protecting RLR in the USA are advanced. Its RLR policy has the most policy links with other countries.
} 
implementation, what situation might result if no more reform measures were taken, and what influences the reform strategies and measures have had.

Do serious issues of the RLR exist in China? If so, are they serious enough to demand the close attention of the Chinese government and foreign States? Building on reference to the RLR in international migration law and selected States in chapters three and four, chapters eight to thirteen attempt to answer these questions based on an analysis of the Chinese regulatory framework governing the RLR. These chapters form the centre of the thesis - that many serious issues demand prompt resolution in order to protect the RLR in China.

Chapter eight argues that there are bureaucratic barriers to the RLR posed by the formalities of passport application and passport administration. Chapter nine argues that there are many unacceptable prohibitions and limits on the right to leave in China. Chapter ten discusses regulatory measures that limit the right to return of Chinese citizens. Chapter eleven questions and critiques the control over the travel of Mainland Chinese to and from the HKSAR, MSAR and Taiwan. In particular, to question the principles of processing applications, which are questions overlooked by past researchers and officials, as a consequence to their being too accustomed to them. Chapter twelve considers the unique institution of the emigration intermediary agencies. Chinese emigration intermediary agency laws are an indispensable part of the regulatory framework governing the RLR. An advanced agency can help realise the RLR. Chapter thirteen argues that Chinese exit and entry administrative system faces serious issues.

It is worth noting that many of the limits on the RLR identified in chapters from eight to thirteen have been ignored or have received little attention in China because research into the RLR in China is a politically sensitive topic, which brings big risks and little economic benefit to researchers. Further, research into the exit and entry administration in China is underdeveloped, which has the effect of weakening the RLR. Many of the arguments regarding the limits on the RLR in China presented in this thesis have not been previously raised in the academic literature.

Chapter fourteen investigates why it is necessary and feasible to protect the RLR, and explodes 
the myths which justify opposing protection of the RLR in China. Chapter fifteen, by a series of recommendations, seeks to find a possible solution to the issues addressed from chapters eight to thirteen.

\subsection{Research methodology and sources}

\section{Research methodology}

The multi-disciplinary nature of this thesis has required adopting a number of approaches for evaluating the Chinese regulatory framework governing the RLR, including an analysis of migration law, of international law, of substantive and procedural administrative law, and of public policy and economics. The overall approach is based on traditional legal methods, such as the analysis of the legal provisions, combined with insights from other disciplines including a comparative methodology, historical methodology and critical theory. The overall approach for this study allows a suitable method to be applied to a specific area of the analysis where that technique is the most relevant. Each research strategy has its limitations and no single strategy is adequate for the complete analysis undertaken. It is only by adopting a multi-disciplinary approach that the constraints of individual disciplines are overcome.

\section{Reference sources}

The reference sources used for this thesis include primary legal sources, policies and formal reports; as well as secondary sources such as texts, journal articles, research theses, news reports and governmental speeches. Data, ministerial provisions and reports about exit and entry and the RLR in China, are not totally open to the public, as they can be in Western countries, due to the political sensitivity of the RLR and the lack of freedom of information legislation in China. Textbooks and academic papers regarding the RLR and exit and entry are only published within public security departments. Because it is so difficult to access to Chinese materials from Australia, I returned to Beijing in August 2003 and May 2004 to collect materials. ${ }^{18}$ To better

\footnotetext{
${ }^{18}$ I retuned to Beijing in August 2005 and May 2004 to collect materials which include works, journal articles, newspaper articles, the Master theses, the doctoral theses, the collection of relevant laws, regulations and policies. These materials are reliable as they are officially published or internal published in public security authorities or communist party organizations in Mainland China. They are in Chinese only.
} 
understand Chinese statutes, besides the English and Chinese title of Chinese statutes, I also give the promulgation bodies, promulgation date and effective date in the List of Chinese Statutes.

Three more points must be noted. Firstly, no Chinese legal cases are quoted to support the thesis because China has a civil law system. Earlier higher Courts' verdicts are not legal sources for the purpose of making later determinations by the lower Courts. Secondly, I have had to personally translate some materials from Chinese into English because only some Chinese texts have been officially translated into English. Thirdly, the changing nature of existing Chinese laws governing exit from and entry into China requires updated materials to be included in the thesis. Limited by the fact that some provisions are not open to the public, the analyses of the updated provisions are mainly based on official news and speeches, usually found on the Chinese official websites.

Governmental dynamics continue to operate and many aspects of the RLR remain in transition. Thus, it is necessary to establish a cut-off date after which no further legal information would be sought or included. The currency of this research is limited to October 30, 2004.

\subsection{Research significance}

Although considerable research has been devoted to human rights in the world and in China ${ }^{19}$, less attention has been paid to the RLR in China, especially from the perspectives of universal

\footnotetext{
19 Ingles, Jose D, Study of Discrimination in Respect of The Right of Everyone to Leave any country, including His Own, and to Return to His Country: Special Repporteur of the CPDPM, United Nations Publication Sales No.: 61.4. XIV. 2 New York, 1963; Freedman, Warren, The Right to Travel: A Right or a Privilege? Work Paper of Sao Paulo Conference on the Law of the World, the World Peace Through Law Centre, Washington, the USA 1981; Hannum, Hurst, The Right to Leave and Return in International Law and Practice, Martinus Nijhoff Publishers, Dordrecht, the Netherlands, 1987; Plender, Richard, International Migration Law, Revised 2nd ed, Martinus Nijhoff Publishers, Dordrecht, the Netherlands, 1988; Vasak, Karel etc (ed), The right to Leave and Return: Papers and Recommendations of the International Colloquium Held in the Uppsala, Sweden, 19-21 June 1972, The American Jewish Committee, Ann Arbour, the USA, 1976
} 
principles and Chinese realities. ${ }^{20}$ The limited research about the RLR in China has tended to focus on a few limited aspects of economics, social science, demography and history, such as Chinese coolie (unskilled labourer) migration and Chinese life and integration in host countries, rather than law. ${ }^{21}$ The limited research regarding Chinese migration law has been descriptive rather than analytical. ${ }^{22}$ Chinese researchers have thus in the past considered that there are no

${ }^{20}$ Baehr, Peter R. et al (ed), Human Rights: Chinese and Dutch Perspectives, Kluwer Law International, The Hague, the Netherlands, 1996; Bradley, Catherine, What Do We Mean by Human Rights: Freedom of Movement, Franklin Watts, London, 2002; Cranston, Maurice, What are Human Rights? Taplinger Publishing Co., Inc. New York, 1973; Edwards, R. Randle, Henkin, Louis and Nathan, Andrew J., Human Rights in Contemporary China, Columbia University Press, New York, 1986; Friedmann, Daniel and Barak-Erez, Daphne (ed), Human Rights in Private Law, Hart Publishing c/o, Oregon, the USA 2001; Hegarty, Angela and Leonard, Siobhan (ed), A Human Rights: An Agenda for the 21st Century, Cavendish Publishing Limited, London, 1999; Kent, Ann, Human Rights in PRC, Discussion Paper No.3, 1989-90, Legislative Research Service, the Parliamentary of the Commonwealth of Australia, 1990; Ness, Peter Van, Human Rights and Democracy in China: Four Theories on Why the World Need Care, working paper No.167, Peace Research Centre, Research School of Pacific Studies, Canberra, The Australian National University 1996; Wu, Yuanli et al, Human Rights in PRC, Westview Press, Boulder, Colorado, the USA 1988; and Human Rights White Papers of The Chinese Government, Reports of Human Rights in China, and IOM reports, and UN reports

${ }^{21}$ Campbell, Persia Crawford, Chinese Coolie Emigration to Countries within the British Empire China Frank Cass and Company Ltd. London, 1923, Etienne Dennery, Asia's Teeming Millions: and Its Problems for the West, Kennikat Press, Port Washington, 1931; Irick, Robert L., Ch'ing Policy Toward the Coolie Trade 1847 - 1878 , Chinese Materials Centre Asian Library Series No. 18, 1982; Judith M. Brown \& Rosemary Foot, Migration: The Asian Experience, The Macmillan Press Ltd. London, 1994; Sun, Wangning, Leaving China: Media, Migration, and Transnational Imagination, Rowman \& Littlefield Publishers, Inc., Maryland, the USA, 2001, T.P.Buggy, Chinese Immigration and the Emergence of an Australian Image of China 1848-1861, the thesis of Master of Arts Macquarie University, 1978; Wang, Gungwu, Don't Leave Home: Migration and The Chinese, Times Academic Press, Singapore, 2001; Wang, Sing-wu The Organization of Chinese Emigration 1848-1888 with special reference to Chinese Emigration to Australia, Chinese Materials Centre Inc. San Francisco, 1978

${ }^{22}$ Committee of Exit and Entry Administration under Chinese Association of Police, (ed), The Collection of Papers on the Control of Exit and Entry (III) (Churujing Guanli Lunwenxuan (san)), Interior Published within Public Security Organs (Gongan Jiguan Neibu Faxing), the Publishing House of Qunzhong, Beijing China, 2001; Committee of Exit and Entry Administration under Chinese Association of Police, (ed), The Collection of Papers on the Control of Exit and Entry (II), (Churujing Guanli Lunwenxuan (er)), Interior Published within Public Security Organs (Gongan Jiguan Neibu Faxing), the Publishing House of Qunzhong, Beijing China, 1999; Department of Exit and Entry Administration, Beijing Public Security Bureau, the Kit of Exit and Entry (Churujing Xuzhi), the Publishing House of Renshi, Beijing, 2000; Ministry of Public Security of the PRC, The Textbook Control of Country Board and Administration of Exit and Entry (Bianfang Yu Churujing Guanli), the Publishing House of the University of People's Public Security, Beijing, 1999; Wong, Li, International Immigration Law and the Practices (Guoji Yimin Fa Lilun Yu Shijian), the Publishing House of Law, Beijing, China, 2001; Xiang, Dang, The Guide to the Law of Exit and Entry in China and Foreign Countries, (Zhongwai Churujing Falv Zhinan), the Publishing House of China University of People's Public Security, Beijing, 1998. 
gaps and deficiencies in the protection of the RLR in China, or that any gaps and deficiencies are not serious enough to require urgent reform of relevant laws. The reason for this is that the most-used research methodology is that of vertical, rather than horizontal, comparison. ${ }^{23}$ With vertical comparison, the main conclusions focus on achievements in the protection of the RLR in China - and tend to unrealistic optimism in regard to the protection of the RLR. An inclination towards vertical comparison may stem from a lack of full understanding of the protection of the RLR in international migration law and comparable States.

This underdeveloped research becomes particularly relevant as the importance of the "the partnership with the countries of origin" is increasingly acknowledged by receiving countries when devising their migration policies. ${ }^{24}$ It is time to accelerate research on the current status of the RLR, the issues that affect it, and possible solutions in the Chinese context. It is hoped that this thesis will fill the research gaps in the area of the RLR and Chinese migration law by conducting a comprehensive and critical legal analysis.

This research is significant in several respects. It will help to lay the legal groundwork for reform of Chinese regulatory framework governing the RLR, enhancing the effective protection of the RLR in China. Establishing this legal groundwork is an essential precondition for further reform of Chinese regulatory framework governing the RLR. Advancing a legislative reform strategy may turn a theoretically possible the RLR into a the RLR that is real in practice. The Chinese government, in pursuing policies of openness and reform, needs a more comprehensive legal framework as a reference to then support the reform and improve the effective protection of the RLR.

23 See "Simplified Exit-entry Rules Seen as Vital to China", 23 November 2001, The China Daily, http://wwwchinadaily.com.cn/en/doc/2001-11/23/content 9497htm (19/12/2003); "China to Give Its Citizens More Freedom in Foreign Currency Purchase", 04 Sep. 2003, The China Daily, http://wwwchinadaily.com.cn/en/doc/2003-09/04/content_26117htm (9/10/2003) and Information office of the State Council of The People's Republic of China, "Fifty Years of Progress in China's Human Rights (June 2000)", http://www.fmprc.gov.cn/eng/32282.html (20/05/2003)

24 Biao, X, "Emigration from China: A Sending Country Perspective”, International Migration, September 2003, vol. 41 , no. 3, pages 21-48 (28) 
It is hoped that this research will contribute to the development of a more effective regulatory framework, by advocating a regulatory model, and by making practical recommendations to afford effective protection of the RLR in China. It provides a more comprehensive series of recommendations to protect the RLR in China than undertaken to date.

It is also hoped this research will assist the international community to better understand the RLR in China, and promote a better understanding within China of the RLR as it operates internationally. The detailed discussions of the foundations of the RLR in international migration law, and in selected State practice may offer the Chinese government and academics an objective basis for understanding how the RLR can be legislatively implemented. No research of this kind has been previously undertaken by Chinese government or academics. This discussion also partially fills research gaps in the area in international migration law. 


\section{Chapter Two \\ The Foundations of the RLR}

\section{Introduction}

Although the RLR has been affirmed as a fundamental human right in the UDHR, the ICCPR and other international and regional conventions, ${ }^{25}$ violations of the RLR are common. By its very nature, the RLR has implications for neighbouring States; violations of the RLR may therefore have important implications for the security and order of neighbouring States. The issue of the RLR thus easily transcends the borders of the State of origin. ${ }^{26}$

It is therefore necessary to analyse both China-related factors and international-related factors when discussing the RLR in China. An analysis from an international perspective provides the international criteria and a point of reference for China when evaluating the actual situation and issues of the existing Chinese law governing exit and entry. It also provides experiences to consider when designing any reform plan to deal with the RLR in China.

To appreciate the RLR and its special role as a fundamental national and international human right and to appreciate the particular factors that drive it in China, one must first understand the foundations of the RLR. This Chapter seeks to explore the foundations of the RLR from the

${ }^{25}$ Article 5 (d) (ii) of International Convention on the Elimination of All Forms of Racial Discrimination 1966, Article 22 (3), (4) of American Convention on Human Rights 1969, Article VI of Inter-American Convention on Forced Disappearance of Persons 1994, Article 12 (2) of African Charter on Human and People's Rights 1981, Article 30 of European Convention on the Legal Status of Migrant Workers 1977, Article 2 of Protocol No.4 as amended by Protocol No. II, European Convention for the Protection of Human Rights and Fundamental Freedoms 1950, Article 45 (2) of Charter of Fundamental Rights of the European Union 2000.

${ }^{26}$ This point of view is supported by Antonio Cassese, who fully discussed common characters of RLR in "On the Universal Level" in Vasak, Karel and Liskofsky, Sidney, (ed), the Right to Leave and Return: Papers and Recommendations of the International Colloquium Held in Uppsala, Sweden, 19-21 June 1972, The American Jewish Committee, Arbour, the USA, 1976, pages 493-520; also by Russell, Sharon Stanton in "Migration and Development: Reframing the International Policy Agenda", http://www.migrationinformation.org/Feature/display.cfm/ID=126 (05/06/2003); also and Tiburcio, Carmen, “The Human Rights of Aliens under International and Comparative Law", Kluwer Law International, 2001, page 215. 
three aspects of philosophy, history, globalisation and international migration.

\subsection{Philosophical foundations}

All legal theories must contain elements of philosophy. ${ }^{27}$ The legal theory of the RLR is no exception. The nature of the RLR cannot be understood effectively without understanding the nature of migration. The analysis of the nature of the RLR to follow focuses on natural rights rooted in natural law, which have evolved into positive rights. This section ends by discussing the consequences of violating the RLR and justifications of the limits on the RLR.

\subsubsection{The definition of the RLR}

In basic terms, the RLR is the right of a person to be able to freely leave and return to a nation-State. In fact, the RLR has been integrated into international instruments. Before the ICCPR came into force, the RLR was most clearly proclaimed in the UDHR. Article 13 (2) of the UDHR provides that "Everyone has the right to leave any country, including his own, and to return to his country." the RLR is most clearly contained in the ICCPR provisions on the right to freedom of movement. This is the most comprehensive and well-established UN treaty on civil and political rights, and has yielded the lion's share of UN jurisprudence in this area. ${ }^{28}$ The ICCPR also provides for applicable limits on the RLR that are not stated in the UDHR. Article 12 (2) (3) (4) of the ICCPR State that:

(2) Everyone shall be free to leave any country, including his own.

(3) The above-mentioned rights shall not be subject to any restrictions except those which are provided by law, are necessary to protect national security, public order (ordre public), public health or morals or the rights and freedoms of others, and are consistent with the other recognized in the present Covenant.

(4) No one shall be arbitrarily deprived of the right to enter his own country.

Article 5 (d) of the International Convention on the Elimination of All Forms of Racial

\footnotetext{
27 . Friedmann thought "all systematic thinking about legal theory is linked at one end with philosophy and, at the other end, with political theory.” See Friedmann, W., Legal Theory, Law Publishers, London, 1944, page 3.

28 Joseph, Sarah and Sehultz, Jenny et al, The International Covenant on Civil and Political Rights: Cases, Materials, and Commentary, Oxford University Press, New York, 2000, page 4.
} 
Discrimination 1965 (CERD) stresses that States parties are duty-bound to prohibit and eliminate racial discrimination in all its forms and to guarantee the rights of everyone without distinction as to race, colour, or national or ethic origin, to equality before the law, notably in the enjoyment of the RLR.

Jose Ingles, ${ }^{29}$ Hurst Hannum, ${ }^{30}$ Richard Plender ${ }^{31}$ and Warren Freedman ${ }^{32}$ regarded the above-mentioned provisions as a statement of the RLR. Later attempts of the international community to codify the RLR have been unsuccessful. While Draft Principles on Freedom and Non-Discrimination in respect of the Rights of Everyone to Leave Any Country, including His Own, and to Return to His Country 1963 (1963 UN Draft Principles on the RLR), Declaration on the Right to Leave and the Right to Return 1972 (1972 Uppsala Declaration on the RLR) and Strasbourg Declaration on the Right to Leave and Return 1986 (1986 Strasbourg Declaration on the RLR) have been accepted as the most known specific international instruments in this area, these regulations have not developed into a unified codification of the RLR. The following statement regarding the RLR, from Article 1 of the 1986 Strasbourg Declaration on the RLR, must be borne in mind.

Everyone has the right to leave any country, including one's own, temporarily or permanently, and to enter one's own country, without distinction as to race, colour, sex, language, religion, political or other opinion, national or social origin, property, birth, marriage, age (except for unemancipated minors independently of their parents), or other status.

With the development of evolving jurisprudence of the RLR, the RLR may be defined as the right of the person to leave any country and return to one's country without the discrimination and according to one's own will.

${ }^{29}$ Ingles, Jose D, Study of Discrimination in Respect of the Right of Everyone to Leave any country, including His Own, and to Return to His Country: Special Repporteur of the Sub-commission on Prevention of Discrimination and Protection of Minorities, United Nations Publication Sales No.: 64. XIV. 2, New York, 1963, pages 9-12.

${ }^{30}$ Hannum, Hurst, The RLR in International Law and Practice, Martinus Nijhoff Publishers, Dordrecht, the Netherlands, 1987, page 20.

31 Plender, Richard, International Migration Law, Revised. $2^{\text {nd }}$ ed., Martinus Nijhoff Publishers Dordrecht, the Netherlands, 1988, pages 133 and 96.

${ }^{32}$ Freedman, Warren, The Right to Travel: A Right or A Privilege? Work Paper of Sao Paulo Conference on the Law of the World, the World Peace Through Law Centre, Washington, the USA, 1981, page 1. 
the RLR can be variously classified by different criteria. According to general purpose, the RLR can be classified as the right to leave, and right to return. Based on the general purpose and the subject the RLR may be classified into the right of a national to leave one's country, the right of a national to return to one's country and the right of a foreigner (including a stateless person) to leave the country. Pursuant to the period of leaving and returning, the RLR can be classified into the RLR permanently and the RLR temporarily. In relation to leaving a country, the RLR can also be classified as the right to seek asylum, the right not to be expelled, the right to travel abroad, the right to leave to study, the right to leave to unite with family members and the right to leave to do business. The right to return can be translated into the right to be admitted to one's own country.

\subsubsection{The nature of the migration}

The basis of migration is found in the nature of humanity. The focus of migration has gone from seeking a better natural environment in ancient times, into the pursuit of better economic, social, cultural and political environments in modern times. John Hosack contended in 1882 that, "the enterprising nature of man and his migratory habits would lead him frequently to wander beyond the limits of birthplace." 33 A similar view was expressed by the Organisation of Economic and Cooperation Development (OECD) in 1990, that:

\footnotetext{
Man is naturally mobile. In every epoch, in every part of the world and in every civilization, there has been migration. Migration must not therefore be regarded as abnormal phenomenon disturbing the natural order of things. The migrants are no exception because migration is a normal part of people's individual and collective lives. This is an essential truth that is little appreciated nowadays and of

which we should all become more fully aware. ${ }^{34}$
}

The United Nations (UN) declared in 2002, that "a fundamental characteristic of people is their movement from place to place." 35

\footnotetext{
${ }^{33}$ Hosack, John, On the Rise and Growth of the Law of Nations, as Established by General Usage and by Treaties, from the Earliest Time to the Treaty of Utrecht, Jas. Wade, Covent Garden, the UK, 1882, page 1.

${ }^{34}$ Laroque, Pierre, "Conclusionss' in The Future of Migration, the OECD, 1990, page 27.

35 Population Division Department of Economic and Social Affairs, United Nations Secretariat, International Migration Report 2002, ST/ESA/SER.A/220, the United Nations, New York, 2002, 62 pages, page 1.
} 
The RLR is originally derived from people's migratory nature. As with all living beings on earth, human's respond when they face an unbeneficial environment is to escape or quickly move. All people strive for longevity and better living conditions. One of the most important means to realise this basic purpose is to move from an unbeneficial environment to a beneficial one. All detailed causes, such as war, political pressure, employment, education and family union for migration stem from this basic need or purpose.

By nature each human person evaluates the costs and benefits of 'escaping' one environment for another. Different conditions and environments produce different demands and perceptions of escape. In 'pure' theory, it is unnecessary for the government or community to affect or intervene in a person's decision to migrate. Migration is wholly natural phenomenon and needs to be fully recognised as such - the human urge to migrate, where it exists, can be neither ignored nor oppressed. It is my own belief that humans will always have the orientation of migration, when a need presents itself, unless they are psychologically or physically incapable.

Human instinct, however, does not demand that migration should be allowed unconditionally or uncontrolled - people must live together peaceably to pursue their largest interests in the face of sustained challenges from an imperfect world. Peaceably cohabitation requires rules and migrants must follow rules of migration designed by the State on the basis of sovereignty.

\subsection{3 the RLR is a natural right rooted in natural law}

the RLR has evolved from a natural right to a positive right. The notable legal philosopher Maurice Cranston asserted that the RLR was the first and most fundamental of human rights, ${ }^{36}$ because it is from human nature or instinct and is the basis of other human rights. Depriving people of the RLR is to oppress human nature or instinct and inhibit human development. Hurst Hannum observed that the RLR gave meaning to other fundamental rights of speech, expression and communications. ${ }^{37}$ Warren Freedman summarized that the right to travel as a right as

\footnotetext{
${ }^{36}$ Cranston, Maurice, What are Human Rights, Taplinger Publishing Co., Inc. New York, 1973, page 31

${ }^{37}$ Hannum, Hurst, The right to Leave and Return in International Law and Practice, Martinus Nijhoff Publishers, Dordrecht, the Netherlands, 1987, page 4
} 
solemn and imperative as the right to breathe. It is indivisible from such other human rights as justice, equality, liberty and peace. ${ }^{38}$

The ancient Greeks most commonly contrasted their freedom to being bound or tied, and being, from this cause, unable to move. ${ }^{39}$ The freedom of human action based on the will and activity of the individual is the starting point of Samuel Pufendorf's natural law theory. ${ }^{40}$ Samuel Pufendorf's natural law obliges and entitles man to protect one's life, body, migration and all that belongs to him or her to the utmost within his or her power (self-preservation). Thomas Aquinas emphasised self-migration in the theory of natural law — that:

Man is said to be made to God's image, in so far as the image implies an intelligent being endowed with free-will and self-migration: now that we have treated of the exemplar, i.e., God, and of those things which come forth from the power of God in accordance with his will; it remains for us to treat of his image, i.e., man inasmuch as he too is the principle of his actions, as having free-will and control of his actions. ${ }^{41}$

To, John Stuart Mill, rights are "grounded on the permanent interests of a man as a progressive being." ${ }^{42}$ John Locke meticulously explored the motives for the formation of the social contract to protect individual liberty. ${ }^{43}$ Rousseau made the surrender of all natural rights of the individual to the State dependent on the fulfilment of two conditions: a political one and a social

38 Freedman, Warren, The Right to Travel: A Right or A Privilege? Work Paper of Sao Paulo Conference on the Law of the World, the World Peace Through Law Centre, Washington, the USA, 1981, page 1; See also Bradley, Catherine, What Do We Mean by Human Rights: Freedom of Movement, Franklin Watts, London, 2002, page 7. Bradley though that RLR is an important human right. Restricting people's ability to move around is a loss of freedom.

39 Pohlenz, Max, Freedom in Greek Life and Thought, Dordecht, Reidel, 1966, page 181

${ }^{40}$ Pufenddorf, Samuel, ed., On the Law of Nature and Nations, C.H. and W.A. Oldfather (Oxford, 1934), 1, 1, 8; The concept of natural law was firstly elabourated by Cicero, the foremost scholar of the Stoics of the Hellenistic period, who contended that "there is true law, right cause, in accordance with nature; it is unalterable and eternal."

41 Aquinas, Thomas, Summa Theologiae, 1-2, Prologue, Benzinger 1947.

42 Mill, John Stuart, “On Liberty”, in Warnack, May (ed). Mill, John Stuart, Utilitarianism, “On Liberty, ” Essay on Bentham, Fontana Press, London, 1962, 17 $7^{\text {th }}$ Impression, 1985, page 138

43 Neumann, Franz, The Rule of Law: Political Theory and the Legal System in Modern Society, Berg Publishers Ltd, Warwickshire, the UK, 1986, pages 117 and 118. Locke used the notion of the social contract to demonstrate the transfer of all natural rights to authority, but on the contrary, to justify government by majority and to show that governments hold their power in trust, with the duty to preserve the individual rights whose protection the individuals have entrusted to them. See Friedmann, W., Legal Theory, Law Publishers, London, 1944, page 123. 
one, to fulfil the two conditions, the individual will may and must be made powerless as against the will of the State. ${ }^{44}$ Immanuel Kant transformed the social contract, which Rousseau regards as an ideal to be realised in history, into a transcendental idea; that is to say, into a rational principle for the judgment of all compulsions. In Kant's theory nothing is left but the postulate that the State ought to realise the idea of right. He envisaged that freedom of thought, feeling and migration was the one sole, original, inborn right, belonging to every man by virtue of his humanity. ${ }^{45}$ As Margaret $\mathrm{Ng}$ commented, the concept of rights was quite clear in classical liberalism, and its strength lay in that clarity and in its nature. These rights may not be all that is needed to bring about an ideal society, but they are fundamental, axiomatic and inviolate. ${ }^{46}$

Emmer de Vattel wrote, "every man has a right to quit his country, in order to settle in any other, when by that step he does not expose the welfare of his country." ${ }^{47}$ William Blackstone stated it as the right "to go out of the realm for whatever cause he pleaseth, without obtaining the King's leave, providing he is under no injunction of staying home." ${ }^{48}$

The feature of the RLR as a natural right derived from nature law reveals the moral aspect of the RLR. Legal positivists mainly claim that law and morality are strictly separable. They assert that although legality and morality are of course combinable, they are likewise disjoinable. ${ }^{49}$ The theory of legal positivism is usually taken to be analytical, descriptive and explanatory. The point of legal positivism, on this view, is to provide an accurate account of law as it actually is,

\footnotetext{
44 Rousseau, Jean-Jacques, The Social Contract, Translated and introduced by Cranston, Maurice, Penguin Books Ltd, Harmondsworth, Middlesex, England, 1968, page 33.

${ }^{45}$ Quoted in Neumann, Franz, The Rule of Law: Political Theory and the Legal System in Modern Society, Berg Publishers Ltd, Warwickshire, the UK, 1986, page 144.

${ }^{46} \mathrm{Ng}$, Margaret, “Are rights Culture-bound?” in Davis, Michael C. (ed), Human Rights and Chinese Values: Legal, Philosophical, and Political Perspectives, Oxford University Press, New York, 1995, page 60.

${ }^{47}$ Emmer De Vattel, The Law of Nations or Principles of the Law of Nature Applied to the Conduct and Affairs of Nations and Sovereigns, bk. 1, Ch. 19, para. 220.

48 William Blackstone, Commentaries on the Laws of England I, bk. 1, ch. 1, 2, ch. 7

${ }^{49}$ Kramer, Matthew H., In Defence of Legal Positivism: Law without Trimmings, Oxford University Press, 1999, page 1
} 
rather than, as it ought to be..$^{50}$ By the very inclination of their argument, legal positivists opposed the RLR as a natural right.

John Austin asserted, "There are no laws merely creating rights. There are laws, it is true, which merely create duties: duties not correlating with correlating rights, and which, therefore may be styled absolute." ${ }^{, 51}$ Jeremy Bentham believed that the State existed for the greatest good of the greatest number. Bentham insisted that from real laws came real rights, but from imaginary laws, from laws of nature came imaginary rights; that natural right was simple nonsense. ${ }^{52} \mathrm{He}$ also believed that talking about natural rights was mischievous. Governments issuing declarations of the rights of man were merely making rhetorical utterances costing them nothing, instead of getting on with the real work of reform. Certain critics of natural rights, such as David Hume and Edmund Burke, shared his attitude. Both of them were conservatives who disliked talking about the rights of man because it inflamed the common people to revolutionary action. It led men to think they were entitled to have things, which they could not possibly have. In the words of Burke, the rights of man were mere "abstractions": the rights of Englishmen were realities a "positive recorded hereditary title to all that can be dear to the man and citizen." from Grotius to Kant is a scientific foundation for revolution. ${ }^{54}$

The question becomes, what is wrong with common people thinking of rights progress and revolution? The Bill of Rights enacted by the English Parliament after the Glorious Revolution

${ }^{50}$ Campbell, Tom, “The Point of Legal Positivism”, in Campbell, Tom D. (ed), The International Library of Essays in Law and Legal Theory Second Series: Legal Positivism, Dartmouth Publishing Company Ltd., Ashgate Publishing Limited, Aldershot Hants England and Brookfield Vermont the USA, 1999, page 323.

51 Austin, John, “A Positivist Conception of Law”, Feinberg, Joel and Gross, Hyman, (ed), Philosophy of Law, 3rd, Wadsworth Publishing Company, Belmont, the USA, 1986, page 33.

52 Quoted in Cranston, Maurice, "The Political and Philosophical Aspects of the Right to Leave and Return", Vasak, Karel and Liskofsky, Sidney, (ed), the Right to Leave and Return: Papers and Recommendations of the International Colloquium Held in Uppsala, Sweden, 19-21 June 1972, The American Jewish Committee, Arbour, the USA, 1976.

${ }^{53}$ Quoted in Cranston, Maurice, "The Political and Philosophical Aspects of the Right to Leave and to Return", Vasak, Karel and Liskofsky, Sidney, (ed), the Right to Leave and Return: Papers and Recommendations of the Internation Colloquium Held in Uppsala, Sweden, 19-21 June 1972, The American Jewish Committee, Arbour, the USA, 1976, page 23.

${ }^{54}$ Stahl, F. J., Uber die gegenwartigen Parterien in State und Kirche, Berlin, 1883, page 23. 
in 1689 raised the curtain of capitalist revolution. ${ }^{55}$ Another the Bill of Rights which was adopted by a representative convention in Virginia, the United States of America (USA) in 1776, proclaimed "all men are by nature equally free and independent, and have certain inherent rights." ${ }^{, 56}$ Similar words recur in the Declaration of Independence in 1776 and the United States Constitution 1787. Following the English and USA models closely, the French National Assembly adopted the Declaration of the Rights of Man and Citizen after the great revolution in 1789. It can be argued that the above revolutions exerted a plenarily positive influence on civilised society. ${ }^{57}$

Conversely, Germany did not follow English and American models. The later legal theory of national socialist Germany appears to have concentrated on the justification of absolute State supremacy and racial conception of law. ${ }^{58}$ In order to attain this end, it was necessary to abolish all systems of checks and balances in all spheres. The result was absolute obedience to the positive law imposed by the State, tempered by an expression of respects for the idea of right or natural law. ${ }^{59}$ Germany under Hitler promulgated numerous laws on the basis of Neo-Hegelian theories and Duguit positive legal theory. Unfortunately, most Westerners, including millions of deluded Germans, accepted the belief, and therefore required obedience. The consequence, it may be argued, was that it contributed to German provocation of two World Wars which

55 Stipp, John L., Dirrim, Allen, W. and Hollister, C. Warren, The Rise and Development of Western Civilization: 1660 to the Present, John Wiley \& Sons, Inc., New York, London and Sydney, 1967, page 43.

${ }^{56}$ Quoted in Cranston, Maurice, What are Human Rights?, Taplinger Publishing Co., Inc., New York, 1973, page 1.

57 Potter, David, Goldblatt, David, Kiloh, Margaret and Lewis, Paul (ed), Democratization, Blackwell Publishers Inc. Malden MA the USA, 1997, page 54; also see Willis, F. Roy, Western Civilization an Urban Perspective: Volume II from the 17th Century to the Contemporary Age, D. C. Heath and Company, Lexington, the USA, 1973, pages 586 and 603

58 The Nazis believed that the aim of life was to live in an "ecstasy" of power which some argue is one dictum of the philosophy of Friedrich Nietzsche. Pidder Lung, a pedagogue who tried his hand at organising Nazi philosophy, said that "Humanity is an abstraction which cannot be translated into practical life." Chamberlain elabourated the myth of racism in his Foundations of Nineteenth Century. He said that blood was the bearer of virtue; that the purest, most virtuous blood was Aryan; that the Germans were Aryan elite; that the worst corruptors of virtuous blood were the Jews. The implication was obvious: as the bearers of the highest culture, Germans were under solemn obligation to carry all Jews out of the coming Aryan dominated world. Quoted in Stipp, John L., Dirrim, Allen, W. and Hollister, C. Warren, The Rise and Development of Western Civilization: 1660 to the Present, John Wiley \& Sons, Inc., New York, London and Sydney, 1967, pages 539, 544 and 541.

59 Friedmann, W., Legal Theory, Law Publishers, London, 1944, pages 235-239. 
wrought such havoc on the rights of millions during the course of those conflicts over a period of 30 years. ${ }^{60}$

Another example can be found in communist regimes that accepted Marxist-influenced legal theory. In contrast to a natural rights view, in which law is seen as a constraint on the power of the State, law in the Union of Soviet Socialist Republics (USSR) was regarded as a means of enforcing and strengthening government authority. ${ }^{61}$ The underlying principle of law was that it should regulate society, rather than the actions of the government; it was designed to impose duties on the people rather than to protect their rights. This situation is greatly changing since 1990s. The rise of communist regimes eventually led to strict emigration controls that lasted up until the early of 1990s. The reunification of Soviet Jews with their families in Israel, for instance, was not permitted before mid-1960s. ${ }^{62}$

\subsection{4 the RLR translation from natural right to positive right}

Right comes necessarily into existence as soon as people live together. ${ }^{63}$ In its broad sense, the right is a formation of relationships of life, with a view to the attachment of freedom, which is realised and developed as the destination of the individual. In its narrowest sense, the right is used as the correlative of duty; and, to convey this meaning, the synonym 'claim' seems best. ${ }^{64}$ the RLR is more than the aspiration or assertion of the good - it is essentially a claim of entitlement founded on a moral order under natural law. Hugo Grotius characterised the right to

\footnotetext{
${ }^{60}$ Stipp, John L., Dirrim, Allen, W. and Hollister, C. Warren, The Rise and Development of Western Civilization: 1660 to the Present, John Wiley \& Sons, Inc., New York, London and Sydney, 1967, pages 449, 450 and 608.

${ }^{61}$ According to Marxism-Leninism, law originating with the State is an expression of the will of the ruling class, and the same causes gave rise to the appearance of private ownership and of antagonistic classes. Law protected the interests of the ruling classes and reflected only their will. The law retained its exploitative character and was adopted to new circumstance and requirements in order to serve the ruling classes. Quoted in Butler, W. E., Soviet Law $\left(2^{\text {nd }}\right.$ edition), Butterworth \& Co. (Publishers) Ltd., London, 1988, page 28.

${ }^{62}$ Population Division, Department of Economic and Social Affairs, United Nations Secretariat, International Migration from Countries with Economies in Transition: 1980-1999, ESA/P/WP.176, New York, 2002, 123 pages, page 12 .

${ }^{63}$ Hastie, W., Outlines of the Science of Jurisprudence: an Introduction to the Systematic Study of Law, Gaunt, Inc., Holmes Beach, the USA, 200, page 150.

${ }^{64}$ Wellman, Carl, A Theory of Rights: Persons Under Laws, Institutions, and Morals, Rowman \& Allanheld Publishers, Totowa, New Jersey, the USA, 1985, page 54.
} 
depart as the "most specific and unimpeachable axiom of the law of nations". ${ }^{65}$ the RLR creates the corresponding obligations not only from the State itself but from anyone that might try to stop the person from exercising their right. Anyone endowed with the RLR may apply for the remedies when his or her the RLR is violated.

We additionally need to admit that the positive law is the creation of people, and natural law, however, is not. The creation of law logically has a moral purpose, usually for the sake of the common good. ${ }^{66}$ The natural law itself requires that people exercise authority in political communities and that the authority fulfils one's moral functions by translating certain principles of natural law into positive law and reinforcing and backing up these principles with the threat of punishment for law breaking. A morally valid authority, in a sense, thus derives positive law from natural law; or translates natural principles of justice and political morality into rules and principles of positive law. ${ }^{67}$

Among the achievements of recent analytical jurisprudence is its virtual elimination of false opposition between natural law theory and legal positivism. Theorists of natural law such as John Finnis and legal positivists such as Neil MacCormick have developed refined understandings of relationships between law and morality, in the light of which it no longer makes sense to suppose that a commitment to legal positivism logically excludes belief in natural law. ${ }^{68}$

H. L. A. Hart argued that statutes might be a mere legal shell and demand by their express terms to be filled out with the aid of moral principles. No positivist could deny that the stability of

\footnotetext{
${ }^{65}$ Quoted in Plender, Richard, International Migration Law, Revised 2nd ed, Martinus Nijhoff Publishers, Dordrecht, the Netherlands, 1988, page 96.

${ }^{66}$ According to Aquinas, "we can only accept the saying that the ruler's will is law, on the proviso that the ruler's will is ruled by cause; otherwise a ruler's will is more like lawlessness." See Aquinas, Summa, 1a2ae, 90.1, Quoted in Hunter, Ian, and Saunders David, "Introduction", in Hunter, Ian, and Saunders, David (ed), Natural Law and Civil Sovereignty: Moral Right and State Authority in Early Modern Political Thought, Palgrave Macmillan, New York, 2002, page 2 .

${ }^{67}$ George, Robert P., In Defence of Natural Law, Clarendon Press, London, 1999, page 107.

${ }^{68}$ George, Robert P., In Defence of Natural Law, Clarendon Press, London, 1999, page 108.
} 
legal systems depends in part upon such types of correspondence with morals. ${ }^{69}$ Philosophically and historically the RLR was thus conceived to exist before the State, and the State developed as the means to its realisation. Given the widely accepted influence of morality on law, modern civilisation translated the RLR from natural rights to positive rights, serving as a limit of the power of the State.

Human society develops well if positive rights are more consistent with natural rights, and if they are otherwise, society lacks both stability and order. As far as the RLR is concerned, it is the fact that the RLR is a right provided in positive way only late in the evolution of States. The State has an obligation to preserve itself and its resources including human resources, therefore the State has a duty to develop the regulatory regime of the RLR, as it deems necessary. The more effectively realised the RLR, the more developed human society might be in the area of the reallocation of natural and human resources, and the more positive the change of attitudes to and quality of life, thus affecting human and social evolution.

Human rights are a 20th century name for what has been traditional known as natural rights or, in a more exhilarating phrase, the rights of man. ${ }^{70}$ Human rights are not rights which derive from a particular station, they are rights which belong to individuals simply because they are human. ${ }^{71}$ In Kent Ann's opinion, human rights embrace three generations of rights, which are civil and political rights as the first generation of human rights, economic and social rights, as the second generation of human rights, and the third generation being group rights. ${ }^{72}$ As one right reaffirmed in the ICCPR, the RLR is usually regarded as one of the civil and political rights. Civil and political rights may be understood as conferring "rights of immunity upon the individual, as requiring non-interference from others and as not normally dependent upon

${ }^{69}$ Hart, H. L. A., The Concept of Law, Oxford University Press, London, 1961, pages 199 and 200.

${ }^{70}$ Cranston, Maurice, What are Human Rights, Taplinger Publishing Co., Inc. New York, 1973, page 1.

71 The Right of Man, London, 1944, page 37.

72 Kent, Ann, Human Rights in the People's Republic of China, Discussion Paper No.3, 1989-90, Legislative Research Service, the Parliament of the Commonwealth of Australia. 
general social conditions." ${ }^{, 73}$ Lester B. Orfield thought in 1965 that the Charter of the United Nations, the UDHR and the proposed Covenant on Human Rights showed the recent trend had been to extend the scope of international law to cover matters of interest to the individual. ${ }^{74}$

In practice 152 countries had ratified the ICCPR up until to June $2004,{ }^{75}$ and therefore recognised the RLR as a fundamental human right. Most ratifying States have translated 'paper' the RLR into real the RLR, few have yet to do so. ${ }^{76}$ Hurst Hannum has reminded us that:

\begin{abstract}
Whatever theory one adopts to explain the original source of the RLR, they now have acquired the status of positive law through the widespread acceptance of the international covenants and numerous other international agreements. ${ }^{77}$
\end{abstract}

This international practice and acceptance has consolidated the RLR as part of customary international law. The party States to the ICCPR thus accepted the international obligations under the ICCPR to respect the RLR in domestic law. The non-party Staes to the ICCPR must salute the university of the RLR in domestic law. In this context, we call the RLR a positive right. Admitting the RLR as a positive right is mainly to describe the wide legal recognition in the world, rather than to implicitly accept the utilitarian, or to deny the nature of the RLR as a natural right.

\title{
2.1.5 Consequences of violating the RLR
}

It may be that the effect of barring the RLR can have consequences far more serious than the

73 Kamenka, Eugene, "Human Rights, Peoples' Rights”, in Bulletin of the Australian Society of Legal Philosophy, vol. 9, No. 33, June 1985, page 157.

74 Orfield, Lester B. and Re, Edward D., Cases and Materials on International Law, Revised Edition, The Bobbs-Merrill Company, Inc., Indianapolis, Kansas City and New York, 1965, page 178.

75 International Services for Human Rights, "The Ratification Status of the Main Human Rights Treaties", ishr-06-2004， http://ww.ishr.ch/About\%20UN/Ratification/Ratification\%20-\%20Human\%20Rights\%20treaties.htm $(18 / 05 / 2003)$.

${ }^{76}$ Being a member of the ICCPR, Egypt however provided an illustration of the restrictions on RLR of resident of Palestinians. See Human Rights Watch, Human Rights Watch Policy on the Right to Return: Relevant Background: Treatment and Rights in Arab Host States, https://nadaily.com/cgi/bin/nph/proxyb.cgi/010000A/http/www.hrw.org/// (05/07/2003).

${ }^{77}$ Hannum, Hurst, The right to Leave and Return in International Law and Practice, Martinus Nijhoff Publishers, Dordrecht, the Netherlands, 1987, page 5. 
actual restrictions on the RLR. Restricting emigrants, even when their numbers are only few, creates the general feeling for people of being shut within their own territories. A country seems smaller as soon as individuals are forbidden to leave it, and the desire to leave becomes more urgent. The feeling in the breasts of a whole nation that they are being pent in is perhaps a greater source of danger than the strictures of the lands in which they dwell. Restricting people's ability to move around is a loss of freedom. Someone who is prevented from travelling or is unable to choose where to live, for no good cause, is being denied his or her human rights. ${ }^{78}$

Without freedom of human migration, or the freedom of movement of knowledge and goods, other inherent freedoms and human rights cannot be realised completely. In the words of one international instrument, the denial of the RLR is "the cause of widespread human suffering, a source of international tensions, and an object of international concern." ${ }^{, 79}$ The protection of the RLR is said elsewhere to be essential for "the effective enjoyment of other human rights and fundamental freedoms, and promotes mutual understanding and co-operation among the peoples of the world." $" 80$

\subsubsection{Justification of the limits on the RLR}

If the freedom of individuals may truly exist, it has to be rational, and that means it must maintain itself within the limits of human nature. In practice, there are certain fundamental rights, which cannot be alienated even the Constitution permits amendment. ${ }^{81}$ The idea of fundamental rights including the RLR contains the demand for justice on the one hand, and the demand for the satisfaction of vital human and State needs in the various spheres of social life

\footnotetext{
${ }^{78}$ Bradley, Catherine, What Do We Mean by Human Rights: Freedom of Movement, Franklin Watts, London, 2002, page 7.

79 Preamble paragraph 5, Strasbourg Declaration on the Right to Leave and Return, adopted by Experts on the Right to Leave and Return on 26 November 1986.

${ }^{80}$ Preamble paragraph 3, Declaration on the Right to Leave and the Right to Return, adopted by the Uppsala Colloquium, Uppsala, Sweden, on 21 June 1972.

${ }^{81}$ Haines, C. Groves, The Revival of Natural Law Concepts, Harvard, 1930, page 336; and Willoughby, W. W., The Constitution Law of the USA, 2nd edition, vol. I, page 598.
} 
on the other. ${ }^{82}$ In response to the above spirit, almost all current international instruments and national laws recognise the principle of freedom and equity in everyone's dignity and rights. ${ }^{83}$ These international instruments meanwhile recognise the limits on the RLR to harmonise the possible conflict of every individual's interests.

\subsection{Historical foundations}

Given the legal basis of the RLR, the history of the RLR is inextricably linked with the history of the laws governing it. The basis of those laws will be dealt with first. The historical development of the laws governing the RLR will be then described in an annalistic style. As passport laws and international instruments related to the RLR play an important role in the historical development of the laws governing the RLR, they will also be described. The factors driving the RLR will be finally analysed from the perspective of the economics and politics.

\subsubsection{The basis of the laws governing the RLR}

The sovereignty of States forms the basis of the laws governing the RLR. While retaining the character of the RLR as a fundamental human right, each State also has the sovereign right to regulate the RLR in accordance with its own laws. Each State establishes its own legal system to distinguish citizens from foreigners, for border controls to inspect people who wish to enter, and to implement policies that affect the settlement and integration of non-citizens.

The sovereignty of the State is derived from the allegiance of its subjects to the State. In feudal terms it existed in that all persons born within the power or protection of the Crown owed natural allegiance to the King, and were natural-born subjects of the realm, while all who were born out of the allegiance or protection of the King, were aliens born, and remain aliens unless

\footnotetext{
82 Orkheimer, Max, Zum Rationlismusstreit in der gegenwartigen Philosophie, Zeitcschrift fur Soziaforschung, 1934, p1ff; Mill, John Stuart, “The danger of asking why?”, Dissertation and Discussions, vol.I, 3rd edition, page 332.

83 Article 29 of the UDHR promulgated that "in the exercise of his right and freedoms, every one shall be subject only to such limits as are determined by law solely for the purpose of securing due recognition and respect for the rights and freedoms of others and of meeting the just requirements of morality, public order and the general welfare in a democratic society."
} 
they are subsequently made denizens or naturalised. ${ }^{84}$ Blackstone described the natural allegiance in these terms:

A debt of gratitude which cannot be forfeited, cancelled or altered by any change of time, place or circumstance, nor by anything but the united concurrence of the legislature. An Englishman who removes to France or to China owes the same allegiance to the King of England there as at home, and twenty years hence as well as now [...] Natural allegiance was intrinsic and primitive and antecedent to the other. [...] indeed, the natural-born subject of one prince, to whom he owes allegiance, may be entangled by subjecting himself absolutely to another; but it is his own act that brings him into these straits and difficulties, of owing service to two masters; and it is uncauseable that, by such voluntary act of his own, he should be able at pleasure to unloose those bonds of by which he is connected to his natural prince. ${ }^{85}$

The term 'subject' was brushed aside as a feudal term, and replaced with the term 'citizen' in countries with democratic constitutions. ${ }^{86} \mathrm{He}$ who before was a 'subject of King' is now a 'citizen of the State' ${ }^{87}$ Citizenship is conceived of as a territorially determined relationship between subjects and sovereign, by which the subject is tied to one's sovereign. ${ }^{88}$ There are no essential distinctions between nationality and citizenship, the former is a norm of international law, and the latter is a norm of domestic law. Since the 18th century, the concept of human rights has become an important argument in the campaign to obtain freedom for the individual in relation to the State. ${ }^{89}$ The Nottebohm case [1955] ICJ Reports 4 support it as well.

The regulation of international law since the end of Second World War has expanded to include individuals and non-governmental organisations. The idea of membership of a national

${ }^{84}$ Henriques, H. S. Q., The Law of Aliens and Naturalization including the Text of the Aliens Act, 1905, Butterworth \& Co., London, 1906, page 29.

${ }^{85}$ Blackstone, Volume 1, pages 369 and 370

${ }^{86}$ Koessler, “ "subject”, "Citizen". "National” and "Permanent Allegiance”“, in Yale Law Journal, 1946-1947, p58-76, page 59.

${ }^{87}$ Quoted in Henriques, H. S. Q., The Law of Aliens and Naturalization including the Text of the Aliens Act, 1905, Butterworth \& Co., London, 1906 page 29 in State v. Manuel (1838) Dev. \& Bat. 20, pages 24-26; Minor v. Happersett (1874) 21 Wall. 162, page 166.

"Weis, P., Nationality and Statelessness in International Law, Sijthoff \& Noordhodd International Publishers B. V., Alphen aan den Rijn, the Netherlands, 1979, page 4.

89 Jagerskiold, Stig A. F., "Historical Aspect of the Right to Leave and Return", in Vasak, Karel and Liskofsky, Sidney, (ed), the Right to Leave and Return: Papers and Recommendations of the International Colloquium Held in Uppsala, Sweden, 19-21 June 1972, The American Jewish Committee, Arbour, the USA, 1976, page 3. 
community, subject to a specific sovereign authority, has begun to lose force. In the sphere of international relations at least a partial limit of the sovereign rights was imposed on each State. People have become more independent and free from the State than ever. The regulation of the RLR is therefore not only an attribute of the sovereignty, but also an issue with important international implications for States. While this is the case links of allegiance between individuals and States still exist, because allegiance continues to be intrinsic and primitive and one is antecedent to the other. The independence and freedom gained are not enough to be divorced from the sovereignty. The sovereignty of States remains a dominant theme in the relationship between the citizen and the State.

\subsubsection{The historical development of the laws governing the RLR}

It was only in the early 20th century that the system of passports and visas developed to regulate the RLR. ${ }^{90}$ Practical prohibitions and limits on the RLR existed and were serious prior to that time and were gradually relaxed in the 20th century. Since the emergence of the modern idea of the passport it has become the major instrument governing the RLR. With the establishment of international and regional organisations such as the UN and European Union (EU), the RLR has become universally recognised at a regional and world level. During the process of universal recognition, international and regional instruments governing the RLR play an increasingly important role.

\subsubsection{Laws governing the RLR in ancient times}

Ancient societies did not impose prohibitions and limits on the leaving and returning of subjects by law, while the slaves, bondmen, serfs and peasants of those societies were not considered subjects or complete subjects. In other words, the nobility and free townspeople were given the exclusive privilege of leaving and returning, subject to the will of the King. ${ }^{91}$

\footnotetext{
90 Martin, Philip and Widgren, Jonas, International Migration: Facing the Challenge, Population Reference Bureau, Wahington D.C., 2002, 39 pages, pages 3-4.

91 The privilege is the foundation of slave and feudal societies and its chief curse. See Stipp, John L., Dirrim, Allen, W. and Hollister, C. Warren, The Rise and Development of Western Civilization: 1660 to the Present, John Wiley \& Sons, Inc., New York, London and Sydney, 1967, page 119.
} 
People in remote regions, such as nomads, often moved from deserts and steppes of Asia and Africa to the vast reaches of the Pacific and Indian Oceans. The extent of migration depended on the spirit of adventure and ability of the relevant population, alongside the practical requirements of trade and agriculture. Some examples of decisive mass movement include the Hebrew exodus from Egypt, the settlement of Eastern Europe, and colonisation of the Americas. ${ }^{92}$ Vinogradoff has pointed out that the country now called Hellas was not regularly settled before. The people were migratory, and readily left their homes whenever numbers overpowered them. They could obtain a bare subsistence anywhere and they were always ready to emigrate. ${ }^{93}$ From the very earliest times foreigners in large numbers have entered England. ${ }^{94}$

Something akin to the RLR was legally recognised as early as 1215 in the Magna Carta. ${ }^{95}$ Article 41 guaranteed to merchants "safe and secure exit". Article 42 proclaimed:

It shall be lawful to any person, for the future, to go out of our Kingdom, and to return, safely and securely, by land or water, saving his allegiance to us, unless it be in time of war, for some short space, for the common good of the Kingdom: excepting prisoners and outlaws, according to the law of the land, and of the people of the nation at war against us, and Merchants who shall be treated as it is said above. ${ }^{96}$

These regulations developed in succeeding centuries a common law writ of ne exeat regno. ${ }^{97}$

92 Ingles, Jose D, Study of Discrimination in Respect of The Right of Everyone to Leave any country, including His Own, and to Return to His Country: Special Rapporteur of the Sub-commission on Prevention of Discrimination and Protection of Minorities, United Nations Publication Sales No.: 64. XIV. 2 New York, 1963, page 1

93 Vinogradoff, Paul, Outlines of Historical Jurisprudence, Volume Two, The Jurisprudence of the Greek City, Oxford University Press, Oxford, the UK, 1922, pages 1-2.

94 Henriques, H. S. Q., The Law of Aliens and Naturalization including the Text of the Aliens Act, 1905, Butterworth \& Co., London, 1906, page 2.

95 The Magna Carta was a worthy climax of the first stage of growth of English law. See Harding, Alan, A Social History of English Law, Penguin Books Ltd. England, 1966, pages 55-57

96 Article 42 in the version confirmed by King Edward I in 1297; 6 Halsbury's Statutes (3rd ed.) 401. See Sieghart, Paul, The International Law of Human Rights, Oxford University Press, New York, 1983, page 180

97 “...the King would command a man that go not beyond the seas or out of the realm without a license", by issuing a writ based upon information "that you design to go privately into foreign parts and intend to prosecute many things prejudicial to us --- . Many English King issued the writs on a number of occasions, mostly for political causes, but this royal prerogative gradually lost its importance and fell into desuetude, except as a restraint upon absconding debtors' Ingles, Jose D, Study of Discrimination in Respect of The Right of Everyone to Leave any country, including 
Chao JU-KUA, Ibn Batuta and Marco Polo enjoyed the comparative freedom to leave and return to their respective countries, as well as in entering and leaving the many kingdoms of Asia and the outlying islands through which they travelled in the Middle Ages. Francisco de Victoria said at the start of 16th century: "It was permissible from the beginning of the world for anyone to set forth and travel wheresoever he would." 98

The right to return to one's country was popularly recognised in ancient times. This can be partly proved by the record of perpetual exile being the only means of avoiding capital punishment in ancient Athens. ${ }^{99}$

Mercantile and military considerations led most States to view their slave populations as valuable commodities to be retained rather than permitted to leave, whereupon they could increase the prosperity of other States. ${ }^{100}$ They were bound to the cultivating land in ancient Europe, ancient Asia and America of the 19th century. According to the law of colonial Virginia (1705), Kentucky (1798), and the Louisiana Territory (1806), the slaves were regarded part of the land. ${ }^{101}$ In ancient Europe, the nobility and free townspeople could move between regions as they pleased. ${ }^{102}$ In ancient China, only merchants could be permitted to go abroad, and if people who went abroad were not merchants, they would be given a flogging. ${ }^{103}$ Given the fact

His Own, and to Return to His Country: Special Repporteur of the Sub-commission on Prevention of Discrimination and Protection of Minorities, United Nations Publication Sales No.: 64. XIV. 2 New York, 1963, page 3.

98 Quoted in Ingles, Jose D, Study of Discrimination in Respect of The Right of Everyone to Leave any country, including His Own, and to Return to His Country: Special Repporteur of the Sub-commission on Prevention of Discrimination and Protection of Minorities, United Nations Publication Sales No.: 64. XIV. 2 New York, 1963, page 2.

99 Vinogradoff, Paul, Outlines of Historical Jurisprudence, Volume Two, The Jurisprudence of the Greek City, Oxford University Press, Oxford, the UK, 1922, page 179.

${ }^{100}$ Hannum, Hurst, The right to Leave and Return in International Law and Practice, Martinus Nijhoff Publishers, Dordrecht, the Netherlands, 1987, page 4.

101 Friedman, Lawrence M., A History of American Law, Simon and Schuster, New York, 1973, page 197.

102 Quoted in Cranston, Maurice, "The Political and Philosophy Aspects of the Rights to Leave and Return", in Vasak, Karel and Liskofsky, Sidney, (ed), the Right to Leave and Return: Papers and Recommendations of the International Colloquium Held in Uppsala, Sweden, 19-21 June 1972, The American Jewish Committee, Arbour, the USA, 1976, page 29.

103 Merchants' freedom to travel abroad was protected by Commentaries of Law Codes the Tang Dynasty (618-907), Uniform Penal Code, the Song Dynasty (960-1279). The control of exit and entry in ancient China had been 
that slaves, bondmen, serfs and peasants were the overwhelming majority of the population in ancient times, ${ }^{104}$ it could be accepted that most people were not entitled to the RLR.

\subsubsection{Laws governing the RLR in modern and contemporary times}

the RLR in modern times, especially in contemporary times has become an entitlement for everyone, without distinction as to one's social status. Recognition of the RLR by States increased following the Second World War; and international instruments have also evinced that the recognition of the RLR is being gradually moved beyond the national borders.

Settlement Laws 1691 was refined to ease the labour mobility in Britain. ${ }^{105}$ Blackstone has pointed out that English citizens enjoyed an absolute the RLR in the second half of 18th century. ${ }^{106}$ Title I of French Constitution of 1791 guaranteed "the freedom of everyone to go, to stay, or to leave, without being halted or arrested unless in accordance with procedures established by the Constitution." The 1830s helped to establish the future shape of Australian society, during which time it was possible to freely immigrate. ${ }^{107}$

The US Supreme Court has given constitutional protection to the right to travel since $1823 .{ }^{108}$ The right to travel abroad is protected under the Fifth Amendment of The Constitution of the

regulated in some special regulations such as Guangzhou Regulations Governing Exit and Entry (Amendment) 1080 of Song Dynasty, and the Regulations of Further Governing Exit and Entry 1293 of Yuan Dynasty and the Rules of Exit and Entry 1314 of Yuan Dynasty (1206-1368). See Wong, Li, International Immigration Law and the Practices (Guoji Yiminfa Lilun Yu Shijian), the Publishing House of Law, Beijing, China, 2001, page 13.

104 Serfs under private landlords were about half of the population in Russian in 1767. See Stipp, John L., Dirrim, Allen, W. and Hollister, C. Warren, The Rise and Development of Western Civilization: 1660 to the Present, John Wiley \& Sons, Inc., New York, London and Sydney, 1967, page 118.

${ }^{105105} \mathrm{Yu}$, Shutong and Wen, Jia (ed), A New Chinese-English Law Dictionary (Xin Hanying Faxue Cidian), Publishing House of Law, Beijing, 1998, page 1263.

${ }^{106}$ Blackstone, The Great Charter and Charter of the Forest, 3rd edition, 1771, Quoted in Ingles, Jose D, Study of Discrimination in Respect of The Right of Everyone to Leave any country, including His Own, and to Return to His Country: Special Rapporteur of the Sub-commission on Prevention of Discrimination and Protection of Minorities, United Nations Publication Sales No.: 64. XIV. 2, New York, 1963.

107 Molony, John, History of Australia, Penguin Books Australia Ltd., Ringwood, Australia, 1987, page 61.

108 Freedman, Warren, The Right to Travel: A Right or A Privilege? Work Paper of Sao Paulo Conference on the Law of the World, the World Peace Through Law Centre, Washington, the USA, 1981, page 6. 
USA as an aspect of the 'liberty' of which an individual cannot be deprived save by due to process of law. ${ }^{109}$ The Indian Supreme Court has held that the right to travel abroad, though not specially provided for, is implied in the right to personal liberty of which a person may not be deprived according to a procedure established by law. ${ }^{110}$ Twenty-four countries have formally recognised the RLR in constitutional texts or laws and in 196112 countries recognised the RLR through judicial interpretation. ${ }^{111}$ According to the statistics of Richard Plender, up to 1988 the right to depart from a State's territory was recognised expressly in the constitutions of 44 States. $^{112}$

The international community recognised that the RLR as an equal and inalienable right of all members of the human family, and is based upon attributes of human personality, and not derived from one being a national of a particular State, in the UDHR, ${ }^{113}$ the ICCPR, ${ }^{114}$ the Protocol No. 4 of European Convention for the Protection of Human Rights and Fundamental Freedoms 1950 (EHR P4), ${ }^{115}$ American Convention on Human Rights 1969 (AMR), ${ }^{116}$ African Charter on Human and People's Rights 1981 (AFR), ${ }^{117}$ and Arab Charter on Human Rights 1994 and other international or regional human rights conventions. ${ }^{118}$ The number of States that had ratified the ICCPR was 35 in 1976, 85 in 1985 and increased to 148 in $2002^{119}$ and 152 in

\footnotetext{
109 Plender, Richard, International Migration Law, Revised 2nd ed, Martinus Nijhoff Publishers, Dordrecht, the Netherlands, 1988, page 102.

${ }^{110}$ Maneka Gandhi v. Union of India and another [1978] SCR 312; Satwant Singh Sawhney v. Ramarthnam et al. [1967] 3 SCR 525.

111 Ingles, Jose D, Study of Discrimination in Respect of The Right of Everyone to Leave any country, including His Own, and to Return to His Country: Special Rapporteur of the Sub-commission on Prevention of Discrimination and Protection of Minorities, United Nations Publication Sales No.: 64. XIV. 2 New York, 1963, page 4.

112 Plender, Richard, International Migration Law, Revised 2nd ed, Martinus Nijhoff Publishers, Dordrecht, the Netherlands, 1988, page 95-96.

113 Article 13 (2) of the UDHR.

114 Article 12 (2) (3) (4) of the ICCPR.

115 Article 2 of the EHR Protocol 4

116 Article 22 (3), (4) of the AMR

117 Article 12 (2) of the AFR

118 Article VI of Inter-American Convention on Forced Disappearance of Persons 1994, Article 30 of European Convention on the Legal Status of Migrant Workers 1977.

119 Joseph, Sarah and Sehultz, Jenny et ac, The National Covenant on Civil and Political Rights: Cases, Materials, and Commentary, Oxford University Press, New York, 2000, page 5
} 
2004. ${ }^{120}$ The States parties to above international conventions owe an international duty to give effect to relevant provisions of international conventions by protecting the RLR through domestic law and international cooperation.

\subsubsection{Historical development of laws governing passport}

A national must possess a passport or other travel documents if he or she wishes to leave or return to one's country. Without being entitled to the right to be issued with travel document, especially a passport, the RLR cannot be realised.

Historically, the RLR did not involve the modern document of a passport, for the simple reason that that there was no international traffic of travellers, so no need for laws to govern traffic. Possession of a passport was not generally a requirement for the crossing of national borders in Europe prior to 20th century. ${ }^{121}$ The growth of the Roman Empire and improvement in means of communication meant that international travel was more easily achieved, and occasionally a traveller could cover hundreds of miles for commercial purposes. ${ }^{122}$ In 1548, the term 'passport' was first used in by English statute, where it referred to a license given by a military authority to a soldier to go on furlough. ${ }^{123}$ In the 18 th and early 19th centuries, the passport was mainly issued to aliens by the territory in which the documents were effective. In the course of 19th century the practice of issuing passports to aliens for travel in the issuing country seems to have fallen into disuse.

The people in ancient China who intended to go abroad had to apply for a letter of approval from the local government. In the Han dynasty (206 B.C.-A.D. 220), the approval letter for

\footnotetext{
${ }^{120}$ International Services for Human Rights, “The Ratification Status of the Main Human Rights Treaties", ishr-06-2004, http: ww.ishr.ch http://ww.ishr.ch/About\%20UN/Ratification/Ratification\%20-\%20Human\%20Rights\%20treaties.htm (18/05/2003).

121 Weis, P., Nationality and Statelessness in International Law, 2nd revised edition, Sijthoff \& Noordhodd International Publishers B. V., Alphen aan den Rijn, the Netherlands, 1979, pages 222 - 223

122 Freedman, Warren, “The Right to Travel: A Right or A Privilege?" Work Paper of Sao Paulo Conference on the Law of the World, the World Peace Through Law Centre, Washington, the USA, 1981, page 7

${ }^{123}$ Sibley, "The Passport System", in Journal of the Society of Comparative Legislation (1906), pages 26-33, page 32
} 
businessmen was called "Chuan", for government officers it was "Jie". It was then named "Guoso" in the Tang dynasty (618-907), "Gongju” in the Song dynasty (960-1279), "Gongyan" in the Yuan dynasty (1206-1368) and "Wenyin" in the Ming dynasty (1368-1644). ${ }^{124}$

In 1905, Lord Alverstone CJ , in Rex v. Brailsford defined a passport as:

A document issued in the name of the Sovereign on the responsibility of a Minister of the Crown to a named individual, intended to be presented to the Governments of foreign nations and to be used for that individual's protection as a British subject in a foreign country, and it depends for its validity upon the fact that the Foreign office in an official document vouches the respectability of the person named. ${ }^{125}$

This definition illuminates the significance of the modern passport. Since the end of the First World War, it has been almost universally recognised that a passport is largely issued to the State's own nationals as an identity and travel document.

The League of Nations Passport Conference of 1926 reiterated the recommendation of 1920 Passport Conference for the abolition of exit visas. That recommendation has been accepted by a large number of States, however the process of achieving uniform international rules governing passports is a long way off. Daniel Turack has reminded us that:

Although the UN has convened an international meeting of experts on passport and a conference on international travel and tourism during which passports were widely discussed and concrete recommendations adopted, is has not yet prepared a compilation of the passport laws of its members and the member States of specialised agencies similar to the works produced on nationality. The fruit of such an undertaking would stimulate greater activity in an area deserving of independent research. ${ }^{126}$

\footnotetext{
124 "Above laws contain the provisions about the establishment of administrative organs, application for approval letter, inspection of exit and entry, restrictions on the people going abroad and staying period abroad, and punishment." Wong, Li, International Immigration Law and the Practices, the Publishing House of Law, Beijing, China, 2001, pages 13-15

125 [1905] 2 K. B. 730 at 745, Quoted in Turack, Daniel C., The Passport in International Law, Lexington Books, D.C. Health and Company, Toronto, Canada, 1972, page 16.

126 Turack, Daniel C., The Passport in International Law, Lexington Books, D.C. Health and Company, Toronto, Canada, 1972, page 33.
} 


\subsubsection{Historical development of international instruments related to the RLR}

Numerous conventions dealing with the RLR entered into force after the Second World War. The UN and regional organisations have made efforts to arrive at uniform rules governing the RLR, to avoid repeating the tragedy of the persecution and murder of six millions Jews' during the 1930s and 1940s.

In the words of a UN General Assembly representative from France, the UDHR represented "a world milestone in the long struggle for human rights",. ${ }^{127}$ Article 13 (2) of the UDHR affirmed that the RLR should be enjoyed fully and without discrimination. the RLR may in no case be exercised contrary to the purposes and principles of the UN.

The Convention Relating to the Status of Refugees 1951 (CSR) is the most important international instrument protecting refugees, Article 28 of which obligates States parties to issue travel documents to refugees in their territory, especially those unable to secure such documents from the country of their lawful residence, and to issue travel documents to Stateless persons lawfully staying in their territory.

Article 7 (3) of The Convention on the Reduction of Statelessness 1961 proclaimed that, "a national of a contracting State shall not lose his nationality, so as to become Stateless, on the ground of departure, residence abroad, and failure to register or on any similar ground." Article 9 further regulated that "a contracting State may not deprive any person or group of persons of their nationality on racial ethnic, religious or political grounds."

the RLR was formally protected in the ICCPR, which is the most important international covenant in this regard. Article 12 (2) provides the general circumstance of the RLR as being that "everyone shall be free to leave any country, including his own." Article 12 (3) detailed general restrictions on the RLR:

127 The Office of the High Commissioner for Human Rights, "The Universal Declaration of Human Rights: A Magna Carta for All Humanity”, www. Unhchr.ch/udhr/miscinfo/carta.htm (18/05/2003) 
The above-mentioned rights shall not be subject to any restrictions except those which are provided by law, are necessary to protect national security, public order (ordre public), public health or morals or the rights and freedoms of others, and are consistent with the other recognized in the present Covenant.

These restrictions were reaffirmed and cited in the conventions about the RLR to follow. Article 12 (4) stressed the right to return, as being that "No one shall be arbitrarily deprived of the right to enter his own country." Article 13 provides procedural rights against expulsion.

Article $5 \mathrm{~d}$ (ii) of the CERD regulated that in the enjoyment of the RLR, States parties undertake to prohibit and to eliminate racial discrimination in all its forms and to guarantee the right of everyone, without distinction as to race, colour, or national or ethnic origin, to equality before the law.

The Convention on the Rights of the Child 1989 (CRC) entered into force in 1990. It is an elaboration of human rights standards in respect of the child. It contains several provisions respecting and safeguarding the RLR of the child and one's parents. ${ }^{128}$

Guiding Principles on Internal Displacement 1997 were "noted" by the Commission on Human Rights and have been referred to in various General Assembly resolutions. Principle 15 provides that:

...internally displaced persons have (a) the right to seek safely in another part of the country; (b) the right to leave their country; (c) the right to seek asylum in another country; and (d) the right to be protected against forcible return to or resettlement in any place where their life, safety, liberty and/or heath would be at risk.

\footnotetext{
128 Article 10 of the Convention on the Rights of the Child 1989 provides "1. In accordance with the obligation of States Parties under Article 9, paragraph 1, applications by a child or his or her parents to enter or leave a State Party for the purpose of family reunification shall be dealt with by States Parties in a positive, humane and expeditious manner. States Parties shall further ensure that the submission of such a request shall entail no adverse consequences for the applicants and for the members of their family. 2. ...States Parties shall respect the right of the child and his or her parents to leave any country, including their own, and to enter their own country. The right to leave any country shall be subject only to such restrictions as are prescribed by law and which are necessary to protect the national security, public order (ordre public), public health or morals or the rights and freedoms of others and are consistent with the other rights recognized in the present Convention."
} 
The 1963 UN Draft Principles on the RLR were adopted by UN Sub-Commission on Prevention of Discrimination and Protection of Minorities (CPDPM) in 1963. The 1972 Uppsala Declaration on the RLR was adopted by the Uppsala Colloquium in 1972, and which contains the right to leave, the right to return, and addresses travel documents and general procedures for responding to violations.

The 1986 Strasbourg Declaration on the RLR was adopted by the Meeting of Experts on the RLR in 1986 and developed procedural safeguards of the RLR. The above instruments are only three international instruments focused on the RLR. They offer the most comprehensive and detailed regulations up to now in this regard. Despite their non-binding character they are of significant importance in the development of laws governing the RLR.

In 1980s and 1990s some international instruments reaffirmed the RLR. They are the Declaration on the Human Rights of Individuals Who are not Nationals of the Country in Which They Live 1985, ${ }^{129}$ the International Convention on the Protection of the Rights of All Migrant Workers and Member of Their Family 1990, ${ }^{130}$ the Declaration on the Protection of All Persons from Enforced Disappearance 1992, ${ }^{131}$ the Draft United Nations Declaration on the Rights of

\footnotetext{
129 The Declaration on the Human Rights of Individuals Who are not Nationals of the Country in Which They Live 1985 was adopted by General Assembly Resolution 40/144 without a vote in December 1985. Article 5 (2) (a) sets forth that aliens shall enjoy "the right to leave the country" subject to "such restrictions as are prescribed by law and which are necessary in a democratic society to protect national security, public safety, public order, public health or morals or the rights and freedoms of others, and which are consistent with the other rights recognized in the relevant international instruments and those set forth in this declaration."

${ }^{130}$ International Convention on the Protection of the Rights of All Migrant Workers and Member of Their Family 1990 was adopted without a vote by General Assembly Resolution 45/158 of December 1990. It constitutes an elabouration of human rights standards, and consequently migrant workers will remain protected by human rights standards even in States, which do not become parties to the Convention. Article 8 provides "Migrant workers and members of their family shall be free to leave any State including their State of origin. This right shall not be subject to any restrictions except those that are provided by law, are necessary to protect national security, public order (ordre public), public health or morals or the rights and freedoms of others and are consistent with the other rights recognized in the present part of the Convention. Migrant workers and members of their families shall have the right at any time to enter and remain their State of origin."

131 The Declaration on the Protection of All Persons from Enforced Disappearance 1992 is annexed to General Assembly Resolution 47/133, adopted without a vote on December 1992. Article 8 regulates that "No State shall expel, return (refouler) or extradite a person to another State where there are substantial grounds to believe that he
} 
indigenous Peoples 1994, ${ }^{132}$ the Declaration on the Right and Responsibility of Individuals, Groups and Organs of Society to Promote and Protect Universally Recognised Human Rights and Fundamental Freedoms 1998, ${ }^{133}$ and Nationality of Natural Persons in Relation to Succession States 2000. ${ }^{134}$ The above international instruments are not effective yet.

As of June 2004, 104 of the 152 States parties to the ICCPR were also parties to the First Optional Protocol to the ICCPR. ${ }^{135}$ Under the optional protocol, individuals of ratified party States can claim any of the rights enumerated in the ICCPR, including the RLR. They can submit communications to the Human Rights Committee (HRC) when all domestic remedies have been exhausted. The HRC has made some notable comments regarding the RLR, such as

would be in danger of enforced disappearance. For the purpose of determining whether there are such grounds, the competent authorities shall take into account all relevant considerations including, where applicable or mass violations of Human rights."

132 Draft United Nations Declaration on the Rights of Indigenous Peoples 1994 was duly submitted to the Commission on Human Rights and the Secretary-General in 1994. Article 1 regulates that "Indigenous peoples have the right to the full and effective enjoyment of all human rights and fundamental recognised under the Charter of the United Nations, the Universal Declaration of Human Rights and international human rights law.” Article 10 regulates that "Indigenous peoples shall not be forcibly removed form their lands or territories. No relocation shall take place without the free and informed consent of the indigenous peoples concerned and after agreement on just and fair compensation and, where possible, with the option of return."

${ }^{133}$ The Declaration on the Right and Responsibility of Individuals, Groups and Organs of Society to Promote and protect Universally Recognized Human Rights and Fundamental Freedoms 1998 was adopted by the General Assembly in Resolution on December 1998, without a vote. Article 1 provides that "Everyone has the right, individually and in association with others, to promote and to strive for the protection and realization of human rights and fundamental freedoms at the national and international levels." Article 2 Paragraph 1 provides that "Each State has a prime responsibility and duty to protect, promote and implement all human rights and fundamental freedoms, inter alia, by adopting such steps as may be necessary to create all conditions necessary in the social, economic, political and other fields, as well as the legal guarantees required to ensure that all persons under its jurisdiction, individually and in association with others, are able to enjoy all those rights and freedoms in practice."

134 Nationality of Natural Persons in Relation to Succession States 2000 was annexed to General Assembly Resolution in December 2000, adopted without a vote. Article 1 provides that "Every individual who, on the date of the succession of States, had the nationality of the predecessor State, irrespective of the mode of acquisition of that nationality, has the right to the nationality of at least one of the State concerned, in accordance with the present Articles." Paragraph 2, Article 14 provides that "A State concerned shall take all necessary to allow persons concerned who, because of events connected with the succession of States, were forced to leave their habitual residence on its territory to return thereto."

135 International Services for Human Rights, "The Ratification Status of the Main Human Rights Treaties”, ishr-06-2004, http://ww.ishr.ch/About\%20UN/Ratification/Ratification\%20-\%20Human\%20Rights\%20treaties.htm $(18 / 05 / 2003)$. 
Vidal Martins v. Uruguay, ${ }^{136}$ Stewart v. Canada, ${ }^{137}$ and Peltonen v. Finland. ${ }^{138}$

Since 1948, Europe has made the most significant inroads into advancing human rights. Doubtless, the achievements are linked with the origin of the human rights including the RLR in Europe. the RLR is emphasised in the EHR, ${ }^{139}$ the Final Act of the Helsinki Conference $1975,{ }^{140}$,

${ }^{136}$ In Sophie Vidal Martins v. Uruguay Communication No. R.13/57, Sophie Vidal Martins was refused the issuance of a passport without any justification therefor, thereby preventing her from leaving any country including her own. Accordingly, the Committee is of the view that the State party is under an obligation pursuant to article 2 (3) of the Covenant to provide Sophie Vidal Martins with effective remedies which would give her the possibility of enjoying the rights under article 12 of the Covenant, including a passport valid for travel abroad. See http://wwwserver.law.wits.ac.za/humanrts/undocs/session37/13-57.htm (07/07/2005)

137 In Stewart v Canada (538/93), UNHRC commented that long-term resident could not regard country as his own, and long-term resident could still be deported. The Committee mainly held: (1) that the phrase 'his own country' in Art 12(4) applied to individuals who were nationals and to certain categories of individuals who were not nationals in a formal sense but, because of their special ties to or claims in relation to a given country, were not 'aliens' within the meaning of Art 13 even though they might be considered as such for other purposes; (2) that the country to which a person has immigrated did not become 'his own country' when it facilitated acquiring its nationality but that person refrained from doing so either by choice or by committing acts which thereby disqualified him. See http://www.worldlii.org/int/cases/IIHRL/1996/84.html (07/07/2005)

138 In the Comments of UNHRC on Peltonen v. Finland 492/1992 (1994), HRC comments that it would not be justified to interpret paragraph 3 of article 12 as entitling a State party to deny a passport to a person if a passport would enable him to leave a country other than Finland because he avoids military service in Finland. Such an interpretation would allow the State party to use and abuse the refusal of a passport as a means of exerting pressure on a conscript, so as induce him to return to Finland and perform his military service and be disciplined for his non-appearance in the military call-ups. It is not necessary either for the protection of national security, public order or public morals to use the refusal of a passport for restrictions on a person's freedom to leave any country for such purposes. This would be entirely incompatible with the object and purpose of paragraph 3; I therefore am of the opinion that the State party has violated article 12, paragraph 2, by refusing a passport to the author, which is a prerequisite for the exercise of his freedom to leave any country. See http://wwwl.umn.edu/humanrts/undocs/html/vws492.htm (07/07/2005)

139 The European Convention for the Protection of Human Rights and Fundamental Freedoms 1950 entered into force in September 1953. It was the first comprehensive treaty in the world in this regard; it established the first international complaints procedure and the first international court for the determination of human rights matters; it remains the most judicially developed of all the human rights system. Following the entry into force of Protocol No. 11 in November 1998, the control machinery was substantially restructured. All alleged violations of human rights are referred directly to the court. Article 2 (2) (3) Protocol No. 4, as Amened by Protocol No. 11 provides that " 2. Everyone shall be free to leave any country, including his own. 3. No restrictions shall be placed on the exercise of these rights other than such as are in accordance with law and are necessary in a democratic society in the interests of national security or public safety, for the maintenance of ordre public, for the prevention of crime, for the protection of health or morals, or for the protection of the rights and freedoms of others." Article 3 and 4 provides that "3 (1) no one shall be expelled, by means either of an individual or a collective measure, form the territory of the State of 
the Document of the Copenhagen Meeting of the Second Conference on The Human Dimension of the CSCE 1990, ${ }^{141}$ the European Social Charter (Revised) $1996,{ }^{142}$ and the Charter of Fundamental Rights of the European Union 2000. ${ }^{143}$

America has generally followed the European model, and made encouraging achievements. Article VIII of the American Declaration of the Rights and Duties of Man 1948 States that "every person has the right $[\ldots]$ not to leave the State of which he is a national, except by his own will”. the RLR is formally guaranteed under Article 22 of American Convention on Human Rights 1969 (AMR) that provides for a Commission and a Court, and bears a general resemblance to the European Convention. ${ }^{144}$

which he is a national. (2) No one shall be deprived of the right to enter the territory of the State of which he is a national. 4. Collective expulsion of aliens is prohibited."

140 Conference on Security and Cooperation in Europe, the Final Act 1975 (1975 Helsinki Final Act) plays a certain role to catalyze the collapse of Communist in Europe. Part 1. d of Co-operation in humanitarian and other fields specially regulate the travel for personal or professional causes. Part 1. $\mathrm{d}$ of Co-operation in humanitarian and other fields of 1975 Helsinki Final Act The participating States intend to facilitate wider travel by their citizens for personal or professional causes and to this end they intend in particular: gradually to simplify and to administer flexibly the procedures for exit and entry; to ease regulations concerning movement of citizens from the other participating States in their territory, with due regard to security requirements. They will endeavour gradually to lower, where necessary, the fees for visas and official travel documents.

${ }^{141}$ Article 9.5 of the Document of the Copenhagen Meeting of the Second Conference on The Human Dimension of the CSCE 1990 provides that "they will respect the right of everyone to leave any country, including one's own, and to return to his country, consistent with a State's international obligations and CECE commitments. Restrictions on this right will have the character of very rare exceptions, will be considered necessary only if they respond to a specific need, pursue a legitimate aim and are proportionate to that aim, and will not be abused or applied in an arbitrary manner."

142 Article 19 (6) of European Social Charter (Revised) 1996 prescribe "(6) to facilitate as far as possible the reunion of the family of a foreign worker permitted to establish himself in the territory."

${ }^{143}$ Article 45 of the Charter of Fundamental Rights of the European Union 2000 provide "1. Every citizens of the Union has the right to move and reside freely within the territory of the Member States. 2. Freedom of movement and residence may be granted, in accordance with the Treaty establishing the European Community, to nationals of third countries legally resident in the territory of a Member State."

144 Article 22 (2), (3), (5), (6), (7), (8) and (9) of the AMR States that "2. Every person has the right to leave any country freely, including his own. 3. The exercise of the forgoing rights may be restricted only pursuant to a law to the extent necessary in a democratic society to prevent national security, public order, public morals, public health, or the right or freedoms of others. 5. No one can be expelled form the territory of the State of which he is a national or be deprived of the right to enter it. 6. An alien lawfully in the territory of a State Party to this Convention may be expelled form it only pursuant to a decision reached in accordance with law. 7. Every person has the right to seek and be granted asylum in a foreign territory, in accordance with the legislation of the State and international conventions, 
Taking into account the evolution in the understanding and content of regional instruments related to the RLR, African countries and the Arab world have made great efforts to effectively protect the RLR. the RLR was recognised separately in the African Charter on Human and People's Rights 1981 (AFR), ${ }^{145}$ the Cairo Declaration on Human Rights in Islam 1990, ${ }^{146}$ the Declaration on the Protection of Refugees and Displaced Persons in the Arab World $1992^{147}$ and the Arab Charter on Human Rights $1994 .{ }^{148}$

in the event he is being pursued for political offences or related common crimes. 8. In no case may an alien be deported or returned to a country, regardless of whether or not it is his country of origin, if in that country his right to life or personnel freedom is in danger of being ciliated because of his race, nationality, religion, social status, or political opinions. 9. The collective expulsion of aliens is prohibited."

${ }^{145}$ The African Charter on Human and People's Rights 1981 entered into force in October 1986. Article 12 (2), (3), (4) and (5) set forces that " 2 . Every individual shall have the right to leave any country including his own, and to return to his country. This right may only be subject to restrictions, provided for by law for the protection of national security, law and order, public health or morality. 3. Every individual shall have the right when persecuted, to seek and obtain asylum in other countries in accordance with the law of those countries and international conventions. 4. A non-national legally admitted in a territory of a State Party to the present Charter, may only be expelled form it by virtue of a decision taken in accordance with the law. 5. The mass expulsion of non-nationals shall be prohibited. Mass expulsion shall be that which is aimed at national, racial, ethnic or religious groups."

146 The Cairo Declaration on Human Rights in Islam 1990 was adopted by the Organization of the Islamic Conference in August 1990. It believes that "fundamental rights and universal freedoms in Islam are an integral part of the Islamic religion and that not one as a matter of principle has the right to suspend them in whole or in part or violate or ignore them." It provides that "all human being are God's subjects. --- Human beings are born free. Every man shall have the right, within the framework of Shari'ah, to free movement and to select his place of residence whether inside or outside his country and if persecuted, is entitled to seek asylum in another-country. The Country of refugee shall ensure his protection until he researches safety, unless asylum is motivated by an act which Shari-ah regard as a crime."

147 The Declaration on the Protection of Refugees and Displaced Persons in the Arab World 1992 was adopted by a Group of Arab Experts, which met in Cairo in November 1992, at the Fourth Arab Seminar on "Asylum and Refugee law in the Arab World". Article 1, 2 reaffirms "the fundamental right of every person to the free movement within his own country, or to leave it for another country and to return to his country of origin." and "the importance of the principle prohibiting the return or the expulsion of refugee to a country where his life or his freedom will be danger and considers this principle as an imperative rule of the international public law." Article 3 considers that "the granting or asylum should not as such be regarded as a unfriendly act vis-a-vis any other State."

148 The League of Arab States adopted the Arab Charter on Human Rights, in September 1994. Article 21, 22 and 23 provides that "No citizen shall be arbitrarily or unlawfully prevented from leaving ant Arab country, including his own, nor prohibited from residing, or compelled to reside, in any part of his country." "No citizen shall be expelled form his country or prevented form returning thereto." "Every citizen shall have the right to seek asylum in other countries in order to escape persecution. Persons facing prosecution for an offence under the ordinary law shall not enjoy this right. Political refugees shall not be extraditable." 
It should also be noted that at present there are no Asian conventions pertinent to the RLR, and no regional intergovernmental institution created to protect the RLR. The gist of the Asian countries' rejection of developing a regional convention is that "human rights, as propounded in the West, are founded on individualism and therefore have no relevance to Asia, which is based on the primacy of the community." 149 Asian countries adopted the Bangkok Declaration in April 1993. It contains the aspirations and commitments of the Asian regions on human rights, including the RLR. ${ }^{150}$

The RLR norms is crystallising into customary international law, and commanding universal observance, binding even those States that are not parties to the conventions setting forth the RLR norms will thus become the trend. Efforts to promote the universality of the RLR by attempts to assure concordant behaviour, both by non-parties to the pertinent instruments and by those States that have dissented from their adoptions, will and must continue, despite the tension, which these efforts generate between the important values embodied in the relevant norms and the sovereignty of non-parties.

The credibility of the norms requires that attempts to extend their universality and further to reduce the already contracting domain of domestic jurisdiction. The fabric of international law need not be torn to establish the legitimate place of the RLR in general international law. Unlike most other fields of international law, the observance of the RLR is not based on reciprocal interests of States, but on the broader goal of States to establish orderly and enlightened international and national legal regimes. By the creative adaptation of the traditional and classical concepts and methods, it is possible to build the customary law of the RLR and humanitarian norms in a process that will enhance their credibility and effectiveness.

\subsubsection{The factors driving the historical development of the laws governing the RLR}

149 Ghal, Yash, "Human Rights and Governance: the Asia Debate" in Steiner, Henry J. and Alston, Philip, International Human Rights in Context, $2^{\text {nd }}$ edition, Oxford University Press, New York, 2000, page 550.

${ }^{150}$ Asian countries have had some preliminary discussions to establish regional human rights documents. The Draft Asian Human Rights Charter, proposed by the non-governmental Asian Human Rights Commission after regional consultations in 1993. See Council of Europe Information Sheet no. 35 (July - December, 1994) 
There are many factors that drive the historical development of the laws governing the RLR. They include politics, economics, culture and law. Among these factors politics and economics are foremost. The former decides the grant of the RLR by governments. The latter decides the practical demands of the RLR by people. The influence of politics on the RLR is more significant than the influence of economics. An advanced economic system demands the RLR more, since the realisation of the RLR can benefit economic development. The greater the economic development, and the less economic differences between States, the fewer limits imposed on the RLR.

This correlation can be seen in history. An agrarian society requires a dense and stable labour force to be bound to the land. Although the absence of the systems of ports and customs further increased the need of travel in some senses, the travellers of agrarian societies were mainly youth seeking knowledge, artists, foreign spectators, traders, those seeking cures for bad health, and wealthy people travelling for distraction and recreation. ${ }^{151}$ The slave in Rome Empire was a man who could not go where he wished, and the free man was a man who could. If the Roman or Greek slave, or European serf could freely leave the castle or manor, the Mediterranean ancient civilisations and European feudal society would not have developed as they did.

Demographic theories assert that economic development involves evolution from a predominantly agrarian, peasant economy to an industrialised, market-oriented economy, characterised by a greater division of labour, urbanisation and weakening of traditional migratory customs. ${ }^{152}$ An industrial technology demands inventiveness and depends upon a labour force that is skilled or capable of being trained. The population must be induced to undergo the social dislocations of a mobile labour force and often also undergo a shift of social,

\footnotetext{
${ }^{151}$ Cantor, Norman F. and Werthman, Michaels (ed), The History of Popular Culture to 1815, The Macmillan Company, New York and Collier-Macmillan Ltd., London, 1968, page 40.

${ }^{152}$ Coale, A. J. and Hoover, E. M., "The Effects of Economic Development on Population Growth and the Effects of Population Growth on Economic Development" in Drake, Michael (ed), Population in Industrialization, Methuen \& Co. Ltd., London, 1969, page 12-14.
} 
economic, and political power. ${ }^{153}$ The institutions and policies focused on the liberalisation of the RLR may enhance the social dislocations of a mobile labour force. One of the changes industrialisation underwent has been the conversion of the majority of the labouring population from peasants to an urban proletariat, and the increase of international migrants. ${ }^{154}$

According to the International Migration Report 2002 published by the UN, with the great progress of the world's economy the number of international migrants stood at 175 million in 2000, up from 75 million in 1965. International migrants are not distributed evenly across countries or regions. Sixty percent of the world's migrants currently reside in the more developed regions and 40 percent in the less developed regions. In 2000, international migrants made up 8.7 percent of the population in developed countries, while they accounted for only 1.5 percent of the population in developing countries. ${ }^{155}$

Politics has then simultaneously driven the development of the laws governing the RLR, along with economic imperatives. Civilised political systems can improve the recognition of the RLR and the effectiveness of its protection. By contrast, the centralisation of State power or autocracy has the inclination to deny the RLR.

This correlation can also be seen historically. It is widely accepted that slave-owner and feudal King had autocratic powers in slave societies and feudal societies. Feudal monarchy could be interpreted as a lord-subject relationship without reciprocal rights and obligations of the lord-vassal concept. Absolute monarchs built royal supremacy into the machinery of their governments and subjects. Therefore, the slave and bondsman who were numerous could not move freely unless they were liberalised. The word "liberal" in Latin has it origin in the idea of

\footnotetext{
153 Stipp, John L., Dirrim, Allen, W. and Hollister, C. Warren, The Rise and Development of Western Civilization: 1660 to the Present, John Wiley \& Sons, Inc., New York, London and Sydney, 1967, page 228.

154 Willis, F. Roy, Western Civilization an Urban Perspective: Volume II from the $17^{\text {th }}$ Century to the Contemporary Age, D. C. Heath and Company, Lexington the USA, 1973, page 659.

155 Population Division, Department of Economic and Social Affairs, International Migration Report 2002, United Nations Secretariat, 2002, ST/ESA/SER.A/220, the United Nations, New York, 2002, 62 pages, pages 2 and 11.
} 
being unimpeded in the exercise of movement. ${ }^{156}$ David Potter regarded communist rule as the opposite of democracy. ${ }^{157}$ The communist States present the most consistent policy, generally very restrictive in the areas of travel and emigration, despite their geo-political differences. None of the countries in this group recognise the RLR by constitutional provision or statute, although Mongolia, North Korea, and Vietnam are parties to the ICCPR. ${ }^{158}$

The post-Cold War era has seen the creation of a number of new States, particularly in the former USSR and Eastern Europe. They have changed their political systems from communist systems to Western-style democracies. Most of these States have liberalised the RLR. ${ }^{159}$ The rate of economic increase in China is greater than that of the former USSR and eastern European countries, however Chinese laws governing the RLR have not yet fundamentally changed as they have in those countries. This is largely because a dramatic change in the political system has not occurred in China. In other words the advent of socialism in China along with one party rule has as yet brought no strong commitment to human rights which would include the RLR. ${ }^{160}$

The influence of the political system on the RLR is ultimately more significant than the influence of economics. The ability to exploit a right and the demand to a right are not the precondition to the rights necessity. As far as the RLR is concerned, the ability to financially afford the leaving and returning, and the demand to leave and return, are not the premise of

\footnotetext{
156 Maurice Cranston, "the Political and Philosophical Aspects of the Right to Leave and to Return”, in Vasak, Karel and Liskofsky, Sidney, (ed), the Right to Leave and Return: Papers and Recommendations of the International Colloquium Held in Uppsala, Sweden, 19-21 June 1972, The American Jewish Committee, Arbour, the USA, 1976, page 29.

157، As a result of result of the end of communist rule many democracies were established, although a definition of the precise form of democracy that came into existence was often hazardous and - at the end of 1995 - could only be tentative on the basis of just six years of systemic change." See Potter, David, Goldblatt, David, Kiloh, Margaret and Lewis, Paul (ed), Democratization, Blackwell Publishers Inc. Malden MA, the USA, 1997, page 394.

${ }^{158}$ Hannum, Hurst, The right to Leave and Return in International Law and Practice, Martinus Nijhoff Publishers, Dordrecht, the Netherlands, 1987, page 76.

159 Joseph, Sarah and Sehultz, Jenny et al, The National Covenant on Civil and Political Rights: Cases, Materials, and Commentary, Oxford University Press, New York, 2000 page 5.

${ }^{160}$ Edwards, R. Randle, Henkin, Louis and Nathan, Andrew J., Human Rights in Contemporary China, Columbia University Press, New York, 1986, page 22.
} 
upholding the RLR. It is thus possible for States to entitle people to the RLR in paper only under law. Upholding the RLR plays a catalytic role in helping people to realise the RLR in practice. Some developing States, such as Burundi and Cambodia grant people the RLR, even though their nationals are unable in practice to exercise those rights. In contrast, some developed States, such as Saudi Arabia and Singapore do not officially grant people the RLR, even though their nationals more often have the financial ability to exit and re-enter their countries. ${ }^{161}$

\subsection{Globalisation and international migration}

\subsubsection{Globalisation}

Globalisation is an inevitable international trend. ${ }^{162}$ According to McGrew, globalisation is the multiplicity of linkages and interconnections that transcend the nation-State (and by implication the societies) which make up the modern world order. It defines a process through which events, decisions and activities in one part of the world significantly effect distant individuals and communities. ${ }^{163}$ Capitalism relies upon the market-oriented system, which underlines competition and free-flow of human resources among States. Of the 100 largest economies in the world, 51 are global corporations, whereas only 49 are States. ${ }^{164}$

Yet the contemporary age is not the first global epoch. In the words of D. Held:

Globalisation, as an historic process, cannot be characterised by revolutionary logic. Historical patterns of globalisation have been punctuated by great shifts and reversals, while the temporal

\footnotetext{
161 Burundi and Cambodia are party members of the ICCPR, while Saudi Arabia and Singapore are not.

162 "Many analysts have concluded that, like it or not, we live in an era of globalisation, and humanity increasingly shares a common fate. ... The peoples of the world are linked more closely through a greater participation by virtually all States in the global market, and thanks to the evolution of modern communications technology." See Ness, Peter Van, Human Rights and Democracy in China: Four Theories on Why the World Should Care, working paper No.167, Peace Research Centre, Research School of Pacific Studies, ANU, 1996, pages 13-14.

163 McGrew, T. "A Global Society”, in Hall, S., Held D. and McGrew T. (ed), Modernity and Its Future, Cambridge, Polity Press, 1992, page 65.

164 Quoted in Amnesty International, “AI on human Rights and Labour Rights” at Lechner, Frank J. and Boli John (ed), Globalisation Reader, Blackwell Publishers, Malden, the USA, 2000, page 187.
} 
rhythms of globalisation differ between domains. ${ }^{165}$

Although the Roman, Germanic and Mongol people were known to have engaged in large scale migration during times of ancient imperialist expansion, and similarly significant movement from 1500 to 1900 , contemporary patterns of migration can be distinguished from historical examples on the basis of their extent and intensity. ${ }^{5}$

Globalisation significantly influences international migration. It has made more people aware of conditions and opportunities abroad to study, work and live. Global restructuring generates or amplifies international migration and, in turn, that movement of people across borders is an indication of the globalisation of societies, and of the obsolescence of national boundaries. ${ }^{166}$ New development in information and transportation technology increases the volume of temporary-, repeat- and circulatory migration. Globalisation — as the increased international flow of trade, capital, information and people - has delivered undeniable wealth and opportunity and created millions of jobs. ${ }^{167}$ Positively speaking, some countries have grown through entering the global economy. In 2003, the IOM observed that like other flows, whether financial, commercial, or flows of information or ideas, the rising tide of people crossing frontiers is among the reliable indicators of the intensity of globalisation. ${ }^{168}$ Kofman even suggested that international migration is central to the study of globalisation. ${ }^{169}$

Globalisation has underpinned the interdependence of markets, production, culture and

165 Held, D., McGrew, A., Goldblatt, D., and Perraton, J., Global Transformations: Politics, Economics, and Culture, Polity Press, Cambridge, 1999, page 414.

${ }^{5}$ Kirkbride, Paul, (ed), Globalisation: The External Pressures, John Wiley \& Sons, Ltd., West Sussex, the UK, 2001, page 35 .

166 Pellerin, Helene, "Global Restructuring and International Migration: Consequences for the globalisation of Politics', in Kofman, Eleonore and Youngs, (ed) Gillian, Globalisation: Theory and Practice, Pinter, New York, 1996, page 6 .

167 Human Rights Watch, "Human Rights Watch World Report 2001: A Human Rights Framework (Introduction)”, http://www.hrw.org/wr2k1/intro/intro01.html (25/07/2003).

168 "Facts and Figures on International Migration", Migration Policy Issues, No. 2, March 2003, IOM International Organization for Migration, Geneva, Switzerland, page 1.

169 Kofman, Eleonore and Youngs, Gillian, (ed), Globalisation: Theory and Practice, Pinter, New York, 1996, page 6. 
languages by the exchange of goods, services, capital, information, skills and people. The process has inextricably tied trade, competition and employment to international migration more than ever. The effect on private companies is that their employees, in the course of their employment, need to become "international" citizens in accessing foreign countries. Managing their international mobility is inherent to their human resource value. In relation to multilateral agreements between States, the General Agreement on Trade and Services (GATS) clearly articulates the relationship between trade barriers and immigration controls. The use of immigration laws to restrict the movement of services providers is a non-tariff barrier to the trade of services. ${ }^{170}$

\subsubsection{International migration}

Some introductory facts are that:

- The rate or the distribution of international migration has not dramatically changed over the last 40 years. ${ }^{171}$ Although the international migration rate grew rapidly in the closing years of the last century, the growth has been evolutionary rather than revolutionary. ${ }^{172}$

- Furthermore, there has not been an even distribution of migrants between countries, but a steady increase in the number of immigrants travelling to developed countries. ${ }^{173}$

\footnotetext{
${ }^{170}$ Keely, Charles B., Globalisation Transforms, Trade-Migration Equation, Blackwell Publishing Ltd. Oxford, 2003

171 Around 175 million persons currently reside in a country other than where they were born in 2000. Compared with 6057 million persons in the world, it suggests that most people never cross national borders to live or work in another country. In the 25 years from 1975 to 2000, the number of migrants in the world increased by 100 million persons, but the proportion of international migrants within the total population of the world did not change significantly, ranging from close to 2.3 percent to 2.9 percent. International migrants increased 1.9 percent per year since 1965; it is only slightly ahead of the annual world population growth rate of about 1.8 percent. See Population Division, Department of Economic and Social Affairs, United Nations Secretariat, Measuring International Migration: Many Questions, Few Answers, UN/POP/MIG/2002/BP/1, New York, 2002, 10 pages, page 4.

172 Papademetrious, Demetrios, G., Reflections on International Migration and its Future, International Organization for Migration, Geneva, Switzerland, 2002, 58 pages, page 10.

${ }^{173}$ International migrants in 1990 constituted 4.5 percent of the population in more developed countries, while accounted only for just 1.6 percent of the population in developing countries. "The percent of the world's international migrants living in more developed countries increased from 52.9 percent to 59.6 percent during the period of 1990 to 2000. International migrants live in Europe (56 million), Northern America (41 million), Oceania (6 million), Asia (50 million) and Africa (16 million) in 2000. Its increased by $15.8 \%, 48 \%, 22.8 \%,-0.4 \%$ and $0.3 \%$
} 
- The official number of migrants accounts for a small percentage of estimated actual migration. ${ }^{174}$

- The effect of international migration on population growth and distribution rates for some receiving States is significant. This is in large part due to the fact that these countries exhibit persistently low rates of natural population growth.

- Migrants' remittances continue to be a major source of some developing countries' national income. ${ }^{175}$

With globalisation, new patterns of international migration are emerging, which are closely linked and interdependent with pre-existing patterns. It can be observed that permanent and temporary migration stimulate one another. Some examples of these newer forms of migration include circular migration, the "astronaut phenomenon", and the migration of retired people, women, students and parents.

\section{Causes of international migration}

The most fundamental cause of international migration is the quest for personal security and economic improvement, or rather, the attempt to defend oneself against personal insecurity or economic deterioration or underdevelopment. ${ }^{176}$ In terms of family migratory patterns, the cause is generally related to family reunion, the hope for a better future, political stability and

from 1990", Calculated according to the data at Population Division Department of Economic and Social Affairs, International Migration Report 2002, United Nations Secretariat, 2002, ST/ESA/SER.A/220, the United Nations, New York, 2002, 62 pages, page 2.

174 "In comparison with the total number of 3 million people a year cross national borders and settling in another country, 1.2 million immigrants were officially accepted a year collectively in the USA, Canada, Australia, Israel and New Zealand in 2000, which implies that most people who take up residence in another country each year are irregular migrants including refugees seeking protection and unauthorized or illegal foreigners', Martin, Philip and Widgren, Jonas, International Migration: Facing the Challenge, Population Reference Bureau, Washington D.C., 2002, 39 pages, page 4 .

${ }^{175}$ For example, as a proportion of total financial inflows, remittances amounted to $66 \%$ and $51 \%$ of the Moroccan and Egyptian national incomes respectively. See "Facts and Figures on International Migration", Migration Policy Issues, No. 2, March 2003, IOM International Organization for Migration, Geneva, Switzerland, page 1.

${ }^{176}$ Papademetrious, Demetrios, G., Reflections on International Migration and its Future, International Organization for Migration, Geneva, Switzerland, 2002, 58 pages, page 25. 
marriage. ${ }^{177}$ Emigrants in the humanitarian stream prefer to move in order to escape war or the political situation in their homeland, and to seek better employment opportunities. ${ }^{178}$ Skilled migratory patterns prove that immigration may yield economic benefits to the host country.

Circular migrants mainly prefer to temporally return to their home country because they find it very hard to realise their initial hopes, such as finding a better job and having a better future for their family in the host country. Other causes for circular migration can also be due to policies in the country of origin and host country that encourage temporary migration. Some of the essential characteristics of circular migrants are that they retain their original citizenship, consider themselves to be expatriates, maintain important links with their home country, may intend to return to it, and are often highly paid and skilled. ${ }^{179}$

The frequency of international migration is more likely to increase because of the above causes. The result may be a strong set of "pull and push" factors, from changing circumstances, which may encourage a growing number of people to migrate in the near future. Other macro motivations will also trigger a future increase of international migration, such as that:

- Some countries regard international migration as one of important measures to relax the ageing of the overall population. ${ }^{180}$

177 Hugo, Graeme, Rudd, Dianne and Harris, Kevin, Emigration from Australia: Economic Implications, Second report on an ARC SPIRT grant CEDA Information Paper No. 77, Adelaide University Australia, June 2001, page 72.

${ }^{178}$ Hugo, Graeme, Rudd, Dianne and Harris, Kevin, Emigration from Australia: Economic Implications, Second report on an ARC SPIRT grant CEDA Information Paper No. 77, Adelaide University Australia, June 2001, page 74.

179 Newland, Kathleen, "Migration as Factor in Development and Poverty Reduction,"

(http://www.migrationinformation.org.Feature/display.cfm?ID=136) (05-06-2003).

180 "Demographic explanations point to the structural disparities between areas with stagnant economies but high rates of fertility, and areas with fast-growing economies but declining fertility." (See Hugo, G., "The Demographic Underpinning of Current and Future International Migration in Asia", Asian and Pacific Migration Journal, 7 (1) 1998, page 1-25.) Western and Southern Europe, Japan and Oceania are dramatic cases in the later regard, as of North Africa in the former regard. The proposed ration of those aged 65 and over to those aged 15 to 64 will increase from 2010 and 2020 in Australia (19.0 percent to 24.6 percent), the USA (19.2 percent to 25.4 percent), Japan (32.3 percent to 42 percent) and Italy (30.4 percent and 36.4 percent). Additional working age population required in 2020 for old-age dependency ratio to remain page 2010 levels are 4.4 million, 66.4 million, 22.6 million and 6.8 million respectively. (Calculated from medium variant projections in the United Nations, World Population Prospects, the 1996 Revision.) Western and Southern Europe, Japan and Oceania are dramatic cases in the later regard, as of North Africa in the former regard. The proposed ration of those aged 65 and over to those aged 15 to 64 will increase from 
- The income gap between different countries is sufficient cause to make a rational choice to migrate. Growing disparities lead to increased migration in the near future.

- The labour migratory movement, once started, develops its own dynamics and cannot easily be stopped. This can be explained by competition between interest groups in receiving countries. ${ }^{181}$

- It is well known that most migrants follow "beaten paths' and go where their compatriots have established a bridgehead, making it easier to find a job and integrate into the host country. This may be called "chain migration" or "networks migration".

- Migration for the purpose of seeking asylum, or undocumented migration, is likely to increase, with little hope that global conflicts will be resolved in the foreseeable future.

- More free trade treaties will eliminate the many barriers of all kinds erected between States and parties within States over centuries, bringing freedom of movement in free trade regions for persons pursuing economic activities, and for goods, services and capital.

\section{Management of international migration}

The management of international migration is likely to become more controversial, difficult and urgent in the 21 st century. It will bring into play many sensitive issues of national security and identity, of social change and cultural adaptation, and of economic vitality and development. Properly managed, immigration may provide important answers to some of the world's more developed countries' most intractable current and long-term dilemmas, and it might give some balance and foundation for a more mature international dialogue. The key to dealing with the

\footnotetext{
2010 and 2020 in Australia (19.0 percent to 24.6 percent), the USA (19.2 percent to 25.4 percent), Japan (32.3 percent to 42 percent) and Italy (30.4 percent and 36.4 percent). Additional working age population required in 2020 for old-age dependency ratio to remain page 2010 levels are 4.4 million, 66.4 million, 22.6 million and 6.8 million respectively. Also see other reports pertinent world population shows that the old-age dependency ratios in more developed countries will be much higher in 2030 and 2050, such as the USA ( 31.9 percent and 33.5 percent) and Japan (43.5 percent and 50.2 percent). Quoted in Papademetrious, Demetrios, G., Reflections on International Migration and its Future, International Organization for Migration, Geneva, Switzerland, 2002, 58 pages, page 34.

181 Castles, Stephen, "Migration and Community Formation under Conditions of Globalisation", International Migration Review, Winter 2002 v36 i4 page 1143 (26), http://web6.infotrac.galegroup.com/itw/infomark/740/651/37374829w6/purl=rc1_EAI...(25-07-2003)
} 
patterns of international migration is not to prevent or obstruct movement, but to make the order of movement effective. If all actors in the migration process are to gain the maximum benefit from migration, the policy effort must focus on some of the grossly under-explored topics in the public discourse on international migration. ${ }^{182}$ Policies at a local level play a considerable role in the management of migration.

\subsubsection{International migration policy}

An increased number of countries have formulated new immigration policies to face the trend of globalisation and the reality of international migration. Firstly, a diverse group of countries, including Italy, Portugal, South Korea and Germany, have boosted the numbers of immigrants. ${ }^{183}$ Secondly, since the 1980s, many immigrant-receiving countries, including the USA, Canada, Australia, and New Zealand have implemented immigration policies that are designed to attract economic migrants such as entrepreneurs, executives, scientists, professionals and technical specialists. ${ }^{184}$

Thirdly, receiving countries have tightened the management of immigration services. The immigration service industry is already regulated in Australia and the UK. Canada and New Zealand are developing a system that aims to provide a dependable mechanism to prevent unscrupulous immigration consultants from using their fiduciary position for their own profit, or

\footnotetext{
182 Papademetrious, Demetrios, G., Reflections on International Migration and its Future, International Organization for Migration, Geneva, Switzerland, 2002, 58 pages, page 9.

${ }^{183}$ Hamilton, Kimberly, "Italy’s Southern Exposure”, http://migrationinformation.org/Profiles/display.cfm?id=121 (02/05/2003); Malheiros, Jorge, "Portugal Seeks Balance of Emigration, Immigration”, http://www.migationinformation.org/feature/display.cfm?ID=77 (19-05-2003); Issues Paper from the Republic of
} South Korea, Asia Pacific Migration Research Network, Migration Issues in the Asia Pacific, 11 pages, page 1; Munz, Rainer, New German Law Skirts Comprehensive Immigration, http://www.migaitoninformation.org/Feature/display.cfm?id=241(03/08/2004).

184 Economic stream migrants between 200,000 and 225,000 in 2000 make up the majority of that immigration to Canada, accounting for slightly more than half of total immigration. See Yale-Loehr, Stephen and Erhardt, Christoph, Immigration and Human Capital: A Theoretical, Comparative and Practical Perspective; and Australian governments encourage skilled migration recent years. 66,050 skilled migrants visas have been issued during the period of July 2002 - July 2003, which accounts for 61 percent of Australian non-humanitarian immigration program. See Shen, Juguang, "The New Record of Skilled Migration 2002-2003” (2002-2003 Niandu Jishu Yimin Chuang Xingao), in The Daily Chinese Herald, Australia, 26, 27 July 2003. 
mismanaging their clients' immigration affairs. ${ }^{185}$ Similar policies can be found in emigration services in those countries. In China, regulations introduced in 1999, 2001 and 2002 paved the way for comprehensive regulation of several of emigration intermediary agencies through the Ministry of Public Security (MPS), the Ministry of Labour and Social Security (MLSS), the Ministry of Education (MOE) and China National Tourism Administration (CNTA).

Fourthly, asylum seeking and other forms of migration have long been viewed as separate issues by some governments. Asylum policies are now at the core of the discussion of migration in many parts of the world. The international asylum regime prevailed from the early 1950s through the late 1990s, and eventually challenged the States' prerogative to decide on the recognition of asylum seekers. Extensive media coverage of the plight of refugees has contributed to the politicisation of international migration. Restrictions on asylum have become quite common in both developed and developing countries. ${ }^{186}$ However, some analysts think that regardless of whether migration has a positive or negative effect, more developed countries will be unable to stop the arrival of desperate migrants, and that only military intervention will prevent large numbers of poor migrants attempting to enter affluent countries, threatening their security. ${ }^{187}$

Finally, countries increasingly view flexible citizenship as an important and practical tool of integration. Recent North American and European research indicates that immigrants quickly adopt many conventional norms and values of the receiving society, while still maintaining a strong positive valuation of their own culture and language. ${ }^{188}$ Acknowledging the realities of

\footnotetext{
185 The National Citizenship and Immigration Law Section of the Canadian Bar Association, Submission on Immigration Consulting Industry, 2000, 16 pages, page 1; and Hon Dalziel, Lianne, the Minister of Immigration. Options for Setting Enforceable Standards for Immigration Consultants, 2001, 8 pages, page 1.

186 Population Division Department of Economic and Social Affairs, United Nations Secretariat, International Migration: Explicit Policies, Uncertain Consequences, UN/POP/MIG/2002/BP/2, New York, 2002, 15 pages, page 10.

187 Martin, Philip and Widgren, Jonas, International Migration: Facing the Challenge, Population Reference Bureau, Washington D.C., 2002, 39 pages, page 5.

188 Newland, Kathleen, "Migration as Factor in Development and Poverty Reduction", http://www.migrationinformation.org.Feature/display.cfm?ID=136 (05-06-2003).
} 
permanent residence abroad, and the process of accessing citizens' rights in receiving countries, many sending countries tend to stress the importance of legal regulations that permit emigrants to qualify for foreign naturalisation without surrendering their original citizenship. Sending countries wish to maintain close contacts with their citizens abroad and tend to encourage emigrants to retain their citizenship and transfer it to their children. The complex situation created by dual citizenship can be limited by bilateral and international conventions. ${ }^{189}$

As globalisation creates multi-ethnic societies, and traditional notions of citizenship become increasingly inadequate, some States are considering multiple citizenship, which is occurring both within existing nation-States and in new regional entities such as the European Union (EU). ${ }^{190}$ The facts outlined below support the finding that regional free trade agreements usually precede the free flow of people, which simultaneously enhances free trade.

- Following Schengen Agreement in 1995 and Treaty of Amsterdam in 1999, the EU became a zone of free movement for EU nationals. The EU established a common asylum and immigration policy after May 2004.

- The North America Free Trade Agreement permits the temporary entry of highly qualified workers in 64 professions. It allowed open borders for professionals among three countries after $2003 .{ }^{191}$

- The Managua Agreement, which was adopted by the E1 Salvador, Guatemala, Honduras and Nicaragua in 1993, provided for the creation of a system to facilitate the movement of people without requiring a passport or visa, the functions of which are instead supplied by a valid identity card from the respective country, and an application form as provided for in the Agreement. Travellers are authorized to a 90-day, non-extendable stay in the region, without any territorial limits. ${ }^{192}$

\footnotetext{
189 Icduygu, Ahmet, "Citizenship at the Crossroads: immigration and the Nation-State", at Kofman, Eleonore and Youngs, Gillian, (ed), Globalisation: Theory and Practice, Pinter, New York, 1996, page 157.

190 Davidson, Alastair, "Globalisation and Citizenship", ARENA Journal No. 12 1998, p83-105, page 83

191 Martin, Philip and Widgren, Jonas, International Migration: Facing the Challenge, Population Reference Bureau, Washington D.C., 2002, 39 pages, page 11.

192 International Organization for Migration, The State of Migration Management in Central America: an Applied Research, Final Report, International Organization for Migration, Geneva, Switzerland, 2002, 89 pages, page 13.
} 
The Closer Economic Partnership Arrangement (CEPA) was signed between the HKSAR and Mainland China in June 2003, creating a unique free trade zone. Under the arrangement, many HKSAR products will enjoy a zero tariff rate in the Mainland market. ${ }^{193}$ Both the Mainland and the HKSAR have been taking measures to simplify passport and visa application procedures. Since May 2002, it is easier for Mainland Chinese to obtain a visa for Hong Kong. ${ }^{194}$ Since August 2003, residents in South China's Guangdong Province have been able to commute to Hong Kong with only an identification card rather than a passport. ${ }^{195}$ It is predicted that further increases in the number of people moving between the regions will occur.

\subsection{Conclusions}

Migration stems from human nature or instinct. It provides the basis for a "natural right" to leave and return. With a progression from agrarian to industrial societies, the RLR has correspondingly progressed and crystallised into a recognised legal right. Admitting the RLR as a positive right is mainly to describe the wide legal recognition in the world, rather than to accept the utilitarian aspect or deny the nature of the RLR as a natural right. In actuality, the more the RLR in the sense of positive law conforms to the RLR in the sense of natural law, the more the relevant laws are efficient and violations lessen. Meanwhile, the RLR needs be rational; to maintain itself within the limits of human nature.

The history of laws governing the RLR reveals that the right developed from the privilege of people with special status, to the right of all people. Following the Second World War, recognition of the RLR by States has increased and international instruments have also evinced that the recognition of the RLR is moving gradually beyond the national borders. While the

\footnotetext{
193 “Guangdong Could Win big form the CEPA", 4 August 2003, The China Daily, http://www3.chinadaily.com.cn/en/doc/2003-08/04/content_251571.htm (05-08-2003); Wong, Alan, Hong Kong: Stronger than Ever at dinner talks at Four Seasons Hotel, Sydney, Thursday 10 July 2003. 
formal recognition of the RLR is not enough to ensure its enjoyment, it is undoubtedly a significant starting point for its effective protection. Since the emergence of the modern concept of the passport, the passport has become the major instrument governing the RLR. The trend is toward simplification and easing of passport application procedures and the standardisation of forms. Among the factors driving the development of the laws governing the RLR, political imperatives decide the grant of rights and economic imperatives set the practical demands of the RLR by people. The influences of politics on the RLR are more significant than the influences of economics.

Global restructuring generates or amplifies international migration and, in turn, the movement of people across borders is an indication of the globalisation of societies. An increased number of countries have formulated new immigration policies to face the trend of globalisation and the reality of international migration, for example, to attract more economic migrants and be inclined to accept flexible multi-citizenship policies. Although the causes of international migration do not change much, the management of international migration is likely to become more controversial, difficult and urgent in the 21 st century, because it brings into play many sensitive issues of national security and identity, of social change and cultural adaptation, and of economic vitality and development. 


\section{Chapter Three \\ The RLR in International Migration Law}

\section{Introduction}

Few rights are more generally proclaimed or more widely abridged than the RLR. ${ }^{196}$ This chapter will define the current legal status of the RLR in international migration law, to identify important issues that determine criteria by which the RLR may be reasonably restricted.

The analysis begins with the recognition and standards of the RLR, and sources of evolving jurisprudence of the RLR. Given that an individual's the RLR is bound with the possession of a passport and enough foreign exchange, this chapter will then analyse rights related to those possessions. Permissible limits on the RLR have always emerged as the most contentious issue in this area and are therefore a focus of attention here. A necessary extended analysis of the right to leave and the right to return then follows in two sections. The analysis in Chapter three may provide an objective criterion and reference by which China could compare its laws.

\subsection{General considerations on the RLR}

This section examines the recognition of the RLR in international migration law, to clarify the standards of the RLR internationally and domestically, to then consider disputes with respect to standards and review the sources of evolving jurisprudence of the RLR.

\subsubsection{The recognition of the RLR}

By whichever criterion it is classified, the RLR has considerable international recognition as a human right. Its wide recognition is one of the most important reasons for its significance. Where the RLR is concerned, countries can generally be placed in two groups. The first comprises 152 countries that have ratified the ICCPR before June 2004, and recognised the

196 Plender, Richard, International Migration Law, Revised 2nd ed., Martinus Nijhoff Publishers, Dordrecht, the Netherlands, 1988, page 95. 
RLR as a fundamental human right, with an international obligation to effectively protect it. ${ }^{197}$ Most of these countries fulfil their international obligations by incorporating the terms of the international instruments into the detail of their domestic laws, including their Constitutions. The second group of about 40 countries including Indonesia, Malaysia, Pakistan, Turkey, Saudi Arabia, China and Cuba that have not yet ratified the ICCPR. While they ratified the Charter of the United Nations and the UDHR, and accordingly might recognize the RLR as a human right, they usually do not regard the RLR as a real right in practice — it remains an aspirational right, on paper.

The recognition of the RLR and the recognition of the freedom of movement within a territory do not necessarily follow one another. In China, for example, the fact that people do not enjoy freedom of movement within the territory is not the key cause for preventing them from leaving China. ${ }^{198}$ This is contrary to the idea that "when he is confined to a particular locality or reservation, he is in effect prevented from leaving the State itself." 199 Freedom of movement and the RLR are not always indivisible.

\subsubsection{Standards of the RLR}

There is a widely accepted common standard of human right in international migration law, while a particular standard of human rights simultaneously exists in some countries. The UDHR established that:

A common standard of achievement for all peoples and all nations, ... to secure their universal and effective recognition and observance, both among the peoples of Member States themselves and

\footnotetext{
197 International Service for Human Rights, “The Ratification Status of the Main Human Rights Treaties”, http://www.ishr.ch/About\%20UN/Ratification/Ratification/Ratification\%20-\%20Human\%20Rights20treaties.htm (18-05-2003).

198 Though millions of Chinese people might move around mainland China, their households, personal dossiers, medical treatments, employment, education, housing could not be moved together. There are much differences in these fields between the original resident areas and migration areas. From this angle, Chinese people have not truly enjoyed the freedom of movement. Most Chinese scholars, forexample Liu Wujun, Zeng Wenhong, Peng Xiuzhi, Zhang fan etc. accpted this point.

199 Ingles, Jose D, Study of Discrimination in Respect of the Right of Everyone to Leave any Country, Including his Own, and to Return to His Country, the UN Publication Sales No.: 64. XIV. 2 New York, 1963, page 9.
} 
among the peoples of territories under their jurisdiction. ${ }^{200}$

As far as the RLR is concerned, the common standard is stated in Article 13 (2) of the UDHR, which express a universal minimum standard for well-ordered political institutions for all people, as members in good standing and, to a just political society.

The UN Human Rights Committee (HRC) considers that the RLR contained in the ICCPR is the universal minimum standard. ${ }^{201}$ The ICCPR is not merely the codification of our highest values. It is elsewhere considered that it is also a formula for the effective defence of democratic societies from terrorism. ${ }^{202}$ The ICCPR consider that States have the obligations under the Charter of the United Nations to promote universal respect for, and observance of, human rights and freedoms, which certainly include the RLR. ${ }^{203}$ The efforts of the international community on human rights have drawn upon earlier notions from religion and natural law that implied the existence of a common humanity. ${ }^{204}$

It is not surprising that the universal minimum standard mentioned above reflects Western, particularly American values and institutions. This is due to American dominance after the Second World War in the very period that contemporary concepts of international human rights have taken shape. Therefore, some countries do not accept it. The standard and model preferred by Asian countries, for instance, places a heavy emphasis on economic development. ${ }^{205}$ Asian States have recognised that:

While human rights are universal in nature, they must be considered in the context of dynamic and

\footnotetext{
200 Preamble, the UDHR, 1948, UDHR, G.A. res.217 A(III), U.N. Doc. A/810, page 71

201 Joseph, Sarah and Schultz, Jenny et al, The International Covenant on Civil and Political Rights: Cases, Materials, and Commentary, Oxford University Press, New York, 2000, page viii.

${ }^{202}$ Charter, Jimmy, "Introduction” in Williams, Paul (ed), The International Bill of Human Rights, Entwhistle Books, Glen Ellen, the USA, 1981, page xxi.

${ }^{203}$ Preamble, Paragraph 5 of the ICCPR

${ }^{204}$ Li, Victor, "Human Rights in a Chinese Context", in Lee, Tahirih V. (edit), Law, the State and Society in China, Garland Publishing Inc., New York, 1997, page 223

${ }^{205}$ Hoof, Fried van, Asian Challenges to the concept of Universality: Afterthoughts on the Vienna Conference on Human Rights, of Baehr, Peter R. \& Hoof, Fried van, Liu, Nanlai, Tao, Zhenghua, Human Rights: Chinese and Dutch Perspectives, 1996, Kluwer Law International, The Hague, the Netherlands, page 5
} 
evolving process of international norm-setting, bearing in mind the significance of national and regional particularities and various historical, cultural and religious background. ${ }^{206}$

The Chinese government contends that the core of exit and entry administration is in the examination and approval of applications. Chinese citizens cannot go abroad without justification. ${ }^{207}$ This is quite different from the international standard that regards the protection and realisation of the RLR as the core of exit and entry administration, and therefore that it is unnecessary for the authorities of a State to require reasons for going abroad.

The international community respects the various national standards of human rights. The same legal logic can be used in regard to the RLR. The UN has declared, in the Second World Conference on Human Rights that "the significance of national and regional particularities and various historical, cultural and religious backgrounds must be borne in mind." ${ }^{208}$ In other words, the Second World Conference on Human Rights did not effectivelu negate the notion of cultual relativism espoused by the earlier Bankok Declaration. Scholars have also asserted that Western countries should not and cannot regard their own human rights standards as the only proper ones to which all other countries must conform. ${ }^{209}$ Meanwhile, countries and regions preferring particular standards need also to accept and respect the universal minimum standard particularity does not justify the denial of a common standard or its substitution with another. Fortunately, Asian countries have reaffirmed their commitment to principles contained in the Charter of the United Nations and the UDHR. The Chinese have officially accepted that it will

\footnotetext{
206 Article 8 of the Bangkok Declaration 1993, adopted by the Asian Preparations Conference of the Second Conference on Human Rights.

207 Mao, Fengping, (ed), The Explanation of the Law and Regulations Governing exit and entry and the Collections of Related Regulations (Chujing Rujing Falv Fagui Sijie Yu Xiangying Fagui Zhaibian), the Publishing House of Jilin Renmin, Changchun, China, 1994, page 75. Also see Department of Politics under the Ministry of Public Security, Frontier Defence and Exit and Entry Administration, the Series of Basic Textbook of People's Police Operation: (Bianfang Yu Churu Jing Guanli, Renmin Jingcha Gongan Yewu Jichu Jiaochai), examined by Committee of Textbook Editing and Examination of the Ministry of Public Security, the Publishing House of Qunzhong, internal Publication in Public Security Organs (Gongan Jiguan Neibu Faxing), Beijing, 1999, page 318.

208 The United Nations General Assembly, Report of the World Conferences on Human Rights Vienna, 14-25 June 1993 Report of the Secretary-General, Distr. General A/CONF.157/24 (Part I), 13 October 1993, page 18.

${ }^{209}$ Liu, Shengping, Xia, Yong, (ed), Human Rights and the World (Renquan Yu Shijie), the Publishing House of People's Courts, Beijing, 1996, page 126-130.
} 
perform its international obligations with respect to the RLR in the light of the Charter of the United Nations, the UDHR and the ICCPR. ${ }^{210}$

It is a difficult but necessary task to find a way to resolve the differences between national and international standards, because unlike other human rights, usually limited to one country's territory, the RLR is distinguished by its transnational character. The violation of the RLR in one country may lead to the abuse of other fundamental human rights in other countries. The acceptance of the same common standard of the RLR internationally and within all countries will not occur without a joint effort of particular countries, the international community and the West. the RLR in the South can only be empty paper promise without the cooperation and assistance of the North.

The West in this regard is faced with a dilemma. If it requires certain countries to reform the national standard of the RLR, they may receive a mammoth flow of immigration in the short term. If the West ignores the violation of the RLR in certain countries who do not perform their international obligations, their national interest in those countries will be damaged in the long term. ${ }^{211}$ In practice, the West has been trying to balance national interests and human rights idealism. As the US Secretary of the State commented in 2003, the "combination of idealism and practical policy implementation has become a hallmark of our foreign policy in the area of international human rights. ${ }^{, 212}$

\subsubsection{Sources of evolving jurisprudence of the RLR}

As discussed earlier, the RLR has been widely recognised in numerous international

${ }^{210}$ Committee of Textbook Editing and Examination of the Ministry of Public Security, Frontier Defence and Exit and Entry Administration, the Series of Basic Textbook of People's Police Operation (Renmin Jingcha Gongan Yewu Jichu Jiaocai: Bianfang Yu Churu Jing Guanli), the Publishing House of Qunzhong, Internal Publication in Public Security Organs (Gongan Jiguan Neibu Faxing), Beijing, 1999, page 279.

${ }^{211}$ For more information, please see part 14.2.4 of this thesis International environment favouring protection of RLR in China.

212 Colin L. Powell, "Preface", at "Supporting Human Rights and Democracy: The U.S. Record 2002-2003", the Bureau of Democracy, Human Rights, and Labour, 2003, http://www.State.gov/g/drl/rls/shrd/2002/21763.htm (05-07-2033). 
conventions, international declarations and domestic laws. The HRC was established under Part IV of the ICCPR in 1977. ${ }^{213}$ The European Human Rights Commission (EUCM), the inter-American Human Rights Commission (AMCM) and the African Commission on Human and People's Rights (AFCM) have become far more active in recent years. As Hurst Hannum has pointed out, an increasingly large corpus of jurisprudence of the RLR has emerged since the 1972 Uppsala Declaration on the RLR. ${ }^{214}$ Although the evolving jurisprudence of the RLR does not possess formal institutions responsible for law creation, there are recognised and accepted methods by which legal rules come into existence and several ways in which the precise content of legal rules can be identified. These are the sources of evolving jurisprudence of the RLR.

The first source is international conventions or treaties. Article 38(1)(a) of the Statute of the International Court of Justice (Statute of ICJ) speaks of "international conventions, whether general or particular, establishing rules expressly recognised by the contesting States." Treaty means formal agreement between two or more countries. ${ }^{215}$ Treaties range from those generally defining the RLR, such as the ICCPR and the 1975 Helsinki Final Act, to those specially dealing with one part of the RLR, such as the CERD and the CRC and those focusing on the RLR in regional area such as the EHR, AMR, AFR and Benelux Agreement 1960. Given the character of consciousness and deliberation, international conventions are the most important source of evolving jurisprudence of the RLR.

The second source is international custom. Article 38(1)(b) of the Statute of ICJ refers to "international custom, as evidence of a general practice accepted as law". ${ }^{216}$ Article 102(2) of The Third Restatement of the Foreign Relations Law of the United States 1987 provides that

\footnotetext{
213 The HRC has the competence to receive complaints from other States, and mediate in order to achieve a settlement. See part IV of the ICCPR.

${ }^{214}$ Hannum, Hurst, The Right to Leave and Return in International Law and Practice, Martinus Nijhoff Publishers, Dordrecht, the Netherlands, 1987, page 46.

215 Hornby, A. S., Oxford Advanced Learner's English-Chinese Dictionary (Niujin Gaojie Yinghan Shuangjie Cidian ) , $4^{\text {th }}$ editon, The Commercial Press and Oxford University Press, Hong Kong and Beijing, 1997, page 1625.

${ }^{216}$ Brierly remarks "what is sought for is a general recognition among States of a certain practice as obligatory." See Judge Read in the Fisheries case, ICJ Reports (1951), I9I: "Customary international law is the generation of the practice of States."
} 
more specifically, customary international law "results from a general and consistent practices of States which is followed by them from a sense of legal obligation." Although there has been a tendency to codify customary international law, ${ }^{217}$ and codification brings with it divergences between the opinions of different States and a certain amount of compromise and slow process, international custom has a definite advantage in enabling international law to develop in line with the needs of the time.

The evidence of international custom may be found in the actual practice of States. A rough idea of a State's practice can be gathered from a State's statutes, as for instance with the Norwegian Immigration Act 1988, ${ }^{218}$ and from reports of actions taken by States. For instance here, the Chinese Xinhua News Agency reports that the Foreign Affairs Committee of the USA agreed to cancel the restrictions on travelling to $\mathrm{Cuba}^{219}$ It can also be gathered from statements made by government representatives to Parliament, to the press, at the international conferences and meetings of international organisations, as for instance in China when spokesperson Zhang Qiyue of the Ministry of Foreign Affairs, China (MFA) told the press that the Chinese government has always committed itself to protecting human rights and fundamental freedoms of the Chinese people. ${ }^{220}$

The third source is general principles of law. Article 38(1)(b) of the Statute of ICJ mentions "the general principles of law recognised by civilised nations." It is designed to provide a solution in cases where treaties and custom provided no guidance, and to ensure that there is always some rule to fall back on. ${ }^{221}$ It means the general principles of both international law and national law.

\footnotetext{
217 Akehurst, Michael, A Modern Introduction to International Law, 6th edition, Harper Collins Academic, London, 1987 and Routledge, New York, 1987, page 33.

218 Section 17 of the Norwegian Immigration Act 1988 regulate "Any refugee who is in the realm or at the Norwegian border has on application the right to asylum (refuge) in the realm."

${ }^{219}$ Chinese Xinhua News Agency, "The Foreign Affairs Committee Agree to Cancel the Restrictions on Travelling to Cuba" (Mei Canyiyuan Waiweihui Tongyi Jiechu Dui Guba Lvxing Xianzhi), Australian Chinese Daily, at International News (8, 9 November 2003).

220 "Spokesperson Zhang Qiyue's Remarks on the Country Report on Human Rights Issued by the US (26/02/2004)", http://www.fmprc.gov.cn/eng/xwfw/2510/t69782.htm (02/03/2004).

221 Dixon, Martin, Textbook on International Law, Blackstone Press Ltd., London, 1990, page 30.
} 
In a decision of the European Court of Justice in 1975, it was said that it was a principle of international law, which the (at that time) European Economic Community (EEC) Treaty could not be assumed to disregard in the relations between Member States, that a State is precluded from refusing to its own nationals the right of entry or residence. ${ }^{222}$

The fourth source can be found in judicial decisions, which are described in Article 38(1)(d) of the Statute of ICJ as a subsidiary means for the determination of law. This direction is made subject to the provisions of Article 59 of Statute of ICJ, which states, "the decision of the court has no binding force except between the parties and in respect of that particular case". However it is widely agreed that judges can also create new law. Many of its decisions introduced innovations into international law, which have subsequently won general acceptance to avoid accusations of bias. The international Court of Justice, European Court of Human Rights (EUCT) and inter-American Court of Human Rights (AMCT) play a key important role in this regard.

The case law of some quasi-judicial international and domestic bodies like the HRC, Ombudsman's offices, administrative human rights commissions, and/or legislative human rights committees, cannot be ignored. For example, the prevailing majority interpretation of “one's own country" in Stewart v Canada $(538 / 93)^{223}$ seems quite harsh to a State's long-term alien residents. States parties have raised limits to justify restrictions on the RLR in Peltonen $v$ Finland. ${ }^{224}$ They often provide a progressive interpretive approach — albeit not always legally binding, however at times more creative than those found in judicial decisions.

The fifth source is "the teachings of the most highly qualified publicists of the various nations" which is also set forth as subsidiary means for the determination of rules of law in Article 38(1)(d) of the Statute of ICJ. The Study of Discrimination in Respect of the Right of Everyone

\footnotetext{
222 Van Duyn v. Home office [1975] I C.M.L.R. I, I8. See also Weis, Nationality and Statelessness in International Law (1956), page 49-50, Quoted in Goodwin-gill, Guy S., International Law and the Movement of Persons Between States, Oxford University Press, Oxford, 1978, page 137.

${ }^{223}$ See footnote 137.

${ }^{224}$ See footnote 138.
} 
to Leave any Country, including his Own, and to Return to His Country (1963 Ingles Study on the RLR), including 1963 Ingles Draft Principles on the RLR (1963 Ingles Draft Principles on the RLR) made by Jose D. Ingles ${ }^{225}$ has had some formative influence on the jurisprudence of the RLR.

They are many other sources analogous to the 'publicists', and at least as authoritative. ${ }^{226}$ As far as the RLR is concerned, it is mainly the reports and declarations accepted by the UN, the HRC and other international experts conferences. For example, the 1963 UN Draft Principles on the RLR adopted by the CPDPM, the 1972 Uppsala Declaration on the RLR adopted by the Uppsala Colloquium, the 1986 Strasbourg Declaration on the RLR adopted by the Meeting of Experts on the RLR, and 1999 General Comment No.27 on Freedom of Movement (Article 12) adopted by the HRC.

\subsection{State acceptance of the RLR}

the RLR is generally conceptualised as a right, or the freedom from arbitrary State interference with an individuals' rights. It requires States to accept citizens leaving and returning to the territory. The minimum expected of a State, by way of positive activity, are the guarantee of a passport $^{227}$ and the ability to exchange foreign currency. In this section, the right to obtain necessary travel documents, particularly a passport, will be outlined, followed by a discussion of passport administration, and the effect on the RLR of not having a passport. Finally, the right to access foreign exchange will be analysed.

\footnotetext{
${ }_{225}$ Mr. Jose D. Ingles is one Philiphine Judge. He, as the Special Rapporteur, drafted The Study of Discrimination in Respect of the Right of Everyone to Leave Any Country, Including His Own, and to Return to His Country. The study was finally submitted to the Sub-Commission on Prevention of Discrimination and Protection of Minorities at its fifteenth session in 1963. The principles respecting this right, drafted the study was adopted by the Sub-Commission at the same session. The study is the first comprehensive work focused on the RLR. The principles respecting the RLR is the first international instrument. Both of them exerted great influence on future research on this field.

${ }^{226}$ Brownlie, Ian, Principles of Public International Law, 4th edition, Oxford University Press, Oxford, the UK, 1990 , page 25 .

${ }^{227}$ Foldesi, Tamas, The Right to Move and Its Achilles' Heel, The Right to Asylum, Spring 1993 (8) Conn. J. Int”l L. 289 , page 12 .
} 


\subsubsection{The right to obtain necessary travel document, particularly a passport}

An individual's the RLR, in the overwhelming majority of cases, is inextricably linked to one's possession of a passport. In order to enable an individual to enjoy the RLR, obligations are imposed both on the State of residence and on the State of nationality. ${ }^{228}$ The State of residence is primarily obliged to avoid interfering with an individual's freedom to leave. The State of nationality owes a positive duty to ensure that it is effectively possible to leave by issuing the necessary travel documents, usually a passport. ${ }^{229}$

A passport is intended to distinguish between those who may and may not enter or leave. ${ }^{230}$ It is primarily an expression of the attempt by modern nation-States to assert exclusive control over the legal means of international movement. The passport has developed into serving as both a travel and identity document for the nationals of the issuing State, stateless persons, and aliens who are unable or unwilling to obtain passports from the authorities of their countries of nationalities. ${ }^{231}$ The passport cannot be reduced to an instrument of State control, even if that is its principal function today. ${ }^{232}$

Possession of a passport equates with having permission to leave one's State. ${ }^{233}$ With respect to the right to be admitted into a State, the passport provides a certificate of identification. Passports have come to be universally required for admission to foreign territory, but they may

\footnotetext{
${ }^{228}$ Communication No. 106/1981, Montero v. Uruguay, Paragraph 9.4; Communication No. 57/1979, Vidal Martins

v. Uruguay, Paragraph 7; Communication No. 77/1980, Leichtenstein v. Uruguay, Paragraph 6.1.

${ }^{229}$ Article IV (b) (c), V (a) (b) (c) of Ingles Draft Principle on RLR, Article V of the UN Draft Principle on RLR and Article 14, 15, 16 of the 1972 Uppsala Declaration on RLR and Article 10 (c) (d) (e) of the 1986 Strasbourg Declaration on $R L R$.

230 Torpey, John, The Invention of The Passport: Surveillance, Citizenship and the State, Cambridge University Press, Cambridge, the UK, 2000, page 1.

${ }^{231}$ Weis, P., Nationality and Statelessness in International Law, 2nd revised editions, Sijthoff \& Noordhodd International Publishers B. V., Alphen aan den Rijn, the Netherlands 1979, page 223.

${ }^{232}$ Torpey, John, The Invention of The Passport: Surveillance, Citizenship and the State, Cambridge University Press, Cambridge, the UK, 2000, pages 159-160.

${ }^{233}$ Turack, Daniel C., The Passport in International Law, 1972, Lexington Books, D.C. Health and Company, Lexington, page 13.
} 
not, in themselves, be sufficient to gain admission. ${ }^{234}$ In the case of the right to return, the passport is evidence that the bearer has an incontestable right to enter the territory controlled by its issuing State, if the bearer is denied entry into or expelled from other States.

\subsubsection{Passport administration}

As analysed in last sub-section, States are obliged to grant their nationals the right to obtain the necessary travel documents, particularly a passport. Although the issuance of a passport to a citizen is clearly a matter within the jurisdiction of State authorities, the following rules for the administration of passports need to be followed.

(1) No State shall refuse to issue a passport on the ground of the applicant's inability to present authorisation to enter another country, such as a letter of invitation, detailed route schedule, or financial evidence.

(2) Procedures for the issuance of passports shall be expedient, not be uncauseably lengthy or burdensome. In the environment of information technology, online or telephone applications play a vital role of facilitating efficiency. It is unacceptable to fail to reply to an application.

(3) Every applicant shall be entitled to promptly obtain a certified receipt for the application. The receipt must clearly state the date of application.

(4) Where a passport is denied, withdrawn, cancelled or postponed, the applicant shall be informed officially in writing of the decision, with the facts upon which the decision is based and the available avenues to appeal against the decision. ${ }^{235}$ Rejection of the application without providing detailed causes is inconsistent with international law and practice.

\footnotetext{
${ }^{234}$ Torpey, John, The Invention of The Passport: Surveillance, Citizenship and the State, Cambridge University Press, Cambridge, the UK, 2000, page163.

${ }^{235}$ Mr. Mamdouh Habib, the Australian who spent three years in Guantanamo Bay prison. Habib returned to Australia without being charged with an offence in January 2005. Upon arrival, his passport was seized by the Federal Government, amid claims that he remains a security threat. He Mamdouh Habib is appealing that decision to Australian Appeal Tribunal (AAT). See http://www.abc.net.au/worldtoday/content/2005/s1296064.htm (2005-7-7)
} 
(5) No one shall be arbitrarily denied passport under domestic law. ${ }^{236}$

Further, "The formalities for the issuance of any travel document, including the conditions for its denial, withdrawal or cancellation, shall be provided by law or regulations which shall be made public." ${ }^{237}$ The applicant shall access to all laws and regulations. In countries which have freedom of information laws, such as Australia, people have the right to "see documents (including those containing information about the applicant) held by Commonwealth Ministers, their Departments and some statutory authorities" and to "see rules and practices which are used in making decisions", and to "look at and buy copies of manuals and guidelines which agencies use in making decisions". ${ }^{238}$ In contrast, in countries without freedom of information laws, such as China, numerous unpublicised administrative measures and policies are inaccessible, reflecting a closed legal culture and presenting a bureaucratic barrier to information concerning the cause for administrative decisions.

\subsubsection{The effect on the RLR of not having a passport}

Passports or other travel documents certify an individual's claim to the RLR in some countries and regions, ${ }^{239}$ the lack of a passport significantly influences the RLR. In Vidal Martins $v$ Uruguay, the HRC commented that:

The refusal by a State to issue a passport or prolong its validity for a national residing abroad may deprive this person of the right to leave the country of residence and travel elsewhere. ${ }^{240}$

\footnotetext{
236 These five rules of the administration of passport are draw from Article IV of 1963 Ingles Draft Principles on RLR, Article IV of 1963 UN Draft Principles on RLR, Article 13 to 16 of the 1972 Uppsala Declaration on RLR, and Article 4 (g), Article 9 and Article 10(c) to (e) of the 1986 Strasbourg Declaration on RLR

237 Article II (d) of 1963 Ingles Draft Principles on RLR, adopted by the UN Sub-Commission on the Prevention of Discrimination and Protection of Minorities, Res. 2B (XV), UN Doc. E/CN. 41846 (1963).

238 Window on the Law Home Page, http://law.gov.au/publicaitons, quoted in Healey, Justin (ed), Human Rights and Civil Rights, Issues in Society, Volume 139, The Spinney Press, Independent Educational Publisher, Balmain, Australia, 2000, page 33.

239 Some countries in Northern American and European Union recognize other travel document for example the identity of nationality or driving license as the replacement of the passport.

240 The HRC, "Freedom of movement (Art.12): 02/11/99. CCPR/C/21/Rev.1/Add.9, the ICCPR General comment 27. (General Comments)",
} http://www.unhchr.ch/tbs/doc.nsf/(symbol)/CCPR.C.21.Rev.1.Add.9,+CCPR+General+comment+27.En?OpenDocu ment (30-05-2003). 
Additionally, the effect of not having a passport on the right to return are less than on the right to leave. The UN Sub-Commission on Prevention of Discrimination and Protection of Minorities (CPDPM) determined that "[n]o one shall be denied the right to return to his own country on the ground that he has no passport or other travel document." ${ }^{, 241}$ It is presumed that the effect of not having a passport on the right to return might be greatly reduced if this is accepted and exercised in practice.

Refusal to issue a passport, so restricting the right to leave, must be justified pursuant to Article 12(3) of the ICCPR. The issuance of other identity and travel documents is not an acceptable cause. This point was enunciated by the HRC in the Liechtenstein Case, where it was stated that the issuance of identity and travel documents by the State of residence in no way releases the State of nationality from its obligation to issue or renew a passport. ${ }^{242}$

States that deny their citizens a passport violate Article 12(2) of the ICCPR, insofar as this denial is not justified pursuant to Article 12(3) of the ICCPR. ${ }^{243}$ Even if refusal of a passport did not prevent the applicant from moving to another State, it would still interfere with the freedom of movement. The freedom to leave a country implies that there is freedom to leave any country into which a person has been admitted. ${ }^{244}$

\subsubsection{The right to access foreign exchange}

The right to access foreign exchange is not an issue in States that have a freely convertible foreign exchange market. It is a significant issue for the RLR in States that have a managed foreign exchange system. Deprivation of the right to access foreign exchange could result in financial difficulties when travelling abroad. Thus, despite being issued with a passport, the RLR cannot be realised without access to foreign exchange.

\footnotetext{
241 Article II (d) of the 1963 Ingles Draft Principles on RLR, adopted by the UN Sub-Commission on the Prevention of Discrimination and Protection of Minorities, Res. 2B (XV), UN Doc. E/CN. 41846 (1963).

242 Nowak, Manfred, U.N. Covenant on Civil and Political Rights: the ICCPR Commentary, Kehl am Rhein, Strasbourg, Arlington, Germany, 1993, page 206.

243 Nowak, Manfred, U.N. Covenant on Civil and Political Rights: the ICCPR Commentary, Kehl am Rhein, Strasbourg, Arlington, Germany, 1993, page 206.

244 19583/92 Finland, (Dec.) February 20, 1995, 80 D.R. 38, Quoted in Reid, Karen, A Practitioner's Guide to the European Convention on Human Rights, Sweet \& Maxwell, London, 1998, page 245.
} 
Incontrovertibly, States owe a positive obligation to allow access to a minimum amount of foreign currency. ${ }^{245}$ "A minimal amount foreign currency" means the amount to meet one's financial requirements while abroad, consistent with the living standards of the destination State, rather the living standards of the home country. The CPDPM has accepted "economic controls or currency restrictions imposed with a view to safeguarding the national economy shall not be abused to deny any national the right to leave his country."246

Three matters need to be addressed in order to aid the realisation of the RLR. Firstly, the applicant is entitled to exchange enough currency before leaving the country. Obviously, the applicant cannot plan into the future without adequate funds. Secondly, the applicant must be able to carry outwards enough foreign exchange, as preferred by the applicant, whether in cash or non-cash forms. The capping of carrying foreign exchange sums need to accommodate the sum needed by the emigrant or traveller. Thirdly, applicants need to be entitled to freely remit foreign exchange from their home countries to deal with ordinary and unexpected costs. Otherwise, the right to leave, especially the right to leave for business or investment, will be adversely affected.

\subsection{Permissible limits on the RLR}

Although the RLR and limits on the RLR have been widely accepted and acknowledged in the international community, permissibility of the limits on the RLR are disputed. This section will clarify the universally permissible limits on the RLR, or reasonable restrictions, to provide a reference point for the assessment of other issues regarding the RLR in international and Chinese migration law.

\subsubsection{General permissible limits}

\footnotetext{
245 Foldesi, Tamas, The Right to Move and Its Achilles' Hell, The Right to Asylum, spring 19938 Conn. J. Int”' L. 289 , page 12 .

246 Article I (f) of the 1963 Ingles Draft Principles on RLR, adopted by the UN Sub-Commission on the Prevention of Discrimination and Protection of Minorities, Res. 2B (XV), UN Doc. E/CN. 41846 (1963), page 40.
} 
Clearly, limiting the RLR can be justified. No reasonable person would wish to assert that the RLR is absolute. States must refrain from violations of the RLR, and any limits on any of those rights must be permissible. ${ }^{247}$ The question is, what limits are acceptable? ${ }^{248}$ Article 29 (2) of the UDHR applies to the RLR, which provides:

In the exercise of [one's] rights and freedoms, everyone shall be subject only to such limits as are determined by law solely for the purpose of securing due recognition and respect for the rights and freedoms of others and of meeting the just requirements of morality, public order and the general welfare in a democratic society.

In specifically addressing the RLR, Article 12(3) of the ICCPR adds three new terms, beyond those contained in Article 29(2), namely: national security, ordre public and public health; and omits the expression "the general welfare in a democratic society". According to Article 12 (3) of the ICCPR, States may limit the RLR in order to protect the kinds of interests enumerated in the ICCPR, provided that the limits:

- are provided by law;

- are consistent with the other rights recognized in the Covenant;

- to protect national security, public order (ordre public), public health or morals or the rights and freedoms of others; and

- are necessary for achieving this purpose. ${ }^{249}$

The limits permitted by Article 12(3) of the ICCPR are more extensive than those permitted by Article 29(2) of the ICCPR. However, given the relatively limited cases law of the HRC on the RLR, it can be surmised that the above limits may be interpreted in a similar manner to the way they have been in the context of other ICCPR rights. Similar limits are found in Article 2(3) of the EHR P4, Articles 18 and 19 of European Social Charter 1961 (ESC), Article 22(3) and (4) of the AMR, Article 12(2) of the AFR, and other international human rights conventions.

\footnotetext{
${ }^{247}$ Paragraph 6 of General Comment No.31 [80]: the Nature of the General Legal Obligation Imposed on State Parties to the Covenant, adopted on 29 March 2004 (2187th meeting) by Human Rights Committee, ICCPR/C/21/Rev.1/Add.13.

248 Cranston, Maurice, What are Human Rights, 1973, Taplinger Publishing Co., Inc. New York, New York, the USA, page 31 .

${ }^{249}$ Henkin, Louis, (ed), The International Bill of Rights: the Covenant on Civil and Political Rights, Columbia University Press, New York, 1981, page 178.
} 
Permissible limits are statements of duties, rather than rights, because the RLR is framed in negative terms. ${ }^{250}$ That is, States must not prohibit or obstruct a person's attempt to leave and return. ${ }^{251}$ The permissible limits on the RLR are of a general nature. Individual States are free to enact specific rules regulating the RLR within their jurisdiction. In many cases, permissible limits relating to the RLR apply to other human rights. Although the words used by international instruments should be uniformly interpreted, their practical significance may vary according to character of the right to which they relate.

If States correctly interpret permissible limits, abuse of the RLR is less likely. Examples of permissible limits include road rules, access to nature reserves or animal sanctuaries, earthquake, avalanche or quarantine zones, areas of civil unrest and private property. Specific individuals may be subjected to legitimate limits on their the RLR, such as convicted criminals ${ }^{252}$ and those performing military service. ${ }^{253}$

\subsubsection{State practice}

Almost all States impose various limits on the RLR. Generally speaking, they are similar to the terms used in international instruments. However terms concerned vary in the laws of different countries. It is necessary to judge these limits from international migration law rather than only from domestic law.

In the USA:

In the case of comparable magnitude, Koremastu v. United States, 323 US 214, 218, the court

\footnotetext{
${ }^{250}$ Copenhagen Conference on the Human Dimension of the CSCE, June 1990, Article 9.5.

251 Baubock, Rainer, Transnational Citizenship: Membership and Rights in International Migration, Edward Elgar, Cheltenham, the UK, 1994, page 325.

252 Joseph, Sarah and Sehultz, Jenny et ac, The International Covenant on Civil and Political Rights: Cases, Materials, and Commentary: Cases, Materials, and Commentary, Oxford University Press, New York, 2000, page 259.

253 the HRC "acknowledges that it is normal for individual performing military service to be subjected to restrictions in their freedom of movement." Quoted in Joseph, Sarah and Sehultz, Jenny et ac, The International Covenant on Civil and Political Rights: Cases, Materials, and Commentary: Cases, Materials, and Commentary, Oxford University Press, New York, 2000, page 237.
} 
allowed the Government in time of war to exclude citizens from their homes and restrict their freedom of movement only on a showing of "the gravest imminent danger to the public safety". ${ }^{254}$

In the case of Egypt:

Egyptian males who have not competed compulsory military service, may not travel abroad or emigrate, although this restriction can be circumvented. Unmarried women under the age of 21 must have permission from their fathers to apply for passports; unmarried women over 21 have their applications for passports checked by the police; married women require permission from their husbands. ${ }^{255}$

For Fiji, Section 34 (7) of the Constitution of the Republic of the Fiji Islands provides:

A law may limit, or may authorize the limit of, the right of a person to freedom of movement:

(a) in the interests of national security, public safety, public order, public morality or public health; or

(b)for the purpose of protecting the economy of a particular area or the ecology or distinctive culture of the area;

(c) for the purpose of imposing a restriction on the person that is caused by required to secure the fulfilment of an obligation imposed on the person by law; or

(d) for the purpose of imposing causable restrictions on the holders of public offices as part of the terms and conditions of their employment; but only to the extent that the limit is causable and justifiable in a free and democratic society.

In Sri Lanka, Article 12(2)(3) and 13 of the Constitution of the Republic of Sri Lanka stipulate restriction on the RLR as following:

Article 12 Freedom of movement.

12. $[\ldots]$

(2) Every person shall be free to leave the Republic.

(3) Any restrictions shall not be placed on the exercise of the rights declared and recognized by this Article other than such restrictions prescribed by law as are necessary in a democratic society in the interests of national security or public order or national economy or the protection of public health or morality or for the purpose of securing due recognition and respect for the rights and freedoms of others or for the extradition of persons from the Republic.

Article 13 Freedom to return to Sri Lanka.

254 "Right to Travel: the constitutional Case", http://www.ibike.org/cuba/ofac/law.htm(15/11/2004) 16 pages, page 2.

255 Baehr, Peter, Sadiwa, Lalaine and Smith Jacqueline (ed), Human Right in Developing Countries 1996 Yearbook, Kluwer Law International, the Hague, the Netherlands, 1996, page 145. 
13. Every citizen shall be entitled to return to the Republic.

\subsubsection{Interpretation of permissible limits}

Diversity of experience, background, language, and culture of the ICCPR parties ensure that the interpretation of the RLR is not based on one system of law or set of values. The HRC, the authoritative UN body for interpreting the ICCPR, considers that the RLR should have a universal common meaning. ${ }^{256}$

The interpretation of Article 12(3) of the ICCPR is based on customary international law and related international conventions. Article 31 (1) of the Vienna Convention on the Law of Treaties 1980 provides:

A treaty shall be interpreted in good faith in accordance with the ordinary meaning to be given to the terms of the treaty in their context and in the light of its object and purpose. ${ }^{257}$

The "context" refers to the text itself, including its preamble and annexes, any agreements relating to the treaty, and instruments connected with the treaty. Other relevant agreements between States parties that are governed by international law should also be taken into account. ${ }^{258}$ As a central rule of interpretation, an instrument should be construed in accordance with its dominant purpose. In the case of the ICCPR, the purpose is to protect individuals against government excesses.

Further, 'limit clauses' permitting derogations from and limit of rights, should be strictly and narrowly construed. ${ }^{259}$ This point is widely supported. In 1999, the HRC produced a thorough

\footnotetext{
256 Joseph, Sarah and Sehultz, Jenny et ac, The International Covenant on Civil and Political Rights: Cases, Materials, and Commentary: Cases, Materials, and Commentary, Oxford University Press, New York, 2000, page viii

257 Vienna Convention on the Law of Treaties, 1960 adopted 22 May 1960, entered into force 27 January 1980, UN Doc. A/CONF. 39/27.

258 Henkin, Louis, (ed), The International Bill of Rights: the Covenant on Civil and Political Rights, Columbia University Press, New York, 1981, page 293.

259 Quoted in Hannum, Hurst, The right to Leave and Return in International Law and Practice, Martinus Nijhoff Publishers, Dordrecht, the Netherlands, 1987, page 22.
} 
commentary on Article 12 of the ICCPR (General Comment No.27 of the HRC on Freedom of Movement). This represents the most authoritative interpretation of the ICCPR available. ${ }^{260}$ According to Article 5(1) of the ICCPR, any limit must be strictly construed. It provides:

Nothing ... may be interpreted as implying for any State, group or person any right to engage in any activity or perform any act aimed at the destruction of any of the rights and freedoms recognised herein or at their limits to a greater extent than is provided for in the present Covenant.

The EUCM concluded that restrictions of rights might not be applied so as to completely suppress the freedom, but are only necessary for preserving the values which the provision enumerates and protects. Accordingly, the Commission considered whether or not there had been an interference with the right protected and, whether or not this interference was justified in the light of the prescribed restrictions. ${ }^{261}$ Article 29(c) of the AMR have more detailed provisions in this regard:

No provisions of this Convention shall be interpreted as: (a) permitting any State Party, group, or person to suppress the enjoyment or exercise of the rights and freedoms recognised in this Convention or to restrict them to a greater extent than is provided for herein; (b) restricting the enjoyment or exercise of any right or freedom recognized by virtue of the laws of any State Party or by virtue of another convention to which one of the said State is a party; (c) precluding rights or guarantees which are inherent in the human personality or derived from representative democracy as a form of government; (d) excluding or limiting the effect that the American Declaration of the Rights and Duties of Man and other international acts of the same nature may have.

This is consistent with the objective of the limits, which is to ensure the effective enforcement of the RLR, rather than to permit an increase in State power.

\subsubsection{The meaning of the terms used in the limit clauses}

\footnotetext{
${ }^{260}$ Paragraph 11 summary as following: "Article 12, paragraph 3, provides for exceptional circumstances in which rights under paragraph 1 and 2 may be restricted. This provision authorises the State to restrict these rights only to protect national security, public order (order public), public health or morals and the rights and freedoms of others. To be permissible, restrictions must be provided by law, must be necessary in a democratic society for the protection of these purposes and must be consistent with all other rights recognized in the Covenant."

${ }^{261}$ Hanydside v. UK, App. No. 5493/72, European Court of Human Rights, Judgment of 7 December 1976, Ser. A No. 24. Quoted in Sieghart, Paul, The International Law of Human Rights, Oxford University Press, New York, 1983, page 91 .
} 
This subsection will consider the interpretation of limits to the RLR, according to the rules of construction discussed above. These are "provided by law", "national security", "public order" (ordre public), "public health", "public morals", "the rights and freedoms of others" and the "test of necessity", and "consistent with the other rights recognised in the present Covenant".

\subsubsection{1 "Provided by law"}

"Provided by law,"262 suggests that an act must be authorised by specific legal provisions. It presumes that an act illegally authorised can never be justified, regardless of whether it is consistent with other rights. The terms "prescribed by law"263, "in accordance with law"264 and, "pursuant to law" ${ }^{265}$ are found in other international instruments. The former has the same meaning with "provided by law" expressed in the ICCPR. The two latter connote that the action must be satisfied by reference to general legal principles, common law, the rule of law, or accepted government authority ${ }^{266}$ as to provide a rational legal basis to a decision.

"Provided by law" is designed to ensure that citizens are plainly advised of any restrictions on the RLR. ${ }^{267}$ In contrast to Article 13, limits under Article 12(3) must be set down in law or by the judiciary. ${ }^{268}$ As such, the law must be accessible to the public and formulated with sufficiently certain as to enable a person to regulate their conduct and foresee the legal consequences of their action. ${ }^{269}$ General Comment No.27 of the HRC on Freedom of

\footnotetext{
262 The term of "provided by law" was used in Article 12 (2) of the ICCPR and Article 12 (2) of the AFR

263 Article 10 (2) of the CRC; and Article 5 (2) (a) of the Declaration on the Human Rights of Individuals Who are not Nationals of the Country in Which They Live, 1985.

264 Article 2 (3) of the EHR P4.

265 Article 22 (3) of the AMR.

26610 GAOR Annexes, UN Doc. A/2929 1955 pages 58-59.

267 De, Sous La Direction (ed), The Limit of Human Rights in Comparative constitutional Law, Les Edition Yvon Blais Inc. Canada, 1986. Also see opposite opinion, the term of "provided by law" could be satisfied only by a statute by either national congress or provincial congress." pages 11-12.

268 Nowak, Manfred, U.N. Covenant on Civil and Political Rights: CCPR Commentary, Kehl am Rhein, Strasbourg, Arlington, Germany, 1993, page 209.

269 Malone v. the UK, App. No. 8691/79, European Court of Human Rights, Judgment of 2 August 1984, Ser. A No. 82, page 30; Silver et al v. the UK, App. No. 5947/72, European Court of Human Rights, Judgment of 25 March 1983, Ser. A No. 61; Handyside $v$. the UK, App. No. 5493/72, European Court of Human Rights, Judgment of 7 December
} 
Movement stated that laws should adopt precise criteria for the application of restrictions of freedom, and may not confer unfettered administrative discretion.

'Law' means the domestic law of a State. Importantly, legal limits may either relate to the limit of the substantive right to leave and return or to administrative procedure. It is possible to detract from the RLR protection by erecting bureaucratic barriers that deny access to appeals against administrative decisions. The EUCT asserted that the word "law" covers not only statute law, but also unwritten law, subordinate legislation and Royal the Decrees. ${ }^{270}$ In Silver $v$ United Kingdom, the Court held that:

A norm cannot be regarded as a "law" unless it is formulated with sufficient precision to enable the citizen to regulate his conduct: he must be able - if need be with appropriate advice - to foresee, to a degree that is causable in the circumstances, the consequences which a given action may entail. $^{271}$

Mere administrative provisions are insufficient. Unfettered administrative discretion, without clear legislative directives and adequate notice to an applicant of the grounds on which a request is to be granted or denied, would not be sufficient to meet the requirement that limits be "provided by law". ${ }^{272}$ Limiting the right to leave by way of administrative act, directive or plan is only permissible when the grounds upon which the right is interfered with are sufficiently certain. It is noted that the HRC is not qualified to evaluate whether the responsible departments of a State have correctly interpreted and applied its domestic law, unless it is established that they acted in bad faith or committed an abuse of power. ${ }^{273}$

1976, Ser. A No. 24; Pinkney v. Canada, Communication No. 27/1978, Human Rights Committee, Annual Report, 37 UN GAOR, Supp. No. 40, 1982 page 10.

${ }^{270}$ Sunday Times v. the UK, X. v. Switzerland, (7055/75) Report: DR 19.5; and De Wilde, Ooms and Versyp v. Belgium (2832/66; 2835/66; 2899/66) Judgment: 1 EHRR 373; Quoted in Sieghart, Paul, The International Law of Human Rights, Oxford University Press, New York, 1983, page 91-92.

271 Silver et al v. the UK, App. No. 5947/72, European Court of Human Rights, Judgment of 25 March 1983, Ser. A No. 61; and Sunday Times v. the UK, (7055/75) Report: DR 19.5.

272 Response of the representative of the Ukrainian S.S.R. to questions by members of the Human Rights Committee, UN Doc. the ICCPR/CSR. 612, 1985, page 9.

${ }^{273}$ Maroufidou v. Sweden (R. 13/58) the HRC 36, 160, Quoted in Sieghart, Paul, The International Law of Human Rights, Oxford University Press, New York, 1983, page 92. 
As a final point, one must be careful to assess what is lawful in the context of the RLR because of the complex relationship between international and domestic law. I am mindful of the words of Sam Blay and Ryszard Piotrowicz about lawfulness in the context of human rights. Their words can be cited to argue for a way to judge the lawfulness of domestic provisions related to the RLR:

It is difficult to maintain the argument, as Australia did in $A V$ Australia, that the municipal law is in itself sufficient to provide the standard to assess the lawfulness of State conduct where international law seeks to reply on municipal standards and oversight, on the one hand, and national sovereignty and responsibility, on the other hand. Nevertheless, the point still remains that international obligations, particularly in the domain of human rights, if they are to be implemented in municipal law, would have little meaning if the eventual standard for compliance is the municipal law regime alone. ${ }^{274}$

\subsubsection{2 "National security"}

The "nation" is a political entity constituted by a large group of people having a common origin, language and tradition. ${ }^{275}$ Nationhood does not contemplate the survival of any particular government or ruling elite, whether that government has been democratically elected or imposed upon the population. ${ }^{276}$ In the context of international law, "security" should be consistently interpreted with the Charter of the United Nations, in which means political independence and territorial integrity, ${ }^{277}$ including the ongoing existence of a State. ${ }^{278}$

National security is generally understood to mean protection of a State from espionage, sabotage, politically motivated violence, the promotion of communal violence, attacks on its

\footnotetext{
274 Blay, Sam and Piotrowicz, Ryszard, "the Awfulness of Lawfulness: Some Reflections on the Tension between International and Domestic Law", in Charlesworth, Hilary, McCorquodale, Robert etc (ed), The Australian Year Book of International Law Volume 21, the Centre of International and Public Law, Faculty of Law, Australian National University, 2001, page 19.

275 Garner, Bryan A., (Editor in Chief), Black's Law Dictionary, 7th edition, West Group, St. Paul, Minn., 1999

${ }^{276}$ Hannum, Hurst, The right to Leave and Return in International Law and Practice, Martinus Nijhoff Publishers, Dordrecht, the Netherlands, 1987, page 28.

277 Kiss, Permissible Limits on Rights, in Henkin, Quoted in Hannum, Hurst, The right to Leave and Return in International Law and Practice, Martinus Nijhoff Publishers, Dordrecht, the Netherlands, 1987, page 28.

${ }^{278}$ Hannum, Hurst, The right to Leave and Return in International Law and Practice, Martinus Nijhoff Publishers, Dordrecht, the Netherlands, 1987, page 28.
} 
defence installations, and from acts of foreign interference. ${ }^{279}$ National security could be invoked as a justification for limiting human rights. ${ }^{280}$ Article 4 of the 1986 Strasbourg Declaration on the RLR provides that:

A restriction based on "national security" may be invoked only in situations where the exercise of the right poses a clear, imminent and serious danger to the State. When this restriction is invoked on the ground that an individual acquired military secrets, the restriction shall be applicable only for a limited time, appropriate to the specific circumstances, which should not be more than five years after the individual acquired such secrets.

The EUCT does not require the declaration of a state of war or national emergency as a precondition to the imposition on limiting the RLR. Limits can be imposed in peacetime to prevent activities such as espionage or to protect military secrets. ${ }^{281}$ Under the ICCPR, an individual cannot be prevented from leaving a country merely on the grounds that he or she holds of State secrets, ${ }^{282}$ other than in times of war or national emergency. ${ }^{283}$

According to Ingles view, a person's activities should only be deemed prejudicial to national security if such activities are criminal, and criminal prosecution would be the best safeguard against the arbitrary denial of the right to leave any country on the grounds of national security. A threat to national security is not established on the grounds of political opinion, religious

\footnotetext{
279 Nygh, Peter E and Butt, Peter (ed), Butterworths Australian Legal Dictionary, Butterworths Australia, page 774. ${ }^{280}$ Hannum, Hurst, The right to Leave and Return in International Law and Practice, Martinus Nijhoff Publishers, Dordrecht, the Netherlands, 1987, page 38; and Human Rights Committee, cited in Joseph, Sarah and Sehultz, Jenny et ac, The International Covenant on Civil and Political Rights: Cases, Materials, and Commentary: Cases, Materials, and Commentary, Oxford University Press, New York, 2000, page 400; However, Kiss, Alexandre Charles opposed this opinion. "A threat to territorial integrity or economic well-being is not in itself sufficient to constitute a threat to national security." Henkin, Louis, (ed), The International Bill of Rights: the Covenant on Civil and Political Rights, Columbia University Press, New York, 1981, page 296.

${ }^{281}$ Henkin, Louis, (ed), The International Bill of Rights: the Covenant on Civil and Political Rights, Columbia University Press, New York, 1981, page 292.

282 Paragraph 5 of General Comment No.27 of the HRC on Freedom of Movement (Article 12)

283 Ingles, Jose D, 1963 Ingles' Study on RLR, the UN Publication Sales No.: 64. XIV. 2 New York, 1963, page 40.
} 
belief, or if the person is specially trained. ${ }^{284}$ Terrorist activities are widely accepted as providing a threat to national security.

Acts constituting threats to national security have been enumerated In Article 4 of the Law of State Security 1993 (PRC) as follows:

An act committed by institutions, organizations or individuals outside the territory of the People's Republic of China, or by other persons under the instigation or financial support of the afore-mentioned institutions, organisations or individuals, or by organisations or individuals within the territory in collusion with institutions, organisations or individuals outside the territory:

(1) plotting to subvert the government, dismember the State or overthrow the socialist system;

(2) joining an espionage organisation or accepting a mission assigned by espionage organisation or by its agent;

(3) stealing, secretly gathering, buying, or unlawfully providing State secrets;

(4) instigating, luring or bribing a State functionary to turn traitor; and,

(5) committing any other act of sabotage endangering State security."

National security assessments are often made by the executive government, with minimal judicial review. Joseph and Schultz observe that:

If executive governments are unprepared to reveal evidence grounding national security decisions to their own judiciary, they are extremely unlikely to reveal such evidence to an international body such as [the HRC]. ${ }^{285}$

\subsubsection{3 "Public order (ordre public)"}

Public order is an ambiguous term that lacks a uniform meaning across jurisdictions. The term generally relates to orderly or peaceful behaviour in public places. "Public order (ordre public)" provides a basis for restricting the RLR in order to promote the efficient functioning of the public institutions. Article 4(e) of the 1986 Strasbourg Declaration on the RLR explains:

\footnotetext{
${ }^{284}$ Kent v. Dulles, 357 the USA 116 (1958); Aptheker v. Secretary of State, 378 the USA 500 (1964); Zemel v. Rusk, 381 the USA 1 (1965); Henkin, Louis, (ed), The International Bill of Rights: the Covenant on Civil and Political Rights, Columbia University Press, New York, 1981, page 178.

285 Joseph, Sarah and Sehultz, Jenny et al, The International Covenant on Civil and Political Rights: Cases, Materials, and Commentary: Cases, Materials, and Commentary, Oxford University Press, New York, 2000, page 274.
} 
A restriction based on "public order (order public)" shall be directly related to the specific interest which is sought to be protected. "Public order (order public)" means the universally accepted fundamental principles, consistent with respect for human rights, on which a democratic society is based.

Loss of public order could cause instability or administrative confusion, affecting society as a whole. Criminal laws provide for a number of public order offences, such as riot and affray, offensive, indecent or obscene conduct, and damage of property. ${ }^{286}$ Public law also regulates activities such as change of name.

The addition of the French concept of ordre public may broaden the concept of "public order". Ordre public applies to the sphere of private law, whereas the common law notion of "public order" relates to the public arena. ${ }^{287}$ The concepts of public order and ordre public form an overarching principle designed to protect a minimum level of public interest and social organisation, consistent not only with the values of the individual society but with universal social norms.

Nowak has questioned, in respect of civil law obligations, whether an individual's freedom to leave the country might be restricted on account of private legal obligations, or to secure payment of a tax liability where there is no accompanying criminal allegation. Article 11 of the ICCPR prohibits imprisonment for private contractual breaches or financial obligations owed to the State or to private entities. Unpaid tax has recently been acknowledged as an acceptable limit on the right to leave. In the Peltonen Case, the HRC concluded that non-performance of a national obligation justifies deprivation of the RLR. ${ }^{288}$ This principle applies to States that require the performance of military service.

\footnotetext{
${ }^{286}$ Nygh, Peter E and Butt, Peter (ed), Butterworths Australian Legal Dictionary, Butterworths, Australia, page 955.

${ }^{287}$ Lockwood, B. Jr., Finn, J. and Jubinsky, G., Working Paper for the Committee of Experts on Limit Provisions, 7 HRQ 35, 1985. Order public may be used to negate private law contacts "in the interest of higher imperatives'; "public order" is not used in the same way in common law jurisdictions.

288 Joseph, Sarah and Sehultz, Jenny et al, The International Covenant on Civil and Political Rights:: Cases, Materials, and Commentary, Oxford University Press, New York, 2000, page 252.
} 


\subsubsection{4 "Public health"}

Limiting the RLR on the grounds of public health, especially through the imposition of quarantine laws, can be regarded as a measure to preserve public order. Henkin points out that psychiatric evaluations cannot be used to deny the RLR. ${ }^{289}$ However, the quarantining of geographic areas following an outbreak of disease or other acute health risks, such as in the vicinity of a nuclear power plant, is permissible. Temporary restrictions on movement to prevent the breakdown of sanitation services are also acceptable. ${ }^{290}$ Support for limiting the RLR on the basis of public health can be adduced from Article 12 of the International Covenant on Economic, Social and Cultural Rights (ICESCR), which provides that:

1. The States Parties to the present Covenant recognise the right of everyone to the enjoyment of the highest attainable standard of physical and mental health.

2. The steps to be taken by the States Parties to the present Covenant to achieve the full realisation of this right shall include those necessary for:

(a) The provision for the reduction of the stillbirth-rate and of infant mortality and for the healthy development of the child;

(b) The improvement of all aspects of environmental and industrial hygiene;

(c) The prevention, treatment and control of epidemic, endemic, occupational and other diseases;

(d) The creation of conditions which would assure to all medical service and medical attention in the event of sickness.

In addition, public health is expressly protected in Article 11 of the ESC and the ESC (Revised) 1996. Under these instruments, such measures can be taken to remove of the causes of ill health and prevention of epidemic, endemic and other disease. ${ }^{291}$ The Additional Protocol to the American Convention on Human Rights in the Area of Economic, Social and Cultural Rights 1988, recognises health as a public good and broadens it terms to include "the enjoyment of the highest level of physical, mental and social well-being". States Parties are obliged to adopt

\footnotetext{
${ }^{289}$ Henkin, Louis, (ed), The International Bill of Rights: the Covenant on Civil and Political Rights, Columbia University Press, New York, 1981, page 179.

290 Jagerskiold, The Freedom of Movement, in Nowak, Manfred, U.N. Covenant on Civil and Political Rights: CCPR Commentary, N. P. Engel, Publisher, Kehl am Rhein · Strasbourg · Arlington, 1993, page 215.

291 Brownlie, Ian and Goodwin-Gill, Guy S. (ed), Basic Documents on Human Rights, 4th edition, Oxford, the UK, 2002, pages 428, 461 and 462 .
} 
measures to provide universal immunisation against the principal infectious diseases and, prevent and treat endemic, occupational and other diseases. ${ }^{292}$

During the Severe Acute Respiratory Syndrome (SARS) epidemic, unaffected countries adopted temporary measures including limiting the freedom of movement and imposing quarantine restrictions, to prevent its proliferation, ${ }^{293}$ in April 2003, 94 countries had imposed travel restrictions on Chinese nationals. ${ }^{294}$ For example, Australia enacted laws to permit the cancellation of a visa where its holder was suspected of SARS infection. SARS affected countries, such as China, adopted temporary measures to limit persons leaving the territory, whether the person was a national or an alien. The Entry and Exit inspection Service and Quarantine Bureau, China, advised people within the territory to postpone overseas travel if SARS symptoms appeared, and to seek diagnosis and treatment. ${ }^{295}$

It is uncertain whether a State must prohibit an individual who presents a health risk from travelling abroad, or may only recommend an individual not travel abroad. If a person must be prohibited from leaving on public health grounds, given that the permissible limits are not applicable to the right to return to one's own country, there is a potential for inconsistency between the right to exercise the permissible limits and the right to return. The situation demonstrates that the right to leave and the right to return can never be entirely separated, despite assertions to the contrary. To overcome this possibility, international co-operation during times of disease outbreak is important.

\footnotetext{
292 Article 10 of Additional Protocol to the AMR in the Area of Economic, Social and Cultural Rights, 1988, Ermacora, Felix, Nowak, Manfred and Tretter, Hannes (ed), International Human Rights: Documents and Introductory Notes, Law Books in Europe, Vienna, Austria, 1993, page 320.

293 “Zhang, Qiyue, Foreign Ministry Spokeswoman, China Understands Travel Restrictions on Nationals", http://www. service.china.org.cn/link/wcm/Show_Text?info_id=64522\&p_qry=enrty (20-05-2003)

294 “The country list of restricting Chinese Travel Nationals" (Buzhun Zhongguo Gongmin Rujing De Guojia) http://www.cnd.org/my/modules/newbb/viewtopic.php\%3Ftopic id=7362\&forum=6 (02-05 2003).

295 Xinhua News Agency, "Proposals on the Health for Exit and Entry, Proclamation: Strengthen Medical Examination for Exit and Entry, Prevent SARS from Spreading worldwide (15-04-2003)", http://news.21 cn.com/domestic/guoshi/2003-04-15/1008114.html (23-07-2003).
} 


\subsubsection{5 "Public morals"}

Public morality is derived from social, philosophical and religious traditions. Limits on the RLR on the grounds of protecting public morals should reflect a pluralist view of society rather than the dominant culture. The HRC has acknowledged, in Hertzberg et al $v$ Finland, that public morals differ widely. There is no universally applicable common standard. Consequently, a margin of discretion must be accorded to the responsible national authorities. ${ }^{296}$ The "margin" seems to mirror the "margin of appreciation" conferred on States Parties to the EHR P4. The margin of appreciation confers the benefit of the doubt with respect to a State compliance with the provisions of the EHR P4. The European Court of Justice (ECJ), in Handyside v. UK, indicated that it was not possible to find a uniform European conception of morals in the domestic law of the various European States. ${ }^{297}$

\subsubsection{6 "The rights and freedoms of others"}

The permissible limits on the RLR to protect the rights and freedoms of others are potentially somewhat of a catchall. The HRC has never commented on its outer limits. It is hoped that "rights' refers to other human rights, though unnecessarily in the ICCPR. ${ }^{298}$ Others are certainly obliged not to interfere with the RLR. Paragraph 6 of General Comment No.27 of the HRC on Freedom of Movement regulates that the State must ensure that the RLR is protected from public and private interference. ${ }^{299}$ Family members (other than parents of minors), employers or other persons may not prevent the departure of any persons from the State. ${ }^{300}$ the RLR should not be inhibited by a husband in relation to one's legal or de facto wife, by parents of adult daughters, or by the State in relation to the movement of women generally. ${ }^{301}$ Restrictions may

\footnotetext{
296 Joseph, Sarah and Sehultz, Jenny et al, The International Covenant on Civil and Political Rights: Cases, Materials, and Commentary, Oxford University Press, New York, 2000, page 393.

${ }^{297}$ Handyside v. the UK, App. No. 5493/72, European Court of Human Rights, Judgment of 7 December 1976, Ser. A No. 24.

298 Joseph, Sarah and Sehultz, Jenny et al, The International Covenant on Civil and Political Rights: Cases, Materials, and Commentary: Cases, Materials, and Commentary, Oxford University Press, New York, 2000, page 407.

299 Paragraph 6 of General Comment No.27 of the HRC on Freedom of Movement (Article 12)

300 Article 4 (f) of Strasbourg Declaration on the Right to Leave and Return, adopted by Experts on the Right to Leave and Return on 26 November 1986.

301 Paragraph 16 of General Comment No.27 of the HRC on Freedom of Movement (Article 12)
} 
be imposed to avert avoidance of an individual's duty to support their children; but it is otherwise difficult to deny the RLR unless the right of another will be adversely affected. ${ }^{302}$

\subsubsection{7 "The test of necessity"}

the RLR can be limited if it is "necessary" to do so. The ICCPR refers only to "necessary", Article 22(3) of the AMR and Article 2 of the EHR P4 qualify the term with the expression "in a democratic society". Neither term is used in Article 12 (2) of the AFR or Articles 18 and 19 of the ESC.

The absence of the words 'in a democratic society' in the ICCPR seems to stem from the understanding that the concept of democracy might be interpreted differently in various countries. However, a democratic society could be characterised by its respect for the principles of numerous human rights conventions. Paragraph 16 of General Comment No.27 of the HRC on Freedom of Movement plainly requires a restriction of the RLR on the grounds of necessity to be based on clear legal grounds and be proportionate to the circumstances of the case. Finally, paragraph 12 of General Comment No.27 of the HRC on Freedom of Movement accepts that permissible restrictions must be necessary in a democratic society.

The term "necessary" infers that the act is essential or unavoidable. ${ }^{303} \mathrm{P} \mathrm{K} \mathrm{McWilliams} \mathrm{argues}$ that an act is necessary if performed in "an emergency to causeably protect health, life or property" and "there is no alternative". Where an act "interferes with the interests of another for the purpose of preventing harm to self or others', "imminent peril must exist." 304 Paul Sieghart argues that the notion "necessary" implies the existence of a "pressing social need" which may include a "clear and present danger," determined by the circumstances of a given case. ${ }^{305}$

\footnotetext{
302 Hannum, Hurst, The right to Leave and Return in International Law and Practice, Martinus Nijhoff Publishers, Dordrecht, the Netherlands, 1987, page 43.

303 Hornby, A. S., Oxford Advanced Learner's English-Chinese Dictionary, $4^{\text {th }}$ edition, The Commercial Press and Oxford University Press, Hong Kong and Beijing, 1997, page 983.

304 McWilliams, P.K., Canadian Criminal Evidence, 3rd edition, Canada Law Book, Aurora, 1988, pages 4-11.

305 Arrowsmith v. the UK (7050/75) Report : DR 19.5; Golder v. the UK (4451/70) Judgment: 1 EHRR 524; James, Young and Webster $v$. the UK; Sunday Times $v$. the UK, (7055/75) Report: DR 19.5; Handyside v. the UK, App. No.
} 
The application of the justification of necessity involves balancing the rights of the individual and the utilitarian 'greater good'. The State should attach priority to the rights of individuals when restricting the RLR. The HRC has indicated that the mere assertion by a State that an individual was engaged in 'subversive activities' is not sufficient to discharge the burden of showing that detention of that individual was "necessary" within the meaning of Article 19 (3) of the ICCPR. Article 4(c) of the 1986 Strasbourg Declaration on the RLR defines a restriction as 'necessary', "only if it responds to a pressing public and social need, pursues a legitimate aim and is proportionate to that aim." The requirement of necessity underscores the principle that restrictions on the RLR are always the exception, not the rule.

\subsubsection{8 "Consistent with the other rights recognised in the present Covenant"}

The phrase "consistent with the other rights recognised in the present Covenant" concedes that a person's the RLR may be inconsistent with other rights or freedoms recognised in international conventions. the RLR cannot be used to interfere with other rights or freedoms. To overcome an inconsistency under international law, domestic laws must be "consistent with the other rights recognised" in the ICCPR. Whether States are to conform to the permissible scope of limits on human rights is a question of international law. It is questionable that States are capable of determining the permissible limits of the RLR. It is therefore vital to create an appropriate international supervisory body to supervise State acts, and determine whether international standards have been complied with.

\subsubsection{The principle of proportionality}

The principle of proportionality is used to clarify the requirement of necessity. A limitation will only be proportionate to the circumstances that gives rise to the necessity if (i) the measures are carefully designed and rationally connected to achieve the objective; (ii) the right or freedom at issue is minimally impaired; (iii) a proportion exists between the effect of the measures which

5493/72, EUCT, Judgment of 7 December 1976, Ser. A No. 24. Quoted in Sieghart, Paul, The International Law of Human Rights, Oxford University Press, New York, 1983, page 93. 
limit the right and the objective. ${ }^{306}$ The HRC has endorsed the need for proportionality between the restriction of individual rights and the objective. ${ }^{307}$ Thus, the severity, duration and, geographic scope of any limits on the RLR are justified only to the extent that they are strictly necessary and proportionate to achieve the objects of protecting national security, public order, public health and morals, and the rights and freedoms of others.

\subsection{The right to leave the country}

Grotius characterised the right to leave as the most specific and unimpeachable axiom of the law of nations. ${ }^{308}$ According to Article 12(2) of the ICCPR, the right to leave implies the right to leave a country at one's own will, whether the country of nationality, residence or any other country in which an individual finds oneself.

The right to leave is expressly recognised in the Constitutions of numerous States, diverse in their geographical locations, legal traditions and political inspirations. ${ }^{309}$ Some of the more rigorous rules have operated in France, which once required exit visas and China, which has required various forms of exit passes or certificates for its nationals ${ }^{310}$ and aliens. ${ }^{311}$ In practice,

\footnotetext{
306 Dukelow, Daphne A. The Dictionary of Canadian Law, A Carswell Publication, Barrie, Ontario, Canada, 1991, page 835 .

307 Paragraphs 14-15 of General Comment No.27 of the HRC on Freedom of Movement (Article 12). Also see paragraph 6 of General Comment No.31 [80]: the Nature of the General Legal Obligations Imposed on the States Parties to the Covenant, "Where such restrictions are made, States must demonstrate their necessity and only take such measures as are proportionate to the pursuance of legitimate aims in order to ensure continuous and effective protection of Covenant right."

308 Plender, Richard, International Migration Law, Revised 2nd edition, 1988, Martinus Nijhoff Publishers, the Netherlands, page 96.

309 Plender, Richard, International Migration Law, Revised 2nd edition, 1988, Martinus Nijhoff Publishers, the Netherlands, page 95.

310 Article 2, the Provisional Measures on the Exit and Entry National Border of Overseas Chinese 1951 (PRC), promulgated by the Ministry of Public Security.

311 Exit certificates for aliens required under Article 4, the Provisional Measures on Exit of Aliens in China 1954 (PRC), promulgated by the Ministry of Public Security; Exit visas for aliens required under Article 7, Regulations on the Administration of Entry, Exit, Transit, Residence and Travel of Aliens in China 1964 (PRC), promulgated by the State Council; Exit registration cards for aliens, see: Mao, Fengping, (ed), Chujing Rujing Falv Fagui Sijie Yu Xiangying Fagui Zhaibian (The Explanation of the Law and Regulations Governing exit and entry and the Collections of Related Regulations), the Publishing House of Jilin Renmin, Changchun, China 1994, page 77.
} 
a State might violate the right to leave. The most extreme example is that of Cuba, which is party to inter-American Convention on Asylum and the ICCPR. Nevertheless, Cuban nationals have been imprisoned or executed for attempting to leave the territory. This was graphically illustrated in October 1994, when over 40 men, women and children were killed for attempting to flee the island. ${ }^{312}$

This section will firstly analyse who may exercise the right to leave. Recognised grounds for limiting the right to leave and bureaucratic barriers of the right to leave will then be discussed in detail. Finally, this section explores the loss of technical expertise from the State through emigration.

\subsubsection{Who may exercise the right to leave?}

International human rights instruments attribute the right to leave to "everyone", 313 "every person" ${ }^{314}$ and "every individual". ${ }^{315}$ The right to leave is based on citizenship. ${ }^{316}$ Citizens' right to leave cannot be discriminated against on the grounds of social status, occupation, age, gender, religion, ownership of property, race or colour, or political opinion. An example of impermissible discrimination can be found in North Korea, where ordinary people are not allowed to travel abroad, unlike diplomats or members of the department of Foreign Affairs. ${ }^{317}$ The status of a dual national's right to leave is determined by the law of their country of residence, rather than by the law of their State of nationality. For the purpose of establishing the right to leave of dual nationals, the test of effective nationality is applied. ${ }^{318}$

\footnotetext{
312 Section 2 (18) of the Act of Cuban Liberated and Democratic Solidarity, 1996 (the USA), H.R.927, One Hundred Fourth Congress of the United States of America, http://usinfo.State.gov/usa/infousa/laws/majorlaw/h927 enr.htm $(4 / 09 / 2003)$

313 Article 13 (2) of the UDHR; Article 12 (2) of the ICCPR; Article 2 (2) the EHR P4

314 Article VIII of American Declaration of the Rights and Duties of Man, Article 22 (1) the AMR;

315 Article 12 (2) of the AFR.

316 Rubenstein, Kim, Australian Citizenship Law in Context, Lawbook Co., Pyrmont, Australia, 2002, page 285

317 Young, Song Ji, “The Invisible Refugees: North Korean Asylum Seekers in China”, http://iso.hrichina.org/iso/article.adp?article id=4248\&subcategory id=287 (18/05/2003), 8 pages, page 2.

318 Weis, P., Nationality and Statelessness in International Law, 2nd revised editions, Sijthoff \& Noordhodd International Publishers B. V., Alphen aan den Rijn, the Netherlands 1979, page 202.
} 
The right to leave is available to aliens in the territory of a State, ${ }^{319}$ even those unlawfully in the country. ${ }^{320}$ Stateless persons within a State are thus entitled to leave the territory. No provisions in international migration law deny the right of stateless person to leave the country. "Everyone", "every person" or "every individual" implies the inclusion of stateless person. It can also be supported by the principle of non-discrimination on the grounds of race, religion or country of origin.

\subsubsection{Recognised grounds for limiting the right to leave}

States should give effect to the right to leave by enacting legislation or by other means. Conditions cannot be imposed on the right, such as insisting that the right is used for a prescribed purpose, limiting the destination of individuals, or limiting the period of time that a person may remain overseas. ${ }^{321}$ However, the right to leave one country does not mean that a person has the right to enter another, nor does it guarantee the right of return to a country other than the national State. The right to leave can only be limited under the recognised grounds.

\section{Criminal cases}

According to the AMCM, the right to leave is deniable if the individual is accused or has been convicted of a crime. The restriction may also apply to the RLR. ${ }^{322}$ The extent to which the right is denied varies between States. For instance, German law permits the denial of a passport to a person who is accused of any offence. ${ }^{323}$ In China, people who are suspected of any crime by the public security department, "persons undergoing rehabilitation through labour," and people who have been convicted of a crime and are serving a sentence are denied the right to

\footnotetext{
319 Article 13 of the ICCPR; Article 22 (6) of the AMR; Article 12(4) the AFR.

320 Joseph, Sarah and Sehultz, Jenny et al, The International Covenant on Civil and Political Rights: Cases,

Materials, and Commentary, Oxford University Press, New York, 2000, page 250; and also see paragraph 8 of General Comment No.27 of the HRC on Freedom of Movement (Article 12).

321 Paragraph 8 of General Comment No.27 of the HRC on Freedom of Movement (Article 12).

322 Inter-American Commission on Human Rights, Sixth Report on the Situation of Political Prisoners in Cuba, 1979, O.A.S Doc. No. OEA/Ser. L/V/II 48; doc. 7, page 9.

323 Section 7 (1) Passport Law of Germany 1952, Quoted in Plender, Richard, International Migration Law, Revised 2nd ed, Martinus Nijhoff Publishers, Dordrecht, the Netherlands, 1988, page 114.
} 
leave. ${ }^{324}$ By contrast, Japanese legislation imposes fewer limits. A Japanese national will only have their passport confiscated if they are subject to prosecution for criminal offences that are punishable by a term of imprisonment of not less than two years, or if a warrant for the persons arrest has been issued. ${ }^{325}$

\section{Civil cases}

It is unclear whether a pending civil suit justifies denial of the right to leave. In Australia, Belgium, Brazil, Ghana, the Netherlands, Poland and the USA, ${ }^{326}$ the right can be denied if the person is liable for an outstanding debt. In China, permission to leave is denied if the person is party to an unresolved civil dispute. ${ }^{327}$ Under German law, an alien may be prevented from leaving if the person is liable to provide maintenance. ${ }^{328}$ However, denial of the right on the grounds of debt is strongly opposed by the international community. At its most extreme, debt bondage, such as that found in India, ${ }^{329}$ can result in the forcible return of a person to their creditor, effectively resulting in a form of constructive imprisonment.

\section{Performance of public service}

The right to leave can be limited in order to ensure that a person performs a compulsory public service, such as national military service. ${ }^{330}$ The restrictions of the right to leave of individuals who have not yet performed their military service are in principle to be considered necessary for

\footnotetext{
${ }^{324}$ Article 6 Paragraph 2 of the Suggestions of the Ministry of Public Security on Some Issues Concerning the Execution of Law on the Control of Exit and Entry of Citizens 1985 (PRC) and its Detailed Rules of the Implementation 1987 (PRC)

${ }^{325}$ Kenkyusho, Buraku Kaiho, Human Rights in Japan, 1984, Quoted in Plender, Richard, International Migration Law, Revised 2nd ed, Martinus Nijhoff Publishers, Dordrecht, the Netherlands, 1988, page 113.

326 Tiburcio, Carmen, The Human Rights of Aliens under International and Comparative Law, Kluwer Law International, 2001, page 233.

327 Article 8(2) the Law on the Control of Exit and Entry of Citizens 1985 (PRC).

328 German Aliens Law 1965 s 19(2).

329 Bradley, Catherine, What Do We Mean by Human Rights: Freedom of Movement, Franklin Watts, London, 2002, page 39.

${ }^{330}$ Reid, Karen, A Practitioner's Guide to the European Convention on Human Rights, Sweet \& Maxwell, London, 1998 page 246; see German Aliens Law 1965 s 19(2).
} 
the protection of national security and public order. ${ }^{331}$ The people having the obligation to perform public service can be extended to the people who conduct scientific experiments on specific sites. ${ }^{332}$ If an individual was prevented from leaving a country merely on the grounds that he or she is the holder of 'state secrets', or if an individual was prevented from travelling internationally within a specific permit, the basic grounds do not meet the test of necessity and requirements of proportionality. ${ }^{333}$ Despite this, some countries, such as China, restrict people leaving the country who hold national secrets, or have been discharged from active service related to secrets before the known secrets expire. ${ }^{334}$

\section{Aliens}

If aliens violate the law of their residence State, limits may be imposed on their right to leave that are different to those affecting nationals. Each State may determine the extent of those limits. In China, aliens are unable to leave if he or she is (i) a criminal defendant or suspect; (ii) is party to an unresolved civil dispute; (iii) is awaiting decision for any violation of Chinese law and whose case, in the opinion of the responsible department, calls for investigation. ${ }^{335}$

By contrast, Japanese law will only refuse to allow an alien to leave (i) if the person is subject to criminal proceedings for an offence punishable by imprisonment for a minimum of two years, or if a warrant has been issued for their arrest; (ii) if the person has been sentenced to a term of

\footnotetext{
331 Joseph, Sarah and Sehultz, Jenny et al, The International Covenant on Civil and Political Rights: Cases, Materials, and Commentary, Oxford University Press, New York, 2000, page 255.

332 Bradley, Catherine, What Do We Mean by Human Rights: Freedom of Movement, Franklin Watts, London, 2002, page 21.

333 Paragraph 16 of General Comment No.27 of the HRC on Freedom of Movement (Article 12)

334 According to Article 8 (5) of the Law on the Control of Exit and Entry of Citizens 1985 (PRC), if persons who exit from the territory will be harmful to State security or cause a major loss to national interests, approval to exit China shall not be granted to them. Article 6 Clause 3 and 4 of the Explanations of Sixth Bureau of Ministry of Public Security on Issues of Providing Comments of Employed The organisation where the applicant is services of Citizens Exiting Abroad 1989 (PRC) further provides that persons who exit from the territory will be harmful to State security or cause a major loss to national interests, meaning the persons who hold important political, military, economic and technological secrets of the Communist Party of China and the State. After known secrets expire, involved persons may be granted exit of China.

335 Article 23 of the Detailed Rules for the Implementation of the Law on the Control of Exit and Entry of Aliens 1985 (PRC).
} 
penal servitude and the person has not yet served the sentence; (iii) if a warrant for the provisional confinement of the person has been issued for the purpose of extradition. ${ }^{336}$

\subsubsection{Bureaucratic barriers}

According to Oxford Advanced Learner's English-Chinese Dictionary (OAED), 'bureaucracy' means "excessive or complicated official routine, esp. because of too many departments and offices". ${ }^{337}$ The bureaucratic barrier to exercising the right to leave usually occurs when procedures are complex, difficult to obtain information about, when the responsible department cannot be readily accessed, or when there is a delay in processing applications. Procedures for issuing passports should be expeditious, and the applicant should be informed in writing of the cause for a refusal or revocation of the document. ${ }^{338}$ In Gonzalez del Rio v Peru, the HRC accepted that pending judicial proceedings justified delaying the issue of a passport. ${ }^{339}$ However, if the proceedings are unduly delayed, the right to leave the territory cannot be denied. In that case, the applicant had not been permitted to leave Peru for seven years, pending trial. His right to leave had been unjustifiably denied by cause of an undue administrative delay.

The imposition of high administrative costs may adversely affect the right to leave. The cost of applying to leave must be causable. ${ }^{340}$ "Cost" refers both to administrative service fees and taxes. "Causable cost" has been narrowly construed to mean "nominal fees' by Article 13 of

\footnotetext{
336 I.e, Surrender of a Fugitive from Justice Law, No. 68 of 1953, Quoted in Plender, Richard, International Migration Law, Revised 2nd ed, Martinus Nijhoff Publishers, Dordrecht, the Netherlands, 1988, page 113.

${ }^{337}$ Hornby, A. S., Oxford Advanced Learner's English-Chinese Dictionary (Niujin Gaoji Yinghan Shuangjie Cidian), 4th edition, The Commercial Press and Oxford University Press, Hong Kong and Beijing, 1997, page 181

338 Article 10 (d) (e) of the 1986 Strasbourg Declaration on RLR.

339 Gonzalez Del Rio $v$ Peru (263/87) 28/10/1992, Human Rights Committee, cited in Joseph, Sarah and Sehultz, Jenny et al, The International Covenant on Civil and Political Rights: Cases, Materials, and Commentary:, Oxford University Press, New York, 2000, page 252

${ }^{340}$ Henkin, Louis, (ed), The International Bill of Rights: the Covenant on Civil and Political Rights, Columbia University Press, New York, 1981 page 380; Article IV (a) of the 1963 Ingles Draft Principles on RLR, adopted by the UN Sub-Commission on the Prevention of Discrimination and Protection of Minorities, Res. 2B (XV), UN Doc. E/CN. 41846 (1963), page 40.

341 Article IV (c), the 1963 UN Draft Principles on RLR.
} 
the 1972 Uppsala Declaration on the RLR, ${ }^{342}$ and Article 4(g) of the 1986 Strasbourg Declaration on the RLR sets the inspirational target that travel documents should be issued free of charge, or subject only to nominal fees. In 1997, the UN criticised the former Iraqi government for the high administrative costs associated with the issuing of passports to its nationals. ${ }^{343}$

A further bureaucratic barrier to the right to leave is imposed by the requirement of a deposit or return ticket. Chinese residents cannot travel abroad in a group unless a bond is paid. The bond ranges from US $\$ 4,000$ to $\$ 6,000$. This represents a significant sum of money for an ordinary person, in a country where per capita GDP was US\$1,058 in $2003 .{ }^{344}$ Further, according to the CPDPM, a national should not be required to pay a deposit or provide any other form of guarantee of their return to the State. ${ }^{345}$

According to customary international law, a person should not be denied the right to leave on the grounds that they lack authority to enter another State, ${ }^{346}$ or cannot provide a letter of invitation from a foreigner, letter of approval from an employer or family member, or detailed travel route. Were it necessary to obtain the approval of an employer or family member, the individual's right to leave could be subverted by the interests of a third party. Restrictions on families travelling as a group, harassment of applicants by administrators, or refusing an application to leave on the basis that the applicant may damage the reputation of the State present impermissible limits on the right to leave.

\subsubsection{Loss of technical expertise from the State through emigration: the "brain drain"}

\footnotetext{
342 “...Such documents or permits shall be subjected only to nominal fees.” See Article 13 of the 1972 Uppsala Declaration on RLR

343 Concluding Comments on Iraq (1997), the UN Doc. the ICCPR/C/79/Add. 84, paragraph. 14

344 Market Information and Analysis Section, Department of Foreign Affairs and Trade, Australia, China: the Fact Sheet, using the latest data from the ABS, the IMF and various international sources, October 2003

345 Article I (e) of the 1963 UN Draft Principles on RLR.

346 Article 10 (c) of the 1986 Strasbourg Declaration on RLR
} 
The loss of technical expertise from a State through emigration is one of most important issues connected with the right to leave. The three aspects for discussion here are (i) the development of skilled emigration; (ii) the impacts of this type of emigration on original and host countries; and (iii) the debates about depriving the right to leave based on the 'brain drain' or loss of intellectual talent; and (iv) resolving issues related to skilled emigration in migration law.

\subsubsection{The development of skilled emigration}

The term 'brain drain' was coined in the UK in the 1960s to describe the loss of skilled workers and their technical expertise through emigration to States seeking technological development, especially the USA and the former USSR. ${ }^{347}$ This pattern of migration was regarded as a very serious problem by OECD countries during this period, ${ }^{348}$ on the grounds that, in relation to the UK, the loss of its "most talented and highly trained citizens" would cause "incalculable damage" to the British economy. ${ }^{349}$

The notion of the 'brain drain' of skilled emigration has since acquired a connotation of people moving from developing countries to the industrialised West, especially the USA. ${ }^{350}$ The international Monetary Fund (IMF) has estimated that Iran loses $25 \%$ of its professionals through emigration, South Korea loses 15\%, the Philippines lose 10\%, and India and China lose $3 \%{ }^{351}$ In order to avoid the possible loss caused by the 'brain drain', the GDR and Czechoslovakia, the former Warsaw Pact Countris require that emigrating citizens of working age pay back to the State the costs of their education.

\footnotetext{
347 Simanovsky, et al., 1996, Quoted in Iredale, Robyn, “The need to Import Skilled Personnel: Factors Favouring and Hindering its International Mobility", International Migration Vol. 37(1) 1999, 89-114, page 92.

348 Fabian, Y. Muzart, G. and Young, A., "International Movements of Scientists and Engineers in the 1960s as An Aspect of the Mobility of Highly Qualified Manpower" in Friborg, Coran (ed), Brain Drain Statistics: Empirical Evidence and Guidelines, Report on International Expert Meeting in Stockholm 1973 and Guidelines for Future Studies, offset originals i Sundt offset, Stockholm, 1975, page 107.

349 Hogg, Quinton, The Brain Drain, CPC Outline Series No. 1, the Conservative Political Centre, London, 1967, page 3 .

${ }^{350}$ Hannum, Hurst, The right to Leave and Return in International Law and Practice, Martinus Nijhoff Publishers 1987 Dordrecht, the Netherlands, page 35.

351 Stalker, Peter, The No-Nonsense Guild to International Migration, New Internationalist Publications Ltd, Oxford, the UK, 2001, page 104.
} 
The causes of skilled emigration include more career opportunities and higher incomes in destination counties, and concerns about political and economic stability in the national State. In the 1960's Quinton Hogg first rejected the idea of "levelling down" — the pursuit of a crude form of egalitarianism, as a way of promoting talent at home and dissuading skilled people from emigrating. $^{352}$

Skilled emigration has been promoted by the immigration policies of developed countries, which are keen to attract qualified immigrants and students. Globalisation is, in part, a product of this pattern of migration. The USA, Canada, Australia, and New Zealand have implemented "skill selective" and "wealth selective" immigration policies to help highly skilled or professional people relocate. ${ }^{353}$

\subsubsection{The effects of skilled emigration on original and host countries}

\section{Original country}

Peter Stalker has mindfully identified five principle effects of skilled emigration, namely:

(i) a reduction in the country's capacity for long-term economic growth and human development; (ii) deprivation of many urgently needed skills; (iii) the loss of investment dollars for higher education, as university graduates and skilled workers take their qualifications elsewhere; (iv) the social cost borne of family separation as one spouse emigrates, generally a young man, as to place extra burdens on the shoulders of women who have to maintain the household; and (v) the cultural cost of emigration, as young men, who have few opportunities at home have come to regard emigration as a rite of passage. ${ }^{354}$

However, skilled emigration is not necessarily detrimental to the country of origin. Many developing countries have more graduates than they need; and as Graeme Hugo has identified,

\footnotetext{
352 Hogg, Quinton, The Brain Drain, CPC Outline Series No. 1, the Conservative Political Centre, London, 1967, at 7.

353 Findlay, A.M., Li, F.L., et. al., "Doctors diagnose their destination: an analysis of the length of employment abroad for Hong Kong doctors', Environment and Planning, Vol. 26 1994, 1605-1624

354 Stalker, Peter, The No-Nonsense Guild to International Migration, New Internationalist Publications Ltd, Oxford, the UK, 2001, page 106-107.
} 
highly skilled graduates can contribute more to the development of their home country by working abroad than by staying home. ${ }^{355}$ This emigration pattern means that emigration States need to regard overseas remittance from ex-patriots as a source of national income. On balance, the effect of skilled emigration is negative, despite long-term economic benefits.

\section{Host country}

Both Rachel Freidberg and Jennifer Hunt comment that the effect of immigration on the labour market of host countries is small, and that the impact of immigration on the earnings of the local population depends upon the quality of the immigrants in terms of representing "human capital". ${ }^{356}$ Host countries need to balance the benefit of receiving skilled immigrants who can supplement local shortages, while finding a way to maximise the gain from skilled immigration, without creating additional domestic pressures. They need to maintain a balance between permanent and temporary skilled immigration, facilitate the entry of skilled immigrants, and ensure that the immigrants satisfactorily integrate into the labour market.

\subsubsection{The debates about depriving the right to leave based on the 'brain drain'}

Whether the 'brain drain' caused by skilled emigration is an acceptable cause of depriving an individual of the right to leave is controversial. Jose D Ingles ${ }^{357}$, J Bhagwati ${ }^{358}$ and Richard Plender ${ }^{359}$ independently contend that it is acceptable to impose limits on skilled emigration from developing countries, because the community has some legal claim on the skills and

\footnotetext{
355 Hugo, Graeme, Rudd, Dianne and Harris, Kevin, Emigration from Australia: Economic Implications, Second report on an ARC SPIRT grant CEDA Information Paper No. 77, June 2001, Adelaide University Australia, page 39. 356 Friedberg, Rachel M. and Hunt, Jennifer, “The Impact of Immigrants on Host Country Wages, Employment and Growth”, Journal of Economical Perspectives, Volume 9, Number 2, Spring 1995, pages 23-44, page 42.

357 "Such restrictions are understandable in the case of developing countries which find it necessary to prohibit the departure of persons having specified skills in order to prevent their limited supply of skilled manpower from being drained away by the better conditions offered in industrialized countries”, Ingles, Jose D, 1963 Ingles'Study on RLR, the UN Publication Sales No.: 64. XIV. 2, New York, 1963, pages 44-45.

358 "Developing countries should levy a tax on the earnings of professional, technical and kindred persons who emigrate from less developed countries to developed countries." Bhagwati, J. (ed) in Taxing the Brain Drain: A Proposal (Vol. I) and The Brain Drain and Taxation, (Vol II), Quoted in Plender, Richard, International Migration Law, Revised 2nd ed, Martinus Nijhoff Publishers, Dordrecht, the Netherlands, 1988, page 301.

359 Plender, Richard, International Migration Law, Revised 2nd ed, Martinus Nijhoff Publishers, Dordrecht, the Netherlands, 1988, page 101.
} 
talents developed by its members at the community's expense. They have also argued that it is justified for those States to impose a "return of service" obligation on people who have been trained at public expense.

Louis Henkin asserts that many countries have more skilled professionals than they can use and can afford to have them to emigrate. Even if there were a shortage of skilled labour, he concludes that States should not prohibit emigration, because to do so would violate the ICCPR. ${ }^{360}$ Carmen Tiburcio agrees with Henkin on the point that deprivation of the right to emigrate would unjustifiably contravene the ICCPR. Moreover, she suggests that the skills of an individual belong to that individual, "not to the community where he or she was educated" and as such, the person cannot be denied the right to leave on the grounds of "owing" their community for their education. ${ }^{361}$ Henkin and Tiburcio's arguments seem more persuasive.

\subsubsection{Solving skilled emigration in migration law}

Although the most direct way of stemming the loss of skilled nationals is by prohibiting their emigration, there are less drastic means of discouraging skilled emigration, or encouraging skilled repatriation. The UN has found that family connections heavily effect a person's decision to repatriate. ${ }^{362}$ The imposition of income tax on the income of an ex-patriot could be used as a restraint on the right to leave. However, the RLR experts agree that citizenship is not a proper foundation for the imposition of taxes, and such taxes would be difficult to enforce without the co-operation of the immigration States. ${ }^{363}$

\footnotetext{
${ }^{360}$ Henkin, Louis, (ed), The International Bill of Rights: the Covenant on Civil and Political Rights, Columbia University Press, New York, 1981, page 378-179.

361 Tiburcio, Carmen, The Human Rights of Aliens under International and Comparative Law, Kluwer Law International, 2001, pages 319-320.

362 Glaser, William A., The Brain Drain: Emigration and Return, Findings of a UNITAR Multinational Comparative Survey of Professional Personnel of Developing Countries who Study Abroad, Pergamon Press, London, 1978, page XXV.

${ }^{363}$ Hufbauer, Gary Clyde, "The State, the individual, and the Taxation of Economic Migration”, in Bhagwati, Jagdish N. and Wilson (ed), John Douglas, Income Taxation and International Mobility, the Massachusetts Institute of Technology, Massachusetts, the USA, 1989, page 93.
} 
Robyn Iredale has addressed the need for a co-ordinated international response to deal with the effects of skilled migration. ${ }^{364}$ A global strategy founded on co-operation, which includes the payment of compensation by immigration States to the original States, through a series of bi-lateral agreements, is needed. Compensatory measures could include the provision of increased training within, and technology transfer to, developing emigration States.

On the domestic plane, governments need to encourage skilled workers to stay at home, and implement migration policies designed to encourage the return of skilled nationals. In the 1960's Quinton Hogg, during the run-up to a general election in the UK asserted that the government should:

Provide an environment in which the pursuit of excellence in every department could flourish. Talent would be encouraged and hard work and distinguished qualifications, unlike virtue, would not have to be their own reward. ${ }^{365}$

India encourages professionals to return home by offering five years of tax-free employment and providing incentives to set up a business. The HKSAR has developed home ownership projects and has mooted the idea of double passport provisions. ${ }^{366}$

\subsubsection{The right to enter another State}

In order to enjoy the right to leave, there must be another country to which a person can enter. ${ }^{367}$ However the right to enter does not form part of the RLR under international conventions. According to Havana Convention on the Status of Aliens 1928, States are free to determine, through legislation, the conditions of entry and residence of aliens in their territory. ${ }^{368}$

\footnotetext{
364 Iredale, Robyn, “The need to Import Skilled Personnel: Factors Favouring and Hindering its International Mobility”, International Migration Vol. 37(1) 1999, 89-114, page 310.

${ }^{365}$ Hogg, Quinton, The Brain Drain, CPC Outline Series No. 1, the Conservative Political Centre, London, 1967, page 7.

366 Iredale, Robyn, “The need to Import Skilled Personnel: Factors Favouring and Hindering its International Mobility", International Migration Vol. 37(1) 1999, 89-114, page 308.

367 Baubock, Rainer, Transnational Citizenship: Membership and Rights in International Migration, Edward Elgar, the UK, 1994, page 326.

368 Article 1 of Havana Convention on the Status of Aliens 1928 "states have the right to establish by means of laws the conditions under which foreigners may enter reside in their territory."
} 
Historically, aliens have never been entitled to enter another country. Blackstone has asserted, "No member of one society has a right to intrude into another." 369 The right to enter, similar to the right to leave, touches on the self-interest of States, and it is common to find the view expressed that these are matters pre-eminently within the reserved domain of domestic jurisdiction. It is thus understandable that the State enjoys an absolute and uncontrolled discretion, or sovereign power, to determine whether, and on what conditions, it will permit the entry of aliens

States generally require aliens to possess identity documents, such as a passport and a visa. In 2000, approximately 190 States required aliens to obtain an entry visa. ${ }^{370}$ Some States discriminate in their treatment of visa applicants, pursuant to the States national interest. ${ }^{371}$ An alien should be admitted once they have been issued with a visa. Justifications for refusal need be on the grounds of upholding public security, public order, public health or morality, or the rights and freedoms of others.

\subsubsection{Procedural right against expulsion}

Nobody can be forced to leave any country, including one's own, without justified causes. ${ }^{372}$ Article 9 of the UDHR provides "no one shall be subjected to arbitrary exile". Article 13 of the ICCPR further provides that:

An alien lawfully in the territory of a State Party to the present Covenant may be expelled therefrom only in pursuance of a decision reached in accordance with law and shall, except where

\footnotetext{
369 Henriques, H. S. Q., The Law of Aliens and Naturalisation including the Text of the Aliens Act, 1905, Butterworth \& Co., London, 1906, page 9.

${ }^{370}$ Martin, Philip and Widgren, Jonas, International Migration: Facing the Challenge, Population Reference Bureau, Washington D.C., 2002, pages 39, page 4.

${ }^{371}$ For example, in relation to the granting of student visas, Australia classifies countries into five groups. The applicant will be treated differently, depending on the group into which their country has been classified. Following September 11, the USA amended its immigration regulations such as to require applicants from Arab States to meet additional requirements.

372 There are three different expressions, "free" or "freely" or "has the right" relating to the act of the right to leave in international instruments. What they claim in nature is the way in which everyone is entitled to the right to leave in the line with one's own will, rather than government or others' will. Based on the right to leave, nobody can be forced to leave any country including one's own, without justified causes.
} 
compelling causes of national security otherwise require, be allowed to submit the causes against his expulsion and to have his case reviewed by, and be represented for the purpose before, the competent authority or a person or persons especially designated by the competent authority.

Article 13 regulates only the procedure and not the substantive grounds for or against expulsion. ${ }^{373}$ It thus does not strictly protect an alien from expulsion, so long as procedural guarantees to expulsion are available. Adherence to procedural safeguards helps ensure that the State Party's substantive law regarding expulsion is not being administered in an arbitrary manner. $^{374}$

\section{"Lawful aliens"}

the RLR protected by Article 12 of the ICCPR is subject to the condition that everyone is "lawfully within the territory of a State". ${ }^{375}$ Without the words "an alien lawfully within the territory of a State" the national authorities would be prohibited from expelling an alien who has managed to enter the country legally. The words not only express non-interference with the admission policy of national authorities in regards to aliens, but confine the eligibility of aliens under the procedural right against expulsion. In this context, an alien includes stateless persons.

The provisions do not cover illegal entrants and aliens who have stayed longer than the law or their permits allow. An alien is only lawfully within the territory if they comply with the conditions of their admission ${ }^{376}$ and hold a valid visa. ${ }^{377}$ The domestic law of the State concerned determines "lawfulness'. This means that national law regarding the requirements for entry and stay must be considered in determining the scope of the procedural right against

\footnotetext{
373 Paragraph 10 of General Comment No.15 of the HRC on the Rights of Aliens.

374 Joseph, Sarah and Sehultz, Jenny et al, The International Covenant on Civil and Political Rights: Cases, Materials, and Commentary, Oxford University Press, New York, 2000, page 268.

375 Celepliv. Sweden (456/91) 18/07/1994, Human Rights Committee, cited in Joseph, Sarah and Sehultz, Jenny et al, The International Covenant on Civil and Political Rights: Cases, Materials, and Commentary, Oxford University Press, New York, 2000, page 247.

376 14102/88 Sweden, (Dec.) October 9, 1989, 63 D.R. 195; 12068/86 Germany, December 1, 1986, 51 D. R. 237, Quoted in Reid, Karen, A Practitioner's Guide to the European Convention on Human Rights, Sweet \& Maxwell, London, 1998, page 247.

377 21069/92 S. Mar., (Dec.) July 9, 1993, 75 D.R. 245, Quoted in Reid, Karen, A Practitioner's Guide to the European Convention on Human Rights, Sweet \& Maxwell, London, 1998, page 271.
} 
expulsion. If the legality of an alien's entry or presence in the territory is in dispute, any decision on this point leading to expulsion or deportation ought to be taken in accordance with Article 13 of the ICCPR. ${ }^{378}$ Article 13 protects lawful aliens against being arbitrarily expelled, regardless of the content of the domestic law of a State party. Causes for the expulsion of an unlawful alien must be given if the decision is based on public interest. ${ }^{379}$

\title{
"In pursuance of a decision reached in accordance with law" 380
}

The phrase "in pursuance of a decision reached in accordance with law" means that a decision must be made lawfully and in a manner that is procedurally fair and free from discrimination. ${ }^{381}$ The HRC has comprehensively explained the meaning of the term in Maroufidou v. Sweden, which is worth reproducing:

\begin{abstract}
The reference to "law" is to the domestic law of the State party concerned, though of course the relevant provisions of domestic law must in themselves be compatible with the provisions of the ICCPR. ... The interpretation of domestic law in the context of protecting aliens against arbitrary expulsion is essentially a matter for the courts and authorities of the State party concerned. It is not within the powers or functions of the Committee to evaluate whether the competent authorities of the State party in question have interpreted and applied the domestic law correctly in the case before it under the Optional Protocol, unless it is established that they have not interpreted and applied it in good faith or that it is evident that there has been an abuse of power. ${ }^{382}$
\end{abstract}

Generally, the HRC will not overturn a State's decision in the absence of clear procedural defects.

\section{Procedural guarantees}

Article 13 of the ICCPR establishes certain procedural guarantees to protect aliens against arbitrary expulsion. Domestic law determines the nature and content of procedural rights against

\footnotetext{
378 Paragraph 9 of General Comment No.15 of the HRC on the Rights of Aliens.

379 Plender, Richard, International Migration Law, Revised 2nd ed, Martinus Nijhoff Publishers, Dordrecht, the Netherlands, 1988 page 475; also for example, A western scholar, who had advised a Chinese dissident, was arrested and expelled from China in 1992. The cause given was that his actions were "incompatible with his status as a tourist." See Decision of 1992, “3 Asian Yearbook of International Law”, pages 344-345 (1993).

${ }^{380}$ For more details of the word of the term 'law', see part 3.3.4.1 "provided by law" of this thesis

381 Article 26 of the ICCPR.

382 No. 58/1979, § 10.1 Cf. also de Zayas \& Moller, 1986 NJIL page 387 f.
} 
expulsion. However, for review of the grounds upon which the person is to be expelled, a decision by a competent tribunal is the minimum requirement. As a feature of procedural fairness, an alien must be allowed to make submissions and be represented to resist expulsion.

The phrase "to have his case reviewed" supports this interpretation. Paragraph 10 of General Comment No. 15 of the HRC on the Rights of Aliens, provides that the principle of Article 13 is related to not only the entitlement to review, but to appeal against expulsion. Article 13 also introduces the requirement of a hearing, although less settled is the question of whether a hearing must be permitted to the alien. ${ }^{383}$ In general, the alien should be afforded an oral hearing, although written submissions may suffice. In the cases of Hammel v. Madagascar, Giry v. the Dominican Republic and Canon Garcia v. Ecuador, the HRC found that the right against expulsion had been violated because the affected person had been denied an opportunity to appeal against the decision. ${ }^{384}$

The term "be represented" means the right to represent oneself, or to appoint suitably qualified counsel. In Chahal $v$. United Kingdom, the EUCT found a decision made by an advisory panel was invalid because there were insufficient procedural safeguards. In that case, the details of the case against the applicant had not been disclosed, and legal representation had not been allowed. 385 The HRC noted with concern, "that adequate legal representation is not available for asylum-seekers effectively to challenge administrative decisions". ${ }^{386}$

\section{"Compelling causes of national security",387}

An alien must be given an effective opportunity to pursue a remedy against expulsion. Those opportunities cannot be granted in a discriminatory manner. ${ }^{388}$ The right against expulsion can

\footnotetext{
383 Goodwin-gill, Guy S., International Law and the Movement of Persons Between States, Oxford University Press, Oxford, 1978, pages 263-265.

${ }^{384}$ Nos. 155/1983, 193/1985, 319/1988, Quoted in Nowak, Manfred, U.N. Covenant on Civil and Political Rights: the ICCPR Commentary, N. P. Engel, Publisher, Kehl am Rhein · Strasbourg · Arlington, 1993, page 229.

385 November 15 1996, R.J.D., 1996-II, No. 22 Quoted in Nowak, Manfred, U.N. Covenant on Civil and Political Rights: the ICCPR Commentary, N. P. Engel, Publisher, Kehl am Rhein · Strasbourg · Arlington, 1993, page 283.

386 The UN doc. the ICCPR/C/79/Add. 55 (1995), paragraph.16.

${ }^{387}$ For more details about the term 'national security', please see part 3.3.4.2 of this thesis.
} 
only be departed from where there are "compelling causes of national security". The HRC held the view in V.M.R.B v Canada that the term "compelling" contained in Article 13 of the ICCPR means that States must provide persuasive evidence of serious national security threats if the person remains in the territory. ${ }^{389}$ Based on the word "compelling" in Article 13 of the ICCPR, States Parties are required to furnish persuasive evidence of serious national security danger. ${ }^{390}$

Obviously, the above widely accepted interpretation of 'compelling' is still too ambiguous to fundamentally reduce the possibility for the State to consider not applying the procedural guarantees against expulsion. A similar issue occurs in the words 'competent authority,' which might well be the same body that has taken the original decision, and there could, therefore, be no right of impartiality. Both of the above weakness may severely reduce the effectiveness of the procedural right against expulsion.

The practice in Europe needs to be noted because Europe rejected the proposal of inserting certain procedural rights against expulsion to the HER P4 in favour of aliens about to be expelled.

The grounds were that to limit rights to those of a procedural nature, was insufficient — it was better to have no provision at all. Firstly, the guarantees would not apply where the State 'considers' compelling reasons other required. Secondly, the 'competent authority' might well be the same body which had taken the original decision, and there could, therefore, be no guarantee of impartiality. ${ }^{391}$

\subsection{The right to return to one's country}

\subsubsection{The general considerations of the right to return to one's country}

\footnotetext{
388 Quoted in Joseph, Sarah and Sehultz, Jenny et al, The International Covenant on Civil and Political Rights: Cases, Materials, and Commentary, Oxford University Press, New York, 2000, pages 268-276.

389 V.M.R.B v Canada (236/87), See Joseph, Sarah and Sehultz, Jenny et al, The International Covenant on Civil and Political Rights: Cases, Materials, and Commentary, Oxford University Press, New York, 2000, page 274.

390 Jagerskiold, S., "Freedom of Movement" Henkin, L. (ed), The International Bill of Rights: The Covenant on Civil and Political Rights, Columbia University Press, New York, 1981, page 184.

391 Goodwin-gill, Guy S., International Law and the Movement of Persons Between States, Oxford University Press, Oxford, 1978, page 291.
} 
The right to return to one's country includes the right to remain in one's own country, the right to return after having left one's own country, and the right to enter the country for the first time if he or she was born outside the country. It also includes the right of return for refugees, and the prohibitions enforced population transfers to other countries. ${ }^{392}$

The right to return is expressly recognised in Article 13 (2) of the UDHR and Article 12 (4) of the ICCPR, which provides that "No one shall be arbitrarily deprived of the right to enter his own country". It is also recognised in Article 3 (2) of the EHR P4, Article 22 (5) of the AMR, Article 12 (2) of the AFR, and other international and regional human rights instruments. These instruments place no restrictions on the right to return, and is guaranteed to nationals in the Constitutions of many countries. ${ }^{393}$ Paragraph 13 of the Schedule to the CSR entitles a stateless person to whom a travel document has been issued according to Article 28 to re-enter the territory of the issuing State at any time during the period of passport validity. Thus the right to return is accepted so widely that its existence as a rule of law is virtually beyond dispute.

Without being admitted to return freely, exiled nationals have to continually move around nobody obviously would like to be subjected to that. Without the right to return, an individual may be subject to political repression, prevented from observing their religion, from obtaining an education or a job of their choice, or may be frustrated in efforts to enjoy family life. If a person cannot return to his or her State of nationality, the person will be stateless.

\footnotetext{
392 Paragraph 19 of General Comment No.27 of the HRC on Freedom of Movement (Article 12)

393 Article 11.1 of German Constitution 1949; Article 44 of Algerian Constitution 1976; Article 50.1 of Cape Verdian Constitution 1992; Article 22 of Congolese Constitution 1992; Article 22 of Congolese Constitution 1992; Article 22 of Costa Rican Constitution 1949; Article 19 of Spanish Constitution 1978; Article 19.1.d of Indian Constitution 1950; Section 6.b of Israel Constitution (Basic Law 13, 1992); Section 6.b of Israel Constitution (Basic Law 13, 1992); Article 16.1 of Italian Constitution 1987; Article 31 of Nicaraguan Constitution 1987; Article 8 of Swedish Constitution 1975; Article 10 of the Constitution of the ROC 1978; Article 8.1 of Antiguan Constitution 1981; Article 14 of Argentinean Constitution 1853; Article 10.1 of Belizean Constitution 1981; Article 10.1 of Belizean Constitution 1981; Article 5, XV of Brazilian Constitution 1988; Article 19.7 a of Chilean Constitution 1980; Article 19.7 a of Chilean Constitution 1980; Article 81 of Honduran Constitution 1982; Article 81 of Honduran Constitution 1982; Article 58.1 of Hungarian Constitution 1949; Article 13. a of Liberian Constitution 1984; Article 11 of Mexican Constitution 1917; Article 56 of Paraguayan Constitution 1967; Article 2.11 of Peruvian Constitution 1993; Article 52.1 of Polish Constitution 1997; Section 36 of Thai Constitution 1997; Article 23 of Turkish Constitution 1982.
} 
Different opinions about the meaning of the terms "one's own country" and "arbitrarily" hamper the complete enforcement of the right to return in the world. Violations of the right to return emerge from time to time, especially not to accept expelled nationals and to exile nationals. Considering the above issues, this section will analyse (i) consequences of violating the right to return; (ii) the term "one's own country"; (iii) the meaning of "arbitrarily"; (iv) the duty to accept expelled nationals and the duty not to expel nationals.

The right to return is fundamental because exile is a fundamental deprivation of one's homeland, a deprivation that goes to the heart of those immutable characteristics that comprise our personal and collective identities. ${ }^{394}$ It is unacceptable to deprive any person of close contact with one's family, friends, or the series of relationships that form one's social environment. As Van P. Panhuys has contended, "the duty to admit nationals is considered so important a consequence of nationality that it is almost equated with it." ${ }^{, 395}$

\subsection{2 "One's own country"}

Customary international law provides that an individual outside his/her country cannot be arbitrarily denied the right to return to it. ${ }^{396}$ Nevertheless, the precise meanings of "one's own country" and "arbitrarily" are disputed and in some respects obscure. An individual must prove that the State in which they wish to enter is their “own country' before being entitled to the right to return to that country. Article 12 (4) of the ICCPR promulgated that "no one shall be arbitrarily deprived of the right to enter his own country", it does not distinguish between nationals, stateless persons and aliens. Thus, it is only possible to identify the persons who are entitled to exercise this right by interpreting "one's own country". 397

\footnotetext{
394 Rosand, Eric, The right to Return under International Law following Mass Dislocation: the Bosnia Precedent? Summer 199819 Michigan Journal of International Law 1091, page 11.

395 Panhuys, P. Van, The Roles of Nationality in International Law: An Outline, 1959, A. W. Sythoff, Leyden, the Netherlands, page 56.

396 Rosand, Eric, “The right to Return under International Law following Mass Dislocation: the Bosnia Precedent?", Summer 199819 Michigan Journal of International Law 1091, page 11. Also see 1974] ECR 11337, page 1351.

397 Paragraph 20 of General Comment No.27 of the HRC on Freedom of Movement (Article 12)
} 
Compared with "the right to enter his own country" in the ICCPR, "the right to enter the State of which he is a national" was used in the $\mathrm{EHR}^{398}$ and the $\mathrm{AMR}^{399}$, "the right to return to his country" was used in 13 (2) of the $\mathrm{UDHR}^{400}$ and Article 12 (2) of the AFR ${ }^{401}$ Obviously, the meaning of the former term is more narrow than "the State of which he is a national" and to "his country".

This term of "one's own country" was initially chosen in favour of "country of nationality" and "country of one's permanent home". This means that individuals who have never lived in their country of citizenship can "enter" the State, although, since they have never resided there, cannot "return". ${ }^{402}$ The intention of having a broader and more precise meaning can be supported by the preparatory work on Article 12 (4) of the ICCPR. Marc J. Bossuyt summarised the preparatory work as following after an overview of the three important international sessions regarding the draft of the ICCPR, Commission on Human Rights, 5th Session (1949), 6th Session (1950) and 8th Session (1952).

Difficulties arose in connection with this provision connecting the right to enter one's own country for States in which the right to return to one's country was governed, not by rules of nationality or citizens, but by the idea of a permanent home. The early drafts dealt only with the right of nationals to "enter" their country. It is intended to cover cases such as those of persons born abroad who have never been to the country of their nationality. Such a formula was not satisfactory for a State which granted the right of "return" to persons who were not nationals but who had established their home in the country. A compromise was reached, based on Article 13, paragraph 2, of the UDHR, by replacing the reference to "country of which he is a national" by the words: "his own country". The right to "enter" the country was retained. ${ }^{403}$

\footnotetext{
398 Article 3 (2) of the HER P4 regulated "no one shall be deprived of the right to enter the territory of the State of which he is a national."

399 Article 22 (5) of the AMR regulated "no one can be expelled from the territory of the State of which he is a national or be deprived of the right to enter it."

${ }^{400}$ Article 13 (2) of the UDHR promulgated "Everyone has the right to ... return to his country."

401 Article 12 (2) of the AFR promulgated "Every individual shall have the right to ... return to his country ..."

402 Hannum, Hurst, The right to Leave and Return in International Law and Practice, Martinus Nijhoff Publishers, Dordrecht, the Netherlands, 1987, page 56.

403 Bossuyt, Marc J., Guide to the Travaux Preparatoires' of the International Covenant on Civil and Political Rights, Martinus Nijhoff Publishers, Dordrecht, the Netherlands, 1987, page 261.
} 
However, Jose Ingles and Richard Plender supported the narrow interpretation. Ingles referred to "[t] he right of a national to return" throughout his study and incorporated the expression in his draft principles. The Ingles Draft Principles on the RLR II (b) provides that "[n] o one shall be arbitrarily deprived of [their] nationality, or forced to renounce [their] nationality, as a means of divesting [them] of the right to return to country." ${ }^{, 404}$ This was adopted by the CPDPM in 1971. Plender asserted that "every State must admit its own nationals to its territory" and that "each State has the right to deny admission to aliens."

Above interpretation was then broadened to include permanent residents by the 1972 Uppsala Declaration on the RLR and the 1986 Strasbourg Declaration on the RLR. Articles 9 and 10 of the 1972 Uppsala Declaration on the RLR affirm that "every person is entitled to return to the country of which [they are] a national," and that "no person shall be deprived of [their] nationality for the purpose of divesting [them] of the right to return to [their] country." Article 12 of the 1972 Uppsala Declaration on the RLR affirms "the re-entry of long-term residents who are not nationals, including stateless persons, maybe refused only in the most exceptional circumstances". Articles 6(b) and 7 of the 1986 Strasbourg Declaration on the RLR expanded the interpretation of "one's own country" in, where is it provided:

Article 6(b): No person shall be deprived of nationality or citizenship in order to exile or to prevent that person from exercising the right to enter his or her country.

Article 7: Permanent legal residents who temporarily leave their country of residence shall not be arbitrarily denied the right to return to that country.

Hurst Hannum, Jagerskiold, Knisbacher, and Mazzawi are supporters of the broadened interpretation. Hannum noted "a newly independent State, might create a right of entry for large numbers of previously stateless persons or even those who held another nationality at one time. $" 406$

\footnotetext{
404 Ingles, Jose D, 1963 Ingles' Study on RLR, the UN Publication Sales No.: 64. XIV. 2 New York, 1963

405 Plender, Richard, International Migration Law, Revised $2^{\text {nd }}$ ed., Martinus Nijhoff Publishers, Dordrecht, the Netherlands, 1988, page 133.

${ }^{406}$ Hannum, Hurst, The right to Leave and Return in International Law and Practice, Martinus Nijhoff Publishers, Dordrecht, the Netherlands, 1987, pages 59-60.
} 
In 1999, the HRC ruled that the scope of "one's own country" is broader than the concept "country of one's nationality". It is not limited to nationality in a formal sense, that is, nationality acquired at birth or by conferral; it embraces, at the very least, an individual who because of his or her "special" ties to or claims in relation to a given country, cannot be considered to be a mere alien. This would be the case, for example, for nationals of a country who have been stripped of their nationality in violation of international law, and of individuals whose country of nationality has been incorporated into or transferred to another national entity, whose nationality is being denied them. ${ }^{407}$

In order to claim rights under Article 12(4) of the ICCPR, the person must either be a national of the relevant State, or has been stripped of his or her nationality by that State, or denied nationality by that State in violation of international law, where the country of nationality has been incorporated into or transferred to another State whose nationality has being denied to them. ${ }^{408}$ Individuals who do not claim rights under Article 12(4) of the ICCPR are deemed to have elected to remain as aliens in the country of residence.

Sarah Joseph, Jenny Schultz and Castan envisaged that it was open to an alien to show that there are well-established links with a State, and that he or she is entitled to claim the protection of Article 12 (4) of the ICCPR. However, this broad interpretation does not appear to be widely accepted or easily implemented. Article 12 (4) of the ICCPR permits an interpretation that might embrace other categories of long-term residents, including stateless persons arbitrarily deprived of the right to acquire the nationality of the country of residence. ${ }^{409}$ The HRC stated that "his own country" as a concept applies to individuals who are nationals and to certain categories of individuals who, while not nationals in a formal sense, are also not "aliens' within

\footnotetext{
407 Paragraph 20 of General Comment No.27 of the HRC on Freedom of Movement (Article 12).

408 Stewart $v$ Canada (538/93) 1/11/1996, Quoted in Joseph, Sarah and Sehultz, Jenny et al, The International Covenant on Civil and Political Rights: Cases, Materials, and Commentary, Oxford University Press, New York, 2000, page 264 .

409 Paragraph 20 of General Comment No.27 of the HRC on Freedom of Movement (Article 12).
} 
the meaning of Article 13, although they may be considered as aliens for other purposes. ${ }^{410}$ This inclusive interpretation provides protection for those who have a special connection with a country. If a person, after entering a foreign country, loses his citizenship in one country, without acquiring citizenship in another, then the State of earlier citizenship is bound to readmit the person at the request of the State in which the person is residing. ${ }^{411}$

Lawrence M. Freidman has observed that the Scott Act 1888 (USA) prohibited 20,000 Chinese immigrants, who had temporarily left the USA, from returning. ${ }^{412}$ Current international instruments endeavour to prohibit similar violations of the RLR in the future. Under the ICCPR, the right to return does not depend on a person's refugee status. Human Rights Watch contended that every individual who has maintained "genuine and effective links" with a territory in question should enjoy the right to return to their own country, regardless of whether he or she is a refugee..$^{413}$

"A genuine and effective link" was defined in the Nottebohm decision of the ICJ. According to the ICJ, "a genuine and effective link to one's own country" can be constituted from various factors, including language, long-term residence, cultural identity, participation in public life, and family ties. The relative importance of each factor depends on the circumstances of the case. ${ }^{414}$ On this basis, a genuine and effective link could diminish over time. However, this would be rare in the case of those who fled from persecution. A determination should not be made in respect of people who have fled until they have had the opportunity to exercise the right to return over a reasonable period of time, have chosen not to exercise the right, or have taken

\footnotetext{
${ }^{410}$ Stewart $v$ Canada (538/93) 1/11/1996, Quoted in Joseph, Sarah and Sehultz, Jenny et al, The International Covenant on Civil and Political Rights: Cases, Materials, and Commentary, Oxford University Press, New York, 2000, page 262 .

411 Weis, P., Nationality and Statelessness in International Law, 2nd revised editions, Sijthoff \& Noordhodd International Publishers B. V., Alphen aan den Rijn, the Netherlands 1979, page 55.

412 Friedman, Lawrence M., A History of American Law, Simon and Schuster, New York, 1973, page 444.

413 Human Rights Watch, "Human Rights Watch Policy on the Right to Return: Relevant Background, the International Covenant on Civil and Political Rights 1966", https://nadaily.com/cgi-bin/nph-proxyb.cgi/010000A/http/www.hrw.org--- (05-07-2003), page 2.

414 Liechtenstein v. Guatemala (Nottebohm Case) Second Phase, Judgement, International Court Journal Reports 1955 , Rep 4.
} 
steps to cut the link. ${ }^{415}$ The right to return is not restricted to nationality or permanent residency status.

In other words, the right to return to the country of one's habituated residence is acceptable. Principle 22 of Concluding Document of the Vienna Meeting of January 15, 1989 provides that, "[the States parties] will allow all refugees who so desire to return in safety to their homes." However, the meeting failed to clarify the conditions under which the refugees would be admitted. This has resulted in some practical problems. ${ }^{416}$

Many Palestinian refugees were born in Egypt, Lebanon and other Middle East countries, where they have lived for more than 50 years. However, these countries have not afforded them the right to return, despite the international obligation to "take the necessary measures" to guarantee Palestinians full freedom of movement between Arab countries in accordance with Protocol for the Treatment of Palestinians in Arab States 1965. In 1960, Palestinians were entitled to receive Egyptian travel documents. However, these documents "did not grant the bearer the right to enter Egypt unless a visa is obtained from the Egyptian consulates abroad". 417 Thus, holders of such documents who were born in Egypt or who had lived there for most of their lives had no right to re-enter Egypt. Egyptian consulates have reportedly refused to grant a re-entry visa to Palestinians born in Egypt, without providing reasons. ${ }^{418}$

\footnotetext{
415 Human Rights Watch, "Human Rights Watch Policy on the Right to Return: Relevant Background: The Human Rights Committee General Comment on Article 12 of the International Covenant on Civil and Political Rights, 1966" https://nadaily.com/cgi-bin/nph-proxyb.cgi/010000A/http/www.hrw.org--- (05-07-2003), page 2.

${ }^{416}$ For example, negotiations between the governments of Nepal and Bhutan to resolve the Bhutanese refugee crisis have failed to find a solution. The governments have been unable to guarantee that Bhutanese refugees would be able to return to their homes, or enjoy basic human rights, or gain access to social services such as education. These factors are critical to achieving a sustainable outcome for the returning refugees. See Human Rights Watch, Nepal/Bhutan: Bilateral Talks Fail to Solve Refugee Crisis International Community Should Take Concerned Action, 28 October 2003, http://www.hrw.org/press/2003/10/nepal-bhutan102803.htm $<15 / 04 / 2004>$

417 Abdul Khader Yassin, The Palestinians in Egypt, Shaml, 1996

418 Human Rights Watch, "Human Rights Watch Policy on the Right to Return: Relevant Background: Treatment and Rights in Arab Host States" https://nadaily.com/cgi-bin/nph-proxyb.cgi/010000A/http/www.hrw.org--(05-07-2003).
} 
In relation to the problems facing Palestinian refugees, "one's own country" should mean a country with which the person has a causable connection through a combination of race, religion, language, ancestry, birth and prolonged domicile. Governments come and go, but political fluctuation should not affect the right to return to one's own country and to have a homeland.

\subsection{3 "Arbitrarily"}

During the drafting the ICCPR, a provision prohibiting arbitrary exile was inserted into Article 12 (4), based on two grounds. The first is Article 9 of the UDHR, which affirms, "no one shall be subjected to arbitrary arrest, detention or exile". The second was the fact that, while in most countries exile no longer existed as a penalty, in some circumstances it might be more humane to exile a person than to inflict on him or her more severe punishment. ${ }^{419}$ Some delegations submitted that the term "arbitrary" was equivalent to "unlawful", but it is clear that this narrow definition is not appropriate - despite the possible preference of the drafters for "deliberate ambiguity" in this area. ${ }^{420}$

According to Black's Law Dictionary, an arbitrary decision is one that "depend[s] on individual discretion; specifically determined by a judge rather than fixed rules, or law; found on prejudice or preference rather than on cause or fact." ${ }^{421}$ Paragraph 21 of General Comment No.27 of the HRC on Freedom of Movement (Article 12) provides that:

The reference to the concept of arbitrariness in this context is intended to emphasise that it applies to all State actions, legislative, administrative and judicial. It guarantees that interference provided for by law should be in accordance with the provisions, aims and objectives of the Covenant and should be, in any event, causable in the particular circumstances.

\footnotetext{
419 Bossuyt, Marc J., Guide to the “Travaux Preparatoires' of the International Covenant on Civil and Political Rights, Martinus Nijhoff Publishers, Dordrecht, the Netherlands, 1987, page 260.

${ }^{420}$ Pechota, The Development of the Convention on Civil and Political Rights, in Henkin, L. (ed), The International Bill of Rights: the Covenant of Civil and Political Rights, Columbia University Press, New York, 1981, pages 32 and 57.

${ }^{421}$ Garner, Bryan A., (Editor in Chief), Black's Law Dictionary, 7th edition, West Group, St. Paul, Minn., 1999, page 100.
} 
According to the HRC, there are few, if any, circumstances in which deprivation of the right to enter one's own country could be causable. A State party must not arbitrarily prevent a person from returning to his or her own country, by stripping that person of nationality or by expelling an individual to a third country. ${ }^{422}$ A country can only derogate from their responsibilities under Article 12(4) of the ICCPR during the extreme circumstances described in Article 4. Article 4 refers to time of national emergency, such as a state of war or a threat of war, ${ }^{423}$ a terrorist emergency, internal political instability, or natural disaster. Paragraph 2 of General Comment 29, States of Emergency (article 4) provides that before a State moves to invoke article 4, two fundamental conditions must be met: the situation must amount to a public emergency which threatens the life of the nation, and the State party must have officially proclaimed a state of emergency.The latter requirement is essential for the maintenance of the principles of legality and rule of law at times when they are most needed. ${ }^{424}$ Even in these situations, States should ensure that their actions are not inconsistent with their other duties under international law, and that they do not involve discrimination on the ground of race, language, religion or ethnicity. ${ }^{425}$

For Article 12(4) to apply, the whole population must be affected by a public emergency. ${ }^{426}$ Paris Standard 1(b) provides that "public emergency" means an exceptional situation of crisis or public change, actual or imminent, which affects the whole population, or the whole population of the area to which the declaration applies, and constitutes a threat to the organisation of the community life of the State. The declaration of a State of emergency may cover the entire territory of the State or any part thereof, depending upon the areas actually affected by the circumstances motivating the declaration. This will not prevent the extension of emergency

\footnotetext{
422 Paragraph 21 of General Comment No.27 of the HRC on Freedom of Movement (Article 12).

423 According to Canada War Measures Act, civil liberties were severely restricted by regulations during the First

World War, the Second World War and the “October crisis' of 1970. See Hogg, P.W., Constitution Law of Canada, 2nd edition. 1985, pages 324-325.

${ }^{424}$ Human Rights Committee, General Comment 29, States of Emergency (article 4), U.N. Doc. CCPR/C/21/Rev.1/Add.11 (2001), http://wwwserver.law.wits.ac.za/humanrts/gencomm/hrc29.html (07/07/2005)

425 Human Rights Watch, "Human Rights Watch Policy on the Right to Return: Relevant Background", https://nadaily.com/cgi-bin/nph-proxyb.cgi/010000A/http/www.hrw.org--- (05-07-2003), page 1.

${ }^{426}$ Ghandhi, P. R., “The Human Rights Committee and Derogation in Public Emergencies', 1989, 32 German Yearbook of International Law 323, page 326.
} 
measures to other parts of the country whenever necessary, nor the exclusion of those parts where such circumstances no longer prevail. ${ }^{427}$ The Paris Standards considered that States with large territorial areas such as Canada, China or the USA, should be allowed to derogate from the terms of Article 12(4) in proportion to the geographical area that is affected by the public emergency, rather than requiring the whole population to be affected.

While exercising emergency powers, States need ensure that the fundamental functions of the legislature remain intact, despite the relative expansion of the authority of the executive. Thus, the legislature should provide general guidelines to regulate executive discretion; and legislative prerogatives, immunities and privileges should remain intact. ${ }^{428}$

A State could prohibit its citizens from returning by refusing to issue a passport or refusing to prolong its validity, or by depriving the person of their nationality. In either event, procedural fairness should be guaranteed so that the decision is not arbitrary. Article II (b) of the 1963 UN Draft Principles on the RLR provide "No one shall be arbitrarily deprived of [their] nationality or forced to renounce [their] nationality as a means of divesting [them] of the right to return to [their] countries." Similar provisions are found in Article 15 (2) of the UDHR, Article 9 of the 1972 Uppsala Declaration on the RLR and Article 6 (b) of the 1986 Strasbourg Declaration on the RLR.

In Marcos v. Manglapus, former President Marcos, his family and supporters were in Hawaii and requested travel documents to return to the Philippines. President Aquino refused the application. The Supreme Court found that the President had not acted arbitrarily because the return of the ousted president threatened the national interest. ${ }^{429}$ If an applicant who has been

\footnotetext{
${ }^{427}$ Quoted in Joseph, Sarah and Sehultz, Jenny et al, The International Covenant on Civil and Political Rights: Cases, Materials, and Commentary, Oxford University Press, New York, 2000, page 625.

428 (B) 3 of Paris Standard, Quoted in Joseph, Sarah and Sehultz, Jenny et al, The International Covenant on Civil and Political Rights: Cases, Materials, and Commentary, Oxford University Press, New York, 2000, page 629.

429 Marcos et al. v. Manglapus et al., 177 SCRA (1989), reproduced in 4 Asian Yearbook of International Law pages 298-299 (1994), page 225.
} 
refused permission to enter the territory attempts to do so, the person may be detained, investigated, and possibly deported to the country from which they have departed.

\subsubsection{The duty not to exile nationals and to accept expelled nationals}

The corollary of requiring a State to permit the entry of a national is that it may not expel a national. In Concluding Comments on the Dominican Republic, the HRC has noted that punishment by exile is inconsistent with the terms of the ICCPR. ${ }^{430}$ Withdrawal of nationality for the purpose of expulsion would be considered arbitrary in light of the UDHR. ${ }^{431}$ The AMR guarantees a right to nationality and prohibits any arbitrary deprivation of that right. ${ }^{432}$ The EHR provides that arbitrary expulsion would occur if a State refused to confer nationality for the purpose of expulsion from the territory. ${ }^{433}$

In ancient Athens, perpetual exile was the only means of avoiding capital punishment. ${ }^{434}$ In some countries, it may be regarded as an alternative to other forms of punishment, such as lifetime imprisonment. There is a reluctance to sanction exile as a form of punishment. ${ }^{435}$ In socialist countries, the issue of expelling nationals mainly concerns the expulsion of political dissidents. Expulsion was used by the former Eastern European socialist regimes as a way of removing political opposition, where imprisonment within the State was undesirable. ${ }^{436}$ Socialist States are also reluctant to allow expelled nationals to return to the territory. For

\footnotetext{
${ }^{430}$ (1993) UN doc. CCPR/C/790/Add. 18, paragraph 6. See Joseph, Sarah and Sehultz, Jenny et al, The International Covenant on Civil and Political Rights: Cases, Materials, and Commentary Oxford University Press, New York, 2000 , page 259 .

431 Article 15 of UDHR provides "Everyone has the right to a nationality. No one shall be arbitrarily deprived of his nationality nor deprived the right to change his nationality."

432 Article 20 (3) of the AMR provides "No one shall be arbitrarily deprived of his nationality or of the right to change it."

433 Jacobs, F. “European Convention on Human Rights'. Quoted in Henkin, Louis, (ed), The International Bill of Rights: the Covenant on Civil and Political Rights, Columbia University Press, New York, 1981, page 183

${ }^{434}$ Vinogradoff, Paul, Outlines of Historical Jurisprudence, Volume Two, The Jurisprudence of the Greek City, Oxford University Press, Oxford, the UK 1922, page 179.

435 Henkin, Louis, (ed), The International Bill of Rights: the Covenant on Civil and Political Rights, Columbia University Press, New York, 1981, page 181

${ }^{436}$ Foldesi, Tamas, The Right to Move and Its Achilles' Hell, The Right to Asylum, spring 19938 Conn. J.. Int'1 L. 289 , page 6 .
} 
example, Chinese authorities granted many political prisoners passports or exit permits to allow them to leave the State in response to sustained diplomatic pressure by the USA in relation to China's most favoured nation status. However, these people were placed on a black list and barred from re-entry. ${ }^{437}$

It should be emphasised that the right to return is - apart from the exception of punishment provided by law - guaranteed without restriction to all nationals, and to stateless persons and aliens who have established a permanent home in the territory of the State into which they wish to enter. It is permissible for States to require proof of nationality or a "genuine and effective link" with the territory. The reduction of statelessness by international agreement may positively moderate the possibility if being exiled. Article 7 1. (a) of Convention on the Reduction of Statelessness 1961 prescribes that if the law of a Contracting State entails loss or renunciation of nationality, such renunciation shall not result in loss of nationality unless the person concerned possesses or acquires another nationality. Article 7 1. (a) further reguates that the provisions of subparagraph (a) of this paragraph shall not apply where their application would be inconsistent with the principles stated in articles 13 (the RLR) of the UDHR.

By contrast, a host country may expel aliens from the territory. This right produces a duty of the country of origin to permit the re-entry of those people. An individual, who is the national of one State, but who resides and is ultimately expelled from another State, has the guaranteed right to return to the State of nationality. This is important because if an individual becomes stateless, the State of nationality is obliged to receive him or her. ${ }^{438}$

An alien may be returned to their country of origin if no other country is prepared to accept them. ${ }^{439}$ States cannot deprive a person of their citizenship in order to prevent that person from

\footnotetext{
${ }^{437}$ Human Rights Watch/Asia and Human Rights in China, China: Enforced Exile of Dissidents: Government “Re-entry Blacklist” Revealed", Vol.7 No.1, January 1995, page 1.

438 Tiburcio, Carmen, The Human Rights of Aliens under International and Comparative Law, Kluwer Law International, 2001, page 215.

439 Nowak, Manfred, U.N. Covenant on Civil and Political Rights: CCPR Commentary, Kehl am Rhein, Strasbourg, Arlington, Germany, 1993, page 228.
} 
exercising the right to return. Currently, States do not directly denaturalise citizens (as was the case in the 1920s and 1930s). Indirect methods are adopted to deprive citizens of the right to return, such as rejecting an application to return on the grounds of an infringement of the host countries' laws or a national law. The cause that implicitly supports this decision is that there will be an unacceptable financial burden placed on the State in relation to dealing with the offence, if the person returns.

\subsection{Conclusions}

The RLR has been affirmed as a fundamental human right in several international instruments and the Constitutions of many States. While retaining its character as a fundamental human right, each State also has the sovereign right to regulate the RLR in accordance with its own laws. The regulation of the RLR however is not only an attribute of sovereignty but an issue with important political, economic and security implications for the State. Limits are thus imposed on the RLR. Given its significance it is understandable and indeed desirable that States regulate or limit the RLR. The regulation or limitation of the RLR must however take account of both the interests of the State and the human rights dimension of the RLR. In other words, only permissible limits are acceptable. The analysis in this chapter will basically correspond to the analysis, from chapters eight to thirteen, dealing with the current issues of the RLR in China. 


\section{Chapter Four \\ The RLR in Selected States and Regions' Practice}

\section{Introduction}

The purpose of this chapter is to provide examples of the way in which the RLR has been implemented in other States and regions in order to assist the Chinese government to determine its reform strategy. Vietnam, Taiwan and the USA have been selected for analysis. Vietnam has been chosen because it represents one of the countries with communist political systems in the world, and the current political and economic climate of reform is similar to that of China. Taiwan has been chosen because it shares the same traditional culture, language and ethnicity of Mainland China, and because there has been a strong migratory interaction between Taiwan and Mainland China since 1949. The USA has been included to illustrate the operation of the RLR in developed countries, for the purpose of assisting China to move forward in its the RLR reform. The structures of each section are similar to that of Chapter three.

\subsection{Vietnam}

\subsubsection{The context in which the RLR exists}

Driving factors of the RLR

Four factors limit the international movement of Vietnamese. For economics, even though Vietnam has had a remarkable development record since 1986, in which the economic reform process (Doi moi) officially started with a focus on a gradual shift from traditional central planning to a market-oriented economy, ${ }^{440}$ it remains one of the poorest countries in the world

\footnotetext{
440 The GDP growth rate was over 8 percent per year during the period 1990-1995, and has averaged nearly 7 percent since then. Real per capital GDP has roughly tripled since 1990 and the share of the population living below the international poverty line has fallen from 58 percent in the early 1990s to 28 percent in 2003. See Kokko, Ari and Sjoholm, Fredrik, Stockholm School of Economics, The Internationalisation of Vietnamese SMEs, draft version: 3 April 2004.
} 
as one of results of many years of war until $1975 .{ }^{441}$ Another basic character of Vietnam is overpopulation. In mid-2002, the population of Vietnam was 80.6 million, one of the largest and densest in Asia. Its population growth rate is 1.3 per 1,000 people. ${ }^{42}$ It has only 0.09 hectares of farmland per head of population, compared with 0.42 in Thailand, and 0.27 in Malaysia. ${ }^{443}$ Vietnam's underdevelopment and overpopulation have created a marked push for its people to go abroad.

In the case of politics, the Communist Party of Vietnam (CPV) has been a leading force of the State and society. It ended political reform after witnessing the Tiananmen Square event in 1989. ${ }^{444}$ No essential human rights reform has been undertaken since then. The persistence of a Confucian heritage in Vietnam, where people have been governed by ethics rather than by law, and exhorted not to leave home, is quite significant. ${ }^{445}$ Lastly, freedom of movement within the territory, and convertibility of the Dong are not guaranteed. ${ }^{446}$

Vietnamese international migration and its official attitude

Vietnamese migration increased with the relaxation of limits on the RLR. The current number of

\footnotetext{
441 According to the World Bank, 51\% of Vietnamese people earn less than US $\$ 100$ per annum, and 25\% of Vietnamese people are food-poor. See World Bank, Vietnam - Poverty Assessment and Strategy, Report No. 13442-VN, World Bank, Washington, D.C. the USA, 1995.

442 Population Division, Department of Economic and Social Affairs, the UN, "Population and Development indicators for Asia and the Pacific, 2002" at International Migration Report 2002, the UN, 2002, http://www.un.org/esa/population/publications/ittmig2002/locations/900.htm (23/05/2003).

443 The UN, Poverty Elimination in Vietnam, the UN, Hanoi, 1995 Quoted in, Nguyen, D.T. and Bandara, J.S., Emigration Pressure and Structural Change: Vietnam, A report prepared under UNDP Technical Support Services 1, ILO East Asia Multidisciplinary Advisory Team (ILO/EASMAT) and ILO Regional office for Asia and the Pacific, Unpublished document issued without formal editing by ILO, Bangkok 199635 pp, pages 18-19.

444 Le, Long, "Vietnamese Communist Party not Interested on "Real Reform", at The Washington Times, Sunday, $8^{\text {th }}$ September 2002, http://www.fva.org/200209/story01.htm (29/11/2004).

445 Thayer, Carlyle A. and Marr David G. (ed), Vietnam and the Rule of Law, Department of Political and Social Change, Research School of Pacific Studies, Australian National University, Canberra, 1993, page 83.

446 The freedom to movement within territory was subject to certain limits established by law for causes of security and public order. Such limits are applied against, "persons considered as a peril to public order and security". See Andreassen, Bard-anders and Swinchart, Theresa, Human Rights in Developing Countries Yearbook 1992, Nordic Human Rights Publications and the Norwegian Institute of Human Rights, Oslo, Norway, 1993, page 356.
} 
Vietnamese emigrants is $250,000,{ }^{447}$ which represents $0.02815 \%$ of the population. This is well below the average migration stock (percentage population) of the least developed countries, which is $1.57 \%$; or of the global average, which is $2.9 \%{ }^{448}$ The above figures demonstrate that on the one hand Vietnam's emigration rate has considerable potential to increase in future, and on the other hand, there are some issues impeding the protection of the RLR in Vietnam, which will be discussed in next six sub-sections. Fortunately, the Vietnamese government has realised a need to bridge or narrow the current gap between Vietnam and the rest of the world. According to the UN, Vietnam accepted that its emigration level is 'too low' and would like to raise it. ${ }^{449}$

\section{The legislation governing the RLR, and its evaluation}

Vietnam has incorporated the RLR into its Constitution and has improved the laws governing exit and entry. The Vietnamese Constitution 1992 and Independent Declaration affirm that human rights are respected. ${ }^{450}$ Article 68 and 82 of the Constitution affirms that citizens shall enjoy the freedom to "freely travel abroad and return home from abroad in accordance with the provisions of the law"; and to afford asylum to refugees. ${ }^{451}$ In 2000, Laws with respect to the

${ }^{447}$ Among 250,000, 50,000 contract workers, 50,000 permanent emigrants and 150,000 informal and illegal emigrants. It will soon reach 300,000. See Nguyen, D.T. and Bandara, J.S., Emigration Pressure and Structural Change: Vietnam, A report prepared under UNDP Technical Support Services 1, ILO East Asia Multidisciplinary Advisory Team (ILO/EASMAT) and ILO Regional office for Asia and the Pacific, Unpublished document issued without formal editing by ILO, Bangkok, 1996, 35 pages, pages 3-4.

448 The migration stock was calculated from the data of the Population Division Department of Economic and Social Affairs, International Migration Report 2002, the UN Secretariat, 2002, ST/ESA/SER.A/220, the UN, New York, 2002, 62 pages, attached table.

449 Population Division Department of Economic and Social Affairs, International Migration Report 2002, the UN Secretariat, 2002, ST/ESA/SER.A/220, the UN, New York, 2002, 62 pages, attached table.

${ }^{450}$ In Vietnam Independence Declaration, former President Ho Chi Minh repeated the civil rights in declaration of the bourgeois (capitalist) revolutions of France and the United States, which read: "Men are created equal. The creator gives them the inalienable rights of right to life, to liberty and to pursuit of happiness. By the liberation of the country, the Vietnamese people turned from slaves into free men." Also see Article 50 of the Constitution of Vietnam 1992, "In the Socialist Republic of Vietnam, human rights in all aspects, political, civil, economic, cultural and social, are respected. They are embodied in the rights of the citizens and provided by the Constitution and the Law."

${ }^{451}$ Under Article 82 of the Vietnamese Constitution 1992, Vietnam shall consider granting asylum to foreigners struggling for freedom, national independence, socialism, democracy and peace, or if they are persecuted because of their scientific work. 
entry and exit of Vietnamese citizens, previously contained in separate instruments, were unified by the Decision No. 210/QD-TTg of 27 October 1999 on the Policy Towards Vietnamese Living Abroad, the Decree on Exit and Entry of Vietnamese Citizens. ${ }^{452}$ The main relevant regulations were strengthened by the Decree on Exit and Entry of Vietnamese Citizens 2000 and the Ordinance on Entry, Exit, Residence and Travel of Foreigners in Vietnam 1993.

The significance of the incorporation of the RLR into the Constitution and the improvement of legislation is of marginal significance. The constitutional provision for the RLR has more meaning from the perspective of ideal desire, than from the perspective of criteria that needed in judging detailed cases. Additionally, the freedom of movement confirmed in the Civil Code of Vietnam 1995 is limited to movement within the territory. ${ }^{453}$ The unification of regulations do not give effect to the RLR, but merely create favourable conditions for the residence and travel of Vietnamese citizens, and relate to national security, social order and safety. ${ }^{454}$ The creation of favourable conditions for residence and travel of citizens forms only part of the RLR. Moreover,

452 Prior regulations include that (1) the Provisions on Exit and Entry of Vietnamese Citizens 1997;

(2) the Regulations on exit and entry of Vietnamese citizens and provisions on the exit, entry, residence and travel of overseas Vietnamese bearing Vietnamese passports in the Government's the Decree No.76/CP of November 6, 1995 amending and supplementing a number of Articles of the Decree No.24/CP of March 24, 1995 on the exit and entry procedures;

(3) the Regulations on exit and entry of Vietnamese citizens and provisions on the exit, entry, residence and travel of overseas Vietnamese bearing Vietnamese passports in the Government's the Decree No.24/CP of March 24, 1995 on the exit and entry procedures;

(4) the Government's the Decree No.48/CP of July 8, 1993 on passports and visas;

(5) the regulations on management of exit and entry of Vietnamese citizens and overseas Vietnamese bearing Vietnamese passports who are on exit, entry, residence and travel as prescribed in the Regulation on management of Vietnamese delegations going abroad and foreign delegations visiting Vietnam, issued together with the Government's the Decree No.12/CP of December 1st, 1992.

453 The Civil Code of Vietnam 1995 creates legal basis for furthering the liberalisation of all productive activities, strengthening democracy, and ensuring social equality and the civil rights of human beings. Article 44 right to free movement and residence provides that "An individual has the right to freedom of movement and residence in accordance with the provisions of law. The movement and selection of place of residence of an individual are decided by the individual in conformity with his/her own needs, capacity and situation. The right of an individual to freedom of movement and place of residence shall only be restricted by a decision of the competent State authorities and in accordance with the orders and procedures provided for by law."

454 Article I 3 of Joint Circular Guiding the Granting of General Passports and Laissez-Passers to Vietnamese Nationals Overseas According to the Government's the Decree No. 05/2000ND-CP of March 3, 2000 on Exit and Entry of Vietnamese Citizens 2002, No.03/2002/TTLT/BCA-BNG. 
the absence of detailed complaint provisions hampers the ability for an individual to seek remedy for a violation of the RLR. Even though Article 22 (2) of the Decree on Exit and Entry of Vietnamese Citizens 2000 provides, "Vietnamese citizens may lodge complaints [...] when their passport applications are rejected $[\ldots]$ or they are not yet permitted to leave the country." Yet the detailed procedural provisions are lacking.

Therefore, the RLR in Vietnam is not strong enough to remove limits imposed, despite the significant advances the country has made towards establishing a more sophisticated legal framework since $1987 .{ }^{455}$ From the international perspective, Vietnam has acceded to the ICCPR (1982), the CERD (1982), and the CRC (1990). ${ }^{456}$ Vietnam is obligated to harmonise national law with its international obligations. The government seems determined to introduce reform at its own pace - "in the light of the historical, social and cultural conditions of the country". 457 The special conditions are easily cited to delay the process of harmonisation. Consequently, in the words of the HRC, there are limits upon the RLR, which are incompatible with the requirements of international human rights treaties to which Vietnam is a party. ${ }^{458}$

\subsubsection{The right to be granted passport}

Vietnamese nationals are entitled to a passport under Articles 2 and 3 of the Decree on Exit and Entry of Vietnamese Citizens 2000 and do not require a visa for exit or entry into the territory. The passport is the only valid foreign travel document in Vietnam. A passport is valid for five years, can be renewed once for a maximum of three years, which is much shorter than the usual period of validity for passports elsewhere in the world of ten years. ${ }^{459}$

In 2003, the US State Department reported that although the Vietnamese government no longer

\footnotetext{
455 "Legal Environment”, http://members.iinet.net.au vembassy (17/11/2003)

456 International Service for Human Rights, "The Ratification Status of the Main Human Rights Treaties", (02-2002) http://www.ishr.ch/About\%20UN/Ratification/Ratification/Ratification\%20-\%20Human\%20Rights20treaties.htm (18-05-2003).

457 “Criminal law revised for better child protection”, Vietnam News. The English Daily, 22 December 1996, page 5.

458 Andreassen, Bard-anders and Swinchart, Theresa, Human Rights in Developing Countries Yearbook 1992, Nordic Human Rights Publications and the Norwegian Institute of Human Rights, Oslo, Norway, 1993, page 349.

459 Article 5 (3) of the Decree on Exit and Entry of Vietnamese Citizens 2000.
} 
requires citizens travelling abroad to obtain exit or re-entry visas, nationals may be prevented

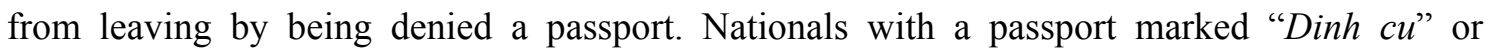
"resettlement" apparently needed a permit to re-enter. Additionally, "persons who publicly or privately expressed critical opinions on religious or political issues" were sometimes prohibited from travelling abroad. ${ }^{460}$

Under Article 9 (1) (a) of the Decree on Exit and Entry of Vietnamese Citizens 2000, general passport shall be granted to State officials, public servants, employees of State enterprises, military and police personnel, and people dispatched by State agencies to work in social, private economic, or foreign organisations. They must supply a photograph sealed and certified by head of the agency or unit directly managing him/her, and documents issued by the person competent to send or permit people to go abroad. The documents requirement may mean that an individual dismisses the idea of applying for a passport if they believe that the suitable person will not support their application, or that they stand to lose their job or opportunities for promotion. Moreover, these additional requirements discriminate between public officials and the general public. $^{461}$

${ }^{460}$ Bureau of Democracy, Human Rights and Labour, U.S. Department of State, Vietnam Country Reports on Human Rights Practices: 2002, Washington D.C., 2003, 26 pages, page 16.

461 Under Article 15 of the Decree on Exit and Entry of Vietnamese Citizens 2000, "The competence to send or permit officials, public employees and staff members of the State agencies, organizations or enterprises to go abroad is stipulated as follows:

(1). The Prime Minister shall decide the exit of the ministers, the heads of the ministerial-level agencies, the heads of the agencies attached to the Government, the presidents of the People's Committees of the provinces and centrally-run cities (hereinafter referred to as the ministerial or provincial heads); the chairmen of the managing boards and the general directors of the corporations directly under the Prime Minister.

(2). The ministerial or provincial heads shall decide the sending or permitting of officials, public employees and staff members of the State agencies, organizations or enterprises (including people working under Labour contracts with a term of 1 year or more) under their direct management competence, to go abroad for public missions or private business.

(3). The ministerial or provincial heads may authorise the heads of the General Departments, Departments or Institutes under their respective ministries; or the heads of the provincial services, boards or branches in their respective provinces to decide the sending or permitting of officials, public employees and staff members under their management (including people working under Labour contracts with a term of 1 year or more) to go abroad. The ministerial or provincial heads shall have to notify in writing the said authorisation, and at the same time introduce the authorisation scope, seals and signatures of the authorised to the Ministry of Public Security and the Ministry for Foreign Affairs. 
Limiting the right of public officials to be granted a passport is consistent with the communist political system, but it is scarcely convincing that the same limits are imposed on citizens employed by foreign-owned enterprises. Nevertheless, Article 9 (1) (b) of the Decree on Exit and Entry of Vietnamese Citizens 2000 establishes similar limits for this group as appear under Article 9(1)(a). ${ }^{462}$ A possible justification for the limits imposed by Article 9(1)(b) is to prevent a loss of skilled labour through emigration. Most employees working in foreign enterprises are highly educated. The head of the enterprise may decide not to consent to the issuance of a passport, in order to retain valuable staff. From the legal perspective, it is unacceptable that private organisations can exercise public power in order to advance their own interests when they are inconsistent with those of their employees

The absence of regulations governing the criteria against which a passport can be refused, or governing time limits on the processing of applications, means that a decision may be based on irrelevant considerations, or made in pursuit of an improper purpose. Citizens' access to passports is also sometimes constrained by factors outside the law, such as by bribery and corruption. ${ }^{463}$

\subsubsection{The right to leave}

\section{The right of Vietnamese citizens to leave}

A Vietnamese citizen can be prevented from leaving if they fall into one of the following cases

(4). The sending of officials, public employees and staff members under the management of such bodies as the Party, the National Assembly, the State President, the Supreme People's Court, the Supreme People's Procuracy, socio-political organizations and other organizations, to go abroad for public missions or the permission of such people to go abroad for private business shall comply with the regulations of the Political Bureau and the regulation on management of officials, public employees and staff members of such agencies and organisations."

462 Article 9 (1)(b) of the Decree on Exit and Entry of Vietnamese Citizens 2000 provide: "For employees working in enterprises with $100 \%$ foreign-owned capital or joint-venture enterprises, the passport application dossier shall comprise: declaration for passport granting, stuck with the applicant's photograph sealed and certified by the chief police of the ward or commune where the applicant registers his/her permanent residence or long-term temporary residence; the document on sending him/her abroad for a public mission or permitting him/her to go abroad for private business, issued by the head of the enterprise."

463 Bureau of Democracy, Human Rights and Labour, the USA Department of State, Vietnam Country Reports on Human Rights Practices: 2002, Washington D.C., 200326 pages, page 16. 
in accordance with Article 14(1) of the Decree on Exit and Entry of Vietnamese Citizens 2000, which provides that:

a. Persons who are examined for penal liability, obliged to serve penal sentences or are neither permitted to leave the country nor granted passports at the request of the investigation agency in service of the criminal investigation.

b. Persons who are obliged to serve their sentences; awaiting the settlement of civil, economic or administrative disputes; awaiting to serve the administrative-sanction decisions; obliged to pay taxes or perform other financial obligations as prescribed by Vietnamese law, except for cases where they make monetary or property deposits or property guarantees or take other security measures for the performance of such obligations.

c. Persons who have violated the regulation on exit and entry and been imposed with administrative warning or more severe sanctions, shall not be permitted to leave the country for 1 to 5 years after their violations are handled.

d. Persons who have been expelled by foreign countries for their violations of the laws of such host countries, if their acts are serious and detrimental to the interests and prestige of Vietnam, they shall not be permitted to leave the country for 1 to 5 years after their return to Vietnam.

e. Persons who are not permitted to leave the country at the Ministry of Health's requests for medical causes.

f. Other cases for causes of safeguarding the national security ${ }^{464}$ and social order and safety.

In practice, some religious leaders and former political prisoners have been denied the right to leave, such as Nguyen Dan Que, a prominent dissident, Thich Tue Sy, a member of the banned Unified Buddhist Church of Vietnam, and Thich Thai Hoa, a leader of the Buddhist order in Hue. ${ }^{465}$ In fact, an absence of access to public records makes it difficult to know just how many people have not been granted permission to leave Vietnam. It does seem clear however that the cases are not isolated. A person who breaches an overseas recruitment contract shall not be recruited overseas again, ${ }^{466}$ and administrative officials within the central government are not

\footnotetext{
464 The lack of definitions of national security may result in arbitrariness. See Stokke, Hugo, Suhrke, Astri and Todtersen, Arne (ed), Human Rights in Developing Countries Yearbook 1997, Kluwer Law International Nordic Human Rights Publications, the Hague, the Netherlands, 1998, page 342.

465 Human Rights Watch, "Human Rights Watch Report 2001: Vietnam: Human Rights Development", www.hrw.org/wr2k1/asia/vietnam.html (4/12/2003), page 2.

466 Article 9 (2) (c) "Vietnam Provisionally Stipulating a Number of Measures to Prevent and Handle Violations in the Field of Sending Labourers and Experts to Work Abroad, 1999", http://asemconnectvietnam.gov.vn/laws/la.asp?idlaw=213 (17/11/2003).
} 
eligible to work abroad. ${ }^{467}$ It is impermissible to exercise administrative power to prevent a person from leaving on the grounds of a contractual breach, because contractual remedies exist to compensate the affected party. The right to leave should only be restricted if the contractual breach threatens national security, social order or public safety.

Additionally, Vietnamese citizens are required to pay a deposit prior to leaving the territory. Labourers, skilled nationals or students who are travelling to the Republic of Korea, Japan or Taiwan are required to pay the equivalent of a one-way airfare and one month's wages. People who are sent to work in any country, other than the Republic of Korea, Japan or Taiwan, are required to pay the equivalent of a one-way airfare. ${ }^{468}$ The deposit is forfeited if the person does not return to Vietnam. ${ }^{469}$ The deposit requirement interferes with the RLR, particularly as many people need to borrow the money to make the payment.

\section{The right of foreigners to leave}

Foreigners are not restricted from leaving Vietnam. Exit visas, entry-exit visas and exit-entry visas were abolished in 2000 under the Ordinance on Entry, Exit, Residence and Travel of Foreigners in Vietnam. The departure of a foreigner may only be delayed if they are currently:

1. the subject of a criminal investigation for criminal responsibility, or is the defendant in a civil, economic or labour dispute;

2. obliged to serve a criminal sentence;

3. obliged to perform a civil, economic or labour order;

4. obliged to perform a decision or pay a fine for an administrative breach, or a tax or other financial obligation. ${ }^{470}$

\footnotetext{
467 Article 2 Clause (a) of the Circular Providing Guidance on the Implementation of the Decree No.07/CP dated 20 January 1995 of the Government, on Sending Vietnamese Labourers Abroad to Work for a Limited Period of Time 1995, The Ministry of Labour, War Invalids and Social Affairs No. 20/LD TBXH-TT.

468 Article 4 of Joint Circular Guiding the Amendments and Supplements to Joint Circular No. 16/2000/ttlt-btc-bldtbxh of February 28, 2000 on Financial Regime for Vietnamese Labourers and Specialists Sent Abroad to Work for Definite Periods of Time 2001, The Ministry of Finance and the Ministry of Labour, War Invalids and Social Affairs No.33/2001/TTLT-BTC-BLDTBXH.

469 Article IV Clause 2 (a) of the Circular Providing Guidance on the Implementation of the Decree No.07/CP dated 20 January 1995 of the Government, on Sending Vietnamese Labourers Abroad to Work for a Limited Period of Time 1995, The Ministry of Labour, War Invalids and Social Affairs No. 20/LD TBXH-TT.

${ }^{470}$ Article 9 the Ordinance on Entry, Exit, Residence and Travel of Foreigners in Vietnam 2000.
} 
However, political causes can hamper the right of foreigners to leave. The 1992 and 2000 Ordinances on Entry, Exit, Residence and Travel of Foreigners in Vietnam aim to create favourable conditions for the exit of foreigners within the legal framework. ${ }^{471}$ The 2000 Ordinance emphasises that it is to:

Contribute towards the implementation of State policies on the development of friendly relations and cooperation with foreign countries, and to protect the interests and sovereignty of the nation. ${ }^{472}$

"Friendly relations and cooperation with foreign countries" is not a legal notion but a political one. The meaning is ambiguous and elastic and may vary over time. This raises doubt as to the extent to which the right of foreigners to leave is protected by law. The 2000 Ordinance requires foreigners exiting Vietnam to respect traditions, customs and habits of the Vietnamese people. ${ }^{473}$ This presupposes that foreigners understand Vietnamese traditions, which is not necessarily the case. Thus, this provision is impractical and likely to be difficult to implement.

Government departments, private organisations and individuals may apply to the immigration authority to delay the exit of a foreigner on the grounds of criminal, civil or administrative liability. ${ }^{474}$ To ensure that these measures are not applied abusively or in relation to small economic claims, exit may be permitted if the foreigner provides a guarantee of money or property, or there is some other measure to ensure fulfilment of the obligation under Vietnamese law. ${ }^{475}$ Alternatively, an applicant who requests that the foreigner's right to leave is interfered with, must compensate the foreigner if the claim is unfounded or if it causes them material loss. ${ }^{476}$ The Immigration Department may suspend the visa or direct security officials stationed at ports to prevent the foreigner's exit. There are no regulations governing either the suspension or the direction.

\footnotetext{
471 Article 2 (1) of the Ordinance on Entry, Exit, Residence and Travel of Foreigners in Vietnam 1992, the Decree No.04-CP date 18 January 1993; and Article 1 (1) of the Ordinance on Entry, Exit, Residence and Travel of Foreigners in Vietnam 2000.

472 Preamble of the Ordinances on Entry, Exit, Residence and Travel of Foreigners in Vietnam 2000.

473 Article 1 (2) of the Ordinance on Entry, Exit, Residence and Travel of Foreigners in Vietnam 2000.

${ }^{474}$ Pursuant to Chapter 1 of the Circular on Entry, Exit, Residence and Travel of Foreigners in Vietnam 1993.

475 Article 9 (2) of the Ordinance on Entry, Exit, Residence and Travel of Foreigners in Vietnam 2000.

${ }^{476}$ Article 9 (5) of the Ordinance on Entry, Exit, Residence and Travel of Foreigners in Vietnam 2000.
} 
According to the US State Department, the Vietnamese government seized the passports of foreigners to prevent their departure in cases of commercial dispute, and hotels commonly retain the passports of their guests until checkout. ${ }^{477}$ In fact, the seizure or retention of a foreigner's passport is not a solution to prevent the exit of foreigners, because their government may issue a new passport to them. On the contrary, the practice is likely only to exacerbate inconvenience to foreigners.

A distinction is drawn between foreigners with and without Vietnamese permanent residency. The former must apply to the Immigration office of Provincial Public Security Department to leave. ${ }^{478}$ The office determines whether the foreigner's departure should be delayed ${ }^{479}$ and withdraws the applicants Certificate of Permanent Residence. It is inconsistent with the norms that permanent residency allows travel between the States of residence and nationality.

\section{The limits on the right to access foreign exchange}

Under Article 14 of the Decree on Foreign Exchange Management 1998, Vietnamese citizens who have a demand for foreign currencies to transfer abroad for allowance and/or inheritance to their families and/or relatives or to pay the costs of tourism, study, work, visits, medical treatment, membership fees and other fees to foreign countries, shall be allowed to buy, transfer or bring foreign currencies abroad. In practices, strict limits are imposed on the right to access foreign exchange, especially that of citizens.

The scope of the right to access foreign exchange is too narrow to fully enjoy the right. The purposes of remitting and/or carrying abroad foreign currency are limited to travel, study, overseas employment, visitation of relatives, medical treatment, payment of membership fees or

\footnotetext{
477 Bureau of Consular Affairs, US Department of State, "Consular Information Sheet: Vietnam”, http://travel.State.gov/vietnam.html (17/11/2003), at 9.

478 Chapter 1(2)[1] the Circular on Entry, Exit, Residence and Travel of Foreigners in Vietnam 1993.

${ }^{479}$ Chapter I 2 Par. 3 of the Circular on Entry, Exit, Residence and Travel Providing Guidelines on the Implementation of the Decree No. 04/CP of the Government dated 18 January 1993 Stipulating in Detail the Implementation of the Ordinance on Entry, Exit, Residence and Travel of Foreigners in Vietnam 1992.
} 
allowances, or to permit family members to inherit funds. ${ }^{480}$ Recipients of remitted funds are limited to parents, children, spouses and siblings. ${ }^{481}$ Furthermore, individuals are not permitted to obtain foreign currency for the purpose of individual overseas investment. ${ }^{482}$

The level of access to foreign exchange is not enough and is ambiguous. For the purpose of allowances for family and relatives living abroad, no more than US \$5,000 can be remitted per year. In the case of inheritances, the maximum is US $\$ 10,000 .{ }^{483}$ Additionally, Vietnamese nationals must be licensed to carry foreign currency out of Vietnam in accordance with a formula. ${ }^{484}$ The approval process is generally very slow, and even often terminated because the applicants must spend a great deal of time gaining required documents, while their demand for foreign currency, especially in relation to the payment of an allowance, may be pressing.

\subsubsection{The right to return}

The right to return is limited by four principal measures. First of all, the passport of a Vietnamese national who is overseas can be revoked, suspended, not extended, or not renewed, on the grounds of national security, social order and safety; or if the person permits another person to buy, borrow or use their passport, or the passport is intentionally damaged. ${ }^{485} \mathrm{Next}$, nationals who are residing in a foreign country as refugees may be refused the right to return. While accurate data is difficult to obtain, some estimates suggest that the total number of

\footnotetext{
${ }^{480}$ Part III Chapter IV Item 1 Article 1 of the Circular Providing Guidelines on the Implementation of Governmental the Decree No.63/ND-CP Dated August 17, 1998, on Foreign Exchange Management 1999.

481 Part III Chapter IV Item 1 Article 1 (a) (5) of the Circular Providing Guidelines on the Implementation of Governmental the Decree No.63/ND-CP Dated August 17, 1998, on Foreign Exchange Management 1999.

482 Circular No.05/2001/TT/BKH, the Ministry of Planning and Investment, quoted in Vietnam Business Forum, Sub-Working Group on Administrative Reform Review of Licenses/Permits and Related Issues, 2002.

483 Part III Chapter IV Item 1 Article 1 (b) (3) and (4) of the Circular Providing Guidelines on the Implementation of Governmental the Decree No.63/ND-CP Dated August 17, 1998, on Foreign Exchange Management 1999.

484 Part III Chapter IV Item 1 (1) (c) Par 1 of the Circular Providing Guidelines on the Implementation of Governmental the Decree No.63/ND-CP Dated August 17, 1998.

485 Article III of Joint Circular Guiding the Granting of General Passports and Laissez-Passers to Vietnamese Nationals Overseas According to the Government's the Decree No. 05/2000ND-CP of March 3, 2000 on Exit and Entry of Vietnamese Citizens 2002, No.03/2002/TTLT/BCA-BNG.
} 
Vietnamese refugees and asylum seekers in foreign countries could be as high as 1 million. ${ }^{486}$ Some of them are not allowed to return. ${ }^{487}$

Thirdly, Vietnamese nationals who have emigrated are generally permitted to return only temporarily. In theory, this group are regarded as nationals for the purpose of being subject to the obligations of citizens, even if they have become dual nationals, unless their former renunciation of Vietnamese citizenship was approved by the President of Vietnam. In practice, expatriates are usually treated as aliens and as having the nationality of their adopted country. ${ }^{488}$ If overseas-based Vietnamese nationals intend to invest or become employed in Vietnam, or are sponsored by relatives, they may be considered for resettlement. According to inter-Ministerial Circular No. 06/TT/LT Guidelines on Decision No. 875/TT 1997, these applicants must satisfy certain preconditions, including being able to demonstrate economic self-reliance, as well as submitting to a formal application process. These conditions interfere with the right of Vietnamese nationals to return.

Lastly, and notably, expatriates may be forced to return if they breach an overseas employment contract, or abscond upon its completion. If this is the case, the individual is made to bear the cost of their return, forfeit their pre-departure deposit, and forego the opportunity to work overseas in the future. ${ }^{489}$

\footnotetext{
${ }^{486}$ Nguyen, D.T. and Bandara, J.S., Emigration Pressure and Structural Change: Vietnam, A report prepared under UNDP Technical Support Services 1, ILO East Asia Multidisciplinary Advisory Team (ILO/EASMAT) and ILO Regional office for Asia and the Pacific, Unpublished document issued without formal editing by ILO, Bangkok 1996, 35 pages, page 13 .

487 Nguyen Van Thuan, a well-known Catholic priest in exile in the Vatican, was not allowed to return to Vietnam, despite the Vatican's request. See Andreassen, Bard-anders and Swinchart, Theresa, Human Rights in Developing Countries Yearbook 1992, Nordic Human Rights Publications and the Norwegian Institute of Human Rights, Oslo, Norway, 1993, page 358.

488 Bureau of Democracy, Human Rights and Labour, US State Department, Vietnam Country Reports on Human Rights Practices: 2002, Washington D.C., 2003, 26 pages, page 16.

489 Article 9 (2) (a) and 9 (2) (d) of Vietnam Provisionally Stipulating a Number of Measures to Prevent and Handle Violations in the Field of Sending Labourers and Experts to Work Abroad, 1999, http://asemconnectvietnam.gov.vn/laws/la.asp?idlaw=213 (17/11/2003).
} 


\subsubsection{Administration of overseas recruitment services}

Given the fact that $20 \%$ of Vietnamese emigrants are contract workers, it is necessary to analyse the management of overseas recruitment services. Their management is characterised by the regime of an operation permit and license to execute contracts and control by State monopoly. Permitted and licensed enterprises need to coordinate with labour-receiving organisations in managing and training labourers, and handling problems that arise overseas during the term of the contract ${ }^{490}$ mainly through the appointment of the government's own overseas officials. ${ }^{491}$

Without the permission to operate, and a license to execute contracts granted by the Ministry of Labour, War invalids and Social Affairs (MLWS), enterprises may not offer overseas recruitment services. The conditions and procedures for issuing operation permits and licenses to execute contracts are rigorous ${ }^{492}$ and complicated. ${ }^{493}$ The State monopoly over recruitment has been a key feature since workers were first sent overseas in 1980. By contrast, government recruitment represents no more than $2 \%$ of the total in the Philippines, Bangladesh, India, or

490 Article 4 (1) of Vietnam Provisionally Stipulating a Number of Measures to Prevent and Handle Violations in the Field of Sending Labourers and Experts to Work Abroad, 1999, http://asemconnectvietnam.gov.vn/laws/la.asp?idlaw=213 (17/11/2003).

491 Article 4 (2) of Vietnam Provisionally Stipulating a Number of Measures to Prevent and Handle Violations in the Field of Sending Labourers and Experts to Work Abroad, 1999, http://asemconnectvietnam.gov.vn/laws/la.asp?idlaw=213 (17/11/2003)

492 Any economic organizations wanting to obtain and operation permit must (i) be a State owned enterprise and have the function to send workers abroad; (ii) have a capital base of at lease 1 billion VN dong (approximately US\$71,000); (iii) ensure that at least two-thirds of its managers and $50 \%$ of its professional cadres are college graduates, and ensure that it has enough cadres with proficient English; and (iv) be knowledgeable about the labour market, labour law, immigration law and international law. See Article III Clause 1 (b) of Circular Providing Guidance on the Implementation of the Decree No.07/CP (20 January 1995) of Sending Vietnamese Labourers Abroad to Work for a Limited Period of Time 1995.

493 The operation permits are valid for three years. The license to execute contracts can only be granted to an economic organization having an operation permit. The scope of the license is determined by the nature of the proposed contracts, but cannot exceed 6 months from the date of issue. In order to obtain a license, the applicant must have a contract from a foreign employer to send a Vietnamese worker abroad; or a contract of an individual worker who wants to execute it through an economic organization. See Article III Clause 2 (b) of Circular Providing Guidance on the Implementation of the Decree No.07/CP (20 January 1995) of The Vietnamese governments, on Sending Vietnamese Labourers Abroad to Work for a Limited Period of Time 1995. 
Thailand. ${ }^{494}$ State organisation can cause inefficiency in delivery of overseas recruitment services. Kuala Lumpur observed that, “The heavy administrative characteristics of Vietnam's labour co-operation system with other countries [are] a grave shortcoming." ${ }^{495}$

Acknowledging the shortcoming of State-owned overseas recruiting agencies, the Vietnamese government requires recruitment enterprises to publicise (i) the number of workers needed; (ii) the criteria for employment; (iii) a job description; (iv) the location of the employment and its working and living conditions; (v) details of wages; ${ }^{496}$ (vi) medical and social insurance; (vii) and the terms of the contract. ${ }^{497}$ In addition, the terms of contracts are regulated by the relevant ministries ${ }^{498}$ and the contract must be explained to the worker and strictly complied with. ${ }^{499}$ Nevertheless, as Clare Waddington points out, these measures do not address the issue of competition in the recruitment services sector. ${ }^{500}$ Therefore, it would be interesting to re-examine the role played by State agencies in the recruitment process and consider whether foreign recruitment operations should be transferred to the private sector, as in other

${ }^{494}$ Nguyen, D.T. and Bandara, J.S., Emigration Pressure and Structural Change: Vietnam, A report prepared under UNDP Technical Support Services 1, ILO East Asia Multidisciplinary Advisory Team (ILO/EASMAT) and ILO Regional office for Asia and the Pacific, Unpublished document issued without formal editing by ILO, Bangkok 1996, 35 pages, pages 11-12.

495 Lumpur, Kuala, Reality of Labour Migration of Vietnam and Her Policies, Paper presented at a Meeting on the Implications of Changing Patterns of Asian Labour Migration, 1991.

496 Article 3 of Vietnam Provisionally Stipulating a Number of Measures to Prevent and Handle Violations in the Field of Sending Labourers and Experts to Work Abroad, 1999, http://asemconnectvietnam.gov.vn/laws/la.asp?idlaw=213 (17/11/2003).

497 Article 1 (1) of Vietnam Provisionally Stipulating a Number of Measures to Prevent and Handle Violations in the Field of Sending Labourers and Experts to Work Abroad, 1999, http://asemconnectvietnam.gov.vn/laws/la.asp?idlaw=213 (17/11/2003).

498 Article 2 of Vietnam Provisionally Stipulating a Number of Measures to Prevent and Handle Violations in the Field of Sending Labourers and Experts to Work Abroad, 1999, http://asemconnectvietnam.gov.vn/laws/la.asp?idlaw=213 (17/11/2003).

499 Article 5 of Vietnam Provisionally Stipulating a Number of Measures to Prevent and Handle Violations in the Field of Sending Labourers and Experts to Work Abroad, 1999, http://asemconnectvietnam.gov.vn/laws/la.asp?idlaw=213 (17/11/2003).

500 Waddington, Clare, International Migration Policies in Asia: A Synthesis of ILO and other Literature on Policies Seeking to Manage the Recruitment and Protection of Migrants, and Facilitate Remittances and Their Investment, Paper presented at Regional Conference on Migration, Development and Pro-Poor Policy Choices in Asia 2003, 21 pages, www.livelihoods.org, $(05 / 12 / 2003)$, at i. 
labour-exporting countries. Alternatively, it may be commercially viable and economically efficient to privatise State owned recruitment businesses. ${ }^{501}$

\subsubsection{The exit and entry administrative system}

In contrast to Western States in which a sole authority is usually responsible for exit and entry administration, in Vietnam various ministries are together responsible. The Ministry of Public Security is the prime authority responsible for exercising exit and entry control over citizens ${ }^{502}$ and foreigners. ${ }^{503}$ Its jurisdiction covers the processing of general passport applications, including the power to extend or revoke a passport, border protection and punishment of breaches. ${ }^{504}$

The Ministry of Public Security coordinates with the Ministry of Foreign Affairs and the Ministry of Defence (with respect to border protection) to control exit and entry of Vietnamese citizens. Diplomatic missions and consular offices are responsible for the administration of passports for overseas Vietnamese citizens pursuant to Article IV 4 of Joint Circular Guiding the Granting of General Passports and Laissez-Passers to Overseas Vietnamese. This function is conducted with the advice of the Ministry of Public Security via the Ministry of Foreign Affairs. ${ }^{505}$

The Department for Management of Labour Cooperation with Foreign Countries under the MLWS is responsible for implementing overseas employment agreements and issuing licenses

\footnotetext{
501 Nguyen, D.T. and Bandara, J.S., Emigration Pressure and Structural Change: Vietnam, A report prepared under UNDP Technical Support Services 1, ILO East Asia Multidisciplinary Advisory Team (ILO/EASMAT) and ILO Regional office for Asia and the Pacific, Unpublished document issued without formal editing by ILO, Bangkok 1996, 35 pages, page 25 .

502 Article 17 of the Decree on Exit and Entry of Vietnamese Citizens 2000.

503 Article 19(1) of Circular on Entry, Exit, Residence and Travel of Foreigners in Vietnam 2000 and The deportation of foreigners is administered by the Ministry of the Interior, under Chapter IV of the Circular on Entry, Exit, Residence and Travel of Foreigners in Vietnam 1993.

${ }^{504}$ Article 17(1) [5] - [6] of the Decree on Exit and Entry of Vietnamese Citizens 2000.

505 Article 17 (1) [4] of the Decree on Exit and Entry of Vietnamese Citizens 2000.
} 
to organizations which operate as recruitment agencies, ${ }^{506}$ and for addressing violations of relevant regulations. ${ }^{507}$ The Ministry of Justice is responsible for verifying the accuracy of information contained in applications for non-Vietnamese Nationality Certificates of foreigners, and requesting the President of the relevant provincial or municipal People's Committee to consider the application. ${ }^{508}$ By contrast, Australian immigration authorities have the power to process and grant non-nationality certificates with consultation of the foreign affairs department.

\subsection{Taiwan (Republic of China) ${ }^{509}$}

\subsubsection{Historical development of regulatory framework governing the RLR in Taiwan}

Taiwan (the Republic of China (ROC)) has officially been a local administrative area of China since 1683, apart from a brief period of Japanese occupation between 1885 and 1945. Taiwan has inherited most of China's socio-economic and cultural values. During the Cold War, exit and entry of Taiwanese nationals was strictly controlled, but since the end of that time, Taiwan's the RLR policy has been relaxed in comparison to that of China.

Even though the freedom of movement is provided in Article 10 of the Constitution of Republic of China $1946,{ }^{510}$ exit and entry were restricted in Taiwan until 1987. Based on an emergency regime, ${ }^{511}$ the Regulations of the Taiwan Province on the Registration of the Exit of the

\footnotetext{
506 Article 8 (2) Vietnam Provisionally Stipulating a Number of Measures to Prevent and Handle Violations in the Field of Sending Labourers and Experts to Work Abroad, 1999, http://asemconnectvietnam.gov.vn/laws/la.asp?idlaw=213 (17/11/2003).

507 Pursuant to Article 12 of Vietnam Provisionally Stipulating a Number of Measures to Prevent and Handle Violations in the Field of Sending Labourers and Experts to Work Abroad 1999.

508 Pursuant to Article 4 (a) of the Circular on Guiding the Granting of Non-Vietnamese Nationality Certificates 1999.

509 Since 1949, at which time the national government moved to Taibei due to the failure in Civil War between the National Party and Communist Party during the period of 1946-1949, the dominated areas of the ROC are limited to Taiwan areas.

510 Article 10 of the Constitution of ROC 1946 provides: "people have the freedom of residence and movement."

511 When promulgating a democratic Constitution, the Kuomingtang also established an emergency regime in Taiwan. On May 10, 1948, ROC government promulgated in the mainland Provisional Amendments for the Period of Mobilisation of the Suppression of Communist Rebellion, Commonly known as the temporary provision. These provisions, designed as supplements to the constitution, were subsequently extended to Taiwan. Moreover, President Chiang Kaishek in January 1950 issued an emergency decree that applied the 1934 martial law to Taiwan. The
} 
Servicemen, Government Employees, Teachers and Travellers of the Taiwan Province 1949 (ROC) suspended Article 10. The Regulations were designed to avert communist attempts to invade Taiwan ${ }^{512}$ and prevent Taiwanese nationals from leaving the territory. This marked the beginning of the exit and entry control system of Taiwan. Originally, the system was administered by the Travel office of the Taiwanese Provincial Police, which was responsible for government officials and civilians, and the Taiwanese Provincial Garrison Command, which was responsible for military personnel. In 1952, these entities merged to form the Military-Civilian Joint Entry and Exit Application Division.

The legislation was amended to the Regulations on the Entry and Exit in Taiwan during the Rebellion Suppression Period 1957 (ROC), because of increased political stability. In 1958, the Military-Civilian Joint Entry and Exit Application Division was replaced by the Entry and Exit Service Division, under the control of the Taiwanese General Garrison Headquarters. By 1972, continued economic growth ${ }^{513}$ and an awareness of democratic principles and human rights ${ }^{514}$ necessitated a transfer of the exit and entry administration from the military to a civilian agency. As such, the Immigration office National Police Agency within the Ministry for the Interior was established.

authorities justified these two emergency measures on the grounds that China's civil war remained technically unfinished; Taiwan was to be treated as combat area. The temporary provisions and the martial law literally turned the ROC on Taiwan into an emergency regime. The martial law and other attached laws severely restricted civil rights and liberties as protected by the constitution. See Simon, Denis Fred and Kau, Michael, Y. M., Taiwan: Beyond the Economic Miracle, M. E. Sharpe, Inc., New York, 1992, page 7.

512 Based on Article 11 (9) of the Martial Act of the ROC.

513 Over the period from 1965 to 1990, annual growth in real GNP per capita averaged around 9 per cent. See Stahl, Charles, "Asia and the Pacific", in Stahl, Charles, Ball, Rochelle, Inglis, Christine and Gutman, Pamela, Global Population Movements and Their Implications for Australia, Australian Government Publishing Service, Canberra, Australia 1993, page 43.

514 Taiwan has a western-style democratic, market-orientated system. The checks and balances in a political system of legislation, executive jurisdiction, examination and supervision is established in the Constitution of the ROC 1946. The awareness of human rights is rooted in the ROC. A representative of ROC attended the drafting of the UDHR. Also, the Kuomingtang was never a monoparty. Local elections were held even during the 1950s and 1960s.

Nonparty candidates were permitted to participate in the elections. See Simon, Denis Fred and Kau, Michael, Y. M., Taiwan: Beyond the Economic Miracle, M. E. Sharpe, Inc., New York, 1992, page 5. 
Following the suspension of martial law in 1987, restrictions on exit and entry began to be relaxed. Since 1996, Taiwan has implemented the general direct election of the President of the ROC, and the democratic political system has significantly improved. ${ }^{515}$ The Immigration Law of the ROC (the 1999 Act) was finally enacted to unify exit and entry control, safeguard national security, regulate immigration and implement immigration guidelines. Under Article 5, from May 2000 nationals with registered permanent residence could enter or exit the State without permission. The government promised to assist nationals who sought to emigrate by providing consultation services, and skills training. ${ }^{516}$ The government nevertheless dissuaded emigration to countries or regions where wars or epidemics were ongoing, or where Chinese nationals are refused entry. ${ }^{517}$ Following the 1999 Act, a raft of other legislation has been enacted or amended $^{518}$ to produce an advanced and comprehensive system of migration law. The codification of immigration law symbolised the start of protection of the RLR in Taiwan. Significantly, from a population of 23 million, 7.1 million persons exited or entered Taiwan in 1988, compared with 19.8 million in $2001 .^{519}$

\subsubsection{The right to leave}

\footnotetext{
${ }^{515} \mathrm{Wu}$, Wenxin, "Honestly Review the Functions and Significances of Overseas Chinese Affairs Committee" (Zhengshi Qiaoweihui De G, ngneng Yu Jiazhi), Microview Weekly, the ROC, at Domestic News, Volume 493, 5 May 2004.

516 Article 42 of the Immigration Law of the ROC 1999.

517 Article 43 of the Immigration Law of the ROC 1999.

518 1.Enforcement Regulations of Immigration Law 1999 (ROC); 2. the Regulations on Guidance and Management on Migration Service Organizations and Their Employees 1999 (ROC); 3. the Regulations Governing Visiting, Residence and Permanent Residence of Aliens 1999 (ROC); 4. the Regulations on Passport (Amendment) 2000 (ROC); 5. The Regulations on the Exit and Entry Means of Nationals with Registered Permanent Residence and Hong Kong or Macau Permanent Residence 2001(ROC); 6.Enforcement Rules of the Nationality Law 2001 (ROC); 7.The Regulations on the Exit of the People having been Waiting Conscription 2001 (ROC); 8. Enforcement Rules of the Implementation of Regulations on Passport (Amendment) 2002 (ROC); 9. The Regulations on Permission of Hong Kong Permanent Residents Enter into and Permanently Resident in Taiwan area (Amendment) 2002 (ROC); 10. The Regulations on the Entry Permission of Mainland Permanent Residents to Taiwan area (Amendment) 2002 (ROC); 10. The Regulations on the Entry Permission of Taiwan Residents to Mainland Regions (Amendment) 2002 (ROC); 11. The Regulations on the Certificate of Overseas Chinese Identity 2002 (ROC); 12. The Law of National Security Protection 2003 (ROC); 13. The Regulations on Permission of Exit and Entry of Nationals (Amendment) 2003 (ROC).

519 "The Report of Improving Service Quality of the Immigration office National Police Agency of the Ministry of Interior of the ROC 2001”, http://www.immigration.gov.tw, (26/11/2003) 15, page 1.
} 
Prior to 1999, Taiwan nationals could be provided with a passport ${ }^{520}$ upon presentation of a reference from either two employed Taiwanese nationals or a company whose registered capital exceeded T $\$ 10,000 .{ }^{521}$ The acceptable forms of reference were set out by a Taiwanese delegate in the Uppsala Conference in $1972 .^{522}$ These requirements obviously interfered with exercising the right to leave. Holding a passport did not imply that a person could leave Taiwan at any time, as the passport could only be used once. ${ }^{523}$ If a national holding a passport wanted to exit Taiwan within six months of returning, he or she had to additionally apply for an exit certificate. ${ }^{524}$ The issuance of passports to family members was strictly controlled. For example, a passport would not be granted to the family member of an overseas student, or if a relative of the applicant had lived overseas for more than two years. ${ }^{525}$ Where one spouse had a passport, the other would only be issued with the same if he or she provided the favourable reference from a foreign embassy or consular office.

These restrictions were abolished by the 1999 Act and its regulations. Pursuant to Articles 9 and 11, passports are now valid for ten years, and form the sole travel document. Citizens only need to fill in an application form and provide some identification, rather than providing references.

\footnotetext{
520 Article 9 of Enforcement Rules of the Implementation of Regulations on Passports Abroad 1952 (ROC).

521 Article 13 of Enforcement Rules of the Implementation of Regulations on Passports Abroad 1952 (ROC).
}

522 1. in the case of returned overseas Chinese and their family members as well as impersonators, such references are delivered by Chinese Overseas offices; 2. in the case of teaching staff employed by overseas Chinese schools, such references are delivered by Chinese embassies or general consulates; 3 . in the case of businessmen, such references are delivered by the Ministry of Economy; 4. in the case of personnel of the banking industry, such references are delivered by the Ministry of Treasury; 5 . in the case of personnel of the transportation industry and seafarers, such references are delivered by the Ministry of Transportation; 6 . in the case of personnel of the journalism industry, personnel of public institutions, doctors, pharmacists and patients, such references are delivered by the Ministry of Internal Affairs; 7. in the case of academic staff of higher education institutions and students, such references are delivered by the Ministry of Education; 8. in the case of personnel employed by foreign embassies or general consulates, such references are delivered by foreign embassies or general consulates. See "ROC - Taiwan" at Vasak, Karel and Liskofsky, Sidney, (ed), the Right to Leave and Return: Papers and Recommendations of the International Colloquium Held in Uppsala, Sweden, 19-21 June 1972, The American Jewish Committee, Arbour, the USA, 1976, page 386.

523 Article 4 of Enforcement Rules of the Implementation of Regulations on Passport Abroad, 1952 (ROC).

524 Article 18 (1) and (6) of Enforcement Rules of the Implementation of Regulations on Passport Abroad, 1952 (ROC).

525 Article 9 of Enforcement Rules of the Implementation of Regulations on Passport Abroad, 1952 (ROC). 
These reforms mean that the formal requirements for applications in Taiwan are almost as simple as in many Western States.

Like many States, Taiwan imposes some restrictions on the right to leave. Nationals are prohibited from leaving if they fit within a class of persons prescribed by Article 6 Clause 1 of the 1999 Act. $^{526}$ However, Article 6 clauses 2-5 of the 1999 Act guarantee various procedural rights if an application is refused. The grounds for restricting the right to leave are consistent with those permitted by the UHRD, the ICCPR, and other international human rights instruments.

Nationals who do not permanently reside in Taiwan, that is those who have lived abroad for more than two years, ${ }^{527}$ need to apply for permission to enter and exit the territory. ${ }^{528}$ The difference in treatment of nationals who reside or do not reside in Taiwan can be accounted for on the grounds of Taiwan's indirect dual nationality policy.

\footnotetext{
526 Article 6 of Immigration Law 1999 (ROC) provides "Nationals shall be denied or banned from exiting the State if they

Have been sentenced to punishments of imprisonment or greater after exhaustion of their appellate rights and have not served or have not completed the term of sentence; or

Have been wanted or have been restricted from exiting the State at the request of the civilian or military judicial authorities; or

Have been strongly suspected, on the basis of sufficient factual evidence, to endanger national security or social stability; or

Have been strongly suspected to be involved in rebellion or to cause it and have been restricted from exiting the State at the request of the authorities concerned; or

Have been strongly suspected to be involved in major economic crimes or major criminal cases and have been restricted from exiting the State at the request of the authorities concerned; or

Have been waiting for conscription or have not completely fulfilled their military services obligation except if permitted to exit the State in accordance with law; or

Have used a passport, flight crew ID, seaman service book, or entry and exit permit that has been illegally acquired, counterfeited, or tampered with, or that belongs to another persons; or Have failed to have their passports, flights crew IDs, seaman service books; or entry and exit permits inspected in accordance with Article 4; or Have been restricted or banned from exiting the State by other laws."

527 Article 7 of Operation Points of Population Circular of Nationals Who Exited Two Years Ago and Re-entry 2000 (ROC)

${ }^{528}$ Article 7 of the Regulations on Permission of Exit and Entry of Nationals (Amendment) 2003 (ROC)
} 
Aliens can be prevented from leaving Taiwan upon the request of the Courts or taxation authority; or if the subject of lawful investigation. The alien is entitled to be notified in writing of the cause for the decision to refuse their application to leave. ${ }^{529}$ Criminal sanctions are imposed on people who unlawfully enter or exit the territory under Article 54 of the 1999 Act. Penalties include imprisonment for up to three years, or a fine of up to T $\$ 90,000$.

\subsubsection{The right to return}

Like the right to leave, the right to return under Taiwanese law was strictly controlled until 1999. Currently, nationals who permanently reside in Taiwan enjoy an unlimited right to return.

Prior to 1999, a Taiwanese national needed to apply to re-enter the territory at the same time as they applied to leave. The Ministry of Foreign Affairs would endorse the applicant's passport with a return certificate, following approval by the Taiwan Province Peace Preservation Commander office. ${ }^{530}$ Servicemen and government employees wanting to enter the territory for private purposes needed to submit a written pledge with their application from two senior colleagues. ${ }^{531}$ The procedure for returning students was simpler than for many others, as part of the government's policy to encourage repatriation of skilled nationals. ${ }^{532}$ Nevertheless, returning students needed to submit a written reference with their application from either a Taiwanese company with registered capital in excess of $\mathrm{T} \$ 5,000$ or an employed Taiwanese national. These references could be submitted within a month of returning if the applicant did not have a relative who was living in the territory. ${ }^{533}$

Under Article 5 of the 1999 Act, Taiwanese nationals who do not permanently reside in the

\footnotetext{
529 Article 20 of Immigration Law 1999 (ROC).

530 Bao, Dazhang, The Explanation of Regulations and Procedures Governing exit and entry in Taiwan (Taiwan Diqu Chujing Rujing Faling Shouxu Xiangjie), Bao Da Zhang, Taibei, China 1957, page 45.

531 Article 12 (1) of the Regulations on the Entry and Exit in Taiwan during the Rebellion Suppression Period 1957 (ROC).

532 Bao, Dazhang, The Explanation of Regulations and Procedures Governing exit and entry in Taiwan (Taiwan Diqu Chujing Rujing Faling Shouxu Xiangjie), Bao Da Zhang, Taibei, China 1957, page 15.

533 Article 10 (4) of the Regulations on the Entry and Exit in Taiwan during the Rebellion Suppression Period 1957 (ROC).
} 
territory must obtain permission to enter. The duration of permission to remain in the territory depends on the applicant's qualification, and may vary from six months to ten years. Permission to enter may be granted on a multiple or single entry basis. Under Article 4 of the Regulations on Permission of Exit and Entry of Nationals (Amendment) 2003 (ROC), these nationals who wish to return to Taiwan must apply to Taiwanese overseas immigration authorities. Article 13 of above regulations provides that temporary permission with the same period of passport may be granted, if the applicant has a immediate relative who permanently resides in the territory, has been studying overseas, has made a contribution to Chinese affairs, has been approved to invest in Taiwan, represented China overseas, or worked for an international organisation. ${ }^{534}$

Under Article 7 and 17 of the 1999 Act, Taiwanese nationals who hold dual citizenship and have never resided in Taiwan are treated as aliens for the purpose of entry. ${ }^{535}$ The reason for this is to protect the interests of nationals who permanently reside in Taiwan.

The nature of Taiwan's return policy influences the chance of repatriation of skilled nationals. During the 1970s and 1980s, an estimated 20 percent of Taiwanese graduates emigrated for the purpose of undertaking further study. In 1979, the peak of the 'brain drain', only $8 \%$ of students who studied abroad returned to Taiwan. This rate has climbed to $33 \%$ in recent years. ${ }^{536}$ Data from Mainland China indicates the rate was $90 \%$ in $2003 .{ }^{537}$ This increased rate of repatriation can mainly be attributed to Taiwan's economic growth and democratisation. A focus on facilitating the return of skilled nationals is also a factor that cannot be ignored.

\footnotetext{
534 Article 11,12 and 13 of the Regulations on Permission of Exit and Entry of Nationals (Amendment) 2003 (ROC).

535 According to Article 7 of Immigration law 1999 (ROC), if they: have joined a rebellious organisation or its activities; or have joined a violent or terrorist organization or its activities; or have been strongly suspected to be involved in rebellion or to cause it; or have been suspected to be involved in major crimes or to be habitual criminals; or have used a passport or entry permit that is illegally acquired, counterfeited, or tampered with, or that belongs to another person.

536 ONeil, Kevin, "Brain Drain and Gain: The Case of Taiwan", http://www.migtationinformation.org/Feature/display.cfm?ID=155 (03/09/2003).

537 Xie, Xiuying, "The Economical Analysis on Overseas Study at Their Own Expense and the trend of Junior Age of the Age of Students(Zifei Chuguo Liuxue Re Jiqi Dilinghua Qushi De Jingjixue Fengxi)”, in Vol. 16 No. 1 of Journal of Shanxi Youth Managerial Cadres Institution (Shanxi Qingnian Guanli Ganbu Xueyuan Xuebao), pages 24-26
} 


\subsubsection{Exit and entry between Taiwan and Mainland China}

Although the exit and entry between Taiwan and other countries has been liberalised, the control over travelling to or from Mainland China remains restrictive because hostilities between two sides have not been resolved.

Residents in Taiwan must apply for a Certificate of Exit and Entry from Taiwan authorities prior to entering Mainland China under Article 9 (1) of the Regulations on the Relationship between Residents in Taiwan and Mainland China 1992 (ROC). Failure to obtain permission is an offence under Article 91 of the Regulations, punishable by a fine of between T\$20,000 and T\$100,000. The Regulations on the Entry Permission of Taiwan Permanent Residents to Mainland China (Amendment) 2002 (ROC) reiterate the requirements for permission to travel to or from the Mainland. Ordinary Taiwanese residents who do not have a passport must fill in an exit and entry application form and provide relevant certificates. Ordinary residents who have a passport may either fill in an entry into Mainland China application form and provide relevant certificates for themselves, or arrange their travel through a travel agency.

Overseas staff of the ministries and personnel who are employed without the status of civil servants in the Bureau of National Security, Ministry of National defence, the Bureau of investigation under the Ministry of Justice, are prohibited from travelling to Mainland China. Government affairs personnel and individuals working in areas relating to Taiwanese national security and development are prohibited from entering Mainland China, unless granted permission by the Examination Committee. ${ }^{538}$ Civil servants are also prohibited from entering Mainland China, unless to visit Mainland relatives of the first degree of kinship, stepparents, parents-in-law and spouses, or when sent by the authorities. ${ }^{539}$

Activities endangering the national security or interests of Taiwan in Mainland China are strictly

\footnotetext{
538 Article 4 of the Regulations on the Entry Permission of Taiwan Permanent Residents to Mainland Chinas (Amendment) 2002 (ROC).

539 Articles 4-10 of the Regulations on the Entry Permission of Taiwan Permanent Residents to Mainland Chinas (Amendment) 2002 (ROC).
} 
prohibited. ${ }^{540}$ Article 13 of the Regulations on the Entry Permission of Taiwan Permanent Residents to Mainland China (Amendment) 2002 (ROC) prohibits Taiwanese civil servants from entering into any agreements or releasing any joint declaration with legal entities in Mainland China. These activities are punishable with a term of imprisonment of not less than five years or a maximum fine of T\$1 million. ${ }^{541}$

The term of entry into China is limited to two years, ${ }^{542}$ compared to the 10 -year term attached to travel to other countries. The definition of a resident of "Mainland China" has been extended to include residents of Hong Kong and Macao, and permanent residents of Taiwan who have continuously settled in China for more than four years. ${ }^{543}$ The widening of the definition has the practical effect of narrowing the meaning of "Taiwanese resident" and a loss of rights enjoyed by people with that status.

Exit and entry laws between Taiwan and Mainland China can be criticised on the grounds that a person can enter China through a third State, in which case it would be difficult to enforce the restrictions. As to the status of civil servants and individuals in relation to Taiwanese national security and development, it is possible to disguise one's real occupation so as to avoid detection, since identity cards, driver licenses and household certificates do not include that information. Additionally, both Taiwan and Mainland China acknowledge the trend toward globalisation, which demands greater freedom to travel between regions. Further reforms are urgently needed to simply administrative processes.

Opinion is divided as to whether the current restrictions are necessary. Xie Lixian a Taiwanese scholar has questioned whether the current system of regulating travel between Taiwan and

\footnotetext{
540 Article 9 (2) of the Regulations on the Relationship between Residents in Taiwan and Mainland Chinas (Amendment) 2002 (ROC).

541 Article 5 (1) of the Law of National Security (ROC).

542 Article 18(1) of the Regulations on the Entry Permission of Taiwan Permanent Residents to Mainland Areas (Amendment) 2002 (ROC).

543 Article 18(1) the Regulations between Residents in Taiwan and Mainland China (Amendments) 2002 (ROC).
} 
China is still needed as relations between two sides improve. ${ }^{544}$ By contrast, Tan Zhimin has argued that the system should remain in place but should be improve. ${ }^{545}$ The issue of controlling travel between Taiwan and Mainland China is as much a legal one as it is political. It is not practicable to fully ease the restrictions against a background of hostility between two sides.

\subsubsection{Administration of migration service organization}

Before 1999, Taiwan did not have legalised migration service firms. Private companies that provided services to assist people to move abroad were technically breaking the law. Since the Introduction of the 1999 Act, private migration services were legalised and regulated. ${ }^{546}$ Taiwan has subsequently established an advanced administrative system governing the migration services organisation from the following five perspectives.

Firstly, migration service firms must be registered under company law and licensed. Following international practice, natural ${ }^{547}$ or legal person can establish a migration service in Taiwan. Foreign-owned companies that want to provide migration services in Taiwan must apply for a permit from the relevant department and be approved under company law. ${ }^{548}$ Although migration service providers must be companies, registered under the Company Act, an exception is made for lawyers. The quality of migration services was strengthened with the relaxation of the restrictions concerning those who can provide services.

\footnotetext{
544 Tan, Zhimin, "The Discuss on Current Permission System of Entry into Mainland Area of Residents in Taiwan Area” (Taiwan Diqu Renming Jingru Dalu Diqu Xianxing Xukezhi Zhi Tantao) (12 October 1998), www.immigraiton.gov.tw $(28 / 11 / 2003)$.

545 Tan, Zhimin, "The Discuss on Current Permission System of Entry into Mainland Area of Residents in Taiwan Area” (Taiwan Diqu Renming Jingru Dalu Diqu Xianxing Xukezhi Zhi Tantao) (12 October 1998), www.immigraiton.gov.tw $(28 / 11 / 2003)$.

546 The Regulations on Guidance and Management on Migration Service Organization and Their Employees 1999 (ROC) (Yimin Yewu Jigou Jiqi Congye Renyuan Fudao Guanli Banfa). Taiwan drafted a proposal on Regulations Governing Companies That Provide Immigration services 1990, see "Emigration Services Firms", The Free China Journal, 11 October 1990, http://global.factiva.com/en/arch/display.asp (25/07/2003).

547 Article 10 of the Regulations on Guidance and Management on Migration Service Organizations and Their Employees 1999 (ROC).

548 Article 46 (2) of Immigration Law 1999 (ROC).
} 
Migration services cannot be established unless the organisation holds at least $\mathrm{T} \$ 5$ million in capital, and has deposited T\$1.5 million as security in an approved financial institution. ${ }^{549}$ The Taiwanese government has emphasised that the requirements are calculated according to the range of services provided by an individual business. A migration service that provides investment advice must hold $\mathrm{T} \$ 8$ million capital, and lodge a security of $\mathrm{T} \$ 2.5$ million. The purpose of the requirements is to improve the quality of migration services. Security deposits are used to pay compensation in the event of a dispute and are refunded when the business is wound up. ${ }^{550}$

Thirdly, the government supervises migration service firms that provide investment advice and brokerage services. They must first provide evidence that they have negotiated 100 successful migration applications. ${ }^{551}$ Further, approval from the Finance Ministry must be obtained under Article 47(2) of the 1999 Act. Migration service firms that provide investment advice, cannot act as agents to conduct securities investment or receive investment funds. ${ }^{552}$ There must be a contract between the migration service and the client detailing the rights and obligations of each party and the manner in which funds will be managed. ${ }^{53}$ Details of each investment-involved case must be provided to the government. ${ }^{554}$ The purpose of these regulations is to protect investors and the Taiwanese economy generally, by ensuring that investment advisors are skilled and honest in their dealings.

\footnotetext{
549 Article 48 Immigration Law 1999 (ROC); and Article 4 and 6 of the Regulations on Guidance and Management on Migration Service Organizations and Their Employees 1999 (ROC).

${ }^{550}$ Article 7 and 8 of the Regulations on Guidance and Management on Migration Service Organizations and Their Employees 1999 (ROC).

551 Article 9 of the Regulations on Guidance and Management on Migration Service Organizations and Their Employees 1999 (ROC).

552 Article 47 (3) of Immigration Law 1999 (ROC).

553 Article 11 (1) of the Regulations on Guidance and Management on Migration Service Organizations and Their Employees 1999 (ROC).

554 Article 16 (1) of the Regulations on Guidance and Management on Migration Service Organizations and Their Employees 1999 (ROC).
} 
Migration services must employ at least three qualified specialists. ${ }^{555}$ Qualifications must be obtained from the migration institute. The institute must verify who has completed its training and examinations to the government. ${ }^{556}$ Specialists must attend further training and pass an examination every three years. Their qualifications can be revoked if the exams are failed twice. $^{557}$

Lastly, a migration service can be fined between $\mathrm{T} \$ 200,000$ and $\mathrm{T} \$ 1$ million if it operates without a license. ${ }^{558}$ The severity of the penalties helps law enforcement and protect the interests of clients. Licenses can be revoked or cancelled under Article 50 of the 1999 Act if the migration service has:

- been convicted of submitting false information, or assisting their client to submit false information to migration authorities;

- embezzled funds in relation to a migration matter;

- permitted third parties to use their license;

- been ordered to suspend their operation;

- violated any law concerned with migration services.

\subsubsection{The exit and entry administrative system}

With the liberalisation of exit and entry, the exit and entry administrative system has been greatly improved.

\section{Administrative authorities}

The matters of visa applications, visa overstay, applications for residency and addressing illegal entry, are dealt with by separate administrative processes under Article 2(2) of the 1999 Act, by

\footnotetext{
555 Article 5 (1) of the Regulations on Guidance and Management on Migration Service Organizations and Their Employees 1999 (ROC).

556 Article 5 (2) and (3) of the Regulations on Guidance and Management on Migration Service Organizations and Their Employees 1999 (ROC).

557 Article 22 of the Regulations on Guidance and Management on Migration Service Organizations and Their Employees 1999 (ROC).

558 Article 55 of Immigration Law 1999 (ROC).
} 
the Bureau of Immigration and the National Police Administration. Control over exit and entry by a civil authority is consistent with international practice. The separation of these functions means that administrative service provision is improved, violations of migration laws more easily identified, and power is not concentrated in any particular group of administrators.

Administrative responsibility for migration is shared between the Ministry of the Interior, local Household offices, and the Ministry of Foreign Affairs. The Ministry of the Interior is responsible for accepting an application and issuing a certificate of nationality; ${ }^{559}$ local household offices receive passport applications and have the responsibility of forwarding them to Ministry of Foreign Affairs; ${ }^{560}$ and Ministry of Foreign Affairs receives and processes those applications. ${ }^{561}$ Prior to the establishment of the Bureau of Migration, the Household offices and the Ministry of the Interior were also responsible for the management of migrations service organisations. ${ }^{562}$ According to Article 12 of the Regulations on the Entry Permission of Mainland Permanent Residents to Taiwan of the Republic of China (Amendment) 2002 (ROC), the Ministry of Foreign Affairs is responsible for deciding if residents with a registered permanent residence in Mainland China hold a special status with respect to an application.

\section{Independent committees}

The Review Committee of Non-permission and Banning from Exit and Entry, of the Ministry of the Interior ${ }^{563}$ is an independent review panel, constituted by impartial members of the public under the 1999 Act. Its functions are to:

1.Review a decision to prevent an individual from leaving the territory when that person is strongly suspected to endanger national security or social stability, or be involved in rebellion or to cause it, and; ${ }^{564}$

\footnotetext{
559 Pursuant to Article 21 Nationality Law 2000 (ROC).

560 Pursuant to Article 2 of Enforcement Regulations of the Law of Nationality (ROC).

${ }^{561}$ Pursuant to Article 2 of Enforcement Rules of the Regulations on Passport 2002 (ROC).

562 Article 29 of the Regulations on Guidance and Management on Migration Service Organizations and Their Employees 1999 (ROC).

563 Article 10 of Key Points of Establishment of Review Committee of Non-permission and Banning from Exit and Entry, the Ministry of Interior (Amendment) 2000 (ROC).

${ }^{564}$ Article 6 (1) (b) -(c) of Immigration Law 1999 (ROC).
} 
2. Review a decision to prevent an alien from entering the territory on the grounds that the person is believed to endanger national interest, public security, public order, or the good customs of the State; ${ }^{565}$

The Immigration office organises a review committee to check and examine if permanent residency needs to be granted to aliens who have not satisfied the formal requirements for permanent residency, but have made an exceptional contribution to the State, or possess technical skills needed by the State. ${ }^{566}$ The mechanism of an independent review committee was developed to overcome departmental shortcomings with respect to the absence of timely and fair decision-making, and to reduce the frequency of complaints about administrative processes.

The Examination Committee of the Ministry of the Interior is responsible for examining applications for the entry into China of senior public servants and national security personnel. The Examination Committee is composed of individuals from the Ministry of the Interior, the State Security Bureau, the Ministry of Justice, and the Mainland Committee of the Executive Yuan. ${ }^{567}$

It may seem that the jurisdiction of the various migration authorities is limited by reason of the separation of administrative functions between departments and independent committees. The arrangement is consistent with customary international law, and was designed to impose order on migration administration. The current system improves the quality of services and protects the rights of individuals who wish to emigrate.

\section{The services of the Immigration office}

The government argues that the administrative structure provides services to all people and

\footnotetext{
565 Article 17 (1) (m) of Immigration Law 1999 (ROC).

566 Article 23 (3) of Immigration Law 1999 (ROC).

567 Article 8 (4) of the Regulations on the Permission of Short-stay, Residency and Registered Permanent Residency of Hong Kong and Macao Residents in Taiwan 2002 (ROC).
} 
secures the national borders. According to the Immigration office, its goal is to facilitate the exit and entry of the people by providing sincere service, and to simplify exit and entry requirements, ${ }^{568}$ to give effect to the concept of service marketing (Yinyong Fuwu Xingxiao Lilian), to enlarge the scope of government services (Kuoda Zhengfu Fuwu Shiye), and to provide the best quality service (Zhanxian Zuoyue Fuwu Pingzhi). ${ }^{569}$ The Immigration office has formulated a series of detailed measures to implement its service ideals. ${ }^{570}$ These measures provide an encouraging safeguard for the quality of exit and entry administration. An advanced administrative system has been established in Taiwan, which undoubtedly plays a significant role in protecting the RLR.

\subsection{The USA}

The USA is a typical example of a developed country with a market economy. China is endeavouring to develop its market economy in a similar direction to that of the USA. Analysis of the RLR in the USA will assist in rationally thinking about the future of the RLR in China. Many aspects of the RLR in the USA need to be noted. This section has selected some aspects

\footnotetext{
568 Immigration office National Police Agency of the Ministry of Interior of ROC, "Manual of Service for the People, Immigration office" (Ruchujing Guanliju Weimin Fuwu Shouce), September 2002, www.immigraiton.gov.tw (28/11/2003) page 1; further explained in Enforcement Plan of Upgrading Service Quality all Round (2002).

569 Immigration office National Police Agency of the Ministry of Interior of ROC, "Enforcement Plan of Upgrading Service Quality all the Round in 2002" (Neizhengbu Jingzhengshu Ruushujing Guanliju Jiushiyi Niandu Quanmian Tisheng Fuwu Pingzhi Zhixing Jihuashu), www.immigraiton.gov.tw (28/11/2003), page 1.

${ }^{570}$ Firstly, the office is looking to the private sector to identify measures to improve performance, for example, invite managers and scholars to introduce the ideals and practices of business management. Secondly, formal administrative processes are being reformed to reduce waiting time. These include setting up counter service in its offices, regularly updating service manuals, establishing internal and external supervisory mechanisms, and introducing online and facsimile-based systems for some categories of applications. Thirdly, the office is attempting to create a customer service environment by improving equipment, training its staff, developing mobile services, permitting some public scrutiny of facilities, and implementing a regular and random performance audit process. Fourthly, the office has attempted to improve communication with the public by inviting experts to give seminars on customer service, developing websites to publicise migration regulations, government white papers and performance reports. Lastly, the office has joined with travel agents, the Red Cross, the [Taiwan] Strait Funds Association and Chinese groups located overseas to assist in developing its service. See Immigration office National Police Agency of the Ministry of Interior of ROC, "Enforcement Plan of Upgrading Service Quality all the Round in 2002 (ROC)" (Neizhengbu Jingzhengshu Ruushujing Guanliju Jiushiyi Niandu Quanmian Tisheng Fuwu Pingzhi Zhixing Jihuashu), www.immigraiton.gov.tw (28/11/2003), pages 2-7.
} 
for review, which are significant to compare with the RLR in China, including the legal status of the RLR, passport administration, the limits on the right to be granted passport, and the extent of restrictions placed on international travel. Foreign the RLR policy will also be analysed to examine the relationship between the RLR policy in the USA and the RLR policy in other States such as China.

\subsubsection{Legal status of the RLR in the USA}

Under International Migration Report 2002, the USA is the country with the largest international migrant stock of $34,988,000$. The migration stock rate (percent of population) in USA in 2002 was $12.353 \%$, which is much higher than the $8.739 \%$ average rate in more developed countries. ${ }^{571}$ The USA government has a satisfactory emigration outlook. In Measures of Legal and Political Rights in 31 Countries 2002, it scored highest in relation to the right to emigration. ${ }^{572}$

Influenced by English law, the USA has recognised its citizens' the RLR without government permission in times of peace, as a matter both of law and policy. ${ }^{573}$ The laws governing the RLR are contained in the Constitution, in the USA Code of Federal Regulations, the Passport Act 1926, various presidential proclamations and cases in law. ${ }^{574}$ the RLR in the USA has been inferred from the Fifth Amendment's due process clause and the equal protection clause of the Fourteenth Amendment of US Constitution. ${ }^{575}$ Courts did not expressly interpret the

\footnotetext{
571 The population of the USA was $283,230,000$. Compared with $8.739 \%$ of average migration stock in more developed regions, calculated from data in Population Division Department of Economic and Social Affairs, International Migration Report 2002, the UN Secretariat, 2002, ST/ESA/SER.A/220, the UN, New York, 2002, 62 pages, attached table.

572 Janoski, Thomas and Gran, Brain “Political Citizenship: Foundations of Rights' in Isin, Engin F. and Turner, Bryan S. (ed), Handbook of Citizenship Studies, Sage Publications, London, 2002 pages 31-33.

573 Ennis, Edward, “The United States of America”, at Vasak, Karel and Liskofsky, Sidney, (ed), the Right to Leave and Return: Papers and Recommendations of the International Colloquium Held in Uppsala, Sweden, 19-21 June 1972, The American Jewish Committee, Arbour, the USA, 1976, page 232.

574 This proclamation was codified in the Passport Act 1926, and the Presidential Executive Order 7856 of March 31, 1938. These are now found in Part 51 of the USA Code of Federal Regulations.

575 Nowak, J., Rotunda, R. and Young, J.N. constitutional Law, 2nd edition, West Publishers, St. Paul, 1983, pages 802-816.
} 
constitutional the RLR in respect of the RLR until World War One. ${ }^{576}$ the RLR was first clearly affirmed in Bauer v Acheson (1952) decided by the Federal District Court of Columbia, which held that the freedom to travel outside the USA was an aspect of personal liberty. In Kent $v$ Dulles (1958), the US Supreme Court declared that:

The right to travel is part of the "liberty" of which the citizen cannot be deprived without due process of law ... Freedom of movement across frontiers in either direction ... is a part of our heritage. Travel abroad ... may be necessary for livelihood. It may be as close to the heart of the individual as the choice of what he eats, or wears, or reads ... ${ }^{577}$

The USA ratified the ICCPR in 1992, later than many Western States, such as the UK (1976), Japan (1979), Germany (1973) and France (1980). The USA ratified the CERD in $1994,{ }^{578}$ Protocol Relating to the Status of Refugees 1967 in 1968, but did not ratified the CSR, and the Convention on the Protection of the Rights of All Migrant Workers and Members of their Families 1990 until 2002. ${ }^{579}$ Ratification of international human rights conventions partly changed the USA's image as a State that adhered to virtually no important human rights covenants.

\subsubsection{Sole departmental authority for passport administration}

Since a presidential proclamation in 1918, a US citizen must hold a passport to travel abroad or re-enter the USA. ${ }^{580}$ The Secretary of State is sole departmental authority responsible for

\footnotetext{
576 Ennis, Edward, "The United States of America”, at Vasak, Karel and Liskofsky, Sidney, (ed), the Right to Leave and Return: Papers and Recommendations of the International Colloquium Held in Uppsala, Sweden, 19-21 June 1972, The American Jewish Committee, Arbour, the USA, 1976, page 233.

577 Quoted in Freedman, Warren, The Right to Travel: A Right or A Privilege? Work Paper of Sao Paulo Conference on the Law of the World, the World Peace Through Law Centre, Washington, the USA, 1981, page 9.

578 International Service for Human Rights, "The Ratification Status of the Main Human Rights Treaties”, (02-2002) http://www.ishr.ch/About\%20UN/Ratification/Ratification/Ratification\%20-\%20Human\%20Rights20treaties.htm (18-05-2003).

579 Population Division Department of Economic and Social Affairs, International Migration Report 2002, the UN Secretariat, 2002, ST/ESA/SER.A/220, the UN, New York, 2002, 62 pages, attached tables.

${ }^{580}$ HR Rep No.485, 65 ${ }^{\text {th }}$ Congress, 2nd Sess. Quoted in, Freedman, Warren, The Right to Travel: A Right or A Privilege? Work Paper of Sao Paulo Conference on the Law of the World, the World Peace Through Law Centre, Washington, the USA, 1981, page 7.
} 
passport administration. Before 1856, state governors and local officials also issued passports. ${ }^{581}$ The system of sole departmental authority was established by Passport Act 1926, which provides that:

The Secretary of State may grant and issue passports, and cause passports to be granted, issued and verified in foreign countries by diplomatic representatives of the United States [...] under such rules as the President shall designate and prescribe for persons on behalf of the United States, and no other person shall grant, issue, or verify such passports.

\subsubsection{Limits on the right to be granted a passport}

Even in States such as the USA, which generally favours a policy of free travel, restrictions have been imposed against a limited number of citizens on grounds of national security or foreign policy. A passport, except for direct return to the USA, shall not be issued in any case in which:

1) The applicant is the subject of an outstanding federal arrest warrant for a felony, including a warrant issued under the Federal Fugitive Felon Act;

2) The applicant is subject to a court order, condition of parole, or condition of probation which forbids departure from USA;

3) The applicant is subject to a court order committing him or her to a psychiatric facility. ${ }^{582}$

A passport application may be refused in any case in which:

1) The applicant has not repaid a loan received from USA to effectuate his return from a foreign country in the course of travel abroad;

2) The applicant has been legally declared incompetent unless accompanied in his travel abroad by the guardian or other person responsible for the applicant's custody and wellbeing;

3) The applicant is under the age of 18 years, unmarried and not in the military service of USA, unless a person having legal custody of such a person authorizes issuance of the passport and agrees to reimburse the United States for any monies advanced by the United States for the minor's to return to USA;

4) The Secretary determines that the applicant's activities abroad are causing or are likely to cause serious damage to the national security or the foreign policy of USA;

\footnotetext{
581 Ennis, Edward, "The United States of America”, at Vasak, Karel and Liskofsky, Sidney, (ed), the Right to Leave and Return: Papers and Recommendations of the International Colloquium Held in Uppsala, Sweden, 19-21 June 1972, The American Jewish Committee, Arbour, the USA, 1976, page 233.

$582 \$ 51.70$ (a) of the USA Code of Federal Regulations Title 22 - Foreign Relations.
} 
5) The applicant has been the subject of a prior adverse action under the Passport Act, and has not shown that a change in circumstances since the adverse action warrants issuance of a passport;

6) The applicant is subject to an order of restraint or apprehension issued by an appropriate officer of USA military, pursuant to the United States Code. ${ }^{583}$

A passport shall cease to be valid for travel into or through restricted countries or areas. A country is restricted if it is:

1) A country with which USA is at war;

2) A country or area where armed hostilities are in progress;

3) A country or area to which travel must be restricted in the national interest because such travel would seriously impair the conduct of US foreign affairs. ${ }^{584}$

Although the right to due process must be respected, ${ }^{585}$ a passport may be denied if the Secretary of State has causable grounds for believing that the activities of an applicant would interfere with the national security of the USA by:

1) transmitting without proper authority security information;

2) inciting hostilities or conflicts which might involve USA;

3) inciting attacks by force upon USA; or

4) inciting attempts to overthrow the government by force or violence. ${ }^{586}$

The US government takes measures to ensure that the limits imposed on passports do not interfere with the right to procedural fairness and due process. Any person whose passport application has been denied, or who has otherwise been subject to an adverse administrative decision with respect to their right to receive or use a passport, is entitled to written notice of the decision. The notice must set out the procedure for review of the decision. Additionally, the administrative decision may be judicially appealed.

\footnotetext{
$583 \$ 51.70$ (b) of the USA Code of Federal Regulations Title 22 - Foreign Relations.

$584 \$ 51.72$ Passports invalid for travel into or through restricted countries or areas, the USA Code of Federal Regulations Title 22 - Foreign Relations.

${ }^{585}$ Hannum, Hurst, The right to Leave and Return in International Law and Practice, Martinus Nijhoff Publishers, Dordrecht, the Netherlands, 1987, page 85.

586 Freedman, Warren, The Right to Travel: A Right or A Privilege? Work Paper of Sao Paulo Conference on the Law of the World, the World Peace Through Law Centre, Washington, the USA, 1981, page 9.
} 


\subsubsection{The extent of restrictions placed on international travel}

The US government usually limits the so-called "export of services" in relation to countries that endanger the national security of the USA. Foreign travel of US citizens, in Edward Ennis' view, is in effect a large hidden export of services from the USA. ${ }^{587}$ The current George W. Bush administration shares this view. However the positive economic influence of the "export of services' is limited to developing countries. The same positive economic effects are not apparent in a developed country like the USA.

In practice, the restricted countries or areas are either Communist countries or non-Christian countries, with different political systems to the USA. US citizens were restricted from travelling to China, Iran and Cuba in the 1970's and 1980's other than with special permission. ${ }^{588}$ Since 1963 , US citizens have not been permitted to travel to Cuba, on the grounds that the US has not approved Cuba's communist regime. ${ }^{589}$ Any person who violates this restriction may be fined up to US $\$ 250,000$ or be imprisoned for up to ten years. The restrictions on travelling to certain countries are thus based on the political rather than economic grounds.

In October 2003, George W. Bush stated that the USA would strengthen the restriction on travel to Cuba in order to promote a change of government on the island. The rationale for this restriction was that the Cuban economy would suffer is US travel dollars were withdrawn. However, the US Senate passed a bill in late 2003, providing that the USA will cancel travel

\footnotetext{
587 Ennis, Edward, "The United States of America”, at Vasak, Karel and Liskofsky, Sidney, (ed), the Right to Leave and Return: Papers and Recommendations of the International Colloquium Held in Uppsala, Sweden, 19-21 June 1972, The American Jewish Committee, Arbour, the USA, 1976, page 243

588 If the applicant is considered to be in the national interest of the USA, the application may be approved. See $\S 51.73$ Special Validation of Passport for Travel to Restricted Countries and Areas, Subpart E Limit on Issuance or Extension of Passports, Part 51 Passport, the USA Code of Federal Regulations Title 22 - Foreign Relations.

589 Bradley, Catherine, What Do We Mean by Human Rights: Freedom of Movement, Franklin Watts, London, 2002, page 21 .
} 
restrictions to Cuba. ${ }^{590}$ Current debates in Congress tend to be in favour of cancellation of the restriction.

\subsubsection{Foreign the RLR policy}

The USA has tried with mixed results to bring economic and political pressure to bear upon States to secure compliance with Article 13(2) of the UDHR and Article 12(2) of the ICCPR. For example, Jackson-Vanik Amendment to the Trade Reform Act 1974 prohibits the granting of most-favoured nation (MFN) status to countries without free market economies and which violate the RLR. ${ }^{591}$ The USA releases Country Reports on Human Rights Practices and Supporting Human Rights and Democracy: USA Record every year, to detail the attitudes and measures taken by countries towards human rights. ${ }^{592}$ The measures imposing economic and political pressure spring from human rights ideals and national interest. The administration tirelessly works to promote democratic structures and respect for human rights in every region of the world, on the basis that freedom and the rule of law may prevent human rights abuses and terrorism. This combination of idealism and policy implementation has become a hallmark of

\footnotetext{
${ }^{590}$ China Xinhua News Agency, "The Foreign Affairs Committee Agree to cancel the restrictions on Travelling to Cuba" (Mei Canyiyuan Waiweihui Tongyi Jiechu Dui Guba Lvxing Xianzhi), Australian Chinese Daily, at International News (8, 9 November 2003).

591 The Jackson-Vanik Amendment was enacted primarily in response to ban erected by the Soviet Union to emigrate. Those bars particularly affected members of several groups anxious to leave, including principally Soviet Jews by stating "To assure the continued dedication of the United States to fundamental human rights... products from any non-market economy country shall not be eligible to receive non-discriminatory treatment (most-favoured-nation treatment) ... during the period beginning with the date on which the President determines that such country (1) denies its citizens the right or opportunity to emigrate; (2) imposes more than a nominal tax on emigration ...; or (3) imposes more than a normal tax ... or other charge on any citizen as a consequence of the desire of such citizen to emigrate to the country of his choice ...." See [full reference missing] and Materials, 2nd edition, Oxford University Press, New York, 2000, pages 1109-1110.

592 Powell, Colin L. "Preface", at Supporting Human Rights and Democracy: The USA Record 2002-2003, the Bureau of Democracy, Human Rights, and Labour, 2003 http://www.state.gov/g/drl/rls/shrd/2002/21763.htm (05-07-2003).
} 
USA foreign policy. ${ }^{593}$ Unfortunately, this initiative has received little supports from other States. ${ }^{594}$

Former President Jimmy Carter thought that human rights were "the soul" of US foreign policy. He extended diplomatic recognition to China in December 1978, boosting the Chinese Communists reputation. Chinese leaders however characterised the extension of diplomatic recognition as a "hypocritical farce". ${ }^{595}$ The Chinese government did not believe that the USA intended to take serious measures to assist China to address its human rights record, but merely sought to bolster US interests by drawing political attention to the issues in China.

Like many Western countries that are strong on human rights rhetoric, the US is reluctant to take action against China with its rapidly growing economy, offering fresh markets and new trading opportunities. The Jackson-Vanik Amendment allows the President to waive the emigration requirement only when it would substantially promote the goals of the Amendment and the President has received assurance that the country's emigration practices will lead substantially to such objectives. From 1980 to 2000, three presidents have used the waiver method to grant most favoured nation status to China.

US foreign policy has moved from prioritising human rights ${ }^{596}$ to encouraging trade, ${ }^{597}$ and safeguarding national security. This is evidenced by US reluctance to accept migrants from countries with poor the RLR records, and the USA Visitor and Immigration Status Indication Technology System (USVISIT) aimed at tracking all those coming to the USA to work, study

\footnotetext{
593 Colin L. Powell, "Preface", in Supporting Human Rights and Democracy: The the USA Record 2002-2003, the Bureau of Democracy, Human Rights, and Labour, 2003 http://www.state.gov/g/drl/rls/shrd/2002/21763.htm (05-07-2003).

594 Meron, Theodor, (ed), Human Rights in International Law: Legal and Policy Issues, Volume I, Clarendon Press, Oxford, the UK, 1984, page 152.

$595 \mathrm{Wu}$, Yuanli et al, Human Rights in the People's Republic of China, Westview Press, Boulder, Colorado, the USA, 1988 , page 5 .

596 “'Bottom line for the USA and China: no Kowtows on Human Rights' The New York Times, New York, 27 March 1994.

597 “Clinton U-turn as He Defends links with China” The Daily Telegraphy, New York, 25 October 1997, page 11; “America Retreats from Human Rights Motion against China” The Times, 16 March 1998, page 13.
} 
and visit. From April 2003, undocumented immigrants can be detained indefinitely, without bond, if the government provides evidence that their release might threaten national security. ${ }^{598}$

US migration policy aims to select the people who can best contribute either through their existing connections within the USA, or through potential economic contribution. The USA will only respond to economic and political pressure from developing countries with poor human rights records if it is consistent with its national interests. The government has shown that it will cease providing international aid if an inconsistency between American national interest and economic and political interests of another State emerges.

\subsection{Conclusions}

For Vietnam, the background of the protection of the RLR is remarkably similar to that of the RLR in China. This means that the overall trends and features in Vietnam's policies on the RLR are likely to emerge in China as well. There has been a clear trend that liberalisation of the RLR is increasing. Vietnam will not have growth in the long run until individual rights are respected. ${ }^{599}$ Incorporating the RLR into the Constitution was an epoch-making start, followed by many legislative changes related to the RLR. This means unprecedented freedom for individuals. Furthermore, limited by public ownership of the means of production, which is still the basis of the socialist economic system ${ }^{600}$ underdevelopment and the Confucian tradition,

\footnotetext{
598 Jachimowicz, Maia and McKay, Ramah, “Justice, Homeland Security Departments Announce Changes”, http://www.migrationinformation.org/Usfocus/display.cfm?ID=120, (05/06/2003).

599 Le, Long, "Vietnamese Communist Party not Interested on "Real Reform", at The Washington Times, Sunday, 8 September 2002, http://www.fva.org/200209/story01.htm (29/11/2004).

${ }^{600}$ Article 19 of the Constitution of the Socialist Republic of Vietnam 1992 prescribe "The State sector shall he consolidated and developed, especially in key branches and areas, and play the leading role in the national economy." Article 17 of the Constitution sets forth "The land, forests, rivers and lakes, water supplies, wealth lying underground or coming from the sea, the continental shelf and the air, the funds and property invested by the State in enterprises and works in all branches and fields - the economy, culture, society, science, technology, external relations, national defence, security - and all other property determined by law as belonging to the State, come under ownership by the entire people." Article 15 of the Constitution regulates "The State promotes a multi-component commodity economy functioning in accordance with market mechanisms under the management of the State and following a socialist orientation. The multi-component economic structure with various forms of organization of production and trading is based on a system of ownership by the entire people, by collectives, and by private individuals, of which ownership by the entire people and by collectives constitutes the foundation."
} 
the RLR cannot be fully and practically realised. Vietnam has difficulties in accommodating the RLR concerns even if legislative and judicial efforts are made, because the role of the Communist party cannot be challenged. There are considerable vested interests in the present system of exit and entry control that involve the CPV, such as possible social instability caused by the exodus of party members.

In the case of Taiwan, mainly for the purposes of national security, Taiwan has had restrictive limits on the RLR for a half century. Economic development and democratisation greatly stimulated the movement of people across its borders. The 1999 Act, focussing on the protection of the RLR was then implemented. Outstanding achievements have since occurred in regard to the RLR. Almost all prior restrictive limits have been lifted. Meanwhile, some limits on exit and entry between Taiwan and Mainland China remain, even though prohibitions on travelling to or from Taiwan have been partially cancelled. Restrictions mainly due to unchanged hostility between the two sides across the Taiwan Strait. Generally speaking, the RLR enjoyed in today's Taiwan is not less than the RLR enjoyed in other Western countries. Mainland China is on the similar course as that so far experienced by Taiwan. It is believed that the today of Taiwan will be the tomorrow of Mainland China, if no sudden change occurs in the current political situation.

Leaving aside the clear fact that USA has established an advanced regime to protect the RLR within the territory, based on a developed economy and mature political system, the US the RLR policy has been characterised, first and foremost, by ambivalence, a mood manifested in measures that both welcome and restrict the RLR. On the one hand, the US spared little effort to promote the RLR in USA and other States for "the non-negotiable demands of human dignity" ${ }^{601}$ On the other hand, the US imposed limits on nationals' travelling to designated States, and aliens' travelling to the territory, so that it serves the national interest. The adoption of the National Security Entry-Exit Registration Program and the USVISIT after 11 September are convincing examples. How these conflicting policies are to be reconciled remains to be seen.

601 Amnesty International, "Despite Releases, Guantanamo Remains an Affront to the Rule of Law”, AI Index: the AMR 51/041/2004, http://256.com/qrav/kerry/web.amnesty.org/library/Index (15/11/2004). 
The history of the RLR in the USA demonstrates that the assertion of the RLR has a tendency to be under the umbrella of national interest. So long as the State sense national security as being far from fully safeguarded, the tendency to limit the RLR will remain.

Four common points could be drawn from the foregoing cases studies. Firstly, the relaxation of the limits on the RLR has been instrumental as a protective measure. This has enabled the entry and exit administration to formulate law and policy that strongly protects the RLR. Secondly, express constitutional and statutory recognition of the RLR is a very important, but not necessarily indispensable, factor for the protection of the RLR. For example, the RLR is not constitutionally protected in the USA in precise terms, but is nevertheless well protected. In contrast, the Vietnamese Constitution acknowledges the RLR, but the RLR is restrictive. Thirdly, the political system and economic circumstances of a State play a vital role in improving the RLR. The more democratic the political system and the better developed the economy, the better the protection of the RLR. This is persuasively supported by the experiences of Taiwan and the USA. Lastly, it was observed that the safeguarding of national interests takes priority over pursuing of the RLR when there is an inconsistency between such interests and the pursuance of ideals. 


\section{Chapter Five \\ Driving factors of the RLR in China}

\section{Introduction}

To systematically explain the RLR, as it exists in China, it is necessary to first analyse the motivations, or driving factors, behind the RLR in China. This chapter concentrates on the common factors of politics, economics, culture and law. The political and legal factors are the foremost and most direct factors affecting the RLR in China. The four perspectives are further divided into a host of subsidiary aspects. These include the one party system, it being one member of former communist bloc, basic economic facts, public ownership, interaction between economic development and laws governing exit and entry, the community orientated culture, loyalty (Zhong) and filial piety (Xiao), the duty orientated culture, sublating (Yangqi), agrarian society and geographical isolation, absence of the Constitutional foundation of the protection of the RLR, the nature of law, the aim of law, and the research on the RLR in China. The analysis here will lay a basis for understanding the development and specific issues of the RLR to be explored in the next eight chapters.

\subsection{Politics}

While migration can provide wide-ranging benefits, it also imposes costs. One major problem with evaluating the costs of migration in China is the way in which it affects different groups in different ways; some gain significantly, others marginally, while yet others lose. The different groups have different degrees of solidarity and political power. Thus, it needs to be remembered that it is often political power that shapes migration policy. Migration policy is related to the perceptions of those with the power to dictate policy. ${ }^{602}$

The Chinese political system is the communist system. Simply speaking, it determines what

\footnotetext{
${ }^{602}$ For example, the absence of the remedies for RLR in public affairs is consonant with the interests of government and the $\mathrm{CPC}$ who might control the movement of subordinates and solidify their privileges.
} 
power and rights people can enjoy, and how they can be enjoyed. The communist political system has operated in China since 1949, when the People's Republic of China was established. This provides theoretical and political basis of the transitional market economy and Marxist legal theory and significantly affects the changing of traditional Confucian culture. Accordingly, the communist political system decides issues of the RLR in China. This first section will be divided into two parts to first consider one party reign and then consider China as one member of the former communist bloc.

\subsubsection{One party reign (Yidangzhi)}

The most marked feature of the Chinese communist political system is the one party reign of the Communist Party of China (CPC). China is ruled and controlled by the CPC. The system has been legalised in the Constitution ${ }^{603}$ and reiterated in important national documents. ${ }^{604}$ The State organ and armed forces ${ }^{605}$ are subordinate to the CPC; whose role is to implement the party’s policies. ${ }^{606}$ The CPC's constitutionally-mandated leadership and of its having almost all top positions of the State organ or apparatus and armed forces occupied by party members,

${ }^{603}$ Preamble Paragraph 7 of the Constitution of the PRC (Amendment) 2004 stipulates "under the leadership of the Communist Party of China and guidance of Marxism-Leninism...the Chinese people of all nationalities will continue to...build China into a strong, prosperous culturally advanced, democratic socialist nation."

${ }^{604}$ Jiang, Zemin, the former president of China, stated in his report of the 16th CPC National Congress in November 2002, that the practices of the 13 years between 1989 and 2002 demonstrates that China must adhere to the leadership of the CPC and persevere in the CPC's absolute leadership over the Army. See Jiang, Zemin, the President of the PRC, "Build a Well-off Society in an All-Round Way and Create a New Situation in Building Socialism with Chinese Characteristics: Report page 16th China Communist Party Congress (8/11/2002)", http://www.fmprc.gov.cn/eng/37816.html (19/07/2003).

${ }^{605}$ State organ in China means the organ that carries out State power and runs State affairs, including organ of State power, organ of administration, judicial organ, procuratorial organ, military armies, etc, e.g. National People's Congress (NPC), the Chinese People's Political Consultative Conference (CPPCC), the State Council, the people's congresses at all levels, the people's governments at all levels, the people's Courts at all levels, the people's Procuratorates at all levels, the public security organs at all levels. See Dictionary Department, Institute of Linguistics, Chinese Academy of Social Sciences, The Contemporary Chinese Dictionary (Chinese-English edition), Foreign Language Teaching and Research Press, Beijing, 2002, page 741. According to Article of 93 and 94 of the Constitution of the PRC (Amendment) 2004, the President of the PRC is also a part of the State organ.

${ }^{606}$ Political "redness" has been used as the chief criterion for appointing cadres into the leading positions of judicial authority. See “Judiciary in Line With International Norms', Beijing Review, No. 49 (5-11 December 1994), pages 5-6, Quoted in Teather, David C. B. and Yee, Herbert S. (ed), China in Transition, Macmillan Press Ltd. London and St. Martin's Press Inc., New York, 1999, page 76. 
ensures the primacy of Party Politburo guidelines and has enabled the CPC to set the broad parameters of national policy. ${ }^{607}$ The structure of Chinese State organisations is listed in Appendix 1 of this thesis.

The situation of one party reign discussed above results in the established fact that CPC vests most of interests in China. Although Article 33 Clause 2 of the Constitution of the PRC (Amendment) 2004 set forth "all citizens of the People's Republic of China are equal before the law", the absolute leadership of the CPC means that, in practice, citizens' social and political status is not independent and equal. Because the CPC is fully integrated into the State organ and important enterprises and institutions, the status of party member becomes the basic qualification to be one of ruling elite. High status within the CPC translates as having high social and political status. The Secretary-General of CPC's Central Committee is the highest-ranking person in the central State organ, and can also be, as for example with Jiang Zemin or Hu Jingtao, the President of the People's Republic of China and chairman of the Central Military Committee. The secretary of the CPC's provincial branch is the highest-ranking individual in the provincial State organ. It is logically accepted that the members of the CPC, especially the cadres of the $\mathrm{CPC}$ will further vest economic interests in China.

While too little reform creates social change and instability that might challenge those interests, too much reform can do the same. In regard to the reform relevant to the RLR, Compared with the relaxtion of the restriction on the non-member of the CPC, it is acceptable that the limits over exit and entry of all party members, especial cadres of the CPC are much strict. Given the number and status of party members, ${ }^{608}$ the limits on their exit and entry equates to limits on exit and entry of the elite of Chinese society. The strict control over exit and entry of all party members is thus the foremost reason or basis for a number of issues to be discussed in later chapters of this thesis. Issues of exit and entry within public affairs will be discussed in part 8.2;

\footnotetext{
${ }^{607}$ US Department of State, “China (Including Hong Kong and Macao): Country Reports on Human Rights Practices 2002", http://www.state.gov/g/frl/rls/hrrpt/2002/eap/684.htm (2/02/2004), page 1.

${ }^{608} \mathrm{Up}$ to the end of 2003 , the amount of members of CPC is over 68.2 million, which accounts $5.2 \%$ of the whole population in China. See "Number of CPC members in China Exceeds 68 Million", http://english.peopledaily.com.cn/200407/01/eng20040701_148214.html (02/07/2004).
} 
prerequisite certificates from the departments in which the applicants are employed in parts 9.3, 11.1.3 and 11.2.2 of this thesis; retention of passports by designed departments in part 8.3.3; and the right of nationals not to be exiled in part 10.4. These issues have not been subject to the reform of laws governing exit and entry, which will be discussed in chapters six and seven.

Secondly, one party reign can effectively undermine the independence of the State organ and armed forces. The absolute leadership of the CPC means that the acts of the CPC can be seen as synonymous with acts of the State organ. This may lead departments of the State organ applying CPC policy as the criteria for the practical exercise of discretionary power, and to enact regulations and rules based on CPC policy. Some relevant issues from this, to be discussed in part 9.1.2 of this thesis, concern the legitimacy of acts of the CPC in cases when public security departments are instructed to prevent individuals with knowledge of important political, military, technological, or economic secrets from exiting China.

A further influence of one party reign is that, by conformity to CPC norms, and aspirations to social status, it can reduce an individual's urge or motivation to acquire the RLR. It follows that the acquisition of a high position within the $\mathrm{CPC}$ is an important life goal. As a result, no effort will be spared by the individual in dealing with CPC affairs in a manner that will please more senior members, even when this means that an individuals' potential to have personal rights and freedoms is greatly reduced.

Moreover, there are no independent political powers opposing the Communist Party in China. Article 35 of the Constitution of the PRC (Amendment) 2004 provides that the citizens enjoy freedom of association. However, the government restricts this right in practice. According to 2001 Human Rights Report of China released by the US State Department, the formation of truly autonomous politics, human rights, religious, environment, labour, and youth organisations that directly challenge government authority is prevented. ${ }^{609}$ The opposition party is illegal. ${ }^{610}$

${ }^{609}$ US Department of State, "China (Including Hong Kong and Macao) Country Report on Human Rights Practices for 2001", http://www.State.gov/g/frl/rls/hrrpt/2001/eap/8289.htm (2/02/2004), page 18. 
In this circumstance, no social and political association may legally strive for the RLR on behalf of Chinese citizens. Without the support and assistance of truly autonomous social and political associations, it is very hard to produce satisfactory results in the pursuit of the RLR for citizens. The absence of independent political powers may reliably explain why the government, rather than other sources, initiate all changes of the RLR in China.

One party reign in China makes the research of the RLR from a non-Marxist perspective a sensitive topic. Citizens who seek to express openly dissenting political views continue to live in an environment of repression. Critical analysis of the RLR in China is generally prohibited. Few academic scholars in China are willing to risk their future by conducting in-depth research in relation to the RLR. It is difficult, therefore, to objectively, fairly or comprehensively understand the realities of the RLR in China. Many of the issues concerning the RLR, argued in chapters eight to thirteen, have had very little attention from academics and have been ignored by government. For that reason, the materials to support the arguments made in this thesis are in general derived from legislative provisions, reports and news items, rather than from the work of academics.

In recent years, the CPC has gradually reduced its formal involvement in government operations. This has allowed the government to exercise significant discretion in implementing policy. The CPC has continued to strengthen the capacity of members of the National People's Congress (NPC) and to reform the bureaucracy. The congresses at all levels play an increasingly independent role as a forum for local and provincial concerns, particularly as critics of local and national corruption and inefficiency. ${ }^{611}$ Rural and village people have been learning about the practice of local elections. $^{612}$

\footnotetext{
610 The CPPCC is a key institution for multi-party cooperation and political consultations under the leadership of the CPC, a Chinese people's patriotic united front organization, and a major channel for promoting socialist democracy. See “CPPCC Annual Session Opens (03/03/2002)”, http://www.fmprc.gov.cn/eng/26138.html (19/07/2003).

611 "Chinese President Calls For Developing Socialist Democracy", http://english.peole.com.cn/200409/21/eng20040921 157751.html (22/09/2004).

612 "China to Further Promote Grass-roots Democracy", http://english.peopledaily.com.cn//200405/29/eng20040529 144736/html (31/05/2004).
} 
Although these reforms touch on an important and sensitive issue in China - of political democracy - the CPC unfortunately fails to provide a valid answer to the question of democracy. This is because all democratic reforms are based on one party reign that, on the one hand can help reformers to popularise limited reform measures, so to safeguard the long-term interests of the CPC but, on the other hand, do not allow comprehensive reform from the perspective of the State rather than the Party which could undermine the status of the CPC. ${ }^{613}$ For this reason, the absolute leadership of the CPC over the State organ and armed forces will not be changed in the near future. One party reign will continue to be a fundamental factor which restricts the improvement of the RLR in China.

\subsubsection{China as a member of the former communist bloc}

Despite of the collapse of the USSR and Eastern European communist countries in 1989, and China's commencement of the transition from a planned economy to a free market economy, we still find that the former socialist bloc casts dark shadows over Chinese exit and entry laws. C. P. Fitzgerald has suggested that the impression the USSR made on China was immense. ${ }^{614}$ Some exploration of the former socialist bloc may help to understand why the starting point and theme of exit and entry administration are designed to control, rather than to ensure that citizens enjoy the RLR.

Historically, all newly established communist regimes imposed strict emigration controls, which were kept in place until drastic political and economic changes occurred. Migration from communist countries to countries with established market economies was practically forbidden. Migration between communist countries occurred on a very limited scale and was usually not described as migration, but as temporary transfers of manpower for the coordinated use of the

\footnotetext{
${ }^{613}$ As Zhu, Rongji, the then premier stressed in his Report on the Work of the Government 2002, "the remarkable achievements in China's economic and social development in 2001... are attributed to the correct policy decisions and timely measures taken by CPC Central Committee..." See Zhu, Rongji, Premier of the State Council, "Report on the Work of the Government 2002 (16/03/2002)", http://www.fmprc.gov.cn/eng/26804.html (19/07/2003).

${ }^{614}$ Fitzgerald, C.P., The Chinese View of their Place in the World, Oxford University Press, Amen House, London, E.C.4 1964, page 44.
} 
productive resources of friendly countries. ${ }^{615}$ Although the former USSR recognised the RLR in its Constitution and ratified the ICCPR and the CERD in 1973 and 1979, it actually imposed numerous superfluous requirements on those applying for exit and entry. ${ }^{616}$

After the civil war from 1946 to 1949, which destroyed the Republic of China on the Mainland, and as a new socialist system was being built, China faced enormous economic problems and sought foreign help. The former USSR, Bulgaria, Romania, Hungary, North Korea and Poland successively established diplomatic relationships with and offered assistance to the new People's Republic of China, all within just six days of its establishment ${ }^{617}$ The Western countries that had imposed sanctions on the PRC during the 1950s and 1960s. ${ }^{618}$ Chinese people were called upon to follow in the footsteps of established communist countries, especially the former USSR. Mao Zedong exhorted that, "the Communists of the USSR are our best teachers, so we must learn from them". ${ }^{119}$ Although China tried to relax its hostile relationships with Western nations during this period, diplomatic ties were not improved until

615 The United Nations, International Migration Policies and Programs: A World Survey. Sales No. E.82 XIII.4, page 35 .

${ }^{616}$ (1) Having close relatives abroad is almost a prerequisite for obtaining permission to leave the USSR. The applicant will typically be asked to supply an invitation from close relatives, although the degree of closeness is not clearly defined. The relative, in return, must see that the invitation-called a vyzov is properly notarised; sometimes, OVIR also requires authentication of notarised invitation, which means the relative must get the original notarisation certified by government officials. (See Washington: Government Printing office, Senate Hearings on Soviet Pentecostals Residing in the U.S. Embassy in Moscow, 19 November 1981, ser. J-97-82, page 125); (2) Applicants are required to fill out long questionnaires asking for all sorts of information, such as whether they belong to the Communist Party; (3) Applicant must present references/a certificate of good character from their place of employment, signed by the director of the institution, the local party secretary, and the secretary of the trade union. (Chalidze, Valery, To Defend These Rights, Random House, New York, 1974 page 98-99); (4) Persons not intending to return must also present a document showing their parents' attitude toward the requested departure and, if the spouse is staying behind, an affidavit of spousal agreement. (See Magstadt, Thomas M., Emigration and Citizenship: Implications for Soviet-American Relations, page 6.

617 "The Lists of the Countries having Diplomatic Relationship with the PRC" (Yu Zhongguo Jianjiao Guojia Yilanbiao), http://www.fmprc.gov.cn (2/02/2004).

618 The USA Congressional -Executive Commission on China, “The People's Republic of China”, http://www.cecc.gov/pages/virtual/Acad/his/prc.php (04/01/2005)

619 Shen, Chen, "Language and Culture: Two Goals of Foreign Language Teaching in China, Lessons from History and Perspectives for the future", Australia Review of Applied Linguistic 12 / 2, 1989, page 51. 
the 1970s, when Italy, the UK, Japan, Germany, Australia and the USA recognised the PRC. ${ }^{620}$

For a time, Soviet culture was the only foreign culture that impacted on China. In the 1950s laws of the former USSR governing exit and entry were followed when the PRC devised its own laws. Enemies of the State were allegedly so pervasive and menacing that security could only be achieved through State-enforced unity, order, solidarity, and discipline. The collective imperatives of internal order and national defence took precedence over individual freedom. Hence, the RLR is practically denied in China, which imposed repressive migration policies similar to all communist countries. By 1958, diplomatic relations between the PRC and the USSR had cooled. Even though Chinese jurists at that time tried to break away from Soviet influences, no essential changes were made.

By the late 1980s and early 1990s, the Cold War had ended, drastic political and economic changes occurred in Eastern Europe and the former USSR, and the communist bloc had disintegrated. The hostile relationship between communist and Western countries had greatly eased. Some former Eastern European communist States have become members of the European Union (EU) and North Atlantic Treaty Organisation (NATO). Since the late 1980s, some communist countries began to soften their grip on the foreign travel of their citizens, or became more lenient to the demands of members of certain ethnic groups to emigrate. The UN summarised in International Migration from Countries with Economies in Transition: 1980-1999, that in the late 1980s and early 1990s, "most legal restrictions to migration were lifted and became practically non-existent." ${ }^{\prime 621}$

However, with no drastic political change in China having occurred, improvements of the RLR in China have been considerably less effective than those in former communist countries. After the death of Deng Xiaoping in 1997, Jiang Zemin announced that he would continue with

\footnotetext{
620 "The Lists of the Countries having Diplomatic Relationship with the PRC" (Yu Zhongguo Jianjiao Guojia Yilanbiao), http://www.fmprc.gov.cn (2/02/2004).

${ }^{621}$ Population Division, Department of Economic and Social Affairs, United Nations Secretariat, International Migration from Countries with Economies in Transition: 1980-1999, ESA/P/WP.176, New York, 2002, 123 pages, page 5 .
} 
Deng's reforms, including the reform of the political structure. However, as the Australian Department of Foreign Affairs and Trade stated in 2003, "there was little evidence of political liberalisation." ${ }^{922}$ Compared with the historical development of former communist countries' laws governing exit and entry of citizens, there is a long way to go before the RLR in China moves from the strict repression of the past to full liberalisation.

\subsection{Economics}

\subsubsection{Basic economic factors}

The Chinese economy is complex, unique and difficult for foreigners to understand. The largest population, economic underdevelopment and regional economic disparities are basic economic factors that China must face. In 2002, the Chinese population was approximately 1.3 billion, or 21 percent of the world's population. ${ }^{623}$ Premier Wen Jiabao explained that problems caused by China's vast population as being that:

Any small individual shortage, if multiplied by 1.3 billion, becomes a big, big problem. Any considerable amount of financial and material resources, if divided by 1.3 billion, becomes a very low per capital level. ${ }^{624}$

China's per capital GDP stood at a mere US\$911 in 2001, a far cry from developed countries, such as Japan, where the per capita GDP was US\$32,535. ${ }^{625}$ Of the 129 countries covered by the World Development Report, China ranked 76th on per capital GDP. ${ }^{626}$ According to official

\footnotetext{
${ }^{622}$ Australian Foreign Affairs and Foreign Trade Ministry, "the People's Republic of China: Country Information," http://www.dfat.gov.au/geo/china/cb_background.html (22/10/2003).

623 "Population and Development Indicators for Asia and the pacific, 2002", http://www.unescap.org/pop/data sheet/2002/tab1.htm (23-05-2003).

624 "The Premier of Wen, Jiabao Accepted the Interview of the Chief-editor of Washington Post" (Wenjiabao Zongli Jieshou Huashendun Youbao Zhubian Caifang), 23 November 2003, http://www.fmprc.gov.cn/chn/zxxx/t44934.htm (04/12/2003).

${ }^{625}$ World Bank calculations based on purchasing power parity reckon that China's per capital GDP in 2004 equals Japan's level in 1950. See “Analysis: Will China's Growth Sustain 30 More Years?” http://english.people.com.cn/200411/08/eng20041108 163104.html (15/11/2004).

${ }^{626}$ Quoted in Kwan, Chi Hung, "China in Transition: How Far is Coastal Behind the Industrialized Countries? An Analysis Based on Purchasing Power Parity (August 2002)”, http://www.rieti.go.jp/en/china/02080901.html (2/02/2004).
} 
Chinese statistics:

There are still 30 million farmers lacking food and clothing, 23 million city-dwellers living on a subsistence allowance, and 60 million disabled and handicapped people in need of social security aid. $^{627}$

At the same time, economic growth differs from region to region. ${ }^{628}$ In 2000 , the per capita GDP for China was US\$849, ${ }^{629}$ whereas in Shanghai it was US\$4,180, ${ }^{630}$ and urban per capita income was 2.7 times that of rural per capita income. ${ }^{631}$ In 2001 the US State Department reported that the economic disparity between coastal and inland regions, and between urban and rural areas continued to widen. ${ }^{632}$ Premier Wen Jiabao predicted that China's economy would deteriorate unless this disparity could be resolved. ${ }^{633}$

In the light of these three basic economic factors, the Chinese government has been concerned with instability caused by extensive reform. Jiang Zemin has pointed out that "stability is a prerequisite for reform and development," and that reform and development should occur "amidst social stability" ${ }^{634}$ In order to avoid or reduce the possibility of instability, the government has seldom embarked on sweeping reforms over a short period. The gradual nature

\footnotetext{
${ }^{627}$ Wen, Jiaobao, the Premier of the State Council, “Turning Yours Eyes to China”, Speech at Harvard University on 11th December 2003, http://www.fmprc.gov.cn/eng/Zxxx/t56076.htm (19/12/2003).

628 "Foreign Ministry Spokesman's Press Conference on September 3 2002", http://www.china-botschaft.de/ger/34525.html (17/11/2003).

629 "Shanghai Per Capita GDP Exceeds US 4,000 dollars, 1st January 2001", The People's Daily, http://fpeng.peopledaily.com.cn/200101/01/eng20010101_59339.html (2/02/2004).

630 “China's GDP Predicted to Top US\$1 Trillion: SIC, 2 November 2000”, The People's Daily, http://fpeng.peopledaily.com.cn/200011/02/eng20001102_54181.html (2/02/2004).

${ }^{631}$ US Department of State, "China: Country Report on Human Rights Practices 2001”, http://www.State.gov/g/frl/rls/hrrpt/2001/eap/684.htm (2/02/2004), page 1 .

${ }^{632}$ US Department of State, "China: Country Report on Human Rights Practices 2001”, http://www.State.gov/g/frl/rls/hrrpt/2001/eap/684.htm (2/02/2004), page 1 .

633 "The Premier of Wen, Jiabao Accepted the Interview of the Chief-editor of Washington Post" (Wenjiabao Zongli Jieshou Huashendun Youbao Zhubian Caifang), 23 November 2003, http://www.fmprc.gov.cn/chn/zxxx/t44934.htm $(04 / 12 / 2003)$.

634 Jiang, Zemin, the President of the PRC, "Build a Well-off Society in an All-Round Way and Create a New Situation in Building Socialism with Chinese Characteristics: Report page 16th China Communist Party Congress (8/11/2002)", http://www.fmprc.gov.cn/eng/37816.html (19/07/2003).
} 
of reform is also obvious in relation to the reform of exit and entry laws and administration. The biggest overhaul will be gradually implemented between 2002 and 2005. Pilot reform projects were initially carried out in relatively developed areas, such as Guangdong, where some limits on the RLR were eased for the purpose of a trial. The introduction of this process into all medium and large cities will be discussed in part 7.2.2 of this thesis.

Regional economic disparities relate especially to exit and entry administration of the HKSAR and MSAR, and to the emigration intermediary agencies. Only residents in Guangdong, Shanghai and Beijing, of all 33 provincial administrative areas, can freely travel to and from the HKSAR and MSAR. In various provincial administrative areas, the requirements for the application for exit can vary, which will be discussed in part 7.2.3 of this thesis. The establishment and operation of the emigration intermediary agencies is explained and analysed in part 12.3.2 of this thesis.

The size of China's population also affects the administration of permanent residency. According to an OECD report in 2001, when compared to other countries where foreigners are granted permanent residency to fill labour shortfalls, China has a large labour force and low labour costs. ${ }^{635}$ China, in protecting its own workforce, has therefore not sought to attract external labourers. China's policies with respect to the return of overseas Chinese citizens are addressed in parts $10.1,10.2$ and 10.3 of this thesis, in which it is noted that financial independence, rather than nationality is the key determinant in granting permission to resettle.

\subsubsection{Socialist public ownership of the means of production and a transitional economy}

Article 6 of the Constitution of the PRC (Amendment) 2004 stipulates:

The basis of the socialist economic system of the People's Republic of China is socialist public ownership of the means of production, namely, ownership by the whole people and collective ownership by the working people.

635 Chapter 4. China, the OECD, Migration and the Labour Market in Asia: Recent Trends and Policies, the OECD, Paris 2001. 
Socialist public ownership of the means of production is also called State ownership. In theory, everyone is the owner of social resources. The task of China's parliamentarians is not to decide what resources the government should own, but how the government utilises those resources effectively. ${ }^{636}$ Under this system, individuals and private businesses are not completely independent participants in the economic interests of China.

Before reform and opening up, the 'binding net' between individuals and working units (gongzuo danwei) was the most important channel through which individuals could participate and co-operate in social activities. Individuals did not have the right to own or deal with resources. Every working urban resident belonged to a public working unit, since the State owned all working units. These working units provided their employee's with cradle-to-grave welfare guarantees and pensions. In turn, the working units approved almost all acts of their employees, including their employees' applications to go abroad. These 'binding nets' effectively turned employees into de facto appendages to their working unit. The approval requirements constituted a general violation of individual rights by the State, and controlled personal mobility. There was little ground to challenge the extensive exercise of public power by working units during this period, in relation to private affairs. Consequently, it is not meaningful to discuss the RLR or other rights during this period. Because exit and entry policies were those of the working units, this partially explains why there were so few laws governing the processing of the applications for exit and entry between 1949 and 1985 , which will be discussed in parts 6.3 and 6.4 of this thesis.

China officially embraced market economics and abandoned the planned economy after the constitutional amendment of 1993. Foreign industries were legal in 1979 when the Law on Chinese and Foreign Equity Joint Ventures was promulgated, and private industries were legal after the constitutional amendments of $1988 .{ }^{637}$ After that time private industries and the

\footnotetext{
${ }^{636}$ Shih, Chih-yu, Collective Democracy Political and Legal Reform in China, The Chinese University Press, 1999 , page 54.

637 “Citizens' legal private property is inviolable" was inserted as Article 13 Clause 1 when the Constitution was further amended in 2004.
} 
extent of foreign investment greatly developed. In 2002, "the non-State sector accounted for more than 70 percent of China's gross industrial output". ${ }^{638}$ As of December 2003, 80 million persons were employed in private industry. Private firms contributed 23 percent of yearly GDP growth, and 65 percent of exported products were made by enterprises supported by foreign investment. ${ }^{639}$

The flourishing non-State sector has cultivated a new workforce beyond the working unit framework. Restructuring of the State sectors, including the streamlining of government offices and mass lay-offs from State enterprises, has left a great number of people without a working unit. Working units no longer form a binding net that covers all working people. The development of non-State industry provides an economic basis upon which to cancel the requirement of working unit approval for an application to leave China, which will be discussed from different angles in parts 9.3, 10.1.2, 11.1.3 and 11.2.2 of this thesis. A goal of the reform strategy is to enable a person to access a passport on demand. This will become more feasible if the structure of the working unit is further weakened.

Extensive development of private industry has fostered awareness among employees of their rights and interests. More Chinese people are growing rich, and are no longer dependent on the State. They will have increasing control over their own lives, particularly as they can enjoy private ownership. Increasing public awareness of individual legal rights and interests will cause people to doubt the legitimacy of their working units' control over intrinsically personal affairs which in effect limit the RLR, which will be discussed in part 9.3 of this thesis.

\subsubsection{Interaction between economic development and laws governing exit and entry}

Three key events have made China increasingly open to the world: the 1978 new policy of reform; the establishment of a socialist market economy as the goal of reform in 1992; and

\footnotetext{
638 Australian Foreign Affairs and Foreign Trade Ministry, The People's Republic of China: Country Information, http://www.dfat.gov.au/geo/china/cb_background.html (22/10/2003).

639 "The Premier of Wen, Jiabao Accepted the Interview of the Chief-editor of Washington Post" (Wenjiabao Zongli Jieshou Huashendun Youbao Zhubian Caifang), 23 November 2003, http://www.fmprc.gov.cn/chn/zxxx/t44934.htm $(04 / 12 / 2003)$.
} 
China's entry into the World Trade Organisation (WTO) in 2001. China achieved an average annual GDP growth of above 9 percent from 1978 to 2003, a stunning record worldwide. ${ }^{640}$ These economic achievements have created suitable conditions for the advancement of the RLR in China, and had a profound effect on the extent to which the right operates.

\section{8 reform policy}

The economic boom in China started with the implementation of Deng Xiaoping's economic reform policy in 1978. The demand for international integration has followed from the pattern of sustained economic development since then. The Law on the Control of Exit and Entry of Citizens (PRC), the Law on the control of Exit and Entry of Aliens (PRC) and their detailed rules of the implementation, were introduced in 1985 and 1986 to aid in the assessment of the numerous applications to leave China. Article 1 of the Law on the Control of Exit and Entry of Citizens 1985 (PRC) provides that "this law is formulated with a view ... to promote international exchange." Article 1 of the Law on the Control of Exit and Entry of Aliens 1985 (PRC) sought to "facilitate international exchange" as one of its three legislative purposes.

The establishment of a socialist market economy as the goal of reform in 1992

Learning from the lessons of the drastic political and economic changes in Eastern Europe and the former USSR, in 1992 the CPC opted to establish a socialist market economy. Its establishment consolidated close links between China and the rest of the world and resulted in a doubling of the number of Chinese people leaving China. The number of emigration intermediary agencies mushroomed in response to demand. At the same time, the dramatic growth in the number of people wishing to exit and exit the territory raised a great number of issues. The laws governing exit and entry and the RLR began to be improved after 1994, "In order to be suitable for reform and opening up and the development of [the] socialist market

\footnotetext{
640 “Analysis: Will China's Growth Sustain 30 More Years?” http://english.people.com.cn/200411/08/eng20041108 163104.html (15/11/2004).
} 
economy." ${ }^{641}$ Laws governing intermediary agencies were hastily enacted.

The entry to the WTO in 2001

With membership of the WTO in 2001, China reached a new phase in its embrace of the global economy. ${ }^{642}$ It now needed both talented people from overseas to enter, and its own citizens to go abroad - the reforms of exit and entry served this purpose exactly. In November 2001, ten days after China joined the WTO, the biggest overhaul in the history of Chinese migration law was announced, which will be discussed in part 7.1 of this thesis. The reforms, just as China promised to open its market to the outside world, helped China to open its door for its own people.

\subsubsection{Impacts of the limits of the movement within the territory on the RLR}

Under the household registration system established in 1958, to be discussed in part 6.3.1 of this thesis, movement within China is prohibited. It has been accepted that if an individual could not freely move within China, he or she seldom considered overseas travel. This was particularly true for residents in remote areas in China who may have had feelings of trepidation about leaving China. The household registration system led to the prohibition of non-registered resident area applications, which will be discussed in part 8.3.1 of this thesis. The requirements of household registration after returning to China, will be discussed in part 10.1.3, and the requirements of household deregistration before leaving China, will be discussed in part 9.4 of this thesis.

Undoubtedly, the outdated household registration system became a barrier to the free-flow of human resources needed by a market economy and globalisation. As Cai Fang, director of the

\footnotetext{
${ }^{641}$ Article 1 Clause 1 of the Explanation of the Enforcement of the Amendment of Two Detailed Rules of the Implementation 1995 (PRC) (Zhixing Liangge Shishi Xize Xiuding Neirong De Shuoming), promulgated by the Ministry of Public Affairs on 13th February 1995 and effective on the same day. See also the Detailed Rules of the Implementation of Law on the Control of Exit and Entry of Citizens 1985 (PRC) and the Detailed Rules of the Implementation of Law on the Control of Exit and Entry of Aliens 1985 (PRC) which were separately revised in 1994.

${ }^{642}$ Zhu, Rongji, the Former Premier of the State Council, "Report on the Work of the Government 2002 (16/03/2002)", http://www.fmprc.gov.cn/eng/26804.html (19/07/2003), page 16.
} 
Population institute of the Chinese Academy of Social Sciences, has argued, the outdated household registration system had long been blamed for the inefficient distribution of human resources, resulting in an excessive concentration of people in urban areas and a 'brain drain' from developing areas. ${ }^{643}$ For this reason, a new household registration system was implemented in 2001 under the Circular of the State Council on Transmitting the Opinions of the Ministry of Public Security Concerning the Expedition of the Small Town Registered Residence Management System Reform. This allowed all rural residents and non-natives, (who have a legal and static dwelling place, a stable occupation and source of income) and their families, to apply for permanent residence in urban area towns where they work and live. By the end of 2001, several provinces, such as Jilin, Hunan, Guangdong, Fujian and Liaoning, had abolished the division between agricultural and non-agricultural household categories. ${ }^{644}$

The right to freely move within China will create the conditions for the individual awareness and enjoyment of the RLR. The relaxation of the prohibition of non-registered resident area applications is discussed in part 7.2.3 of this thesis, alongside the cancellation of the deregistration of individuals who have been abroad for more than one year, ${ }^{645}$ and the establishment of a mutual information network that combines exit and entry information and household registration management during 2005. ${ }^{646}$ However, as Bao Suixian, deputy director of the Public Security Bureau of the MPS, emphasised in 2002, the registered residence management system will continue to exist for a long time, as it is an important component of China's administrative management. ${ }^{647}$ Restrictions on the RLR related to household registration can be predicted to remain in the near future.

\footnotetext{
${ }^{643}$ Quoted in “Residence System Reform Speeds up Human Resources Flow,” 31 October 2001, The People's Daily, http://english.peopledaily.com.cn/200110/31/eng20011031 836216.html (30/12/2003).

644 “China to Cut Limits on Population Mobility,” 26 February 2002, The People's Daily, http://english.peopledaily.com.cn/200202/26/eng20020226_909816.shtml (30/12/2003).

645 "Reforms Make Life and Travel Much Easier", 8 August 2003, The China Daily, http://www1.chinadaily.com.cn/en/doc/2003-08/08/content_252954 (19/12/2003).

646 "State to Simplify Entry-exit Rules", 11/22/2002, The China Daily, http://www1.chinadaily.com.cn/news/2001-11-22/44711.html (18-04-2003).

647 “MPS: China's Registered Residence Management System Will Not Be Abolished”, 26 February 2002, The People's Daily, http://english.peopledaily.com.cn/200202/26/eng20020226 91010.shtml (30/12/2003).
} 


\section{$5.3 \quad$ Culture}

Apart from political and economic factors, the RLR in China is widely influenced by culture. Without doubt, the very heart of Chinese culture is Confucianism. Confucianism has existed for more than 2,500 years. ${ }^{648}$ Although countless dynasties and governments have changed hands, the reverence paid to Confucianism has never waned. In Confucianism, the position of the individual in the society is relative independent in comparison with the in Christianity. A man in Confucianism must pay more loyalty to the State and his/her family than in Christianity. Confucianism pays more attention to the duty than right. Confucianism's attitude to the foreign cultures is sublating (from Hegelian philosophy, to put aside but not wholly dispense with). The existence and influences cannot be divorced from Chinese agricultural civilisations, its geographical environment. An analysis of the influences of Confucianism on the RLR in China might be achieved by above main elements.

\subsubsection{The community-orientated culture}

Western democratic systems stress individuality, privacy, diversity, and protection of the individual from undue outside interference. A person should have freedom of movement, and then ask under what circumstances this freedom may be restricted. The traditional Chinese approach has been quite different.

Chinese traditional social mores have revolved around Confucian philosophical norms and ideals. Confucianism advocates the rule of rites and traditional ethics. Everyone forms part of a patriarchal social network, and has a node in the broader homogeneous structure. All nodes, which consist of the three cardinal rules (Sangang) and the five cardinal virtues (Wuchang), are inextricably interrelated by a number of threads. The three cardinal rules are that a monarch rules over the subjects (Junjun chenchen), a father rules over his child (Fufu zizi), and a husband rules over his wife (Fufu qiqi). The five cardinal virtues are benevolence (Ren), dutifulness (Yi), decency $(L i)$, knowledge $(Z h i)$, and faithfulness (Xin). Everyone must obey their fixed social

\footnotetext{
648 "In China, Confucius started in about 520. B.C. to disseminate knowledge of benevolence (ren) and decency (Li), and persists for decades." Yu, Shutong and Wen, Jia (ed), A New Chinese-English Law Dictionary (Xin Hanying Faxue Cidian), Publishing House of Law, Beijing, 1998, page 1250.
} 
position within the three cardinal rules and the five cardinal virtues. This position cannot be altered. Individuals, who are closely intertwined in this structure, are taught that it is their duty to suffer their treatments.

Chinese culture appreciates the importance of individuals but places greater emphasis on how a person functions within the context of a larger group. ${ }^{649}$ In the Chinese language, the term for 'individuals' (Geren) has the same meaning as 'oneself' (Ziwuo) ${ }^{650}$ The term for 'oneself' often connotes selfishness (Zisi), and is frequently used as a contrast to the term 'public' (Gong) and 'collective' (Jiti), which implies the 'common' (Gonggong). ${ }^{651}$ Preference for the larger collective unit over the individual continues into the present day, although there are certainly groups in China who are defined by loyalties other than kinship and hold to Communist rather than Confucian ideology. As Sun Changjiang has stated:

In this social order, neither man nor one's personality is free. There is no true respect towards people, since one cannot speak of man's independence when there is no independent individual. ${ }^{652}$

The Australian Human Rights Centre has observed that the core of Confucianism puts the emphasis on community. Within such an environment, a code of ethics has evolved which places a duty on the individual to uphold group harmony, even if this necessitates suppression or subordination of individual claims and grievances. ${ }^{653}$ In this context, the RLR based on the independence of individual, is hardly to be recognised by the society.

\footnotetext{
${ }^{649}$ Li, Victor, "Human Rights in a Chinese Context", in Lee, Tahirih V. (ed), Law, the State and Society in China, Garland Publishing Inc., New York, 1997, page 226.

${ }^{650}$ Dictionary Department, Institute of Linguistics, Chinese Academy of Social Sciences, The Contemporary Chinese Dictionary (Chinese-English edition), Foreign Language Teaching and Research Press, Beijing, 2002, page 656.

${ }^{651}$ Dictionary Department, Institute of Linguistics, Chinese Academy of Social Sciences, The Contemporary Chinese Dictionary (Chinese-English edition), Foreign Language Teaching and Research Press, Beijing, 2002, pages 667 and 668.

${ }^{652}$ Sun, Changjiang "Chinese Society, Chinese Confucianism, and the Modernisation of China", at Krieger, Silke and Trauzettel, Rolf (ed), Confucianism and the Modernization of China, v. Hase \& Koehler Verlag, Mainz, Eschwege, Germany, 1991, pages 393.

653 Australian Human Rights Centre, "Human Rights in Taiwan: Issues for the 21st Century", http://www.ahrcentre.org/reports/Human Rights in Taiwan.htm (04/09/2003).
} 


\subsubsection{Loyalty (Zhong) and filial piety (Xiao)}

Loyalty and filial piety, which link the principle of benevolence and the action, are the two most important concepts of traditional Confucian ethics. Loyalty is the root of social morality, and usually interpreted as meaning sincerity, conscientiousness, or the exhaustion of one's self in the performance of one's moral duties. Those who ignored the country's interests but instead keenly pursued individual wealth and blindly obeyed the orders of the monarch were considered 'traitors' ${ }^{654}$ Travel might expose Chinese inhabitants to other ideas and wider horizons, which may challenge the established social and ideological structures. Chinese leaders routinely punish political dissidents by imprisonment or exile on the grounds that dissent and disloyalty are indistinguishable.

Filial piety is the foundation of familial ethics, and should be a desire of one's innermost heart and practiced with respect and sincerity to one's parents. According to Analects, the bible of Confucianism, a child should keep oneself at one's parents' side at all possible times and try one's best to refrain from distant travels, in order to relieve their anxiety. Confucius said, "While his parents are alive, the son may not go abroad to a distance. If he does go abroad, he must have a fixed place to which he goes."

The doctrines of loyalty and filial piety have been important factors in maintaining the stability of Chinese government and family. These doctrines provided good reasons to persuade people never to move away from the State or one's ancestral home, in other words to deny the RLR. Seeking settlement elsewhere was unwelcome. The act of an individual leaving home voluntarily was one of disloyalty (Buzhong) to the monarch and one of filial non-piety (Buxiao) to the parents. Any voluntary departure amounted to rejection of the family; and life as an exile from home was a serious form of punishment. Migration was simply not an option, only sojourning on official duty, or as a trader, was permissible.

\footnotetext{
${ }^{654}$ Lee, Cheuk-yin, "the Dichotomy of loyalty and Filial Piety in Confucianism: Historical Development and Modern Significance", at Krieger, Silke and Trauzettel, Rolf (ed), Confucianism and the Modernization of China, v. Hase \& Koehler Verlag, Mainz, Eschwege, Germany, 1991, page 99.

655 Analects, Chapter XIX, quoted at Chen, Lifu, The Confucian Way: A New and Systematic Study of "the Four Books', translated from the Chinese by Liu, Shih Shun, KPI Limited, London, 1986, page 382.
} 
As a consequence, "China is a country without a tradition of voluntary migration." ${ }^{656}$ Yimin which today translates to "migrant" and literally means "moving people" comes from two phrases, "moving" (Yi) and "people" (Min), which imply an official decision to have people moved - either to strengthen defences on the border or to respond to changing economic demands. Chinese regarded their emigration as a temporary sojourn (Qiao), ${ }^{657}$ or as the beginning of the idea of 'overseas Chinese' (Huaqiao), and would generally leave his wife and children at home to reaffirm his links with the village. ${ }^{658}$ Chinese people believe that people residing elsewhere will finally return to their ancestral home (Yeluo Guigen). ${ }^{659}$ If they did not, officials and even members of the family would treat them as vagabonds, outlaws, or a threat to social order. The term 'overseas Chinese' become politically loaded in order to encourage the Chinese so described to be loyal and patriotic to China. ${ }^{660}$

\subsubsection{The duty orientated culture}

Western culture has nurtured the concept of inherent and sacred individual rights. The Confucian code of ethics, which places emphasis on duty, does not mean that there is no the conception of right in China. However, the concept of a 'right' in China is different to the Western notion. The Chinese term that corresponds to the concept of a right is quanli. The Chinese character 'quan' seems to have the meaning 'just', when it is used as a standard for the measurement of affairs and things. The traditional use of the term quanli relates to authority, power and profit, rather than the modern sense of 'rights'. ${ }^{661}$ The modern term quanli, by which

\footnotetext{
${ }^{656}$ Wang, Gungwu, Don't Leave Home: Migration and The Chinese, Times Academic Press, Singapore, 2001, pages $8-9$.

${ }^{657}$ Dictionary Department, Institute of Linguistics, Chinese Academy of Social Sciences, The Contemporary Chinese Dictionary (Chinese-English edition), Foreign Language Teaching and Research Press, Beijing, 2002, page 1549.

658 Buggy, T.P., Chinese Immigration and the Emergence of an Australian Image of China 1848-1861, the thesis of Master of Arts Macquarie University, 1978, pages 19-20.

659 Dictionary Department, Institute of Linguistics, Chinese Academy of Social Sciences, The Contemporary Chinese Dictionary (Chinese-English edition), Foreign Language Teaching and Research Press, Beijing, 2002, page 2239.

${ }^{660}$ Wang, Gungwu, Don't Leave Home: Migration and The Chinese, Times Academic Press, Singapore, 2001, pages 38 and 144.

${ }^{661}$ Dictionary Department, Institute of Linguistics, Chinese Academy of Social Sciences, The Contemporary Chinese Dictionary (Chinese-English edition), Foreign Language Teaching and Research Press, Beijing, 2002, page 1595.
} 
the modern concept of rights is expressed, ${ }^{662}$ seems to be relatively recent creation.

Rights and obligations in Confucianism are reciprocally preconditioned, yet arise from a different relation to both culture and the natural world. Confucian culture focused on obligation (Quanli Yiwuhua). Confucianism gives rise to the assumption that man is born with the virtue (Renzhichu, Xingbenshan). Virtue obliges one to respect fellow members of the human race and all other living things in the natural world. Rights are relative and conditioned by circumstances. The Confucian concept of rights and obligations can only be seen by examining how, when, where and with what presupposed conditions they function in relation to social relationships as a whole. Dr. Sun Longji, an Amreican professor in history has a quite brilliant exposition regarding the relationship between the parents and the kids in Western culture. He found that the Western people focused on the independence of the kids, the relationship between the parents and the kids is a equal friend reltionship. Granting special consideration to one's parents is from one's love rather than one's obligations. ${ }^{663}$ Instead the Confucian focused on the duty of the son to grant his father special consideration. Article 21 (1) of Marriage Law 2001 (PRC) expressly regulates that children shall have the duty to support and assist their parents.

The emphasis of Chinese tradition was duty. ${ }^{664}$ Kim Hyung discussed this in Fundamental Legal Concepts of China and the West: A Comparative Study, concluding that:

While the Western tradition in the modern period emphasised the sphere of "rights' possessed by a person, traditional Chinese thought transposed the sphere of "rights' to the sphere of "duty", that is, the right act for one to do in virtue of the right of the other person. This is the reason why the Chinese tradition appears to be without a definite concept of rights and only with an emphasis on duty. The relationship between "right" and "duty" is so intimately related in Chinese tradition that one may often be puzzled and left without a clear concept of right in the area of the rights of

${ }^{662}$ Dictionary Department, Institute of Linguistics, Chinese Academy of Social Sciences, The Contemporary Chinese Dictionary (Chinese-English edition), Foreign Language Teaching and Research Press, Beijing, 2002, page 1596.

${ }^{663}$ Sun, Longji, The Deep Structure of Chinese Culture, The Publishing House of Guangxi Normal University, Guiling, China, 2004

${ }^{664}$ Li, Victor, "Human Rights in a Chinese Context", in Lee, Tahirih V. (edit), Law, the State and Society in China, Garland Publishing Inc., New York, 1997, page 226. 
persons. ${ }^{665}$

The idea that rights and obligations are reciprocally preconditioned still dominates philosophical thinking in contemporary China. According to the Contemporary Chinese Dictionary (Chinese-English Edition), quanli is defined as a "right to be performed by a citizen or juristic person and the interests he enjoys, opposed to 'obligation"." ${ }^{666}$ At the 58th Session of the UN Commission of Human Rights, Wang Guangya, then Vice Foreign Minister, stated that China was not in favour of the Western approach to human rights or its processes in realising human rights. He said, "While protecting individual rights, we also advocate fulfilment of social responsibilities." ${ }^{967}$ Under such circumstance, individuals seldom question the reasonableness of the exhortation not to leave home and do not have the incentive to struggle for the RLR.

\subsubsection{Sublating (Yangqi)}

It is widely accepted that there are big differences between existing Chinese law governing exit and entry, the migration laws of the Western countries, and international norms, which are duly discussed in this thesis. The attitude of Chinese culture toward the migration laws of the Western countries and international norms helps to understand the motivation for, and pattern of Chinese legislative reform in this area.

The philosophy of sublating (Yangqi) dominates any investigation of foreign culture in contemporary China. According to the authoritative Chinese dictionary, 'sublating' means to, "(in metabolism (Xinchen Daixie)) develop what is positive and discard what is negative." 668

\footnotetext{
${ }^{665}$ Kim, Hyung I, Fundamental Legal Concepts of China and the West: A Comparative Study, Kennikat Press Corp. Port Washington, the USA 1981, page 121.

${ }^{666}$ Dictionary Department, Institute of Linguistics, Chinese Academy of Social Sciences, The Contemporary Chinese Dictionary (Chinese-English Edition), Foreign Language Teaching and Research Press, Beijing, 2002, page 1596.

${ }^{667}$ Wang, Guangya, "Statement by H. E. Vice Foreign Minister WANG Guangya at the $58^{\text {th }}$ Session of the United Nations Commission on Human Rights, Geneva, 2 April 2002, United Nations High Commissioner For Human Rights”, http://www.unhchr.ch/huricane/huricane.nsf/view01/3D9E089928BFD46AC (04/09/2003)

${ }^{668}$ Dictionary Department, Institute of Linguistics, Chinese Academy of Social Sciences, The Contemporary Chinese Dictionary (Chinese-English Edition), Foreign Language Teaching and Research Press, Beijing, 2002, page 2218.
} 
Western scholars refer to 'sublating' as 'critical inheritance'. ${ }^{669}$ 'Sublating' or 'critical inheritance' stresses the doctrine of using the foreign to serve China (Yangwei Zhongyong).

In modern society, the nature of migration has undergone profound changes ${ }^{670}$ The migration laws have been changed accordingly. For instance, there has been a recent shift in emphasis from migrants with rare skills to those who are trained and educated in interchangeable skills. Although the existing legislation has been reformed to take the requirements of a modern legal system into account, it is apparent that political and administrative factors still shape the interpretation and application of existing entry and exit legislation. Without doubt, it is necessary to accept a new Western doctrine to replace the inadequate Confucian teachings and Marxist legal theory, in order to meet the need of migration law reform.

Guided by the doctrine of sublating, China selects from foreign migration laws and international norms for its own purposes. Local Chinese legal cultures, which concentrate on instrumentalism, determine the selection and influences of international norms. Chinese governments generally selects laws that facilitate the control over exit and entry, rather than protect the RLR. Accordingly, although China has ratified some international conventions concerning the RLR such as the UDHR, ICESCR, CERD, CEDAW, CSR, and CRC, and acceded to the ICCPR, these conventions and foreign migration laws have had little effect on the basic normative premise underlying China's migration law system. Existing entry and exit law remains an instrument of the CPC-led model of governance, the typical example is the denial of Western skilled migration in 1995, which will be discussed in part 12.2.2 of this thesis.

A changing tide in social attitudes has not negated the cultural norms engrained in China from centuries of Confucianism. In spite of increased public awareness of the RLR, the cultural bias has manifested a general lack of real understanding of the right in everyday life.

\footnotetext{
${ }^{669}$ Chang, King-yuh, "Confucianism in the Republic of China and its Role in Mainland China's Reform”, at Krieger, Silke and Trauzettel, Rolf (ed), Confucianism and the Modernization of China, v. Hase \& Koehler Verlag, Mainz, Eschwege, Germany, 1991, page 237.

${ }^{670}$ OECD the Future of Migration The secretary-general of the OECD 1986, pages 28, 33 and 34.
} 


\subsubsection{Agrarian civilisation and geographical isolation}

To exhort agricultural workers not to leave home was probably common to all agricultural civilisations, as mentioned in part 2.2.3 of this thesis, because of the labour loss caused to the family and the community in rural societies. It is also not generally necessary to make contact outside in a self-sufficient society.

The discouragement from leaving home in Chinese agricultural society permeates much more deeply than in the West, because China has four millennia of agrarian history, ${ }^{671}$ much longer than the history of Western agriculture societies. The agricultural population and output in China still accounts for a large proportion of overall population and national economy. According to the data released by the State Bureau of Statistics, China (SBS) in 2002, there were 782 million rural residents, accounting for $60.9 \%$ of the overall population, agriculture contributed US $\$ 180$ billion to the economy and accounted for in $14.5 \%$ of GDP. ${ }^{672}$ China is at the stage of industrialisation rather than post-industrialisation. ${ }^{673}$ In this context, the recognition and improvement of the RLR cannot be high on the Chinese government's agenda. ${ }^{674}$

China's geography has favoured the development of a civilisation with little or no foreign contacts. The term "China" (Zhongguo), which derives from two phrases, "centre" (Zhong) and "Kingdom" (Guo), means the central kingdom in the world. The traditional view was that China was the centre of the world, the sole upholder of true civilisation, and the lawgiver to the

\footnotetext{
671 The first dynasty, Xia Dynasty started in 2070 BC. See Dictionary Department, Institute of Linguistics, Chinese Academy of Social Sciences, The Contemporary Chinese Dictionary (Chinese-English edition), Foreign Language Teaching and Research Press, Beijing, 2002, page 2069.

${ }^{672}$ State Bureau of the Statistics, "Statistics Gazette of the People's Republic of China on 2002 National Economy and Social Development" (Zhonghua Renmin Gongheguo 2002 Guomin Jingji he Shehui Tongji Gongbao), 28 February 2003, http://www.stats.gov.cn/tjgb/ndtjgb/qgndtjgb/1200302280214.htm (30/12/2003).

673 “Analysis: Will China's Growth Sustain 30 More Years?" http://english.people.com.cn/200411/08/eng20041108_163104.html (15/11/2004).

${ }^{674}$ The government affirmed in 2000, that it would "continue to put the safeguarding and promotion of the people's rights to subsistence and development on the top of its agenda, and spare no effort to develop the economy, enhance the comprehensive national strength and improve the people's access to subsistence and development" and that "[w]hile improv[ing] the people's living standards across the board, the Chinese government has attached great importance to ensuring that poverty-stricken people have enough to eat and wear." See Information office of the State Council of the PRC, Human Rights in China 2000, White Paper of Human Rights, Beijing, 2000, pages 1 and 3.
} 
barbarians. This worldview facilitated the notion that China neither needed foreign allies, nor that any neighbour was worthy of being an ally. This view has not fundamentally changed. It has been adjusted to take account of the modern world, but China retains its central importance in relation to other countries. ${ }^{675}$ In light of all these cultural and demographic factors, it has been difficult to raise awareness of leaving China and settling abroad.

\subsection{Law}

Compared to political, economic and cultural factors, law has the most direct impact on the RLR in China. In this section, the impact of law on the RLR will be considered by considering (i) the absence of a constitutional foundation to protect the RLR; (ii) the nature of law governing exit and entry as the 'ruling tool' to control exit and entry; and (iii) the aim of law governing exit and entry: to control exit and entry (iv) the conflicts of laws regarding exit and entry; and (v) legal research of the RLR in China. ${ }^{676}$

\subsubsection{Absence of a constitutional foundation to protect the RLR}

A Constitution is a good starting point for studying the extent to which international human rights standards have been implemented by a State, because it represent a negotiated consensus of at least some dominant groups in a society on basic political questions. There are no regulations relevant to the RLR in the Constitution of the PRC 1982 and its four amendments.

Although Article 33 Clause 4 of the Constitution of the PRC (Amendment) 2004 stipulates "the State respects and safeguards human rights", it is doubtful that the reference to "human rights" includes the RLR. The Chinese government's understanding of right, as discussed in part 5.3.3 of this thesis, and human rights will be discussed in part 14.1 .1 of this thesis, is generally different from understandings in the West. In Western society, the RLR is part of an individual's

\footnotetext{
${ }^{675}$ Fitzgerald, C.P., The Chinese View of their Place in the World, Oxford University Press, Amen House, London, E.C.4 1964, pages 2 and 52.

${ }^{676}$ Lack of advanced legislative technique and lax law enforcement are two important issues in Chinese migration law. However they are also common issues in other Chinese branch law. The studies on these will not the centre of RLR study. Giving the length, this thesis excludes these two topics.
} 
political rights. By contrast, the Chinese government has appealed to the international community to put more emphasis on economic, social and cultural rights and the right to development. ${ }^{677}$

If the Chinese government is inclined to recognise the RLR as an indispensable aspect of human rights, Article 33 (4) of the Constitution then raises the issue of how to interpret "respect and safeguard." In Western societies, restrictions on the RLR must be provided by law, must be necessary for the protection of a democratic society, and must be consistent with all other rights recognised in the ICCPR, which was discussed in part 3.3 of this thesis. The Chinese government has stressed the indivisibility of rights and duties and the special characteristics of measures used to protect Chinese society. ${ }^{678}$ In March 2000, Tang Jiaxuan, the then Foreign Minister said, that "the international community should respect the measures countries take to promote and protect human rights according to their particular situation and reality" ${ }^{679}$ The lack of constitutional recognition and protection of the RLR clearly hinders the reform of the Chinese regulatory regime governing the RLR.

\subsubsection{The nature of law governing exit and entry as the 'ruling tool' (Tongzhi Gongju) to control exit and entry}

The Chinese communist regime rejected the legal codes along Western lines drawn up after the fall of imperial rule and, after a brief hesitation, repudiated the Soviet communist model. The Chinese communist model has afforded a very narrow place for the law. ${ }^{680}$ From the official and popular Chinese perspective, law or juristic method is:

[A] code of conduct formulated by a legislative body, whose enforcement is guaranteed by State

\footnotetext{
677 Sha, Zukang, Chinese Ambassador of the United Nations, "China Calls for Cooperation in Human Rights Field 03/04/2003", http://www.cctv.com/special/1016/1/2.html (20/05/2003).

${ }^{678}$ Under Article 33 Clause 3 of Constitution of the PRC (Amendment) 2004, "every citizen is entitled to the rights, and at the same time must perform the duties, prescribed by the Constitution and the law."

679 “Chinese FM Meets Russian Human Rights Representative (16/03/2000)”, www.fmprc.gov.cn/eng/4020.html $(1 / 07 / 2003)$.

${ }^{680}$ David, Rene and Brierley, John E. C., Major Legal System in the World Today: An Introduction to the Comparative Study of Law, 3rd edition, Stevens \& Sons, 1985, page 30.
} 
power, which embodies the will of the ruling class, and serves as one of the ruling tools. ${ }^{681}$

Laws are intended to be instruments of policy enforcement to achieve the immediate policy objectives of the regime. According to Pittman B. Potter:

[Chinese] law is not a limit on State power; rather, its is a mechanism by which State power is exercised, as the legal forms and institutions that comprise the Chinese legal system are established and operate to protect the CPC and State's political power." ${ }^{162}$

Chinese constitutional and legal arrangements must conform to China's special circumstances, which in turn sets the conditions for policy enforcement and the justification for China's departure from international or Western legal norms. ${ }^{683}$

Based on above analysis, the existing exit and entry laws serve as the principle instrument of the $\mathrm{CPC}$ and the government to control exit and entry in China (Xianxing Churujing Guanli Fa Shi Dang He Zhengfu Guanli Churujing De Gongju). The discretionary powers of the exit and entry administration are hence overly broad, which will be discussed in part 13.2.1 of this thesis. Yet more seriously, the enforcement and reforms of existing laws are confined to the discourse of 'politico-legal work', in which the CPC leadership continues as a dominant player. Chen Yaotao underlined the notion that "public security organisations shall control exit and entry of aliens in accordance with the way and policy of the CPC" ${ }^{684}$ Without CPC consent, some applications for exiting China are not granted, which will be discussed in part 9.1.2 of this thesis. In analysing the relationship between research of the exit and entry administration and the CPC,

${ }^{681}$ Dictionary Department, Institute of Linguistics, Chinese Academy of Social Sciences, The Contemporary Chinese Dictionary (Chinese-English Edition), Foreign Language Teaching and Research Press, Beijing, 2002, page 527.

682 Potter, Pitman B., The Chinese Legal System: Globalisation and Local Legal Culture, Routledge, London and New York, 2001, page 10.

${ }^{683}$ Zhang, Youyu, "A Constitution that Reflects the Special Characteristics of China in the Present Stage” (Yibu Juyou Xianjieduan Zhongguo Tese De Xianfa), Chinese Jurisprudence (Zhongguo Faxue), 1988, No. 2, pages 36-40, Quoted in Potter, Pitman B., The Chinese Legal System: Globalisation and Local Legal Culture, Routledge, London and New York, 2001, page 10.

${ }^{684}$ Chen, Yuetao, The Writing on the Documents of the Exit and Entry Administration of Public Security Organs (Gongan Churujing Guanli Wenshu Xiezuo), Series of the Applicable Writing of Public Security Organs (Gongan Yingyong Xiezuo Congshu), Interior Published within Public Security Organs (Gongan Jiguan Neibu Faxing), the Publishing House of China University of People's Public Security, Beijing, 1999, page 7. 
Wang Guoliang has observed that "research of the exit and entry administration [...] provides [...] constructive suggestions [for] reform of [the] administration of exit and entry with the CPC and the State". 685

\subsubsection{The aim of law governing exit and entry: to control exit and entry}

The emphasis of laws regarding exit and entry administration is control, rather than the protection of the RLR. The legal theory, together with the traditional culture, make the theme of the development of the RLR in China, discussed in chapters six and seven, inclined towards easing restrictions on the RLR rather than to protect those rights.

The Law on the Control of Exit and Entry of Citizens 1985 (PRC) is the most important of laws germane to the RLR in China. Article 1 of the Law provides that "this law is formulated with a view to safeguarding the legitimate rights and interests of Chinese citizens with respect to their exit from and entry into China's territory...." There are distinctions between the RLR and 'legitimate' rights and interests. Article 1 permits the government to interpret the scope of the RLR in the context of "legitimate". The opinion of Mao Fengping is representative; he has proposed that 'legitimate rights and interests' implies that Chinese citizens have the right to apply to exit China, provided that there is a good reason for doing so and that there are no circumstances prohibiting their exit. ${ }^{686}$ Thus, the purpose of this law is not to recognise and protect the RLR — at most, the Law on the Control of Exit and Entry of Citizens 1985 (PRC) could be construed as affording partial recognition and protection of the RLR.

The aims of other three most important laws regarding exit and entry, the Law on the Control of Exit and Entry of Aliens 1985 (PRC), the Provisional Measures on the Control over Chinese

\footnotetext{
${ }^{685}$ Wang, Guoliang and Zhu, Lin, The Administration on Exit and Entry, one of Planning Textbooks of Higher Education of People's Police (Renmin Jingcha Gaodeng Jiaoyu Guihua Jiaocha: Churujing Guanlixue), Interior Published within Public Security Organs (Gongan Jiguan Neibu Faxing), the Publishing House of China University of People's Public Security, Beijing, 2002, page 10.

${ }^{686}$ Mao, Fengping, (ed), The Explanation of the Law and Regulations Governing exit and entry and the Collections of Related Regulations (Chujing Rujing Falv Fagui Sijie Yu Xiangying Fagui Zhaibian), the Publishing House of Jilin Renmin, Changchun, China 1994, pages 76-77.
} 
Citizens Travelling for Private Affairs to or from the Regions of Hong Kong or Macao 1986 (PRC), and the Measures on the Control over Chinese Citizens Travelling to or from the Region of Taiwan 1992 (PRC) have neglected the RLR. ${ }^{677}$ Eight Articles of the Law on the Control exit and entry of citizens 1985 (PRC), which accounts for 40\% of all Articles of the statute and $61.5 \%$ of its substantive content, effectively limit the RLR, by using terms such as "apply to", "approve" "certificate" or "complete the relevant procedures". Fourteen Articles of the Detailed Rules of the Implementation of the Law on the Control of Exit and Entry of Citizens (Amendment) 1994 (PRC), which accounts for 57\% of all Articles, and 63.6\% of substantive content, limit the RLR as well. Limiting the RLR is the most simple and direct means to control the exit form and entry into China.

\subsubsection{The conflict of laws regarding exit and entry}

\subsubsection{The Chinese exit and entry legislative system}

It is necessary to explain the legislative system before discussing the conflict of exit and entry laws. As a first principle of difference, the sources of the RLR are multiple in China, which is inconsistent with Western norms that there is usually only one source of the RLR and administrative discretion. ${ }^{688}$

The supreme legislative authority in China is the National People's Congress (NPC). It enacts legislation, called " $F a L v$ " (law), ${ }^{689}$ in much the same manner as other legislatures in modern bureaucratic States. the RLR is referred to by ordinary statute. These include the Law on the

\footnotetext{
${ }^{687}$ Article 1 of the Law on the Control of Exit and Entry of Aliens 1985 (PRC) provides "the present law is enacted for the purpose of safeguarding the sovereignty and maintaining the security and public order of the PRC and facilitating international exchanges." Article 1 of the Measures on the Control over Chinese Citizens Travelling for Private Affairs to or from the Regions of Taiwan 1992 (PRC) regulates "the present measures is enacted for the purposes of safeguarding the communication of the people in the two sides of the Taiwan Straits and facilitating various sides exchanges and maintaining the social order." There are not the provisions of legislative aim in the Interim Measures on the Control over Chinese Citizens Travelling for Private Affairs to or from the Regions of Hong Kong or Macao 1986 (PRC).

${ }^{688}$ For example, in Australia, s 4(2) Migration Act 1958 (Commonwealth) "provides for visas permitting non-citizens to enter or remain in Australia and the Parliament intends that this Act be the only source of the right of non-citizens to so enter or remain."

689 Article 7 and 8 of the Law of Legislation 2000 (PRC).
} 
Control of Exit and Entry of Citizens 1985 (PRC) and the Law on the Control of Exit and Entry of Aliens 1985 (PRC) which are $\mathrm{Fa} \mathrm{Lv}$, promulgated by the Standing Committee of the NPC.

The highest executive authority in China is the State Council. The State Council has the power to make rules, which are also regarded as a form of legislation. They are called "Xingzheng Fagui" (administrative provisions) as opposed to the Fa Lv of the People's Congress. ${ }^{690}$ The Bureau of Legislative Affairs drafts some $\mathrm{Fa}$ Gui. Other $\mathrm{Fa}$ Gui are drafted by the individual ministries that are under the State Council's jurisdiction, and then submitted to the Council for enactment. The Provisional Measures on the Control over Chinese Citizens Travelling for Private Affairs to or from the Regions of Hong Kong or Macao 1986 (PRC), and the Measures on the Control over Chinese Citizens Travelling to or from the Region of Taiwan 1992 (PRC) are Xingzheng Fagui.

Individual ministries have the power to issue various orders, directives, notifications, circulars, measures, detailed implementation rules and subsidiary rules, which are called "Xingzheng Guizhang" (administrative rules or regulations). The matters governed by rules are related to the enforcement of laws or the administrative regulations, decisions or orders of the State Council. ${ }^{691}$ the RLR is mainly realised and improved through ministerial-level implementing of provisions, discussed in part 13.1 of this thesis, such as the Detailed Rules for the Implementation of Law on the Control of Exit and Entry of Citizens (Amendment) 1994 (PRC), the Detailed Rules for the Implementation of Law on the Control of Exit and Entry of Aliens (Amendment) 1994 (PRC) and the Measures for the Implementation on Preventing Defaulting Taxpayer from Exiting Abroad 1997 (PRC).

The People's Congresses, their standing committees and the governments of provinces, autonomous regions and municipalities directly under the Central Government may, according to the specific situations and needs of their administrative regions, enact "Difang Fagui" (local

\footnotetext{
690 Article 56 of the Law of Legislation 2000 (PRC).

691 Article 71 of the Law of Legislation 2000 (PRC).
} 
regulations) which do not contravene the Constitution, laws and administrative regulations, ${ }^{692}$ for example Implementation Opinion of Shanghai Municipality on Provisional Regulations of the Establishment and Administration of Sino-Foreign Equity or Cooperative Joint Venture Employment Agency 2002 (Shanghai).

The above mentioned two $\mathrm{Fa} L v$ should take precedence over hundreds of Xingzheng Guizhang; but in practice, Xingzheng Guizhang and Difang Fagui form the basis of assessing entry and exit applications and may take precedence over $\mathrm{Fa} \mathrm{Lv}$ and $\mathrm{Fa}$ Gui. The policy contained in $\mathrm{Fa}$ $L v$ and $F a$ Gui only operates superficially and is therefore doomed to failure, because it can be overridden and made obsolete by implementing Guizhang.

Moreover, frequent updating is a distinctive feature of migration laws, while the two $F a L v$ have not been amended since their enactment in 1985. Conflict within China's exit and entry laws is a major problem bewildering the exit and entry law community, and which creates an opportunity for government officials to become corrupt, or degenerate or abuse power for personal gain.

\subsubsection{The conflict of laws regarding exit and entry}

The conflicts of laws regarding exit and entry are serious and obvious. One example of a conflict between exit and entry laws and other Chinese laws is in the laws regarding the limits on emigration intermediary agencies. Article 14 (2) of the Law on Administrative License 2003 (PRC) provides that:

\footnotetext{
When necessary the State Council may establish administrative license by issuing decisions. After implementation of administrative license (excluding temporary administrative license items), the State Council shall timely ask the National People's Congress and its standing committee to enact relevant laws or formulate administrative laws and regulations by itself.
}

Article 15 (2) the Law on Administrative License 2003 (PRC) further provides that:

Local regulations and provincial governments' regulations shall create the administrative license of the qualification of citizens, legal persons or other organisations that should be determined by the

692 Article 63 (1) and 73 (1) of the Law of Legislation 2000 (PRC). 
State, or administrative license or proposed administrative license of the registration of establishment of the enterprises or other organisations. The administrative license established thereby shall neither prevent the individuals or enterprises of other areas from carrying out production and operation and providing services in the local area nor prevent the commodities of other areas from entering local market.

Under the above provisions of the Law on Administrative License 2003 (PRC), the legal validity of the legislations governing administrative license for the establishment of emigration intermediary agencies which were promulgated by ministerial or local government regulations, will be analysed in details in Chapter 12 of this thesis, is doubtful. Nonetheless, administrative license for the establishment of emigration intermediary agencies still remain.

The other example relates to laws placing limits on the exit of individuals from China on the grounds of public order. Under Regulations on Conscription 2002 (Beijing), which was promulgated by the Standing Committee of the Beijing Municipal People's Congress, individuals who avoid compulsory military service shall be prohibited from exiting China for two years. Surely, the question of avoidance of military service would be a national nor a local matter. According to Article 19 of the Law on the Control of Exit and Entry of Citizens 1985 (PRC) and Article 27 of the Detailed Rules of the Implementation Law on the Control of Exit and Entry of Citizens (Amendment) 1994 (PRC), local congress is not empowered to promulgate interpretative law prohibiting the right to leave. The legal validity of the Regulations on Conscription 2002 (Beijing) is therefore questionable, although it plays a conspicuous role in protecting public order, and would be regarded as permissible by international standards.

The conflicts of laws regarding merits review of exit and entry administrative decisions and external remedies of violating the RLR are considerable. The legislation referred to in Appendix 2 of this thesis post dates the provisions in appendices 11 and 12, and by contrast is more sophisticated because certain elements are derived from Western States. The external remedies listed in Appendix 2 hence complement internal remedies listed in appendices 11 and 12. Article 13 and 14 of the Law on the Control of Exit and Entry of Citizens 1985 (PRC), for example, provides that the passport and travel certificate could be cancelled by the original issuing 
authority or their authorised agencies, or declared invalid, and any person who violates that law may be given a disciplinary warning, however, under Article 15 of the same law the affected person cannot appeal against the cancellation, invalidation or disciplinary warning in either an administrative or judicial forum. Instead, Article 6 Clause 1 (1) of the Law on Administrative Review 1999 (PRC) and Article 6 of the Law of Administrative Penalty 1996 (PRC) entitles penalised persons to appeal in either an administrative or judicial forum.

Although the legislation referred to in Appendix 2 partially resolves issues, which will be discussed in parts 13.3.1 to 13.3.3 below, as regards merits review of administrative decisions and external remedies, there is a measure of inconsistency between the two forms of relief for violations of the RLR. The inconsistency is serious enough to affect the remedies for the RLR. The provisions regarding the restriction of personal freedom and an order of deportation are two typical examples.

Article 9(2) of the Law of Administrative Review 1999 (PRC) provides "administrative penalties involving the restriction of personal freedom shall only be created by law," however there are many exit and entry administrative provisions restricting personal freedom, such as Articles 48 and 49 of the Detailed Rules for the Implementation of the Law on the Control of Entry and Exit of Aliens (Amendment) 1994 (PRC), Articles 24 and 25 of the Detailed Rules for the Implementation of the Law on the Control of Entry and Exit of Chinese Citizens (Amendment) 1994 (PRC), Article 26 to 28 of the Interim Measures on the Control over Chinese Citizens Travelling for Private Affairs to or from the Regions of Hong Kong or Macao 1986 (PRC), and Article 35 of the Measures on the Control over Chinese Citizens Travelling to or from the Region of Taiwan 1992 (PRC). These have been enacted by the MPS, or jointly promulgated by the MPS and MFA, or the MPS, MFA and Ministry of Communication.

According to Article 42 of the Law of Administrative Review 1999 (PRC), this law prevails over any other earlier inconsistent legislation. As a result, the law referred to in the preceding paragraph should be invalid. Despite this, individual departments sometimes apply the earlier inconsistent law. According to The People's Daily, Chinese police detained a Japanese national, 
who allegedly assisted two North Koreans and Chinese national to leave China illegally, under Article 49 of the Detailed Rules for the Implementation of the Law on the Control of Entry and Exit of Aliens (Amendment) 1994 (PRC). ${ }^{693}$ The practice of giving priority to earlier inconsistent legislation was also officially reaffirmed in $2002 .{ }^{694}$ This apparent disregard for valid and current law can affect the extent to which the RLR is realised in China.

\subsubsection{Resolving conflicts of exit and entry laws}

The issues mentioned above can be partially attributed to the inefficient resolution of conflicts between exit and entry laws. Article 5(2) and (3) of the Constitution of the PRC (Amendment) 2004 provides that, "the State upholds the uniformity and dignity of the socialist legal system. No laws, administrative or local rules, or regulations may contravene the Constitution". This provision is too obscure to be practically enforced because there is a lack of attached detailed legislation.

This situation was improved by the Law of Administrative Review 1999 (PRC), of which Article 7 provides:

If citizens, legal persons or other organisations consider the following provisions (which the administrative departments take as the basis for their specific administrative acts) to be illegal, they may apply for examination of these provisions when applying for administrative review:

(1) provisions formulated by departments under the State Council;

(2) provisions formulated by local people's governments at or above the county level and the department under them; and

(3) provisions formulated by a township or town people's governments.

The provisions listed in the preceding paragraph do not include rules and regulations formulated by the ministries and commissions under the State Council, and by local people's governments. The examination of rules and regulations shall be carried out in accordance with laws and administrative regulations.

693 “Japanese Detained for Helping Koreans to Flee”, 14 January 2004, People’s Daily Online, http://english.peopledaily.com.cn/200401/14/eng20040114_132570.shtml (15/01/2004).

${ }^{694}$ Wang, Guoliang and Zhu, Lin, The Administration on Exit and Entry, one of Planning Textbooks of Higher education of People's Police (Renmin Jingcha Gaodeng Jiaoyu Guihua Jiaocha: Churujing Guanlixue), Interior Published within Public Security Organs (Gongan Jiguan Neibu Faxing), the Publishing House of China University of People's Public Security, Beijing, 2002, page 299. 
On the one hand, it is questionable as to whether these provisions could ensure the independence of the examination, because administrative review is conducted by legal departments within the relevant departments, as will be discussed in part 13.3.3 below. On the other hand, the right to apply for administrative review of subordinate legislation is greatly limited. Rules and regulations formulated by the ministries and commissions under the State Council, and by local governments - which are the most commonly used provisions in China — are excluded from the Law of Administrative review 1999 (PRC). Approximately 90\% of the provisions quoted in this thesis fit into those categories. Consequently, these provisions and policies promulgated by the CPC and other ministerial level authorities cannot be reconsidered.

Responding to a number of issues raised by legislative conflicts, the Law of Legislation 2000 (PRC), the Regulations on the Procedure for Formulation of Rules 2001 (PRC), the Regulations on the Record-keeping for Regulations and Rules 2001 (PRC), the Measures of Beijing Municipal People's Government on Formulation of Rules and Regulations 2002 (Beijing), and the Measures of Taiyuan Municipal People's Government on Legislation 2002 (Taiyuan), were enacted to clarify the national legislative system. Articles 78 to 84 of the Law of Legislation 2000 (PRC) provide the principal means to reconcile conflicts between inconsistent laws. ${ }^{695}$

695 Article 78: "the Constitution has the highest legal authority. All laws, administrative regulations, local regulations, autonomous regulations and separate regulations shall not contravene the Constitution." Article 79: "The authority of laws is higher than administrative regulations, local regulations and rules. The authority of administrative regulations is higher than that of local regulations and rules." Article 80: "The authority of local regulations is higher than that of the rules enacted by the local governments of the same or lower level. The authority of rules by the people's governments of provinces and autonomous regions are higher than that of those by the people's governments of the large cities of the same administrative regions." Article 81: “Autonomous regulations and separate regulations which have made adjustments to the laws, administrative regulations and local regulations shall apply within the relevant autonomous regions. Regulations adopted by the Special Economic Zones, which have made adjustments to the laws, administrative regulations and local regulations shall apply within the relevant Special Economic Zones.” Article 82: "Departmental rules by different departments shall have the same authority. The departmental rules and local rules shall have the same authority. They shall apply within the scope of the authority of the respective departments or local governments." Article 83: "For the laws, administrative regulations, local regulations, autonomous regulations and separate regulations promulgated by the same authority, the special provisions shall prevail in case the special provisions are inconsistent with the general provisions. The new provisions shall prevail in case the new provisions are inconsistent with the previous provisions." Article 84: "All laws, administrative regulations, local regulations, autonomous regulations, separate regulations and rules other than those which are enacted for the better protection of the rights and interests of citizens, legal persons and other organizations shall not have retrospective effect." 
Despite of all theses resolutions, conflicting laws in China are still a major problem, because there is neither an independent responsible authority nor due process to make the necessary changes.

According to Articles 85 to 89 of the Law of Legislation 2000 (PRC), the responsible authorities include the NPC, the Standing Committee of the NPC, the State Council, the people's congress of provinces, autonomous regions and municipalities directly under the Central Government, the standing committees of the local people's congresses, the people's governments of provinces and autonomous regions, the enacting authority, and the delegating authority. The subject and procedure of submitting a written suggestion to review the laws are regulated in Articles 90 and 91 of the Law of Legislation 2000 (PRC). ${ }^{696}$

Besides the issues discussed earlier, the Law of Administrative Review 1999 (PRC) does not fully entitle persons affected by an administrative decision to seek judicial review of the subordinate legislation upon which the determination was based. The recent enactment of new exit and entry laws, which fail to include remedies for violations of the RLR, provide more scope for individuals' the RLR to be violated by administrative authorities. As a consequence,

\footnotetext{
${ }^{696}$ Article 90 of the Law of Legislation 2000 (PRC) provides "The State Council, the Central Military Commission, the Supreme Peoples' Court, the Supreme Peoples' Procuratorate and the standing committees of peoples' congresses of provinces, autonomous regions and municipalities directly under the Central Government which are of the opinion that certain administrative regulations, local regulations, autonomous regulations or separate regulations contravene the Constitution or the laws, may make a written suggestion (Jianyi) to the Standing Committee of [NPC] for review. The working organ of the Standing Committee shall examine the matter and, when necessary, forward the matter to the special committees concerned for examination and comment. Other government bodies or social organizations, enterprises, institutions and citizens not mentioned in the previous paragraph who are of the opinion that certain administrative regulations, local regulations, autonomous regulations or separate regulations contravene the Constitution or the laws may make a written suggestion to the Standing Committee of the [NPC] for review. The working organ of the Standing Committee shall examine the matter and shall, when necessary, forward the matter to the special committees concerned for examination and comment." Article 91 prescribes that "Where the special committees of [NPC] are, after examination, of the opinion that the administrative regulations, local regulations, autonomous regulations or separate regulations contravene the Constitution or the laws, they may give a written opinion to the enacting authority; the Law Committee and the relevant special committees may convene a joint examination and ask the enacting authority to explain the situation at the examination before giving a written opinion of the examination to the enacting authority. The enacting authority shall within two months decide whether to make any amendment and report to the Law Committee and the special committees concerned..."
} 
disputed regulations that adversely affect the RLR, continue to be unlawfully applied. Conflicting laws continue to be an obstacle for Courts when they apply laws in specific cases.

The scope of the right to appeal against the contravention of laws is greatly narrowed. According to Article 90 of the Law of Legislation 2000 (PRC), Article 35 of the Regulations on the Procedure for Formulation of Rules 2001 (PRC), ${ }^{697}$ Article 9 of the Regulations on the Record-keeping for Regulations and Rules 2001 (PRC), ${ }^{698}$ and Article 39 of the Measures of Beijing Municipal People's Government on Formulation of Rules and Regulations 2002 (Beijing), ${ }^{699}$ government bodies or social organisations, enterprises, institutions and citizens is entitled to "make a written suggestion" rather than to initiate an "appeal" and "review". That means the relevant authorities are not legally bound to process this application, or initiate the examination. Meanwhile, there are no detailed rules to regulate the procedure how to "make a written suggestion".

The terms of "when necessary" of Article 90 of the Law of Legislation 2000 (PRC), "study and handle" of Article 39 of the Measures of Beijing Municipal People's Government on

697 Article 35 of the Regulations on the Procedure for Formulation of Rules 2001 (PRC) provides "Any state organ, social organization, enterprise and institution or citizen, who deems the rules contravene the laws and administrative regulations, may make written suggestions to the State Council for examination, and the legal affairs agency under the State Council shall handle such matter after investigation. Any state organ, social organization, enterprise and institution or citizen, who deems the rules of the people's government of a major city contravene the laws and administrative regulations or the provisions of other superior laws, may make written suggestions to the people's government of their respective province or autonomous region for examination, and the legal affairs agency of the said government concerned shall handle this matter after investigation."

698 Article 9 of the Regulations on the Record-keeping for Regulations and Rules 2001 (PRC) provides "The State Organs, mass organizations, enterprise and institutional organizations, and citizens who consider local regulations contradict administrative regulations, or consider that rules and other generally binding administrative decisions and orders promulgated by the various State Council departments and the people's governments of provinces, autonomous regions, municipalities directly under the Central People's Government and comparatively large municipalities contradict laws and administrative laws may submit written opinions for examination to the State Council. The legislative affairs institutions under the State Council shall study the opinions, make disposal proposals, and settle the differences according to specified procedures."

699 Article 39 of the Measures of Beijing Municipal People's Government on Formulation of Rules and Regulations 2002 (Beijing) provides "the government agencies, organizations, and individuals who are of the opinion that the administrative measures contradict with laws, regulations, and rules may introduce remarks to the Municipal People's Government, and the Legal office of the Municipal People's Government shall study and handle them.” 
Formulation of Rules and Regulations 2002 (Beijing), and "handle this suggestions after investigation" of Article 35 of the Regulations on the Record-keeping for Regulations and Rules 2001 (PRC), further narrow the scope of the right to appeal against the contravention of laws, because the meaning of "necessary", "study", "handle" and "investigation" are not clear enough. It is thus possible for relevant authorities to abuse their discretion so to deny the suggestions of other government bodies or social organisations, enterprises, institutions and citizens. It will therefore fall to the person in power's discretion to decide when they should or should not be applied. ${ }^{700}$ It is perhaps not unsurprising to find that it has not yet been relied upon.

According to international norms, the supervisory mechanism of subordinate legislation plays an irreplaceable role in remedying violations of the RLR. The establishment of a supervisory mechanism in China must account for and define the relationship between the subject matter of the law, the administration and the community. How to establish such a mechanism is mainly a topic in legislative science and beyond the scope of this thesis.

\subsubsection{Legal research on the RLR in China}

Almost all the literature on the RLR is focused on the West, especially traditional immigration nations. Very little has been written about the RLR in China. This sub-section is to explore the reasons why the sum and depth of legal research on the RLR in China is unusually low.

The Chinese official view, cited in instances below, is that the RLR, like many other human rights, is too sensitive to be studied in China. The Chinese government thinks that the theory of human rights overriding sovereignty should be adamantly rejected, ${ }^{701}$ China should be allowed to establish its own human rights models, in line with their own circumstances, and the so-called "Country Report" on human rights issued by the USA, has made groundless accusations against China's human rights situation. The Chinese side expresses its strong indignation and firm

\footnotetext{
${ }^{700}$ Cheng, Jie, "Conflict of Laws in China", http://www.qis.net/chinalaw/lawtran1.htm (08/05/2003).

701 “Chinese FM Meets Russian Human Rights Representative (16/03/2000)”, www.fmprc.gov.cn/eng/4020.html $(1 / 07 / 2003)$.
} 
opposition. ${ }^{702}$ Beijing has stressed that the "rampant" practice of political confrontation in the name of human rights, is the biggest problem in the area of human rights. ${ }^{703}$ Any research on the RLR from a Western perspective risks raising questions as to the politics and patriotism of the researcher. Consequently, the RLR in China are usually discussed from the perspective of administrative law, ${ }^{704}$ international law ${ }^{705}$ or the exit and entry administration. ${ }^{706}$

To avoid risk, legal education and research institutions in China shed little light on the RLR. It is sometimes not even discussed in works on exit and entry administration. ${ }^{707}$ Law schools teach nationality law as part of their international law curriculum and exit and entry administration is offered as an elective course in police higher education institutions, while the limited research on exit and entry administration is mainly focused on practical issues rather than theory. ${ }^{708}$ Very few legal education and research institutions in China provided a degree course with a major in Chinese migration law, and there is no special department for the study

702 "Spokesperson Zhang Qiyue's Remarks on the Country Report on Human Rights Issued by the US (26/02/2004)", http://www.fmprc.gov.cn/eng/xwfw/2510/t69782.htm (02/03/2004).

703 Sha, Zukang, 'Chinese Ambassador of the United Nations, China Call for Cooperation in Human Rights Field 03-04-2003', http://www.cctv.com/special/1016-1/2.html (20-05-2003).

${ }^{704}$ Chen, Yuetao, The Writing on the Documents of the Exit and Entry Administration of Public Security Organs (Gongan Churujing Guanli Wenshu Xiezuo), Series of the Applicable Writing of Public Security Organs (Gongan Yingyong Xiezuo Congshu), Interior Published within Public Security Organs (Gongan Jiguan Neibu Faxing), the Publishing House of China University of People's Public Security, Beijing, 1999, page 9.

705 Wong, Li, International Immigration Law and the Practices (Guoji Yiminfa Lilun Yu Shijian), the Publishing House of Law, Beijing, China, 2001, page 25.

${ }^{706}$ Wang, Guoliang and Zhu, Lin, The Administration on Exit and Entry, one of Planning Textbooks of Higher Education of People's Police (Renmin Jingcha Gaodeng Jiaoyu Guihua Jiaocha: Churujing Guanlixue), Interior Published within Public Security Organs (Gongan Jiguan Neibu Faxing), the Publishing House of China University of People's Public Security, Beijing, 2002 page 93; also see Department of Politics under the Ministry of Public Security, Frontier Defense and Exit and Entry Administration, the Series of Basic Textbook of People's Police Operation:( Bianfang Yu Churu Jing Guanli, Renmin Jingcha Gongan Yewu Jichu Jiaocai), examined by Committee of Textbook Editing and Examination of the Ministry of Public Security, the Publishing House of Qunzhong, Internal Publication within Public Security Organs (Gongan Jiguan Neibu Faxing), Beijing, 1999, page 276.

707 Mo, Qibo, (ed), The Administration of Citizen's Exit and Entry (Gongmin Churu Jing Guanli), the Publishing House of Giuangxi Minzu, Nanling, China 1997.

708 Yu, Huaying and Gong, Yu, The Legal Study on Exit, Entry and International Trade (Churu Jing Yu Guoji Jingmao Falv Wenti Yanjiu), the Publishing House of Xinan Normal University, Chongqing, China 1997, pages 7-8. 
of migration law. ${ }^{709}$

From a commercial perspective, Chinese legal scholars are not very interested in the research of migration law, but pay more attention to business law and other branches of law more closely aligned to daily life and the economy. As China establishes a socialist market-oriented economic system, there is financial support available to academics involved with the drafting and amendment of laws related to this field. The Legal Papers Database of China Persecution Daily demonstrates that between 1993 and 2001, only one academic legal paper focused on the RLR was published in a national legal journal in Mainland China. ${ }^{710}$ Meanwhile, Chinese migration consultants spare little effort to study the existing exit and entry legislation. The foremost business of the emigration intermediary agencies is to assist in visa applications. As such, agencies are inclined to spend their time becoming familiar with foreign immigration laws and ensuring that they maintain a high success rate for visa applications.

In practice, police higher education institutions and public security authorities are mainly responsible for the research into exit and entry legislation. Most of the researchers graduated from police colleges or police universities, or retired from active military services. Few have formal legal qualifications and their research methodology is questionable. The main collections of papers related to the RLR in China are the Collection of Papers on the Control of Exit and Entry (III), ${ }^{711}$ the Collection of Papers on the Control of Exit and Entry (II), ${ }^{712}$ which were edited in 1999 and 2001, and the Review of the control of exit and entry: the Collection of Papers on the Control of Exit and Entry of Shanghai Public Security Organisations, edited by

\footnotetext{
709 Yu, Shutong and Wen, Jia (Chief editors), A New Chinese-English Law Dictionary (Xin Hanying Faxue Cidian), Publishing House of Law, Beijing, 1998, pages 1164-1174. The situation was improved recently. Zejiang University provided the course of LLM with the direction of international migration in 2004.

${ }^{710}$ Legal Papers Database of Prosecution Daily (Jiancha Ribao), “The Search of Keyword of Immigration”, Http://review.jcrb.com.cn/lw/yimin.htm (18/04/2002)

711 Committee of Exit and Entry Administration under Chinese Association of Police, (edit), The Collection of Papers on the Control of Exit and Entry (III) (Churujing Guanli Lunwenxuan (san)), Interior Published within Public Security Organs (Gongan Jiguan Neibu Faxing), the Publishing House of Qunzhong, Beijing China, 2001.

712 Committee of Exit and Entry Administration under Chinese Association of Police, (edit), The Collection of Papers on the Control of Exit and Entry (II), (Churujing Guanli Lunwenxuan (er)), Interior Published within Public Security Organs (Gongan Jiguan Neibu Faxing), the Publishing House of Qunzhong, Beijing China, 1999.
} 
Li Wenyan, the Director of Shanghai Exit and Entry Administration in 1999. Unfortunately, none of the 120 papers forming these collections were footnoted, ${ }^{713}$ which means that the quality of the research is compromised because their primary and secondary sources cannot be traced. ${ }^{714}$

\subsection{Conclusions}

The factors driving the RLR in China exposes what is certainly the complex situation of China. For politics, one party reign colours the RLR with the protection of vested interests of the CPC, which dominates society in China. The origin of restrictions on exit and entry are easily traced to China's experience as a member of the former communist bloc.

Given the largest population, underdevelopment and considerable regional economic disparities, it is understandable for China to gradually reform exit and entry administration, to avoid the possible instability. A further depth of reform is however inevitable with economic development - past interactions between the development of the economy and laws governing exit and entry also prove this point. Meanwhile, it is hard to break through the restriction on persons employed in State-owned industry, because the public ownership of the means of production is still the basis of the economic system. The adverse impacts on the RLR of limits on the right to move within China must also not be underestimated.

An analysis of the culture of Confucianism reveals that there is a long way to go before an awareness of the RLR in China is fully fostered. Individuals, under Confucianism, are inclined to integration into the society, innately obliged to respect fellow members of the human race, and pay loyalty to China and filial piety to one's parents. Chinese culture is therefore a culture orientated toward duty, in which the RLR is not easily recognised and the exhortation not to

\footnotetext{
${ }^{713} \mathrm{Li}$, Wenyan, Review of the Control of Exit and Entry: the Collection of Papers on the Control of Exit and Entry of Shanghai Public Security Organs (Churujing Guanli Zongheng: Shanghai Gongan Churujing Guanli Lunwenji), internal publication (Neibu Faxing), the Publishing House of Police Education, Beijing, 1998.

714،"Referencing Using the Note System”, the Faculty of Law of the University of Technology, Sydney, Australia, http://www.science.uts.edu.au/research/Thesis.pdf (13/04/2003).
} 
leave home is embraced. The philosophy of sublating, namely the subjective selection of foreign cultural aspects, isolates Chinese culture from other rights-oriented cultures. Agrarian society, from which Confucianism was born, is still an important part of the cultural fabric of China, with a proportionately large agrarian population and output.

Compared with politics, economics and culture, legal factors most directly affect the RLR in China. If the laws governing exit and entry are accepted as one of the ruling tools of a ruling elite, it is not surprising to find that the law mainly facilitates the control of exit from and entry into China, rather than to protect the RLR. The bias is to the community and not to the individual. Meanwhile, conflict within China's exit and entry laws is a major problem, bewildering exit and entry law community, and which creates opportunities for government officials to act degenerately or abuse exit and entry discretion for personal gain. The dispute of the constitutional foundation of the RLR has produced ambiguity in regard to the protection of the RLR.

Resolving conflicts of laws regarding exit and entry is important because it relates to the internal functioning of the administrative arms of government, their interpretation of the rights and obligations and penalties in primary legislation, and perhaps more deeply, the ethical and social foundation of the whole field of law. Neither the Constitution nor relevant laws provide practicable remedies for violations of the RLR by legislative acts. The mechanism for resolution of conflicts of laws regarding the administration of exit and entry is far from efficient. 


\section{Chapter Six \\ Historical Development of \\ Chinese Regulatory Framework Governing the RLR}

\section{Introduction}

With ratification of the ICCPR by 152 countries, international concern on the RLR appears to have passed its peak, ${ }^{715}$ and yet remains problematic for China. In the Handbook of Citizenship Studies on the right to emigrate, for instance, China scored zero out of a possible 100 points. $^{716}$ A careful and well-coordinated immigration strategy with a well-defined the RLR focus has the potential to enhance China's economic progress and to improve its international human rights image. Such a strategy would demand careful evaluation of China's the RLR policies, with the view to making them consistent with international law and practice. There are many issues pertaining to the protection of the RLR in China that demand prompt solutions. A critical analysis of the realities and issues of the RLR in China in the context of international norms has never been undertaken.

The notions of 'the RLR' and 'Chinese migration law' have only a very short history in China; the terms are mainly used by Chinese scholars. ${ }^{717}$ There are no recorded attempts to precisely stipulate the RLR and draw up a distinct code governing migration matters. Planned reforms (2001-2005) of the exit and entry administration do not introduce the specific notions of "the

\footnotetext{
715 International Services for Human Rights, “The Ratification Status of the Main Human Rights Treaties”, ishr-06-2004, http://ww.ishr.ch/About\%20UN/Ratification/Ratification\%20-\%20Human\%20Rights\%20treaties.htm $(18 / 05 / 2003)$.

716 Janoski, Thomas and Gran, Brain "Political Citizenship: Foundations of Rights', in Isin, Engin F. and Turner, Bryan S. (ed), Handbook of Citizenship Studies, Sage Publications, London, 2002, pages 31-33.

717 Xiang, Dang, the Guide to the Law of Exit and Entry in China and Foreign Countries (Zhongwai Churujing Falv Zhinan), the Publishing House of China University of People's Public Security, Beijing, 1998, page 1; Wong, Li, International Immigration Law and the Practices (Guoji Yiminfa Lilun Yu Shijian), the Publishing House of Law, Beijing, China, 2001, page 28; also see Wang, Leiming, "Citizens May Exit Abroad for Private Purpose Easier and Faster" (Woguo Gongmin Yinsi Chuguo Gengjia Bianjie), http://www.sina.com.cn (26/12/2002), quoted in Xinhua News Agency, 18/04/2003; and "Exiting Abroad is Becoming the Individual Needs of Chinese Citizens", 28 December 2003, Xunahuanet, http://news.sdinfo.net/72350064130916352/20031228/1233069.shtml (30/12/2003).
} 
RLR' and 'Chinese migration law'. The substance of the RLR and Chinese migration law are mainly regulated in statutes governing exit and entry. ${ }^{718}$

To better understand the issues, and appreciate the political, social and legal complexities of the RLR in China, to then make valid observations about current reforms and future trends, it is important to first trace its historical development. The greatest emigration in Chinese history occurred in the Qing dynasty (1611-1911). The ancestry of many current overseas Chinese can be traced to these emigrants. The Qing government's exit and entry policies are therefore a logical starting point for analysis, to be followed by an analysis of the policies of the Republic of China (ROC) on the Mainland (1911-1949). This section will focus primarily on development since 1978, but will briefly consider the period between 1949 and 1958 to provide an essential backdrop against which the reform strategy can be viewed.

\subsection{The Qing dynasty: from complete prohibition to practical relaxation}

The Qing government for most of its reign did not accept that their subjects had the RLR. Decrees to forbid overseas trade and emigration were passed in 1712 and $1724 .^{719}$ The decrees were primarily meant to prevent any remaining forces of the Ming dynasty (1368-1644) from emigrating and establishing a financial and political base overseas that could threaten the stability of the incumbent government. Local officials and citizens, in the interests of trade, frequently disregarded the prohibition, and many Chinese, particularly those from Guangdong and Fujian provinces, established themselves as merchants throughout South Eastern Asia during the 17 th and 18 th centuries. ${ }^{720}$

After the first Opium War (1840-1842), the prohibition on emigration was partially broken

\footnotetext{
718 Yu, Huaying and Gong, Yu, the Legal Study on Exit, Entry and International Trade (Churu Jing Yu Guoji Jingmao Falv Wenti Yanjiu), the Publishing House of Xinan Normal University, Chongqing, China, 1997, pages 3-8. 719 Buggy, T.P., Chinese Immigration and the Emergence of an Australian Image of China, 1848-1861, the thesis of Master of Arts Macquarie University, Australia, 1978, page 128.

${ }^{720}$ Purcell, Victor, the Chinese in South East Asia, London, 1965, pages 24 and 29.
} 
down and coolie emigration began. The Treaty of Nanking 1842 gave Britain extraterritorial rights in five treaty ports, ${ }^{721}$ but gave nothing to China in return. This provided Britain with the infrastructure and opportunity to develop the trade in unskilled labourers, or Coolies. ${ }^{722}$ After the second Opium War in 1860, the restrictions on emigration were virtually lifted. The Peking Convention 1860 and the Burlinghame Treaty with the USA in 1868 included clauses allowing Chinese to live abroad. Some Coolies left China as free migrants and paid their own way. Many more left as indentured or contracted labourers, enlisted directly by governments or labour recruiters. Others left on the "credit-ticket" system where their travel expenses were payed by employer and they were expected to repay the sum after working in the destination States. ${ }^{723}$ Additionally, emigration agencies operated by Western States were established in Guangdong, Shantou and other coastal cities, with the approval of the Chinese authorities. Chinese who wished to obtain employment in foreign countries were invited to register at these agencies and sign a labour contract. ${ }^{724}$

The following years saw migration increase. According to UK statistics, before the destruction of the Qing government in 1911, 4.2 million Chinese people had emigrated, ${ }^{725}$ the majority of whom went to Southeast Asia. Chinese emigrants established large and fairly stable communities in Spanish America, the Caribbean, the Pacific Islands, South Africa, North America and Australasia. This migration pattern and the establishment of trans-national community ties would greatly affect future migration policies.

\footnotetext{
721 Five treaty ports are Amoy, Canton, Foochow, Ningpo and Shanghai.

${ }^{722}$ According to the Treaty of Nanking, Chinese citizens had the right to settle in any part of the British Empire and were free to enter into arrangements with British subjects for that purpose, as well as being allowed to board any British vessel in one of the Treaty ports. Chinese people were able to emigrate opportunistically with the arrival of some European powers. However, Chinese people knew almost nothing about the British Empire and the outside world after about 200 years of closed policy. Thus in practice, they were usually sold as commodities.

723 Sinn, Elizabeth, "Emigration from Hong Kong Before 1941: Organisation and Impact" in Skeldon, Ronald (ed.) Emigration from Hong Kong: Tendencies and Impacts, the Chinese University Press, Hong Kong, 1995, page 37.

${ }^{724}$ Wang, Sing-wu, the Organisation of Chinese Emigration 1848-1888 with Special Reference to Chinese Emigration to Australia, Chinese Materials Centre Inc. San Francisco, 1978, pages 47-58.

725 The Collection of the Branch Committee of Royal Asian Arts Committee (Huangjia Yazhou Wenhui Beihua Fenhui Jikan), in Chen, Haoshen (ed), the Collection of Historical Materials on Overseas Labour Exiting Abroad (Huagong Chuguo Siliao Hvbian), the Publishing House of China, Beijing, 1985, page 5.
} 
With the increase of emigration, protection of Coolies and migrants formed a significant part of late Qing policy towards its overseas subjects. Reports of abuses in the coolie trade in Cuba led to the dispatch of a Commission headed by Chen Lan-ping, who later negotiated an immigration treaty with Spain in 1877 , to improve the circumstances of Chinese coolies in Cuba. ${ }^{726}$ In trying to come terms with the Coolie issue, the Qing government was compelled to question its traditional policy towards overseas subjects and the issue of emigration in general. It began to establish Chinese embassies and consulates in the places of overseas Chinese residence, to protect it subjects against discrimination. ${ }^{727}$

However, in this the government was constrained by the old prohibitive edicts that considered free emigrants undeserving to be protected because they were not within the government-sponsored program. In the late 19th century, the Qing government began to look upon overseas Chinese as assets to China. There had long been an awareness of the importance of their remittances to the economies of Fujian and Guangdong. In 1893, the Imperial Court finally repealed prohibitive edicts that criminalised those who ventured abroad. In other words, this liberalisation of going abroad was finally legalised.

\subsection{2 to 1949: limits and encouragement}

The second significant period is in the 38 years from the foundation of the Republic of China in 1912 and its movement into Taiwan in 1949. This period was marked by continual civil and foreign wars. The substitution of a monarchy with a republic provided many opportunities for the realisation of the RLR. The nationalist government enacted a series of laws governing passports, overseas study, overseas employment and administrative structures, as well as adopting measures to promote communication with the outside world. Unfortunately, due to the economic depression in the capitalist world and the disruption caused by continuous wars, these laws were not completely implemented.

\footnotetext{
${ }^{726}$ Buggy, T.P., Chinese Immigration and the Emergence of an Australian Image of China, 1848-1861, the thesis of Master of Arts, Macquarie University, Australia, 1978, page 128-129.

727 Wichberg, Wdgar, "The Chinese as Overseas Migrants' in Brown, Judith M. \& Foot, Rosemary Migration: the Asian Experience, 1994 the Macmillan Press Ltd., London, page 32.
} 
The first set of measures to protect the RLR in China was the system of exit visas and exit registration. Citizens did not need to apply for an exit visa if they were going abroad for the first time. An exit visa and a valid passport were only required for subsequent overseas travel. After 1935, citizens were banned from exiting without an exit registration certificate (Chuguo Dengji Zheng). They could either personally apply for an exit registration certificate or appoint an agent.

The second set of measures was to encourage and welcome the return of overseas Chinese. The Committee of Overseas Chinese Affairs was established to be responsible for the exit and entry administration. Overseas Chinese could apply for an overseas Chinese registration certificate to affirm their overseas Chinese status. This allowed them to apply for a passport and diplomatic protection. The nationalist government also encouraged the founding of overseas Chinese schools and provided financial and curriculum aid, especially during the 1920s and 1930s. ${ }^{728}$

The third set of measures regulated the emigration of the labour force. In order to cover the serious scarcity of human resources caused by World War One, the UK, France, Russia and other Western countries between 1916 and 1918 recruited approximately 230,000 labourers from China. The Regulations on Chinese Labour Exiting China 1918 (Qiaogong Cuyang Tiaoli), the Outline of Chinese Labour Contract 1918 (Qiaogong Hetong Gangyao) and the Regulations on Labour Exiting China 1935 (Gongren Chuguo Tiaoli) were promulgated soon after. Under their provisions, labour needed to apply for exit permission, accompanied by a signed labour contract with one's employers and a guarantee from the Chinese embassy or general consulate at the destination country.

Fourthly, the selection and administration of overseas students were improved. The nationalist government, in its quest for modernisation and appropriate skilled individuals, sent substantial numbers of students to Japan and the West for higher education. Many families in China saw

\footnotetext{
728 Wichberg, Wdgar, “The Chinese as Overseas Migrants in Brown”, in Brown, Judith M. \& Foot, Rosemary (ed), Migration: the Asian Experience, the Macmillan Press Ltd., London, 1994, page 32.
} 
overseas education as a new kind of migration opportunity and family strategy. ${ }^{729}$ The government enacted the Rules of Administration of Overseas Students in the USA (Guanli Liumei Xuesheng Shiwu Guicheng) and the Measures on Dispatching Overseas Students at One's Own Expense (Zifei Liuxuesheng Paiqian Banfa) among other statutes during this period. $^{730}$

Because of the shortage of foreign exchange after continuous wars, the number of students sent overseas during this period was small. ${ }^{731}$ Chinese migration was also limited by the immigration policies of destination countries. America and Canada attempted to limit Chinese immigration by legislation and practice. Sometimes discrimination uniquely targeted the Chinese. In Canada, between 1903 and 1923, only Chinese immigrants were required to pay a $\$ 500$ tax to be admitted to the country. From 1923 to 1947, Chinese people were the only people prohibited by law from immigrating to Canada. ${ }^{732}$

The nationalist Republican government adopted many active measures to promote communication with the outside world. Restricted by an unstable political climate, poorly developed economy and unwillingness to afford individual human rights, the RLR was severely limited in practice. Nonetheless, migration law made great progress and was objectively beneficial to the improvement of the RLR in China.

\subsection{9 to 1978: the return of the prohibition policy of the}

\footnotetext{
729 Wichberg, Wdgar, “The Chinese as Overseas Migrants in Brown”, in Brown, Judith M. \& Foot, Rosemary (ed), Migration: the Asian Experience, the Macmillan Press Ltd., London, 1994, page 15.

730 Also see Provisional Measures of Restriction on Studying Abroad 1938 (ROC); Provisional Measures of Restriction on Studying Abroad 1939 (Amendment) (ROC); the Program of Ministry of Education of Education of Studying Abroad 1943 (ROC) and Measures of Ministry of Education of Sending of Overseas Students 1943 (ROC). 731 In the harsh environment of the 1937 - 1945 War of Resistance against Japan, 1,566 students were sent abroad. These students were mainly enrolled in engineering and science, in order to enable China to develop the skill base for the period of post-war State reconstruction; according to the statistic of Ministry of Education of ROC files, which were stored in the Second History Archive of China. The number of overseas students between 1937 and 1945 did not include 246 persons who were invited to lecture abroad.

${ }^{732}$ Wichberg, Wdgar, “The Chinese as Overseas Migrants in Brown”, Judith, M. \& Foot, Rosemary (ed), Migration: the Asian Experience, 1994, the Macmillan Press Ltd., London, page 24.
} 


\section{Qing Dynasty}

The period from 1949 to 1978 marks the start of the People's Republic of China (PRC), through to the introduction of significant reforms and the 'opening up' of China in 1978. During this period, as discussed and analysed elsewhere in this thesis, going abroad was subject to strict scrutiny. ${ }^{733}$ Even though its population swelled in the same period from 400 million in 1949 to 1 billion in 1978, China only approved about 7,000 annual exits abroad for private affairs in that time. $^{734}$

\subsubsection{9 to 1958: the establishment of the restrictive framework governing the RLR}

In the period from 1949 to 1958 China's door to the outside world was basically closed because the consolidation of the new government was deemed the most important priority of State reconstruction, however the RLR was respected, and the legal system governing exit and entry was gradually established. Most notably, freedom of movement was recognised in the Constitution of PRC 1954. The legalisation of freedom of movement stimulated the exit and entry. According to the Ministry of Public Security (MPS) statistics, 379,505 persons exited or entered China in 1951, approximately 7.7 times that of $1950 .^{735}$

\section{The policy to encourage overseas Chinese to return}

Encouraging overseas Chinese to return to China to assist in the State's reconstruction was a foremost legislative purpose during this period. Under Article 2 and 3 of the Provisional Measures on Exit and Entry National Border of Overseas Chinese 1951 (PRC);

Overseas Chinese may exit and enter with a valid passport and visa. Where they do not hold a valid passport and visa, as they are from the countries without a diplomatic relationship with the PRC,

\footnotetext{
${ }^{733}$ Mr. Ren, Yingchao, Director of the Entry and Exit Administration of the MPS, Quoted in Wu, Inner, "Passport Gain Wider Currency in China", China Central Television, 15:10:23 17/10/2002, English Channel http://www.cctv.com/news/China/FinanceABusiness/20021017/100400/html (18/04/2003).

${ }^{734}$ Wang, leiming, "Citizens May Exit Abroad for Private Purpose Easier and Faster” (Woguo Gongmin Yinsi Chuguo Gengjia Bianjie), http://www.sina.com.cn 19/09/2002 quoted in Xinhua News Agency, 18/04/2003

735 Department of Exit and Entry under the Ministry of Public Security \& Department of Border Security Checking and Administration, Great Change over the Last 50 years: the Analysis of the Data of Exit and Entry of Individuals (Fenyun Bianhuan Wushi Nian: Cong Churujing Renyuan Tongji Shuju Kan Jianguo Yilai De Jubian), No. 22 (1999) of People's Public Security (Renmin Gongan).
} 
[they] must apply for an Overseas Chinese certificate (Guiguo Huaqiao Zhengmingshu) to ensure their overseas status when arriving in China. The government will look after them if necessary.

In addition, where a destination country hindered an overseas Chinese person from returning, they could indirectly return to China through Hong Kong or Macao. Simultaneously, unyielding efforts were made to negotiate with the West, especially with the USA, to permit overseas Chinese return to China. The Treaty on the Issues Regarding to Civilian Returning to China between the PRC and the USA was reached in 1955.

The control of return from Hong Kong or Macao was more extensive. Article 2 Clause 2 of the Proclamation of the Ministry of Public Security, the Central People's Government Concerning the Control over Passengers Travelling to and from the Regions of Hong Kong and Macao 1951 (PRC) provided that "the passengers who leave for the Mainland from Hong Kong or Macao must apply for the exit and entry pass (Churu Tongxingzheng) to the Public Security authority [in their] ancestral hometown or destination county or city". Given the physical distance and the underdeveloped state of communications, this process was lengthy and difficult.

\section{The right to leave}

Chinese citizens needed to apply for exit permission. Under Article 4 of Provisional Measures on the Exit and Entry National Border of Overseas Chinese 1951, "overseas Chinese exiting the country must apply for an overseas Chinese exit permit (Huaqiao Chujing Tongxingzheng) upon the authority of the document of proof prescribed by township government". Passengers exiting to Hong Kong or Macao, in accordance with Article 2 Clause 1 of the Proclamation on the Ministry of Public Security, the Central People's Government Concerning the Control over Passengers Travelling to and from the Regions of Hong Kong and Macao 1951 (PRC), needed to "apply for an exit and entry pass from the Public Security authorities of resident county or city upon the authority of a household certificate or written certificate prescribed by the township government".

More detailed restrictions were adapted to control aliens leaving China. According to Articles 2 
and 4 of the Provisional Measures on Exit of Aliens in China 1954 (PRC), "aliens exiting the country must lodge an exit application in person to the public security departments of the municipality or county in which their residence is registered". After examining the prescribed document of proof, the provincial public security departments would issue an exit visa (Chujing Qianzheng) to aliens whose country had a diplomatic relationship with China, and exit permission (Chujingzheng) to aliens whose country had no diplomatic relationship with China. Article 3 of the Provisional Measures on the Exit of Aliens in China 1954 (PRC) further set forth, "where an alien is party of a civil or criminal case, he or she has the duty to pay debt or tax, and will therefore be banned from exiting".

\section{Administrative system}

From 1957, the MPS and various public security departments were wholly responsible for the administration of exit and entry. In accordance with the Preface and Article 1 of the Circular of the State Council on the Unified Responsibility of Ministry of Public Security Regarding the Administration of the Exit and Entry for Private Affairs of Citizens 1956 (PRC), the administration on citizens' exit and entry, passports and visas, previously the responsibility of the Ministry of Foreign Affairs (MFA) and local foreign offices, were devolved to the MPS and local public security authorities. Specifically, the Bureau of Public Order within the MPS was responsible. Article 3 of the above Circular prescribed how local exit and entry administrative organs were to be established. ${ }^{736}$ A national exit and entry administrative authority based around provincial departments was established.

\section{Events that influenced the RLR}

Events, such as the land reform, after the establishment of the PRC had a far greater influence on Chinese migration than those of the period 1911-1949. The influence is best summed up by C. Y. Choi who has asserted that:

\footnotetext{
${ }^{736}$ For example, Guangdong and Fujian Provinces were permitted to establish a special team in each provincial-, municipal-, or county-level public security department, to be responsible for the administration of exit and entry of citizens for private affairs. By contrast, other provinces could only appoint a full or part-time cadre for the same function.
} 
...[A]mong these events, the Land Reform of 1950-1953 probably had the most far reaching effect because it greatly weakened the binding strength of the community due to the elimination of the ownership of large land holdings, especially clan land, and confiscation of land owned by overseas families. As the lineages began to disintegrate, loyalty among Chinese emigrants towards their families and lineages started to lose its basic foundation. ${ }^{737}$

Persecution, harassment and discrimination also encouraged emigration. Many Chinese left the Mainland once the Communists assumed power in 1949. ${ }^{738}$ Against an unfavourable backdrop at home, Chinese migrants began to settle permanently abroad, and tried to bring their family to join them overseas. There began a mushrooming outflow of wealthy Chinese people seeking to avoid being persecuted as landlords and capitalists. This partially accounts for the imposition of stricter controls on migration.

\section{Household registration}

Household registration (Hukou) is closely linked to the RLR. The initial goal of establishing household registration system in 1951 was to maintain public security and freedom of residence and movement. ${ }^{739}$ Only persons residing in urban areas were subject to control. ${ }^{740}$ It was intended to be temporary and imposed no limits on the movement within the territory. However, in 1955 , the scope of registration was extended to the whole country including rural areas, and the system made permanent. Chinese still enjoyed the freedom of movement within territory at that time. ${ }^{741}$

Driven by rapid industrial development and the establishment of a planned central economy, the legislative goal of "safeguard[ing] people's freedom of movement" was repealed by the Regulations on Household Registration 1958 (PRC). This regulation essentially set out the

\footnotetext{
737 Choi, C.Y., Chinese Migration and Settlement in Australia, Sydney University Press, 1975, pages 57-58.

${ }^{738}$ Brown, Judith M. \& Foot, Rosemary Migration: the Asian Experience, the Macmillan Press Ltd., London, 1994, page 5 .

739 Article 1 of the Provisional Regulations on Administration of Urban Household 1951 (PRC) (Chengshi Hukou Guanli Zanxing Tiaoli).

740 Article 2 of the Provisional Regulations on Administration of Urban Household 1951 (PRC) (Chengshi Hukou Guanli Zanxing Tiaoli).

741 The Directive of the State Council on Establishing Regular Household Registration System 1955 (Guowuyuan Guanyu Jianli Jingchang Huikou Dengji Zhidu De Zhishi).
} 
limits of freedom of movement. Article 10, Clauses 2 and 3, prohibited citizens from permanently moving from rural areas to urban areas unless formally varying their household registration. In order to register elsewhere, the applicant needed to produce an employment certificate issued by an urban labour department, or a letter of offer from a higher education institution, or proof document of movement permission issued by an urban household registration organ. Temporary movement for over three months was also prohibited under Article 16 of the Regulations on Household Registration 1958 (PRC). From the perspective of the RLR, Chinese could not apply for exit permission or a passport at the public security departments in which their residence was not registered.

\section{Simplistic style of regulations}

Statutes promulgated during this period were very general and simple in form. One regulation was usually no longer that 100 to 200 Chinese characters. From the legal point of view, these might be regarded as directions rather than laws.

In conclusion, the development of the exit and entry legal system during this period was encouraging, because freedom of movement was recognised in the statutes, though exit permission was the prerequisite of leaving. Limits and general regulations on entry and exit were primarily established to facilitate the entry and exit of overseas Chinese, to control travel to or from Hong Kong and Macao, and strictly manage aliens exiting China. The effect of restricting limits, household registration and a simplistic form of regulations on the RLR remains to date. The regime established in this period laid the foundation and direction for later exit and entry administration.

\subsubsection{8 and 1978: the development of the restrictive framework governing the RLR}

Regretfully, China's communist policies, poor economic conditions, political instability and hostility towards foreign countries brought an end to the encouraging trends in the development of regulatory framework governing the RLR.

From 1958, the Chinese government introduced policies to suppress right-wing political 
opposition. Many of the opponents were Chinese people who had been educated abroad and may have had family members overseas. They were sent to labour camps in remote rural areas and seriously restricted from leaving China. Anyone who wanted to leave China generally remained silent, out of fear of being regarded as right wing.

China adopted a highly concentrated emigration system, which adversely affected the RLR. In April 1959, the MPS announced further restrictions on exit and entry. The Rules for the Administration on Citizens Exit and Entry for Private Affairs 1958 (PRC) were repealed. In 1964, the State Council promulgated the Regulations on the Administration of Entry, Exit, Transit, Residence and Travel of Aliens in China 1964 (PRC), Article 7 required all aliens to apply for a visa for the purposes of entry, internal travel and exit.

During the Cultural Revolution between 1966 and 1976, the RLR was seriously abused. The provisions regarding the freedom of movement were deleted from the Constitution in 1974. Any person who applied to leave China was regarded as being dissatisfied with the Chinese socialist system, and suspected of having colluded with a foreign country to carry out illicit activities against China. This meant that many citizens and overseas Chinese refrained from applying to enter or exit the State. ${ }^{742}$ In 1974, 1.6 million people exited and entered China for private affairs and public affairs, $26 \%$ less than in $1966 .{ }^{743}$

Hostility towards China by many countries initially motivated China's restrictive migration policy. This was especially true of the Western countries, such as the USA and Australia, where the governments of the time were suspicious of communist sympathisers; in Malaya after the 1948-1960 'emergency'; and in India after the 1962 Sino-Indian War. China was still sanctioned

\footnotetext{
${ }^{742}$ Wong, Li the Theory and Practice of International Immigration Law, Law Press, Beijing, 2001, page 77.

743 Department of Exit and Entry under Ministry of Public Security \& Department of Border Security Checking and Administration, Great Change over the Last 50 years: the Analysis of the Data of Exit and Entry of Individuals (Fenyun Bianhuan Wushi Nian: Cong Churujing Renyuan Tongji Shuju Kan Jianguo Yilai De jubian), No. 22 (1999) of People's Public Security (Renmin Gongan).
} 
under the decree of the UN. ${ }^{744}$ A 'one nationality' policy was introduced during this period. It was designed to encourage overseas Chinese to assimilate into their local foreign community and to abandon their Chinese nationality. This policy remains in force.

The draconian exit restrictions were politically indefensible then and still are. China was probably concerned that the disgruntled element within the emigrant population would form foreign counterpart groups for subversive movements within China. In such circumstances, there was almost no demand for the exit and entry for private affairs. For the others, political instability and danger in Mainland China during the Cultural Revolution of 1966-1976 encouraged irregular emigration, mostly in the form of refugees.

\subsection{9 to 1985: the start of the reform of the restrictive framework governing the RLR}

Since 1978, China has adhered to the policy of reform and opening-up, with the focus on economic reconstruction and the establishment of a socialist market economy. This has resulted in great economic achievements. Nevertheless, special laws regarding exit and entry were not promulgated until 1985. During this period, the Chinese government began to reform the exit and entry administration and started to relax restrictions on the RLR.

\section{Recognition of the right to leave: a very advanced form of legislative thinking}

Limits were primarily eased on the right to leave of overseas Chinese and their families who had re-entered the country. Encouragement of overseas Chinese to return is a traditional Chinese custom, and stood to attract overseas investment. In June 1978, the State Council approved and transmitted the Suggestions of the Ministry of Public Security, the Ministry of Foreign Affairs and Overseas Chinese Office of the State Council on Relaxing and Improving Exit abroad Examining and Approving for Returned Overseas Chinese and Their Family Members 1978 (PRC).

\footnotetext{
744 The USA Congressional - Executive-Commission on China, "The People's Republic of China", http://www.cecc.gov/pages/virtualAcad/his/prc.php (04/01/2005)
} 
Most significantly, exiting was firstly recognised as a legitimate right of citizens in China, even though the prerequisite of "legitimate" may offer opportunities to demolish the legal recognition. ${ }^{745}$ Additionally, the government commenced the first overhaul of the exit and entry administration in 35 years with the publication of the Suggestions of the Ministry of Public Security on Relaxing the Conditions of Examination and Approval of Exiting China for Private Affairs 1984 (PRC). Unfortunately, influenced by leftist policy, many local administrative authorities ignored the reforms and legal recognition of the RLR. ${ }^{746}$ In order to redress the problem, the Circular of the Ministry of Public Security on Seriously Carrying out the File of Gongfa (Jing) [84] 59 and Further Relaxing Exiting China for Private Affairs (Abstract) 1984 (PRC) was published. Both instruments dramatically relaxed the limits on exit and entry of Chinese citizens and relatively relaxed limits applied to aliens.

Article 1 of the later instrument underlined that administrative authorities had to respect and safeguard the lawful rights and interests of Chinese citizens wanting to exit China, to encourage and assist them to travel abroad, and to better consider the perspective of the applicant when processing their application. This was a very advanced form of legislative thinking, even in comparison to the 2001 amendments. Unfortunately, these advanced ideas were not enforced in practice, demonstrating that the communist ideology is deeply ingrained in administrative processes.

\footnotetext{
745 Article 1 of the Suggestions of the Ministry of Public Security on Relaxing the Conditions of Examination and Approval of Exiting from China for Private Affairs 1984 (PRC); and the Circular of the Ministry of Public Security on Seriously Carrying out the File of Gongfa (Jing) [84] 59 and Further Relaxing Exiting from China for Private Affairs (Abstract) 1984 (PRC) creatively provided that "application for exiting from China is a legitimate right and interests of Chinese Citizens." and that [E]xcepting Chinese citizens prohibited from exiting from China, the application for self funded exit from China for permanent residence, visiting relatives and friends, marriage, inheriting property, medical treatment, employment and tourism, without distinction to social class or origin, political thinking or family situation, should be granted if the visa of destination countries is possibly granted.

${ }^{746}$ As Hu Yaobang, the former General Secretary of the Central Committee of Communist Party of China (CPC) of that time pointed out, Some of our comrades have a very serious left leaning thinking in this regard, the strict limits on exiting from China have not been relaxed from the bottom despite the reiteration of the Central Committee. These issues must be solved quickly. See Preface of the Circular of the Ministry of Public Security on Seriously Carrying out the File of Gongfa (Jing) [84] 59 and Further Relaxing Exiting Abroad for Private Affairs (Abstract) 1984 (PRC) (Gonganbu Guanyu Renzhen Guance Zhixing Gongfa (Jing) 59 Hao Wenjian Jinyibu Fangkuang Yisi Chuguo De Tongzhi), promulgated by the Ministry of Public Security on 22 November 1984.
} 


\section{Passport application and passport administration}

Even though Article 8 of the Regulations on Passport and Visa 1980 (PRC) confers a right on all Chinese citizens to obtain a passport, in practice, only individuals with specific qualifications could apply. ${ }^{747}$ Individuals exiting China for public affairs had to submit documents alongside the application form, undertake strict examination and hand in their passport for unified administration. ${ }^{74}$ In fact, these limits on exit for public affairs had the effect of limiting almost all individuals likely to exit the State, given that only people employed by the government or a State owned enterprise could afford to travel abroad. ${ }^{749}$ Additionally, lack of provisions for the processing of passport applications, resulted in the exercise of unfettered administrative discretion and arbitrary decision-making.

Notably, it was more difficult to obtain a passport if the applicant was a member of the Communist Party of China (CPC). Under Article 1 of the Rules of Personal Department of Central Committee of Chinese Communist Party on Some Issues Regarding Party Members Exiting China, Hong Kong or Macao Areas for Private Affairs 1981, a "member of Chinese Communist Party exiting abroad for private affairs must lodge the application [with the] work unit's Party Committee and local public security authority". After approval was obtained from both of these 'authorities', the "application [was] reported to senior Party Committee". An

\footnotetext{
747 Article 8 of the Regulations on Passport and Visa 1980 (PRC) set forth "An ordinary passport is to be issued to the following persons: the ordinary passport for public affairs is issued to postgraduates, individuals attending advanced studies, overseas students, labourers and seamen employed by foreign companies; the ordinary passport for private affairs is issued to Chinese citizens exiting from China for private affairs and Chinese citizens residing overseas; other individuals for whom it is necessary to be granted an ordinary passport under the consideration of the issuing passport authority.'

748 Article 3 clauses 1 and 2 the Circular of Application for Passport and Visa for Individuals Exiting from China Temporarily for Public Affairs 1983 (PRC) required individuals to be provided with an exit abroad task document and political examination document with a leader's instruction. Article 6 Clause 2 and 4 required that individuals exiting from China immediately hand in their passport (whether diplomatic, business or ordinary) to public affairs [meaning unclear here] to work unit upon return to China. If the person needed to exit China again, they would need to apply for a certificate issued by bureau-level work unit.

749 According to official Chinese statistics, in 1985 the average annual per capita income for a rural person was C $¥ 574.31$ (US\$66.18), whereas the average annual per capita income in urban areas was C $¥ 748.92$ (US\$90.56). See “Per Capita GDP from 1952 to 2002" (1952 Nian - 2002 Nian Renjun Guomin Shengchan Zongzhi), http://www.menet.com.cn/shuju/gmjj/gmjj-rjgdp.htm (15/04/2004).
} 
ordinary passport could then be granted. Given that Party members occupied all senior government positions and most positions in State-owned enterprises and institutions, these limits effectively restricted the exit of China's elite.

\section{Exit visa}

In 1980, the exit visa system was established. Under Article 2 of the Regulations on Passport and Visa 1980 (PRC) the exit visa is a permission document that would permit Chinese citizens and aliens to exit the Chinese border. Article 9 required Chinese citizens, overseas returnees and aliens must apply for a visa if they exit China. ${ }^{750}$ Multiple entry and exit visas could be obtained if the applicant was involved in setting up a factory or other investments, or had bought a house and lived in the province for extended periods. This system was obviously outdated by international standards.

\section{Single nationality}

Also in 1980, the Law of Nationality (PRC) was enacted. It summarised the nationality policy that had operated since 1949. In particular, Article 3 expressly refused to recognise dual nationality. This policy had been introduced to avoid diplomatic issues with countries in which a Chinese national was resident and also a citizen. However, the policy significantly undermined the ability of overseas Chinese to maintain close links with China, as they needed to apply for a visa to enter, transit, settle or exit the country. This adversely affected their living, employment and educational opportunities.

The Bureau of Administration of Exit and Entry of Aliens under the MPS was established in 1983, creating a dedicated exit and entry administrative body. Furthermore, limits on overseas Chinese exiting China were eased. Economic development and reform measures outlined saw a

\footnotetext{
750 The exit visa system was also contained in other regulations such as Article 3 Clause 1 of the Interim Provisions of the Special Economic Zones in Guangdong Province for the Control of Personnel Entering and Leaving China, 1981 (Guangdong, the PRC). That provision required foreigners and overseas Chinese to comply with entry and exit procedures and to obtain a visa.
} 
marked increase in the number of people entering and exiting China. ${ }^{751}$ China approved approximately 50,000 individual applications to exit for private affairs each year between 1979 and $1985 .^{752}$

Looking back, the liberalisation of exit and entry during this period was very limited, while some improvements were made to exit and entry administration. The advanced legislative thinking in the regard of exit and entry administration was not carefully executed. Outdated passport administration and nationality administration continue to be a dominant theme.

\subsection{5 and 2001: the development of the reform of the restrictive framework governing the RLR}

From 1985 to 2001, over 400 statutes paved the way for comprehensive governance of exit and entry, mainly through the MPS. These laws gradually lifted the restrictions placed on Chinese citizens exiting China, encouraged the return of overseas Chinese, eased the restrictions on the entry and permanent residence of aliens, and established emigration intermediary agencies. Although the development did not extend to constitutional protection of the RLR, or the liberalisation of exit and entry contained in ordinary statutes, it further improved the RLR in China.

The return of legal recognition of citizen's the RLR

Legal recognition of citizens' the RLR was resumed in February 1986, when the Law on the Control of Exit and Entry of Citizens 1985 (PRC) came into force. Article 1 was:

...formulated with a view to safeguarding the legitimate rights and interests of Chinese citizens

\footnotetext{
751 In 1978, 1.88 million people passed across China's borders, compared to 12.8 million by 1984. of this, the number of aliens travelling into and out of China in 1978 was 450,000, compared to 3 million in 1984. Committee of Textbook Editing and Examination of the Ministry of Public Security, Renmin Jingcha Gongan Yewu Jichu Jiaocai: Bianfang Yu Churu Jing Guanli (Frontier Defence and Exit and Entry Administration, the Series of Basic Textbook of People's Police Operation), the Publishing House of Qunzhong, Internal Publication within Public Security Organs (Gongan Jiguan Neibu Faxing), Beijing, 1999, page 281.

752 Wang, leiming, "Citizens May Exit Abroad for Private Purpose Easier and Faster" (Woguo Gongmin Yinsi Chuguo Gengjia Bianjie), http://www.sina.com.cn 19/09/2002 quoted in Xinhua News Agency, 18/04/2003.
} 
with respect to their exit from and entry into China's territory and to promoting international exchange.

the RLR was respected in qualified terms. The right was precondition upon being "legitimate". This excluded the possibility of full or unqualified protection of the RLR and suggested that in-depth issues regarding the RLR and Chinese migration law could not be resolved through non-essential migration law reform. But the lack of express recognition of alien's the RLR was not changed. According to Article 1 of the Law on the Control of Entry and Exit of Aliens 1985 (PRC) "for the purpose of safeguarding the sovereignty and maintaining the security and public order of the PRC and facilitating international exchanges".

\section{Legislation of the exit and entry}

Although the provisions of these two laws provide for the formulation of later relevant laws, their contents were generalised and ambiguous. The enactment of the Detailed Rules for the Implementation of the Law on the Control of Entry and Exit of Citizens 1986 (PRC) and the Detailed Rules for the Implementation of the Law on the Control of Entry and Exit of Aliens 1986 (PRC) did not resolve the issue of ambiguity. The degree of ambiguity fostered the enactment of a large number of subsidiary orders, directives, rules and circulars. ${ }^{753}$ Based on the incomplete collection of the Bureau of Party and Government Foreign Affairs Cadre, under the Organisation Department of the Central Committee of the CPC, 42 ministries, committees, State bureaus, Courts and banks promulgated 235 orders, directives, subsidiary rules and official documents and letters during the period between May 1980 and July $1994 .{ }^{754}$

\footnotetext{
753 The major regulations include the Provisional Measures Concerning the Control over Chinese Citizens Travelling on Private Affairs to or from the Regions of Hong Kong or Macao 1986 (PRC), the Circular of the General office of the State Council on the Measures for Receiving Compatriots from Taiwan Coming to the Mainland to Visit Their Relatives or as Tourists 1987 (PRC), the Circular of the General office of the State Council on Students Studying Abroad 1992 (PRC), the Provisional Measures on Procedures for Contract Workers Sent Abroad Leaving the Country 1996 (PRC), the Provisional Measures on the Administration of Chinese Citizens' Tours Abroad at Their Own Expense 1997 (PRC) and the Law of the Rights and Interests of Returned Overseas Chinese and the Family Members of Overseas Chinese (Amendment) 2001 (PRC).

754 Calculated according to the Bureau of Party, Government Foreign Affairs Carder under Department of Personal of Central Committee of Chinese Communist Party, the table of content of the Collection of Popular official Documents and Letters, Regulations and Laws Governing Examination and Administration of Exiting Abroad
} 
These subsidiary regulations suggest that during this period, the legislative process was not unified. This model can be attributed to the influence of a planned central economy, in which individual ministries were separately responsible for managing different sections of the national economy and national development, in which competition did not play a key role. Each ministry had the power to enact regulations in a relatively autocratic manner, which led to the inconsistencies and disputes that arose within the body of legislation. The Regulations on the Administrative Legislation Procedure (PRC) 1989 that governed the rule-making activities of the State Council and its ministries was widely regarded by Chinese authorities as unsatisfactory. ${ }^{755}$

The public had little access to government policies and rules because there was no freedom of information legislation. The Bureau of Party and Government Foreign Affairs Cadre, under the Organisation Department of the Central Committee of the CPC, stated in the Collection of Popular Official Documents, Regulations and Laws Governing Examination and Administration of Exiting China that:

Most of the collections in this book are internal official documents and must be safely kept. They are banned from being copied, publicly released, or cited unless publicly released. ${ }^{756}$

Consequently, a large number of unpublished official documents formed a bureaucratic barrier to the RLR.

Formalities associated with passport applications and obtaining permission to exit China

(Chuguojing Shenpi Ji Guanli Gongzuo Changyong Wenjian Fagui Xuanbian), the Publishing House of Danjian Duwu, Interior Publication (Neibu Faxing), Beijing, 1994, pages 1-33.

755 Rubin, Edward L. "Administrative Law and the Complexity of Culture”, in Seidman, Ann, Seidman, Robert B. and Payne, Janice (ed.), Legislative Drafting for Market Reform: Some Lessons from China, Macmillan Press Ltd., London, 1997 and St. Martin's Press, Inc. New York, 1997, page 91.

756 The Bureau of Party, Government Foreign Affairs Carder under the Department of Personal of Central Committee of Chinese Communist Party, the Collection of Popular official Documents and Letters, Regulations and Laws Governing Examination and Administration of Exiting Abroad (Chuguojing Shenpi Ji Guanli Gongzuo Changyong Wenjian Fagui Xuanbian), the Publishing House of Danjian Duwu, Internal Publication (Neibu Faxing), Beijing, 1994, in "the Introduction of the editor". 
A Chinese citizen needed to go through complicated formalities when applying for a passport, including approval from one's work unit, producing household registration documents, an invitation letter from overseas, as well as the financial guarantee for the duration of the visit. Having close relatives abroad was almost a prerequisite for obtaining permission to travel abroad. the RLR was further restricted by the controls placed on access to foreign exchange. As Bard-Anders Andreassen and Theresa Swinehart observed in Human Right in Developing Countries Yearbook 1990, "foreign travel for private affairs is severely restricted [in China]."757 In 1994, Mary Shi noted in Human Right in Developing Countries Yearbook 1994 that:

Freedom to leave and enter [China] remains under government control. Citizens who have not shown any sign of improper political attitude, however, will more easily be granted permission to study abroad than before. The time needed to obtain a passport will rather depend on the amount of contacts (Guanxi) one has within the bureaucracy of local authorities, the work unit or the neighbourhood committee, than on the relevant Ministry. ${ }^{758}$

No one knows how many Chinese wanting to go abroad were discouraged from applying because they are aware of the complications and, more importantly, because they may have feared reprisals against themselves and their families. Fortunately, the restrictive framework governing the RLR was experiencing further reform. In 1986, the first round of reforms characterised the effectiveness of the Law on the Control of Exit and Entry of Citizens 1985 (PRC) and the Law on the Control of Entry and Exit of Aliens 1985 (PRC). The system of entry-exit visas for citizens ${ }^{759}$ was accordingly replaced with an exit registration card, ${ }^{760}$ and

\footnotetext{
757 "China" at Andreassen, Bard-Anders and Swinehart, Theresa (ed), Human Rights Institutes in Norway, Denmark, the Netherlands, Finland and Sweden (Compilation), Human Right in Developing Countries Yearbook 1990, N. P. Engel, Publisher, Kehl, Strasbourg and Arlington, 1991, page 125.

758 Shi, Mary, "China" at Baehr, Peter, Hey, Hilde, Smith Jacqueline and Swinehart, Theresa (ed), Human Right in Developing Countries 1994 Yearbook, N. P. Engel, Publisher, Kehl, Strasbourg and Arlington, 1995, page 180. 759 "Chinese citizens may leave or enter the country with valid passports or other valid certificates issued by the competent department of the State Council or other departments authorised by them. They shall not be required to apply for visas." Article 2 of the Law on the Control of Exit and Entry of Citizens 1985 (PRC)

760 "The Chinese passport, together with the exit registration card, shall be issued by the entry-exit control department of the public security organ to the citizens residing in China whose exit applications have been approved." Article 6 of the Detailed Rules for Implementing the Law of Exit and Entry of Citizens 1985 (PRC) made pursuant to the Law of Exit and Entry of Citizens 1985 (PRC) promulgated by the MPS, MFA and Ministry of Communications, and approved by the State Council.
} 
aliens exit visa was abolished. ${ }^{761}$

The second round of reforms took place in 1992. After 1991, China set up the goal of establishing a socialist market economy. The demand for the RLR was more pressing than ever. At this time, the registration card for exiting a second or subsequent time was abolished. ${ }^{762}$ In addition, the MPS simplified the procedure for exiting China for private affairs for intermediate and senior science and technology personnel. This group no longer needed to provide a certificate of approval from a provincial, regional and municipal level of government with their application. $^{763}$

The third and fourth round of reforms occurred in 1996 and 2000. At the third, partial Chinese and overseas Chinese who had returned to China; as well as their families, no longer needed to submit a foreign letter of invitation with their application to leave. ${ }^{764}$ The fourth permitted citizens to apply for a passport upon evidence of a foreign exchange deposit, rather than a certificate from the work unit.

Occurrence of political and economic exile from 1980

After 1980, especially the Tiananmen crackdown in 1989, the number of Mainland Chinese

\footnotetext{
761 "For exit from China, aliens shall present their valid passports or any other valid certificates." Article 22 of the Law on the Control of Exit and Entry of Aliens 1985 (PRC).

762 Article 1 of the Circular of Sixth Bureau of the Ministry of Public Security on Simplifying the Formality of Citizens Exiting from China again for Private Affairs 1992 (PRC) provided that an "[o] rdinary passport holder desiring to exit abroad again after returning to China need not apply for exit registration card again No matter how long the individuals stayed after returning to China, whether the causes for exiting from China have changed or not, as well as whether the destination country has changed."

763 The exit application of a research assistant, lecturer, engineer, medical practitioner and other intermediate and senior scientific and technical personnel will be processed pursuant to the Law on the Control of Exit and Entry of Citizens 1985 (PRC). Article 1 of the Circular of the Ministry of Public Security on Simplifying the Formality of Intermediate and Senior Science and Technology Personals Exiting Abroad for Private Affairs 1992 (PRC) (Gonganbu Guanyu Jianhua Zhongji Gaoji Keji Renyuan Yinsi Chujing Shouxu De Tongzhi), promulgated by the Ministry of Public Security on 27 August 1992.

764 Operational Norms of Application, Examination and Approval of Exiting from China and Passport For Private Affairs of Citizens 1996 (PRC).
} 
students in Western universities who became political or economic exiles swelled. ${ }^{765}$ It represented the biggest wave of Chinese migration since the gold rush of nineteenth century. ${ }^{766}$ The expansion of the overseas Chinese network ensures the feasibility of further development of the RLR in China in the near future.

Effects of reforms of legislation governing exit and entry on the levels of exit and entry

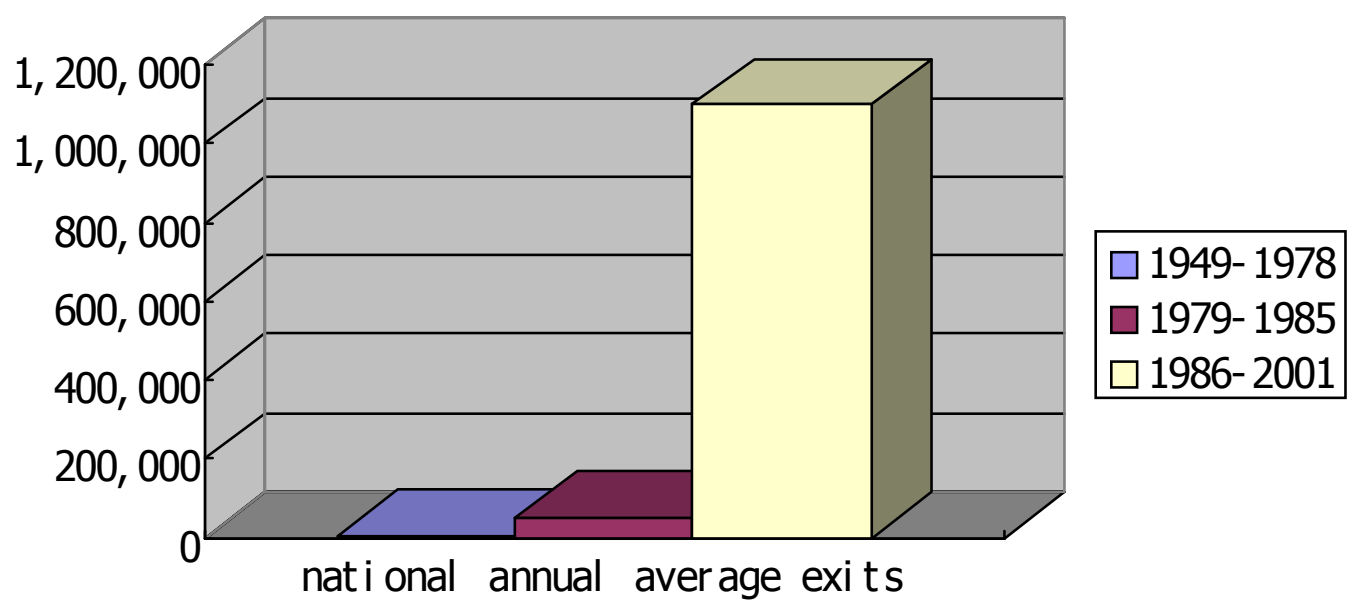

Graph 1: Average National Annual Exits in Three Migration Legislative Stages. Source: the Ministry of Public Security (MPS), China 2002

The above graph dramatically shows average annual exit numbers in three different legislative stages. From 1949 to 1978, China had operated under a planned central economic system. The average number of exits each year was 7,000. From 1979 to 1986, China initiated its policy of reform and opening up but did not enact entry and exit laws. The average number of exits was

\footnotetext{
${ }^{765}$ Wichberg, Wdgar, “The Chinese as Overseas Migrants in Brown”, Judith, M. \& Foot, Rosemary (ed), Migration: the Asian Experience, 1994, the Macmillan Press Ltd., London, page 16.

${ }^{766}$ For example, more than 42,000 Chinese students were granted permanent visas in Australia following the 1989 events in Beijing. This number grew to 100,000 when the students were allowed to bring their families to Australia to be reunited. That number accounts for $70.42 \%$ of all Chinese mainlanders who now live in Australia. See Banham, Cynthia, "Children of the revolution", the Sydney Morning Herald, Australia, Christmas Weekend Edition, pages 26-28, December 2003.
} 
50,000 per year. From 1987 to 2001, the legal system of exit and entry was established and China began to integrate into the rest of the world. Limits on external travel were gradually lifted. The annual average increased to 1.1 million.

At present, more than 10,000 passports are issued daily by the MPS, the daily number is more than the yearly total issued during the 1950 s through to the 1970 s. ${ }^{767}$ Dating from 1989, when the first national conference on exit and entry administration was held, 1.334 billion entries and exits have been recorded by China's exit and entry administration, an annual growth of $27.91 \%{ }^{768}$ In 1990, Chinese migration stock was 380,000 , and 513,000 in $2000 .^{769}$ The above graph and figures demonstrate that legal reform played a positive role of promoting the realisation of the RLR.

\section{Emigration intermediary services}

The rapid growth in the number of people exiting China has resulted in the development of an emigration intermediary service market, the formation of which, as a result of complex economic and socio-ideological causes, has been chaotic. The Provisions on the Administration for Overseas Employment Intermediary Agencies 1992 (PRC), the Regulations on the Administration for Travel Agencies 1996 (PRC) and the Regulations for the Administrative on Intermediary Agencies for Self-funded Studying Abroad 1999 (PRC) were enacted to regulate the industry. The new regulations developed a system of reserve funds related to overseas employment and overseas study intermediary agencies, and overseas travel agencies.

\section{Final remarks}

By 2001, some important achievements were reached in the protection of the RLR, despite its motley historical record. Nevertheless, restrictions on the RLR are still severe, and issues fundamental to the system of migration control remain. For example, most reform measures

\footnotetext{
767 Wang, Chuyan, "Passport Gain Wider Currency in China”, China Central Television, 18 October 2002, http://www.cctv.com/english/news/TVNews/MorningNews/20021018/100241/html (19/06/2003).

768 "China to Reform Exit-Entry Administration", http;//www1.chinadaily.com.cn/en/doc/2001-12/21/content_99065.htm (19/12/2003).

769 Population Division, Department of Economic and Social Affairs, International Migration Report 2002, United Nations Secretariat, 2002, ST/ESA/SER.A/220, the United Nations, New York, 2002, 62 pages, attached table.
} 
failed to integrate new policies into the Law on the Control of Exit and Entry of Citizens 1985 (PRC), and the Law on the Control of Entry and Exit of Aliens 1985 (PRC) and its detailed rules of implementation. Consequently, the achievements are perhaps unstable in the sense that their legal validity is in dispute.

\subsection{Conclusions}

Rich and complex experiences of historical development are two sides of a coin for China today. China can play a catalytic role in helping protect the RLR, or place a heavy burden on and hamper the improvement of the RLR. The Chinese government needs thus to objectively discriminate its position in relation to the RLR by reference to international human rights ethics, rather than exclusively to Chinese national experience or tradition.

Given the long years of war and abnormal relations with Western countries, it is understandable that a relaxation of limits has only been intermittent; restriction has been a dominant theme. Issues of the RLR in China are not only the issues of today but also those accumulated over time. That history cannot be cited as an excuse not to solve the current issues of the RLR.

As a rule, inertia of historical development can be affected and overcome by outside force, though such change is often reactionary and overly sudden. With the RLR in China, the dominant theme of restriction will remain until the legislation governing exit and entry is reformed. In respect of the complexity underlying a history of accumulated issues in China, a well-designed reform strategy focused on the RLR needs to be gradual.

In the development of rights in China, the RLR is a very new issue, the discussion and conception of which is mainly provided by contemporary scholars. Government authorities have not yet completely accepted the idea of the RLR. In Chinese society all electronic and print media are controlled by the $\mathrm{CPC}$, hence there is little ground for building awareness of the existence and the need to improve upon the RLR of individuals. This lack of awareness of the RLR in the public domain hinders the complete execution of laws to enhance exit and entry and may also, if overlooked, hinder the design of an advanced reform strategy to solve the issues of 
the RLR in China. 


\section{Chapter Seven}

\section{Planned Reform Strategy and Measures for the Exit and Entry Administration}

\section{Introduction}

In principle, China has acknowledged the importance of protecting the RLR, and has taken steps to have its practices conform to international norms. Restrictions on the RLR in China will be gradually relaxed from 2002 to 2005 . Procedures will be greatly simplified. ${ }^{770}$ According to the official media, this round of reforms will be the biggest overhaul of Chinese migration law in history. ${ }^{771}$ This chapter will discuss (i) the context of the reforms; (ii) the contents of the reform strategy and its implementation, including the sub-round reform measures from 2002 to 2004 and local governments reform measures; and (iii) the impacts, deficiencies and nature of the reforms, with some forecast of the RLR and migration law in China in the near-future.

\subsection{The context of the reforms}

The fundamental reason for reforming exit and entry administration is that strict controls are incompatible with China's economic and social development. The then President Jiang Zemin argued in 2002 that, "reform and opening up have yielded substantial results. The socialist market economy has taken shape initially." ${ }^{, 772}$ Meanwhile, an absence of corresponding reform of exit and entry administration has diluted China's ability to develop and integrate into the world. By international standards, since 1949 the Chinese government has exercised too much power over migration and the RLR, yet this has received less attention than other aspects of the reform.

\footnotetext{
770 “Simplifying Exit-entry Procedures, a Vital Step for China”, 23 November 2001, The People's Daily, http://english.peopledaily.com.cn/200111/23/eng20011123 85161.shtml(18/04/2003).

771 "State to Simplify Entry-exit Rules", 11/22/2002, The China Daily, http://www1.chinadaily.com.cn/news/2001-11-22/44711.html (18-04-2003).

772 Jiang, Zemin, the President of the People's Republic of China, Part I Par 4 of "Build a Well-off Society in an All-Round Way and Create a New Situation in Building Socialism with Chinese Characteristics: Report at 16th China Communist Party Congress (8/11/2002)", http://www.fmprc.gov.cn/eng/37815.html (19/07/2003).
} 
China's accession to membership of the World Trade Organisation (WTO) sparked exit and entry administration reform. The government widely recognised the need to simplify procedures. The then Prime Minister Zhu, Rongji said in 2002 "China's accession to the WTO benefits its reform and opening up and its economic development as a whole.",773 Further, that "We need to actively participate in international economic cooperation and competition on a broader scale and in greater depth." 774 The then minister of the MPS Jia Chunwang, said in 2001:

China's entry into the WTO will ensure the country participates in international cooperation in a more comprehensive manner, while these measures will deepen the reforms and serve the economic construction. ${ }^{775}$

Chinese society was in favour of these opinions. China Radio International, the most authoritative multi-language State-owned radio station, announced that a flood of tourists and businessmen were expected to enter and exit the country after China's entry into the WTO. ${ }^{776}$ The China Daily, the leading authoritative English newspaper owned by the State said "a far-reaching overhaul of border administration is to be kick started following China's entry to the WTO to cope with the expected deluge of tourists and businessmen". ${ }^{777}$ Ten days after accession, the 2002 national annual meeting on exit-entry administration was held in Beijing in which the reform strategy was announced.

\subsection{The content of the reform strategy and its implementation}

The content of the reform strategy and its implementation provide the basis for analysing the influences, deficiencies and nature of the reforms — an analysis not previously undertaken.

\footnotetext{
${ }^{773}$ Zhu, Rongji, the Premier of the State Council, Par. 1 of Part II of "the Report on the Work of the Government (16/03/2002)", http://www.fmprc.gov.cn/eng/26804.html (19/07/2003).

774 Zhu, Rongji, the Premier of the State Council, Par 1 of Part IV of "the Report on the Work of the Government (16/03/2002)", http://www.fmprc.gov.cn/eng/26804.html (19/07/2003).

775 Quoted in “Simplifying Exit-Entry Procedures, A Vital Step for China”, The People's Daily 23-11-2001 http://english.peopledaily.com.cn/200111/23/eng20011123_85161.shtml (18 April 2003).

776 Wang, Ling, “China Simplifies Entry-exit Rules”, November 2001, China Radio International, http://english.cri.com.cn/english/2001/Nov/36826.htm (18/04/2003).

777 "State to Simplify Entry-exit Rules", 11/22/2002, The China Daily, http://www1.chinadaily.com.cn/news/2001-11-22/44711.html (18-04-2003).
} 


\subsubsection{Reform goals}

Six reform goals were announced at the annual national meeting on exit-entry administration in November 2001. With the exception of two goals related to the simplification of Chinese tourist group visas and permanent resident visa applications, the four remaining reform goals announced were pertinent to the RLR. The "passport on demand" policy is the centre of the reforms. By 2005, Chinese citizens in large and medium-sized cities will be able to obtain a passport merely by presenting their identity cards and household registration documents to the appropriate authorities. ${ }^{778}$ Jia Chunwang, in 2001, explained that the reform was aimed at gradually supplying passports to those who required them. ${ }^{779}$ The key to this measure is that applicants are no longer needed present written permission from work units; thereby better protecting individual privacy. Clearly, the policy of passport on demand advantages the urban population rather than people living in small towns and rural areas. It was adopted after the experience of Zhongshan in Guangdong Province, where a passport on demand policy was initiated in April 2001. ${ }^{780}$ The other three reform goals are:

- The cancellation of the requirement of providing invitation letters when applying for passport;

- The establishment of special channels at the airports for Chinese citizens; and

- The relaxation of restriction on travelling to the HKSAR or MSAR.

By the end of 2002, Chinese citizens no longer needed to provide invitation letters from the foreign country of destination when applying for a passport; and authorities no longer issued the exit registration card attached to the passports of citizens residing in China whose exit application had been approved. ${ }^{781}$ During 2002, special channels for Chinese citizens were set up at ten airports in Nanjing, Kunming, Shenyang and other parts of China, as is currently being

\footnotetext{
778، Simplifying Exit-Entry Procedures, A Vital Step for China”, The People' s Daily 23-11-2001

http://english.peopledaily.com.cn/200111/23/eng20011123_85161.shtml ((18/04/2003).

779 Quoted in China Simplifies Entry-exit Rules, November 2001, China Radio International, http://english.cri.com.cn/english/2001/Nov/36826.htm (18/04/2003).

780 “Guangdong Residents May Apply for Passport with ID and Resident Cards within 2003", 6 March 2003, Southern Net, http://travel.21cn.com/news/focus/2003-03-06/958982.html (23/07/2003).

781 “China Simplifies Entry-exit Rules”, November 2001, China Radio International, http://english.cri.com.cn/english/2001/Nov/36826.htm (18/04/2003).
} 
practiced in the Capital Airport and Shanghai-based Pudong Airport. ${ }^{782}$ From September 2002, Mainland Chinese residents have been allowed to travel to the HKSAR and MSAR on business for up to three years before their visas expire. Those who stay for less than three months are now able to obtain a visa without the need to fulfil extra requirements on taxation or foreign exchange; and the number of travellers to these places is no longer limited. These measures were to accommodate increasing business travel to or from the HKSAR and MSAR. ${ }^{783}$

\subsubsection{Three rounds of national reform measures in 2002, 2003 and 2004}

To reduce the social disruption that may have been caused by the reforms, the measures were gradually introduced in three rounds in 2002, 2003 and 2004. The 2002 reform measures focused on the pilot programs and trial implementation of reform strategy. The 2003 and 2004 reform measures aimed to deepen and extend the 2002 reform.

\section{2: the pilot programs and trial implementation of reform strategy}

In 2002 measures emphasising pilot programs and trial implementation were adopted. The first was related to passport on demand. Twelve cities were selected for this pilot of program in the first half of $2002^{784}$ and passport applications in these cities increased by over $40 \%{ }^{785}$ By the end of 2002, the policy had been introduced into 24 large and medium-sized cities including, Shanghai, Nanjing, Qindao and Xiamen, whereupon passport applications increased by 30 to

\footnotetext{
782 “Simplifying Exit-Entry Procedures, A Vital Step for China”, the People's Daily, Vol 18 April 2003 http://english.peopledaily.com.cn/200111/23/eng20011123_85161.shtml (18/04/2003)

783 MPS's Bureau of Exit and Entry Administration revealed that, in 2001, more than 2.46 million Mainland citizens entered and left the HKSAR and MSAR, three times the number in 1997. Quoted in Jiang, Zhuqing, "Mainland SAR Visa Procedures Simplified”, 30 May 2002, The China Daily. http://www3.chinadaily.com.cn/en/doc/2002/05/30/content_121719.htm (05/08/2003).

784 The 12 cities are Zhongshan, Shunde, Jiangmen, Fushan, Huizhou, Shantou, Shenzhen, Zhuhai, Guangzhou, Fushun, Qionghai and Zibo. See "Trial of New Passport Application Procedure Goes Smoothly: Shanghai will become China's Thirteen City to Try Out a Simplified Procedure for Passport Applications", August 2002, http://english.cri.com.cn/eglish/2002/Aug/69224.htm (18/04/2003).

785 "Trial of New Passport Application Procedure Goes Smoothly: Shanghai will become China's Thirteen City to Try out a Simplified Procedure for Passport Applications", August 2002, http://english.cri.com.cn/eglish/2002/Aug/69224.htm (18/04/2003).
} 
$50 \%{ }^{786}$

According to the Circular of the Ministry of Public Security on Simplifying the Formalities of Mainlanders Short-term Exiting and Entry the Areas of HKSAR and MSAR 2002 (PRC), the MPS adopted seven reforms for Mainland citizens' short-term visits to the HKSAR and MSAR from June 2002:

1.The types of visas available to entry into the HKSAR and MSAR were extended from family visits and tourist visas (as at 1997) to include visas for business, training, work and study.

2. The scope of visiting relatives was extended. ${ }^{787}$

3. The terms of business visas were expanded and their formalities simplified. ${ }^{788}$

4. Tourist visas were given to people aged over 60 or under 14. Applications could be made at the local exit-entry administration bureau even if applicants were members of transient households.

5. Other visas will be issued to those who need to deal with property, attend court or be present at a migration interview.

6. Overseas Chinese who have returned to the Mainland can apply for passes or visas for the HKSAR and MSAR at exit-entry authorities of the city or county in which their residence is registered, or where they are employed. ${ }^{789}$

\footnotetext{
786 Wang, leiming, "Citizens May Exit Abroad for Private Purpose Easier and Faster” (Woguo Gongmin Yinsi Chuguo Gengjia Bianjie), http://www.sina.com.cn 19/09/2002 quoted in Xinhua News Agency, 18/04/2003

787 A visa is available to visit a relative who is living, studying or working in the HKSAR or MSAR. The definition of "relative" has been extended to include a spouse, parents or parents in law, children, grandparents, grandchildren, siblings, aunts and uncles, and nieces and nephews and their spouses. Visas can be issued to allow entry once a month, once in three months, or three-month multi-entry visa. A visa to visit a spouse will generally be a three-month multi-entry visa.

788 A business visa may be granted on the basis of being used once a fortnight, as a three months multiple-entry, a one-year multi-entry visa, or three-year multi-entry visa. The first two categories are issued on demand. Prior tax and foreign exchange requirements have been cancelled. It is no longer necessary to provide documentary evidence when applying for a one-year multi-entry visa. Further, if two different public security administrations operate on the applicant's permanent resident area and work unit, the applicant may apply to the public security authorities of the city or county in which their residence is registered.

789 Jiang, Zhuqing, "Mainland SAR Visa Procedures Simplified”, 30 May 2002, The China Daily, http://www3.chinadaily.com.cn/en/doc/2002/05/30/content 121719.htm (05/08/2003).
} 
7.A certificate from the applicant's work unit or a police station is not required under certain circumstances. ${ }^{790}$

Lastly, the Chinese government has attempted to improve ordinary passports for public affairs. ${ }^{791}$ According to Article 1 and 2 of the Circular of Ministries of Education, Public Security and Foreign Affairs on Some Affairs Regarding Fulltime Students Exit China Short-term with Ordinary Passport for Private Affairs 2002 (PRC), since February 2002, fulltime students have, in principle, been allowed to exit China with an ordinary passport for private affairs. ${ }^{792}$ A representative of the MOE stated that the student-related reforms, "will play a proactive role for China to foster talent and enhance China's reputation in the educational fields". ${ }^{793}$ However, in an objective sense, the improvements outlined above concerning ordinary passports for public affairs still fall short of international norms, such as in the continued requirement of documentary evidence from a school or educational institution.

\section{3: extension of 2002 reforms}

Based on the experience of 2002, with emphasis on the results of the pilot program in Guangdong province, the MPS introduced three new rulings in August 2003 designed to facilitate the daily life of ordinary people in regard to exit and entry. ${ }^{794}$ These rulings were intended to enhance the 2002 reforms. With respect to passport applications, residents in 100 designated large- and medium-sized cities, accounting for one third of all Chinese cities, were

\footnotetext{
${ }^{790}$ Where Mainlanders holding valid passports are applying for subsequent exit and entry to HKSAR and MSAR, or overseas Chinese who have returned to the Mainland are applying for exit and entry to HKSAR and MSAR.

791 Part 8.1 and 8.2 will analyse ordinary passport for public affairs in details.

792 According to the Circular of Ministries of Education, Public Security and Foreign Affairs on Some Affairs

Regarding Fulltime Students Exit China Short-term with Ordinary Passport for Private Affairs 2002 (PRC), students need to provide documentary evidence from their school or institution with their passport application. The student, or the school acting on the student's behalf, can make applications to the relevant foreign embassy or consulate in China. Previously, an application had to be made for a public affairs passport to attend short-time governmental exchanges, international conferences, undertake cooperative research, attend study tours, training, international competitions, or other exchange activities.

793 Quoted in "Student Can Go Abroad with Private Passport February 1 on, 4 March 2002", Xinhuanet, http://www.edu.cn/20020304/3021674.shtml (19/12/2003).

794 "New Rulings to Bring a Freer Life", /1208//2003 China Business Weekly, http://ww1.chinadaily.com.cn/en/doc/2003-08/12/content 255194.htm (19/12/2003).
} 
allowed to directly apply for a passport on demand, using their identity card and residence booklets. ${ }^{795}$ Since September 2003, working citizens no longer require approval of their work unit in order to apply for a passport, unless they are serving government officials, intermediate or senior management in State-owned enterprises or a member of the CPC.

Furthermore, from 2003, residents from Guangzhou, Shenzhen and Zhuhai, Shanghai and Beijing may apply for travel permission to the HKSAR and MSAR on an individual basis by showing their identity card and resident's booklets. These visitors are not allowed to stay for more than seven days, but can apply an unlimited number of times. Residents in the 100 designated cities can travel to the HKSAR and MSAR and Taiwan and do not have to present a letter of approval from the employers or from their public security offices. Lastly, for Chinese who have gone abroad and who have lived overseas for more than one year, the stipulation that their household registration be cancelled, was rescinded. ${ }^{796}$

\section{4: further deepening of the reforms}

2004 was a crucial year for the conclusions of the reform goals. ${ }^{797}$ Four measures were undertaken to further deepen the reforms. First, the passport on demand policy was expanded to $80 \%$ of large and medium sized cities, mainly in the central area. The remaining $20 \%$ of the country's large and medium sized cities will adopt this measure in 2005. Next, a long awaited "green card" system was introduced to grant aliens with permanent residence permits in August $2004 .^{798}$ Thirdly, the issuance and management of credentials for Mainlanders to conduct short-term travel to the HKSAR and MSAR was further improved. Researchers at the MPS are

\footnotetext{
795 “Reforms Make Life and Travel Much Easier", 8 August 2003, The China Daily, http://www1.chinadaily.com.cn/en/doc/2003-08/08/content 252954 (19/12/2003).

796 "New Rulings to Bring a Freer Life", /1208//2003 China Business Weekly, http://ww1.chinadaily.com.cn/en/doc/2003-08/12/content_255194.htm (19/12/2003).

797 Quoted in "China to Further Relax Entry and Exit Control”, 25 December 2003, Xinahuanet, http://news.xinhuanet.com/english/2003-12/25/content 1247315.htm (30/12/2003).

798 "China Begins to Implement its own 'Green Card' System”,
} http://english.people.com.cn/20040820/eng20040820 153939.html (23/08/2004). Also see the provisions of Regulations on Examination and Approval of Permanent Residence of Aliens in China, 2004. 
identifying technologies for automatic passage systems at some Chinese ports. ${ }^{799}$ Lastly, procedures for travelling to and from Taiwan were further simplified. ${ }^{800}$

\subsubsection{Provincial reforms}

Provincial reforms are an indispensable part of the efforts to reform exit and entry administration. Under the MPS reform strategy, provincial governments may implement different reform measures according to individual needs. The provincial reforms are intended to compliment the national strategy and may not be inconsistent with it. Guangdong, Shanghai and Beijing have been selected for review because they are the most economically developed areas in China and their laws are more advanced than in other parts of China.

\section{Guangdong}

Guangdong has attracted the most attention from governments and scholars, not only because it has the widest networks with overseas Chinese, and the closest relationship with the HKSAR and MSAR, but has always implemented pilot reform programs, and provided examples for other parts of China. Guangdong's reforms have therefore gone further towards fully implementing the national strategy than other parts of China.

Materials from the National Symposium on Passport on Demand Pilot Program indicate that prior to March 2003, 9 cities of Guangdong ${ }^{801}$ and the Guangdong Province Exit and Entry Administration had implemented the passport on demand policy. This policy was extended to the whole of Guangdong during 2003. ${ }^{802}$ In addition, the reforms allowed an individual to apply for a passport in Guangdong, even though such individual was not a registered resident of the province, provided that he or she has been continuously employed in Guangdong for a

\footnotetext{
799 "Exit and Entry of Citizens Will be More Easier Next Year" (Mingnian Gongmin Churujing Jiang Geng Bianli), http://www.cnradio.com.cn/news/200312240292.html (30/12/2004).

${ }^{800}$ Zhang, Tao, "Relax the Restrictions Travelling to and from Taiwan, Chongqing Publish Series of Measures to Facilitate Exit and Entry of Resident” (Wanglai Taiwan Fangkuan Xianzhi Congqing Tuichu Xilie Churujing Bianmin Cuoshi), http://www.cq.xinhuanet/news/2004-03/17/content 1797126.htm (20/08/2004).

${ }^{801}$ The nine cities are Shunde, Zhuhai, Jiangmen, Foshan, Yangjian, Shenzhen, Dongwan, Huizhou and Guangzhou.

802 “Guangdong Residents May Apply for Passport with ID and Resident Cards within 2003”, 6 March 2003, Southern Net, http://travel.21cn.com/news/focus/2003-03-06/958982.html (23/07/2003).
} 
minimum of six months, had a certificate of temporary residency, and could demonstrate that the purpose of their travel was business. ${ }^{803}$

Moreover, all Guangdong residents, since January 2004, have been able to apply for up to nine exit and entry certificates by internet or telephone. Applications for individual and package tours to the HKSAR and MSAR and individual passports are covered by these services. ${ }^{804}$ Finally, a series of measures to simplify exit and entry into the HKSAR and MSAR had been adopted in October $2002{ }^{805}$ The requirements to allow locals to reunite with family members in the HKSAR or MSAR had been relaxed in November $2002 .{ }^{806}$ From July 2003, residents in four cities of Guangdong could apply for permission to travel to the HKSAR and MSAR on an individual basis, as against the prior group travel basis. ${ }^{807}$

${ }^{803}$ Exit and Entry Administration of Guangdong Public Security Department, "The Passport Application for Other Provinces (Municipalities) Residents with the Certificate of Temporary Residence in Shanghai” (Waishen(Shi) Zaizhu Renyuan Shenban Huzhao), http://www.gdcrj.com/zggmcg/wsjjy/default.htm (19/06/2003).

${ }^{804}$ Liu, Weifeng, "New measures cut bureaucracy", 15 October 2003, The China Daily, http://www1.chinadaily.com.cn/en/doc/2003-10/15/content 22068.htm (30/12/2003).

8051 . The scope of the HKSAR and MSAR business visas was extended from businesspeople and Chinese staff employed by foreign enterprises, to staff employed in education institutions, research institutions, hospitals, law firms, and accountancy firms; 2. Individuals holding exit and entry passes for the HKSAR and MSAR no longer need to repeatedly apply for visas every time they travel to and from the HKSAR and MSAR; 3. Excluding individuals with special status, an applicant no longer needs to provide a certificate from a police station and work unit when applying for a pass and visa for the HKSAR and MSAR; 4. Limits on the size of travel groups have been abolished; Since 2003, Guangdong residents who want to participate in group travel to the HKSAR and MSAR have been able to obtain a visa merely by presenting their identity cards and household registration documents to the proper authorities; 5. Express Mail Services (EMS) service for passport delivery has gradually been extended across the whole province. See “Guangdong Resident Will Much Easier Exit Abroad” (Wosheng Gongmin Jinhou Chuguo Chujing Jiang Gengjia Fangbian), quoted in Guangdong Public Security Daily, http://www.gdcrj.com/news/t20021104 1406.htm (19/06/2003).

${ }^{806}$ People who applied before the end of 1994 for single-journey permits to the HKSAR to reunite with their husbands or wives received their permits before 1 January 2003. More than 5,000 Guangdong women travelled to the HKSAR to be reunited with their husbands after receiving a permit in January 2003. See "Spouse Reunion Requirements Relaxed" http://www3.chinadaily.com.cn/en/doc/2002-12/11/content_147494.htm (05/08/2003).

807 Four cities are Zhongshan, Dongwan, Jiangmen and Foshan. "Four Cities of Guangdong Province Tried Individual SARS Travel, Re-permission processing is Finished in 10 Seconds" (Guangdong Sishi Shiban Geren Fu Gangao Yao, 10 Miao Nei Wancheng Xuqian), 18 July 2003, http://news.21cn.com/domestic/2003-07-18/1112023.html (23/07/2003). 


\section{Shanghai}

Being the most populous municipality and the economic capital of China, Shanghai's reform measures cannot be ignored. Following Guangdong, the passport on demand policy was launched in Shanghai in September 2002. ${ }^{808}$ Passport application in non-household registration regions was also relaxed. People from other provinces who lived in Shanghai and had worked there for more than one year in a Sino-foreign joint venture cooperative business, foreign-owned enterprises in Shanghai, or in the Shanghai office of an overseas institution, could apply for a passport in Shanghai if they were leaving the country in the course of their employment. ${ }^{809}$ Applicants needed to present an identity card, certificate of temporary residence in Shanghai, the business license of their employer, and a letter from their employer stating that the applicant is travelling for a business-related purpose. ${ }^{810}$

\section{Beijing}

One year after Shanghai, Beijing adopted a series of similar reforms to greatly simplify passport application. ${ }^{811}$ Residents could now apply for a passport upon presentation of their identity card, household registration book, and by filling in a form in person or by a courier. ${ }^{812}$ Passports were generally issued within 10 working days after checking the required documents. ${ }^{813}$ Two exit and entry administration offices were opened in Haidian and Chaoyang districts, in addition to

\footnotetext{
808 According to the Introduction of Hao Zhiyong, the director of the minister's exit and entry administration told a press conference held on 30 August 2002, that by presenting the ID cards or residence booklets, citizens in Shanghai could go to 100 post offices throughout the city for applications as well as police stations, increasing convenience for busy folk. Applicants were expected to receive passports within 10 working days. Shanghai also adopted some measures to improve non-registered resident application.

809 "Passport Application Reform to Undergo Testing", 30 August 2003, The China Daily, http://www1.chinadaily.com.cn/en/doc/2002-08/30/content 134255.htm (19/12/2003).

${ }^{810}$ Bureau of Shanghai Public Security, “Applying for the Passport, 08 2002”, http://gaj.sh.gov.cn/shpolice/zixun/crjgl/item2002 08/5043.shtml (26/11/2003).

811 Quoted in Xiao, Xin, “Passport Application Simplified”, 21 August 2003, The China Daily, http://www1.chinadaily.com.cn/en/doc/2003-08/21/content_256754.htm (19/12/2003).

812 The form that people are required to fill in can be download from the Bureau's website or picked up at one of the three offices. Before that, the form could be only got when applicant present ID card to the officer of the exit and entry administration.

${ }^{813}$ In the past, people had to provide approvals from their employers in additional to ID card and household registration book. It used to usually take 14 working days.
} 
the existing office in Dongcheng District, to improve the processing of applications. Secondly, people from other provinces who lived in Beijing and worked for foreign businesses, joint ventures or firms in the private sector for more than one year were also entitled to apply for a passport in Beijing. The administration is currently creating a database of people who will be restricted from accessing the new system. Lastly, in July 2003 Beijing implemented detailed reform measures to facilitate Mainlander's work and study in the HKSAR and MSAR. ${ }^{814}$

\section{Fujian and Zhejiang}

While residents in Guangdong, Shanghai and Beijing find it easier and much more convenient to obtain an ordinary passport for private affairs, Fujian and Zhejiang provinces, the main source of Chinese irregular migrants, still impose strict restrictions on the passport process. Passports cannot be issued unless a deposit of foreign exchange (e.g. US\$ 5,000) is made with the Bank of China; and women under the age of 35 are prohibited from holding an ordinary passport.

\subsection{Effects of the reforms}

Reform measures are recent and still evolving. They have recorded improvement of exit abroad applications in China. Before examining the effects of current reforms, it is useful to re-examine the impact of prior reforms on average national exits between 1949 and 2001.

\footnotetext{
814 The spokesperson of the Beijing Public Security Bureau announced that Beijing residents could apply for exit and entry passes and visa for the HKSAR and MSAR for work and study purposes from 15 July 2003 if they have been approved to work, study and train by the Immigration Department of the HKSAR SAR, are the spouse of individual who is located in the HKSAR or MSAR, or has received a letter of offer from a MSAR high education institution. See Su, Qiang and Li, Xu, "Detailed Measures of Beijing on Facilitating Mainland Talents Exiting SARS Work and Study, 11 June 2003”, Xinhuanet, http://news.21cn.com/domestic/2003-07-11/1104534.html (23/07/2003).
} 


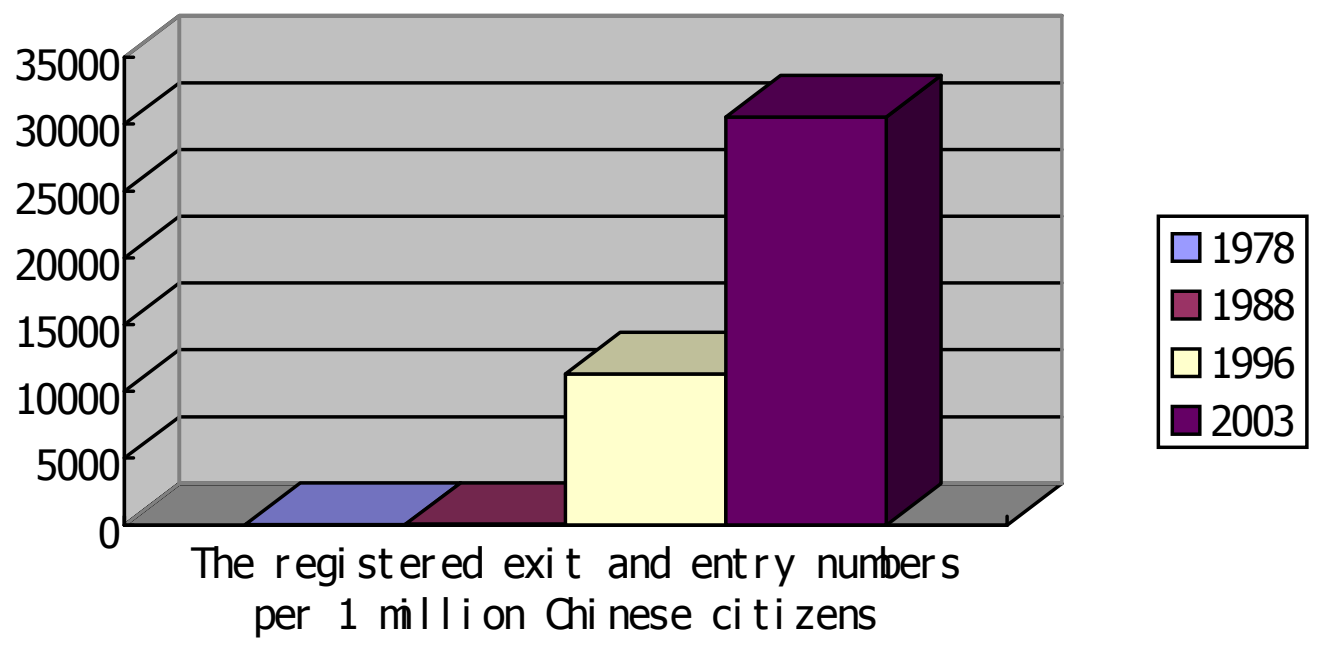

Graph 2: Registered Exit and Entry Numbers Per One Million Chinese Citizens in 1978, 1988, 1996, and 2003. Source: the Research on Population Issues in the Period of Reform and Opening-up ${ }^{815}$ and the MPS $^{816}$

Graph 2 depicts the number of registered exits and entries per one million Chinese citizens over five typical years.

- In 1978, at the start of China's reform and reintegration with the world, there were 14 per million exits and entries.

- In 1988, two years after the enactment of exit and entry laws, there were 62 per million.

- In 1996, the figure stood at 11,321 per million. This was the time at which the first regulations associated with applications, examination and approvals for exits were formulated, and passports for private affairs were made available to all citizens.

- In 2003, the second year of the reforms, the number of exits and entries was 30,538 per million, despite the SARS outbreak in the first half of that year. This figure represented a 20\% increase on the number of citizens crossing China's borders in 2002.

\footnotetext{
815 Sa, Jicai and Cao, Jingcun, the Research on Population Issues in the Period of Reform and Opening-up, the Publishing House of Beijing University, Beijing, 1994, pages 229-232, Quoted in Huang, Ruilong, Bao, Sidun, Liu, Ling, Overseas New Migrants over Last One Decade (Jin Shinian Woguo Dalu Haiwai Xin Yimin), No.1 [1998] the Journal of Population \& Economics (Renkou Yu Jingji).

${ }^{816}$ Calculated according to the date quoted in "China Sees Unusual Fall in Exit-entry Numbers in 2003", 12 January 2004 People Daily Online, http://english.peopledaily.com.cb/200401/12/eng20040112_13262.shtml (13/01/2004).
} 
The next figures illustrate the effects of the current reform measures on international migration flow. One is from national perspective; the other two are from provincial perspectives. At the end of 2001, the Chinese government instituted the biggest process of exit and entry reform. One year later, the number of exits increased from 3,080,000 of 2001 to 4,010,000 of 2002. This suggests that the reforms were integral to promoting overseas travel of Chinese nationals.

The number of passports issued to Guangdong residents increased from 376,923 in 2001 to 490,000 in 2002. These figures are more significant in light of the fact that only 30 million people $(34.71 \%)$ of Guangdong's total population ${ }^{817}$ can take advantage of the passport on demand policy. Since August 2003, Shanghai residents have been able to apply for the travel permission on an individual basis to the HKSAR and MSAR. Dao Shuming, Vice-Director of the Shanghai Travel Administration Committee, forecast that the number of people to travel to the HKSAR would exceed 300,000 after one year of the policy's implementation. According to statistics from the Shanghai Travel Administration Committee, the number of exits to the HKSAR was 136,000 in 2002. 89,000 of this number were tourists. It demonstrates that the policy to permit individual travel to the HKSAR and MSAR stimulated applications to travel to the HKSAR. ${ }^{818}$

\footnotetext{
817 The population of Guangdong Province is 86.42 million in March 2001. "Guangdong Province”, The People's Daily, http://english.peopledaily.com.cn/data/province/guangdong.html (30/12/2003).

818 "Shanghai Residents May Apply for the Travel Permission on an Individual Basis to SARS very Easily, It Only Take 5 Minutes" (Shanghairen Qingsong Ban Geren Gangao You, Quanguocheng Hua 5 Fengzhong), 2 September 2003, Xinhuanet, http://news.21 cn.com/dushi/csts/2003/09/02/1252195.shtml (02/09/2003).
} 


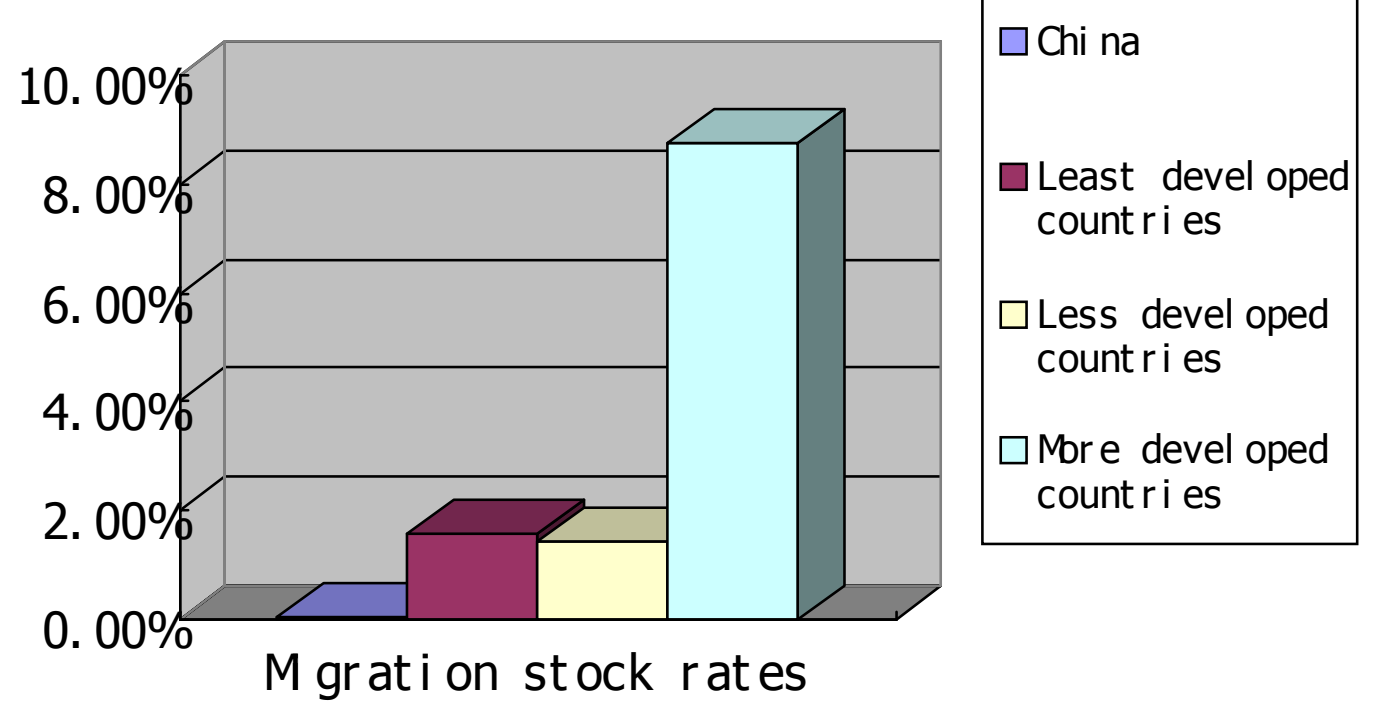

Graph 3: Comparison of international migration stock rates Source: International Migration 2002, the IOM

As discussed in part 1.2 of this thesis, international migrants in China are still considerably lower than that in the rest of the world. ${ }^{819}$ In 2000, 0.04 percent of the Chinese population were international migrants. The average rates in more developed regions, less developed regions and least developed countries are 8.739 percent, 1.452 percent and 1.566 percent respectively. This shows that with the development of China, international migrants will be further increased, and that issues in the protection of the RLR in China follow.

It is perhaps premature to conclude what influence the reform of exit and entry administration has had, because the reform strategy and measures are incomplete. For this reason, the influence so far analysed only pertains to the reform measures in place, along with an element of prediction with respect to future measures. Generally speaking, the future effects of the reform

\footnotetext{
819 According to International Migration 2002, the Department of Economic and Social Affairs, Population Division, the United Nations, October 2002, different countries and regions migration stock rates have been calculated by the author as following: Egypt (0.29 percent), India (0.62 percent), Indonesia (0.19 percent), Romania (1.4.19 percent), Russian Federation (9.11 percent), Hungary (2.97 percent), Cuba (0.73 percent), Brazil (0.32 percent), Japan (1.27 percent), Republic of Korea (1.27 percent), Singapore (33.65 percent), United Kingdom (6.78 percent), France (10.59 percent), USA (11.35 percent), Australia (21.4.58 percent) and New Zealand (22.50 percent). Migration stock rate is just a little higher in China than the same rate in Vietnam ( 0.028 percent).
} 
of exit and entry procedure on the Chinese economy and society, and on Chinese global integration, are subtle and lasting rather than instantaneous and short-term.

The reforms may foster an awareness of, and desire to protect the RLR, among individuals and governments. The impressive response of the Chinese people to the opening up of the country in 1978 demonstrates a compelling need to communicate with the world. The reforms have triggered a high demand to exit China, and have changed the way in which applications to exit are processed. Simplifying passport applications and processing may challenge some old thinking. It may begin to be thought that applying to exit China is exerting a right, rather than just performing a duty, and that the process itself is designed to protect that right, rather than simply to control exit and entry.

The reforms have revealed shortcomings in exit and entry administration and the underdevelopment of migration laws. Residents outside Guangdong, Shanghai and Beijing are aware that the administrative practices governing their applications are relatively more restrictive, and may question this. The exit and entry administration in the pilot program cities are perhaps faced with mounting paperwork in light of the rising number exit applications and number of people entering China. This has created a pressing demand to perfect relevant legislation and reduce the bureaucracy. Arguably, China must relax exit and entry restrictions further and give effect to essential reform measures, before it can achieve the goal of realising the RLR.

It must be accepted that the reforms only benefit a small number of Chinese people, because public officials, or those involved in public affairs, as discussed earlier in this thesis, are not subject to the reforms. Among the people covered by the reforms, only those who can or will travel abroad will be practically affected. Given China's vast population and the notion that lives on of a central empire, the rate of people who actually can or will keep in touch with people in other nations is very small. In the absence of the RLR and with low incomes of many Chinese people, these reforms are not relevant to many ordinary citizens. 


\subsection{Deficiencies in the reforms}

Although the reform strategy and measures have stimulated the remarkable increase of passport applications, four key deficiencies must be kept in mind. In the first place, as above, reforms are limited to private individuals not involved in public affairs. The reforms relate only to applications for ordinary passports for private affairs. Other passport categories, especially ordinary passports for public affairs, have been excluded. This means that about 653 million people are unable to take advantage of the reforms. The scope and adverse influence of reforms to applying to the application for ordinary passports for public affairs will be discussed in part 8.2 of this thesis.

Secondly, the reform strategy does not apply to the whole system of application for ordinary passports for private affairs, not all private affairs passports are included. People with special status, such as some government officials and managers of large and medium-sized State-owned enterprises and institutions, must still obtain permission from their work units when applying for passports. ${ }^{820}$ According to statistics from the Exit and Entry Administration of Hainan Public Security Department, $1 \%$ of the population, or 13 million people, fall into this category. ${ }^{821}$ Not only does that account for a large number of people, but the people affected make up China's elite. It is well known that the Chinese people residning in rural areas are usually poor and lower educated. According to Chinese Industry and Business Times, the income of the rural residents, which comprise $60 \%$ of the whole population, is $20 \%$ of the national income. So, the influences of residnets of rural areas are less than the influences of residents of urban areas. Limits on these individuals are more significant than on residents of rural areas.

Moreover, the laws and the reforms do not correspond the reform policies. Prior laws and regulations were not amended upon announcement of the reform measures. As such, there are

\footnotetext{
820 "Passport More Accessible for Beijingers, 1 September 2003", Http://www1.chinadaily.com.cn/en/doc/2003-09/01/content 260238.htm (19/12/2003).

821 "Extension: Residents in Four Districts of Hainan Province May Apply for Passport Simpler" (Fanwei Kuoda: Hainan Si Diqu Ke Jianhua Shenling Chuguo Huzhao Shouxu) 21 October 2003, Xinhuanet, http://news.21cn.com/domestic/guoshi/2003/10/21/1309848.shtml (15/11/2003).
} 
many vital contradictions between valid laws and statutes and the effective reform measures. For example, in pursuance of the reform strategy and measures, exit registration cards are no longer attached to passports. However, under Article 5 of the Detailed Rules of the Implementation of the Law on the Control of Exit and Entry of Citizens (Amendment) 1994 (PRC), the entry and exit administration of the public security organ shall attach a registration card. The 1994 rules were approved by the State Council and jointly promulgated by the MPS, MOE and Ministry of Communication. Within the Chinese legal system, the 1994 rules prevail over the $2001 / 2002$ policies. The later policy is invalid in theory, but is executed in practice.

Only retrospective amendment of the 1994 rules could overcome the problem. The MPS has stressed that the legal system of exit and entry administration needs to be improved. ${ }^{822}$ In November 2001, Jia Chunwang acknowledged this problem and announced that the MPS would speed up the legal process of entry-exit management to ensure that it is fair, open, and conforms to relevant laws and regulations. ${ }^{823}$ However, the relevant amendments were not adopted for another three years. The inconsistency between laws and reform policy will undermine the authority of the law, and undermine public confidence that the administration will act in accordance with the law. The inconsistency also violates Article 5 Clause 2 of the Constitution of the PRC (Amendment) 2004, which require the State to uphold the uniformity and dignity of the socialist legal system.

Finally, these reform arrangements have affected the relationship between the central authority and local authorities, undermining central authority. The Central government is vested with the power to control the exit and entry by the Constitution. Article 89 Clause 1(9) of the Constitution of the PRC (Amendment) 2004 provides that the State Council exercises the functions and powers to conduct foreign affairs. Exit and entry administration is one of foreign

\footnotetext{
822 Zhu, Daqiang, "Summarisation: China Ensure the Direction of Exit and Entry Administration after Access to the WTO, 23 November 2001”, China News Agency, http://review.jcrb.com.cn/ournews/asp/readNews.asp?id=63921 (18/04/2003).

${ }^{823}$ Quoted in Wang, Ling, "China Simplifies Entry-exit Rules, November 2001”, China Radio International, http://english.cri.com.cn/english/2001/Nov/36826.htm (18/04/2003).
} 
affairs. ${ }^{824}$ Even so, provincial governments often promulgate local regulations and reform measures which actually amend national laws and regulations. As Lin Yicong, an officer of Guangdong Public Security Bureau argued in 2001:

The infringement by provincial governments upon the central government powers became a way of meeting regional or individual interests. It invades the applicants' rights and interests as well as violates the central government's power. ${ }^{825}$

With the development of Guangdong, Shanghai and Beijing local legislation and implementation of local reform measures, central government power is further eroded.

\subsection{The nature of the reforms}

It is vital that the nature of current reforms be seen more clearly so that we can better understand the future evolution of the RLR in China. The official media has accepted that the reform strategy aims to simplify exit and entry procedures. More precisely, it is the simplification of procedures governing the exit of citizens, and the permanent residence of aliens. According to The People's Daily, the newspaper of the Central Committee of the CPC, the reforms will "greatly simplify procedures and are viewed as an important step for the Chinese people to further join the international community". ${ }^{826}$ The China Daily reported that the core of the new reform drive is the simplification of entry and exit procedures for people seeking to invest or travel in the country. ${ }^{827}$ In May 2003, the Ministry's Bureau of Exit and Entry Administration (BEEA), with respect to the reforms for travelling to the HKSAR or MSAR, stated that:

\footnotetext{
${ }^{824}$ The website of the Chinese police states that foreign affairs policemen are responsible for supervising the exit, settlement, residence, tour and entry of Chinese citizens and aliens. See "The People's Republic of China Department of Public Safety Police Specific Set-up”, http://www.chinesecop.com/CNPO1.html (19/12/2003).

${ }^{825}$ Lin, Yicong, "The Review on the Amendment Principle of Amending Current Exit and Entry Laws", in Committee of Exit and Entry Administration, Chinese Association of Police (ed), the Collection of Papers on the Control of Exit and Entry (III) Interior Published within Public Security Organs (Gongan Jiguan Neibu Faxing), the Publishing House of Qunzhong, Beijing China, 2001, pages 20-21.

826 “Simplifying Exit-Entry Procedures, A Vital Step for China”, The People's Daily 23-11-2001

http://english.peopledaily.com.cn/200111/23/eng20011123 85161.shtml ((18/04/2003).

827 "State to Simplify Entry-exit Rules", 11/22/2002, The China Daily,

http://www1.chinadaily.com.cn/news/2001-11-22/44711.html (18-04-2003).
} 
The reason for the change in procedure is to meet the needs resulting from the increasing demand for economic, cultural and personnel exchanges between the Mainland and the HKSAR and MSAR. ${ }^{828}$

In addition to the simplification of procedures, some scholars have asserted that the reform strategy could play a catalytic role on the realisation of the RLR. Meng Yanhong, a leading Chinese historian, contended that the simplification of exit and entry rules was an irreversible trend. He argued that if China's entry into the WTO was considered as a milestone, for its reform and opening up, such measures could be viewed as "natural outcomes" of the drive. ${ }^{829}$ A Shanghai analyst has said, "the change in issuing passports was dramatic. I have a strong feeling that Chinese people are enjoying more freedom and China is becoming more open to the outside world. ${ }^{\circledR 30}$ Professor Xu Xianming, the President of China University of Politics and Law, has argued, "Freely leaving and returning on demand is a vital symbol of the realisation of more citizens' freedom." ${ }^{\$ 31}$

It is accepted that simplifying exit and entry procedure helps to protect the RLR. However the simplification should merely be the means by which reform is achieved, not the nature of reform it. The current approach - which regards administrative simplification as the nature of reform - attends to trifles and neglects the essential needs of citizens. With the deepening of the reform measures, the awareness of the passport as a symbol of prestige may dilute, and the awareness of the RLR will increase. More limitations will be seen in the reforms orientated towards simplifying exit and entry procedure.

\subsection{Conclusions}

\footnotetext{
${ }^{828}$ Quoted in Jiang, Zhuqing, "Mainland SAR Visa Procedures Simplified", 30 May 2002, The China Daily, http://www3.chinadaily.com.cn/en/doc/2002/05/30/content_121719.htm (05/08/2003).

${ }^{829}$ Quoted in "Simplified Exit-entry Rules Seen as Vital to China", 23/11/2001, The China Daily, http://www1.chinadaily.com.cn/en/doc/2001-11/23/content 94971.htm (19/12/2003).

${ }^{830}$ Quoted in "Shanghai Simplifies Passport Application Procedure", 3 September 2002, The China Daily, http;//www1.chinadaly.com.cn/English/2002/Aug/69192.htm (19/12/2002).

831 "Exiting Abroad is Becoming the Individual Needs of Chinese Citizens", 28 December 2003, Xunahuanet, http://news.sdinfo.net/72350064130916352/20031228/1233069.shtml (30/12/2003).
} 
A more liberalised the RLR meets the need to enhance economic progress and integration into the world. China's accession to the WTO sparked the biggest overhaul of Chinese migration law in history. The reforms are characterised by the simplification of the procedures for exit and entry, with a focus on passports on demand. They have not brought the country's administrative procedures for exit and entry into line with international standards. The reforms are superficial, and it is not surprising to find serious deficiencies in them. The scope of reform is too limited to cover the right to return and the right to leave for public affairs, the right to leave of citizens employed by governments, State-owned enterprises and institutions and members of the CPC for private affairs and the RLR of aliens. As such, the nature and content of the reforms benefit only some of the population. The issues of the infringement by provincial governments upon central government powers regarding exit and entry administration remain untouched. Even the integration between prior laws and new policies has been technically ignored.

The deficiencies do not completely undermine the significance of the reforms. The reforms will exert subtle and lasting positive impacts on the social and economic development of China and the country's integration into the world. Encouragingly, the reforms foster the awareness of the RLR among individuals and governments. Given the fact that Chinese international migration stock rate is only $0.46 \%$ of average international migration stock in the world, ${ }^{832}$ it is understandable that the number of entries and exits increased considerably due to the relaxation of severe restrictions.

832 Calculated according to data quoted in Population Division, Department of Economic and Social Affairs, International Migration Report 2002, United Nations Secretariat, 2002, ST/ESA/SER.A/220, the United Nations, New York, 2002, 62 pages, attached table. 


\section{Chapter Eight \\ The Right to be Granted a Passport in China}

\section{Introduction}

As discussed in part 3.2, State acceptance of the RLR internationally means nationals are entitled to travel documents, such as a passport or other certificates needed to leave and return. Any formalities related to the issuing of passports, as well as powers to deny, withdraw or cancel a passport should be appropriate, provided by law and publicly accessible. This chapter examines (i) the categories of passports, the scope of passports, passport issuing authorities and passport legislation; (ii) ordinary passports for public affairs; and (iii) ordinary passports for private affairs.

\subsection{General considerations of the passport}

\subsubsection{Categories of the passport}

The Chinese system of passport categories is more complex than anywhere else in the world with the exceptions of North Korea and Vietnam. ${ }^{833}$ According to Article 1 Clause 2 of the Regulations on Passport and Visa 1980 (PRC):

Passports of the People's Republic of China are classified into diplomatic passports, service passports and ordinary passports. Ordinary passports are further composed of ordinary passports for public affairs and ordinary passports for private affairs.

After China reoccupied the HKSAR in 1997 and the MSAR in 1999, the HKSAR and MSAR passports become part of the Chinese system. In addition to passports, there are travel permits, seafarer's passports, the HKSAR document of identity, the HKSAR seaman's identity book, and the travel permits of the HKSAR and MSAR. ${ }^{834}$ While more complex, the scope of diplomatic

\footnotetext{
${ }^{833}$ Wan, Zhenshan (ed), the General Updated Guide of the Exit and Entry of Individuals (Zuixin Renyuan Churu Jing Quanshu), the Publishing House of Renshi, Beijing, 2002, page 94.

${ }^{834}$ For the one thing, the applicant with passport for public affairs lodge the visa application through one's employer, usually the foreign affairs department in the working unit. The applicant with passport for private affairs do it by the emigration agent or by oneself. The prior is prodiminate. However, it is very few situation that the applicant with
} 
passports, service passports and ordinary passports for public affairs (public affairs passports), while having been expanded in recent times, remains narrower than in other countries, opposed to the shrinking scope of the ordinary passport for private affairs (private passport).

In theory, the Chinese passport is a certificate to prove Chinese nationality for the purpose of travelling or residing in foreign countries. ${ }^{835}$ In practice, it is revered as a symbol of social status, and a product of the influence of China's old feudal history. Diplomatic passports, service passports and public affairs passport are regarded as the passports of officials, whereas the private passport is regarded as the passport of common people. Applicants generally prefer to apply for the former rather than the latter. The preference for an official passport may hinder reforms of the passport system.

\subsection{2 the Scope of various kinds of passports}

The scope of three official passports has been expanded under the Communist political system and socialist public ownership of the economy. The scope of the diplomatic passport in China is broader than in other countries. ${ }^{836}$ In order to avoid the abuse of diplomatic passports, Paragraph 2 of the Circular of State Council on the Amendment of Article 6 of Regulations on Passport and Visa 1984 (PRC) stresses "there is no relationship between the diplomatic passport and the holder's official level and [they are] irrelevant to interior political treatment."

passport for public affairs lodge the visa application by emigration agent as they understand that their application would be easily approved, the agent's assistance is unnecessary. For the other thing, the visas office of foreign country have the different channe to accept the application. For example, in Australian Embassy, Beijing, every working morning, the counter usually do not accept the application from passports for private affairs holders unless all application from passports for public affairs holders has been accepted.

835 Article 1 Clause 1 of the Regulations on Passport and Visa 1980 (PRC), the "passport of the People's Republic of China is issued to Chinese citizens as the certificate to prove their identity abroad for the purpose of entering or exiting Chinese border."

836 The Diplomatic Passport is principally issued to senior officials who currently hold the position of vice-minister or over of the governments, senior officials who currently hold the position corresponding to vice-minister or over of the Communist Party and its attached organs and institutions, and the People's Liberation Army, principle leaders who currently hold the position corresponding to vice-minister or over of the National People's Congress, the Chinese People's Political Consultative Conference, and all democratic parties, people's organs, diplomats, consular officers and their accompanying spouses, underage children, diplomatic couriers, and etc. See the Amendment of Article 6 of Regulations on Passport and Visa 1984 (PRC). 
In the case of service passport, according to Article 7 Clause 1 and 2 of the Regulations on Passport and Visa 1980 (PRC),

A service passport is issued to individuals who are permanently working overseas in Chinese foreign departments, and their accompanying spouses and underage children, and individuals temporarily Exiting China excluding diplomatic passport holders.

However, according to the MFA in 2003, the scope of service passports is yet broader. The MFA has stated that:

[a] service passport is principally issued to officials with the rank of Division Chief and above of governmental offices, staff members of diplomatic and consular missions in foreign countries, the United Nations' Organizations and its specialised agencies, and their accompanying spouses and underage children. ${ }^{837}$

The scope of public affairs passports has also been expanded. According to Article 8(1) of the Regulations on Passport and Visa 1980 (PRC), an "ordinary passport for public affairs is issued to postgraduates, individuals attending in an advanced study, overseas students, labours and seamen employed foreign companies". In 2003, the MFA explained it in a broad sense, that; "ordinary passports for public affairs are principally issued to staff in the governmental departments at all levels, and to employees of State-owned enterprises or institutions." ${ }^{" 838}$

Although the Regulations on Passport and Visa 1980 (PRC) ${ }^{839}$ and the MFA expressively provide the scope of private passports, ${ }^{840}$ the narrowing of its scope is the corollary of the

\footnotetext{
837 The MFA, "Chinese Passport and Other Travel Documents", http://www.fmprc.gov.cn/eng/28947.html $(20 / 05 / 2003)$.

${ }^{838}$ The MFA, "Chinese Passport and Other Travel Documents", http://www.fmprc.gov.cn/eng/28947.html (20/05/2003).

${ }^{839}$ Under Article 8(2) of the Regulations on Passports and Visas 1980 (PRC) an ordinary passport for private affairs is issued to Chinese citizens exiting China for private affairs, citizens residing overseas, and other citizens for whom the passport authorities regard the granting of a private passport appropriate.

${ }^{840}$ According to the MFA, a private passport is issued to people who are travelling for personal affairs, emigrating, visiting friends or relatives, inheriting property, studying, working or sightseeing. The MFA, "Chinese Passport and Other Travel Documents", http://www.fmprc.gov.cn/eng/28947.html (20/05/2003)
} 
expansion of the scope of three official passports. The shrinking scope of private passports implies that more applications will be restricted, and the RLR will in turn be limited.

\subsubsection{Passport issuing authorities}

The authority to issue passport in China is exercised by a variety of governmental authorities, including the MFA, MPS and Chinese diplomatic missions in foreign countries. Under Article 3 Clause 2 of the Regulations on Passport and Visa 1980 (PRC) and Article 12 of the Law on the Control of Exit and Entry of Citizens 1985 (PRC), the MFA and 55 foreign affairs offices of local governments (authorised by the MFA) are responsible for issuing, renewal, page adding and endorsement of passports. The Bureau of Harbor Superintendence and its delegates are authorised to issue seafarers passports. Diplomatic missions can issue passports and travel documents to Chinese people who are abroad.

The central Chinese government has authorised the HKSAR and MSAR governments to issue passports in accordance with Chinese law. ${ }^{841}$ Specifically, this refers to the Immigration Departments of the HKSAR and MSAR. These departments are also authorised to issue alternative travel documents in lieu of a passport, or to cancel or withdraw the passport and alternative travel documents.

As one effect of this, the diversity of passport issuing authorities undermines the unity of passport administration. Different authorities apply different criteria and processing formalities and advance different departmental interests. The separation of issuing authorities increases administrative costs associated with passports. As another effect, the separation provides applicants with an opportunity to exploit the loophole of being able to apply for a passport many times. If an individual is not successful in applying for a public affairs passport from one authority, he or she may be successful in exiting China by applying for a private passport from another authority, and vice versa. This loophole can only be closed by the use of advanced information technology and the introduction of a more advanced administrative system.

${ }^{841}$ Article 154 Clause 1 of Basic Law of the Hong Kong Special Administration Region of the PRC 1990 (PRC) and Article 139 Clause 1 of Basic Law of the Macao Special Administration Region of the PRC 1993 (PRC). 


\subsubsection{Passport laws}

Passport law is inconsistent and outdated. The Regulations on Passport and Visa 1980 (PRC) is currently the most important law regarding passports. ${ }^{842}$ It was promulgated by the State Council in 1980, and most recently amended in 1984 by the Amendment of Article 6 of Regulations on Passport and Visa 1984 (PRC). The great development in China over last 25 years has considerably changed the legislative background of the 1980 laws. It is imperative to enact new laws.

The current laws governing passports are also inconsistent. A large number of regulations, rules, measures and circulars have been promulgated to give detailed effect to laws. Most of the legislative and regulatory provisions are simultaneously effective. As an example of inconsistency between laws, both Supplementary Opinions of State Education Commission, the Ministry of Foreign Affairs and Ministry of Public Security on Issuing Ordinary Passport for Private Affairs for Citizens Studying Abroad Sent by the State 1993 (PRC) and the Circular of State Education Commission, the Ministry of Public Security and Ministry of Foreign Affairs on Holding Ordinary Passport for Private Affairs of Citizens Studying Abroad 1993 (PRC), provide that citizens studying abroad use private passports; even those sent by the State under some circumstances. On the other hand, Article 8(1) of the Regulations on Passport and Visa 1980 (PRC) stipulates that overseas students shall apply for and hold ordinary passport for private affairs.

In theory, the Regulations on Passport and Visa 1980 (PRC) should prevail over later inconsistent subordinate legislation, policies and rules like the above the Supplementary Opinions and the Circular. In practice, this is not the case. Departments usually process passports in accordance with their own policies and rules. This results in chaotic legislation and policy making, which in turn undermines the integrity of the national passport laws.

\section{2 Ordinary passport for public affairs}

${ }^{842}$ The Regulations on Passport and Visa 1980 (PRC) relates to the issuing of passports and visas, the term of validity of these instruments, the management of passports and visas, administrative fees, and penalties. 
Serious issues pertaining to ordinary passport for public affairs, of which Chinese scholars are aware, adversely affect the RLR in China. Wang Zhenshan has contended from a macro-level that:

The issues existing in relation to [...] public affairs [passports] consist of two aspects. One is the system issue, for example, the integration of government functions and enterprises management, multi-level examination and overly-elaborate formalities that contribute to lower efficiency and miss business opportunities; the other is the management issue, mainly the absence of a [...] jurisdictional criteria between public security departments and foreign affairs departments that results in the phenomenon of "one person, two passports." ${ }^{.843}$

In what follows we consider: (i) the scope of public affairs passport; (ii) the application procedure and examination criteria; (iii) the management of public affairs passport; and (iv) the causes of the issues associated with (i), (ii) and (iii).

\subsubsection{The scope of the public affairs passport}

The public affairs passport category is so wide that it encompasses a significant number of people who would otherwise apply for a private passport. In addition to applicants mentioned in part 8.1.2 of this thesis, the following individuals are required to participate in the complicated procedures to apply for this type of passport:

1. Fulltime students who are participating in a group exit of China which has been organised by a government department; ${ }^{844}$

2. Individuals undertaking advanced studies, overseas students, labours and seamen employed in foreign companies, officials in Party Committees and governments, officers and soldiers in armed forces, employees in people's Organizations, State-owned enterprises and institutions, $[\ldots]$ for all affairs related to work units. ${ }^{845}$

\footnotetext{
${ }^{843}$ Wan, Zhenshan (ed), the General Updated Guide of the Exit and Entry of Individuals (Zuixin Renyuan Churu Jing Quanshu), the Publishing House of Renshi, Beijing, 2002, page 94.

${ }^{844}$ Article 5 of the Circular of Ministries of Education, Public Security and Foreign Affairs on Some Affairs Regarding Fulltime Students Exit Abroad Short-term with Ordinary Passport for Private Affairs 2002 (PRC) (Jiaoyubu, Gonganbu, Waijiaobu Guanyu Zaixiao Xuesheng Duanqi Chuguo Chiyong Yinsi Huzhao Youguan Shixiang De Tongzhi), promulgated by the MOE, MPS and MFA on 25 January 2002

${ }^{845}$ Article 3 Clause 1 of the Circular of the General office of the Central Committee of Chinese Communist Party and the General office of the State Council on Refraining of Excessively Sending Group, Team and Individuals Exit China, 1986 (PRC) and the Preface of Some Rules of the General office of the Central Committee of Chinese
} 
3. All students studying religion (who must also be State-funded); ${ }^{846}$

4. Individuals participating in sports, education and cultural exchange, and seamen, crews of trains and planes, staff of the international postal union, individuals exiting China temporarily for enterprise's affairs, individuals exiting China under project contracts. ${ }^{847}$

5. Employees in experimental enterprise groups as which have been approved by the State Council who are travelling for economic purposes or to attend a trade fair; ${ }^{848}$

6. Government sponsored sports coaches, athletes, sports researchers, sports medical professionals and academic staff in sports education institutions exiting China, ${ }^{849}$ and assistant coaches; ${ }^{850}$

7. Individuals temporarily exiting China who are employed by State-owned enterprises. ${ }^{851}$

8. Professionals, technical staff and managers of domestic enterprises, government sponsored institutions, the CPC and government departments, who are travelling for the purpose of

Communist Party and the General office of the State Council on Serious Restriction Cadres in the Departments of Party Committees and Governments Exit China, 1987 (PRC).

${ }^{846}$ Article 3 of the Circular of State Education Commission, State Council Bureau for Religions Affairs, the MPS and MFA on Dealing with Some Issues of Recruiting Students Studying Abroad in China without Allowance by Certain Organizations in China and Individuals of Foreign Countries and International Organizations 1990 (PRC) (Guojia Jiaowei Guowuyuan Zongjiaoju Gonganbu Waijiaobu Guanyu Chuli Mouxie Guojia He Guoji Zuzhi De Zhuhua Jigou Ji Geren Shanzi Zaihua Zaoshou Liuxuesheng Wenti De Tonhzhi), promulgated by State Education Commission, State Council Bureau for Religions Affairs, the MPS and MFA on 26 December 1990

847 Department of Politics under the MPS, Frontier Defence and Exit and Entry Administration, the Series of Basic Textbook of People's Police Operation (Bianfang Yu Churu Jing Guanli, Renmin Jingcha Gongan Yewu Jichu Jiaocai), examined by Committee of Textbook Editing and Examination of the MPS, the Publishing House of Qunzhong, Internal Publication in Public Security Organs (Gongan Jiguan Neibu Faxing), Beijing, 1999, page 324.

848 Article 1 and 2 of the Measures for the Implementation on Examination and Approval of Exit Abroad (Including Hong Kong and Macao) and Invitation Aliens to China of Employees of National Experimental Enterprises Group (for Trial Implementation) 1992 (PRC) (Guangyu Guojia Shidian Qiye Jituan Renyuan Chuguo (Han Gangao) He Yaoqing Laihua Shixiang Shenpi De Shishi Banfa (Shixing)), Promulgated by State Council Foreign Affairs office, State Planning Committee, State Commission for Restructuring the Economic System, State Council Production office on 31 March 1992.

849 Article 2 of the Provisional Measures on Administration of Government Sponsored Sports Technicians Exiting Abroad 1992 (PRC) (Guanyu Gongpai Chuguo (Jing) Tiyu Jishu Renyuan De Guanli Zaixing Banfa), promulgated by State Sport Commission on 12 March 1990.

${ }^{850}$ Article 4 of Provisional Rules on Some Issues of Government Sponsored Coaches Aid for Foreign Countries 1990 (PRC) (Guanyu Gongpai Yuanwai Jiaolian Renyuan Ruogan Wenti De Zaixing Guiding), promulgated by State Sport Commission on 16 November 1990.

851 Article 1 and 2 of the Measures for the Implementation on Examination and Approval of Sending Employees to Temporally Exiting Abroad (Including Hong Kong and Macao) and Inviting Aliens to China by Industry Enterprises of the Ownership by the Whole People (for Trial Implementation) 1993 (PRC) (Quanmin Suoyouzhi Gongye Qiye Panqian Linshi Chuguo (Jing) Renyuan He Yaoqing Waiguo Jingmao Renyuan Laihua Shenpi De Shishi Banfa (Shixing)), Promulgated by State Council Foreign Affairs office, the SHMO, State Commission of Economy and Trade and State Commission for Restructuring the Economic System on 29 June 1993. 
further training; ${ }^{852}$

9. Individuals who are travelling for the purpose of undertaking training in accordance with a technology or enterprise contract, to perform a project, to give effect to a bilateral or multi-lateral economic treaty, to participate in a government-sponsored project which is to be performed in co-operation with a foreign party, or for the purpose of providing foreign aid; ${ }^{853}$

10. Individuals exiting China who have been selected by social mass Organisations; ${ }^{854}$

11. Contract workers who are sent abroad to execute agreements and arrangements concluded by the government with foreign countries; ${ }^{855}$

12. Contract workers selected by their work unit, which had entered into an agreement with a foreign party; ${ }^{856}$

13. Chinese citizens employed in foreign investment enterprises as the representatives of the foreign interest. ${ }^{857}$

This list details the extent to which elite members of Chinese society fall within the category of the public affairs passport. It means that, practically, most people who apply for passports must seek a public affairs passport. According to data from the State Bureau of Statistics (SBS), at the end of 2001, employees and staff in $72.41 \%$ of 'legal persons' (meaning organisations

852 Article 2 of the Provisional Detailed Rules of the Implementation of the Stipulations on Sending Term, Group and Individuals to be Trained Abroad 1990 (PRC) (Guanyu Paiqian Tuanzu He Renyuan Fu Guowai Peixun De Guanding De Zaixing Shishi Xize), promulgated by State Council Introduction of Foreign Intellectuality Leading Panel office on 15 April 1990.

853 Article 3 of the Provisional Detailed Rules of the Implementation of the Stipulations on Sending Term, Group and Individuals to be Trained Abroad 1990 (PRC) (Guanyu Paiqian Tuanzu He Renyuan Fu Guowai Peixun De Guanding De Zaixing Shishi Xize), promulgated by State Council Introduction of Foreign Intellectuality Leading Panel office on 15 April 1990.

854 Article 2 of the Provisional Rules on Qualifications Recognition of Government Sponsored Institutions and Mass Organisations of Sending Group, Team and Individuals Abroad for Training 1993 (PRC) (Guanyu Shiye Danwei Shehui Tuanti Zuzhi Paiqian Tuanzu He Renyuan Fu Guo (Jing) wai Peixun Gongzuo Zige Rending De Zaixing Guiding), promulgated by State Bureau for Foreign Experts on 9 June 1993.

855 Article 8 Clause 1 Sub-clause 1 of the Provisional Measures for the Procedures of Exiting Abroad Examination and Approval and Handling with Passport of Labours Sending Abroad 1990 (PRC) (Guanyu Waipai Laowu Renyuan Chuguo Shenpi Shouxu He Banli Huzhao De Zaixing Banfa), Promulgated by Ministry of Foreign Economic Relations and Trade, Ministry of Labour, MFA and MPS on 14 December 1990.

${ }^{856}$ Article 8 Clause 1 Sub-clause 2 of the Provisional Measures for the Procedures of Exiting Abroad Examination and Approval and Handling with Passport of Labours Sending Abroad 1990 (PRC) (Guanyu Waipai Laowu Renyuan Chuguo Shenpi Shouxu He Banli Huzhao De Zaixing Banfa), Promulgated by Ministry of Foreign Economic Relations and Trade, Ministry of Labour, MFA and MPS on 14 December 1990.

857 Article 4 of the Reply of the Department of Consular under the MFA to Some Questions on Passport Affairs (Excepts) 1993 (PRC). 
participating in civil activities on a legal basis) need to apply for a public affairs passport. ${ }^{858}$ Of employed people $89.5 \%$ or 653.57 million are required to obtain a public affairs passport when applying to leave China in relation to travel associated with their work unit. ${ }^{859}$ As reported by The China Daily in 1996, 77.54\% of individuals exiting China held a public affairs passport. ${ }^{860}$ The percentage of people travelling on public affairs passports has gradually dropped to $39.4 \%$ of travellers in 2002. ${ }^{861}$ Overall passport problems cannot be redressed, without resolving issues associated with the public affairs passport.

\subsubsection{Application procedures and examination criteria}

For most Chinese travelling on a public affairs passport, the prospect of complicated procedures and endless red tape, coupled with uncertain examination criteria, are an ordeal. ${ }^{862}$ Article 2 of the Circular of Organisation Department of the Central Committee of Chinese Communist Party on Strengthening Examination and Management on Individuals Exit China for Public Affairs (Extract) 1989 (PRC) requires the various exit and entry examination authorities to

${ }^{858}$ At the end of 2001, there were 5.1 million legal person units in China. 59.2\% of these were enterprise legal person units, non-enterprises legal person unit account for $40.8 \%$. Among enterprise legal person units, State-owned and collective-owned enterprise legal person units account for $53.4 \%$. 40.8\% $+59.2 \%$ x $53.4 \%=72.41 \%$. See State Bureau of the Statistics, "Gazette of Major Data of the Second Survey on National Basic Unit of Gazette of the Second Survey on National Basic Unit" (Dierci Quanguo Jiben Danwei Pucha Gongbao: Dierci Quanguo Jiben Danwei Pucha Zhuyao Shuju Gongbao) 17 January 2003, http://www.stats.gov.cn/tjgb/tbdwpcgb/qgjbdpcgb/1200301170195.htm (30/12/2003).

${ }^{859}$ Calculated according to the date in State Bureau of the Statistics, $77.4 \%$ were employed by the governments, government-sponsored institutions, mass organizations, urban residents' committees, and village residents' committees. 11.1\% were employed in State-owned enterprises and collective-owned enterprises, "Gazette of Major Data of the Second Survey on National Basic Unit of Gazette of the Second Survey on National Basic Unit" (Dierci Quanguo Jiben Danwei Pucha Gongbao: Dierci Quanguo Jiben Danwei Pucha Zhuyao Shuju Gongbao) 17 January 2003, http://www.stats.gov.cn/tjgb/tbdwpcgb/qgjbdpcgb/1200301170195.htm (30/12/2003); and the data from "Statistic Figures", http://www.china.org.cn/english/shuzi-en/en-shuzi/index.htm (09/05/2003), the number of employed people in China at the end of 2001 totalled 730.25 million.

86024 January 1997 The China Daily (Overseas version), Quoted in Huang, Ruilong, Bao, Sidun, Liu, Ling, Overseas New Migrants over Last One Decade (Jin Shinian Woguo Dalu Haiwai Xin Yimin), No.1 [1998] the Journal of Population \& Economics (Renkou Yu Jingji).

${ }^{861}$ State Bureau of the Statistics, the Statistics Gazette of the People's Republic of China on 2002 National Economy and Social Development (Zhonghua Renmin Gongheguo 2002 Guomin Jingji he Shehui Tongji Gongbao), 28 February 2003, http://www.stats.gov.cn/tjgb/ndtjgb/qgndtjgb/1200302280214.htm (30/12/2003).

${ }^{862}$ The ordeal imposed by the visa officers of some countries is a obstacle to enter into foreign countries. The further research is beyond the research scope of this thesis, and will be done in my future study. 
seriously examine and strictly control applications for public affairs passports. For example, a fulltime student who is participating in a group exit, which was organised by a government department, must sit a national exam and satisfy various approval provisions set by the Department of International Cooperation and Exchange under the MOE and the Department of Consular Affairs under the MFA, prior to being granted permission to leave. ${ }^{863}$ While these restrictions may prevent the expenditure of public funds on overseas travel, and serve to consolidate the communist regime, it is doubtful that such complicated procedures help protect the RLR.

Ambiguous examination criteria create enormous scope for the examination authorities to exercise discretion. Vague criteria such as political reliability, loyalty, devotion to China, "health in idea", "decency in life style", and "abidance of the rules" are applied. ${ }^{864}$ They are non-legal terms or political propaganda terms (Zhengzhi Shuyu) in Chinese language. The examination and approval of public affairs passports is regarded as a task with high political sensitivity and the function of building and strengthening an honest and clean government. ${ }^{865}$ Citizens who have not shown any sign of an improper political attitude will often find it easier to gain permission to exit. The time needed to obtain approval mainly depends on the contacts one has within the examination authorities, and bribery is not unknown because of the lack of precise processing period.

\subsubsection{Management of public affairs passports}

Since 1980, there has been unified management of public affairs passports. This management

\footnotetext{
863 Article 5 of the Circular of Ministries of Education, Public Security and Foreign Affairs on Some Affairs Regarding Fullime Students Exit Abroad Short-term with Ordinary Passport for Private Affairs 2002 (PRC) (Jiaoyubu, Gonganbu, Waijiaobu Guanyu Zaixiao Xuesheng Duanqi Chuguo Chiyong Yinsi Huzhao Youguan Shixiang De Tongzhi), promulgated by the MOE, MPS and MFA on 25 January 2002.

${ }^{864}$ Article 2 of the Circular of Organization Department of the Central Committee of Chinese Communist Party on Strengthening Examination and Management on Individuals Exit China for Public Affairs (Extract) 1989 (PRC). 865 Article 10 of Related rules on Strengthening Examination and Approval of Exit China for Public Affairs (Extract) (PRC) 1993 (Guanyu Jiaqian Yingong Lingshi Chuguo (Jing) Shenpi He Guanli Gongzuo De Youguan Guiding (Zhaibian)), promulgated by the General office of the Central Committee of the CPC and the General office of the State Council.
} 
system was reinforced during the 1990s. Unified management means that relevant departments keep public affairs passports. The departments authorised to retain public affairs passports are prescribed by Articles 2 and 3 of the Provisional Regulations on the Administration of ordinary passport for Public Affairs 1993 (PRC). They include the foreign affairs departments of various ministries, enterprises and institutions under the direction of the State Council, national mass organisations, and provincial governments. These entities can delegate the power to retain passports to subordinate authorities. In addition, the work unit of the holder of a public affairs passport can also retain the passport. ${ }^{866}$ In the case of re-use, individuals must present an Introduction certificate issued by qualified employers unit to apply for permission. ${ }^{867}$

Individuals who breach the provisions for the management of public affairs passports receive serious punishment. Passports must be surrendered within a month of returning to China. ${ }^{868}$ Failure to do so without reasonable excuse will result in a one- to three-year ban on being reissued with another. More seriously, the punishment may extend to the violators' leaders and colleagues; and the person who is responsible for collection of passports within work units will be punished if that person fails to collect a passport in a timely manner. ${ }^{869}$ The practice of joint liability is viewed as outdated and widely criticised. ${ }^{870}$ The denial of a colleagues' right to be granted a passport is an unsuitable penalty for the offence of failing to return a passport.

\subsubsection{Causes of the issues related to public affairs passports}

\footnotetext{
${ }^{866}$ Article 15 Clause 1 of the Regulations on Passport and Visa 1980 (PRC).

${ }^{867}$ Reuse of passport is prescribed in Article 6 Clause 4 of the Circular of the Application for Passport and Visa for Individuals Temporally Exiting China in the Cause of their Duties 1983 (PRC).

${ }^{868}$ Article 10 of the Provisional Regulations on the Administration of ordinary passport for Public Affairs 1993 (PRC).

${ }^{869}$ Article 2 of the Circular of the General office of the State Council on Transmission of the MFA and MPS on Some Issues of Timely Collection and Uniquely Keeping Passport of Individuals Exiting China in the Course of Their Duties and Strengthening Issuance Formality of the Certificate of Exiting China, 1990 (PRC); the extension of the punishment of denying the colleagues of an individual who refused to return their passport is also prescribed by Article 10 of the Provisional Regulations on the Administration of Ordinary Passport for Public Affairs 1993 (PRC) and the Rules of State Council Administration for Affairs of State Organs on the Control of Passport 1990 (PRC). ${ }^{870}$ This practice of joint liability can be traced to the Xia Dynasty (2070 B.C to 1600 B.C.), which is the first dynasty in China. See Yu, Shutong and Wen, Jia (Chief editors), A New Chinese-English Law Dictionary (Xin Hanying Faxue Cidian), Publishing House of Law, Beijing, 1998, page 513.
} 
The existence of the public affairs passport can be seen as a consequence of the socialist system and public ownership of the economy. Based on this, all parties, mass organisations including trade unions, women's associations, academic associations, State-owned enterprises and institutions as well as various level governments, congresses, Courts and Procuratorates were under the leadership of the CPC. Their activities formed part of the State's activities. Their staffs were government officials or quasi-government officials; and travel in the course of their duties was carried out as much for their work unit as for the State. As such, they required a public affairs passport. However, according to international norms, public servants exit their national State in a private rather than public capacity, unless they are acting on behalf of the State in an official capacity, such as in foreign affairs or international relations. The function the person is to perform while overseas, rather than the character of the person's employment, determines the category of the passport.

Until now, there has been no reform strategy to repeal the system in the near future. Maintaining the institution of public affairs passports will doubtlessly pose a great challenge to the RLR in China. In May 2003, Luo Tianguang, the Director of the Department of Consular Affairs under the MFA, argued the reason to maintain the institution of public affairs passport:

It is impossible to repeal the ordinary passport for public affairs in the present [because] the reform thinking of ordinary passport for public affairs is based on the careful consideration of China's actual situation and positive role of current ordinary passports for public affairs. The ordinary passport for public affairs could not be repealed unless it is very convenient for Chinese people exiting China to apply for visas within any [other passport] category. ${ }^{871}$

Yet the existence of public affairs passports does not equate with the ability to easily obtain a visa. The granting of a visa depends on a variety of conditions, of which the category of the relevant passport is only one, and it is not a decisive factor. The argument is unconvincing. Visas are also granted to holders of ordinary private passports. In 1984, the State Council recognised that foreign countries grant visas to Chinese nationals travelling on public affairs passports in light of their foreign policy towards China and the character of the functions of the

${ }^{871}$ Quoted in Zhang, Jin "It is Impossible to Repeal Ordinary Passport for Public Affairs in the Present” (Yingong Putong Huzhao Zaibu Quxiao)”, Beijing Times, 29 May 2003. 
applicant. $^{872}$ The balance between the positive and negative effects of the public affairs passport needs to be more carefully weighed.

\subsection{Ordinary passport for private affairs}

Compared with public affairs passports, private passports are more popular in China. As of October 2002, more than 10,000 passports were issued daily by the MPS. ${ }^{873}$ According to the Hainan Exit and Entry Administration in October 2003, the average national rate of private passport holders had increased to five in one thousand. ${ }^{874}$ Nevertheless, the processing and management of private passports lags behind international standards. This section will discuss (i) the prohibition of non-registered resident area applications for private passports; (ii) application formalities for residents of small cities and rural areas; (iii) the retention of private passports by designated government departments; and (iv) the legality and effects of provisions regarding the revocation or invalidation of private passports.

\subsubsection{Prohibition of the application lodged in non-registered residential area}

According to Article 5 of the Law on the Control Exit and Entry of Citizen 1986 (PRC) and Article 3 Clause 1(1) of the Detailed Rules for the Implementation of Law on the Control of Exit and Entry Citizens (Amendment) 1994 (PRC), citizens must lodge an application for a private passport with the public security department in the place where they are a registered resident. It means that more than 120 million people are inconvenienced and forced to outlay considerable expense to apply for a private passport; and the efficiency of the exit and entry administration is

\footnotetext{
872 Preface Par 2 of the Circular of the State Council on Amending Article 6 of Regulations on Passport and Visa (PRC) 1984 (Guowuyuan Guanyu Xiuding Zhonghua Renmin Gongheguo Huzhao Qianzheng Tiaoli Diliutiao De Tonghzi), promulgated by the State Council on 27 March 1984.

873 Quoted in Wu, Inner, "Passport Gain Wider Currency in China”, China Central Television, 15:10:23 17/10/2002, at English Channel http://www.cctv.com/news/China/FinanceABusiness/20021017/100400/html (18/04/2003).

874 "Extension: Residents in Four Districts of Hainan Province May Apply for Passport Simpler" (Fanwei Kuoda: Hainan Si Diqu Ke Jianhua Shenling Chuguo Huzhao Shouxu) 21 October 2003, Xinhuanet, http://news.21 cn.com/domestic/guoshi/2003/10/21/1309848.shtml (15/11/2003).
} 
reduced. ${ }^{875}$ The Chinese government has noted this problem and adopted some measures, but has unfortunately failed to find a fundamental solution. As discussed in part 7.2.3, people from other provinces who work in Guangdong, Shanghai and Beijing may apply there for a private passport under some circumstances.

The household registration system introduced in 1958, and discussed in part 6.3.1 of this thesis, underlies the prohibition on applying for a passport outside an individual's registered residential area. In addition, there is no central database for issuing authorities in China. The prohibition ensures that a person may only hold one passport.

Cancelling the prohibition will not resolve the issue, because the prohibition is not the corollary of the strict control of household registration, and citizens are unlikely to enjoy freedom of movement within the territory in the near future. ${ }^{876}$ The establishment instead of a mutual information network that combines exit and entry information and household registration by $2005^{877}$ will play a vital role in reducing the residential area limits on private passport applications.

\subsubsection{Over-elaborate formalities for residents in small cities and rural areas}

The reform strategy and measures simplifying over-elaborate formalities have been discussed in part 7.2 of this thesis. Its application has some costs. On the one hand, a simpler system will apply in medium and large cities. Local governments in these cities may lose some powers while their citizens will gain the right to a passport. At the very least, citizens will not need permission from their work unit or to pander to the person responsible for processing their

\footnotetext{
875 There are more than 120 million migrant people in China. See "China at least 30 years away from zero population growth", 20 July 2004, http://english.peopledaily.com.cn/200312/30/eng20031230_131549.shtml (2003-12-The People Daily), and http;//English.people.com.cn/200407/20/eng20040720_150248.html (21/20/2004).

${ }^{876}$ Household registration system officials and experts have warned it takes a long time for crowded big cities in China to provide non-local residents with unrestricted access to residence. See "Residence System Reform Speeds up Human Resources Flow”, 31 October 2001, The People's Daily, http://english.peopledaily.com.cn/200110/31/eng20011031 83627.html (30/12/2003).

877 "State to Simplify Entry-exit Rules", 11/22/2002, The China Daily, http://www1.chinadaily.com.cn/news/2001-11-22/44711.html (18-04-2003).
} 
private passport application.

On the other hand, the elaborate formalities will remain burdensome for citizens of small cities and rural areas. For example, a person in a small city may need to undertake a process whereby:

1.The applicant must obtain a private passport application form from the county exit and entry administration office upon presentation of their identity card.

2.The applicant may be required to ask their work unit head, or, if unemployed, the police from the town of registered residence, to comment on the application form; as well as requiring the applicant to ask the local Court or police to verify that they do not fall into any category by which they would be prohibited from exiting China.

3. The County exit and entry administration may accept the application after formally ensuring the form has been correctly filled in and all relevant authorities have commented on it.

4.The County level exit and entry administration then examine the application by verifying whether the relevant authorities comments are true, false or forged.

5.The County level exit and entry administration would make an initial decision about whether to approve the application.

6.If approved, the application would be transmitted to the municipal level exit and entry administration to make a fresh assessment.

7.The municipal level exit and entry administration would make a final decision whether to approve the application according to their processes of examination.

8. Finally, the passport may be issued by the municipal level exit and entry administration.

The time taken to process an application is also excessive. Under Article 5 Clause 1 of the Detailed Rules for the Implementation of Law on the Control of Exit and Entry of Citizens 1985 (PRC):

The municipal or county public security bureau shall, within 30 days of receipt of the exit application, or within 60 days for rural areas or areas that are not easy to access, make a decision on approving of the exit application or not, and notify the applicant of the decision. 
It actually takes much longer to fulfil the procedures because more time is needed to gain certificates from the relevant authorities and to transmit documents from county and municipal exit and entry administration offices.

The most often citied justification for the limits on application for private passports of residents in small cities and rural areas is their lower quality (Suzhi Di). In the Chinese government's opinion the current quality of China's citizens means that citizens are not fit for more political rights. Premier Wen Jiabao has said, in an interview by Chief-editor of the Washington Post in November 2003, that the more positive political reform measures would not be adopted soon, due to the lower quality of Chinese nationals. ${ }^{878}$ The right to be granted a passport that way becomes a political right — from the point of view of China's government, it is not a good time to endow all citizens with the right to be granted a passport.

In essence, maintaining the old system for residents in small cities and rural areas is a form of discrimination. As discussed in part 3.2.1 of this thesis, the RLR is generally conceptualised as a right or freedom from the arbitrary interference of the State. The nature of the RLR requires the State to accept citizens leaving and returning to the country, regardless of their place of residence. Although the State owes only minimum positive obligations to citizens, it does owe the citizens the obligation of furnishing them with a passport.

\subsubsection{Retention of passports by designated authorities}

Under the Measures on Administration of Passport and Other Travel Abroad Documents of Officials Employed in Communist Party of China, Governments, Courts, Procuratorates, Justice Departments and Public Security Departments 2003 (PRC), passports and other travel documents held by county level cadres ${ }^{879}$ (and above) are retained or withheld by the Personnel

\footnotetext{
878 “ The Premier of Wen, Jiabao Accepted the Interview of the Chief-editor of Washington Post” (Wenjiabao Zongli Jieshou Huashendun Youbao Zhubian Caifang), 23 November 2003, http://www.fmprc.gov.cn/chn/zxxx/t44934.htm (04/12/2003).

${ }^{879}$ Cadres in China means (1) officers of government institutions, military, or mass organizations; (2) personal who assume the office of leadership or management. See Dictionary Department, Institute of Linguistics, Chinese
} 
Department of the government or the Organization Department of a Committee of the CPC. This means that this group of people cannot use their passport without approval from either of those two entities. ${ }^{880}$ The primary reason for this requirement is to prevent corrupt officials from absconding from the territory with large sums of money.

According to Article 16 of the Detailed Rule of the Implementation of Law on the Control of Exit and Entry of Citizens (Amendment) 1994 (PRC);

The Chinese passports and the Chinese travel permits, the major identification documents used by Chinese citizens for entering and leaving he country, shall be kept and used by the holders. No State departments, social Organizations, enterprises, government sponsored institutions or individuals shall withhold those certificates, other than the public security department and original issuing organ which shall have the power to revoke and retain the certificate according to law, and the Procuratorate and the Court which have the power to withhold the certificates according to law.

Yet the policy requiring the retention of private passports is invalid because CPC policy cannot prevail over relevant laws. Further, the retention of a passport based on the status of the holder is discriminatory and cannot be justified according to international norms. The practice restricts the RLR of county (and above) level cadres.

The justification for retaining the passports of cadres on the grounds that they will abscond with large sums of money is anyway unconvincing. Not all will abscond with large sums of money. Those who do can be arrested and charged with criminal offences before leaving China. If it is acceptable to retain the passports of all regulated cadres, because some possibly abscond abroad. This begs the question of how the rights of innocent cadres are protected. The legitimacy and effectiveness of provisions, which safeguard the interests of the State by damaging the interests of innocent people, is obviously questionable.

\footnotetext{
Academy of Social Sciences, the Contemporary Chinese Dictionary (Chinese-English Edition), Foreign Language Teaching and Research Press, Beijing, 2002, page 634.

${ }^{880}$ This system can be traced back to the Regulations on Passport and Visa 1980 (PRC) Article 16 Clause 2 of which stipulates that individuals exiting China for private affairs shall return their passport to the public security department that issued the passport after they return to China. With the significant increase of individuals exiting China for private affairs, this practice has been practically repealed since 1987.
} 


\subsubsection{Revocation of passports or declaring passports invalid}

Revocation of a passport, or declaring it invalid, as a serious punishment for passport-related offences, is seldom exercised, as it deprives or limits the RLR. By international norms, there are very few circumstances in which a passport can be revoked or invalidated. According to Article 22 of the Detailed Rules for the Implementation of Law on the Control of Exit and Entry of Citizens (Amendment) 1994 (PRC), passports can be revoked or declared invalid in China when:

(1) The holder has been sent back to China because he or she illegally entered, resided or stayed in the country of destination;

(2) The holder has used their passport or other overseas travel documents for the purpose of swindling and bluffing; or

(3) The holder has engaged in activities prejudicial to the security, honour and the interests of the State.

The decision to revoke or invalidate passports or other overseas travel documents is made by the original issuing departments or its higher authorities.

These circumstances are detailed in Article 22 Clause 1 of the Measures on the Administration of Chinese Citizens Tours Broad (Amendment) 2002 (PRC). Specifically, Chinese "tourists are strictly prohibited from staying abroad and failing to return to China." Article 32 Clause 2 further provides "where a tourist stays abroad and fails to go back home, and is repatriated, their passport is revoked by the public security department".

It may be argued that the grounds for the first rule are justified. The illegal activities of entry, residence or continued presence in a foreign country violate the immigration laws of those States. Destination States can punish illegal immigrants by deportation, and prohibiting them from re-entering the territory for a set period. However, the principle of double jeopardy, whereby a person should not be punished twice for the same offence, means that the originating State should not punish its national for breaches of foreign laws for which they have already been punished by the foreign State. The provision is also incongruous with international norms. Article I (d) of the 1963 UN Draft Principles on the RLR stipulates that;

The right of every national to leave one's country shall in no case be exercised contrary to the purposes and principles of the UN. This right shall be subject only to such limits as are determined by law solely for the purpose of securing due recognition and respect for the rights and freedoms of 
others and of meeting the just requirements of national security, public order, health or morals and the general welfare in a democratic society. Any limit that may be imposed shall not be aimed at destroying the right and shall be consistent with the purposes and principles of the UN.

It is uncertain whether the illegal activities of entering, residing or staying in a foreign country constitute a clear and present danger to the original State's national security, public order, health or morals, and general welfare. Consequently, it cannot be regarded as an acceptable reason to revoke or invalidate a passport.

Close attention must be paid to the second ground for revocation or invalidation. Where the use of one's passport or other overseas travel documents for the purpose of swindling and bluffing constitutes a crime according to Criminal Law (Amendment) 1997 (PRC), defendants are to be investigated for criminal responsibility; ${ }^{881}$ and prevented from exiting China on the ground that he or she is a suspect in a criminal matter as confirmed by a public security department, Procuratorate or a Court under Article 8 Clause 1(1) of the Law on the Control of Exit and Entry of Citizens 1985 (PRC). As such, this ground appears to be unnecessary.

Where an act does not warrant criminal punishment, it can be dealt with by way of administrative penalty by under Article 2 of the Regulations on the Administrative Penalties for Public Security (Amendment) 1994 (PRC), Article 14 of the Law on the Control of Exit and Entry of Citizens 1985 (PRC) and Article 24 of the Detailed Rules for the Implementation of Law on the Control of Exit and Entry of Citizens (Amendment) 1994 (PRC). An act that has minor adverse effects is not to be used as a basis for prohibiting exit and entry under Article 8 of the Law on the Control of Exit and Entry of Citizens 1985 (PRC). The weight of analysis suggests this provision is invalid. In practice, with the change in the status of the passport from a mark of privilege to a document of identity, the possibility of using a passport or other travel document for swindling and bluffing is extremely low, and as such, the provision should be repealed.

881 The Law of Criminal (Amendment) 1997 (PRC), promulgated by the National People Congress on 14 March 1997. 


\subsection{Conclusions}

There are several bureaucratic barriers to the RLR posed by the formalities of passport application and passport administration. The categories, scope and issuing authorities for passports in China are relatively unique in the world. Besides diplomatic passports and service passports, public affairs passport and private passports also exist. The scope of the first three categories has been intentionally broadened, and the scope of private passport narrowed. A variety of government authorities execute the power to issue passports. Different criteria adopted by passport processing authorities create a loophole in which a person can apply for a passport more than once.

Passport laws are inconsistent and outdated. The Chinese government has not amended passport laws or promulgated a new passport law for 25 years, within which time exit and entry administration has experienced the most significant change in China's history and a range new regulations and policies related to passports have been published. Public confidence in the dignity and integrity of passport laws is therefore undermined.

The issues surrounding public affairs passports attract more attention, not merely because of the category being special by world standards, but because $89.5 \%$ or 653.57 million employed people must obtain a public affairs passport when applying to leave China in relation to travel associated with their employers, ${ }^{882}$ and $39.4 \%$ of all people going abroad held public affairs passports in $2002 .{ }^{883}$ Non-legal terms or political propaganda terms exist in the

\footnotetext{
${ }^{882}$ Calculated according to the State Bureau of the Statistics data, $77.4 \%$ were employed by the governments, government-sponsored institutions, mass organisations, urban residents' committees, and village residents' committees. 11.1\% were employed in State-owned enterprises and collective-owned enterprises, "Gazette of Major Data of the Second Survey on National Basic Unit of Gazette of the Second Survey on National Basic Unit” (Dierci Quanguo Jiben Danwei Pucha Gongbao: Dierci Quanguo Jiben Danwei Pucha Zhuyao Shuju Gongbao) 17 January 2003, http://www.stats.gov.cn/tjgb/tbdwpcgb/qgjbdpcgb/1200301170195.htm (30/12/2003); and the data from "Statistic Figures", http://www.china.org.cn/english/shuzi-en/en-shuzi/index.htm (09/05/2003), the number of employed people in China at the end of 2001 totalled 730.25 million.

883 The State Bureau of the Statistics "Gazette of the Statistics of Economic and Social Development of the People's Republic of China of 2002” (Zhonghua Renmin Gongheguo 2002 Guomin Jingji He Shehui Tongji Gongbao), 28 February 2003, http://www.stats.gov.cn/tjgb/ndtjgb/qgndtjgb/1200302280214.htm (30/12/2003)
} 
provisions of passport examination criteria. Ambiguous examination criteria alongside complicated application procedures, and a stress on strict political examination and unified management, make the exit of most Chinese on a public affairs passport an ordeal. Unfortunately, the reform of the public affairs passport regime is not yet on the Chinese government's agenda.

Despite planned reforms of over elaborate private passport application formalities for residents in large and medium sized cities, at least 120 million Chinese people ${ }^{884}$ have to spend unnecessary money and time on travelling between their living area and registered resident area when applying for a private passport, due to the prohibition on non-registered resident area applications. All county level cadres (and above) are unreasonably required to submit passports and other travel documents to designed authorities. Most of the grounds for the revocation or invalidation of passports have been proved to be gratuitous and might be dealt with instead under criminal law. There is a clearly long way to go before the Chinese authorities fully relax their control over the granting of passports to their citizens.

\footnotetext{
884 There are more than 120 million migrant people in China. See "China at least 30 Years Away from Zero Population Growth”, 20 July 2004, The People's Daily, http;//English.people.com.cn/200407/20/eng20040720_150248.html (21/20/2004).
} 


\section{Chapter Nine}

\section{Limits on the Right to Leave of Chinese Citizens}

\section{Introduction}

As indicated in Chapter seven, since 1992 the Chinese government has adopted a series of reforms to simplify complex passport application procedures. Nevertheless, when compared to international norms, ${ }^{885}$ several limits on the right to leave still exist.

\subsection{General limits on the right to leave of Chinese citizens}

The general provisions to be considered in this section form the legal basis for limiting the right to leave of citizens. The permissibility of those provisions will be analysed according to the appropriateness of the limits and the legal validity of interpretative provisions. The legitimacy of authorities providing prerequisite certificates will be discussed in part 9.3.3.

\subsubsection{Contents of general limits on the right to leave of Chinese citizens}

The foremost provision in this area is Article 8 of the Law on the Control of Exit and Entry of Citizens 1985 (PRC). It provides that:

Approval to exit the country shall not be granted to persons belonging to any of the following categories:

(1)Defendants in criminal cases or criminal suspects confirmed by a public security department, a People's Procuratorate or a People's Court;

(2)Persons who, as notified by a People's Court, shall be denied exit owing to involvement in unresolved civil cases;

(3)Convicted persons serving their sentences;

(4)Persons undergoing rehabilitation through labour; and

(5)Persons whose exit from the country will, in the opinion of the responsible department of the State Council, be harmful to State security or cause a major loss to national interests.

\footnotetext{
885 As analysed in part 3.3, a person's right to leave a country is subject only to such reasonable limits as are necessary to prevent a clear and present danger to national security or public order, or to comply with international health regulations; and only if such limits are provided for by law, are clear and specific, are not subject to arbitrary application and do not destroy the substance of the RLR.
} 
Article 6 clauses 3 of the Explanation of the MPS on Some Issues on Implementation of Law on the Control of Exit and Entry of Citizens and Its Detailed Rules for the Implementation 1987 (PRC) interprets that:

(3) The reference to "approval to exit the country shall not be granted to persons whose exit from the country will, in the opinion (Yijian) of the responsible department of the State Council, be harmful to State security" in Sub-clause 5 shall be examined and approved by provincial public security departments or provincial national security departments. The reference to "persons whose exit from the country will cause a major loss to national interests" in Sub-clause 5 is to the persons who know important secrets of politics, military, technology and economy of the CPC and the governments, who, in the opinions of responsible departments of the Central Committee of the CPC, the State Council, the Central Military Commission and provincial level CPC commission, the governments and military departments, should not be granted approval to exit the country. Under this circumstance, public security departments or national security departments shall ask the approval from relevant departments before deciding whether to approve applications for leaving China....

(4) ... known secrets expire, involve persons may be granted to exit China.

Another basic provision is to prevent defaulting taxpayers from leaving China. ${ }^{886}$

\subsubsection{Appropriateness of the limits}

Compared to the recognised grounds for limiting the right to leave (discussed in part 3.4.2), the above prohibitions are appropriate in principle. However, there are no objective criteria against which "harm to the State" or "causing a major loss to national interests" can be judged. By international norms, knowing secrets cannot be an acceptable limit on the right to leave, especially when the persons have been discharged from active service. ${ }^{887}$ It is also unclear as to what criteria are applied by administrative departments to make a decision, or what procedures

\footnotetext{
886 Article 44 of the Law on the Administration of Tax Collection (Amendment) 2001 (PRC) regulates 'should a taxpayer who has not paid or has underpaid the amount of tax payer need to leave China, they shall settle the amount of tax payable with, or provide a guarantee to the tax authorities before leaving the country. If the taxpayer neither settles the amount of tax payable nor provides a guarantee, the tax authorities may notify the exit administration authorities to prevent the taxpayer from leaving the country." the Measures for the Implementation on Preventing Defaulting Taxpayer from Exiting China, 1997 (PRC) detail the relevant procedures of preventing defaulting taxpayer leaving China. The Measures apply to all defaulting taxpayers, including Chinese citizens and aliens. According to the Measures, the formalities must be completed within 24 hours of the tax office learning of the taxpayer's intention to leave China and the tax office must send a member of its staff to the taxpayer's workplace.

${ }^{887}$ For details, please see part 3.4 .3 of this thesis.
} 
are followed to create an opinion.

The absence of criteria leads to excessive administrative discretion. An example can be found in the limitations based on the outbreak of the SARS. The Chinese governments took measures to prohibit nationals from going abroad during the spring of 2003. Passengers could travel overseas after confirming they were free of the symptoms of the SARS, or were strongly urged to cancel their travel plans and seek medical treatment. ${ }^{888}$ It is generally accepted that the SARS was a risk to public health. However, it is uncertain what constitutes a "risk" in the absence of detailed domestic interpretation.

\subsubsection{Legal validity of interpretative provisions}

According to Article 90 Clause 2 of the Constitution of PRC (Amendment) 2004, the Explanation of the MPS on Some Issues on Implementation of Law on the Control of Exit and Entry of Citizens and Its Detailed Rules for the Implementation 1987 (PRC) and the Some Rules on the Issues of Prohibiting Aliens and Chinese Citizens from Exiting Chinas and Chinese Citizens 1987 (PRC) are of questionable legitimacy.

The Law on the Control of Exit and Entry of Citizens 1985 (PRC) was promulgated by the Standing Committee of the National People's Congress (NPC). According to the hierarchy of Chinese laws, it prevails over laws of the State Council and its ministries. ${ }^{889}$ The Explanation of the MPS on Some Issues on Implementation of Law on the Control of Exit and Entry of Citizens and Its Detailed Rules for the Implementation 1987 (PRC) was promulgated by the Ministry of Public Security (MPS). Article 6 clauses 3 and 4 of the explanation 1987 does not conform to Article 8 Clause 5 of the Law on the Control of Exit and Entry of Citizens 1985 (PRC). Thus, the decisions of the prohibition to exit are based on invalid legal basis. According to Article 88 Clause 1(3) of the Law of Legislation 2000 (PRC) the inconsistencies between the subordinate rules and ministerial explanations with the primary laws can be also be investigated and

\footnotetext{
888 "Beijing Prevents the SARS from Spreading Overseas", http://www.fmprc.gov.cn/eng/47396.html (23 04 2003).

889 Article 67 Clause 1 (7), Article 89 Clause 1 (1) and Article 90 Clause 2 of the Convention of the PRC

(Amendment) 2004.
} 
corrected by the State Council.

\subsection{Special limits on the right to leave of Chinese citizens}

\subsubsection{Overseas employment: skilled emigration}

Under Article 13 of the Provisional Rules on the Administration of Sino-Foreign Joint Venture Skilled Personnel Intermediary Agency 2003 (PRC), that:

... Recruitment of the following personnel for employment abroad is not allowed:

(1)Technical and management personnel undertaking State or provincial level key engineering or scientific research projects who have not obtained approval from the competent unit or department;

(2)Serving government officials;

(3)Personnel sent by the State to develop the western region whose term has not expired;

(4)Secret service personnel still in service or no longer in service but are still bound by the confidentiality clause;

(5)People under legal investigation;

(6)People holding special posts who are temporarily prohibited by law from leaving the country or are subject to approval for leaving the country.

Additionally, under Article 3 of the Provisional Rules on Attendance of Games or Competitions Abroad by Employment of Athletes 1989 (PRC) retired athletes from national sports teams shall not be granted approval to be employed to attend games or competitions abroad, unless they are female athletes over the 26 years old, or male athletes over 28 years old. In accordance with Article 3 Clause 1(1)(4) of the Provisional Rules on Some Issues of State Dispatched Coaches Aid for Foreign Countries 1990 (PRC) coaches and athletes cannot be employed abroad unless the coach is over the age of 50 , and the athlete is over the age of 35 , and they have a "firm stand in politics" and "live in an honest style".

These provisions reflect concerns about the outflow of trained professional personnel. However, their aim is not achieved. Being discriminatory, they infringe on the right to leave, as per the principles outlined in part 3.3.1 of this thesis.

Social disruption and the attraction of a foreign country can spur skilled emigration. Social 
disruption caused by economic restructuring encourages people to look abroad for opportunities. The direct cause of most professional emigration is that suitable employment cannot be found in China. ${ }^{890}$ The loss of an opportunity to work overseas may adversely affect a person's skills and knowledge, which is as much to the detriment of the individual as to the State that wants to retain them. Bill Gates has said that one of the strengths of the US economy is its ability to attract the best and the brightest from India, China and other countries. ${ }^{891}$ Germany, France, Canada, Australia and South Korea adopt many programs aimed at attracting skilled immigrants to make up for local shortfalls. ${ }^{892}$ From an international perspective, skilled emigration is a manifestation of human resource restructuring. It is an essential part of globalisation. The pattern of skilled emigration is not unique to China. The same issue faces all developing countries with an open economic policy. Therefore, if China intends to integrate into the world, and accept the consequences of modernisation and globalisation, the restructuring of human resource cannot be avoided.

The accepted legal solution to the 'brain drain' is to amend relevant laws to 'remove' $(S h u)$ the barriers to keep potential skilled emigrants within the territory rather than to 'block' $(D u)$ them to exit. In fact, the grounds for refusing to permit skilled nationals from leaving China will not stem the outflow. Recruitment through Sino-foreign joint venture personnel agencies is among a number of channels through which an overseas job can be sought. A person can resign from a job, which has placed them within one of the prohibited categories, and seek employment independently. 'Removing' creates an environment in which professionals are encouraged to remain in China and to attract people who are overseas to return or immigrate.

\footnotetext{
890 "The ability to find good jobs and earn much higher pay is the prime reason people are emigrating today." See "Globalization Affects Global Immigration”, Book Review, Workers Without Frontiers - the Impact of Globalization on International Migration, Stalker, Peter, International Labour Organization, 2000, http://search.chinadaily.com.cn/isearch/I_textinfo.exe?bdname=cndy_printedition\&listid=10291\&selectword=MIGR ATION (18/06/2003).

891 Quoted in Xinhua News Agency, "Brain Drain: Asia Warned”, 17 September 2000, http://search.chinadaily.com.cn.isearch/I textinfo.exe?dbname=cndy (19/06/2003).

${ }^{892}$ Xinhua News Agency, "Talents Competition in New Century: Positive Measures in USA and Quick Reply in other Countries" (Xinshiji Rencaizan: Meiguo Jiji Xina, Geguo Jinji Yingdui), http://finance.21cn.com/news/gjcj/2003/12/12/1377890.shtml (12/12/2003).
} 


\subsubsection{Overseas pilgrimage}

The freedom of religious belief is acknowledged in China. ${ }^{893}$ However there are three main limits on the right to leave China for the purpose of pilgrimage - which affect the freedom of religion and also the RLR.

Firstly, individuals cannot freely go abroad for the purpose of pilgrimage. According to Article 4 of the Circular of State Council Bureau for Religion Affairs, State Administration of Foreign Exchange, Ministry of Foreign Affairs, Ministry of Public Security, Bank of China, Customs General Administration and Civil Aviation Administration of China on Several Rules of Self-support Pilgrimage Abroad Administration (Amendment) 1995 (PRC) (Circular of Pilgrimage Abroad 1995), individuals desiring to go on an overseas pilgrimage must start at Urumqi or Beijing. Secondly, the Chinese government has imposed a quota of 2,000 people per year who are permitted to take part in a pilgrimage. ${ }^{894}$ Lastly, Article 3 of the Circular of Pilgrimage Abroad 1995 establishes that individuals who have made an overseas pilgrimage since 1979 shall not be granted permission to participate in an overseas pilgrimage again, and those who are likely to use the pilgrimage to do business or study abroad; or are over the age of 65 , pregnant, senile, or seriously ill, are prohibited from travelling for this purpose.

The Chinese government has recognised that leaving China for the purpose of a pilgrimage is a normal religious activity. ${ }^{895}$ Thus the obvious bias of restrictions is either in ignorance of

\footnotetext{
893 Article 36 of the Constitution of the PRC (Amendment) 2004 provides that "citizens of the People's Republic of China enjoy freedom of religious belief [and that] the State protects normal religious activities."

894 Article 1 (quota) and Article 3 (age) of the Circular of State Council Bureau for Religion Affairs, State Administration of Foreign Exchange, the MFA, MPS, Bank of China, Customs General Administration and Civil Aviation Administration of China on Several Rules of Self-support Pilgrimage Administration (Amendment) 1995 (PRC).

895 Preface of the Circular of State Council Bureau for Religion Affairs, State Administration of Foreign Exchange, the MFA, MPS, Bank of China, Customs General Administration and Civil Aviation Administration of China on Several Rules of Self-support Pilgrimage Administration (Amendment) 1995 (PRC) (Guowuyuan Zongjiao Shiwuju Guojia Waihui Guanliju Waijiao Gonganbu Zhongguo Yinghang Haiguan Zongshu Mingyong Hangkong Zongju Guanyu Zifei Chaojing Ruogan Guiding De Tongzhi), jointly promulgated by State Council Bureau for Religion Affairs, State Administration of Foreign Exchange, the MFA, MPS, Bank of China, Customs General Administration and Civil Aviation Administration of China according to Some Rules on Self-funded Pilgrimage Abroad 1990 (PRC) on 28 January 1995.
} 
international norms of the right to leave or the recognition serves purely as rhetorical propaganda.

\subsubsection{Overseas religious study}

Although the right of education has been accepted in Article 46 of the Constitution and thousands of students have studied abroad over the past two decades, ${ }^{896}$ limits on overseas religious study remain, though in practice the limits are often ignored.

Chinese citizens are prohibited from receiving financial support from foreign missionaries (Chuanjiao Jingfei) to study abroad at religious institutions or to study religion at higher education institutions in foreign countries, under Article 3 of the Circular of State Education Commission, State Council Bureau for Religions Affairs, Ministry of Public Affairs and Ministry of Foreign Affairs on Dealing with Some Issues of Recruiting Students Studying Abroad in China without Permission by Certain Departments and Individuals in China of Foreign Countries and International Organizations 1990 (PRC). In accordance with the Circular on Some Noteworthy Issues of Moslem Foreign Affairs 1990 (PRC) the State Council Bureau for Religious Affairs is responsible for examination, approval and dispatch of Muslims students to study at foreign religious institutions, on the basis of a report from the Chinese Muslim Association. Where Chinese citizens lodge the application for self-funded study at religious educational institutions of Muslim countries, the public security departments will not accept their application unless they present an approval letter issued from provincial level religious authorities. The latter requirement was reiterated in $1996 .{ }^{897}$

The government's official position is that the restrictions on studying religion overseas are justified on the basis of avoiding interference to interior religious matters, avoiding religious

\footnotetext{
${ }^{896}$ Official statistics show that in the past two decades, approximately 400,000 Chinese students have gone to 103 countries to study, making China the world's largest source of students studying overseas. See "China Sees Tide of Returning Talents", The People's Daily 29 June 2002, http://service.china.org.cn/link/wcm/Show Text?info id=35844\&p qry=immigration (24/04/2003).

897 Article 3 Clause 3 (3) of the Operational Norms of Application, Examination and Approval of Exiting China and Passport For Private Affairs of Citizens 1996 (PRC).
} 
infiltration, introducing new religions, and protecting China against hostile forces that may destroy the unity of Chinese nationality. ${ }^{898}$ This essentially paranoid thinking can be traced to left-leaning policy, a poor economic environment, frequent political movements and hostility towards China by foreign countries prior to $1979 .{ }^{899}$ Compared to the freedom to study in other disciplines, prohibitions on studying religious courses abroad are discriminatory. From the point of view of the right to leave, any discrimination on the grounds of studying is hardly justifiable.

\subsubsection{Limits on the right to leave based on the applicants' special status}

The right to leave can also be limited according to the applicant's kinship relationship, social status, health and gender - all unjustifiable grounds. Family members of wanted suspects and traitors are not permitted to leave China according to the Circular of the MPS on Temporarily not Granting Permission to the Application for Exit of China of Domestic Family Members of Wanted Suspects and Traitors 1991 (PRC). ${ }^{900}$ Spouses and the adult children of staff of embassies and consulates in foreign countries may only visit relatives abroad once a year for no more than a month at a time, pursuant to Provisional Measures for the Control of Self-funded Visiting Their Relatives who are the Staff of Embassies and Consulates General in Foreign Countries of Adult Children and Spouse 1999 (PRC).

More limits are imposed on the individuals with the status of cadre and police. In the first place, cadres in active service at a departmental, bureau or municipality level or over are not permitted to exit China for private affairs on short trips. The principle of the management of the exit and entry of cadres is to handle sternly the application of leading cadres in active service, retired

\footnotetext{
898 Preface Par. 1 of the Circular of State Education Commission, State Council Bureau for Religions Affairs, the Ministry of Public Affairs and the MFA on Dealing with Some Issues of Recruiting Students Studying Abroad in China without Allowance by Certain Organizations in China and Individuals of Foreign Countries and International Organizations 1990 (PRC) (Guojia Jiaowei Guowuyuan Zongjiaoju Gonganbu Waijiaobu Guanyu Chuli Mouxie Guojia He Guoji Zuzhi De Zhuhua Jigou Ji Geren Shanzi Zaihua Zaoshou Liuxuesheng Wenti De Tonhzhi), promulgated by State Education Commission, State Council Bureau for Religions Affairs, the Ministry of Public Affairs and the MFA on 26 December 1990.

${ }^{899}$ See part 6.3 of this thesis.

900 The Circular of the MPS on Temporal Prohibition on Exit China Application of Domestic Family Members of Wanted Suspects and Betrayal Criminals 1991 (PRC), promulgated by the MPS in 1991 Gongtongzi No. (1991) 13
} 
cadres and retired, veteran cadres respectively, to less sternly handle the application of leading cadres of the CPC and the government and non-CPC and the government respectively, and to handle leniently the application of cadres with and without the membership of the CPC. ${ }^{901}$ According to Article 1 of the approval of the provincial level or ministerial level party Committees of the CPC must be received if cadres wish to permanently emigrate. ${ }^{902}$ Cadres in active service at a divisional or county level, and their families, are not permitted to visit anyone outside the territory other than spouse, child or parent. This class of applicants is not permitted to take leave from their work in order to go abroad for personal overseas travel. ${ }^{903}$ Senior retired cadres must gain approval from the party Committee of the CPC or a provisional or ministerial authority before leaving the territory. ${ }^{904}$ The applications of police personnel to exit for private affairs or to marry aliens is not be approved unless they have been discharged from active service and the life of secrets know to them has expired..$^{905}$

Applications to exit China can also be rejected on the grounds of ill health, senility or pregnancy. ${ }^{906}$ If the health of the applicant poses a risk to public health, the prohibition may be

901 The Circular on Some Matters of Examining and Management of Individuals Exiting and Entering for Private Affairs 1999 (PRC), promulgated by the Party Committee of Community Party of China of the Ministry of Agriculture on 24 March 1999, Nongdangzufa [1999] page 10 902 The Circular of Department of Cadres under the Central Committee of Communist Party of China on Issues of Examination and Approval of Exiting China for Private Affairs of Senior Cadres 1992 (PRC), "Cadres in active service of deputy provincial or ministerial level or over, including cadres in the processing of resign, shall not be granted to exit abroad for private affairs in principle. The Department of Cadres under Central Committee of CPA will examine and approval if special." Under Article 3 and 7 of the Circular on Some Matters of Examining and Management of Individuals Exiting and Entering for Private Affairs 1999 (PRC).

903 Article 4 Clauses 2 and 3 of the Circular on Some Matters of Examining and Management of Individuals Exiting and Entering for Private Affairs 1999 (PRC).

${ }^{904}$ According to Article 2 of the Circular of Department of Cadres under the Central Committee of Communist Party of China on Issues of Examination and Approval of Leaving China for Private Affairs of Senior Cadres 1992 (PRC) and the Department of Cadres under Central Committee of the CPA. The maximum period of exiting abroad is half year. Article 6 Clauses 1 and 3 of the Circular on Some Matters of Examining and Management of Individuals Exiting and Entering for Private Affairs 1999 (PRC).

905 The period of secrets expiration is three years for top secret, two years for important secret and one year for secret under Article 3 of the Circular of the Political Department of the Ministry of Public Security on Some Detailed Issues of Polices Leaving China for Private Affairs and Marry Aliens 1992 (PRC).

906 According to Article 5 Clause 4 of Provisional Measures for the Administration of China National Tourism Administration on Departments of Tour to Thailand, Singapore and Malaysia 1990 (PRC) those who are too senile to look after themselves, or are more than seven months pregnant are not permitted to travel to Thailand, Singapore or 
permissible from an international perspective, but it is difficult to see how pregnancy, senility and normal sickness present such a risk. Young women are strictly forbidden to leave China in order to work as hairdressers, in dance halls, bars, entertainment venues or massage parlours under the Reiteration of Strictly Forbidding of Sending Young Women to Abroad to Provide Erotic Services in the Name of Work 1997 (PRC), the broad terms of which are very odd and insulting to women by any western perspective. However these women, once granted approval to leave China for some other purposes, can of course switch to a prohibited form of employment once in the foreign country. More importantly, the limits on the right to leave cannot be grounded on the assumption that women may go abroad for employment in an erotic service industry.

\subsection{Prerequisite certificates from the departments in which the applicants are employed (Gongzuo Danwei Yijian Qianzhi)}

Individuals are required to obtain the certificates of the department in which they are employed before lodging an application to leave China (the prerequisite certificates). This applies to normal applicants as well as those with a special identity. The prerequisite certificates for normal applicants ${ }^{907}$ have been relaxed in accordance with the reform strategy discussed in Chapter seven, while the need of a prerequisite certificates for applicants with a special identity remains. According to Su Qiang, an official of BEEA, "there are still some people, including government officials who cannot benefit from the new policy, considering national security and other interests." 908

The emphasis of the remainder of this section is on the prerequisite certificates imposed on

\footnotetext{
Malaya. Article 3 of the Circular of Pilgrimage Abroad 1995 regulate that the applicant must be evidenced healthy with the certificate of health examination issued by county level or over hospital.

907 Article 1 Clause 2 of the Explanation of Sixth Bureau of the MPS on Issues of Providing Comments of Employed the Organization Where the Applicant is Services of Citizens Exiting China, 1989 (PRC) (Gonganbu Liuju Guanyu Gongmin Shenqing Chuguo Tijiao Suozai Gongzuo Danwei Yijian Wenti De Shuoming), promulgated by the Sixth Bureau of the MPS on 11 March 1989.

908 Xiao, Xin, Passport Application Simplified, 21 August 2003, The China Daily, http://www1.chinadaily.com.cn/en/doc/2003-08/21/content_256754.htm (19/12/2003).
} 
applicants with a special identity. In particular, the scope and questions.

\subsubsection{The scope of the prerequisite certificates}

The scope of the prerequisite certificates is very broad for applicants with a special identity. Under Article 2 of the Suggestions of the MPS on Some Issues Concerning the Execution of Law of Exit and Entry of Citizens 1985 (PRC) and its Detailed Rules of the Implementation 1987 (PRC):

1. Members of the CPC, military personnel (...) and public security personnel leaving China for private affairs shall firstly undergo interior examination and approval procedure of the CPC, military and public security departments in accordance with separated department system [...]

2. Key scientific and technical members of professional staff (...) who have applied to exit China in order to permanently reside abroad shall firstly ask for approval from the responsible departments of the Central Committee of the CPC, the State Council and provincial governments. The public security departments will then accept, examine and approve the application;

3. Ex-service army-personnel who have transferred to civilian work, and who possessed [...] important military secrets must ask for the certificates of their previous army service unit, and may not leave China within five years of ceasing their military duties;

4. Above provisions apply to exit to Hong Kong and Macao.

Persons with other special identities also meet the requirements for a prerequisite certificate under Article 4 of the Detailed Rules for Implementing of the Law on the Control of Exit and Entry of Citizens (Amendment) 1994 (PRC). Rather than being narrowed by the reforms, requirements were affirmed in 2002. The affirmation differed in its detail across regions, but was essentially similar. As relevant updated circulars of the MPS are not publicly available, the following evidence is based on a review of official reports and official online instructions for passport applications. For Shanghai, according to online instructions for ordinary passport applications from the Shanghai Exit and Entry Administration:

Certificate from the departments where the applicant is in service is needed for applicants with the following identities:

(1) Municipal level or over government cadres or retired cadres;

(2) Government cadres at an intermediate level;

(3) Personnel holding key positions in government departments and State-owned enterprises, working in the [key fields];

(4) Staff in the Shanghai office of a central government department or Shanghai office of a 
provincial or metropolitan authority who holds one of the abovementioned positions. ${ }^{909}$

The Column of Comments of the Departments where the applicant is in service of Special Identity Applicants (Teding Shenfen Shenqingren Zhi Danwei Yijianlan) has been inserted into the Application Form for Ordinary Passport of the PRC (Shanghai Version) (Zhonghua Renmin Gongheguo Putong Huzhao Shenlingbiao) (Shanghai), which was produced by the BEEA in 2002.

In the case of Guangdong under the online instructions for ordinary passport application in Guangdong province, a broader interpretation is attributed to the term 'special identity applicants' than that attributed in Shanghai:

Certificate from the departments where the applicant is in service is needed for applicants with the following identities:

(1) Retired intermediate (department or county) level cadres;

(2) Serving officials in State departments;

(3) Members of the lading panel and Chief Financial Officer of State-owned enterprises;

(4) Individuals with senior professional titles in higher education, research and medical institutions;

(5) Individuals with special identities in the banking and insurance industries;

(6) Military officers leaving China for private affairs.

Certificate from the departments where the applicant is in service is needed for following affairs:

(1) Members of a tour group;

(2) Fulltime students in secondary schools and higher education institutions;

(3) Self-funded individuals with associate college degrees studying abroad;

(4) Individuals attending an overseas religious course;

(5) Children adopted by aliens who leaving China permanently;

(6) Individuals who have obtained overseas employment via an overseas employment intermediate agency;

(7) Individuals who have obtained overseas employment via a labour service agency;

(8) Individuals leaving China for cultural exchange. ${ }^{910}$

Given most applicants' special identities are government officials, Quanzhou in Fujian Province,

\footnotetext{
909 “Applying for the Passport”, http://gaj.sh.gov.cn/shpolice (06/01/2004).

910 Exit and Entry Administration of Guangdong Public Security Department, "Documents Required for Passport Application" (Shenqing Suoxu Tijiao De Ziliao), http://www.gdcrj.com/zggmcg/sqtj/default.htm (19/06/2003).
} 
has a specially designed Application Form for Leaving China for Private Affairs for Government Officials (Guojia Gongzuo Renyuan Yinsi Chuguo (Jing) Shenqingbiao). ${ }^{911}$ This issue do not attract the attention of the authorities, as discussed in part 7.4 of thesis.

\subsubsection{Questions on the prerequisite certificates}

The legal basis of the prerequisite certificates contained in the Detailed Rules for Implementing of the Law on the Control of Exit and Entry of Citizens (Amendment) 1994 (PRC) and recent reforms is questionable. Article 8 of the Law on the Control of Exit and Entry of Citizens 1985 (PRC) provides that exit approval shall only be withheld from five categories of applicants, and that all other applications are to be approved. However the description in part 9.3.1 above shows that public security departments shall not accept or approve exit applications unless the requirements of the prerequisite certificates are fulfilled. The requirements of prerequisite certificates thus contradict the Law on the Control of Exit and Entry of Citizens 1985 (PRC).

Secondly, the departments where the applicant is employed are not entitled to make certificates. According to Article 5 of the Law on the Control of Exit and Entry of Citizens 1985 (PRC), Chinese citizens who want to leave for private purposes need to apply to the public security department. The department is the sole agency responsible for making a determination. No reference is made to a requirement for additional certificates or consultation between the public security department and other government instrumentalities.

Articel 1(5) of the Law on the Control of Exit and Entry of Citizens 1985 (PRC) expressly provides that a determination of whether the exit of an individual would be harmful to State security or cause a major loss to national interests, is to be made by the responsible departments of the State Council. The Central Committee of the CPC, the Central Military Commission and

\footnotetext{
911 the reference to "government officials' in this context refers to national public servants. National public servants include: individuals engaged in public affairs in the State-owned companies and enterprises, and mass departments appointed by State-owned companies, enterprises and government sponsored institutions. Quoted in Xiao, Juan, “Quanzhou City Adopted Passport On Demand Policy” (Woshi Shixing Anxu Shenling Huzhao), 24 November 2003, The Quanzhou Evening Daily, http://www.fjsen.com/2003/home.nsf/documentview/2003-11-24-E952CF7DBF4CB2 (30/12/2003).
} 
provincial CPC commission, the governments and military departments, are not the responsible departments of the State Council. Therefore, their opinions might not provide a legal basis of limiting individuals from leaving China.

Although the leadership of the CPC is constitutionally entrenched, ${ }^{912}$ and the Central Committee of the CPC, the Central Military Commission and provincial level CPC commissions, the governments and military departments, play conspicuous roles in national security and safeguarding national interests, these entities, according to Article 5 of the Constitution of the PRC (Amendment) 2004, must abide by the law and are not privileged to act beyond the law. Where they think that persons whose exit the country will be harmful to State security or cause a major loss to national interests, they only may make recommendations to the responsible departments of the State Council.

Lastly, the prevention of a person from leaving China on the grounds that he or she is unable to obtain a favourable certificate from their department is unfair. The status a person may have is multifarious and not subject to enumeration. The absence of a legal criterion for clarifying the categories for which a certificate is required, means that categories can be added and subtracted at will by local administrators. It makes for discrimination against applicants on the basis of status.

Therefore the requirements of prerequisite certificates impose an extra burden on passport application, making the procedure more complex and interfering with the right to leave. Yet more seriously, the prerequisite certificates could have long-term effects on the right to leave, as most of provisions were adopted during the period of reform and are regarded as positive and necessary measures.

\subsection{Household deregistration prior to leaving China}

912 Preamble Par. 7 of the Constitution of the PRC (Amendment) 2004, as amended by the Constitution of the PRC 1982, promulgated by the National People's Congress on 14 March 2004. 
Household registration, the genesis of which has been discussed in part 6.3 .1 of this thesis, is vital to Chinese daily life. It is not only a symbol of identity but also the basis of housing, medical, education and employment benefits. Under Article 7 of the Detailed Rules for the Implementation of the Law on the Control of Exit and Entry of Citizens (Amendment) 1994 (PRC):

For anyone leaving to reside permanently in a foreign country, he or she shall go to the local police station or the residence registration office to deregister their household residence. For anyone leaving the country for a short period of time, he or she shall undergo the procedures of residence registration for a short-term absence from the country and, upon return to China, resume their regular household registration at the places of their original residence by presenting their passports.

Deregistration severs an individual's links with China. Unfortunately, the reforms do not change these provisions. ${ }^{913}$ In fact, cancellation of household registration is not effective, since border inspectors do not check if the individual has deregistered their household prior to letting them cross. Border inspector checks pertain only to passports, visas and exit registration cards. ${ }^{914}$ The absence of collaboration between public security departments and border inspection departments, makes it possible for individuals to avoid deregistration.

The measures applied in other countries and regions are exemplary. In Taiwan, households are deregistered if the individual has been absent from the territory for more than two years. In that way, the actual exit has no direct bearing on later household deregistration. ${ }^{915}$

\subsection{The right to access foreign exchange in China}

China has been gradually relaxing restrictions on the right to access foreign exchange since

\footnotetext{
913 "New Rulings to Bring a Freer Life", 12/08//2003 China Business Weekly, http://ww1.chinadaily.com.cn/en/doc/2003-08/12/content_255194.htm (19/12/2003).

914 Article 7 of the Regulations of Inspection of Exit and Entry Border 1995 (PRC) and Article 3 Clause 3 of the Circular of the MPS on Handling Means of Some Issues on the Implementation of Checking, Monitoring and Prevention of Exit and Entry in Regulation of Inspection of Exit and Entry Border 1995 (PRC).

915 Articles 2 and 7 of the Operation Points of Circular of Population of Nationals Who Exited Two Years Ago and Reentry 2000 (Republic of China).
} 
$2002,{ }^{916}$ but current limits still hinder the RLR. As discussed in part 3.2.4, foreign exchange restrictions imposed with a view to safeguarding the national economy should not be used to deny a national the right to leave. ${ }^{917}$ Limits on the right to access foreign exchange can mean that nationals living abroad may lose financial support from home; and nationals at home may abandon the idea of travelling abroad. The restrictions on the right to access foreign exchange should be temporary and where possible avoided.

\subsubsection{Limits on the right to purchase foreign exchange}

Crucial to the right to access foreign exchange in China are the terms of the right to purchase foreign exchange. Under Article I (1) of the Circular on Adjusting the Policies for Domestic Resident Individuals to Purchase Foreign exchange under Current Accounts 2003 (PRC) which is promulgated by State Administration of Foreign Exchange (SAFE):

If a resident needs to purchase foreign exchange due to outbound travel, pilgrimage, to visit relatives, overseas hospitalisation, commercial investigation, employment, permanent emigration, international exchange, overseas training, overseas study, or to provide labour; and the period that he or she will remain outside the territory is less than six months, he or she may purchase foreign exchange to the equivalent value of US\$3,000. If the period for which the person will remain outside the territory is over six months, he or she may purchase the equivalent of US\$5,000. ${ }^{918}$

The preface of the Circular 2003 above further states that it means to satisfy the real foreign exchange demands of residents and to facilitate the purchase of foreign exchange from banks by individuals. It is almost impossible to limit the number of people exiting China by imposing restrictions on purchasing foreign exchange, based on the purpose for which the person is exiting. This then raises the related question as to whether a resident is prohibited from

\footnotetext{
916 Yao, Chen, "National Must Control Surpluses”, China Business Weekly 11/11/2003, http://www1.chinadaily.com.cn/en/doc/2003-11/11/content 281664.htm (26/11/2003).

917 Article I (f) of the 1963 Ingles Draft Principles on the RLR, adopted by the UN Sub-Commission on the Prevention of Discrimination and Protection of Minorities, Res. 2B (XV), UN Doc. E/CN. 41846 (1963).

918 Compared to Article 15 of the Provisional Measures on the Administration of Domestic Resident Individuals Foreign Exchange 1998 (PRC) (Jingnei Jumin Geren Waihui Guanli Zaixing Banfa), Huifa [1999] No. 305. Prior to the enactment of the 2003 Circular, residents could only purchase the equivalent of US\$1,000 in order to travel to Hong Kong or Macao for the purpose of visiting relatives; US\$2,000 to visit relatives in any other country; or a maximum of US $\$ 1,000$ to travel abroad for any other purpose.
} 
purchasing foreign exchange on the basis that they require it for other purposes other than those regulated, such as to pay an inheritance to a person who lives overseas, or to make a donation. Additionally, should the guiding limit of purchasing foreign exchange be calculated in accordance with the length of time that the person will remain outside the territory as indicated on their visa? The unanswerable questions challenge the aims of Circular 2003.

With too few banks providing foreign exchange, procurement is neither convenient nor simple. Since October 2003, residents in all of Mainland China could buy foreign currency at a total of 2,831 branches of 16 banks. ${ }^{919}$ In the context of a population of 1.3 billion, 460,000 people share each designated foreign exchange bank. Most of the designated banks are located in Beijing, Shanghai, Guangdong and coastal provinces, so the rate of $460,000: 1$ is actually much lower. Residents in rural areas or the mid-western regions have even less access to foreign exchange banks.

\subsubsection{Limits on the right to remit outward foreign exchange}

Personal outward remittances may financially support Chinese nationals who live overseas, and who travel abroad. Limits on the right to remit outward foreign exchange are mainly limits on remittance used as expenditure and as overseas investment. According to the Bank of China's ${ }^{920}$ summary of the relevant provisions, individuals must follow complex formalities to remit foreign exchange within the guiding limits. ${ }^{921}$ To avoid these formalities, which are costly and

919 "List of Nominated Bank with License of Selling Foreign Currencies to Individuals Going Abroad for Private Purposes", 27/10/2003, the State Administration of Foreign Currency, http://www.safe.gov.cn/0430/glxx.htm (26/11/2003); the monopoly of the Bank of China in selling foreign exchange was broken down in August 2002 with the help of a foreign exchange purchase information management system for individual buyers, developed by SAFE. See "Chinese Have Easier Access to Foreign Exchange Deals", 2 August 2002, The People's Daily, http://english.peopledaily.com.cn/200208/02/eng20020802 100771.shtm1 (4/12/2003).

920 The Bank of China is only foreign exchange bank designated by the State Council of the PRC before August 2002.

921 1.If less than US\$10,000 is remitted in a lump sum from an account of personal spot exchange deposit, or foreign banknotes less than US $\$ 2,000$ are remitted in a lump sum from a foreign banknote holding or from an account of personal foreign banknote deposit, sender is only required to prove their identity and do not need to disclose the reason for the remittance; 2. If US\$10,000 to US\$50,000 is remitted in a lump sum from an account of personal spot exchange deposit, or foreign banknotes valued at US\$2,000 to US\$10,000 are remitted in a lump sum, an application must be made to the local SAFE. After the application is examined outward remittance procedures may be followed 
time-consuming, senders usually take advantage of a loophole in the regulations. ${ }^{922}$ Because the provisions do not limit the annual remittance amount, the scheme does not affect the ability of the identity card-lenders to remit funds in the future. In any event, there is no national electronic database of remittance activity for banks to cross-reference. Further, banks are not entitled to prevent individuals from remitting at different branches during a short period, even on the same day. Therefore, the set limits do not achieve the goal of strictly controlling foreign exchange outflow. The current provisions also shed little light on personal overseas investment with foreign exchange, ${ }^{923}$ which is one of conditions to apply for business skilled emigration.

\subsubsection{Limits on the right to carry outward foreign currencies}

The formalities for applying for a Permit for Carrying Outward Foreign Currency Across the Border (Xiedai Waibi Chujing Xukezheng) over US\$5,000 are petty and tedious. Under Article 8 of the Provisional Measures for the Administration of Carrying Outward Foreign Currency Cash for Persons Entering or Exiting China 2003 (PRC), it is likely to be time-consuming and costly. Chinese citizens and aliens cannot, in principle and by law, carry more than US $\$ 10,000$ out of China. ${ }^{924}$ If due to a particular circumstance, the individual may lodge the application

at a designated foreign exchange bank against the certificate of approval issued by local SAFE. 3 . If US\$50,000 or more is remitted in a lump sum from an account of personal spot exchange deposit, or foreign banknotes valued at US $\$ 10,000$ US dollars are remitted outward in a lump sum, the local SAFE shall report it to the SAFE for examination and approval. Outward remittance procedures may be followed at the designated foreign exchange bank against the certificate of approval issued by the local SAFE. See the Bank of China, "International Remittance Outward", http://bank-of-china.com/english/alpersonal/a1_3 6.shhtml (04/12/2003)

922 For example, if an individual plans to remit US\$60,000 in cash in one day, the most expedient approach is to borrow ten or twenty identification cards from others, then remit the sum at several banks in US\$2,000 lots.

923 Resident individual may invest B-shares with an individual's own foreign exchange resources other than with purchased foreign exchange. See Article 1 Clause 2 of the Supplementary Circular of the State Administration of Foreign Exchange on Relevant Matters about Investing in the B Stocks by the Domestic Residents 2001 (PRC), Huifa [2001] No.31, 23 February 2001; B shares is a special share with a par value in Renminbi but subscribed and trade in US dollars in the Shanghai stock market, or in Hong Kong dollars in the Shenzhen stock market. See Dictionary Department, Institute of Linguistics, Chinese Academy of Social Sciences, the Contemporary Chinese Dictionary (Chinese-English Edition), Foreign Language Teaching and Research Press, Beijing, 2002, page 2647.

924 Article C (c) of the Circular on Relevant Issues Regarding the Introduction of New Version of "Certificate for Carrying Outward Foreign Currency Across the Border" 1999, Article 2 Clause 2(3) of the Circular of the SAFE and the General Administration of Customs on Printing and Distributing the Provisional Measures for the Administration of Carrying Outward Foreign currency cash for Persons Entering or Exiting China, 2003 (PRC), and 
according to Article 5 Clause 3 of the Provisional Measures for the Administration of Carrying Outward Foreign Currency Cash for Persons Entering or Exiting China 2003 (PRC), the branch or sub-branch of the SAFE at the locality of one's deposit bank or exchange-selling bank is supposed to apply a test of bona fide on the source and use of foreign exchange, in accordance with relevant regulations. ${ }^{925}$

In practice, it is almost impossible to legally carry foreign exchange in excess of US $\$ 10,000$, as most residents exiting China do not fulfil exemption criteria, and have little chance of obtaining a Permit for Carrying Outward Foreign Currency Across the Border. Article 2 Clause 2 of the Circular of the SAFE and the General Administration of Customs on Printing and Distributing the Provisional Measures for the Administration of Carrying Outward Foreign Currency Cash for Persons Entering or Exiting China 2003 (PRC) provides that under any of the following particular circumstances, a resident individual may apply for a Permit for an amount in excess of US\$10,000, if he or she:

(1) Is in a group exiting China composed of a large number of persons;

(2) Is in a scientific inspection group exiting China for a long time or for a long trip;

(3) Is a government leader visiting a foreign country;

(4) Is leaving for a country at war, a country with strict foreign exchange control policies, or a country with bad financial conditions or financial turmoil."

The phrases and terms "a large number", "a long time", "a long trip", "strict", "bad" and "turmoil" leave much scope for administrative discretion. Individuals seem unlikely to successfully apply for a Permit for an amount exceeding the prescribed limit. In order to avoid the guiding limits and overly elaborate formalities, some individuals purchase foreign exchange on the black market ${ }^{926}$ and risk smuggling the excessive foreign currency out of the country.

\footnotetext{
Article 7 Clause 2 of Provisional Measures for the Administration of Carrying Outward Foreign Currency Cash for Persons Entering or Exiting China 2003 (PRC).

925 Article C (B) of the Circular on Relevant Issues Regarding the Introduction of New Version of "Certificate for Carrying Outward Foreign Currency Across the Border" Issued Jointly by State Administration of Foreign Exchange and General Administration of Customs 1999.

926 “Black Market", http://www.chinaonline.com/features/currency (10/12/2003).
} 


\subsubsection{Laws governing foreign exchange}

Underdeveloped foreign exchange laws impose an indirect barrier on the RLR. Strictly speaking, most of the current laws governing foreign exchange are internal policies because the State Administration of Foreign Exchange is not entitled to promulgate national law. The SAFE promulgates most regulations governing foreign exchange for private purposes ${ }^{927}$ and it is a bureau supervised by the People's Bank of China (the Central Bank), which is the Reserve Bank. ${ }^{928}$ The Central Bank has the same administrative level as Ministries and Commissions, which have legislative power. ${ }^{929}$ The SAFE does not have legislative power ${ }^{930}$ and needs to follow above hierarchy to formulate the rules governing foreign exchange. Therefore, the validity of SAFE's regulations is in dispute.

\subsection{The administration of individuals prohibited from leaving China (Xianzhi Chujing Zhidu)}

The Chinese government has imposed the administration for individuals prohibited from leaving China. It places such people into one of the five categories discussed in part 9.1 above. Article 2 of the Some Rules on the Issues of Prohibiting Aliens and Chinese Citizens from Exiting Chinas 1987 (PRC) details the examination and approval authority in this system:

\footnotetext{
927 For example the Circular of the SAFE on Adjusting the Policies for Domestic Resident Individuals to Purchase Foreign exchange under Current Accounts 2003 (PRC), Detailed Rules of the Implementation on the Administration of Domestic Resident Individuals to Purchase Foreign Exchange (Amendment) 2003 (PRC), Provisional Measures on the Administration of Domestic Resident Individuals Foreign Exchange (Amendment) 2003 (PRC) and Provisional Measures for the Administration of Carrying Outward Foreign currency cash for Persons Entering or Exiting China, 2003 (PRC).

928 "The State Council”, http://english.people.com.cn/data/organs/statecouncil.shtml (22/12/2004); and "the State Council of the People's Republic of China”, from Wikipedia, the free encyclopedia, http://en.wikipedia.irg/wiki/State_Council_of the People's_Republic_of_China (22/12/2004)

929 According to Article 71 (1) of the Law of Legislation 2000 (PRC): "the ministries and commissions under the State Council, the People's Bank of China and the Auditing office and other departments with administrative responsibilities directly under the State Council shall, according to the laws and administrative regulations, decisions and orders of the State Council, enact rules within their own authority."

930 According to Article 9 (1) the Regulations on the Procedure for Formulation of Rules 2001 (PRC), "Where an internal agency established by a department under the State Council or any other agency deems it necessary to formulate departmental rules, an application shall be presented to the said department for establishment of the rules."
} 
(1)Provincial level public security departments or national security departments are empowered to prohibit criminal suspects or violators from leaving China whose violation has not been punished and needs to be investigated the criminal responsibility;

(2)The People's Courts and People's Procuratorates are empowered to prohibit criminal suspects or violators from leaving China whose violation has not been punished and whose criminal responsibility needs to be run according to relevant laws, and notify the same level public security departments;

(3) National security departments are empowered to prohibit some aliens or Chinese citizens from leaving China, and notify the same level public security departments;

(4)The People's Court is empowered to prohibit the party of civil lawsuit, including an economic lawsuit, from leaving China, and notify the same level public security departments;

The means of the prohibition are prescribed as following by Article 3 of the Some Rules on the Issues of Prohibiting Aliens and Chinese Citizens from Exiting Chinas 1987 (PRC):

The following means can be adopted separately when the People's Courts, People's Procuratorates, pubic security departments and national security department prohibits aliens and Chinese citizens from leaving China:

(1)The affected person shall be informed orally or in writing that they are prohibited from leaving China unless the lawsuits or issues concerned has been resolved;

(2)The affected person shall be convicted to live at home under surveillance, or post a bail pending trial with restricted liberty of movement; or they may be permitted to leave China after providing a property guarantee or a bond;

(3)The affected person's passport or other valid travel documents shall be retained, however the relevant cases need to be resolved before the expiration of retained passport or other travel documents, the receipt of retaining also need to be issued ...

The procedure of the prohibition must be followed under Article 4 of the Some Rules on the Issues of Prohibiting Aliens and Chinese Citizens from Exiting China 1987 (PRC):

If the aliens and Chinese citizens need to be prohibited from leaving China at the border inspection port, the People's Courts, People's Procuratorates, pubic security departments and national security departments must fill in the Notification of Limiting Individuals Exiting at the Border Inspection Port. For the ports in this province, the notice shall be submitted to provincial public security departments who organize the prohibition activities; under really emergency circumstance, may ask for border inspection office to arrange the prohibition activities first, then complete missing prohibition procedures. For the ports outside of this province, relevant public security departments organise the prohibition activities together.

The administration of reporting and recording plays an important role in giving effect to the 
provisions prohibiting the exit of China. Nevertheless, its adverse effects cannot be ignored. Firstly, it is unacceptable to inform an individual that they have been prohibited from leaving the territory, orally or in writing without giving a reason for the decision. Secondly, there is no need to prohibit the person from leaving China under the exit and entry laws, because the criminal procedure legislation contains provisions to the same effect. ${ }^{931}$ That is, there is already a body of law in place that ensures people who are due to stand trial in a criminal prosecution, or are a party to a civil case, remain in the territory.

Thirdly, only the People's Court, People's Procuratorates, and public security departments have the power to compel a person to live at home under surveillance (Jianshi Juzhu), ${ }^{932}$ post bail pending trial (Qubao Housheng) ${ }^{933}$ or retain passports and other travel documents. ${ }^{934}$ After reviewing the Law of National Security 1993 (PRC) and the Detailed Rules for the Implementation of Law of National Security 1994 (PRC) and other laws regarding military units, it would seem, on balance, that, national security departments do not have the power or means to prohibit individuals from leaving China. Were any of these bodies to do so, they would unlawfully interfere with the individuals' right to leave. Fourthly, with respect to the calculation of a bond or security provision in Article 3(2), there is concern as to how that sum should be calculated in the absence of any guiding law.

\footnotetext{
931 Article 51 of the Law of Criminal Procedure (Amendment) 1996 (PRC) stipulates “the People's Courts, the Peoples Procuratorates and the public security organs may allow criminal suspects or defendants under any of the following conditions to obtain a guarantor pending trial or subject them to residential surveillance: (1) They may be sentenced to public surveillance, criminal detention or simply imposed with supplementary punishments; or (2) They may be imposed with a punishment of fixed-term imprisonment at least and would not endanger society if they are allowed to obtain a guarantor pending trial or are placed under residential surveillance. The public security organs shall execute the decision on allowing a criminal suspect or defendant to obtain a guarantor pending trial or on subjecting him to residential surveillance."

932 Article 50 of the Law of Criminal Procedures (Amendment) 1996 (PRC).

933 Article 51 of the Law of Criminal Procedure (Amendment) 1996 (PRC) stipulates "the People's Courts, the People's Procuratorates and the public security organs may, according to the circumstances of a case, issue a warrant to compel the appearance of the criminal suspect or defendant, order him to obtain a guarantor pending trial or subject him to residential surveillance."

934 Article 16 of the Detailed Rules for the Implementation of the Law on the Control of Exit and Entry of Citizens (Amendment) 1994 (PRC).
} 
Lastly, there are no provisions to limit the processing period. This greatly reduces the efficiency of controls over individuals prohibited from leaving China, especially those who want to abscond abroad and reside in areas where decision-makers have no jurisdiction. ${ }^{935}$ It is not unusual for such individuals to have absconded before the national border inspection office has received notification from the MPS.

\subsection{Conclusions}

There are numerous unacceptable limits on the right to leave of Chinese citizens. General limits on the right to leave are inappropriate and the legal validity of interpretative provisions are doubtful. Special limits on the right to leave are also questionable, based on their discrimination against overseas employment, overseas pilgrimage, overseas study, kinship relationships, social status, heath status and gender.

As 13 million Chinese citizens must follow the rule of prerequisite certification from the department in which they are employed, when applying to leave China, we could not accept that every Chinese exercise the right to leave at one's will. There is a lack of convincing argument to support the legal basis of the prerequisite certificates and the entitlement of the departments in which the applicant is employed. The rule of prerequisite certification discriminates as to the status of applicants. An extra layer of examination and approval are imposed upon application to leave, and the procedures become yet more complex.

\footnotetext{
935 To illustrate the inefficiency of the system, the following hypothetical has been constructed. 1. Gushi County People's Court of Henan Province is of the opinion that Jack Wang (JW), a party to a civil suit, who resides in Shanghai, should be prohibited from exiting China. 2. The Court official notifies JW that he is not to exit China. In order to prevent his absconding abroad, control measures must be put into place at the national border inspection offices. 3. The Court must report its decision to the Gushi County Public Security Bureau. 4. In turn, the Gushi County Public Security Bureau must report the Court's decision to Xinyang Municipality Public Security Bureau, its higher public security department. 5. The Xinyang Municipality Public Security Bureau must report the decision to the Henan Province Public Security Department. 6. As the Henan Province Public Security Department does not have the power to order border inspection offices in non-Henan provinces to prevent JW from exiting China, Henan Province Public Security Department may consult with responsible provincial public security department. 7 . The responsible provincial public security department can then notify national border inspection officers not release JW from China.
} 
The prospects of severing links with China caused by household deregistration prior to leaving China cannot be ignored. Household deregistration inhibits the right to leave and the right to return, the later will be discussed in next chapter. The right to access foreign exchange in China has been significantly limited. The foremost limits are focused on the right to purchase foreign exchange. Individuals are only entitled to purchase foreign exchange within guiding limits, allowing insufficient sums. Strict limits on the right to remit foreign exchange and carry foreign exchange outward exacerbate the effects of the limits on the right to purchase foreign exchange. The limits have discouraged many Chinese people from exiting China or have led them to illegally access foreign exchange on the black market. Laws governing foreign exchange in China lack legal validity and the legislative system of it is inefficient. Problems can only be resolved by improving legislative technique and by having overriding, or macro-level laws pertaining to the administration of foreign exchange.

In an era when information technology has greatly developed and illegal exit means are being emerged in an endless stream, it is difficult to argue that the impermissible limits could effectively prohibit individuals from leaving China. It may be possible for them to subvert the bad-knit formalities of applying to leave China. Meanwhile, the inefficient administration of individuals prohibited from leaving China, strengthens the point. 


\section{Chapter Ten \\ Limits on the Right to Return to China}

\section{Introduction}

As noted in part 3.5 of this book, in international migration law, no one shall be arbitrarily deprived of the right to return to one's own country, and the denial of the right to return is the source of much unnecessary suffering throughout the world. This chapter considers the issue of the right to return to China from four respects: (i) the limits on the right to return of Chinese citizens, especially dissidents; (ii) the limits placed on the right to return of Chinese citizens residing abroad (overseas Chinese or Huaqiao); (iii) the limits placed on the right to return of irregular Chinese migrants and (iv) the right of nationals not to be exiled in China

\subsection{Limits on the right to return of Chinese citizens, especially dissidents}

Human Rights Watch/Asia has argued, from a political perspective, that the Chinese governments' behaviour in imposing prohibitions on citizens, especially dissidents from returning to China is unacceptable. ${ }^{936}$ This section shall, mainly from a legal perspective, discuss the prohibitions along four lines: (i) the scope of limiting Chinese citizens, especially dissidents right to return; (ii) practices of limiting Chinese citizens, especially dissidents in returning; (iii) effects of limiting Chinese citizens, especially dissidents returning to China.

\subsubsection{The scope of limiting Chinese citizens, especially dissidents to return}

\section{Citizens}

Officially, the Chinese government does not recognise that the limits on return are designed for Chinese citizens. ${ }^{937}$ But practically, the limits do predominantly relate to citizens. One reason

\footnotetext{
${ }^{936}$ Human Rights Watch/Asia and Human Rights in China, China: Enforced Exile of Dissidents: Government "Re-entry Blacklist” Revealed", Vol.7 No.1, January 1995, page 6.

937 See Section 6 of Chapter 4 of "the system of individuals prohibited from entering China", Department of Politics under the MPS, Frontier Defence and Exit and Entry Administration, the Series of Basic Textbook of People's Police
} 
for this is that the Circular of Ministry of Public Security on Print and Delivery Measures of Examination, Approval and Circulation of a Circular of the Lists of Individuals Prohibited from Returning to China 1992 (PRC) contains specialised provisions and is not exclusive of citizens. The other reason is that the Law on the Control of Exit and Entry of Citizens 1985 (PRC) and its detailed rules of the implementation are cited as two of legislative foundations of above circular. ${ }^{938}$ If the system of prohibiting certain individuals from returning to China did not cover Chinese citizens, it would have been unnecessary to do so. Given the fact Hong Kong, Macao and Taiwan were not within the sovereignty of the PRC when above Circular 1992 was promulgated, citizens here imply residents of Mainland China.

\section{Overseas Chinese dissidents}

Prohibited citizens are generally dissidents. Article 1 (2)(3)(4)(5) of above Circular 1992 prescribes:

(2)Those engaged in the activities of terrorism, violence and subversion; or are suspected of undertaking these activities; or will return to China to undertake these activities ensured by efficient evidences;

(3)Those who have engaged in activities of endangering Chinese national security, social and political stability, and social stability in minority areas; or will return to China to undertake these activities ensured by efficient evidences;

(4)Those who have engaged in activities against the PRC abroad and do not have any act or other expressions of repentance;

(5)Those who are wanted criminal suspects. ....

One would expect that if the prohibited citizens are convicted criminals or criminal suspects, the government would be most concerned with bringing them to justice in China as soon as possible, rather than banning them from entering the territory. The most realistic explanation as to why they are not seeking justice in China is that the prohibited citizens are overseas Chinese dissidents. Further evidence to support this point is in Article 1 of the Circular of the General

Operation:(Bianfang Yu Churu Jing Guanli, Renmin Jingcha Gongan Yewu Jichu Jiaocai), examined by Committee of Textbook Editing and Examination of the MPS, the Publishing House of Qunzhong, Internal Publication in Public Security Organs (Gongan Jiguan Neibu Faxing), Beijing, 1999, pages 387 and 388.

${ }^{938}$ Preface of the Circular of the MPS on Delivery Measures of Examination, Approval and Circulation of a Circular of the Lists of Individuals Prohibited from Entering China, 1992 (PRC) (Gonganbu Guanyu Yinfa Buzhun Rujing Mingdan Shenpi Tongbao Banfa De Tongzhi), promulgated by the MPS on 17 February 1992. 
Office of the State Council of Some Issues of Overseas Students 1992 which provides:

Overseas students are welcome to return China for a job. [ ...] the Chinese government will not punish those who made wrong statements and activities abroad (Shuoguo Yixie Cuohua, Zuogu Yixie Cuoshi). Even if they have participated anti-government organisations and were engaged in activities of endangering the security, honour and interests of the State; so long as they can withdraw from such organisations and no longer be engaged in the anti-government activities which violate the Constitution and laws of our country.

In fact the dissidents dominate the re-entry blacklist of citizens. The most infamous list is "A List of 49 Overseas Members of Reactionary Organizations Currently Subject to Major Control". 939 Thus emphasis for the following discussion is on Chinese dissidents.

\section{Residents in Taiwan}

Under Article 22 of the Measures on the Control over Chinese Citizens Travelling to or from the Region of Taiwan 1991 (PRC):

Those within either of the following categories shall not be granted permission to enter the Mainland:

(1) Those who are engaged in criminal activities;

(2) Those who are likely to be engaged activities that undermine national security and national interests.

(3) Those who have fabricated situations and presented forged certifications; and

(4) Mental patients.

Those who are for medical treatment and other special purposes may be exempted to grant permission.

The central government of the PRC has not exercised its sovereign powers over Taiwan, even though Taiwan is evermore isolated and marginal in the world. ${ }^{940}$ On this basis, it is understandable that China would extend system of prohibiting individuals of Taiwan from

\footnotetext{
${ }^{939}$ Human Rights Watch/Asia and Human Rights in China, China: Enforced Exile of Dissidents: Government “Re-entry Blacklist” Revealed, Vol.7 No.1, January 1995, page 1.

$940 \mathrm{Wu}$, Wenxin, "Honestly Review the Functions and Significances of Overseas Chinese Affairs Committee" (Zhengshi Qiaoweihui De Zhineng Yu Jiazhi), Microview Weekly, the ROC, at Domestic News, Volume 493, 5 May 2004; Also see "The Conference of Taiwan Affairs of Northern European Five Countries affirm the Democratic Contribution of Taiwan" (Beiou Wuguo Taiwan Yiti Huiyi Kengding Taiwan Minzhu Chengjiu), Microview Weekly, the ROC, Volume 493, 5 May 2004.
} 
returning to China.

\section{Residents in the HKSAR and MSAR}

Similarly, residents of the HKSAR and MSAR are prohibited from returning to China under some circumstances even after 1997 for the HKSAR and 1999 for the MSAR, when the territories returned to Chinese administration. Both regions are subject to Chinese sovereignty. Article 15 of the Interim Measures Concerning the Control over Chinese Citizens Travelling on

Private Affairs to or from the Regions of Hong Kong or Macao 1986 (PRC) provides:

Those within either of the following categories shall not obtain the Home-Visiting Certificates for Compatriots from Hong Kong and Macao (Gangao Tongbao Huixiangzheng) or entry-exit passes:

(1)Those who are likely to be engaged in such criminal activities as robbery, theft, and trafficking in narcotics;

(2)Those who have fabricated situations and presented forged certifications; and

(3)Mental patients.

After 1997 and 1999, the Home-Visiting Certificates for Compatriots from Hong Kong and Macao respectively was replaced with Travel Permits, but the grounds for prohibition remain.

The MPS has argued that the prohibitions can be attributed to "the special situation of China,"941 but have failed to identify what the "special situation" is. It is presumed that the "special situation" refers to the fact that China is one State with separate regimes in the HKSAR and MSAR. It is not convincing that that special situation can transcend State sovereignty.

\subsubsection{Practices of limiting citizens, especially dissidents to return}

Revocation and confiscation of passports

The revoking of passports is the most direct way to prevent Chinese citizens from retuning to China. Article 4(1) of the Measures of Examination, Approval and Notification of a Circular of the Lists of Individuals Prohibited from Returning to China 1992 (PRC) provides that:

\footnotetext{
${ }^{941}$ Department of Politics under the MPS, Frontier Defence and Exit and Entry Administration, the Series of Basic Textbook of People's Police Operation: (Bianfang Yu Churu Jing Guanli, Renmin Jingcha Gongan Yewu Jichu Jiaocai), examined by Committee of Textbook Editing and Examination of the MPS, the Publishing House of Qunzhong Internal Publication in Public Security Organs (Gongan Jiguan Neibu Faxing), Beijing, 1999, page 387.
} 
Where those with Chinese passports have been on the lists of individuals prohibited from returning to China, their passport shall be simultaneously revoked. If they are in the territory, the public security departments where the passport holders are located are responsible for declaring the revocation of passport, and arresting them. When they return to China with revoked passport, border security check and administrative offices shall refuse their entry, confiscate the passport and send it to the original issuing department.

However the legal basis of revoking dissidents' passports is without substance. Article 22 Clause (1) (c) of the Detailed Rules for the Implementation of Law on the Control of Entry and Exit of Citizens (Amendment) 1994 (PRC) prescribes that where the passport holder has engaged in activities prejudicial to the security, honour and the interests of China, the original issuing department or its higher department has the power to revoke the passport and declare the passport invalid. As this provision actually limits the RLR, according to international norms discussed in part 3.3.3 of this book, it must be strictly construed. This would mean that passport holders must be in China when the prejudicial activities occur, and it does not apply to the activities of dissidents abroad.

It is also necessary to question if border security police and administrative offices have the power to confiscate passports and send them to the issuing department. Under Article 9 of the Law on the Control of Exit and Entry of Citizens 1985 (PRC), these government bodies only have the power to refuse a person to enter into China. Pursuant to Article 16 of the Detailed Rules for the Implementation of Law on the Control of Entry and Exit of Aliens (Amendment) 1994 (PRC), the power to confiscate passports is limited to the public security departments and the original issuing department.

\section{Not replacing, reissuing or extending of passports}

The policy of not replacing, re-issuing or extending dissidents' passports may indirectly prohibit dissidents from returning to China. According to Article 4(3) of the Measures of Examination, Approval and Circulation of a Circular of the Lists of Individuals Prohibited from Returning to China 1992 (PRC):

Where those permanently residing in a foreign country with Chinese ordinary passports have been on the lists of individuals prohibited from returning to China, the prohibition on their returning to 
China might be exercised by not granting their application for passport replacement, re-issue and extension. For special circumstances, their passport might be revoked or declared invalid.

This is the main reason why "[no] dissident has ever been formally notified that they are no longer permitted to return to China; some only learned of the prohibition when they attempted to go back." $" 942$

As for not replacing, reissuing or extending of passports, there is a similarly inadequate legal foundation for the practice of revocation and confiscation of passports. According to Article 17(1) of the Detailed Rules for the Implementation of Law on the Control of Exit and Entry of Citizens 1985 (PRC), an overseas Chinese national may apply for an extension before the passports term of validity expires. Under Article 21 of the just-mentioned detailed rules, where the passports held by Chinese are to expire soon, or the attached pages for visas have been used up so that the terms of validity cannot be extended, or they have damaged and can no longer be used, the holder may apply for a replacement or a re-issue of the passport. ${ }^{943}$ Detailed rules for the implementation, which do not distinguish between applicants, suggest that dissidents are entitled to have their passport replaced, re-issued or its term extended.

\section{Flexible duration of the prohibition}

The duration of prohibition on returning to China is flexible. According to Human Rights Watch Asia, the period of prohibition may be described by Chinese authorities as being "unlimited duration", "five years duration" or "currently not subject to control". 944 Under Article 6 of the Measures of Examination, Approval and Circulation of a Circular of the Lists of Individuals Prohibited from Returning to China 1992 (PRC):

The duration of prohibition on returning to China is generally 1 to 5 years. Those whose mental disease, leprosy, AIDS, venereal disease, active tuberculosis and other infectious diseases have not

\footnotetext{
${ }^{942}$ Human Rights Watch Asia and Human Rights in China, China: Enforced Exile of Dissidents: Government “Re-entry Blacklist” Revealed”, Vol.7 No.1, January 1995, page 2.

943 Article 21 of the Detailed Rules for the Implementation of the Law on the Control of Exit and Entry of Citizens 1985 (PRC).

${ }^{944}$ Human Rights Watch/Asia and Human Rights in China, China: Enforced Exile of Dissidents: Government “Re-entry Blacklist” Revealed”, Vol.7 No.1, January 1995, page 4.
} 
treated, cannot enter China. ... the responsible departments may extend the duration to over five years if they clarify the reasons for extension when reporting. They may conceal the list ahead of schedule or change other important items of the prohibitions if they timely notify the BEEA.

The use of the term "generally" is nebulous and elastic. The discretion of extending the period to over five years or concealing the ban ahead of schedule is too broad to keep a balance between the administration and citizens' interests. This could be addressed by defining the terms more accurately or setting them against a criterion to aid the understanding of administrators and citizens alike.

\subsubsection{Effects of limiting citizens, especially dissidents to return}

The three practices of prohibition described above may have the effect of rendering a citizen practically stateless. Human Rights in China has criticised the central government's abusive interpretation of national security laws to restrict overseas dissidents from returning to China, and that in so doing, to have unilaterally denaturalised this group of overseas citizens. The group of effectively stateless dissidents is becoming larger. ${ }^{945}$

The effective deprivation of nationality means that dissidents are not entitled to the rights prescribed by laws. Article 33 (1) and (3) of the Constitution of the PRC (Amendment) 2004 affirms "All persons holding the nationality of the People's Republic of China are citizens of People's Republic of China;" and "Every citizen is entitled to the rights [...] prescribed by the Constitution and Law." In effect, dissidents who are practically stateless are not Chinese citizens, so are no longer protected by the rights afforded to nationals under Chinese law.

From the perspective of law of nationality, it is possible to question the legal basis of depriving

\footnotetext{
945 Wang, Dan, the student leader of the 1989 Beijing protests, and the coordinator of Chinese Justice Observation, commented in 2003. that "Lots of people have been refused to return to China, most of who did not like to publicise their rejection of a passport extension application for different reasons. It is said that a group of Chinese without Chinese nationality has came into being. See Human Rights in China, "Chinese Justice Observation Appeal to Amend Law on the Control of Exit and Entry of Citizens" (Zhongguo Sifa Guancha Huyu Xiugai Churujing Guanli Fa), Http://gb.hrchina.org/gate/gb/big5.hrchina.org/subsite/big5/article.adp?article id=4224\&subcategoryd=187 $(10 / 05 / 2003)$.
} 
the nationality of dissidents. Nationality is usually lost when the citizens renounce it, and that renouncement is accepted by the State, or when the citizen has acquired another nationality. This general rule has been accepted in articles 9 to 11 of the Law of Nationality 1980 (PRC) which provide that:

Article 9 Any Chinese national who has settled abroad and who has been naturalised as a foreign national or has acquired foreign nationality of his or her own free will shall automatically lose Chinese nationality.

Article 10 Chinese nationals who meet the conditions may renounce Chinese nationality upon approval of their applications...

Article 11 Any person who applies for renunciation of Chinese nationality shall lose Chinese nationality upon approval of the application.

Overseas Chinese dissidents do not fall into any of the above categories. Moreover, there are no provisions regarding deprivation of the nationality in the relevant laws including the Law of Nationality 1980 (PRC). That means that the Chinese government does not have a domestic legal basis to deprive any citizens of nationality. The indirect deprivation of nationality is in violation of international law. According to Article 15(2) of the UDHR, "No one shall be arbitrarily deprived of his nationality, nor denied the right to change his nationality." China has ratified it and has a duty to respect the terms.

Presumably, the absence of a domestic or international legal basis for denying nationality is the reason why the Chinese government does not directly deprive dissidents' nationality. On humanitarian grounds, China should give sympathetic consideration to permitting the return of former residents, particularly those who are stateless and have maintained a strong link with it.

\subsection{Limits on the right to return of Chinese citizens residing abroad (overseas Chinese or Huaqiao)}

Overseas Chinese here means Chinese citizens who have settled abroad. ${ }^{946}$ At the end of the

\footnotetext{
${ }^{946}$ Article 2 Clause 1 of the Law on Protection of the Rights and Interests of Returned Overseas Chinese and the Family Members of Overseas Chinese (Amendment) 2000 (PRC).
} 
20th Century, there were 30 million overseas Chinese, of which, $90 \%$ are in Asia. ${ }^{947}$ Members of this group who intend to return to China for permanent residence or employment must meet the requirements and undertake formalities contained in Chapter 3 of the Law on the Control of Exit and Entry of Citizens 1985 (PRC) and Chapter 3 of the Detailed Rules for Implementing of Law on the Control of Exit and Entry of Citizens (Amendment) 1994 (PRC). This section will address (i) conditions of returning to China for permanent residence or employment; (ii) formalities of returning to China for permanent residence or employment; (iii) household registration after returning to China; (iv) reasons for the limits imposed on the return of overseas Chinese; and (v) effects of the limits imposed on the return of overseas Chinese.

\subsubsection{Conditions of returning to China for permanent residence or employment}

The purpose of returning is not an accepted limit on the right to return. The right to return to China permanently is under the right to return to China. To protect the right to return China means to protect the right to return to China permanently, temporarily, for employment, and so on. Access to permanent resident (hukou system) is the precondition of returning to China permanently as every Chinese citizens permanently residing in China must register one's residence. Thus to protect overseas Chinese right to return to China permanently can't be divorced from protecting overseas Chinese right to freely settle down after their returning. Approval to return to China for permanent residence or for employment is conditional.

\section{Conditions imposed on applicants for permanent residence}

Formatted In the absence of efficient original legislative texts related to the conditions of returning to China for permanent residence, relevant official textbooks ${ }^{948}$, academic texts, ${ }^{949}$ and

\footnotetext{
947 Yang, Fajing, The Introduction to Exit Abroad (Chuguo Zhishi Gailan), the Publishing House of Science Popularisation, Beijing, 1990, page 174. According to the statistics of ROC, Chinese people living overseas reached 36 million in 1993. See Overseas Chinese Affairs Commission, the Republic of China, the Republic of China, Overseas Chinese Affairs Statistics, Taipei, Taiwan, 1994. The bookprefers to the data originated from the PRC because this bookconcentrates on the issues of the Mainland China, and the definition of "Chinese people living overseas" is not very clear.

948 The Department of Politics under the MPS, Frontier Defence and Exit and Entry Administration, the Series of Basic Textbook of People's Police Operation:(Bianfang Yu Churu Jing Guanli, Renmin Jingcha Gongan Yewu Jichu Jiaocai), examined by Committee of Textbook Editing and Examination of the MPS, the Publishing House of
} 
government online application instructions ${ }^{950}$ have been used in order to explain how the conditions operate. Five categories of overseas Chinese are eligible for returning to China for permanent residence if they provide the required documentation. They are:

(1) Chinese citizens' overseas spouse, orphans and widows who cannot resolve their living issue independently, and for whom a person in China will resolve the applicant's employment, housing and general needs after the applicant returns to China so that the assistance of the State is not required.

(2) Aged overseas Chinese who insist on returning to China due to being unaccustomed to the climate and customs of their host country, and cannot speak the language of that country, or who have bought property in China and have foreign exchange savings or pensions in China, and whose relatives in China can resolve their living needs.

(3) Overseas Chinese who cannot support themselves due to persecution, where the local Chinese embassy or consulate thinks that it is necessary for persecuted overseas Chinese to return to China, and the person accepts the arrangement proposed by the Chinese government.

(4) Overseas Chinese who make an application to return to China for permanent residence within a short period of time after leaving China to reside permanently in a foreign country. The application needs to submit the approval of their former work unit and resolve their housing and general needs independently.

(5) High-quality overseas Chinese who are in high demanding in China.

With the exception of the fifth category (who are encouraged to return to China for permanent residence due to their potential financial and educational contribution to the development of

Qunzhong Internal Publication in Public Security Organs (Gongan Jiguan Neibu Faxing), Beijing, 1999, page 382; and Wang, Guoliang and Zhu, Lin, the Administration on Exit and Entry, one of Planning Textbooks of Higher Education of People's Police (Renmin Jingcha Gaodeng Jiaoyu Guihua Jiaocha: Churujing Guanlixue), Interior Published within Public Security Organs (Gongan Jiguan Neibu Faxing), the Publishing House of China University of People's Public Security, Beijing, 2002, page 101.

949 Xiang, Dang, the Guide to the Law of Exit and Entry in China and Foreign Countries (Zhongwai Churujing Falv Zhinan), the Publishing House of China University of People's Public Security, Beijing, 1998, page 136.

950 Exit and Entry Administration of Guangdong Public Security Department, "Returning to China for Permanent Residence of Overseas Chinese" (Huaqiao Huiguo Dingju), http://www.gdcri.com/zggmcg/hchgdj (19/06/2003). 
China), the other categories of applicants need to provide many documents to certify their own or their sponsor's ability to support their living and housing needs after returning to China. This can include titles to property, pension certificates, deposit statements and evidence of the relationship between the applicant and sponsor.

Under Article 2 of the Circular of the State Council of Overseas Chinese Affairs Office, the Ministry of Foreign Affairs, Ministry of Public Security, Ministry of Labour and Ministry of Finance on the Arrangement Measures for Returned Korean and Mongolian Chinese for Permanent Residence 1989:

The application for returning to China for permanent residence of Korean and Mongolian Chinese will not be accepted unless the applicants provide the evidence that their housing and employment has been acquired and solved through their own efforts....

It is accepted that the economy of North Korea and Mongolia is less developed than China. Logically, Korean and Mongolian Chinese would like to return to China. But they must meet above cited conditions. According to the report of Southern Municipality Daily, China in 2004, the requirements of conditions imposed on applicants for permanent residence become more and more strict. Besides the requirements of the solution of housing and employment, Korean Chinese need to meet the requirements of the separation duration of the spouse. And so on. . ${ }^{951}$ In short, China only permits overseas Chinese to resume permanent residence if they will not burden the community. In short, China only permits overseas Chinese to resume permanent residence if they will not burden the community.

Returning to China for employment

Formatted

The Chinese government usually persuades applicants to withdraw the application, settle in host

${ }^{951}$ Korean Chinese is discomfiture and longing for returning to China after the explosion of the train In North Korea (, Southern Municipality Daily (Nanfang Dushi Bao)29 April 2004, http://news.sina.com.cn/c/2004-04-29/10182432253s.shtml <03/05/2005> 
countries and integrate into local communities. ${ }^{952}$ Since 1986, applications for returning to China for employment need to be supported by evidence that their qualifications might meet the demands of the domestic employment market, and that they have the ability to find a job.

Chinese citizens who have settled in Taiwan wanting to return to China for permanent residence

Formatted

Chinese citizens who have settled in Taiwan also need to meet the relevant conditions to resume permanent residence. According to Article 1(1)(1) of the Circular of the Ministry of Public Security on Some Issues of Exit and Entry Mainland of Mainland Residents Granted Permanent Residence of Taiwan Regions 1995 (PRC);

The applications of Chinese citizens, who have settled in Taiwan regions, for returning to China for permanent residence shall be severely examined and approved. Where the applicant settled in Taiwan for more than five years, their applications should be processed in accordance with the relevant provisions of No. [1990] 15 document of the Central Committee of the CPC. The Permit of Permanent Residence of Taiwan Compatriot (Taiwan Tongbao Dingjuzheng) shall be issued to approve applicants. Where [the applicant resided in Taiwan] for less than five years, they may undergo the procedure of regular household registration after returning and destroying their Taiwan travel documents and exit-entry documents.

Clearly, Chinese citizens who have settled in Taiwan regions are not treated as Chinese citizens but as Taiwan residents.

It is common sense that aliens need to abide by relevant conditions and undergo the procedures, if they wish to reside permanently in a foreign country; whereas nationals should be free to return to their State for any purpose upon presentation of a passport. By contrast, the imposition of strict conditions on overseas Chinese returning to China equates them with aliens or quasi-aliens rather than nationals. ${ }^{953}$

952 Mao, Qixiong (ed), The Encyclopedia of Overseas Chinese and Foreign Chinese: the Volume of Laws, Regulations and Policies (Huaqiao Huaren Baike Quanshu: Falv Tiaoli Zhengce Juan), the Publishing House of Overseas Chinese of China, Beijing, 2000, page 494.

953 Xiamen Government, "the Regulations for Persons Entering China from Overseas", http://www.xm.gov.cn/eng/investmentguild/ma037.html (17/11/2003); and Xiamen Government, "Entry and Exit Regulations", http://www.xm.gov.cn/eng/investmentguild/ma036.html (17/11/2003). 


\subsubsection{Formalities of returning to China for permanent residence or employment}

With the exception of returning to China for a short period of time, ${ }^{954}$ return either for the purpose of assuming permanent residence or employment requires application to the responsible department in the light of complex formalities.

Returning for permanent residence

Formatted

Article 10 of the Law on the Control of Exit and Entry of Citizens 1985 (PRC) provides that:

Chinese citizens residing abroad who want to return to China for permanent residence shall complete the relevant procedures at the diplomatic missions, consular offices or other agencies located abroad that are authorized by the Ministry of Foreign Affairs, or at public security departments of the relevant provinces, autonomous regions, or municipalities directly under the State Council.

Article 10 of the Detailed Rules for Implementing of Law on the Control of Exit and Entry of Citizens (Amendment) 1994 (PRC) further provides that:

.... They, through their relatives in China, may also make an application to the municipal or county public security bureau in the locality of their destination. Return residence permits shall be granted upon examination by the public security department or bureau of the provinces, autonomous regions or municipalities directly under the State Council.

The Sate Council for Overseas Chinese Affairs Office (OCAO) is responsible for the overall administration of overseas Chinese who want to return for permanent residence. Provincial offices (OCAO) examine and determine the applications in details. Under Article 5 (1) of the Explanation of the Ministry of Public Security on Some Issues on the Implementation of Law on the Control of Exit and Entry of Citizens and Its Detailed Rules for Implementation 1987 (PRC):

The diplomatic [agencies] located abroad that are authorised by the MFA shall report the applications for returning to China for permanent residence of overseas Chinese to the OCAO; Municipal or county public security departments shall refer the applications, which are lodged by overseas Chinese themselves or their domestic relatives on behalf of them, for returning to China

\footnotetext{
${ }^{954}$ Under Article 9 of the Detailed Rules for Implementing of the Law on the Control of Exit and Entry of Citizens (Amendment) 1994 (PRC), "Chinese citizens who are permanent residents of a foreign country and return to China to stay for a short period of time may enter the country by presenting their valid Chinese passport or valid Chinese travel permit or other valid entry-exit certificates."
} 
for permanent residence of overseas Chinese to local office (OCAO). Provincial office (OCAO) shall grant the application upon consulting with relevant responsible departments, including the public security department. Provincial public security departments shall issue Return Residence Permits of Overseas Chinese (Huaqiao Huiguo Dingju Zhengming) pursuant to the approval letter from the OCAO.

\section{Returning for employment}

Article 11 of the Detailed Rules for Implementing of Law on the Control of Exit and Entry of

Citizens (Amendment) 1994 (PRC) stipulates:

Chinese citizens who are permanent residents of a foreign country and request to return to China for employment shall make an application to China's labour and personnel department or to the host or employing organisations.

The application procedure was fully reviewed as following in the Explanation of Law and

Regulations Governing Exit and Entry and the Collections of Related Regulations:

China's labour and personnel department, or the host or employing organisation, shall make the decision according to the demand of the regional employment market. If granted, a Certificate of Engagement or Employment (Pinqing Guyong Zhengming), approved by labour and personnel department, is issued. Overseas Chinese may then return to China for employment and register their household. ${ }^{955}$

Obviously, the multi-staged approval process could take overseas Chinese much time and energy, especially if relatives in China make the application on their behalf. Meanwhile, the absence of a maximum prescribed processing period could mean that the application takes even longer. To avoid these complicated procedures, some overseas Chinese might be inclined to return to China without undergoing the procedure of application and approval.

Under Article 7 of the Regulation of Inspection of Exit and Entry Borders 1995 (PRC) and Article 3(1) of the Circular of the Ministry of Public Security on Handling Means of Some Issues on the Implementation of Checking, Monitoring and Prevention of Exit and Entry in Regulation of Inspection of Exit and Entry Borders 1995 (PRC), border inspection offices must

955 Mao, Fengping (ed), the Explanation of the Law and Regulations Governing Exit and Entry and the Collections of Related Regulations (Chujing Rujing Falv Fagui Sijie Yu Xiangying Fagui Zhaibian), the Publishing House of Jilin Renmin, Changchun, China, 1994, page 88. 
release the individuals returning to China after checking their passport and other entry certificates. The purpose of returning to China is not checked. As such, it is possible that the OCAO and public security departments will not know who has re-entered the territory for the purpose of permanent residence or employment. This loophole provides an opportunity for overseas Chinese to avoid the complex formalities.

\subsubsection{Household registration after returning to China}

In the light of the background of the household registration system in China, it is understandable that all overseas Chinese returning to China must register upon return. The system is also an important aspect of the limits imposed on the return of overseas Chinese.

Article 11 of the Law on the Control of Exit and Entry of Citizens 1985 (PRC) provides that:

After their entry into China, Chinese citizens who have come for permanent residence or employment shall register for regular residence in accordance with the provisions for the administration of residence. Those who have entered for a temporary stay shall register for temporary residence in accordance with the same provisions.

These provisions are detailed in the Detailed Rules for Implementing of Law on the Control of Exit and Entry of Citizens (Amendment) 1994 (PRC). In the case of returning for permanent residence or employment, under articles 12 of the Detailed Rules 1994 provides that returned overseas Chinese for permanent residence or for employment are required to register their household:

...[With] in 30 days of arrival at their destination, undergo the procedures for regular residence registration at the local public security bureau by presenting their return residence permits or the certification of engagement of employment as approved by China's labor and personnel department.

This process creates a vital means of stopping overseas Chinese from returning to China without undergoing the procedure of application and approval, because not to undergo the procedure of application and approval means that the person will not hold the necessary residency permit of employment certificate, and will be unable to register their household. 
For returning for temporary residency, Article 13 of the Detailed Rules 1994 provided that returned overseas Chinese for a short period of time ${ }^{956}$ shall under go the registration procedures for temporary residence:

...Anyone who lodges at such enterprises and institutions as guesthouses, hotels, inns, hostels or schools, or at State departments, social departments or other institutions, he or she shall fill in temporary lodging registration forms, whereas, for anyone who lodges at the homes of one's relatives or friends, one's relatives and friends, shall, within 24 hours, 72 hours for those in rural areas, undergo temporary residence registration at the local police station or residence registration office.

Similar requirements of household registration could be found in Vietnamese law. ${ }^{957}$

\subsubsection{Reasons for the limits imposed on the return of overseas Chinese}

The discussion so far demonstrates that the limits imposed on the return of overseas Chinese for permanent residence or for employment are not consonant with international norms and infringe on the right to return. Carefully exploration of the reasons behind the limits being imposed is needed, before any ideas as to how to essentially relax government control over the return of this group, are advanced. ${ }^{958}$

\footnotetext{
${ }^{956}$ A short period of time means less than a year, according to the Exit and Entry Administration and Bureau of Border Security Check and Administration in Jilin Province. See Exit and Entry Administration under Jilin Province Public Security Department and Bureau of Border Security Check and Administration under Jilin Province Public Security Department (ed), the Kit of Exit, Entry and Frontier Defence (Shiyong Churu Jing Bianfang Zhishi Daquan), the Publishing House of Jilin Wenshi, Changchun, China, 1994, page 37.

957 Chapter III Residence of Ordinance on Entry, Exit and Residence of Foreigners in Vietnam 2000, Standing Committee of National Assembly No. 24-2000-PL-UBTVQH10. Article 11 Clause 1 provides "Upon entry, foreigners must register the purpose and length of stay and their residential address in Vietnam, and their activities must comply strictly with the registered purposes."

958 In 1990, the Consular-General of the PRC in New York submitted Suggestions of Consulate-General of the PRC in New York on Relative Relaxation of Returning to China for Permanent Residence of Overseas Chinese to the OCAO, BEEA under MPS and the Department of Consular Affairs under the MFA in which he expressed the hope that conditions could be relaxed and processing times shortened. These suggestions were rejected in Opinions of State Council Overseas Chinese Affairs office, Exit and Entry Administration under MPS and Department of Consular Affairs under the MFA on Returning to China for Permanent Residence of Overseas Chinese 1991 (PRC). The suggestion that processing of applications should take a maximum of three months was rejected on the grounds that such a proposal was unrealistic given the nature of the examination and approval process, and the time that it takes to post documents. The only suggestion that was accepted was that, in the case of overseas offices where applications
} 
The first reason for the limits can be found in China's policy towards overseas Chinese over time. Since the establishment of the People's Republic of China in 1949, the government has imposed a policy of supporting and encouraging overseas Chinese to freely settle in host countries, assume the nationality of host countries, and to live in harmony with its people. ${ }^{959}$ That implies, although it is not stated, that the Chinese government has a passive policy towards or is uninterested in the return of overseas Chinese, especially for permanent residence. The main reason for the Chinese government to encourage overseas Chinese to settle down in the host country is the evident concerns in many Southeast Asian countries that close connections between overseas Chinese and the PRC may bring in communist uprising. With the improvement of the relationship between China and other countries, the concerns in many Southeast Asian countries have passed its peak. ${ }^{960}$ Another reason is the concerns about China's population. The population of China reached $1,286,975,468$ in July $2003 .{ }^{961}$ This huge population poses a challenge for economic development. In the context of strict national family planning policy ${ }^{962}$ and lack of employment opportunities, it is difficult for the government to

are lodged, the application may be reported directly to a provincial office (OCAO). This removed the requirement of reporting the application to a county or municipal overseas office first.

959 Yang, Fajing, the Introduction to Exit Abroad <Chuguo Zhishi Gailan>, the Publishing House of Science Popularisation, Beijing 1990 pages 173-174; and Wang, Guoliang and Zhu, Lin, The Administration on Exit and Entry, one of Planning Textbooks of Higher Education of People's Police $<$ Renmin Jingcha Gaodeng Jiaoyu Guihua Jiaocha: Churujing Guanlixue>, (Interior Published within Public Security Organs) <Gongan Jiguan Neibu Faxing >, the Publishing House of China University of People's Public Security, Beijing, 2002, at 101.

960 During the visit of President Hu, Jingtao in April 2005, both sides have reached wide consensus on further developing bilateral relations. President $\mathrm{Hu}$ Jintao and Sudan Bolkiah of Brunei unanimously agreed to continue China-Brunei friendly and cooperative relations of good neighbors. President Hu and President Susilo of Indonesia signed the joint statement on establishing the strategic partnership between both countries. Hu Jintao and President Arroyo of the Philippines decided to establish the strategic and cooperative relations committed to peace and development. These have pushed China's traditionally friendly relations with the three countries into a new development phase. See Li Zhaoxing Says That President Hu Jintao 's Tour to Three Southeast Asian Countries Made Fruitful Achievements http://www.fmprc.gov.cn/eng/zxxx/t193962.htm $<01 / 05 / 2005>$

961 CIA, The World Factbook: China, 18 December 2003, http://www.cia.gov/cia/publications/factbook/geos/ch.html $<2 / 02 / 2004>$.

962 The government has undertaken a range of comprehensive measures to control the quantity of population and improve the quality of population, such as "one child in one family policy." A strict national family planning policy has been in place since the 1970 s for this purpose, which was given effect by Article 2 of the Law on the Population and Family Planning 2001 (PRC). 
welcome a large number of overseas Chinese to be back China.

Preferential policies in regard to returned overseas Chinese created another important reason to limit the return of overseas Chinese. The official policy has been captured in Article 3 (2) of the Detailed Rules of the Implementation of Law on the Protection of the Rights and Interests of Returned Overseas Chinese and the Family Members of Overseas Chinese (Amendment) 2000 (PRC):

The State shall, in accordance with the practical conditions and the characteristics of returned overseas Chinese and the family members of overseas Chinese, give them appropriate preferential treatment, and the specific measures thereof shall be formulated by the State Council or the relevant competent departments under the State Council.

Based on this the government has promised to "make arrangements for overseas Chinese who have to return to the country and settle down here permanently." 963 The obligations of the government are contained in Article 4 of the Law on the Protection of the Rights and Interests of Returned Overseas Chinese and the Family Members of Overseas Chinese (Amendment) 2000 (PRC) which prescribes that:

Local governments and departments concerned shall make arrangements for overseas Chinese who have returned to reside permanently in the country pursuant to the relevant provisions of the State.

This obligation places a heavy financial burden on the State. Additionally, the arrangements may not satisfy the returned overseas Chinese, as much of the time, due to the needs of a developing economy in China, they are placed in jobs on farms, in forestry and factories. ${ }^{964}$

\footnotetext{
963 Article 5 the Law on the Protection of the Rights and Interests of Returned Overseas Chinese and the Family Members of Overseas Chinese (Amendment) 2000 (PRC).

964 See Article 9 Clause 1 of the Law on the Protection of the Rights and Interests of Returned Overseas Chinese and the Family Members of Overseas Chinese (Amendment) 2000 (PRC), Article 6 to 8 of the Detailed Rules of the Implementation on Protection of the Rights and Interests of Chinese and Family Members of Overseas Chinese 1993 (PRC) and the Minute of National Working Meeting on Overseas Chinese Farms and Factories (Quanguo Huaqiao Nongchang Gongchang Goongzuo Huiyi Jiyao). Also see Mao, Qixiong (ed), the Encyclopedia of Overseas Chinese and Foreign Chinese: the Volume of Laws, Regulations and Policies (Huaqiao Huaren Baike Quanshu: Falv Tiaoli Zhengce Juan), the Publishing House of Overseas Chinese of China, Beijing, 2000, page 494.
} 
Those who are dissatisfied may prefer to return to the foreign country from which they came. ${ }^{965}$ This in turn escalates the financial cost of the arrangements made and damages China's reputation. Consequently, the current laws and regulations were promulgated to prevent the same series of events from occurring in the future.

In summary, as Wang Guoliang has said in Administration on Exit and Entry, one of Planning Textbooks of Higher Education of People's Police:

The issues of overseas Chinese returning to China for permanent residence $[\ldots]$ concentrate on the enforcement of the policy of arranging a job, housing and life of returned overseas Chinese. Therefore, the application [of the policy] should be considered carefully and comprehensively. ${ }^{966}$

Hence, the right of overseas Chinese to return is not the foundation upon which laws regarding the return of overseas nationals are based, but rather policy concerned with over population and developing economic conditions. ${ }^{967}$

\subsubsection{Effects of the limits on the return of overseas Chinese}

Effects of the limits on the return of overseas Chinese can be analysed from both an international and domestic level. Internationally, as analysed in part 3.5 of this book, no limits are acceptable by international norms. Hence, every Chinese national is entitled to return to

\footnotetext{
${ }^{965}$ China experienced a lot of return migration during the 1950s and late 1970s. During this period, large numbers of Vietnam Chinese returned due to the anti-Chinese policy in South Vietnam. There was similarly a large wave of return migration from Indonesia during the 1960s. By the late 1970s, over 200,000 nationals had returned from Vietnam, Laos and Cambodia and Indonesia. Some of the nationals who had returned from Indonesia re-exited China illegally during the 1970 s.

966 Wang, Guoliang and Zhu, Lin, the Administration on Exit and Entry, one of Planning Textbooks of Higher Education of People's Police (Renmin Jingcha Gaodeng Jiaoyu Guihua Jiaocha: Churujing Guanlixue), Interior Published within Public Security Organs (Gongan Jiguan Neibu Faxing), the Publishing House of China University of People's Public Security, Beijing, 2002, page 101.

967 The MPS contend that even though overseas Chinese may return to China for permanent residence, they must lodge the application and be granted approval because of over population and developing economic situation. See Department of Politics under the MPS, Frontier Defence and Exit and Entry Administration, the Series of Basic Textbook of People's Police Operation: (Bianfang Yu Churu Jing Guanli, Renmin Jingcha Gongan Yewu Jichu Jiaocai), examined by Committee of Textbook editing and Examination of the MPS, the Publishing House of Qunzhong Internal Publication within Public Security Organs (Gongan Jiguan Neibu Faxing), Beijing, 1999, page 382
} 
China. However, current policies towards overseas Chinese and returned overseas Chinese concentrate on the encouragement of their integration into the host country and basic living arrangements in China, rather than the protection of their right to return. An overseas Chinese who does not fit into one of the prescribed categories (see part 10.1.1 above) may be ineligible to return. Similarly, an overseas Chinese who cannot show that their qualifications will meet the needs of the employment market, might also be prohibited from returning. Clearly, the right of overseas Chinese to return is fundamentally limited.

Domestically, the limits are unfair and arbitrary. China only approves the applications of overseas Chinese to return for permanent residence if they will not burden the Chinese community and belong to one of the prescribed classes of eligible entrants. The universal right to return is abused for young overseas Chinese and overseas Chinese' spouses who cannot support themselves, to name just two groups.

In practice the limits on the right to return do not help solve China's underlying problems. Because the limits apply to all overseas Chinese, it is very likely that the limits may simultaneously prohibit the return of overseas Chinese who are a potentially valuable asset. ${ }^{968}$ Ethnic Chinese living outside of China produced as much as wealth as China itself in the early 1990s. ${ }^{969}$ The prohibition may only deepen underlying problems.

\subsection{Limits on the return of Chinese irregular migrants}

In the view of Chinese official authority, Chinese irregular migrant refers to migrants who either illegally entered into a foreign country, or overstayed a legally acquired visa. ${ }^{970}$ There are at

\footnotetext{
968 Then President Jiang, Zemin said in 1999 National Working Conference of Overseas Chinese that several millions overseas Chinese is Chinese unique and valuable resource. Quoted in Mao, Qixiong, the Encyclopedia of Overseas Chinese and Foreign Chinese: the Volume of Laws, Regulations and Policies (Huaqiao Huaren Baike Quanshu: Falv Tiaoli Zhengce Juan), the Publishing House of Overseas Chinese of China, Beijing, 2000, page 493.

969 Tanzer, Andrew, “The Bamboo Network”, Forbes, July 18, 1994, pages 138-145.

970 Preface of the Circular of the MFA and MPS on Replacing, Extending and Re-issuing Passport for Irregular Emigrants 1992 (PRC) (Waijiaobu Gonganbu Guanyu Wei Feifa Yimin Bu Huan Fa Huzhao De Tongzhi), jointly promulgated by the MFA and MPS on 30 October 1992. The definition is similar to that used in international legal
} 
least 11 million Chinese irregular migrants currently. ${ }^{971}$ Irregular migration is a trans-national issue and, as such, host countries of irregular migrants are also affected. ${ }^{972}$ Though Chinese can return to China with a valid Chinese passport, ${ }^{973}$ many Chinese irregular migrants cannot return because their passports have not been reissued, replaced or extended. This section concentrates on the conditions and formalities of passport re-issue, replacement and extension for irregular migrants, and its effects.

\subsubsection{Conditions of passport re-issue, replacement and extension of irregular migrants}

Chinese overseas diplomatic missions, consular offices and other authorised agencies are responsible for handling applications for passport re-issue, replacement, and extension for nationals who are abroad, pursuant to Article 17(2) and Article 21 of the Detailed Rules for the Implementation of Law on the Control of Exit and Entry of Citizens 1985 (PRC). Articles 1 to 7

parlance. See the IOM, Myths and Realities of Chinese Irregular Migration, No. 1 of IOM Migration Research Series, the IOM, Geneva, Switzerland, 2000, 44 pages, page 7.

971 According to the figures released by the IOM in 2000, "conservative estimates gave around 2.7 million irregular migrants in late 1997 in East and South-East Asia alone, no small number in comparison to the estimated 5 million irregular migrants in the USA as of 1996 and 3 million in Europe." See IOM, Myths and Realities of Chinese Irregular Migration, No. 1 of IOM Migration Research Series, IOM, Geneva, Switzerland, 200044 pages, page 12; Also James Chin argued in 2003, "to some extent, it could be said that China provides the largest number of East Asian irregular immigrants to Europe." See Chin, James K., "Reducing Irregular Migration from China". International Migration, Volume 41, Number 3 (September 01, 2003), pages 49-72, http://ejournals.ebsco.com/direct.asp?ArticleID=445TEX0XG8PNYXEQH1X5 (01-10-2003), at 50.

${ }^{972}$ For example, in December 1994, “[t]he Chinese Government was effectively refusing to take back hundreds of people who have recently arrived by boat in Darwin, leaving Australia facing its worst refugee crisis in 15 years. Chinese officials are understood to have said they would not take ant Vietnamese Chinese refugees - who make up the bulk of recent arrivals - unless they gave a written guarantee that they were going voluntarily - something they are considered unlikely to do ... Australian officials were attempting to negotiate a more cooperative arrangement with China." See Middleton, Karen, "China "no" to boat people - Bolkus demands end to "racket", in Age, 29 December 1994; also the Australian Federal Government "has agreed to contributed to the cost of relocating nearly 800 Sino-Vietnamese boat people held in Australia, following the announcement today of a landmark deal under which detainees will be repatriated." See Hutcheon, Stephen, Age, 10 April 1995. Both are in Wright, Jillian, Migration OZ Update, June 1995, published by Bureau of Immigration, Multicultural and Population Research, Carlton South, Australia, page 11.

973 Article 2 of the Law on the Control of Exit and Entry of citizens 1985 (PRC); Xiang, Dang, The Guide to the Law of Exit and Entry in China and Foreign Countries (Zhongwai Churujing Falv Zhinan), the Publishing House of China University of People's Public Security, Beijing, 1998, page 43; Xiamen Government, "Entry and Exit Regulations", http://www.xm.gov.cn/eng/investmentguild/ma036.html (17/11/2003). 
of the Circular of Ministry of Foreign Affairs and Ministry of Public Security on Passport

Re-issue, Replacement and Extension of Irregular Migrants 1992 (PRC) provide the conditions

under which designated authorities process applications. This Detailed Rule is a unique internal

policy in this regard and not accessible to the public. It is thus noteworthy to translate and quote most of them.

(1) Where the applicants left China with a legal passport and visa and overstayed without acquired visas, one's applications for passport re-issue or extension shall not be approved unless they have been granted or will be granted a permanent residence status of host country, or have been granted work permit (the latter is only applied to the USA).

(2) Where the applicants left China with [public affairs passports] or were smuggled from China without passports, then smuggled into a foreign country or enter a foreign country holding a false passport or travel documents, one's applications for passport replacement, re-issue or extension shall be strictly examined, not be granted unless they have been granted or will be granted a permanent residence status of host country, or been granted a work permit. The applicants also need to provide the detailed statement of smuggling and the detailed explanation of one's domestic situation. Where the applicants left China with [public affairs passport] in the name of a contract labour service, one's application for the replacement of an ordinary passport for private affairs shall not be granted unless they have provided the detailed written statement of leaving China, have been or will be granted permanent residence status of host country, or been granted a permanent job and host country might not make diplomatic negotiation with China if the application is granted. The situation of irregular migrants who gain the right of permanent residence in foreign countries due to the status of refugee is very complex. .... Their applications for renunciation of Chinese nationality shall not be accepted. Their application for passport shall be strictly examined. Where they leave for a foreign country with [public affairs passport], the application for reissuing or replacing with [private passport] shall be respectively reported to the [designated authorities] ...

(3) Where they applied for refugee status for only residing permanently, and agreed to honestly explain the purpose of their application for passport, give up refugee status, return old passports they originally held, overseas diplomatic missions and consular offices shall grant the application after criticizing and enlightening.

(4) Where the applicant left China with [private passport], legally entered other countries and overstayed without acquired visas, or illegally entered a foreign country with [private passport], the application for passport extension shall usually be acceptable. Overseas embassies and consulates may prolong the period of processing application according to the actual situation of different application. If the extension of passport might cause host country's to question or gather evidence against China, the application shall not be accepted. (7) Where irregular migrants need to return to China due to being unable to support themselves, or are repatriated by the host country, overseas embassies and consulates may issue single-journey travel certificates and take prior passports back. ... 
As to irregular migrants who have been granted refugee status by the third country or areas, if host country insist in repatriating them, overseas embassy and consulates shall try the best to repatriate them to prior permanently residing country or areas.

With respect to irregular migrants who reject the repatriation of the host country, overseas embassy and consulates shall refuse the repatriation requirements by reason that the irregular migrants do not agree to return to China. Where the host country insists on requiring the Chinese government to accept the repatriated irregular migrants, overseas embassy and consulates shall uphold the principle of checking first and repatriating second.

It is extremely difficult to meet the requirements for permanent residence or work permission, because most irregular migrants do not have professional skills, business skills or immediate relatives who are legally present in the host country. If they did, it is likely that they would lawfully leave China and enter a foreign country. As such, the majority of applications from irregular migrants are not approved because they lack the required documentation.

The limits on the application of Chinese with refugee status in a foreign country for renunciation of Chinese nationality are so serious that they violate the relevant provisions of China and the UN. Article 12 of the Law of Nationality 1980 (PRC) provides that "State functionaries and military personnel on active service shall not renounce Chinese nationality". Article 10 provides that Chinese nationals who have settled abroad may renounce their Chinese nationality upon approval of their applications. Chinese nationals with refugee status in a foreign country do not fall in the categories of Article 10 and 12, so their application for renouncing Chinese nationality should be granted. However, the circular stipulates that their applications shall not be accepted.

The requirement of firstly giving up refugee status in a foreign country, illustrates that China will not take back irregular migrants with refugee status in a foreign country. China argues that the system of political asylum in Western countries connives with the irregular migrant. ${ }^{974}$ This places the issue of repatriated Chinese irregular migrants into the context of a disagreement over refugee systems between China and the West. The International Organisation of Migration

974 Yang, Fajing (ed), the Introduction to Exit Abroad (Chuguo Zhishi Gailan), the Publishing House of Science Popularisation, Beijing, 1990, page 13. 
(IOM) has considered that China appears unwilling to accept asylum seekers whose applications have been denied. ${ }^{975}$ According to Article 12 of the ICCPR, in no case may a person be arbitrarily deprived of the right to enter one's own country. The status of refugees in a foreign country may not be critical to an assessment of the right to return to one's own country, yet the precondition of giving up refugee status before returning to China obviously interferes with the right of Chinese to return to China.

The legal criteria for accepting applications for passport extensions of Chinese who have legally left for a foreign country with a private passport and who have overstayed are inadequate. Under the provisions of the circular, approval does not rely upon the relevant provisions of Chinese law, but references the potential effects of granting the extension. Intergovernmental relations are placed ahead of citizens' rights to have their passport extended.

\subsubsection{Formalities of passport reissue, replacement and extension of irregular migrants}

The processing period of passport extension is normally four working days, and six working days for reissue and replacement in overseas diplomatic mission and general consular offices. ${ }^{976}$ However, according to Article 8 (1)(3) of the Circular of Ministry of Foreign Affairs and Ministry of Public Security on Passport Re-issue, Replacement and Extension of Irregular Migrants 1992 (PRC):

The processing period of passport re-issue and replacement is generally at least three months. Even though the applicant meets the requirements of the conditions, the period may be prolonged if the original passport was secretly altered, damaged, tore open or intentionally concealed, or destroyed by melting or burning. Overseas diplomatic missions and consular offices may decide the period range from six months or over one year depending upon the nature of mistakes, attitude of acknowledgment and the reasons of application for re-issue and replacement.

Because the Circular of Ministry of Foreign Affairs and Ministry of Public Security on Passport Re-issue, Replacement and Extension of Irregular Migrants 1992 (PRC) is an internal policy,

\footnotetext{
975 The IOM, Myths and Realities of Chinese Irregular Migration, No. 1 of IOM Migration Research Series, the IOM, Geneva, Switzerland, 2000, 44 pp, page 30.

976 Consulate General of the People's Republic of China in Sydney, "The Chart of the Consular Affairs Fees and Urgent Fees" (Lingshi Guifei Jiajifei Biaozhun Yilanbiao), April 2003, http://www.chinaconsulatesyd.org.cn/chn/premade/47184/sydney.htm (4/12/2003).
} 
the guidelines for protraction of the administrative process for passport extensions are not publicly accessible. The official explanations about the processing period are often very vague. In 2004, the Sydney Consulate General of the PRC website stated that "the processing period for application for passport re-issue and replacement depends on the reply of domestic departments to Consulate General enquires."977 Faced with an inaccessible policy and vague instruction, applicants are unable to predict how long the process will take or plan to take remedial action to remedy an infringement of their rights.

It is argued that the protraction of the application process is regarded as a way of punishing and preventing illegal migration by the Chinese government. An irregular migrant who violates laws may be punished in accordance with the relevant provisions of Chinese law, such as Article 22 of the Detailed Rules for the Implementation of Law on the Control of Entry and Exit of Aliens (Amendment) 1994 (PRC), Article 15 of the Regulations of Inspection of Exit and Entry Borders 1995 (PRC) and Article 322 of the Law of Criminal 1997 (PRC). It is unacceptable to punish an illegal migrant by drawing out administrative processes, when laws exist to punish specific offences. The administrative strategy results in double punishment on illegal migrants, which could be seen as unfair or oppressive.

Administrative practices suggest that there is not necessarily a link between passport availability and illegal migration. In 2003, Zhang Fang and Ye Youse, the Deputy Director and Deputy Team Leader of the Exit and Entry Administration within the Fujian Province Public Security Department, stated that "passports are possibly an important channel of increasing legal migrants and decreasing illegal migrants." ${ }^{978}$ Protraction of the application process is thus not a persuasive way of decreasing illegal migrants. Clearly, the unacceptable procedural

\footnotetext{
977 Consulate General of the People's Republic of China in Sydney, "The Chart of the Consular Affairs Fees and Urgent Fees" (Lingshi Guifei Jiajifei Biaozhun Yilanbiao), April 2003, http://www.chinaconsulatesyd.org.cn/chn/premade/47184/sydney.htm (12/01/2004)

978 Fujian Province is the largest source of illegal migrants of China. Zhang, Feng and Ye, Youshen, Exit and Entry Administration According to Laws and Crackdown of Illegal Migration (Shilun Yifa Guanli Churujing Xingwei Yu Daji Feifa Yimin Huodong), No. 2 (2003) of Journal of Fujian Public Security College (Fujian Gongan Gaodeng Zhuanke Xuexiao Xuebao) at 36-39, page 38.
} 
requirements further hamper qualified Chinese irregular migrants from returning to China.

\subsection{The abuse of the right of Chinese nationals not to be exiled}

Under international norms, a State is under a duty to allow entry of a national and is prohibited from exiling that national, which has been analysed in part 3.5.4 of this book. Nevertheless, the situation of exiling nationals exists in China. The methodology adopted in this section draws on the case study of domestic dissident being exiled. The high profile attempts to expel dissidents, since the release of Tiananmen student leader Wang Dan from China for the purpose of obtaining medical treatment overseas in 1998, attracted much attention at the time. Under China Country Report on Human Rights Practices for 1998 released by the US State Department:

Tiananmen student leader Wang Dan was released from prison on medical parole in April [of 1997] on the condition that he leaves the country for medical treatment. Liu Nianchun was released under the same conditions in December [of 1997]. Both are now living abroad in exile. ${ }^{979}$

The publication China: Enforced Exile of Dissidents: Government "Re-entry Blacklist"

Revealed released by Human Rights Watch Asia, described that:

[In] mid-1991, dissidents began to be asked by the police whether they would not prefer to leave China rather than face further detention or imprisonment. During several periods of detention during 1991, journalist Zhang Weiguo was apparently repeatedly asked this question. In his months of freedom between September 1993 and April 1994, Wei Jingsheng, China's most prominent dissident, was told that the passport could be issued quickly if he wanted to leave the country. In April-May 1994, China tried to send both of the "black hands' of the 1989 movement, Wang Juntao and Chen Ziming, out of the country. Both were serving thirteen-year prison terms. In late April, Wang was informed that his only chance of freedom was to leave the country, and he was immediately sent to the US. Chen was made the same offer, but refused exile. ${ }^{980}$

Both men have advocated the use of peaceful means for achieving greater democracy and human rights in China. Their alleged offences arose from the exercise of their internationally recognised rights to free speech and association during the protest movement of 1989. Neither is

\footnotetext{
979 US Department of State, "China Country Report on Human Rights Practices for 1998”, http://www.State.gov/www/global/human_rights/1998_hrp_report/china.html (2/02/2004), page 3.

${ }^{980}$ Human Rights Watch Asia and Human Rights in China, China: Enforced Exile of Dissidents: Government “Re-entry Blacklist” Revealed”, Vol.7 No.1, January 1995.
} 
known to have committed any criminal act according to international law. Fortunately, the situation has improved. There have been no reports of exile in China in recent years.

Involuntary exile challenges the Chinese legal system. There are no provisions related to exile in current Chinese law including the Constitution, the Law on the Control of Exit and Entry of Citizens 1985 (PRC) and the Law of Nationality 1980 (PRC). Involuntary exile makes a mockery for "principle of the law as criterion" (Yi Falv Wei Zhunshen) and that "no organisation or individual is privileged to be beyond the Constitution or the law". ${ }^{981}$ It is a typical example of "substituting one's word for legal provisions" (Yiyan Daifa).

It is almost impossible that Chinese authorities know nothing about the detriment to the rights of citizens and dignity of the legal system caused by involuntary exile. The discrepancy between recognition of rights and practices is political. As the IOM contended in People's Republic of China: Migration in 1999, "migration had political uses for dissidents and the State. For the former, exile provided an alternative to repression". ${ }^{982}$ To appease human rights critics from the West, and to prevent them from engaging in "anti-revolutionary" activities, the authorities thus secretly pursued a policy of sending former political prisoners and other dissidents into involuntary exile abroad.

\subsection{Conclusions}

The legal provisions prohibiting Chinese nationals from returning to China seriously breach the right to return to the State of nationality. Prohibitions intended to restrict the right to return of citizens, especially dissidents, such as the revocation and confiscation of passports, and not replacing, reissuing or extending of passports and arbitrarily prolonging the processing period, should be a second priority for reform in the limits on the return of Chinese citizens, especially dissidents. Overseas Chinese dissidents are the most direct sufferers. The group of effectively stateless overseas Chinese dissidents is becoming larger.

\footnotetext{
981 Article 5 Clause 5 of the Constitution of the PRC (Amendment) 2004.

982 The IOM, "the People's Republic of China - Migration in 1999", www.iom.org (18/06/2003).
} 
Few among the 30 million overseas Chinese lodge the applications to return to China for permanent residence or employment. This is not because they do not want to return but they hesitate at the prospect of the unattainable conditions and the complicated application procedures. The strict limits might first be attributed to the Chinese government's policies towards overseas Chinese, based on overpopulation and economic development that aimed at supporting and encouraging their settlement in and assumption of the nationality of host countries. The costs of making arrangements for returned overseas Chinese, born in several waves of return from the 1950s to the 1970s, also helps explain a policy of being uninterested in the return of overseas Chinese.

The return of 11 million Chinese irregular migrants will pose financial burdens for China. However it is not acceptable to impose limits on their return based on that prospect. Chinese irregular migrants have difficulty meeting the impracticable requirements of passport re-issue, replacement and extension. More seriously, an applicant is unable to estimate how long an application will take, because of the overly flexible processing period. It seems convincing to presume that the government regards the protraction of the application process as a means of punishing and preventing illegal migration. This is a trans-national issue and host countries of Chinese irregular migrants are affected.

Even if the expulsion of Chinese nationals has passed it peak since the 1990s, the abuse of the right not to be expelled needs to be checked as an important issue, and is an important issue. If expulsion and exile are the same, Chinese nationals have the right not to be expelled or exiled from China. The expelled Chinese find it difficult to find a place to reside after being exiled, and are an effectively stateless group. Besides the challenges expulsion makes to the dignity of national legal system, it brings individual suffering and social instability. Given the clearly unpersuasive legal validity of involuntary expelling Chinese nationals, it can only be presumed that the foremost motive is political. 


\section{Chapter Eleven \\ The Limits on the Right of Travelling to or from the HKSAR, MSAR and Taiwan}

\section{Introduction}

As a result of the advanced level of political and economic development in the HKSAR, MSAR and Taiwan, regulations for Chinese citizens travelling to or from those regions are similar to regulations governing their exit from and entry to foreign countries, with some distinct features. Statistics from the BEEA under the MPS in 2001-2002 revealed that $73.54 \%$ of people travelling to China came from the HKSAR and MSAR. Of people travelling abroad, $71.90 \%$ went to the HKSAR and MSAR. Travel to and from Taiwan is proportionately much less. In $2001,3.77 \%$ of people travelling to China came from Taiwan, and $3.25 \%$ of people travelling abroad went to Taiwan. This extent of travel, and the principles underlying special arrangements for the regions, suggests that careful attention needs to be paid to the limits imposed on the right of travelling to or from the HKSAR, MSAR and Taiwan.

\subsection{Limits on Mainland Chinese Travelling to or from the HKSAR or MSAR}

The Provisional Measures on the Control over Chinese Citizens Travelling for Private Affairs to or from the Regions of Hong Kong or Macao 1986 (PRC), which was promulgated in accordance with Article 17 of the Law on the Control of Exit and Entry of Citizens 1985 (PRC) by the MPS, is the key law governing the control of Mainland Chinese travelling to or from the HKSAR and MSAR. The MPS and the State Council Hong Kong and Macao Affairs office (SHMO) have also issued some interpretative regulations. ${ }^{981}$

\footnotetext{
981 Such as the Explanation of Some Matters on Implementation of Provisional Measures on the Control over Chinese Citizens Travelling for Private Affairs to or from the Regions of Hong Kong or Macao 1987 (PRC); the Provisional Measures on the Control over Mainland Residents Travelling for Such Business, Training, Employment as Non-Public Affairs to or from Hong Kong Special Administration Regions 1998 (PRC); and the Interpretation by the Standing Committee of the National People's Congress Regarding Paragraph 4 in Article 22 and Category (3) of Paragraph 2 in Article 24 of the Basic Law of the Hong Kong Special Administrative Region of the People's Republic of China 1999 (PRC).
} 
These provisions have established the special system governing Mainland Chinese travelling to or from the HKSAR or MSAR. Although reforms discussed in Chapter seven improved this system, some problems still need scrutiny. The focus of the special system has four administrative principles (i) unilateral examination and approval of the Mainland government (ii) the examination and approval of fixed quotas (iii) strict conditions of applying for travel to the HKSAR or MSAR, and (iv) different treatment of Mainland Chinese as opposed to the HKSAR and MSAR Chinese. This section will question these four principles, which have until now been uncritically accepted by the government and academics alike.

\subsubsection{Unilateral examination and approval of the Mainland government}

The Mainland government is unilaterally responsible for examining and approving the application of Mainland Chinese for travel to the HKSAR or MSAR. According to Article 3 of the Provisional Measures on the Control over Chinese Citizens Travelling for Private Affairs to or from the Regions of Hong Kong or Macao 1986 (PRC), Mainland Chinese travelling to the regions for private affairs must have the passes to Hong Kong and Macao or the passes to and from Hong Kong and Macao signed and issued by the public security departments of Mainland China. This special administration seems to stem from the sovereignty of China over the HKSAR and MSAR.

Unilateral examination and approval of the Mainland government existed after $1951 .^{982}$ After China resumed sovereignty over the HKSAR in 1997 and the MSAR in 1999, the principle of unilateral examination and approval was not changed. The principle was accepted by the governments of the HKSAR and MSAR and extended to travel for public affairs. ${ }^{983}$ The main

\footnotetext{
982 Prior to 1951, residents in Hong Kong, Macao and the Mainland China could travel between the three regions without passes or visas. The Proclamation of the MPS, the Central People's Government on the control over Passengers Travelling to and from the Regions of Hong Kong or Macao 1951 (PRC) established the current system, and a series of relevant measures were then adopted. Article 2 of the 1951 Proclamation stipulates "individuals travelling to or from the HKSAR or MSAR must file an application for Passes of Entry-exit (Churu Tongxingzheng) to the department in charge of public security under the people's government where the applicants are residing or leaving for." This was limited to mainland citizens travelling to or from the HKSAR or MSAR for private affairs. Mainland citizens travelling to or from the HKSAR or MSAR for public affairs, overseas Chinese and Taiwan residents travelling to or from the HKSAR or MSAR for private affairs were required to apply for visas from the British Hong Kong government and Portuguese Macao government. Under the preface of the Proclamation, the purpose of the Proclamation was to solidify social public security during the early establishment of the PRC by preventing counter-revolutionary saboteurs from engaging in undermining activities by secretly travelling to or from the HKSAR or MSAR.

983 "Mainland officials and personnel who wish to enter Hong Kong for a visit are required to obtain an Exit-entry
} 
exceptions cover those persons travelling to the HKSAR for employment, training and studying. In which case, applicants must obtain entry permission from the HKSAR Immigration Department in advance. ${ }^{984}$

At first glance, it may be argued that unilateral examination and approval may improve the protection of RLR of Mainland Chinese, because the Mainland governments seem to have the power to modify or cancel the conditions of leaving for the HKSAR or MSAR. In fact, the reverse occurs in practice.

Firstly, the unilateral nature is mainly a paper claim made by the HKSAR and MSAR governments, rather than a practical power exercised by the Mainland. The focus of the system is the setting of a fixed quota of Mainland Chinese. This fixed quota for settlement is determined by the competent authorities of the Mainland government after consulting with the regions. This has been legalised in Article 22 Clause 4 of the Basic Law of the HKSAR Special Administrative Region 1990 (PRC) and Article 22 Clause 4 of the Basic Law of the MSAR Special Administrative Region 1993 (PRC). In respect of the fixed quota for visiting relatives resident in both regions, and travelling to the HKSAR, the MPS cannot decide without consulting with relevant departments of the HKSAR and MSAR. ${ }^{985}$ Hence, the regions actually play a dominant role in determining the fixed quota of Mainland Chinese entrants.

Moreover, the vague status of the Mainland government seriously affects the unilateral exercise of power of examination and approval. According to the system, the Mainland government is responsible for applications to enter the HKSAR and MSAR, and applications to exit China.

Permit for Travelling to or from Hong Kong and Macao for official purposes and an appropriate endorsement relating to the purpose of entry at the Hong Kong and Macao Affairs Office." See Paragraph 4 of "Arrangement for Entry to Hong Kong from the Mainland China", http://www.immigration.gov.hk/eng(29/0/2003).

984 Article 3 Clause 1 (7) of the Provisional Measures on the Control over Mainland Residents Travelling for Such Business, Training, Employment as Non-Public Affairs to or from Hong Kong Special Administration Regions 1998 (PRC) promulgated by the MPS on 19 March 1998 and effective on 30 March 1998. And Su, Qiang and Li, Xu, "Detailed Measures of Beijing on Facilitating Mainland Talents Exiting SARS Work and Study, 11 June 2003", Xinhuanet, http://news.21cn.com/domestic/2003-07-11/1104534.html (23/07/2003).

985 Department of Politics under the MPS, Frontier Defence and Exit and Entry Administration, the Series of Basic Textbook of People's Police Operation: (Bianfang Yu Churu Jing Guanli, Renmin Jingcha Gongan Yewu Jichu Jiaocai), examined by Committee of Textbook Editing and Examination of the MPS, the Publishing House of Qunzhong Internal Publication in Public Security Organs, Interior Publication within Public Security Organs, (Gongan Jiguan Neibu Faxing), Beijing, 1999, page 342. 
The Mainland government therefore has dual status when handling applications for travelling to the regions. It is well acknowledged that the rights and interests of Mainland Chinese must be carefully considered when their application for leaving China is examined and approved. Meanwhile, the rights and interests of HKSAR or MSAR Chinese must also be considered when applications for entering the HKSAR or MSAR are examined and approved. Disputes inevitably arise between the rights and interests of the two sides when one department is responsible for the examination of two applications.

This dual administrative role has confused the enactment, implementation and interpretation of the relevant provisions. It is sometimes difficult to distinguish if the term "travelling to" in the Provisional Measures on the Control over Chinese Citizens Travelling for Private Affairs to or from the Regions of Hong Kong or Macao 1986 (PRC) refers to leaving China or entering the regions. This uncertainty may affect the protection of the right to leave of Mainland Chinese. Being the sole examination and approval power, the Mainland government needs to make a choice between the protection of the rights and interests of Mainland Chinese and HKSAR or MSAR Chinese. The Mainland government is in a dilemma because choosing the unilateral approach may jeopardize the rights and interests of one group over the other.

More precisely, the Mainland government, based on the requirements of restrictive conditions, multiple-level departmental approval and designated exit ports, seems to prefer to protect the rights and interests of HKSAR or MSAR Chinese. This preference jeopardizes the rights and interests of Mainland Chinese. This allegation can be substantiated under Article 5 of the Provisional Measures on the Control over Chinese Citizens Travelling for Private Affairs to or from the Regions of Hong Kong or Macao 1986 (PRC), which provides that the fixed quota for examination and approval is designed to safeguard and maintain the economic prosperity and social stability of the HKSAR and MSAR. The reason why the provisions are inclined to protect the rights and interests of the regions seems partially to stem from the high human rights consciousness, and the developed legal and political systems of the HKSAR and MSAR.

\subsubsection{Examination and approval of the fixed quotas}


The examination and approval of the fixed quotas has two facets or levels of application. For one, the number of persons of travelling to the HKSAR or MSAR cannot exceed the fixed quota. For the other, the MPS distributes different fixed quotas to various provincial regions on the Mainland in the light of the relationship between residents in those regions and the HKSAR and MSAR. ${ }^{986}$ The initial motivation for fixed quotas was to reduce the number of returned overseas Chinese from inland areas who overstayed in the HKSAR or MSAR to await the results of visa applications to South-eastern Asian countries in the 1960s and 1970s. ${ }^{987}$ These measures were eventually extended to all Mainland Chinese who wanted to enter the HKSAR or MSAR. The policy of controlling numbers (Shidang Kongzhi Renshu) entering the HKSAR or MSAR was officially adopted in 1973. In 1981, it was replaced by a policy of persuading people not to go to the HKSAR or MSAR any more. To further limit numbers, travel to or from the HKSAR or MSAR was divided into single travel or immigration (in 1982), and return travel or visiting (in 1984). The numbers of both types of travellers was limited according to different fixed quotas.

Examination and approval in accordance with fixed quotas was then legalised. Article 5 of the Provisional Measures on the Control over Chinese Citizens Travelling for Private Affairs to or from the Regions of Hong Kong or Macao 1986 (PRC) stipulates that Mainland Chinese travelling to the regions to settle shall be subjected to the measures of examination and approval of the fixed quota. The fixed quotas for travelling to the HKSAR for permanent residence increased from 75 persons per day in 1982 to 150 persons per day in $1999 .{ }^{988}$ The Chinese government made some improvement to the system of the fixed quota of Mainland Chinese travelling to the HKSAR or MSAR for tourism. With the relaxation of the limits on RLR in recent years, the fixed quota for group tours through overseas travel agencies has been cancelled. Since 2003, the fixed quota for individual tourists has not applied to Guangdong, Shanghai and

\footnotetext{
986 Top five provincial level regions fixed quota are Guangdong, Jiangshu, Fujian, Shanghai and Beijing.

987 In the 1960s and 1970s some South-East Asian Countries did not accept visa applications filed in the Mainland China. So, Mainland citizens mainly returned overseas Chinese and their family members who had been approved for exit abroad had to lodge visa applications and wait for the result in Hong Kong or Macao. Application processing usually took a long time, and some of the applications were finally rejected. This leads to many applicants overstaying in Hong Kong and Macao.

988 Quoted in Department of Politics under the MPS, Frontier Defence and Exit and Entry Administration, the Series of Basic Textbook of People's Police Operation: (Beanbag Yu Churl Jingo Gauntly, Rennin Gingham Gongan Yewu Jichu Jiaocai), examined by Committee of Textbook Editing and Examination of the MPS, the Publishing House of Qunzhong Internal Publication in Public Security Organs (Gongan Jiguan Neibu Faxing), Beijing, 1999 , page 342.
} 
Beijing. ${ }^{989}$ The history of examination and approval of fixed quotas shows that although control over Mainland Chinese travelling to or from the HKSAR or MSAR has been relaxed in recent years, it is still restrictive by world standards.

Different fixed quotas in various provincial regions leads to discrimination that is unjustified by international norms. Under the Measures of Examination and Approval of Travelling to the HKSAR or MSAR for Permanent Residence of Mainland Chinese 2004 (PRC) the pass marks for spousal migration for residents of Guangdong to the HKSAR are 255.7 (separation before 31 December 1997), and for residents of other parts of China 201.1 (separation before 30 June 1999). The pass marks of spousal migration to MSAR for residents of Guangdong and Fujian are 255.7 (separation before 31 December 1997), and for residents of other parts of China 182.7 (separation before 31 December 1999). ${ }^{990}$ In order to exploit the preferential policy, and in a context of relaxed household registration, it is possible for the applicants to move to the regions where lower pass marks are required, so undermining the efficiency of fixed quota provisions.

\subsubsection{Strict conditions of applying for travel to the HKSAR or MSAR}

The requirements of applying for travel to the HKSAR or MSAR

The Chinese government has designed restrictive conditions on application for travel to the HKSAR or MSAR in order to maintain the fixed quota system and monitor the flow of traffic. According to Article 7 of the Provisional Measures on the Control over Chinese Citizens Travelling for Private Affairs to or from the Regions of Hong Kong or Macao 1986 (PRC):

Persons may apply for approval to travel to and settle in the HKSAR or MSAR if the applicants conform to any of the following conditions:

(1) Either spouse of a married couple settles down in Hong Kong or Macao, whereby separation between the couple has lasted many years;

(2) A person's parents settling in Hong Kong or Macao are aged and in poor health, and must be taken care of by their son or daughter from an inland area;

(3) Helpless old people and children residing in inland areas, who have to seek support from their lineal relatives or close relatives who live in Hong Kong or Macao;

(4) In the event that lineal relatives settling in Hong Kong or Macao have nobody there to

\footnotetext{
989 For more information on the improvement of the fixed quota, please see part 6.2 of this book.

990 The Measures of Examination and Approval of Travelling to Hong Kong or Macao for Permanent Residence of mainland Residents 2004 (PRC) (2004 Nian Neidi Jumin Fu Gangao Diqu Dingju Shenpi Banfa), promulgated by the
} MPS in December 2003. 
inherit their property, their son or daughter in inland areas may inherit the property in question, on condition that they settle in Hong Kong or Macao; and

(5) A person who is required to settle in Hong Kong or Macao in other special circumstances.

Various provincial governments may separately decide the minimum length of separation of spouses, in the light of the number of local applicants and the use of the local fixed quota. Special circumstances refer to applicants who have a HKSAR or MSAR birth certificate and have been granted an entrance permit. In these cases, the control over travel to Macao of Mainland Chinese is still strict. ${ }^{991}$

In order to redress the lack of applied criteria and supervisory measures, and to specify the processing criteria according to a points system, the MPS issued the Operational Norms of Application, Examination and Approval of Exiting China and Passport For Private Affairs of Citizens 1996 (PRC), and the Operational Norms on the Control of Examination and Approval of Travelling to the HKSAR or MSAR for Permanent Residence of Mainland Chinese 1997 (PRC). This provides for relatively open and fair processing. The pass mark for the points test has changed each year since 1997. The system has benefited the protection of RLR of Mainland Chinese travelling to or from the regions.

According to Article 8 of the Provisional Measures on the Control over Chinese Citizens Travelling for Private Affairs to or from the Regions of Hong Kong or Macao 1986 (PRC):

Persons may apply for the approval to go to the HKSAR or MSAR for short-term visits if any of the following circumstances is conformed to:

(1)The applicant has close relatives settled in the HKSAR or MSAR and needs to visit them;

(2)The applicant's lineal or close relatives are compatriots of Taiwan and he or she needs to go to Hong Kong or Macao to meet them;

(3)The applicant needs to travel to Hong Kong or Macao to visit a lineal relative or sibling of overseas Chinese returning to China or the lineal relatives of the family members of overseas Chinese who are unable to return to the Mainland China;

(4)The applicant must go to Hong Kong or Macao so as to dispose of his or her property; and

(5)The applicant, due to other special circumstances, must go to Hong Kong or Macao for a short

\footnotetext{
991 Article 1 Clause 1 (1)(4)(5) of the Explanations of Some Matters on Implementation of Provisional Measures on the Control over Chinese Citizens Travelling for Private Affairs to or from the Regions of Hong Kong or Macao 1987 (PRC).
} 
term.

The various provincial governments separately decide the detailed conditions of allowing travel for short-term visits, in the light of the numbers of local applicants and the use of the local fixed quota. $^{992}$

\section{Prerequisite certificate from the department in which the applicants are employed}

The prerequisite certificates from the department in which the applicants are employed, discussed in part 9.3 above, is also required in applying to travel to the HKSAR or MSAR. Serving and retired national public servants, who were county- or division-level cadres or above, need a certificate from the department where the applicant is or was in service, when applying to enter the regions for private affairs. Full-time students also need a certificate from their educational institution when applying to enter Honk Kong and Macao for private affairs. ${ }^{993}$

\section{Visa exemptions for transitional travel}

Compared to the immigration policies of the HKSAR to other countries, restrictions are tight and visa exemptions for inland Chinese are significantly limited. Material from the HKSAR Immigration Department demonstrates that, since 1993, the HKSAR exempted Mainland Chinese from carrying a visa when they are transiting through the region for up to seven days, provided that the usual immigration requirements are met, including possession of valid entry documents for the destination and confirmed onward bookings for an overseas journey. Passport holders of over 170 countries or regions such as Angola, Congo, Egypt, Ghana, India, Indonesia, Kenya, Mozambique, Philippines, Rwanda, Sri Lanka, Thailand and Zimbabwe, may visit or transit through the HKSAR for between 14 and 90 days without a visa or entry permit, in accordance with the type of travel documents held, provided the visitor has adequate funds to cover the duration of the stay without working and holds an onward or return ticket (unless in

\footnotetext{
992 Article 2 of the Explanation of Some Matters on Implementation of Provisional Measures on the Control over Chinese Citizens Travelling for Private Affairs to or from the Regions of Hong Kong or Macao 1987 (PRC).

993 Beijing Public Security Bureau, "Application for the Passes to and from Hong Kong and Macao" (Shenban Wanglai Gangao Tongxingzheng), http://www.bjanj.gov.cn (28/01/2004); and Guangdong Public Security Department, "Instructions to the Applications for the Passes to and from the HKSAR and MSAR on Line" (Wangshang Shenban Wanglai Gangao Tongxingzheng Shuoming), http://wwwgdcrj.com/wssq/index.htm (29/01/2003).
} 
transit to Mainland China or the MSAR). ${ }^{994}$

Departure through designated ports

Mainland Chinese travelling to the regions for private affairs must depart through designated ports pursuant to Article 3 of the Provisional Measures on the Control over Chinese Citizens Travelling for Private Affairs to or from the Regions of Hong Kong or Macao 1986 (PRC). The requirement of travelling to the HKSAR or MSAR through a designated port only applies to Mainland Chinese. The designated ports are Shenzhen - for those bound for the HKSAR, and Gongbei - for those bound for the MSAR. Obviously, the designation of ports is convenient for the management of the authority, but results in inconvenience for the travel of Mainland Chinese.

Application conditions for Mainland Chinese travelling to the HKSAR or MSAR are stricter than for Mainland Chinese travelling to foreign countries, or for aliens travelling to the HKSAR or MSAR. The strict limits, especially the fixed quota on short-term visits is almost unrivalled anywhere in the world. The historical background and reality of Hong Kong or Macao does not provide an adequately persuasive basis for continuing restrictions and the consequent violations of RLR.

\subsubsection{Different treatments of Mainland Chinese as opposed to HKSAR and MSAR}

\section{Chinese}

It is much simpler for HKSAR or MSAR Chinese to enter Mainland China, than it is for Mainland Chinese to enter the HKSAR and MSAR. Article 14 and 15 of the Provisional Measures on the Control over Chinese Citizens Travelling for Private Affairs to or from the Regions of Hong Kong or Macao 1986 (PRC) provides the circumstances under which application for travelling to Mainland China is approved or denied.

Article 14 Compatriots from Hong Kong or Macao intending to enter the Mainland areas, [must submit] an application for the Home-Visiting Certificate for Compatriots from Hong Kong

994 "Visit Visa/Entry Permit Requirements for the Hong Kong Special Administration Region, and Holders of Foreign Passports in the Mainland", http://www.immigration.gov..hk/eng (29/01/2003). 
or Macao (Gangao Tongbao Huixiangzhang) ${ }^{995}$...The application for Home-Visiting Certificates shall be subject to the presentation of his or her residential status identification for examination and an application form. Compatriots from Hong Kong or Macao, who do not visit the Mainland areas frequently, may apply for an Entry-Exit Pass (Ruchujing Tongxingzheng) instead. The measures for obtaining the pass shall be the same as those for obtaining the Home-Visiting Certificates for Compatriots from Hong Kong or Macao.

Article 15 A Home Visiting Certificate or Entry-Exit Pass may not be issued to:

(1)Those who are likely to be engaging in such criminal activities as robbery, theft, and trafficking in narcotics;

(2)Those who have fabricated situations and presented forged certificate; and

(3)Mental patients.

Article 17 and 18 of the Provisional Measures 1986 stimulate the application procedure of travelling to the Mainland China:

Article 17 Compatriots from Hong Kong and Macao requesting return to the Mainland areas for a short stay shall, according to the provisions on the administration of residence registration, go through the procedures for the registration stay. ....

Article 18 For compatriots from Hong Kong and Macao requesting return to the Mainland areas and settling there, an application shall be filed in advance to the public security of the municipality or county where the applicants intend to settle. Upon approval, they shall go through the procedures for permanent residence registration with the police station in the places of their destination by presenting the Home-Visiting Certificate for Compatriots from Hong Kong and Macao, with a signed statement justifying the intention of the certificate-holders to return to the Mainland areas and settle there. ${ }^{996}$

These provisions clearly demonstrate that HKSAR and MSAR Chinese are treated more favourably than aliens, and come close to enjoying freedom of movement within China. As Wang Guoliang has penetratingly said, in The Administration on Exit and Entry, one of Planning Textbooks of Higher Education of People's Police:

HKSAR and MSAR Chinese with the valid Home Visiting Certificates or Entry-Exit Passes may enter China at any time from all open ports according to their will. They need not undergo the

\footnotetext{
995 After 15 January 1999, the Home-visiting Certificate for Compatriots from Hong Kong and Macao was replaced with the Entry-exit Mainland Pass for Compatriots from Hong Kong and Macao (Gangao Jumin Laiwang Neidi Tongxingzheng).

996 Article 7 of the Explanation of Some Matters on Implementation of Provisional Measures on the Control over Chinese Citizens Travelling for Private Affairs to or from the Regions of Hong Kong or Macao 1987 (PRC) require that the public security bureau in Guandong process applications for residency in that region; whereas overseas Chinese affairs offices process applications for all other areas.
} 
formalities of application any longer. There are no limits on travel times and affairs. ${ }^{997}$

Limited requirements are never applied. Mainland government regards the likelihood of applications for permanent residence of HKSAR and MSAR Chinese as very low: the responsible departments have not even designed a relevant application form. ${ }^{998}$ Due to the great economic and political differences between Mainland China and the HKSAR and MSAR these regions, ${ }^{999}$ very few HKSAR and MSAR Chinese apply to resettle in Mainland China. The fact that HKSAR and MSAR Chinese enjoy almost the same freedom to enter the mainland as Mainland Chinese is at odds with the fact that the reciprocal liberties don't exist for the benefit of Mainland Chinese. At the very least, Mainland Chinese should enjoy the same treatment as aliens when entering the HKSAR and MSAR.

Given the high population density of the HKSAR and MSAR, it is understandable that Chinese authorities and some scholars contend that Mainland Chinese should not freely settle there. ${ }^{1000}$ However, it is difficult to support the argument that the citizens should be prohibited from travelling freely within the regions. Limits on entry into the HKSAR and MSAR for short-term visits could be significantly relaxed. The restrictive limits and different treatments may also discourage Chinese citizens from recognising the HKSAR and MSAR as parts of China.

\subsection{Limits on Mainland Chinese travelling to or from Taiwan, and Taiwan Chinese travelling to Mainland China}

\footnotetext{
997 Wang, Guoliang and Zhu, Lin, The Administration on Exit and Entry, one of Planning Textbooks of Higher Education of People's Police (Renmin Jingcha Gaodeng Jiaoyu Guihua Jiaocha: Churujing Guanlixue) Interior Published within Public Security Organs (Gongan Jiguan Neibu Faxing), the Publishing House of China University of People's Public Security, Beijing, 2002, pages 110-111.

998 "The Download of Various Application Forms from the Net of Division of Exit and Entry Administration Department of Public Security of Guangdong Province", http://www.gdcrj.com/doc/index.htm (28/01/2004).

${ }_{999}$ Per capita GDP, in 2002, of the HKSAR was US\$27,200. See "Missouri Economic Research and Information Centre, Missouri Department of Economic Development", Hong Kong,

http://www.ded.mo.gov.business/researchandplanning/indicators/interna (15/04/2004); Per Capital GDP of the MSAR was US\$ 18,500 in 2002. See "Missouri Economic Research and Information Center, Missouri Department of Economic Development, Macao", http://www.ded.mo.gov.business/researchandplanning/indicators/interna (15/04/2004); Per Capital GDP of the Mainland China was US\$965. See State Bureau of Statistics, the PRC, “GDP Per Capital from 1952 to 2002", http://www.menet.com.cn/shuju/gmjj/gmjj-rjgdp.htm (15/04/2004).

1000 Exit and Entry Administration under Jilin Province Public Security Department and Bureau of Border Security Check and Administration under Jilin Province Public Security Department (ed), The Kit of Exit, Entry and Frontier Defence (Shiyong Churu Jing Bianfang Zhishi Daquan), the Publishing House of Jilin Wenshi, Changchun, China, 1994, page 57. And Xu, Jiali (ed), The Guide to Going Abroad Consultation (Chuguo Zixun Daquan), the Publishing House of Kexue Puji, Beijing, 1992, pages 513-514.
} 
Taiwan is part of the territory of China, and regulated under the Chinese Constitution. ${ }^{1001}$ As of December 2003, about 164 countries have recognised Taiwan's position within the territory of China, including the USA, Japan, Germany, the UK, France and Australia. ${ }^{1002}$ In theory, to travel to or from Taiwan and Mainland China is to travel within one territory. However, China does not have actual sovereignty over Taiwan.

The relationship between Taiwan and Mainland China has been hostile since the establishment of the People's Republic of China under a communist system in 1949. Prior to China's reform and opening up in 1978, Chinese from the Mainland and Taiwan could only meet in Hong Kong, Macao or other foreign countries. It has since become possible for Chinese in one state to visit and settle in the other. However, the Chinese government has imposed limits on Mainland Chinese travelling to or from Taiwan, which differ from those governing travel to or from the HKSAR, MSAR, foreign States, or within the territory. ${ }^{1003}$

This section will explore (i) the context for limits imposed by Mainland China and Taiwan; (ii) the contents and effects of those limits, including the requirements of prerequisite certificates, invitation letters, and approval from Taiwanese authorities; and (iii) the pre-eminently political nature of the limits.

\subsubsection{Limits on travel to or from Taiwan of Mainland Chinese and the limits on travel to or from Mainland China of Taiwan Chinese}

Analysis of the limits of Mainland China on the travel of Mainland Chinese to or from Taiwan would be incomplete without first discussing Taiwan's limits on its own residents. Any

\footnotetext{
1001 Para. 9 of Preamble of the Constitution of the PRC (Amendment) 2004.

1002 "The Lists of the Countries having Diplomatic Relationship with the PRC" (Yu Zhongguo Jianjiao Guojia Yilanbiao), http://www.fmprc.gov.cn (2/02/2004).

1003 Wang, Guoliang and Zhu, Lin, The Administration on Exit and Entry, one of Planning Textbooks of Higher Education of People's Police (Renmin Jingcha Gaodeng Jiaoyu Guihua Jiaocha: Churujing Guanlixue), Interior Published within Public Security Organs (Gongan Jiguan Neibu Faxing), the Publishing House of China University of People's Public Security, Beijing, 2002, page 112; Department of Politics under the MPS, Frontier Defense and Exit and Entry Administration, the Series of Basic Textbook of People's Police Operation:( Bianfang Yu Churu Jing Guanli, Renmin Jingcha Gongan Yewu Jichu Jiaocai), examined by Committee of Textbook Editing and Examination of the MPS, the Publishing House of Qunzhong, Interior Publication within Public Security Organs (Gongan Jiguan Neibu Faxing), Beijing, 1999, page 345; and Xiang, Dang, The Guide to the Law of Exit and Entry in China and Foreign Countries (Zhongwai Churujing Falv Zhinan), the Publishing House of China University of People's Public Security, Beijing, 1998, page 174.
} 
relaxation in the approach by one side usually receives a positive reply from the other.

In July 1987, Taiwan ceased to operate under a system of martial law, which led to a relaxation of hostilities between the two sides. The Circular of the General office of the State Council on the Measures for Receiving Compatriots from Taiwan Coming to the Mainland to Visit their Relatives or as Tourists 1987 (PRC) was promulgated in October of that year. According to Article 1 of the Circular, Mainland China "warmly and sincerely welcomes compatriots from Taiwan to come to the Mainland to visit their relatives or as tourists, and guarantees that they have complete freedom of entry and exit." ${ }^{1004}$ Taiwan officially permitted ordinary people, other than national public servants and military or educational appointees, to travel to the Mainland China to visit relatives in November 1987.

The number of Taiwanese residents travelling to Mainland China steadily increased from 450,000 exits in 1988 , to one million in $1991 .^{1005}$ To meet this demand, Mainland China announced the Measures on the Control over Chinese Citizens Travelling to or from the Region of Taiwan in October 1991, effective as of May 1992. In 1992, the number of Taiwanese visitors to China jumped to 1.5 million. In response, Taiwan issued the Regulations on the Entry Permission of Taiwan Permanent Residents to Inland Areas in April 1993. These are still the foremost regulations governing this movement between Taiwan and China. In 1995, Taiwan promulgated the Regulations on the Relationship between Taiwan residents Areas and inland Areas to further relax travel restrictions, and permitted public servants below ninth level to visit relatives in Mainland China. In turn, China started to issue Passes for Travelling to or from Taiwan for Mainland Chinese (Dalu Jumin Wanglai Taiwan Tongxingzheng) to further simplify formalities.

Interaction between Mainland China and Taiwan in theory promotes the development of

\footnotetext{
1004 Article 1 of the Circular of the General Office of the State Council on the Measures for Receiving Compatriots from Taiwan Coming to the Mainland to Visit their Relatives or as Tourists 1987 (PRC), promulgated by the General Office of the State Council on $16^{\text {th }}$ October 1987.

1005 Quoted in Xiang, Dang, The Guide to the Law of Exit and Entry in China and Foreign Countries (Zhongwai Churujing Falv Zhinan), the Publishing House of China University of People's Public Security, Beijing, 1998, page 174.
} 
Chinese exit and entry laws. However, there are in practice many examples of the different treatment of Mainland and Taiwan Chinese. According to Article 13 of the Measures on the Control over Chinese Citizens Travelling to or from the Region of Taiwan 1991 (PRC), Taiwan residents may enter Mainland China either directly from Taiwan, or via the HKSAR, MSAR, or another foreign country. Conversely, Article 2 of the Rules of Some Matters of the Application of Mainland Chinese Travelling to Taiwan for Visiting Relatives 1988 (PRC), compels Chinese residents to enter Taiwan only through the HKSAR.

Additionally, the number of Chinese residents travelling to Taiwan is much lower than the number travelling to the HKSAR and MSAR. According to MPS statistics, "in the first half year of 2002, there are 77.58 million from Hong Kong and Macau special administrative regions (SARs), an 8.6-per cent rise; 3.51 million from Taiwan, a 2.95 per cent increase compared with 2001."1006

\subsubsection{The contents and effects of the limits, including the requirements of prerequisite certificates, invitation letters, and approval from Taiwanese authorities}

Application requirements for travelling to Taiwan are stricter when compared with those for travelling to the HKSAR, MSAR and foreign countries. None of the 2001-2005 reforms in China related to travel to or from Taiwan. In effect, the main laws governing travel to or from Taiwan are those promulgated in 1992. The limits on travel to Taiwan mainly focus on three aspects: (i) prerequisite certificates from the department in which the applicants are employed; (ii) documentary evidence, especially an invitation letter from Taiwan, and (iii) the approval from the Taiwan authorities.

Prerequisite certificates from the departments in which the applicants are employed According to Article 7(3) of the Measures on the Control over Chinese Citizens Travelling to or from the Region of Taiwan 1991 (PRC), Mainland Chinese applying for travel to Taiwan:

Shall submit a certificate from the department or educational institution in which the applicant is employed or studying. An applicant who is not employed or studying shall submit a comment from

1006 “China's Ports See Record Traffic”, http://www.chinadaily.com.cn/en/doc/2002-07/16/content 128051.htm $(08 / 07 / 2005)$ 
the police station where the applicant's residence is registered in Mainland China.

These requirements are the same as those for travel to foreign countries before the recent overhaul of 2001 when they were partially abolished. ${ }^{1007}$ As argued in part 9.3 of this book, the prerequisite certificate from the department in which the applicant is employed is unfair, lacks legal foundation, and essentially limits the right to leave.

\title{
Documentary evidence, especially an invitation letter from Taiwan
}

Mainland Chinese must also provide documentary evidence, including an invitation letter from Taiwan, with their application to travel to Taiwan, pursuant to Article 7(4) of the Measures on the Control over Chinese Citizens Travelling to or from the Region of Taiwan 1991 (PRC). Article 8 prescribes documentation as including: an invitation to participate in economic, scientific, cultural, educational, sports or academic activities; certification of the applicant's relationship with a family member or friend in Taiwan; evidence that the applicant can be financially self-supporting while travelling; marriage certificate; property title; and an approval letter from Taiwanese authorities. The Beijing and Shanghai authorities tend to focus on the letter of invitation accompanied by a statement of reasons for the journey. ${ }^{1008}$

The tenuous grounds for justifying the need of an invitation from abroad have been incisively argued by Hurst Hannum:

\begin{abstract}
It might be argued that the requirement of an invitation from abroad before permission to leave is granted also is justifiable on the grounds of ensuring that an emigrant will be accepted by his or her country of destination and therefore will not become a burden on the rights of others. However, this argument confuses the right of an individual to leave with possibility that an individual may have to enter another country. The connection between being granted legal permission to leave and the speculative injury to others in a country of destination is simply too tenuous to be considered to fall within the 'rights and freedoms of others' exception. ${ }^{1009}$
\end{abstract}

From this perspective, the requirement to provide documentary evidences, especially an

\footnotetext{
1007 Only serving national public servants, individuals who are administratively referred to as national public servants, retired national public servants who are county/division level or over and full-time students are still required to provide certificates. For more information, see part 6.2 of this book.

1008 "Mainland Residents Travelling to and from Taiwan" (Dalu Jumin Wanglai Taiwan), http://www.bjgaj.gov.cn/crj/huide/default.htm (28/01/2004); "Visiting Relatives in Taiwan or Settling Down in Taiwan", http://gaj.sh.gov.cn/shpolice (28/01/2004).

1009 Hannum, Hurst, The right to Leave and Return in International Law and Practice, Martinus Nijhoff Publishers, Dordrecht Netherlands, 1987, page 43.
} 
invitation letter from Taiwan, is unacceptable.

\section{Approval from the Taiwan authority}

China does not permit Mainland Chinese to travel to Taiwan until Taiwan has granted permission for that person to enter by issuing a Travel Pass. Article 8 of the Measures on the Control over Chinese Citizens Travelling to or from the Region of Taiwan 1991 (PRC) stipulates that Mainland Chinese applying to travel to Taiwan for permanent residence must provide evidence that they will be granted permanent residence. Article 2(2) of the Circular of Some Matters on Implementation of Measures on the Control over Chinese Citizens Travelling to or from the Region of Taiwan 1991 (PRC) further provides that:

In order to avoid overstaying due to being unable to enter Taiwan via HKSAR, Mainland Chinese shall not be granted permission to leave for Taiwan unless the public security department can ensure that they will be able to enter Taiwan without delay. The documents, which ensure that the applicant may enter Taiwan, include a photocopy of the exit and entry certificate, issued by the Taiwan authority, and a certificate issued by the China Travel Agency, Hong Kong.

In practice, public security departments in Mainland China clearly require Mainland Chinese to "submit a valid permit to enter Taiwan, and copy of a Travel Permit to Taiwan (Taiwan Diqu Lvxingzheng). ${ }^{\prime 1010}$ The suitability of these provisions has been accepted by some Chinese academics. $^{1011}$

Although preconditions of the approval process are stated in relevant provisions and are recognised by some Chinese academics, no research has yet been undertaken as to the effect on those applying. The requirements affect applicants in two key ways. Firstly, the precondition of Taiwanese approval is more serious than the need of documentary evidence such as an invitation letter. It confuses the right of a Mainland Chinese person to leave with the ability of that individual to enter Taiwan. Secondly, applicants have to apply to the Taiwan authorities for

\footnotetext{
1010 "Mainland Residents Travelling to and from Taiwan" (Dalu Jumin Wanglai Taiwan), http://www.bjgaj.gov.cn/crj/huide/default.htm (28/01/2004); "Visiting Relatives in Taiwan or Settling Down in Taiwan", http://gaj.sh.gov.cn/shpolice (28/01/2004).

1011 Mo, Qibo (ed), The Administration of Citizen's Exit and Entry (Gongmin Churu Jing Guanli), the Publishing House of Giuangxi Minzu, Nanling, China 1997, page 265 and Wang, Guoliang and Zhu, Lin, The Administration on Exit and Entry, one of Planning Textbooks of Higher Education of People's Police (Renmin Jingcha Gaodeng Jiaoyu Guihua Jiaocha: Churujing Guanlixue), Interior Published within Public Security Organs (Gongan Jiguan Neibu Faxing), the Publishing House of China University of People's Public Security, Beijing, 2002, page 111.
} 
entry when they do not yet possess the necessary travel documents. Only after being granted an entry permit from Taiwanese authorities, does the possibility of the right to leave China become a reality. Taiwan can refuse to grant a travel permit if the applicant does not have a passport to identify their status.

\subsubsection{Pre-eminently political nature of the limits}

Mainland China's enactment and enforcement of provisions to control travel to or from Taiwan, is in the first place an expression of political pressure. While some consideration of politics, based on hostilities between the two sides, might be accepted, ignoring RLR cannot. Chinese academics and officials are too accustomed to forms of control with an over-emphasis on politics, to call this in question and foreign academics are too unfamiliar with the situation to pay close attention to this matter. This sub-section aims to fill the gap.

\section{Principles of control over travelling to or from Taiwan}

The first principle of control is the aegis or political principle of "one China" (Yiguo), of which Taiwan is an administrative region. Chinese law has never recognised and used the terms of "Republic of China" and "Taiwan". Secondly, the Mainland government recognises the principle of two systems (Liangzhi), in which Taiwanese authorities control Taiwan. Thirdly, no Taiwan law is recognised until it is favourable to Mainland China (Yiwuo Weizhu Duiwuo Youli). The three principles are deeply coloured politically and grant little importance to RLR.

\section{The politics of responsible departments}

According to Article 7 of the Circular of Some Matters on Implementation of Measures on the Control over Chinese Citizens Travelling to or from the Region of Taiwan 1991 (PRC), the Department of United Front Work of the Central Committee of the CPC and various local United Front Work departments ${ }^{1012}$ are responsible for the examination and approval of

\footnotetext{
1012 The Department of the United Front Work is one of five departments under the Central Committee of the CPC that is responsible for united front work. The United Front has always been closely linked with the CPC. Deng, Xiaoping, the architect of China's reform and opening up, said that the most important issue for the United Front is the unification of the motherland. Quoted in "China to Adhere to Patriotic United Front in New Century", http://fpeng.peopledaily.com.cn/200012/04/eng20001204 56813.html (2/02/2004); Also In 2000, Jiang, Zemin, the former General Secretary of the CPC, said at a national conference on United Front Work of the CPC, "the fundamental task of the United Front is to win people's hearts and mobilise all forces to reach the grand goal of the
} 
Taiwanese residents travelling to the Mainland for permanent residence. The responsibility for regulating travel to or from Taiwan is vested in party departments rather than administrative departments of government. Administrative decision-making is in this way politicised.

\section{Policies of the CPC governing travel to or from Taiwan}

The CPC has enacted some provisions in relation to China-Taiwan travel. These include the Opinions on Properly Handling the Work of Taiwan Compatriots Travelling to Motherland to Visit the Relatives, which was promulgated by the Leading Panel of Taiwan Affairs under the Central Committee of the CPC in 1987. The Circular of the MPS on Some Issues of the Application for Travelling to or from Inland of Mainland Chinese who was Granted Permanent Residence of Taiwan Regions (PRC) was promulgated by the MPS after consulting with the Department of United Front Work of the Central Committee of the CPC and Taiwan Affairs office of the State Council. In practice these policies are as effective as law.

\section{Effects of the emphasis of political factors on individual rights and freedoms}

Emphasis on political factors usually leads to limitation or deprivation of the rights and interests of both Mainland and Taiwan Chinese. The following are two representative examples of this. The first concerns the Taiwan permanent resident status of Mainland Chinese. Article 2 of the Circular of the MPS on Some Issues of the Application for Travelling to or from Inland of Mainland Chinese who have been Granted Permanent Residence of Taiwan Regions 1995 (PRC) provides that:

\footnotetext{
Inland China shall not recognise the status of Taiwan permanent residence of Mainland Chinese when they return to the Mainland with Exit and Entry Mainland Pass if they have been granted the status when approved only to temporarily remaining in Taiwan, but have not obtained approval from the relevant inland department responsible for Taiwan permanent residence. The Exit and Entry Mainland Passes of those Mainland Chinese are to be seized and they are to be treated as Mainland Chinese.
}

The inland authority has argued that a primary aim of these measures is to unify and regulate the issuance of travel documents and control over travel. ${ }^{1013}$ This argument is not persuasive

Party and the country." See "President Jiang Zemin On CPC's United Front Work", http://fpeng.peopledaily.com.cn/200012/05/eng20001205 56898.html (2/02/2004).

${ }^{1013}$ Preface of the Circular of the MPS on Some Issues of Exit and Entry Mainland of Mainland Residents Granted 
because the same rule does not apply to Mainland Chinese who have acquired permanent resident status in foreign countries under similar circumstances. Conversely, the Chinese government not only recognises the foreign permanent residence status of persons with inland resident status acquired during a period of temporary travel, but also encourages them to return to China. This form of discrimination seems politically motivated. Whatever the reason, it limits the right of Mainland Chinese people to permanently reside in Taiwan.

The other example concerns Mainland permanent resident status of Taiwan Chinese. The Committee for the Assistance of Retired Veterans of the ROC promulgated the Circular of the Operational Manual of the Application of Retired Veterans for Entering Inland Regions of to Permanently Reside in 1992. Under the Circular, retired veterans who are permanent residents of the Mainland China may apply for an allowance from Taiwanese authorities. In order to do so, they must submit a certificate granting permanent residence, issued by the responsible inland department. Most retired veterans were born in the Mainland and left in 1949. This concession may be due to humanitarian considerations.

However, the Chinese government has indicated that Taiwan's payment of an allowance to veterans is aimed at:

Buying popular support, reducing pressure, and abandoning the burden caused by retired veterans, by stimulating veterans without the ability to work to return to the Mainland China and remit an allowance to them. ${ }^{1014}$

The Department of Unified Front Work (Tongzhan) under the Central Committee of the CPC, and the MPS and the State Council of Taiwan Affairs office, jointly promulgated the Circular on the Prohibition on Issuance of Notarial Certificate of Permanent Residence Certificate for Taiwan Compatriots 1993 (PRC). The Ministry of Justice then issued the Circular on the Prohibition on Issuance of Notarial Certificate of Permanent Residence Certificate for Taiwan Compatriots 1993 (PRC), which prohibits the issuing of notarial certificates of permanent

Permanent Residence of Taiwan Regions 1995 (PRC) (Gonganbu Guanyu Dalu Jumin Huozhun Dingju Taiwan Hou Shenqing Laiwang Dalu Youguan Wenti De Tongzhi), promulgated by the MPS on 8 May 1995.

1014 Mo, Qibo and Zhu, Qiliang, Zhongguo Gongmin Yinsi Chuguo Shouce (the Handbook of Chinese Citizens Going Abroad for Private Purpose), the Publishing House of Guangxi Renmin, Nanling, China 1997, page 269. 
residence certificate to Taiwan residents, whether or not they have been granted permission to settle in China and have registered a household.

The view of the Chinese government regarding reasons for paying an allowance to veterans is questionable. The allowance to veterans is not big enough to be a great burden on Taiwan - it not hard to pay. ${ }^{1015}$ Furthermore, retired veterans may freely choose to stay in Taiwan or return to the Mainland, supported by superannuation and government allowances. More importantly, Taiwan residents with permanent residence status in Mainland China have the right to a certificate attesting to their status. Thus, the reasons for prohibiting the issuance of permanent residence certificates to retired veterans are unacceptable. The prohibition takes away the right to be issued with a notarial certificate, hinders the right to apply for an allowance, and limits their ability to reside permanently in Mainland China.

As a result, the gap between the number of Mainland Chinese travelling to Taiwan and of Taiwanese Chinese travelling to Mainland China is considerable. In 2001, the number of Mainland Chinese travelling to Taiwan was 105,400 , or $0.00008 \%$ of the Mainland population; ${ }^{1016}$ compared with approximately 3.51 million Taiwan residents travelling to Mainland China, or $15.55 \%$ of the Taiwan population. ${ }^{1017}$ The figures illustrate that issues discussed in this section seriously limit the right to leave for Taiwan.

\subsection{Conclusions}

Given that $73.54 \%$ of people travelling to China came from the HKSAR and MSAR, and $71.90 \%$ of people travelling abroad went to those regions, it is imperative to analyse the limits on the right of travelling to or from the HKSAR or MSAR. This chapter has emphatically questioned and criticised the principles of processing applications, to which officials and other researchers have been too accustomed, to call into question.

\footnotetext{
1015 In 2002, Taiwan's per capita GDP was US\$17,400. See Networked Readiness Index Rank: Taiwan.tw, Country Profiles, page 264.

1016 "The People's Republic of China," http://www.dfat.gov.au/geo/china/cb background.html (22/10/2003).

1017 The Numbers of Exits from and Entries into the Chinese Mainland Breakthrough 200 Million in 2001 (2001 Nian Woguo Churujing Renyuan Shouci Tupo 2 Yi Renci), the Bureau of Exit and Entry Administration under the MPS, $18 / 04 / 2003$.
} 
The principle of unilateral examination and approval by Mainland China does not improve the protection of the RLR of Mainland Chinese. It is only a formal claim and the vague double status of the Mainland government in regard to its practice seriously affects the fair exercise of the power of examination and approval. The unilateral approach may jeopardize the rights and interests of one group over the other, to the detriment of Mainland Chinese.

Different fixed quotas in provincial regions are discriminatory. The practice of fixed quotas for temporary visits make for stricter limits on travelling to or from the HKSAR or MSAR. When permission is based on prerequisite certificates from the departments in which applicants are employed, on departure through designated ports, on limited visa exemptions for transit travel, and various provincial legislative limits, it is imperative to further ease these restrictive conditions. The discriminatory principles actually discourage Chinese citizens from recognising the HKSAR and MSAR as parts of China.

The 34-fold difference between the numbers of Taiwan Chinese travelling to the Mainland China and Mainland Chinese travelling to Taiwan clearly highlights the limits on the right to travel to or from Taiwan. The research for this Chapter reveals that an over-emphasis on politics, effected by the politicisation of administrative decision-making, as the foremost reason for this. The restrictive requirements, such as prerequisite certificates from the department in which the applicant is employed, a letter of invitation from Taiwan, and approval from the Taiwanese authorities underpin these issues. RLR is in turn ignored.

In fact, Mainland China controls travel to or from the HKSAR, MSAR or Taiwan of Mainland Chinese, on behalf of the authorities of the three regions. It may be recognised that the HKSAR and MSAR are part of China, so China does not see any thing unusual about asserting control. Presumably, the authorities of the three regions accept this as being a favourable arrangement. However, their acceptance does not mean that the arrangement conforms to international norms 
or improves the protection of the right to leave. 


\section{Chapter Twelve \\ Chinese Emigration Intermediary Agency Laws}

\section{Introduction}

A boom in exit and entry over last two decades triggered the emergence and development of Chinese emigration intermediary agencies (Chujing Zhongjie Jigou), which are unique to China and quite different, for instance, from overseas recruitment services in Vietnam, migration service organisations in Taiwan, registered migration agents in Australia and international travel agencies in China. 'Intermediary' (Zhongjie) in Chinese language means medium, intermedium, vehicle, and instrumentality (Meijie). ${ }^{1018}$ 'Meijie' implies the persons, things, objects or realities that assist both parties to establish a relationship or conduct affairs, ${ }^{1019}$ for example to make contact or handle affairs on behalf of one party by appointment.

Emigration intermediary agencies in Mainland China provide legal services and information for citizens who go abroad for study, permanent residence, visiting family or friends, property inheritance, employment, travel, or training with a license granted by the designated authority. They do this for example by applying for suitable foreign visas on behalf of their clients, as well as providing other relevant services for clients who need Chinese passports and notarial certificates, and providing reception services after arrival in the host country. There are seven types of Chinese emigration intermediary agencies in China that separately provide services for overseas study, exit and entry for private affairs, overseas employment, foreign labour trade and co-operation, overseas travel, overseas training at government expenses, and Sino-foreign joint venture skilled personnel.

The emigration intermediary agencies in China play an indispensable role in the realisation of

\footnotetext{
1018 Dictionary Department, institute of Linguistics, Chinese Academy of Social Sciences, The Contemporary Chinese Dictionary (Chinese-English edition) (Xiandai Hanyu Cidian), Foreign Language Teaching and Research Press, Beijing, 2002, page 2482.

1019 Dictionary Department, institute of Linguistics, Chinese Academy of Social Sciences, The Contemporary Chinese Dictionary (Chinese-English edition) (Xiandai Hanyu Cidian), Foreign Language Teaching and Research Press, Beijing, 2002, pages 1315, 1756 and 522.
} 
RLR. The need of guidance in going abroad provided by intermediary agencies, especially given China's long period of being a closed country, is considerable. Knowledge, understanding and acceptance of foreign countries, as the basis of the desire and decision to go abroad, are cultivated by intermediary agencies. An intermediary agency can offer a wealth of information on foreign countries and emigration to clients.

Besides helping Chinese clients to apply for exiting China, including passport applications, the intermediary agencies also help the clients to choose and apply for the most suitable visa category. The assumption that applicants can lodge visa applications and maintain contacts with foreign immigration authorities rarely applies in China because of language barriers, complex immigration rules and an unfamiliar legal system. Nearly $70 \%$ of self-funded Chinese students, for instance, used an overseas study intermediary agency. ${ }^{1020}$ In 1998 to 1999, 52\% of applications for foreign residency were lodged overseas for New Zealand, ${ }^{1021}$ and almost entirely through intermediary agencies in China. Emigration intermediary agencies also help clients on arrival in the host country, through reception services in-situ that ease concern about arrival and initial integration after successful application for a visa.

An advanced body of emigration intermediary agency law can enhance above-mentioned role of Chinese emigration agencies in realising RLR. This chapter will consider: (i) why the Chinese government regulates emigration intermediary agencies; (ii) the development of emigration intermediary agency laws; and (iii) the issues arising from emigration intermediary agency laws.

\subsection{Why the Chinese government regulates emigration intermediary agencies}

There is a drive to have the Chinese government regulate emigration intermediary agencies. The very ineffectiveness of the agencies, in enhancing conditions for exit and entry, may in fact jeopardise the rights and interests of individuals intending to go abroad. Zheng Zhigeng, the

1020 "Ministry Website to Rate Intermediaries", 28 July 2003, The China Daily, http://www1.chinadaily.com.cn/en/doc/2003-07/28/content 249602.htm (19/12/2003).

${ }_{1021}$ Hon Lianne Dalziel the Minister of Immigration Options for Setting Enforceable Standards for Immigration

Consultants Ministry of Immigration New Zealand Wellington 2001. 
Director of the Zejian Legislative Affairs Office, has said, "There will be a growing demand for intermediary services as governments at all levels step up administrative reforms." ${ }^{1022}$ In 2002, Zhu Rongji, the then Premier, reported that thoroughly standardising and restructuring the market economy was an inevitable choice for China, as a consequence of China's entry into the WTO and new steps taken to open China to the outside world. ${ }^{1023} \mathrm{He}$ further underlined that "it was necessary to regulate and standardise intermediary service organisations."1024

In response to the problems created by chaos in the emigration intermediary agency market and to protect the rights and interests of individuals exiting China, the Circular of the State Council on Strengthening the Management of the Activities of Emigration Intermediary Agencies 2000 (PRC) was promulgated. The measures to regulate emigration intermediary agencies are one part of measures under Article 2 of the Decision of the State Council Relating to Regulating and Regularising the Order of Market Economy 2001 (PRC). ${ }^{1025}$ These laws help protect the rights and interests of individuals exiting China, and reveal the causes of disorder within the emigration intermediary agency services market. Clearly, legal research on emigration intermediary agencies is needed.

\subsection{The development of Chinese emigration intermediary agency laws}

The emigration intermediary agency industry has flourished in China since the 1990s. Illegal agencies rapidly grew in an inadequately regulated market. A series of statutes were then enacted to regulate various categories of intermediary agency. This subsection will review the recent legislative developments in each of the seven categories of agencies. This will then provide a basis for an analysis of the issues associated with the laws in the next section.

\footnotetext{
1022 "Eastern Province Enacts Rules to Regulate Intermediary Services", http://english.cri.com.cn/english/2002/Feb/50498.htm (18/04/2003).

${ }^{1023}$ Zhu, Rongji, then Premier of the State Council, Par. 2 of Part V of "Report on the Work of the Government (16/03/2002)", http://www.fmprc.gov.cn/eng/26804.html (19/07/2003).

${ }^{1024}$ Zhu, Rongji, then Premier of the State Council, Par. 1 of Part V of "Report on the Work of the Government (16/03/2002)", http://www.fmprc.gov.cn/eng/26804.html (19/07/2003).

${ }_{1025}$ Article 2 of Decision of the State Council Relating to Regulating and Regularizing the Order of Market Economy 2001 (PRC), promulgated by the State Council on 8 May 2001.
} 


\subsubsection{Laws governing overseas study intermediary agencies}

The overseas study intermediary agencies (Zifei Chuguo Liuxue Zhongjie) are the agencies that are granted a "Recognition Certificate of Operation Qualification of Self-funded Overseas Study Intermediary Agency Service” (Zifei Chuguo Liuxue Zhongjie Fuwu Jigou Zige Rendingshu), allowing them to offer information about foreign educational institutions, and assist prospective self-funded overseas students with applications for admission and passport and visa applications. In 2003, China had 270 authorised intermediary agencies, with nearly 10,000 staff. $^{1026}$

The Circular of State Education Commission and Ministry of Public Security on Prohibiting Foreign and Domestic Departments and Individuals from Recruiting Students Studying Abroad Self-funded in China Without Allowance (PRC) was promulgated in 1987 to protect self-funded students from being cheated by foreign and domestic agencies and individuals that were recruiting Chinese students to study abroad, and to protect Chinese "educational sovereignty" (Jiaoyu Zhuquan). ${ }^{1027}$ It concentrated on the prohibition of overseas study intermediary agencies for profit. ${ }^{1028}$ Before 1998 , the Shanghai government had only approved one overseas study consultative centre to provide not-for-profit services. ${ }^{1029}$

In 1999, the system of the Recognition Certificate of Operation Qualification of Self-funded Overseas Study Intermediary Agency Service was established to meet growing overseas study

\footnotetext{
1026“"Ministry Website to Rate Intermediaries”, 28 July 2003, The China Daily, http://www1.chinadaily.com.cn/en/doc.2003-07/28/content 249602.htm (09/10/2003).

${ }_{1027}$ Preface of the Circular of State Education Commission on Prohibiting Foreign and Domestic Organs and Individuals from Recruiting Students Studying Abroad Self-funded in China without Allowance 1987 (PRC) (Guojia Jiaowei Gonganbu Guanyu Guoneiwai Zuzhi He Geren Bude Shanzi Zai Woguo Zaoshou Zifei Chuguo Liuxue Renyuan De Tongzhi), jointly promulgated by State Education Commission and the MPS on 21 August 1987.

${ }_{1028}$ Overseas study intermediary agency were regulated in three respects in the Circular of State Education Commission and MPS on Prohibiting Foreign and Domestic Departments and Individuals from Recruiting Students Studying Abroad Self-funded in China Without Allowance (PRC) 1987. Firstly, Article 2 of which provides that Chinese citizens may only contact overseas education institutions by themselves or through relatives and friends. They shall apply for the passport in person to public security departments and the visa in person or through the China Travel Agency to foreign embassies and Consular-General in China. Article 5 further provides that applications for passports for self-funded overseas students, whether submitted by an agency or the applicant, cannot be accepted without the approval from State Education Committee. Furthermore, Article 4 of the Circular stipulates that without the approval from State Education Committee, any organisations and individuals cannot release the recruitment advertisements for foreign education institutions. Moreover, Article 5 provides that the provincial education administration and public security departments have the responsibility of investigating and closing down illegal operations. Lastly, Article 3 sets out that in order to deal with illegal intermediary agency and promote legal self-funded overseas study channels, some non-profit overseas study consultation institutions have been established, with approval from State Education Committee.

1029 Su, Huiyu and Li, Yiran (ed), Yisi Churu Jing Bidu (The Guide to Exit and Entry for Private Purpose), The Publishing House of Wenhui, Shanghai, 1998, pages 3 and 4.
} 
demands, and to protect the rights and interests of prospective overseas students under the Rules on the Control of Intermediary Agency for Self-funded Overseas Study 1999 (PRC). This Rule allowed any educational institutions with the status of legal person to operate an intermediary agency, thereby opening up more channels to facilitate overseas study. The Rule also provides for the management and supervision of legal overseas study agencies by the central government. Meanwhile, local governments enacted regional measures, such as the Measures for the Control of Intermediary Agency for Self-funded Overseas Study (for trial Implementation) 1999 (Beijing).

The enforcement of these laws is lax, and not all violations are prosecuted. Agency that are driven by profit ${ }^{1030}$ have violated the laws by such acts as using a rented license, issuing misleading advertisements, forging documents, providing services in excess of their approved operational scope, and providing services without a license. ${ }^{1031}$ According to the news from Xinhua Network, in 2001, there were 309 overseas study intermediary agencies in Beijing, but only 46 held operational licenses. ${ }^{1032}$ The Circular on Further Regulating Market Order of Self-funded Overseas Studying Intermediary Service 2002 (PRC) was promulgated by the Ministry of Education (MOE) to address these activities. According to the Circular, each province was required to launch a campaign to crack down illegal overseas study agencies and report to the MOE. The MOE was then required to investigate agencies identified in the provincial reports. ${ }^{1033}$

\subsubsection{Laws governing exit and entry intermediary agencies for private affairs}

Exit and entry intermediary agencies for private purposes (Yisi Churujing Zhongjie Jigou) are the agencies granted an "Operation License of Exit and Entry Intermediary Agency for Private

\footnotetext{
1030 In 2003, legal overseas study agencies charged a service fee of between C $¥ 10,000$ to C $¥ 30,000$ (US\$1,207 to US\$3,623) per applicant. Many of these agencies are, in fact, acting as recruitment agencies for overseas educational institutions. See Chen, Tieyuan, Overseas Study without Intermediary Agency: the Interview to Visa Officer of Foreign Countries in China (Piekai Zhongjie Qu Liuxue: Zhuhua Qianzheng Guan Fangtan), the Publishing House of Writer, Beijing, 2002, page 3.

1031 Preface of the Circular on Further Regulating Market Order of Self-funded Overseas Studying Intermediary Service 2002 (PRC), promulgated by the MOE in November 2002

1032 "There are many traps in overseas study intermediary agency", http://learning.21cn.com/liuxue/dongtai/2001-04-11/354145.html (23/07/2003).

${ }_{1033}$ Conclusions of the Circular on Further Regulating Market Order of Self-funded Overseas Studying Intermediary Service 2002 (PRC), promulgated by the MOE in November 2002
} 
Purposes" (Yisi Churujing Zhongjie Jigou Jingying Xukezheng) to provide information and legal advice, make overseas travel arrangements, apply for passports, visas and notarial certificates on behalf of their clients, and other relevant services for citizens who are travelling abroad for permanent residence, to visit family or friends, or to inherit property. By April 2002, 658 exit and entry intermediary agencies for private affairs across approximately 28 provinces, autonomous regions and municipalities directly under the Central Government had been licensed. ${ }^{1034}$

Prior to 2001, all activities of these agencies that involved advertisement were prohibited by the Circular of Ministry of Public Security on Strictly Prohibiting from Illegally Undertaking Activities of Soliciting Clients to Permanently Emigrate 1995 (PRC). ${ }^{1035}$ The prohibitions were aimed at preventing foreign collusion and profit-driven exploitation of applicants. ${ }^{1036}$ However, the demands for the agencies still exist, and with the development of economy, the demands are higher than ever. ${ }^{1037}$

To strengthen the administration of these agencies and to protect the legal rights and interests of citizens, the Measures on the Administration of Emigration Intermediary Agency for Private Affairs 2001 (PRC) were jointly promulgated by the MPS and State Administration of Industry and Commerce (SAIC) in July 2001. The Measures regulated the establishment and operation of agencies, and the management and use of reserve funds. From December 2000 to January 2001,

\footnotetext{
1034 There were 108 agencies in Beijing, 33 agencies in Shanghai and 116 agencies in Guangdong.

1035 Article 1 of the Circular of Ministry of Public Security on Strictly Prohibiting from Illegally Undertaking Activities of Soliciting Clients to Permanently Emigrate 1995 (PRC) provides "an examination shall be made on whether a migration agency for profit is involved when various public security departments to accept and process the application of citizens for exit abroad. If intermediary agency or individuals are found to have provided migration agency services, they must be banned. [...] Applications for "investment migration", "business migration" and "skills migration" introduced or organised by domestic and foreign organisations or individuals that are without the approval from State responsible departments shall not be accepted." Article 2 provides "without the approval from the State responsible departments, advertisement and publicised materials cannot be released in newspapers, journals, televisions and radios. [...]"

1036 Preface of the Circular of MPS on Strictly Prohibiting From Illegally Undertaking Activities of Soliciting Clients to Permanently Emigrate 1995 (PRC) provides Over last few years, [...] some domestic units and individuals [...] in collusion with foreign "migration experts' or "migration services organisations', provide unauthorised "investment", "business' and 'skills' migration services to illegally attract and organize Chinese citizens to emigrate, and exploit others for the benefit of themselves. A few sneak ahead to take the chance of organising and sending illegal emigrants.

${ }^{1037}$ The Circular of the MPS, MOE, the Ministry of Labour and Social security, the State Administration of Industrial and Commerce for Rectifying and Regulating Exit and Entry Intermediary Agencies (Gonganbu Jiaoyubu Laodong He Shehui Baozhangbu Guojia Gongshang Xingzheng Guanliju Guanyu Qingli Zhengdun Churujing Zhongjie Jigou De Tongzhi), promulgated and as effective as 27 November 2000.
} 
various provincial-level public security departments inspected and closed down agencies that were operating illegally. Nationally, 361 unqualified agencies were closed down, and nearly 400 persons are arrested or detained. ${ }^{1038}$ Many provinces announced detailed rules of the implementation of above-mentioned Measures. For example, the Some Rules on the Implementation of Measures on the Administration of Emigration Intermediary Agency for Private Affairs (for Trial Implementation) 2002 (Beijing) was introduced in order to permit the investigation and detailed administration of agencies for private affairs in Beijing.

\subsubsection{Laws governing overseas employment intermediary agencies}

In 2000, there were more than 80,000 Chinese people working abroad. ${ }^{1039}$ The overseas employment intermediary agencies (Jingwai Jiuye Zhongjie Jigou) are those granted a "License of Overseas Employment Intermediary Agency" (Jingwai Jiuye Zhongjie Xukezheng) to offer services to individuals wanting to work overseas. Their functions include providing labour market information to Chinese workers, job recommendations and recruitment, execution of employment contracts, assisting applications for passports and visas, technology and language training, assistance with insurance, and protection of labour rights by mediation, arbitration and litigation.

Overseas employment from China began in the late 1970s. The Regulations on the Administration for Overseas Employment Intermediary Agency 1992 (PRC) prescribe that overseas employment intermediary agencies must be approved by the Ministry of Labour and Social Security (MLSS). This regulation ensures that overseas employment agencies operate lawfully and protect the basic rights and interests of labourers abroad. Some approved employment agencies engaged in illegal conduct, such as participating in illegal migration and sending young women abroad to provide erotic services. In response, the MLSS announced the Circular of Ministry of Labour on Prohibition of Illegal Act of Overseas Employment (PRC) in 1995. However the legal rights and interests, and sometimes even the life and safety of the

\footnotetext{
1038 Xinahua News Agency, 193 Exit and Entry Intermediary agency for Private Purposes were Qualified (193 Jia Yinsi Churujing Zhongjie Jigou Tongguo Zige Rending), 8 February 2002.

${ }^{1039}$ Quoted in the OECD, Migration and the Labour Market in Asia: Recent Trends and Policies, the OECD Paris 2001, page 130 .
} 
labourers, were frequently infringed or put at risk as some agencies single-mindedly pursued profits. The MLSS then took measures to rectify and regulate overseas employment agencies in the Circular on Management of Overseas Employment (PRC) in 2000. ${ }^{1040}$

In 2002, the Regulations on the Administration for Overseas Employment Intermediary Agencies (PRC) were enacted to further regulate overseas employment agencies. These regulations were based on prior legislative experiences and international norms. The regulations relate to procedures, management and scope of operations, obligations and duties of intermediary agencies, record keeping of overseas labour contracts and agency services contracts. ${ }^{1041}$ Agencies that did not comply with the new regulations were closed down following their introduction. ${ }^{1042}$ Agencies licensed prior to the introduction of the regulations needed to re-apply and re-register within 90 days of the date from which they became effective. ${ }^{1043}$

\subsubsection{Laws governing the foreign labour trade and cooperation company}

The foreign labour trade and cooperation companies (Duiwai Laowu Hezuo Jingying Gongsi) are the agencies that operates under a "Certificate of Operation Qualification of Foreign Economy Cooperation" (Duiwai Jingji Heizuo Jingying Zige Zhengshu) issued by the then Ministry of Foreign Trade and Economic Cooperation (MFTEC) ${ }^{1044}$, to undertake foreign projects, engineering, international labour cooperation and consulting services. They are licensed to organise and send workers in accordance with foreign contracts, and are responsible for the management of contract workers abroad. These activities are referred to as "labour export" (Laowu Chukou). According to the SBS, by 1998 the total revenue of overseas projects

\footnotetext{
1040 The measures include: (1) Ensuring that agencies are licensed to operate and closing down those that are not; (2) Using the mass media to inform citizens about the national overseas employment policy, conditions of legal employment, standards to which employment agencies must adhere, so that they can identify illegal agencies; (3) Opening a public hotline and encouraging people to report illegal overseas employment agency activities; (4) Investigation and resolution of reported problems.

1041 Article 2 of the Circular on Some Matters of Implementation and Carrying Out Regulations on the Administration for Overseas Employment Intermediary agency (Amendment) 2002, promulgated by the Ministry of Labour and Social Security on 24 June 2002 and effective at the same day.

1042 Article 3 of the Circular on Some Matters of Implementation and Carrying Out Regulations on the Administration for Overseas Employment Intermediary agency (Amendment) 2002, promulgated by the Ministry of Labour and Social Security on 24 June 2002 and effective at the same day.

1043 Article 39 of the Regulations on the Administration for Overseas Employment Intermediary agency (Amendment) 2002 (PRC), jointly promulgated by the MLSS, MPS and SAIC on 14 May 2002.

1044 The MFERT was renamed as the Ministry of Commerce in 2003.
} 
exceeded US\$11 billion. ${ }^{1045}$

The Provisional Measures on Procedures for Contract Workers Sent Abroad and Undergoing Passport Application 1990 (PRC) established a series of very strict provisions related to sending contract workers abroad. ${ }^{1046}$ The Provisional Measures on Procedures for Contract Worker Sent Abroad Leaving the Country 1996 (PRC) emphasised the licensing system contained in the Provisional Measures $1990 .{ }^{1047}$ It also strengthened requirements for technical and personal training for workers. ${ }^{1048}$

The Provisional Measures 1990 and 1996 were significantly affected by a planned central economy, which could no longer meet the demands of reform and opening-up. The Measures on Procedures for Contract Worker Sent Abroad Leaving the Country 2002 (PRC) promulgated that the public security departments have unified responsibility for the examination and approval of contract workers sent abroad. The authority does not extend to examining the genuineness of overseas projects, and the limitations on trans-province designation of workers have been cancelled.

\subsubsection{Laws governing international travel agencies}

International travel agencies (Guoji Lvxingshe) are those granted an "Operation License of Travel Agency" (Lvxingshe Jingying Xukezheng) for the purpose of handling exit, entry and visa applications on behalf of tourists, to solicit tourists for overseas travel, and to arrange overseas

\footnotetext{
1045 Statistical Communique of the People's Republic of China on the 1998 National Economic and Social Development, Quoted in Biao. Xiang, "Emigration from China: A Sending Country Perspective". International Migration, Volume 41, Number 3 (September 01, 2003), page 21-48. http://ejournals.ebsco.com/direct.asp?ArticleID=P8PYFRBJLETKMYT3KQ4F (01-10-2003), page 32.

${ }^{1046}$ Article 3 of the Provisional Measures on Procedures for Contract Workers Sent Abroad and Undergoing Passport Application 1990 (PRC) provides that the sending unit means enterprises which, with approval of the MFERT and a business license issued by the administration of industry and commerce, are authorised to undertake foreign contracted project engineering and international labour cooperation. Article 4 provides that the sending unit cannot send contract workers abroad unless they are licensed to do so (Waipai Laowu Renyuan Xukezheng), and there is a concluded contract with a foreign party." Article 5 prescribes that no contract workers can be sent abroad unless approved by foreign trade and economic cooperation administration under vice-provincial governments or a relevant ministry.

1047 Article 4 of the Provisional Measures on Procedures for Contract Worker Sent Abroad Leaving the Country 1996 (PRC), jointly promulgated by the MFERT, MFA and MPS on 20 December 1996.

1048 Article 20 of Provisional Measures on Procedures for Contract Worker Sent Abroad Leaving the Country 1996 (PRC): "MOFTEC shall institute and perfect the adaptive training system prior to going abroad conducted for contract workers sent abroad. When issuing passports to contract workers abroad, the passport-issuing agency may examine their training qualification certificates when necessary."
} 
tourist accommodation in return for a fee. According to the World Tourism Organisation, China is among the top 10 nations for outbound tourism. From 1994 to 2003, the total number of outbound Chinese tourists reached nearly 100 million, at an annual growth rate of 12.87 percent. ${ }^{1049}$ This roaring tourist market has lured numerous travel agencies to share the outbound Chinese travellers' market. Only licensed international travel agencies can provide inbound and outbound travel services. ${ }^{1050}$

The Provisional Regulations on the Administration of Travel Agency 1985 (PRC) and the Regulations on the Administration of Travel Agency (Amendment) 1996 (PRC) prescribe the payment of a quality-guarantee deposit, needed for an operational license, and a process of annual inspection. These were the earliest regulations regarding the compulsory standard of service, requirement of operational qualifications, and scope of the government supervision, in the area of emigration intermediary agencies. Similar systems have been incorporated into regulations dealing with other categories of emigration intermediary agencies.

In 2001, the State Council promulgated the Decision on Revising the Regulations on Administration of Travel Agency to systematically regulate Sino-foreign international travel agency. This was a consolidation of the Provisional Regulations of Trial Establishment of Sino-foreign Joint Equity Travel Agency 1999 (PRC) and the Regulations on Administration of Travel Agency (Amendment) 2001 (PRC). Restrictions on foreign investment in international travel agencies were reformed again after China entered the WTO. According to the Provisional Regulations of Administration of Foreign Holding and Foreign Self-funded Travel Agency 2003 (PRC), foreign investors with an annual turnover of US\$ 40 million may apply to establish foreign holdings and foreign self-funded travel agencies. ${ }^{1051}$

\footnotetext{
1049 Also, Data from the Chinese National Tourism Administration indicates that there was a dramatic increase in the number of countries and regions that have signed agreements with China to accept Chinese tourists from 1988 (when there were only three such agreements), to September 2004 (when there were 73) China's outbound travellers reached 14.99 million in the first seven months of 2004, there was a 63.7 percent increase from the same period of 2003. "China's Outbound Travellers Reach 14.99 Million in the First Seven Months", http://english.people.com.cn//200409/17/eng20040917 157376.html (19/09/2004).

${ }^{1050}$ Article 5 Clause 2 of the Regulations on the Administration for Travel Agencies (Amendment) 2002 (PRC) amended pursuant to Travel Agencies Administrative Measures 1996 (PRC), promulgated by the State Council on 11 December 2001 and effective on 1 January 2002.

${ }^{1051}$ Article 3 and 4 of the Provisional Regulations of Administration of Foreign Holding and Foreign Self-funded Travel Agency 2003 (PRC), jointly promulgated by China National Tourism Administration and Ministry of Commerce on 12 June 2003 and effective on 11 July 2003.
} 
The regulations mentioned so far have attempted to promote the order and development of the international travel agency industry. On the other hand, the Provisional Measures on the Administration of Chinese Citizens Tour Abroad at Their Own Expenses 1997 (PRC) and the Measures on the Administration of Chinese Citizens' Tours Abroad 2002 (PRC) emphasise the obligations and duties of international travel agencies with respect to safeguarding the rights and interests of tourists, and ensuring that they are able to make a timely return to China. The Measures on the Administration of Chinese Citizens Tours Abroad 2002 (PRC) strengthens the protection of tourists' rights and interests in the three respects of accessing information, economics and person and property.

\subsubsection{Laws governing overseas training at government expense intermediary agencies}

The overseas training at government expense intermediary agencies (Chuguo Peixun Zhongjie Jigou) are those issued with a "License of Overseas Training Intermediary Agency" (Chuguo Peixun Zhongjie Jigou Xukezheng) to select and dispatch technical and managerial personnel to other countries and regions for training at government expense, and assist them with passport and visa applications. The State Administration of Foreign Experts Affairs (SAFEA) stresses that unauthorised agencies will be punished if they attempt to undertake these activities. ${ }^{1052}$ According to the SAFEA, about 40,000 people are currently sent abroad every year for training. Since 1978, there have been approximately 450,000 people sent for overseas training at government expense. ${ }^{1053}$

The only relevant legislation, the Provisional Rules on the Recognition of Overseas Training Qualification of Dispatching Groups and Personals to Other Countries for Training of the Institutions and the Mass Departments was enacted in 1993, 15 years after the first group of trainees were sent abroad in 1978. Under Articles 5 and 6(3) of the Provisional Rules, overseas training agencies are classified as national or regional agencies. National agencies may select and dispatch personnel from anywhere in China, whereas regional agencies are limited to

\footnotetext{
1052 "20 Agencies Authorized to Send Personnel for Overseas Training", 1 January 2001, China Education and Research Network, www.edu.cn/20010101/21989.shtml (19/12/2003).

1053 “Overseas Training", http://www.safea.gov.cn/?menu=train\&sub=cgpxgz (28/01/2004).
} 
dealing with personnel from that region. The prohibition of agencies operating for profit restrains competition in the industry. The organising and dispatching of personnel overseas for profit is prohibited..$^{1054}$

Moreover, as the aim of the rules is to build an honest and accountable government, and to prohibit government employees from touring overseas at public expense, ${ }^{1055}$ it hardly protects individual trainees' rights to overseas training. Yang Hanyan, the Deputy Director of the SAFEA, observed that the granting of a License of Overseas Training Intermediary Agency is an important anti-corruption practice. ${ }^{1056}$ Finally, recognition of overseas training agencies has been slow. The SAFEA authorised the establishment of regional agencies in 1994 and 1995. The first 20 national agencies were established in 2000. Each is under the direct government control, which can have consequences both for the protection of the right to leave for training and the effective use of public money for training.

\subsubsection{Laws governing Sino-foreign joint venture skilled personnel intermediary agencies}

The Sino-foreign joint venture skilled personnel intermediary agencies (Zhongwai Hezi Rencai Zhongjie Jigou) are those granted an "Operation License of Skilled Personnel Intermediary Agency" (Rencai Zhongjie Fuwu Xukezheng). These are joint ventures between Chinese and foreign companies, both of which are engaged in skilled personnel agency services. These agencies may recruit skilled personnel for employment abroad. In relation to overseas recruitment, these agencies are permitted to recruit for any industry, other than the six prohibited

\footnotetext{
1054 According to Article 2 of Circular on the Recognition of Qualification of Overseas Training of Dispatching Personals to Other Countries for Training of China Communication Centre of Science and Technology and other 19 Institutions and the Mass Departments 2000 (PRC),

Also see similar provisions at Article 4 Clause 5 of the Provisional Rules on the Recognition of Overseas Training Qualification of Dispatching Groups and Personals to Other Countries for Training of the Institutions and the Mass Organs 1993 (PRC) (Guanyu Shiye Danwei Shehui Tuanti Zuzhi Panqian Tuanzu He Renyuan Fu Guo (Jing) Wai Peixun Gongzuo Zige Rending De Zaixing Guiding), promulgated by State Administration of Foreign Experts Affairs in 1993, Waizhuanfa [1993] page 204.

${ }^{1055}$ Preface of the Provisional Measures on the Administration of Dispatching Groups and Personals to Other Countries for Training 1993 (PRC) (Guanyu Panqian Tuanzu He Renyuan Fu Guo (Jing) Wai Peixun De Zaixing Guanli Banfa), jointly promulgated by the State Administration of Foreign Experts Affairs and the MFA on 20 October 1993.

1056 Quoted in "20 Agencies Authorized to Send Personnel for Overseas Training", 1 January 2001, China Education and Research Network, www.edu.cn/20010101/21989.shtml (19/12/2003).
} 
categories of personnel (see part 9.2.1 of this book). ${ }^{1057}$ Sino-foreign skilled personnel agencies are the newest category among the emigration intermediary agencies, and have been actively developed in China over the past two years.

The limitations on foreign investment in the skilled personnel intermediary sector were relaxed after China joined the WTO in December 2001. The Regulations on the Administration of Skilled Personnel Market 2001 (PRC) allowed foreign investment in China's skilled personnel intermediary services in the form of joint ventures. Shanghai and Beijing respectively issued the Circular of Shanghai Municipality of Sino-Foreign Equity or Cooperative Joint Venture Skilled Personnel Intermediary Agency in This Municipality 2002 (Shanghai), and Provisional Measures of the Beijing Municipality for Promotion the Establishment of Sino-Foreign Joint Venture Skilled Personnel Intermediary Agency 2002 (Beijing).

The Ministry of Personnel (MOP), Ministry of Commerce (MOC) and SAIC then jointly promulgated the Provisional Regulations of Administration of Foreign Holding and Foreign Self-funded Travel Agencies 2003 (PRC). Under Article 11 of the Provisional Regulations, enterprises seeking to establish Sino-foreign joint venture skilled personnel intermediary agencies must submit a written application with the necessary documents to provincial personnel departments for approval.

\subsection{The issues arising from Chinese emigration intermediary agency laws}

The rapid development of emigration intermediary agencies has played a conspicuous role in the realisation of RLR in China. However, due to a lack of legislative experience and the inveterate abuses of the separate management of different industries, there are many aspects of the laws greatly in need of improvement. These issues currently impinge on the ability of the agencies to fully perform their role.

\footnotetext{
1057 Article 13 of the Provisional Regulations on the Administration of Sino-Foreign Joint Venture Personnel Intermediary Agency 2003 (PRC) (Zhongwai Hezi Rencai Zhongjie Jigou Guanli Zaixing Guiding), jointly promulgated by the Ministry of Personnel, the MOC and SAIC on 4 September 2003.
} 


\subsubsection{Excessive demand for licenses and certificates}

In addition to a Business License of Industry and Commerce (Gongshang Yingy Zhizhao) issued by the administration of industry and commerce, each category of agency must have a specific license issued by the relevant department responsible for the agency. Most licenses or certificates have only provincial, as opposed to national, validity. Every agency is prohibited from providing services beyond the scope of their license in the guise of authorised services. One example of the prohibition is in Article 2 (2) of the Measures on the Administration of Exit and Entry Intermediary Agencies for Private Affairs 2001 (PRC) which underlines that, "These measures shall be neither applicable to agency service for Chinese citizens going abroad for studying, nor for employment, tourism or labour service".

It appears that the purpose of the separated license system is to protect the rights and interests of individuals exiting China, to foster the development of emigration intermediary agency market, and facilitate the management of agencies. Unfortunately, the system does not completely achieve these goals, on three key grounds.

Firstly, there is an insufficient base of practical experience or theoretical support for the separated license regime. In theory, it is difficult to distinguish between the precise scope of each category of agency, and there are cases when the same applicant needs to seek the services of two or more agents for one journey. For instance, an overseas student may additionally have the demand to become a permanent resident of the destination State. In practice, the authorities may not exactly understand this and therefore not enforce the permissible operational scope of each category of agency. For example, Chongqing Public Security Department responded to complaints made by a local international travel agency that some local exit and entry intermediary agencies for private affairs were providing international travel services. The Chongqing authority thought that the activities of the relevant exit and entry intermediary agencies for private purposes were legal, provided that the word "tour" was not used in advertisements, and no punishment was made. ${ }^{1058}$ Clearly, the terms of advertisement cannot

\footnotetext{
1058 Ding, Xiangle, Snatch Customers Between Exit and Entry Intermediary Agency for Private Purposes and Overseas Travel Agencies (Chuguo Zhongjie Yu Lvxingshe Qiangke Zhuguan Bumen: Cantuan Bie Zoucuo Difang), Chongqing Evening Newspaper, 21 March 2003.
} 
really help distinguish if the operation of one emigration intermediary agency is beyond its permissible scope.

The licensing system also limits the size of intermediary agencies and prevents them from offering comprehensive services. The complexity of being supervised by multiple government departments, coupled with the requirement of paying multiple quality guarantee deposits and reserve funds, discourages applications for multiple licenses. At the same time most agencies have no alternative but to operate regionally rather than nationally. Leaving aside the HKSAR and MSAR, there are 33 provincial administrative regions in China. If one intermediary agency wishes to develop a national business of one just kind of emigration intermediary service, it would have to apply for 33 licenses, and establish 33 reserve funds or quality-guarantee deposits. This represents a practically insurmountable obstacle.

A licensing system that restricts the opportunity for agencies to expand so to cut operational costs and increase their success rate, severely affects the development of the industry. Intermediary agencies may not become more popular and reliable, and so enhance public confidence with respect to individuals' right to leave, until they can. ${ }^{1059}$ The very survival of these businesses may be problematic in the sense that agencies must be able to meet the comprehensive demands of clients, if they are to remain viable.

In order to survive and develop in a competitive market, some agencies will either apply for more licenses and certificates to officially extend the scope of their business, or exploit vague provisions to secretly offer services that exceed the scope of their license. In the later case, the rights of individuals exiting China can be put at jeopardy by the illegal operation of businesses providing unlicensed services. ${ }^{1060}$

\subsubsection{Overly strict admission criteria}

\footnotetext{
1059 Beijing Chuangxintian Investment Consultant Limited Company (Beijing Chuangxintian Touzi Guowen Shiwusuo Youxian Gongsi), "What Exit and Entry Intermediary agency for Private Purposes Can do" (Yimin Zhongjie Gongsi Haiyou Zuowei Ma), 13 August 2003, http://goabraod.sohu.com/53/30/article212083053.shtml (30/12/2003).

1060 For example, the Beijing Yingzhiye Cultural Exchange Company recruits students from Weihai in East China's Shandong Province. The Beijing Education Committee has suspended the company because Beijing is this company's legalised business area. See "Ministry Website to Rate Intermediaries", 28 July 2003, The China Daily, http://www1.chinadaily.com.cn/en/doc.2003-07/28/content 249602.htm (09/10/2003).
} 
License applicants are required to meet the strict demands related to investors, human resources, finance and capital and business premises. The provisions related to admission criteria are set out in Appendix three of this book.

Reserve funds or quality-guarantee deposits impose a significant financial burden on businesses. Their purpose is to provide compensation to clients whose rights have been infringed and to ensure the payment of fines and penalties. The funds must be deposited into a trust fund and held by a designated State-owned bank. The amount to be paid varies between provincial regions. For example, an emigration intermediary agency for private purposes shall have reserve funds of C¥2 million (US\$ 241,546) in Beijing, ${ }^{1061}$ and C $¥ 500,000$ (US\$ 60,386) in Henan Province. And, an overseas study intermediary agency shall have reserve funds of C¥ 1 million (US\$ 120,773) in Beijing, ${ }^{1062}$ and C $¥ 500,000$ (US\$ 60,386) in Anhui Province. Interests accrued from funds is paid to the agency according to the terms of the deposit. The interest rate at the Beijing Commercial Bank is $0.72 \%$ for a flexible term deposit, and $2.79 \%$ for a five-year fixed term deposit. ${ }^{1063}$ Such low rates of interest mean that Beijing agencies, unless they can obtain a return of at least $3 \%$ more, cannot maintain the same profit rate as other businesses.

This loss of revenue is particularly significant given that since 2003, countries such as Canada and Australia have successively increased their criteria for skilled immigration. According to a Beijing survey in 2003, the number of eligible Chinese skilled applicants will decrease by 78.3 $\%$ for Canada and $38.4 \%$ for Australia. ${ }^{1064}$ Many agencies are finding it difficult to remain viable in the marketplace, and materials from the Beijing Administration of Exit and Entry

\footnotetext{
1061 Article 27 of the Some Rules on the Implementation of Measures on the Administration of Exit and Entry Intermediary agency for Private Affairs (for Trial Implementation) 2002 (Beijing), promulgated by Beijing Municipality Public Security Bureau and Beijing Municipality Administration of Industry and Commerce on 1 January 2002 and effective on 1 January 2002.

${ }_{1062}$ Article 7 of the Measures for the Control of Intermediary agency for Self-funded Overseas Study (for Trial Implementation) 1999 (Beijing), promulgated by Beijing Municipality Committee of Education, Beijing Municipality Public Security Bureau and Beijing Municipality Administration of Industry and Commerce on 2 November 1999 and effective at the same day.

1063 "The Interests Lists of Renminbi Deposit" (Renminbi Cunkuan Lilv Biao), Beijing City Commercial Bank, http://www.bccb.com.cn/cunkuablilv.asp (28/01/2004).

${ }_{1064}$ Beijing Chuangxintian Investment Consultant Limited Company (Beijing Chuangxintian Touzi Guowen Shiwusuo Youxian Gongsi), "What Exit and Entry Intermediary agency for Private Purposes Can do" (Yimin Zhongjie Gongsi Haiyou Zuowei Ma), 13 August 2003, http://goabraod.sohu.com/53/30/article212083053.shtml (30/12/2003).
} 
indicate that 33 emigration intermediary agencies in Beijing have cancelled their licenses during 2002-2003. ${ }^{1065}$ To reduce the pressure of operations, Beijing Exit and Entry Administration Department refunded C $¥ 1$ million (US\$ 120,000) to the agencies in 2003 as required.

Secondly, the requirement that agency employ at least five qualified staff also imposes a financial burden on the industry, particularly if the workload reduces to the extent that it is no longer necessary for businesses to maintain a full compliment of staff. The workload may reduce below viable levels as a result of deregistration or changes of market. By comparison, many registered Australian migration agencies not only provide various migration services, but also employ only one or two qualified staff.

Finally, applications for most licenses and certificates filed by foreign investors are not accepted. Law firms are not automatically entitled to the qualification of providing intermediary services in China, as in respect of being qualified in other countries. They must instead submit new applications. ${ }^{1066}$ Investors hesitate at the prospect of overly strict admission criteria. As a consequence, the limitations on the investor affect the development of emigration intermediary agencies.

\subsubsection{Irregular examination and approval}

Applications to establish emigration agencies are often examined and approved in an irregular manner. They are processed in batches rather than in accordance with the order in which they are lodged. Batches of licenses for exit and entry intermediary agency for private affairs were issued in February 2002 (219), March 2002 (193), April 2002 (250) and September 2003 (14 license issued). Overseas education agency licenses were issued by the MOE in 2000 (246) and again in 2003 (242).

Irregular examination and approval of applications creates a bureaucratic barrier to entry into the industry. While the purpose of the agencies is to grasp business opportunities and generate

1065 "The List of 83 Beijing Municipality Exit and Entry Intermediary Agencies", Beijing Administration of Exit and Entry, http://www.bjgaj.gov.cn/crj/guide/default.htm (28/01/2004).

1066 Zhao, Yufei, "Question Why the Application Filed by Law-firm for Exit and Entry Intermediary Agency Shall not be Accepted" (Ziyi Yisi Churujing Zhongjie Huodong Guanli Banfa: Yimin Yewu Zenneng Dui Lvshi Shiwusuo Guanshang Damen), No.2 [2002] Chinese Lawyer (Zhongguo Lvshi), pages 71-72. 
profit, these opportunities are lost if the application process is protracted and unpredictable. This may mean that potential agents lose interest.

The main reason for the irregular examination and approval of applications is to regulate the market and reduce the workload of responsible departments. However, the facts demonstrate that this administrative method fails. The solution to reducing administrative workloads is to create more efficient systems, rather than processing in batches.

\subsubsection{Non-recognition of Chinese emigration intermediary agencies by foreign countries}

Even though Chinese emigration intermediary agencies have established relationships with relevant counterpart services overseas, and have directly signed valid cooperative agreements with them, foreign countries do not necessarily recognise licensed Chinese emigration agencies. This weakens the credibility of the Chinese system.

Chen Tieyuan has found that 16 countries, including the USA, Australia, Canada, France and Japan, do not recognise Chinese-licensed overseas study intermediary agencies. ${ }^{1067}$ Traditional immigration countries do not recognise Chinese-licensed agencies for private affairs. Australia only recognises licensed agencies for private affairs that hold an Australian migration agent's certificate. With respect to group tourism, destination countries only recognise travel agencies approved by their own State.

In the absence of bilateral agreements with destination countries and common standards of regulation and protection for migrants between countries, policy-makers have difficulty in developing a coherent strategy. Bilateral initiatives are important because migration is a dynamic process that involves both the country of origin, or sending country, and the country of destination. These agreements have mainly evolved as a product of the initiatives of destination

1067 Sixteen countries are the USA, the UK, Australia, Canada, Germany, France, Japan, New Zealand, Singapore, South Africa, South Korea, Sweden, Spain, Brazil and Mexico. Chen, Tieyuan, Overseas Study without Intermediary Agency: the Interview to Visa Officer of Foreign Countries in China (Piekai Zhongjie Qu Liuxue: Zhuhua Qianzheng Guan Fangtan), the Publishing House of Writer, Beijing, 2002, pages 2-6. 
countries to improve supervision over emigration agencies. They reflect the weaknesses of the Chinese regime governing emigration intermediary agencies, which is both internally problematic and at one remove from the international community.

\title{
12.3.5 Joint liability of intermediary agencies
}

The joint liability of emigration intermediary agencies, whose clients violate the provisions regarding exit and entry, is inappropriately emphasised by the legislation. Article 22(2) of the Measures on the Administration of Chinese Citizens Tours Abroad (Amendment) 2002 (PRC) sets out that:

When a tourist stays abroad and fails to return to China, the tour guides shall make reports to the tour organiser and China's embassy or consulate in that country. The tour organiser shall make reports to the administration department in charge of tourism and the public security organ in time. When the relevant authorities deal with the affairs concerned, the tour organiser shall give assistance.

The relevant punishment is provided in Article 32 Clause 1 of the Measures on the Administration of Chinese Citizens Tours Abroad (Amendment) 2002 (PRC) which provides that:

\begin{abstract}
Where a tourist stays abroad and fails to return to China, and the tour group guide fails to duly make a report to the tour organiser and China's embassy or consulate in the country of destination, or the tour organiser fails to make a timely report to the relevant authorities in violation of the provisions of Article 22, the tour organiser shall be warned and suspended from operating the business for organising tours abroad, and the tour group guide shall have its Tour Group Guide Certificate suspended by the administrative department in charge of tourism.
\end{abstract}

The aim is to minimise the number of people who stay abroad illegally, by imposing responsibilities on the tour organiser and guide. Similar punishment has been undertaken, as discussed in part 8.3.3 of this book, of individuals who breach provisions for the management of public affairs passports. This rule might be traced to practices of Xia Dynasty (2070 B.C. -1600 B.C.) in which individual was punished for being related to or friendly with somebody who had been convicted of an offence. ${ }^{1068}$ It is fair to assert that it is inappropriate to punish tour

1068 Dictionary Department, Institute of Linguistics, Chinese Academy of Social Sciences, The Contemporary 
organisers and guides when tourists fail to return to China.

\subsubsection{Inadequate supervision of the operations of emigration intermediary agencies}

A lack of suitable supervision of the operations of emigration agencies seriously affects the maintenance and improvement of service quality and professionalism. The issues in this regard mainly focus on the overseas experience, qualifications, and continuing education of professional staff, and the enforcement of service standards.

It is common sense that all professional emigration agency staff should not only to meet the strict admission standards, but must undergo compulsory continuing education. For example, in Australia, registered migration agents cannot renew their annual registration unless they have received 10 'continuing education points' and maintain access to current reference materials. There are no compulsory requirements related to continuing education, overseas experience or qualifications for professional staff in China. With respect to enforcement of professional service standards, agencies may manage their finances, clients' records and staff as they think fit. The most important form of supervision over the operation of intermediary agencies is the annual inspection. Agencies can pass their annual inspection so long as seriously illegal activities have not occurred.

In order to crack down the illegal activities of emigration agencies, the MPS, MOE, MLSS, and SAIC have jointly acted on a national scale. However, only advanced legal measures, rather than ad hoc or erratic reform measures, can maintain an orderly market. The current approach risks undermining public confidence in the existing legal system. The formulation of suitable rules for supervision of the emigration industry is an urgent task.

\subsubsection{The administration of emigration intermediary agencies}

There are some advantages to administering the industry on a regional or agency-type basis. However, supervision of such a broad range of activities places pressure on the bureaucracy,

Chinese Dictionary (Chinese-English edition), Foreign Language Teaching and Research Press, Beijing, 2002, page 513. 
limiting their ability to respond quickly and flexibly to changed circumstances. Administrators tread a fine line between ensuring that they have sufficient power to regulate the emigration industry and not creating incentives for irregular migration. Administrators must be careful to avoid using their licensing powers to create a monopoly in an industry sector. A tightly controlled market may increase the price of services to potential migrants, whereas a liberal system may open the market to fraudulent operators. The State needs to decide whether or not to use the free market to regulate the industry. Use of the market in this way could improve the flow of information and create competition within the industry. Equally, protection of migrants' rights cannot be used to justify the creation of additional bureaucratic hurdles. The regulatory system should form a dependable mechanism to prevent unscrupulous emigration consultants from breaching their fiduciary responsibilities for profit, or mismanaging their clients' affairs.

\subsection{Conclusions}

Emigration intermediary agencies are unique to China and pertinent to any analysis of RLR in China: an increased rate of exit and entry over the last two decades has triggered their emergence. Due to the lack of legislative experiences and correct legislative aims, many issues exist in the laws for the emigration intermediary agencies established since the 1990s and especially 2000s.

Investors are discouraged by the prospect of overly strict industry admission criteria, and the excessive demands of licenses and certificates limit the size of agencies and prevent them from offering comprehensive services. Irregular examination and approval of applications further creates a bureaucratic barrier to entry into the industry. Non-recognition of foreign countries further reflects the weaknesses of the Chinese regime governing emigration intermediary agencies, which is problematic internally and at one remove from the international community.

It is fair to assert that the laws for joint liability of emigration intermediary agencies, whose clients violate provisions regarding exit and entry, are inappropriate. The lack of suitable supervision of the operation of emigration agencies seriously affects the maintenance and 
improvement of service quality and professionalism. Formulation of suitable rules regarding supervision of the industry is an urgent task. These issues combined, while unresolved, mean that the administration of emigration intermediary agencies cannot respond quickly and flexibly to reform. 


\section{Chapter Thirteen \\ Chinese Exit and Entry Administrative System}

\section{Introduction}

This chapter will build on and recount earlier work, to conduct a systematic analysis of the administration of exit and entry in China and related issues and implications for RLR. The chapter examines (i) the functions of exit and entry administrative authorities; (ii) the discretions of those authorities; ${ }^{1069}$ and (iii) the merits review of administrative decisions regarding exit and entry.

\subsection{Functions of exit and entry administrative authorities}

As is clear from the book so far, a wide range of authorities administer the control of exit, entry, transit, residence and travel of Chinese citizens and aliens and supervise the establishment and supervision of emigration intermediary agencies. Exit and entry administrative functions are distributed across 15 ministerial-level authorities — for immigration, emigration, nationality, border inspection, criminal investigation, household registration, foreign exchange control, and emigration agencies, and further divided into various levels between central and local governments. The complexity is far from conforming to the needs of a massively growing number of international travellers. The need of an objective examination of the current system and issues germane to the protection of RLR is vital.

\subsubsection{The division of the functions of exit and entry administrative authorities}

The division of functions between the central and local governments

China's administrative units are currently based on a five-level system dividing the nation into central government, provinces and autonomous regions and municipalities under the central government, municipalities and cities with districts, counties and cities without districts, and townships.

1069 As for general administrative system in the Chinese government, please refer to Appendix 1 of The Structure of the Chinese State Organisations. 
The overall administrative authority for exit and entry is a matter of Chinese foreign affairs. ${ }^{1070}$ Under Article 89 Clause 1(4) (9) of the Constitution of the PRC (Amendment) 2004, the State Council conducts foreign affairs. However, this division is sometimes flexible. For example, the expense of expelling aliens, in theory a cost for central authorities, is in practice afforded by local financial authorities. ${ }^{1071}$ The flexibility of the division of functions has the potential to jeopardize the overall effectiveness of the system. This division between the central and local governments has an historical basis in the period between 1949 and 1958, discussed previously in part 6.3.1.

More recent reform has empowered local authorities, devolving functions to them, and allowing for only selective intervention by central government. Local programs have effectively improved administration, and have more importantly, in some circumstances, engaged and included local communities in their design.

In the light of their expanded functions, local governments have enacted numerous rules and regulations to control and improve exit and entry administration within their administrative areas, as discussed in parts 7.2.3 and 7.4. Local rules can then tend to usurp central government duties and obligations, such as the license of emigration intermediary agencies at the provincial rather than national level, discussed in part 12.3.1 above.

\section{The division of functions among various departments of the central government}

The Ministry for Public Security (MPS) is the principal, yet not the sole ministry responsible for exit and entry administration. There are then two authorities under the MPS. One is the Bureau of Exit and Entry Administration (BEEA), which is responsible for the acceptance and

\footnotetext{
1070 "The PRC Department of Public Safety Police Specific Setup", http://www.chinesecop.com/CNP01.html (19/12/2003).

${ }^{1071}$ Under Article 3 Clause 5 of the Rules of the Supreme People's Court, the Supreme People's Procuratorate, the Ministry of Public Security, the Ministry of Foreign Affairs, the Ministry of Justice and the Ministry of Finance on Implementation Measures of Forced Expelling Aliens 1992 (PRC), if a foreign embassy or general consulate in China cannot afford or refuses to afford the expense caused by the forced expulsion of an alien, the Chinese government shall afford the expense. Based on parity principle of power and responsibility, the "Chinese government" in this context means the Central government. However, Article 7 of the Rules stipulates the opposite: the local financial department that forced the expulsion of an alien shall incur the expense.
} 
processing of passport and visa applications. Local exit and entry administrators mainly do this, although the MPS has an overriding power. The other is the Bureau of Border Security Check and Administration (BBSCA), which is responsible for border inspection. In addition, another 14 ministries, State Council offices and departments affiliated to the State Council are responsible for different parts of exit and entry administration. ${ }^{1072}$

The division of functions of various departments of central government might be accounted for by the structure of the State Council. The ministries and committees under the State Council are responsible for the exit and entry administration in detail. Under Article 8 of the Law of the Organisation of the State Council 1982 (PRC):

The establishment, dissolution or merger of ministries and committees of the State Council shall be proposed by the Premier and decided by the NPC or, when the NPC is not in session, by its Standing Committee.

The Premier may actually decide the establishment, dissolution or merger of ministries and committees of the State Council. Because both the State Council and National People's Congress (NPC) are under the leadership of the CPC, legislative and executive powers are combined in China. The decision of the NPC or the Standing Committee of the NPC is usually a mere formality. The People's Congress can pass all initiatives of the State Council. Nevertheless, adherence to the formality can demand a great deal of time and energy. To strengthen direct control over some special affairs, the State Council at times directs departments affiliated to it and its offices to share the functions of the ministries and committees. ${ }^{1073}$ As for exit and entry administration, seven of the 15 competent departments under the State Council are departments affiliated in this way, and when compared to ministries and committees, those affiliated departments are more dependent on the State Council.

Formulating tasks and responsibilities of the ministries and committees, according to Article 89

\footnotetext{
1072 Fourteen State Council offices and departments affiliated to the State Council of the State Council are Ministry of Foreign Affairs, Ministry of State Security, Ministry of Communication, the MOC, MOE, MLSS, MOP, CNTA, the Central Bank, SAFEA, State Council Bureau for Religious Affairs, STO, SHMO and SOCO.

1073 According to Article 11 of the Law of the Organization of the State Council 1982 (PRC), the State Council may establish a certain number of directly affiliated agencies to take charge of various specialized work and a certain number of administrative offices to assist the Premier in handling specialised affairs.
} 
of the Constitution of the PRC (Amendment) 2004, falls within the jurisdiction of the State Council. Unfortunately, delays in formulation and timely adjustment of tasks are often the case. ${ }^{1074}$ The inertia of a near 40 year-old system, the complication of joint administration of 15 departments under the State Council, and the foreign or international character of exit and entry administration hinder the Central government from complete reform. It is understandable why current reforms progress cautiously, and why almost every aspect of issues discussed from chapters eight to fourteen, relate to public security and other departments.

\section{The detailed divisions of the functions of exit and entry administration}

The detailed divisions of the functions of exit and entry administration in China are more complex than in other countries in the world. The functions of exit and entry administrative authority are organised in the light of the categories of administrative authority in Appendices four to ten of this book. Each appendix lists the functions of different levels of administrative authority. In summary:

1. The MPS and its local authorised public security departments administer:

- Exit and entry for private affairs of Chinese citizens;

- Entry, travel and residence of aliens lodged in China.

2. The MFA and its local foreign affairs departments administer:

- Exit and entry for public affairs of Chinese citizens;

- Entry, transit, travel and residence of aliens, lodged outside China.

3. Chinese diplomatic missions, consular offices or other agencies abroad authorised by the MFA issue, cancel, revoke and retain, or declare invalid Chinese passports and alien's visas.

4. The Bureau of Harbour Superintendence or its authorised harbour superintendent departments issue, cancel, revoke and retain, or declare invalid seafarer's passports.

\footnotetext{
1074 Delay can be contributed to three causes. The first is that China is in transition. There is not enough experiences or time to reform the administrative tasks and responsibilities. The second relates to powers and interests. It is difficult to separate vested powers and functions of the departments under the State Council into other departments. The third factor is social stability. Owing to concern about social instability caused by administrative reform, the State Council seldom adjusts the sensitive powers and functions of the departments. As Jiang Zemin, the former President of China underlined in the report at the 16th CPC Congress in November 2002, "ensur[ing] stability is a principle of overriding importance and balance reform, development and stability." See Jiang, Zemin, the President of the PRC, "Build a Well-off Society in an All-Round Way and Create a New Situation in Building Socialism with Chinese Characteristics: Report at 16th China Communist Party Congress (8/11/2002)", http://www.fmprc.gov.cn/eng/37815.html (19/07/2003).
} 
5. The Bureau of Borders Security Check and Administration under the MPS and Border Inspection Stations administer exit and entry border inspection.

6. The Sate Council of Hong Kong and Macao Affairs office (SHMO) and Sate Council of Taiwan Affairs office (STO) are responsible for the provisional examination and approval of travel to or from the HKSAR, MSAR and Taiwan for public affairs.

7. Overseas Chinese Affairs departments examine and approve applications of overseas Chinese and Chinese in the HKSAR, MSAR and Taiwan for returning to and settling in Mainland China in consultation with provincial public security departments.

8. Six ministries and their authorised local departments are jointly responsible for the administration of emigration intermediary agencies.

9. The CPC and other departments and units are responsible for:

- the provisional examination and approval of exit and entry for public affairs, and

- exit and entry of individuals with special status for private affairs.

\subsubsection{Issues and implications of functions of exit and entry administrative authorities}

The complex system of exit and entry administration seriously affects the efficiency of exit and entry administration and the realisation of RLR in the following three principal respects.

Fragmented and incoherent administration

The fragmentation of administrative authority across 15 ministerial-level departments results in a pattern of inefficient communication and inconsistent or incoherent decision-making. No single department can complete an entire process. Six separate ministerial-level departments, for instance, administer emigration intermediary agencies. This can easily lead to delays in processing applications and reduce the quality of administration. Poor intra-governmental communication, as outlined earlier in the book, can also undermine the identification and control of individuals prohibited from entering or exiting China.

\section{Overlapping functions may lead to administrative oversight and inefficiency}

The tables in Appendices four to ten of this book also show how functions can overlap between departments or sections within departments. The fact that Chinese migration authorities may examine and punish persons who violate migration laws, is a typical example; according to 
international norms, migration and police authorities should exercise separate powers. This can adversely affect communication and co-operation between China and other nations, and among administrative authorities.

The overlapping functions of various government departments may also cause individual departments to ignore their main responsibilities and focus on disputes arising from trivial matters, or to shift responsibility onto others when confronted with a problem. Duplication of administrative functions limits the extent to which the services can be improved or functions performed in a fulsome way.

\section{Concentration of functions on the ministerial and provincial levels of administration}

The functions of the exit and entry administrative authorities are overly concentrated on the ministerial and provincial level administration. Local offices have limited access to processing, which undermines local exit and entry administration. Applicants must spend time and money travelling to the provincial or national capital to lodge applications.

\subsection{Discretions of exit and entry administrative authorities}

The greater the discretion of exit and entry administrative authorities over decisions made, the more easily RLR is infringed. Generally, administrative discretion is too broad in China, and has obstructed RLR.

\subsubsection{The scope of discretion}

The scope for discretion in decision-making for responsible departments, especially public security departments, in regard to exit and entry is broad. Departments are empowered to decide how and if to approve applications in certain situations and within certain bounds. Although the relevant laws generally prescribe the conditions that must be satisfied before a decision is made, the interpretation of those provisions is discretionary.

The exit and entry administrative authorities are entitled to enact interpretative legislation 
regarding the laws promulgated by the Standing Committee of the NPC and the State Council. Article 19 of the Law on the Control of Exit and Entry of Citizens 1985 (PRC) provides that, "The Ministry of Public Security, the Ministry of Foreign Affairs, and the Ministry of Communications shall, pursuant to this law, formulate rules". Article 30 of the Provisional Measures on the Control over Chinese Citizens Travelling for Private Affairs to or from the Regions of Hong Kong or Macao 1986 (PRC) stipulates that, “The Ministry of Public Security shall be responsible for organising the implementation of these Measures and for the interpretation hereof'. Article 43 of the Measures on the Control over Chinese Citizens Travelling to or from the Region of Taiwan 1992 (PRC) prescribes that, "The Ministry of Public Security shall be responsible for the interpretation of these Measures". By international norms, the Congress or Courts usually exercise the power of interpreting statutes in accordance with the doctrinal separation of legislative, executive and judicial powers. Allowing the administrative authority to interpret the scope of their own power, limits the extent to which the Courts can fetter the discretion of the administrative arms of government.

The proliferation of departmental or ministerial rulings further supports the argument that administrative discretion is too broad. The exit and entry administrative authorities are entitled to enact internal policies to give further detail to legislation. Most of these are internal policies and not open to the public. ${ }^{1075}$ This book has mentioned over 300 rules, measures, circulars, explanations, opinions, decisions, rules and regulations relating to exit and entry laws, which are promulgated by approximately 40 ministerial level departments. The circulars and notices cited in this book account for approximately one third of that. The bureaucratic barrier to RLR resulting from unpublished official documents was discussed in part 6.5.

If there are no relevant laws to be applied, the understanding of the exit and entry administrative authority will be implemented. Article 9 of the Measures on the Control over Chinese Citizens travelling to or from the Region of Taiwan 1992 (PRC), for instance, provides that:

\footnotetext{
${ }^{1075}$ The Bureau of Party, Government Foreign Affairs Cadre under Department of Personal of Central Committee of Chinese Communist Party, The Collection of Popular Official Documents and Letters, Regulations and Laws Governing Examination and Administration of Exiting Abroad (Chuguojing Shenpi Ji Guanli Gongzuo Changyong Wenjian Fagui Xuanbian), the Publishing House of Dangjian Duwu Internal Publication (Neibu Faxing), Beijing, 1994, in "the Introduction of the editor".
} 
The public security department shall, within 30 days of receipt of the application for travelling to Taiwan, or within 60 days for the applicants who reside at remote areas with poor transportation facilities (Dichu Pianpi Jiaotong Bubian), make a decision on approving of the application or not, and notify the applicant of the decision. The urgent (Jinji) application shall be processed at any time.

Public security departments may interpret the terms "a remote areas with poor transportation facilities" and "urgent" according to their understanding, which can differ in each case.

\subsubsection{Issues and implications of discretionary scope}

The nature of exit and entry discretion can be classified as the power to (i) decide whether to approve an application; (ii) choose a form of administrative punishment; and (iii) choose an enforcement measure.

\section{Discretion to approve applications}

Appendices four to ten of this book provide many examples of this form of discretion. One example is in the granting of return residence permits for overseas Chinese. Chinese diplomatic missions, consular offices or other agencies located abroad and authorised by the MFA, and provincial public security departments have this power under Article 10 of the Detailed Rules for the Implementation of the Law on the Control of Exit and Entry of Citizens (Amendment) 1994 (PRC), yet its provisions are too vague to be implemented. In practice, these entities examine and approve applications according to their internal policies, as discussed in part 9.1.2. Another example is Article 7 of Law of Nationality 1980 (PRC), under which:

Foreign nationals or stateless persons who are willing to abide by China's Constitution and laws and who meet one of the following conditions may be naturalised upon approval of their applications: ... (3) they have other legitimate reasons.

The MPS has broad discretion in their interpretation of "other legitimate reasons".

\section{Discretion to punish}

Discretion in the choice of administrative punishment is another significant aspect of the broad 
and uncertain powers conferred on administrative authorities. Under Article 23 of the Detailed Rules for the Implementation of the Law on the Control of Exit and Entry of Citizens 1985 (PRC):

If any persons have used or altered certificates or other person's certificates for entering or leaving the country, they shall, in addition to having the forged certificates confiscated, be subject to a warning, or held in detention for up to five days....

The form of the punishment and the period of possible detention are left to the discretion of the public security departments. Similarly, the description of a "minor" offence, contained in Article 28 of the Provisional Measures on the Control over Chinese Citizens Travelling for Private Affairs to or from the Regions of Hong Kong or Macao 1986 (PRC) is so nebulous that public security departments have enough discretion to reach opposite conclusions on the same facts.

Additionally, the public security department has the discretion to determine the nature of the penalty imposed, namely to make a choice between a fine or period of detention, and can even decide the length of an illegal alien's detention under Article 40 of the Detailed Rules for the Implementation of the Law on the Control of Exit and Entry of Aliens 1985 (PRC), by which detention is limited to a minimum of three and maximum of 10 days.

According to Zhan Weiguang in "Features, Causes and Solutions of Crimes Against Control of Exit and Entry", in the Collection of Papers on the Control of Exit and Entry (III);

Officials in charge of exit and entry administration who do not have a strong sense of legality and know little about the laws and rules related to exit and entry administration; do not know how to deal with violations of the exit and entry administration. The violators are often only fined. The majority of people therefore fail to understand that all violations of the exit and entry administration are criminal in character, not merely administrative; and the deterrent function of criminal law is markedly reduced. ${ }^{1076}$

This lack of understanding on the part of officials in charge of exit and entry administration as to the penalties for violation of exit and entry laws, while it hampers the efforts of public

1076 Zhan, Weiguan, the Features, Causes and Solutions of Crimes Against Control of Exit and Entry in Committee of Exit and Entry Administration under Chinese Association of Police (ed), The Collection of Papers on The Control of Exit and Entry (III) (Churujing Guanli Lunwenxuan (san)), Interior Published within Public Security Organs (Gongan Jiguan Neibu Faxing), the Publishing House of Qunzhong, Beijing China, 2001, page 276. 
security departments to investigate and prosecute unlawful acts, may also exaggerate the possibilities of violating an individual's RLR.

\section{Discretion in regard to enforcement measures}

If the discretion in regard to law enforcement measures is not properly exercised, it may interfere with RLR because violators or suspected violators may be subjected to unfair punishment. Article 3 of the Some Rules on the Issues of Exit Abroad Prohibiting Aliens and Chinese Citizens Exiting Abroad 1987 (PRC) provides that:

[The] Following means can be adopted separately when the People's Court, People's Procuratorate, Pubic Security organs and national security organs prohibit aliens and Chinese citizens from exiting China;

(1)The affected party shall be informed orally or in writing that they are prohibited from exiting China unless the lawsuits or relevant issues have been resolved;

(2)The affected party may [either] be ordered to live at home under surveillance, post bail pending trial with restricted freedom of movement, or permitted to travel abroad after providing property guarantee or payment of a bond;

(3)The affected party's passport or other valid travel documents can be retained.

The Courts, Procuratorates, pubic security departments and national security departments have broad discretion in choosing any of the enforcement measures.

In the interest of administrative efficiency, infringements of rights caused by abuses of discretion are not subject to administrative review and do not attract criminal liability. Judicial review of administrative decisions generally focuses on legitimising the discretion. An administrative decision can be set aside if there has been an illegal use of discretion, but this generally only occurs when there has been a manifestly unfair decision, allowing many minor breaches to go unchecked. The implications of the broad administrative discretion are serious. It provides many opportunities for government department and officers to generally profit and abuse their power.

\subsection{Merits review of administrative decisions regrading exit}




\section{and entry}

The development of international migration law has led to some important developments in regard to exit and entry administration in national legal systems, by which States have increasingly limited governmental immunities and have developed innovative responses to RLR violations. The scope of exit and entry administrative decision-making needs to be explained before investigating the current issues of merits review in China. For the purposes of this analysis, a decision includes an approval or refusal of an application, as well as the formulation of administrative recommendations or comments. Appendices 2, 11 and 12 of this book summarise the merits review of administrative decisions in regard to penalties, processing of applications and law. The three appendices show that there are many serious issues in regard to merits review of administrative decisions and limits on RLR, associated with the current remedies.

\subsubsection{The mechanism for merits review of administrative decisions}

Contrary to the list given, Appendix 11 indicates that there is only one decision upon which the merits of an administrative decision can be reviewed, namely refusal to permit a citizen's exit of China or refusal to issue a passport for citizens. Additionally, applicants exiting China for public affairs are not entitled the same review rights as those exiting for private affairs. By international norms, an individual should be informed in writing of the reasons for revoking or invalidating an earlier decision. ${ }^{1077}$ Appendices 2, 11 and 12 show that no such mechanism exists.

Merits review of migration decisions can offer expedient, efficient and relatively inexpensive oversight of primary decisions and allow individuals to seek a fresh decision. To achieve the goals of regularity and fairness, the exit and entry administration must provide individuals with a means of redress when a decision has been made. With the exception of a few circumstances, such as an application lodged by aliens outside the country, it is almost commonplace that an individual be entitled to seek a review of the merits of the decision. Undoubtedly, the lack of a

1077 Article 16 (b) of the 1972 Uppsala Declaration on the RLR 
mechanism for merits review of administrative decisions severely limits the protection of RLR.

\subsubsection{Treatment to applicants of the Mainland, HKSAR, MSAR and Taiwan Chinese}

The second issue is the discrimination between nationality and place of residences in Mainland China, the HKSAR, MSAR and Taiwan, and for aliens, in terms of their rights of appeal against penalties. In effect, the range of available remedies does not correspond with the scope of the penalties that can be imposed.

This inconsistency is illustrated when the Measures on the Control over Chinese Citizens Travelling to or from the Region of Taiwan 1992 (PRC) is compared with the Law on the Control of Exit and Entry of Citizens 1985 (PRC), the Provisional Measures on the Control over Chinese Citizens Travelling for Private Affairs to or from the Regions of Hong Kong or Macao 1986 (PRC), and the Law on the Control of Exit and Entry of Aliens 1985 (PRC). These laws create penalties for illegal entry or exit activities, but only Measures on the Control over Chinese Citizens Travelling to or from the Region of Taiwan 1992 (PRC) provide remedies for all penalties. There is no review for penalties in the Provisional Measures on the Control over Chinese Citizens Travelling for Private Affairs to or from the Regions of Hong Kong or Macao 1986 (PRC). The same issues arise in relation to the Law on the Control of Exit and Entry of Citizens (Amendment) 1994 (PRC) and its detailed rules of the implementation, in which there are reviews only for of the penalties of a fine, a disciplinary warning and confiscation of forged certificates. Accordingly, the availability of some reviews depends on the status, nationality or purpose of travel of individuals.

\subsubsection{Relationship between the merits review and external remedies}

The third issue relates to the choice of an avenue of review to appeal against a decision. Articles 15 of the Law on the Control of Exit and Entry of Citizens 1985 (PRC), Article 50 of the Detailed Rules for the Law on the Control of Exit and Entry of Aliens (Amendment) 1994 (PRC) and Article 39 of the Measures on the Control over Chinese Citizens Travelling to or from the Region of Taiwan 1992 (PRC) permit a citizen against whom a penalty has been imposed to 
appeal to the public security departments at the next highest level for a final decision; or to institute proceedings in Court. This implies that the choice of one avenue or review forecloses the opportunity to use the other.

Because there is no independent tribunal in China, if an individual opts for an administrative review, the fairness of the review may not be questioned. Under Articles 3 and 12(1) of the Law of Administrative Review 1999 (PRC), a legal affairs department within the administrative authority reviews the decision. The legal affairs department is also required to perform various other functions and as such, is not independent of the authority. In complex cases, reviews are conducted in consultation with the next most senior department, which seldom overturns an original decision. In developed countries, such as Australia, there are external independent review tribunals, which can re-examine the evidence used to reach the decision and substitute its own findings for that of the original decision-maker.

If the affected individual chooses to institute proceedings in Court, cost and delay in reaching a final decision are issues. According to Article 5 of the Law of Administrative Procedure 1990 (PRC), a Court finding only results in a review of the legality of the decision, rather than its merits.

\subsection{Conclusions}

The system of administration of exit and entry in China faces serious issues. Its functions are diffusely allocated, sometimes overlap, and are also concentrated on power at the ministerial and provincial levels. The system cannot support administrative authorities in effective decision making. There is potential in this for the evasion of responsibility, unprincipled practice and a focus on trivial issues ahead of substantive matters of administration.

As to discretionary powers, authorities are not only entitled to enact interpretative laws, but may enact internal policies to further detail legislation. If there are not relevant laws to be applied, the understanding of the authorities can prevail. This discretion is far too broad; authorities can 
arbitrarily decide applications for exit and entry. In each case, RLR is undermined in China.

The mechanism of merits review of administrative decisions is almost non-existent. There is only one decision upon which the merits of an administrative decision might be reviewed, namely refusal to permit an individual's exit of China or refusal to issue a passport for citizens. There are no remedies for violations of the right to leave for public affairs. The right of appeal against penalties is discriminatory and for Chinese citizens, exists in terms of their residence in the Mainland, HKSAR, MSAR and Taiwan. The choice of internal remedies forecloses the opportunity to use the external remedies and vice versa. 


\section{Chapter Fourteen}

\section{The need to protect RLR in China, the factors in favour, and resolving practical concerns against it}

\section{Introduction}

The issues analysed from Chapters eight to thirteen do not indicate that protecting RLR in China is prevented in the current political, economic, cultural and legal circumstances. On the contrary, the foundations of RLR, discussed in Chapter two, and its development in China, discussed in Chapters six and seven, demonstrate that the protection of RLR is consistent with principles of legal philosophy, the trend of the development of RLR, international norms and globalisation. The worldwide development of RLR alongside considerable changes in China, have laid a solid foundation to reform the regulatory framework governing RLR in China. This Chapter will examine why it is necessary to protect RLR in China, discuss the factors that favour its protection, and suggest the means of resolving some practical concerns that militate against reform.

\subsection{The need to protect RLR in China}

The issues analysed from Chapters eight to thirteen evinced that the outdated regime of exit and entry administration, established and developed over last 50 years, has hampered China's economic and social development. Since the introduction of reform and opening up policies in 1978, the need to protect RLR in China has gradually increased. In particular, protection of RLR is needed to (i) protect the human rights of Chinese citizens (ii) meet the demands of a socialist market economy and of further opening up to the world; (iii) respond to changing patterns of migration; and (iv) fulfil China's international obligations.

\subsubsection{Protecting the human rights of Chinese citizens}

Without the protection of RLR in China, it is hard to say human rights have been 
safeguarded in China. The conception of human rights is accepted per se in China, even though the Chinese government rejects the Western conception of human rights and opposes human rights being made a political issue, as will be discussed below. Article 33 Clause 4 of the Constitution of the PRC (Amendment) 2004 stipulates "the State respects and safeguards human rights". In 1999 and 2001, the spokesperson of the Ministry of Foreign Affairs (MFA) affirmed that, "The Chinese government has all along respected the universal principle of human rights". ${ }^{1078}$

The then President Jiang Zemin thought in 2002 that to develop socialist democracy China should ensure that the people exercise their rights as the masters of the country. ${ }^{1079}$ Premier Wen Jiabao argued that the tremendous wealth created by China in the past quarter of a century is due to "the policy of reform and opening-up, [and] in the final analysis, to the freedom-inspired creativity of the Chinese people". ${ }^{1080}$ The Chinese Foreign Minister, during a meeting with a Russian Human Rights representative, stated that the Chinese government would like to resolve the differences on the issue of human rights through equal dialogue and on the basis of mutual respect. ${ }^{1081}$

Based on its recognition of human rights and acknowledgement of their importance, the Chinese government has committed itself to effectively protect human rights, and supports the development of the international human rights movement. In Fifty Years of Progress in China's Human Rights, the government affirmed that full realisation of human rights is "a basic goal of China's cross century development." 1082 In the words of State Councillor Tang Jiaxuan, it is the sacred duty of the Chinese government to promote

1078 "Spokesperson on the 1999 Human Rights Report" issued by the US State Department, Ministry of Foreign Affairs of the PRC, http://www.fmprc.gov.cn/eng/3844.html (1/07/2003); and "Spokesperson On Us Annual Human Rights Report (20/02/2001)", Ministry of Foreign Affairs of the PRC, http://www.fmprc.gov.cn/eng/8606.html (1/07/2003)

1079 Jiang, Zemin, the President of the PRC, "Build a Well-off Society in an All-Round Way and Create a New Situation in Building Socialism with Chinese Characteristics: Report at 16th China Communist Party Congress (8/11/2002)", http://www.fmprc.gov.cn/eng/37814.html (19/07/2003) Paragraph 19

1080 Wen, Jiaobao, the Premier of the State Council, "Turning Yours Eyes to China", Speech at Harvard University on 11 December 2003, http://www.fmprc.gov.cn/eng/zxxx/t56076.htm (19/12/2003).

1081 "Chinese FM Meets Russian Human Rights Representative (16/03/2000)", www.fmprc.gov.cn/eng/4020.html (1/07/2003).

${ }^{1082}$ Information Office of the State Council of the PRC, "Fifty Years of Progress in China's Human Rights (June 2000)", http://www.fmprc.gov.cn/eng/32282.html (20/05/2003) at Part VI. 
and protect human rights. ${ }^{1083}$ In February 2004, a spokesperson for the MFA stressed that; "[the] Chinese Government has always committed itself to protecting human rights of the Chinese people." 1084

From the perspective of the universal principle of human rights, as discussed in Chapter three, the recognition and protection of human rights implies the right to leave and return to one's country. Chinese authorities and scholars also directly acknowledge RLR and its protection. In The Administration on Exit and Entry, which is used by the MPS in the education of police, Zhu Lin has contended that "RLR is not only recognised by all States in the world but also by international conventions". ${ }^{1085}$ Wong $\mathrm{Li}$ has claimed, in International Immigration Law and the Practice, that "RLR is widely recognised as one of fundamental human rights by all States in the world [and] should be adopted and detailed in international migration law". ${ }^{1086}$ Significantly, Premier Wen Jiabao has said:

The essence of reform is to [...] respect and protect the freedom of the Chinese people to pursue happiness. There has been gradual lifting of the former improper restrictions, visible and invisible, on people's freedom in choice of mobility, travel [...] and lifestyle. ${ }^{1087}$

Certain Chinese scholars accept that the protection and promotion of RLR should be regarded as one of leading principles guiding the research of migration law ${ }^{1088}$ or the reform of laws governing the exit and entry administration. ${ }^{1089}$

\footnotetext{
${ }^{1083}$ Tang, Jiaxuan, "Statement by Foreign Minister Tang Jiaxuan at the $54^{\text {th }}$ Session of the UN General Assembly", http://www.fmprc.gov.cn/eng/52214.html (20/05/2003).

1084 "Spokesperson Zhang Qiyue's Remarks on the Country Report on Human Rights Issued by the US (26/02/2004)", http://www.fmprc.gov.cn/eng/xwfw/2510/t69782.htm (02/03/2004).

${ }_{1085}$ Wang, Guoliang and Zhu, Lin, The Administration on Exit and Entry, one of Planning Textbooks of Higher Education of People's Police (Renmin Jingcha Gaodeng Jiaoyu Guihua Jiaocha: Churujing Guanlixue) Interior Published within Public Security Organs (Gongan Jiguan Neibu Faxing), the Publishing House of China University of People's Public Security, Beijing, 2002, page 44.

1086 Wong, Li, International Immigration Law and the Practices (Guoji Yiminfa Lilun Yu Shijian), the Publishing House of Law, Beijing, China, 2001, page 26.

${ }_{1087}$ Wen, Jiaobao, the Premier of the State Council, "Turning Yours Eyes to China", Speech at Harvard University on 11 December 2003, http://www.fmprc.gov.cn/eng/zxxx/t56076.htm (19/12/2003).

${ }^{1088}$ Wong, Li, International Immigration Law and the Practices (Guoji Yiminfa Lilun Yu Shijian), the Publishing House of Law, Beijing, China, 2001, page 26.

${ }^{1089}$ Lin, Yicong, "On the Principle of the Amending of Current laws Governing the Exit and Entry Administration", in Committee of Exit and Entry Administration under Chinese Association of Police (ed), The Collection of Papers on The Control of Exit and Entry (III) (Churujing Guanli Lunwenxuan (san)), Interior Published within Public Security Organs (Gongan Jiguan Neibu Faxing), the Publishing House of Qunzhong, Beijing, 2001, page 15.
} 
Major discrepancies still exist between the polices as written and those implemented, even though the government has reformed its enforcement policies and procedures to better align them with international human rights ethics. The UN High Commissioner for Human Rights, Mary Robinson, observed in August 2002 that Chinese law and practice still falls short of international human rights ethics. ${ }^{1090}$ RLR needs to be protected to realise effective protection of human rights, to so maintain the Chinese faith in human dignity and in the universal observance of human rights.

\subsubsection{Meeting the demands of a socialist market economy and further opening} China to the world community

In essence, China's economic reform represents a shift from a centralised planned economy to a more market-oriented system, and a decision to open China to the effects of globalisation. Doing a better job in opening up by "bringing in" and "going out" has been established as a goal of economic development and restructuring in the first two decades of the 21st century. ${ }^{1091}$ Jiang Zemin has explained that, "By both 'bringing in' and 'going out', [China] should actively participate in international economic and technological cooperation and competition and open wider to the outside world". ${ }^{1092}$ Zhu Rongji has emphasised the increase of labour export. ${ }^{1093}$

To fully master the economic opportunities offered by reform, international exchange and cooperation, China needs to accelerate the steps of integration into the world economy. China and the ASEAN agreed, in 2000, to gradually establish a China-ASEAN free trade zone over the next 10 years. New Zealand has agreed, in 2004, to launch negotiations with China for a free trade agreement as soon as possible. ${ }^{1094}$ Exchanges and cooperation

\footnotetext{
1090 "Human Rights Watch World Report 2003: Asia: China and Tibet", http://nadaily.com/cgi-bin/nph-proxyb.cgi/010000A/http/hrw.org/wr2 (5/07/2003).

${ }_{1091}$ Jiang, Zemin, the President of the PRC, "Build a Well-off Society in an All-Round Way and Create a New Situation in Building Socialism with Chinese Characteristics: Report at 16th China Communist Party Congress (8/11/2002)", http://www.fmprc.gov.cn/eng/37814.html (19/07/2003) at Part IV.

1092 Jiang, Zemin, the President of the PRC, Par. 17 of Part I of "Build a Well-off Society in an All-Round Way and Create a New Situation in Building Socialism with Chinese Characteristics: Report at 16th China Communist Party Congress (8/11/2002)", http://www.fmprc.gov.cn/eng/37814.html (19/07/2003).

${ }^{1093}$ Zhu, Rongji, Premier of the State Council, Par 3 of Part IV of "Report on the Work of the Government (16/03/2002)", http://www.fmprc.gov.cn/eng/26804.html (19/07/2003).

1094 China, New Zealand to Launch FTA Talks, http://english.people.com.cn//200411/22/eng20041122 164792.html (29/11/2004).
} 
between the Mainland and Hong Kong and Macao also need to be strengthened. ${ }^{1095}$

The current system of exit and entry administration in China has evolved from a centralised planning system, quasi-agricultural society, and a society and culture closed or quasi-closed to the outside world. China once adopted an 'iron curtain' approach to maintaining social stability, by consolidating its agrarian base and ensuring its security in the international arena. With the improvement of the socialist market economy, increased industrialisation, and membership of the WTO, the current system of exit and entry administration cannot meet the requirements of China's economic development, and lags behind in the protection of RLR.

It is hard to imagine that China's economic goals can be reached, and international exchange and cooperation between China and the rest of the world significantly improved, without the realisation of RLR. According to goals of the CPC, by 2020 China will have, in the main, achieved industrialisation and established a fully-fledged socialist market economy and a more open and viable economic system. ${ }^{1096}$ Transnational movement of Chinese people is an indefeasible requirement of opening wider. The high rate of migration workers' movement is beneficial for the realisation of free trade and a common currency area. Chinese economic development and the protection of RLR are mutually dependent and reinforcing. Economic development creates conditions for the protection of RLR; and RLR assists in economic development.

\subsubsection{Responding to changing patterns of migration}

Patterns of Chinese exit and entry have greatly changed over past 25 years. In 2001, $21.34 \%$ of the Chinese population exited and re-entered for the purpose of overseas tourism, $2.92 \%$ as students and $1.74 \%$ as permanent emigrants. ${ }^{1097}$ By contrast, the

\footnotetext{
1095 Zhu, Rongji, Premier of the State Council, Par 9 of Part VII of "Report on the Work of the Government (16/03/2002)", http://www.fmprc.gov.cn/eng/26804.html (19/07/2003).

1096 Jiang, Zemin, the President of the PRC, "Build a Well-off Society in an All-Round Way and Create a New Situation in Building Socialism with Chinese Characteristics: Report at 16th China Communist Party Congress (8/11/2002)", http://www.fmprc.gov.cn/eng/37814.html (19/07/2003) at Part III paragraph 5.

1097 "The Numbers of Exits from and Entries into the Chinese Mainland Breakthrough 200 Million in 2001" (2001 Nian Woguo Churujing Renyuan Shouci Tupo 2 Yi Renci), the Bureau of Exit and Entry Administration
} 
number of citizens who undertook these forms of travel in 1979 was negligible. In the years 1990 to 2003 Chinese migration grew by an average of 12 percent each year. In 2003, 39.7 million Chinese were registered to leave and re-enter the territory. ${ }^{1098}$ Irregular migrants, discussed in part 10.2 of this book, had increased to 11 million in number at the end of 1990 s.

Chinese migration, however, and as discussed with the aid of dramatic graphs in part 7.3, is still much lower than other countries. With the further development of Chinese society, a huge migration stock may emerge, and the changing pattern of entry and exit will be yet more significant. The director of exit and entry administration under the MPS, Ren Yingchao, has reflected that;

In the early years of the foundation of the PRC, a resident card was all that the people needed to carry because people hardly left their birthplace. After the opening-up, the growing need for mobility gave rise to citizen ID cards. Now in an increasingly international world, even national ID will not do. Passports will be the new substitute in the near future. ${ }^{1099}$

Without facing and solving the challenges of RLR caused by changing patterns of migration, it is very difficult in practice to make passports the new form of ID. The principle challenges are forms of discrimination with respect to RLR of Chinese citizens in Mainland China in regard to (ii) the places of household registration; (ii) status of CPC membership and cadre (iii) the purposes of entry or exit; (iv) residence in the Mainland China, HKSAR, MSAR and Taiwan. Other challenges include the need to:

(1) Improve foreign investment by facilitating investors' exit, entry and residency;

(2) Resolve the issues of Chinese irregular migrants in other countries and foreign irregular migrants in China;

(3) Remove obstacles to the transfer of foreign exchange into and out of China

under the Ministry of Public Security, 18/04/2003.

1098 “China Sees Unusual Fall in Exit-entry Numbers in 2003”, 12 January 2004 The People's Daily Online, http://english.peopledaily.com.cb/200401/12/eng20040112 13262.shtml (13/01/2004).

${ }^{1099}$ Quoted in Wang, Chuyan, "Passport Gain Wider Currency in China", CCTV, 18 October 2002, http://www.cctv.com/english/news/TVNews/MorningNews/20021018/100241/html (1/10/2003). 
when;

(4) Rectify and standardise emigration intermediary services to safeguard not only the interests of the applicants wishing to exit but the interests of intermediary agencies in improving services;

(5) Reform the institutional aspects of exit and entry administration;

(6) Provide efficient remedies for violations of RLR;

(7) Solve the conflicts between Chinese laws for exit and entry, and between ratified international instruments and Chinese law.

Great importance should be attached to these challenges, and effective measures should be found to meet them. The core of solving these challenges is to protect RLR. RLR is a fundamental right of Chinese, which has a direct bearing on their vital interests. Unlike riots, strikes and mass demonstrations designed to dramatise popular grievances against the government, emigration poses no direct threat to the existing political order. To be effective, RLR policy needs to be fine-tuned to take account of this none-too-subtle distinction. As the most populous country in the world, the need to resolve these issues is more urgent in China than in other countries.

\subsubsection{Fulfilling China's international obligations}

Even China has its own methods and reasons, but one thing is for sure: from the perspective of both international law and domestic law, there is no excuse for an open China to refuse to fulfil its international obligations to protect RLR. The Chinese government has accepted citizens' RLR in the light of Article 1 of the Law on the Control of Exit and Entry of Citizens 1985 (PRC) the general provisions of which lay the way to protect RLR in principle.

The Chinese government has ratified the UDHR, CERD, CSR and its Protocol of 1967, The Charter of the UN, the CRC and ICESCR. These conventions contain the provisions 
related to RLR discussed in part 2.2.2 of this book. ${ }^{1100}$ Estoppel by international treaties and agreements of the parties is the basic principle of international law. Under Article 142 General Principles of the Civil Law 1986 (PRC), Article 238 of the Law of Civil Procedure 1991 (PRC), Article 72 of the Law of Administrative Procedure 1990 (PRC) and Article 178 of the Rules on the Procedure of Handling with Administrative Cases of Public Security Organs 2003 (PRC), ratified international conventions prevail over domestic law to the extent of any inconsistency. Thus the Chinese government is bound to perform legal obligations to protect RLR.

Additionally, China is also obliged to ensure that its practices in relation to RLR conform to customary international law, which was discussed in Chapter three of this book. For China, customary international law is mainly based on the UDHR and ICCPR. Initially, the UDHR was not legally binding upon China since the UDHR only encourages States parties to achieve human rights through moral aspirations. However, the UDHR is gradually becoming acknowledged as part of customary international law. Meanwhile, the Chinese government does not deny the status in customary international human rights law of the ICCPR to non-Party States. The ICCPR, as a foremost international human rights instrument is undoubtedly universal in its statement of principle in relation to RLR. ${ }^{1101}$ In Human Rights in China 2000: White Paper of Human Rights, the Chinese government acknowledged that being ratification to the $\mathrm{ICCPR}^{1102}$ implied that the Chinese government attached great importance to the positive role of the ICCPR in promoting and protecting human rights. ${ }^{1103}$

\footnotetext{
${ }^{1100}$ Article 1 Clause 3 of the Charter of the United Nations 1945 provides that one of purposes of the UN is "to achieve international co-operation in...promoting and encouraging respect for human rights and for fundamental freedoms for all without distinctions as to race, sex, language, or religion." The right to work regulated in ICESCR is closely related to RLR. Another 4 conventions' provisions have been mentioned in part 2.2.2.4 of this book.

${ }_{1101} 152$ States ratified the ICCPR up to June 2004. See International Services for Human Rights, "The Ratification Status of the Main Human Rights Treaties", ishr-06-2004,

http://ww.ishr.ch/About\%20UN/Ratification/Ratification\%20-\%20Human\%20Rights $\% 20$ treaties.htm $(18 / 05 / 2003)$

1102 The Chinese government signed the ICCPR in October 1998. See "High Commissioner for Human Rights Welcomes China's Signing of Rights Covenant”, HT/98/72, 5 October 1998, http://www.unhchr.ch/huricane.nsf/view01/(17/06/2003).

${ }^{1103}$ Information Office of the State Council of the PRC, Human Rights in China 2000, White Paper of Human Rights, Beijing, 2000, at Part 7.
} 
As discussed in Chapter three, RLR has become one of the human rights recognised in the UDHR and ICCPR. As a consequence of the development of the UDHR and the acknowledgement of the ICCPR, it is necessary for the Chinese government to promote and protect RLR in China according to both instruments and bring their practices of human rights into conformity.

More significantly, the Chinese government officially recognises customary international law as one of its legal sources. The former Vice Foreign Minister Wang Guangya stated in 2002 that, "human rights can get nowhere without international law and basic norms governing international relations". ${ }^{1104}$ In his 2002 Report, Zeng Peiyan, the then Minster in charge of the State Development Planning Commission said that in order to fully exploit the basic role of the market, "international practices will be taken into consideration". 1105

In practice, the Chinese government made a reference to customary international law when amending the regulations governing RLR. In January 2002, the government introduced measures to reform the use of a passport by overseas students. The Preface of the Circular of Ministries of Education, Public Security and Foreign Affairs on Some Affairs Regarding Fulltime Students Exit Abroad Short-term with Ordinary Passport for Private Affairs 2002 (PRC) stipulates that international norms are to be consulted and followed in relation to fulltime students travelling abroad at the expense of the government. China's domestic legislative practice, ratified international conventions, and official attitude towards the inclusion of the UDHR and ICCPR in customary international law, altogether underscore the need to perform its legal obligations to protect RLR in China.

\footnotetext{
1104 Wang, Guangya, "Statement by H. E. Vice Foreign Minister Wang Guangya at the 58th Session of the United Nations Commission on Human Rights, Geneva, 2 April 2002, United Nations High Commissioner For Human Rights", http://www.unhchr.ch/huricane/huricane.nsf/view01/3D9E089928BFD46AC (04/09/2003).

1105 Zeng, Peiyan, Par. 1 of Part III of "Report on the Implementation of the 2001 Plan for National Economic and Social Development and on the Draft Plan for National Economic and Social Development (12/03/2002)", http://www.fmprc.gov.cn/26935.html (18/07/2003).
} 


\subsection{Factors favouring protection of RLR in China}

Economic reform over the past 25 years is the primary factor in support of RLR protection in China. This has been followed by process of democratisation and constitutional reform, growing awareness of RLR among Chinese people and the emergence of the international environment favouring protection of RLR in China.

\subsubsection{Economic reform}

Twenty-five years of economic reform, bringing democratisation and the "opening up" of China has provided the State with a considerable material foundation for protecting RLR. China's macro-economic achievements have been very impressive. By the end of 2003, Chinese GDP reached C 11.67 trillion (equal to US\$1.41 trillion), placing China sixth in the world in terms of economic aggregate. ${ }^{1106}$ China is expected to chalk up a trade volume of US\$1.1 trillion for 2004 and rank it third in the world. ${ }^{1107}$ Experts forecast the gross direct foreign investment will exceed US\$60 billion in 2004, placing China the No.1 destination of foreign investment. ${ }^{1108}$ According to official statistics, by the end of 2003, China's foreign currency pool totalled US\$403.3 billion, and the country had the world's second largest foreign exchange reserves. ${ }^{1109}$ In 2001, China became a member of the WTO and Beijing won its bid to host the 2008 Olympic Games. These events have exerted a far-reaching influence on the future development of the economy. In 2002, Jiang Zemin observed that, "on the whole, the people made a historic leap from having only adequate food and clothing to leading a well-off life."1110

The considerable material foundation has stimulated overseas travel by Chinese, described in part 12.2 of this book, and produces many spaces for reforming the exit and

\footnotetext{
1106 Wen, Jiaobao, the Premier of the State Council, "Premier Wen Delivers Government Work Report," http://english.peopledaily.com.cn/200403/05/eng20040305 (11/03/2004).$$
1107 \text { "China Likely to be third Largest Trading Power", }
$$$$
\text { http://english.people.com.cn//200411/12/eng20041112 163755.html (11/15/2004) }
$$$$
1108 \text { "China Sees New Record of Foreign Investment", }
$$$$
\text { http://english.people.com.cn//200411/23/eng20041123 164899.html (29/11/2004). }
$$$$
{ }_{1109} \text { Wen, Jiaobao, the Premier of the State Council, "Premier Wen Delivers Government Work Report", }
$$$$
\text { http://english.peopledaily.com.cn/200403/05/eng20040305 (11/03/2004). }
$$$$
1110 \text { Jiang, Zemin, the President of the PRC, Par } 13 \text { of Part I of "Build a Well-off Society in an All-Round }
$$$$
\text { Way and Create a New Situation in Building Socialism with Chinese Characteristics: Report at 16th China }
$$$$
\text { Communist Party Congress (8/11/2002)", http://www.fmprc.gov.cn/eng/37814.html (19/07/2003). }
$$ 
entry administration. The limits on foreign exchange and household registration will be lifted. Guo Shouqing, the director of the SAFE, said in 2003 that China would continue easing restrictions on foreign currency purchases by domestic enterprises and individuals. ${ }^{1111}$ Chinese legislators will make the breakthrough reform of the household registration system. A proposal for reform of household registration on the basis that it is no longer appropriate in the light of the transition to a market economy and increased rates of migration, was submitted to the NPC in 2001. The proposal aimed to put an end to the practice of separating rural and urban household registration in order to facilitate the transfer of excessive rural labour to urban areas. ${ }^{1112}$ Further reform of entry and exit administration is also possible.

\subsubsection{Democratisation and constitutional reform}

China's process of democratisation and constitutional reform to protect human rights, provide China with a political and legal foundation to protect RLR. China's political reform lags behind the reforms of the economic system, however the trend of democratisation is an inevitable consequence of a move towards a market economy. Jiang Ping, a prominent Chinese jurist, has predicted that the government's stronghold on power will be limited by a market economy, because the free market enterprise system requires a suitably modern State. Democracy is the basic characteristic of such a State. Thus, the orientation and pace of the democratisation will continue in accordance with the development of China's market economy. ${ }^{1113}$

China officially adheres to a policy of developing democracy. Hu Jingtao, the President of the PRC stressed in 2004 that citizens' orderly political participation should be expanded and people's democratic election, democratic decision-making, democratic management

\footnotetext{
1111 Yao, Chen, "National Must Control Surpluses", China Business Weekly 11/11/2003, http://www1.chinadaily.com.cn/en/doc/2003-11/11/content_281664.htm (26/11/2003). 112 “2001: Call for New Residence System, 14.03/2001”, Source: www.people.com.cn, http://www.cctv.com/1m/980/721/82533.html (19/06/2003).

1113 Jiang, Ping, Comments on Chinese Democracy and constitutional Development, in Itoh, Fumio (ed), China in the Twenty-first Century: Politics, Economy, and Society, United Nations University Press, Tokyo, Japan, 1997, page 219.
} 
and democratic supervision in line with laws should be guaranteed. ${ }^{114}$ Jiang Zemin underlined in 2002 that China must respect and guarantee the political, economic and cultural rights and interests of the people. ${ }^{1115}$

The development of democracy and the protection of human rights has been the subject of constitutional reform in China. Article 7 of The Amendment of Constitution of the PRC 2004 imposes a duty on the State to respect and safeguard human rights. Article 1 of the Amendment recognises that the development of a socialist market economy, socialist democracy, improved socialist legal system, and coordinated development of the socialist material, political and spiritual civilisation, are important means of achieving reform in the primary stages.

Although the conception of human rights and the relationship between human rights and RLR are at odds, as earlier analysed - incorporating human rights into the Constitution is of epoch-making significance. ${ }^{1116}$ At the least it has clarified, as Professor $\mathrm{Xu}$ Xianming has said, that "China accepts the moral standards of human rights, [and] under that principle the public power that respects and guarantees human rights will be supported, while the disdaining and trampling on human rights should be corrected". ${ }^{1117}$ It is more possible to protect RLR in China than ever before. Democratic reform and incorporating human rights into the Constitution will drive the enactment of laws related to further protecting RLR.

\subsubsection{Growing awareness of RLR and growing Chinese communities abroad}

Since the reforms of 1978, Chinese society has gradually equalised, international communication has become more extensive, and Chinese people have developed an

\footnotetext{
1114 "President Hu Urges People's Democratic Participation", http://english.peopledaily.com.cn/200404/28/eng20040428 141732.shtml (29/04/2004).

1115 Jiang, Zemin, the President of the PRC, Par 7 of Part III of "Build a Well-off Society in an All-Round Way and Create a New Situation in Building Socialism with Chinese Characteristics: Report at 16th China Communist Party Congress (8/11/2002)", http://www.fmprc.gov.cn/eng/37814.html (19/07/2003).

1116 "55 New Economic Terms Since Founding of the PRC - Part Two", http://english.people.com.cn//200411/15/eng20041115 163932.html (29/11/2004).

1117 “Top Legislators Consider Amending Constitution Again”, 9 March 2004 The People's Daily, http://english.peopledaily.com.cn/200403/09/eng20040309 136921.shtml (11/03/2004).
} 
awareness of human rights, social equality and participation in civil society. The development of democracy and increasing importance placed on developing a human rights record will challenge traditional attitudes towards emigration. Global economic integration will demand increased population movement to and from China. Leaving China has begun to be regarded as a normal activity. ${ }^{118}$ The Chinese desire for equal opportunities in standards of living and freedom of movement, as Lu Jing has suggested, is more important than ever. ${ }^{1119}$ The desire among Chinese people to pursue human rights, and create wealth provides an inexhaustible reservoir of motivation to fully implement RLR.

The migration of Chinese from China, over the past 25 years, is a growing phenomenon. Overseas students increased from 3,000 in 1978 to 146,000 of $2001{ }^{1120}$ Based on the theory of Doris Meissner, ${ }^{1121}$ Chinese emigration is likely to increase over the next 10 to 15 years. According to Ronald Skeldon:

The 33 million estimate at the end of the $20^{\text {th }}$ century for the number of Chinese overseas had increased from around 22 million in 1985, and from 12.7 million in the early 1960s. Given the generally low fertility of overseas populations, this suggests a significant role for migration from China (include Hong Kong and Taiwan) over the second half of the 20th century. ${ }^{1122}$

The increase of the migration of Chinese from China has resulted in the formation of large and effective Chinese communities abroad. These communities remit knowledge and understanding to their friends and family members in China about other countries, and produce social, cultural, political and economic links between the destination

1118 Going abroad was only dream for most Chinese before the middle of the 1980s. See "China's Outbound Travelers Reach 14.99 Million in the First Seven Months", http://english.people.com.cn//200409/17/eng20040917 157376.html (19/09/2004).

${ }^{119}$ Lu, Jing, On the Freedom of the Movement (Lun Qianxi Ziyou), the book of LLM, Chinese People's University, Beijing, 2000, page 19.

${ }^{1120}$ Biao. Xiang, "Emigration from China: A Sending Country Perspective". International Migration, Volume 41, Number 3 (September 01, 2003), at 21-48, http://ejournals.ebsco.com/direct.asp?ArticleID=P8PYFRBJLETKMYT3KQ4F 01-10-2003, at 28-29.

${ }^{121}$ Sustaining economic development can simulate emigration over next ten to fifteen years. See Meissner, Doris, "Rapporteur's Conclusions of the Second Session" at the OECD, Migration and Development: New Partnerships for Co-operation, Head of Publications Service, OECD, Paris Cedex, France 1994, at 299.

1122 Skeldon, Ronald, "China: From Exceptional Case to Global Participant", April 2004, http://www.migrationinformaiton.org/Profiles/display.cfm?ID=219 (14/10/2004). 
countries and China. These situations not only help Chinese people in going abroad but also facilitate a more rapid adjustment and orientation on arriving in destination countries. Overseas returnees usually have an overseas educational background and the newest way of thinking. ${ }^{1123}$ They contribute to an increasing awareness of migration and people's capacity to go abroad.

\subsubsection{The international environment favouring protection of RLR in China}

Economic and technological factors bind States in such a way that no country can exist in isolation. In a shrinking world, States must prepare to take responsibility for each other, to achieve global cooperation, and to find mutually acceptable ground rules for developing a co-operative spirit, despite immense differences of culture, history, politics and standards of living. It is impossible to ignore human rights in China in view of the threat that Chinese communism has posed to world peace, the economic relationship that other States want to pursue with China, and the influence that Chinese culture has had on human development. If the world needs China, then presumably a common ground must be found between China and the world to facilitate co-operation.

The concerns on China's human rights records are of interest to the international community and foreign countries and integral to their ability to trade with China and access its markets. Australia's interest in the development and reform of China, and protection of China's human rights, can be understood as an extension of its own interest in China. ${ }^{1124}$ US policy to protect human rights springs from American ideals and its sense of national interest. ${ }^{1125}$

The concerns of Western countries on RLR in China can also be attributed to the

\footnotetext{
1123 The Chinese government reports that more than 20,000 Chinese students studying abroad returned last year, while the number was 18,000 in 2000 and 12,000 in 2001. The number of returned students is expected to hit a new record in 2004. See "China Encourage More Students Studying Overseas to Serve Motherland", http://english.people.com.cn//200411/15/eng20041115_163905.html (29/11/2004).

${ }_{1124}$ Kent, Ann, Human Rights in PRC, Discussion Paper No.3, 1989-90, Legislative Research Service, the Parliamentary of the Commonwealth of Australia, page 6.

1125 Colin L. Powell, "Preface", at "Supporting Human Rights and Democracy: The US Record 2002-2003", the Bureau of Democracy, Human Rights, and Labour, 2003 http://www.State.gov/g/drl/rls/shrd/2002/21763.htm (05-07-2033).
} 
important role of Chinese people living overseas and Chinese skilled and professional workers. Chinese people abroad play a significant role in the economy of Southeast Asia, Europe and America. ${ }^{126}$ China exports skilled and professional workers to all regions of the world, notably the USA, Canada, Australia and New Zealand.

The above conditions create a favourable environment in which the international community, particularly the West, might propose ways of reaching an acceptable common ground for laws governing RLR in China. The US is actively engaged in taking steps to decrease the number and severity of human rights abuses in China. In the US Committee or Refugees publication, China: The Country Reports on Human Rights Practices, the terms "exile" and "foreign travel, emigration and repatriation" always appear in connection with the expressions "respect for human rights" and "respect for civil liberties". ${ }^{1127}$ With the development of China, such concerns will accordingly increase.

Even if the extent to which international pressure has been effective remains open to question, it at least provides another criteria by which Chinese people and Chinese authorities can appraise RLR in China. China is no longer indifferent to international criticism of RLR, especially when made by developed and powerful countries. China has regularly entered into dialogue on human rights with the European Union (EU), Australia, Canada, and Norway ${ }^{1128}$ and also published Human Rights Record of the United States in March 2003, in response to publication of Country Reports on Human Rights Practices for 2003 by the US in February 2003. ${ }^{1129}$ Any efforts to improve RLR in China will find support in the international community and foreign countries. Foreign concern and Chinese responses may exert a subtly positive influence on the thinking of Chinese people and authorities regrading RLR.

\footnotetext{
1126 Sowell, Thomas, Migrations and Cultures: A World View, Basic Books, A member of the Perseus Books Group, 1996, page176.

1127 US Committee for Refugees, Worldwide Refugee Information Country Reports: China (including Tibet) 1998 to 2003.

1128 Information Office of the State Council of the PRC, Human Rights in China 2000, White Paper of Human Rights, Beijing, 2000, at Part 7.

1129 "Spokesperson Zhang Qiyue's Remarks on the Country Report on Human Rights Issued by the US (26/02/2004)", http://www.fmprc.gov.cn/eng/xwfw/2510/t69782.htm (02/03/2004).
} 


\subsection{Practical concerns about protecting RLR in China}

Despite being both necessary and feasible to protect RLR in China, there are concerns as to whether the protection of RLR might give rise to social issues. Some of these concerns have been discussed in parts $9.2 .3,10.1 .5$, and 12.3 .3 of this book. The purpose of this section is to explode representative myths that form the justification for opposing reform of the regulatory framework governing RLR in China.

\subsubsection{It would make no practical difference to many Chinese people}

The absence of any practical difference for the many Chinese people is often cited as a main reason for not granting RLR in China; that even if RLR was conferred, few people could or would ever take advantage of it. In Some Thoughts on Democracy, Judge Zhu Muzhi suggested that, "democracy that fails to take into account the demands of the people or the national interest blurs the essential difference between true democracy and pseudo democracy". He argued that advocates of such ideas either harbour ulterior motives or are muddle-headed. ${ }^{1130}$ Zhang Youyu, a constitutional jurist and one of its framers, explained that the reason freedom of movement is not constitutionally guaranteed is that there were too many practical issues associated with its enforcement to prevent the chaos that it was expected to generate. ${ }^{1131}$

The notion of practical indifference is based on the false premise that the ability to exploit a right is a precondition to its necessity. Mexico-US migration, for example, illustrates this argument. Of 109 million Mexican people, less than 9 million have emigrated to the USA, illegally or legally. ${ }^{1132}$ Mexicans enjoy RLR, even though $90 \%$ will never take advantage of the right. The majority of people never exercise some rights, such as the right to freedom of peaceful assembly and association, the right not to be enslaved, and

\footnotetext{
1130 Zhu, Muzhi, "Some Thoughts on Democracy", No.4 [2002] Human Rights Magazine, http://www.humanrights-china.org/zt/03111201/200312003129103621.htm (26/02/2004).

${ }^{1131}$ Zhang, Youyu, Quoted in Yin, Xiaohu and Lin, Yan, "The Change of the Chinese Legal Stipulations Regarding to the Freedom of Movement and the Thoughts on the Change" (Woguo Falv Guanyu Qianxi Ziyou Guiding De Bianhua Jiqi Sikao), No. 6 [2001] The Journal of Jurisprudence (Faxue), pages 10-14, page 11 .

${ }_{1132}$ Martin, Philip and Widgren, Jonas, International Migration: Facing the Challenge, Population Reference Bureau, Washington D.C., 2002, 39 pages, page 5.
} 
the right to form and join trade union. This does not justify their denial or detract from their importance.

Many low-income families in China are not in a position to send family members overseas. The costs of travel, foreign language difficulties, cultural differences, and lack of support mechanisms in the foreign countries, represent formidable barriers to international mobility. However, the deprivation of RLR to all Chinese people cannot be justified on the grounds that some people will be unable to exercise the right. There are increasing numbers of Chinese people who can.

\subsubsection{It would not benefit Chinese personal development when used for a special purpose}

Other critics of RLR reform argue that exiting China for a "special purpose" such as for religious pilgrimage, or middle school study, is unbeneficial to that person's development. Such limits are inconsistent with RLR, as well as other rights such as freedom of religion and right to an education. Maurice Cranston has argued that a State is only justified in detaining a national within the territory to the extent necessary for the discharge of a duty. Detaining a person within the territory for the purpose of forbidding recreational or any other activity is unjustified. ${ }^{1133}$

Whether exiting China is beneficial or not to an individual's development depends on a value judgment. Article 1 Clause 1 of the ICCPR provides that "All people have the right of self-determination [...] they freely pursue their economic, social and cultural development". As such, the Chinese government is neither qualified nor at liberty to impose a uniform system of values on its citizens.

\subsubsection{It would cause the loss of talented Chinese and internal instability}

\footnotetext{
1133 Cranston, Maurice, "The political and Philosophy Aspects of the Right to Leave and Return" in Vasak, Karel and Liskofsky, Sidney (ed), the Right to Leave and Return: Papers and Recommendations of the International Colloquium Held in Uppsala, Sweden, 19-21 June 1972, The American Jewish Committee, Arbor, the USA, 1976
} 
RLR is limited for members of the CPC, government officials, employees of State-owned enterprises and institutions, and professionals, in order to prevent the loss of talented Chinese and the onset of internal instability, which was analysed in part 9.2.1 of this book. This justification is without legal or practical foundation. From a legal perspective, limiting RLR in relation to these groups does no more than give effect to the policies of the $\mathrm{CPC}$, State-owned enterprises and public institutions, because they are not lawgivers. Their "laws" are only internal policies in effect. The affected individual cannot be detained inside China for the purpose of fulfilling an illegal obligation.

Practically, the loss of talented Chinese to developed States is unacceptable grounds for refusing to grant RLR. In any event, it is unclear whether China would actually suffer a significant loss of its professional class. Emigration might assist the economy of an originating State. According to 2002 global data, US\$ 65 billion was remitted by emigrants to their State of origin. This sum exceeded the foreign aid that these countries received in the same year. ${ }^{1134}$ Additionally, it is difficult to see how emigration is a threat to internal stability, unless relaxing emigration restrictions would lead to a mass exodus, which anyway requires other States welcoming the exodus.

If this elite group in China are detained for the benefit of the whole population, the justification reflects the outdated concept of "the greatest good for the greatest number", discussed in part 2.1.3 of this book. The effect of the justification is that RLR is granted in a discriminatory manner by permitting poorly skilled people to leave China, but not highly qualified people. This discrimination in terms of personal skills is incompatible with RLR.

\subsubsection{It would encourage people to illegally exit China and settle overseas}

The relaxation of RLR may encourage people to illegally exit China and settle overseas, thus creating more opportunities to abscond abroad with dirty money, and be free from

1134 Martin, Philip and Widgren, Jonas, International Migration: Facing the Challenge, Population Reference Bureau, Washington D.C., 2002, 39 pages, page 35. 
worry about returning to China. Thus, the argument goes, with restricted RLR a passport will not be issued to possible corrupt officials absconding abroad, extended or reissued for a person who has illegally exited China and settled overseas, the later of which has been discussed in part 10.2.1 of this book. Actually, the number of people who illegally exit China, approximately 50,000 per annum in the $1990 \mathrm{~s},{ }^{1135}$ compared to the lawful cohort, 1.13 million people who exited China for private affairs per year during the period between 1986 and 2001, ${ }^{1136}$ is very small. As analysed in part 10.2.2 of this book, there is no direct relationship between illegal migrants and passport issuance. Moreover, RLR cannot be denied merely because the possibility that a very small proportion of Chinese people might illegally leave for other countries.

Over 4,000 Chinese corrupt officials with more than US\$5 billion absconded abroad in the past two decades. ${ }^{1137}$ The situation is worsening. ${ }^{1138}$ One of the most important measures adopted to stop this, is the retention of passports. Under the Measures on Administration of Passport and Other Travel Abroad Documents of officials Employed CPC, governments, Courts, Procurator Courts, Justice Departments and Public Security Departments 2003 (PRC), passports and other travel documents of intermediate cadres and above are retained by designated departments. The issues of passport retention have been considered in part 8.2.3 and 8.3.3 of this book to argue that the retention of passports does not reduce the frequency of corrupt officials absconding.

It is difficult to argue the retention of passport alone or at all can effectively prohibit individuals, including corrupt officials with large sums of dirty money, from leaving

\footnotetext{
1135 The IOM, Myths and Realities of Chinese Irregular Migration, No. 1 of IOM Migration Research Series, the IOM, Geneva, Switzerland, 2000, 44 pages, page 13.

1136 Wang, Leiming, "Citizens May Exit Abroad for Private Purpose Easier and Faster" (Woguo Gongmin Yinsi Chuguo Gengjia Bianjie), http://www.sina.com.cn 19/09/2002 quoted in Xinhua News Agency, $18 / 04 / 2003$

${ }^{1137}$ Conference about the pursuit of corrupt officials' absconding abroad, held by the Supreme People's Procuratorate 2001 .

1138 In September 2003, a director of the Provincial Bureau of Anti-Embezzlement and Bribery under the Provincial People's Procuratorates said "up to now, the exact number is impossible to determine. Based on foreign news, during the period of outbreak of SARS in April and May 2003, 180 intermediate (current and retired) cadres disappeared, absconded or remained overseas without an intention of returning to China. See Sun, Yafei and Liu, Jianqiang, "Bowstring of Corrupt Officials Absconding Abroad" (Zongjie Tanguan Waitao), 9 Sep. 2003, Southern Weekend (Nanfang Zhoumo), http://news.21cn.com/domestic/guoshi/2003/09/26/1283769.shtml (26/09/2004).
} 
China. It may be possible for corrupt officials to subvert the badly knit formalities of applying for leaving China. Xiang Biao's opinion that "not all the institutions and staff involved [passport administration] can be tightly regulated"1139 is worth keeping in mind. Meanwhile, there are no laws to regulate how departments in which the applicants are in service, or the responsible departments, issue the certificates. This results in loopholes in the examination and approval of applicants with special identities. As such, under the current system, corrupt officials have the opportunity to gain genuine passports to abscond abroad.

Corrupt officials may bribe police who are responsible for border inspection. The success rate of bribery is very high. ${ }^{140}$ Retention of passports by the designated departments, despite containing the name and photograph of the holder, does not appear to interrupt the flow of corrupt officials, who can obtain a second false passport under another name. Lastly, the co-existence of public affairs passports and private passports enables many officials to hold two passports simultaneously. It has been reported that some corrupt officials who had absconded had obtained a public affairs passport and travelled abroad as part of an official delegation. ${ }^{141}$

From an international perspective, as Zhang Yesui, China's Vice Foreign Minister said in December 2003, “corruption can only be effectively contained and punished through adequate and comprehensive international cooperation". ${ }^{1142}$ Retention of passports as a measure to stem corruption is rather like giving up eating for fear of choking. It runs

\footnotetext{
1139 Biao. Xiang, "Emigration from China: A Sending Country Perspective". International Migration, Volume 41, Number 3 (September 01, 2003), pages 21-48, http://ejournals.ebsco.com/direct.asp?ArticleID=P8PYFRBJLETKMYT3KQ4F 01-10-2003, page 26. 1140 According to Collection of Violation and Crime Cases of Exit and Entry Border inspection Departments 2000 , assisting or secretly releasing persons past border control points whose without an appropriate passport or visa to pass accounted for approximately $80 \%$ of the offences committed by border control police. See Zhang, Yong, the Establishment of Education and Prevention Regime on Professional Violation and Crime of Frontier Inspection Polices in Committee of Exit and Entry Administration, Chinese Association of Police (ed), The Collection of Papers on The Control of Exit and Entry (III) Interior Published within Public Security Organs (Churujing Guanli Lunwenxuan (san)) (Gongan Jiguan Neibu Faxing), the Publishing House of Qunzhong, Beijing China, 2001, page 82.

1141 Biao. Xiang, "Emigration from China: A Sending Country Perspective". International Migration, Volume 41, Number 3 (September 01, 2003), pages 21-48, http://ejournals.ebsco.com/direct.asp?ArticleID=P8PYFRBJLETKMYT3KQ4F 01-10-2003, page 26. ${ }^{1142}$ H.E. Zhang Yesui, "statement by Vice Foreign Minister of the People's Republic of China Said at High-Level Political Conference For The Purpose Of Signing The Unite Nations Convention Against Corruption", Merida, 10 December 2003, http://www.fmprc.gov.cn/eng/zxxx/t56955.htm (30/12/2003).
} 
contrary to the objective of reducing the rate of absconding, and violates the right to leave.

Unless the legislative loopholes are closed, the problem will persist.

\subsubsection{It will damage other States' interests}

The argument against granting RLR to all Chinese people is that China's massive population would damage the interests of other States to whom the population would move. For example, one concern in developed countries - particularly, perhaps, in Europe - is that with a base population of 1.3 billion, China could come to dominate the global migration system and change the character of destination societies. ${ }^{1143}$

In fact, granting RLR to all Chinese will not dramatically alter migration patterns. In 2002, RLR was protected in relation to approximately $75 \%$ of the world's population. International migration accounted for $3 \%$ of that population. ${ }^{1144}$ The Mexican example drawn earlier demonstrates that the freedom to leave a country does not cause people to emigrate as to be separated from their social and cultural environment.

Additionally, the eventual realisation of RLR depends on the receiving States' immigration policy. Foreign States may be expected to adjust their immigration policy in response to any reform of Chinese migration law, to protect their national interests. Australia, New Zealand and Canada successfully control their immigration stock by setting an annual quota. As such, foreign States would determine the actual influence that liberalisation of the Chinese RLR would have.

Moreover, improving economic conditions in China can reduce the effect of a liberalised RLR on immigration States. This will remove a motivating factor behind emigration, namely the chance of better employment prospects abroad, and would answer the concerns raised by critics of RLR reform. A vibrant economy exists to which migrants

\footnotetext{
1143 Skeldon, Ronald, "China: From Exceptional Case to Global Participant”, April 2004, http://www.migrationinformaiton.org/Profiles/display.cfm?ID=219 (14/10/2004). ${ }^{1144}$ The IOM, International Migration Report 2002, ST/ESA/SER.A/220, IOM, Geneva, Switzerland, 2002, 64 pages, page 2 .
} 
and students can return. China may progress through the migration "hump" or transition from emigration to immigration. ${ }^{1145}$

\subsubsection{It would be irrelevant to other countries}

Opponents of reform argue that the expansion of RLR in China is irrelevant to other countries, so therefore unnecessary. However, RLR in China is inextricably related with other countries, especially the countries having great economic, political and cultural interests with China, such as Australia. In 2003, the Australian Prime Minister John Howard affirmed, the importance that Australia attaches to its trading, economic and social ties with China. ${ }^{1146}$ China is Australia's third largest trading partner. Australia is China's twelfth largest trading partner. ${ }^{1147}$ Further, Australia issues about 100,000 students visas each year, of which one in eight is made available to a Chinese student.

Liberalisation of RLR in China will create more trading, tourism and educational opportunities both for China and the States with whom it deals. The total value of foreign trade for China has passed 1 trillion US dollars. The development of China's foreign trade is shared with other countries in the world. ${ }^{1148}$ The economic achievement is not divorced from the movement of people into and out of China. The issue of RLR in China is crucial both for the future of China, and for the part China will play in the future of RLR in the world.

\subsection{Conclusions}

The protection of RLR in China is not only a result of logical legal analysis but also of practical social demands. The protection of human rights in China cannot be divorced from the protection of RLR. The trends market economics, industrialisation and global

\footnotetext{
1145 Skeldon, Ronald, “China: From Exceptional Case to Global Participant”, April 2004, http://www.migrationinformaiton.org/Profiles/display.cfm?ID=219 (14/10/2004).

1146 "Premier Wen Jiabao Holds Talks with Visiting Australian Prime Minister John Howard (18/08/2003)", http://www.fmprc.gov.cn/eng/zxxx/t25065.htm (26/09/2003).

147 "People's Republic of China, China: Relative Importance to Australia" http://www.dfat.gov.au/geo/china/proc bilat fs.html (22/10/2003).

148 "How to Look at the Breakthrough of Trillion US Dollars in China's Foreign Trade?", The People 's Daily, http://english.people.com.cn/200412/11/eng20041211 166937.html (20/12/2004)
} 
integration within China define the need for China to open wider to the world, allowing much more free movement across its borders. A migration program focussed on the protection of RLR needs to be well designed to accommodate greatly changing patterns of migration that have emerged since reform and opening up policies implemented in 1978. The Chinese government also needs to fulfil legal obligations of protecting RLR, if only to improve its image in the world, but more meaningfully, to substantiate its own expression of a Chinese belief in the dignity of human rights.

Today, there are impressive economic achievements, sound political and legal development, and growing awareness of RLR and migration in China, which together lays a solid foundation to improve the protection of RLR. Going abroad is becoming a part of normal life for Chinese people. The trend of democratisation will be an inevitable consequence of market economics. Democratic reform and incorporating human rights into the Constitution will drive the enactment of laws related to RLR. The desire among Chinese people to pursue RLR may provide an inexhaustible reservoir of motivation to protect RLR. Meanwhile, foreign attempts to improve RLR will remain of consequence because such concerns originate from the consideration of their national self-interest. Such attempts and Chinese responses may exert a subtly positive influence on the thinking of Chinese people and authorities regarding RLR.

Impractical concerns about adverse effects arising from the protection of RLR in China risk losing the chance of successful reform. The notion that it makes no practical difference to the majority of Chinese people, in particular, is based on the false premise that the ability to exploit a right is a precondition to its necessity. The deprivation of the RLR to all Chinese people cannot be justified on the grounds that some people will be unable to exercise the right. Chinese people have the right of self-determination and to freely pursue their economic, social and cultural development. The same principle applies to a fear that protection of RLR is unbeneficial to a person's development, when used for a special purpose. Such limits are inconsistent with other rights such as freedom of religion and right to an education. 
If an elite group are detained for the benefit of the whole population, as is the case with limits on RLR for public affairs passports, RLR is effectively granted in a discriminatory manner by permitting poorly skilled people to leave China, but not highly qualified people. Illegal exit is not a justification for denying RLR of all people, because the number of people who illegally exit China is very small compared to the lawful cohort. Moreover, the protection of RLR in China will not damage other States' interests, because the eventual realisation of RLR depends on the receiving States' immigration policies. There appears to be little evidence to indicate that expansion of the RLR in China is of no relevance to other countries, because opportunities created by its expansion are beneficial both for China and the States with which it deals. 


\section{Chapter Fifteen \\ Recommendations and conclusions}

\section{Introduction}

In the Introduction to this thesis, the overall research objective was to explore the Chinese regulatory framework governing RLR to determine its consistency by reference to international human rights ethics. This approach has demonstrated that the development of Chinese society demands a re-examination of the regulatory framework governing RLR, and a greater awareness of the need to protect RLR. Increased priority given to the protection of RLR, may improve the likelihood that an effective legal resolution of issues associated with its protection, is found. This chapter, in drawing together the conclusion of this book, recommends the means by which the Chinese regulatory framework governing RLR might be improved. Six recommendations focused on the design of a new unified migration law are explained separately.

The existing regulatory framework governing RLR is incapable of delivering adequate protection for people who exit and enter China. The recommendations in this chapter are based on the premise that the regulatory structure crushes the possibility of exiting and entering China for part of Chinese population; especially overseas Chinese, irregular Chinese migrants; and all Chinese dissidents who want to return. It has also been argued that these issues undermine the protection of human rights, stifle political and economic reform, and discourage the spirit of creativity and the promotion of international exchange.

The protection of RLR needs a coherent and malleable regulatory system. The existing regulatory framework governing RLR cannot achieve that. A four-year reform strategy published in 2001 supported reforming the exit and entry administration, including the existing laws. Reform is also supported by the newest amendment of the Constitution in March 2004, under which the State is obliged to respect and protect human rights. 
Although the need for reform of law governing RLR is becoming urgent, the measures that need be taken by the Chinese government remain uncertain.

\subsection{Factors that help determine the extent of the reform}

Before providing recommendations for regulatory framework reform, it is important to analyse the factors that help determine the extent of the reform. They consist of six aspects.

The reform of the regulatory framework governing RLR should be part of a systematic process that simultaneously addresses a number of issues currently facing contemporary Chinese society. Along with migration law reform, protection of RLR requires reform of laws governing households, foreign exchange, emigration intermediary agencies, administrative law, administrative procedural law, labour exports, border inspection, the political structure, as well as the content of legal education. In addition to this multifaceted approach to reform, China, as the President of the Supreme People's Court of the PRC, Xiao Yang has accepted:

May learn from the experiences and lessons of safeguarding human rights in the world, collate the universal standard of human rights in concluded or acceded to international human rights conventions, systematically summarise past work of safeguarding human rights, and make a comprehensive plan to guide future work of safeguarding human rights. ${ }^{1149}$

The reform of the regulatory framework governing RLR needs to be a gradual process. In March 2004, The People's Daily reported that “Just 20 years ago, human rights were still regarded as a so-called 'capitalist notion' in China". ${ }^{1150}$ Relevant research and publicity were prohibited. China's history of complete governmental control of exit and entry will

\footnotetext{
1149 Journalist of The Journal of Human Rights, Correct Appliance of the Law and Impartial Trial under the Law: Strengthen the Safeguard of Human Rights in the Realm of Justice in a Down-to-earth Way: the Interview of the Comrade Xiao, Yang, the President of Supreme People's Court (Zunque Shiyong Falv Yifa Gongzheng Caipan Qieshi Jiaqiang Sifa Lingyu De Renquan Baozhang: Fang Zuigao Renmin Fayuan Yuanzhang Shouxi Dafaguan Xiao Yang Tongzhi), No. 6 [2002] The Journal of Human Right, pages 3-8, page 8.

1150 "Human Rights to Be Enshrined in Constitution", 9 March 2004, The People's Daily, http://english.peopledaily.com.cn/200403/09/eng20040309 136924.shtml (11/03/2004)
} 
make it difficult for comprehensive reform of the regulatory framework governing RLR to occur quickly. Hasty reform measures may result in a deadlocked process and social disruption, which could have an adverse effect. Hence, the reform process needs be staged.

It can be expected that any reform process will endure some transitional problems. Indeed, the more extensive the changes are, the greater the adjustment. Initially, there may be an increase in personnel costs as the responsible departments undergo training to become familiar with new requirements. There may also be a risk that some personnel experience difficulty in understanding or complying with the changed rules. The reform strategy and its measures need to ensure that these initial problems are managed so that the regulatory objective can be achieved.

If the scope of administrative discretion is too wide, the application of reformed laws may result in inconsistent decision making. Yet the administrative authority cannot comprehensively implement legislation if their discretion is too narrow. Uncertainty arising from wide administrative discretion may cause individuals to anticipate how the government might apply new laws, and given the fact, argued already, that the discretionary powers of exit and entry administration in China are too broad, reforms need to narrow the scope for discretion.

Reforms modelled on Western human rights notions may not be entirely suitable in China. Human rights theory is useful in analysing the foundations and efficiency of existing law, insofar as the analysis was premised on the full recognition of human rights of the Chinese government. In fact, "China has its own understanding of human rights which differs from that of Western developed countries." ${ }^{1151}$ Reformers need to move beyond human rights theory to adopt a holistic approach in framing new regulations for the protection of RLR in China.

1151 "Human Rights to Be Enshrined in Constitution", 9 March 2004, The People's Daily, http://english.peopledaily.com.cn/200403/09/eng20040309 136924.shtml (11/03/2004). 
Finally, both temporary and permanent solutions are sought here while focusing on the permanent solution. The recommendations provide a strategic direction for the resolution of the issues discussed from Chapters eight to thirteen, rather than detailed plans with respect to each issue. Effective reform will arise from tackling the issues at root, rather than by addressing the issues that flow as their consequence.

\subsection{Recommendations for improving the regulatory framework governing RLR}

Six recommendations have been formulated to assist in reforming the regulatory framework governing RLR in China so that the protection of RLR can be realised. These are (i) incorporating RLR into the Constitution; (ii) enactment of a uniform Chinese migration law; (iii) establishment of an effective administrative system; (iv) reform of relevant laws and regulations; (v) enhancement of public awareness of RLR; and (vi) the use of information technology in exit and entry administration.

\subsubsection{Incorporating RLR into the Constitution}

The highest priority of reform of RLR is constitutional protection. This might be achieved even if China's capacity to give full effect to the right has not matured, because RLR can be stated in abstract terms in the preamble. Dr. Du Chengming has observed that China's constitutional rights are both practical rights, which people can enjoy in life, but also ideal rights, which the Chinese government will spare no effort to develop. ${ }^{1152}$ The current Constitution, which was amended in 1982, clarifies the basic rights of Chinese citizens without referring to RLR. RLR is a basic human right that is constitutionally guaranteed, with some permissible limits, in most Constitutions all over the world, and in most international human rights conventions. Economic and political reforms demand that RLR be constitutionally guaranteed in China, as in other countries. China needs to incorporate RLR into the constitutional norms for the protection of fundamental human

1152 Dr. Du, Chengming, “On Migration Freedom"(Lun Qianxi Ziyou Quan), Vol.54 No.4 July 2001 Wuhan University Journal (Social Sciences) (Wuhan Daxue Xuebao (Shehui Kexue Xuebao)), pages 406-410, page 410 . 
rights or citizens' rights, as well as including a clause to bring international migration law into domestic law.

Although it is hoped that RLR will be constitutionally guaranteed as soon as possible, it is predicted that this is unlikely to occur until 2010. The cycle of constitutional amendment under the procedures contained in Article 64 of the Constitution ${ }^{1153}$ has historically been approximately five years. ${ }^{1154}$

Incorporating RLR into the Constitution is not enough for its protection. Constitutional amendment only provides a legal basis for broader RLR reform under the theory of the Chinese constitutionalism - a constitutional provision cannot compel legislative implementation. Further to parts 5.4 .9 of this book, incorporating RLR into the Constitution does not invalidate inconsistent laws. For this reason, the importance of the application of a constitutional provision regarding RLR in judicial practice and by legislators must be stressed.

\subsubsection{The enactment of a uniform Chinese migration law}

Prior to constitutional reform, it is recommended that a uniform migration law be enacted along the following seven lines.

\subsubsection{Benefits of and favourable conditions for a uniform migration law}

Even though Article 5 Clause 2 of the Constitution of the PRC (Amendment) 2004 expressly prescribes that "no laws or administrative and local regulations need contravene the Constitution", there is no effective mechanism for constitutional review of the validity of legislation. Conflicts of laws governing exit and entry with the Constitution have influenced judicial decisions, resulting in localism and sabotage of the integrity of the national legal system. Reform of the current regulatory framework is concerned with

1153 Article 64 Clause 1 of the Constitution of the PRC (Amendment) 2004 "amendments to the Constitution are to be proposed by the Standing Committee of the National People's Congress or by more than one-fifth of the deputies of the National People's Congress and adopted by a vote of more than two-thirds of all the deputies to the Congress."

1154 Amendments to the Constitution of the PRC 1982 were made in 1988, 1993, 1999 and 2004. 
constitutional amendment and legislative practice. As neither constitutional reform, nor changes to legislative practice are expected to occur quickly, enactment of a uniform scheme of migration law may provide a more realistic means of protecting RLR.

Reform of passport law has laid a useful foundation for enacting a uniform migration law. Passport law reform has emphasised the right to leave, which is only part of the overall RLR. However, other aspects of RLR, including the right to return, the right of nationals not to be exiled, the right against expulsion, the administration of emigration intermediary agencies, and the remedies to violations of RLR, need to be closely considered. These are becoming more important as China develops. In recent years, especially since China's entry into the WTO in December 2001, some work has been done to review the regulatory framework governing RLR. According to the Legislative Program of the Standing Committee of the Tenth National People's Congress, the Bill of the Law of Passport will be deliberated by the Tenth NPC (2003 to 2007). ${ }^{1155}$ The legislature needs resolve to change the Bill of the Law of Passport into the Bill of the Law of Migration, and pass a uniform code before the approximate date of 2007.

\subsubsection{Legislative purpose of Chinese migration law}

The purpose of the existing regulatory framework governing RLR is to promote international exchange, safeguard State sovereignty, and maintain the security and public order of China. The purpose of a uniform migration law would be to protect RLR by unifying entry and exit control, safeguarding national security and public order, regulating migration matters, and implementing migration guidance. To achieve this, the principles of non-discrimination, openness and transparency would need to be adhered to. Policies would need to be formulated through a process that is inclusive of the stakeholders in the migration process, especially emigrants. Policies should reflect the activities and interests of the poor. This might mean decentralising migrant support services, and locating government services, such as 'One-stop shops' for counselling and

1155 Zhang, Shuo, "Five Years Legislative Program was Published, Including 76 Bills" (Zhongguo Gongbu Wunian Lifa Gguihua, 76 Jian Falv An Bangshang Youmin), 18 December 2003, China News Agency, http://news.21cn.com/domestic/guoshi/2003/12/18/1384968.shtml (19/12/2003). 
information services in rural areas.

\subsubsection{The complete regulation of exiting China}

The current Chinese exit and entry administration laws do not comprehensively deal with exiting China. The laws do not cover exiting China for the purpose of public affairs, or to travel to the HKSAR, MSAR and Taiwan for the purpose of public affairs, even though such travel is indispensable. At present, rules governing public affairs related exits are regulated by unpublished departmental and CPC policies. The issues associated with public affairs passports were discussed in part 8.2 of this book.

Applications for travel documents, in particular passports for private travel, are based on a complex range of criteria that discriminates between applicants on the grounds of residential area, occupation, education and social status. There are five major criteria for overseas travel documents. These are (i) residents in rural and small city areas; (ii) residents in medium and large sized city areas; (iii) residents who are public servants and managerial staff in State-owned enterprises and public institutions; (iv) residents in Mainland China who want to travel to the HKSAR and MSAR; and (v) residents in Mainland China who want to travel to Taiwan. Other minor criteria for private passport applications, such as religious pilgrimage, also apply.

On the one hand, a uniform application criterion for travel documents when going abroad for private and public affairs needs be established. Impermissible limitations on exiting China to foreign countries, or to the HKSAR, MSAR and Taiwan need to be further relaxed or abolished. A uniform application criterion might eliminate the discrimination that is caused by different criteria. On the other hand, the scope of restrictions on public affairs passports needs to be dramatically curtailed. This might enable more citizens to gain permission to leave for private affairs. Moreover, to improve administrative efficiency a national database of people who are prohibited from exiting China needs be established. The enactment of a comprehensive exit rules may improve the system of examination and approval of exit applications so as to make them suitable for domestic 
conditions and international norms, and to guarantee fair and efficient law enforcement.

\subsubsection{The complete regulation of returning to China}

Relaxation or abolition of the limits on the rights of Chinese nationals returning to China from overseas is more urgent than the relaxation or abolition of limits on exit. Limiting the right to leave deprives the person of a recognised freedom, limiting a national's ability to re-enter China may cause that person to become effectively stateless, force them to live illegally in a foreign country, in a place that he or she does not like, and prevent talented Chinese people from returning. In other words, the right to return is more absolute than the right to leave. However the issues surrounding the right to return to China have received less attention than those associated with the right to leave. As discussed in Chapter seven, the current reform strategy does not deal with the prohibition and limits on returning to China.

Beyond the general recommendation that the right to return to China needs to be carefully considered, four detailed suggestions can be added.

1) Limits on the return of Chinese citizens residing abroad and irregular Chinese migrants needs to be abolished. These groups need an absolute right to return to China.

2) Prohibitions imposed on the return of overseas Chinese dissidents and residents in the HKSAR, MSAR and Taiwan needs to be relaxed. The grounds upon which permission to return is refused need to be clarified, as the refusal of permission becomes increasingly confused with related policies on national security, public health and martial law. A database of people who are prohibited from entering China needs to be established and the procedure for prohibiting entry needs to be transparent and simplified.

3) Talented overseas Chinese need the right of return as Mainland Chinese residents. Foreign citizens who were originally from China must be given assistance in obtaining permanent residence or Chinese citizenship before other 
aliens.

4) Administrative procedures associated with the movement and residence of overseas returnees and foreigners needs to be simplified. Management of this group of potential immigrants may extend beyond the policy of attracting them to settle in China via migration law. Simplification of the procedures related to movement and residence within China may help their economic and social reintegration.

\subsubsection{The reform of administration of emigration intermediary agencies}

The laws governing emigration intermediary agencies need to be addressed as part of an overall legislative scheme of migration law. The following recommendations relate to the content of Chinese migration law.

1) The various agencies need be consolidated and placed under one umbrella of an administrative authority. ${ }^{1156}$ The MPS is the most appropriate authority for this function. Further, the licensing system needs to be simplified.

2) In order to reduce the cost of managing emigration intermediary agencies and make them more effective, restrictions and barriers to trans-regional emigration intermediary agencies marketing and investment could be abolished. Administrative powers that do not separate the functions of government from the management of enterprises, and which divest institutions of their administrative functions, in addition to powers that hamper market development and fair competition, need be repealed.

3) The control of agencies needs be changed from direct regulation by the responsible government departments to direct supervision by an industry-based association. This will promote administrative efficiency within the agency. The MPS needs to retain an indirect supervisory role over agencies by formulating policy guidelines. Further, the internal disciplinary measures adopted by

\footnotetext{
${ }^{1156}$ In accordance with the statement by Xiang Huaicheng, the Finance Minister in 2000 in China to Further Rectify Intermediary Organs, 24 August 2000, The People's Daily, http://fpeng.peopledaily.com.cn/200008/24/eng20000824 48942.html (30/12/2003).
} 
agencies needs be improved by reference to the standards of the industry-based association.

4) The conditions for establishing an agency need to focus on the qualifications of the agent, in addition to the current capital requirements. As noted in part 12.3.2 of this book, the magnitude of reserve funds that are required to establish an agency, while aimed at reducing the frequency of illegal conduct on the part of individual agents, are prohibitive. The reserve fund concept needs to be replaced by compulsory insurance. A model for the regulation of compulsory insurance in this industry can be found in relation to laws governing overseas travel agencies. ${ }^{1157}$

5) Migration agents need to be familiar with the migration law of China and receiving countries. A license should not be granted to establish an agency unless a minimum legal training requirement has been completed. This will improve the quality of newly established agencies.

6) The limits imposed on agents' access to foreign investment need to be abolished. Under the WTO agreement, China is obliged to expand the services available to foreign businesses with respect to the promotion of Chinese industry. Migration agents are well placed to attract reputable foreign enterprises into China. Foreign investors need to be afforded the same opportunities as their Chinese counterparts. Services need to be improved by making government practices more efficient and predictable, and by fostering competition between agencies.

7) The requirement that five staff members with tertiary qualifications must be employed by each agency needs to be relinquished on the grounds that it is unreasonable to regulate the minimum number of qualified staff in a market economy. The employment of staff, whether qualified or unqualified, is a

\footnotetext{
1157 Article 2 of the Measures of Purchasing Travel Agency Responsibility Insurance of Travel Agencies 2001 (PRC), "travel agencies engaging travel service may purchasing travel agency responsibility insurance (Lvxingshe Zeren Baoxian). Article 10 of the Measures of Purchasing Travel Agency Responsibility Insurance of Travel Agencies 2001 (PRC), the limit of compensation for overseas tourist is 160,000 RMB yuan (equal to 19,350 US dollars). The limit of accumulated compensation for international travel agencies is 4 million RMB yuan (equal to 483,700 US dollars).
} 
commercial decision for each agency depending on the size of the agency and the nature of the services they provide.

8) The annual re-examination of qualified agencies and the possibility that the agent can lose their capacity to practice if the examinations are failed twice is too lenient. Loss of a practicing certificate is currently limited to agents who have engaged in unlawful conduct. Agents need to be required to attend on-going education courses as part of their annual re-certification. To further maintain the standards of agents' practice, the MPS website, or that of an industry-based association, needs to publicise the way in which agents are disciplined.

9) The requirements for extension of the duration of agencies' licenses need to be simplified.

\subsubsection{The improvement of remedies for violations of RLR}

Procedural fairness needs to be applied to administrative decisions that affect RLR, along with other aspects of administrative procedure, and laws concerning administrative penalties and licensing. The following recommendations are aimed at resolving issues related to remedies for violations of RLR.

The conception of a remedy of administrative review needs to be established. A remedial framework would correct the improper use of the term "appeal" (shensu) that appears in Article 15 of the Law on the Control of Exit and Entry of Citizens 1985 (PRC), Article 29 Clause 2 of the Law on the Control of Exit and Entry of Aliens 1985 (PRC); and Article 50 of the Detailed Rules for the Law on the Control of Exit and Entry of Aliens (Amendment) 1994 (PRC). These provisions allow a citizen to "appeal" against an administrative penalty imposed by a public security department. The term "administrative review" (Xingzheng fuyi) is more appropriate than "appeal". A conception of a remedial framework would lay a solid foundation from which to further regulate administrative review in migration law. 
The remedy of administrative review should apply to all administrative penalties and decisions with respect to exit and entry in China. Extending the scope of administrative review may remove the discrimination caused by the imposition of penalties and by administrative decisions generally, such as the discriminatory grounds upon which a person may be permitted to enter or leave, based on the purpose of their travel.

The separate principles of merits review and external remedies, which were discussed in part 13.3.3 of this book, need be merged to form a doctrine of administrative review. It is recommended that the existing merits review structure be changed so that if a person is aggrieved by an initial decision, he or she may apply for review to an administrative review tribunal within a certain period after receiving the notice of the decision. The administrative review tribunal would be required to review the decision within certain period after the receipt of the application. If the applicant is still dissatisfied with the decision, proceedings could be instituted in a Court within a certain period of receiving the tribunal's decision.

\subsubsection{The establishment of an effective exit and entry administrative system}

Without an effective administrative system for exit and entry, these recommendations will be ineffective. Reform of the administrative system will be difficult because it entails partial reform of government departments. Nevertheless, the challenge must be faced in order to comprehensively reform the regulatory framework and protect RLR.

A new uniform exit and entry administration responsible for private affairs and border security

The entities that administer exit and entry, and border security checks and administration need to be merged. Existing functions related to the police need to be vested in the criminal investigation and public security departments. The authorities dealing with aliens' residence registration need be incorporated into the household administration department. This restructuring would be relatively simple because it would fall under the 
existing MPS system. The new exit and entry administration department would remain subordinate to the public security department, which uniformly exercises the functions of assessing passport applications, issuing passports, granting visas and checking passports and visas at the border.

\section{A new uniform exit and entry administration for all private affairs}

Exit and entry authorities for private affairs administration need to be devolved to the new exit and entry administration under the MPS, thereby establishing a uniform private affairs system. The Overseas Chinese Affairs Offices, under this change, would no longer be responsible for the exit and entry administration of overseas Chinese.

A combined uniform exit and entry administration for all private affairs and public affairs Exit and entry administration for public affairs needs to be clearly defined and made transparent and open. Currently, the MFA and its authorised branches are responsible for the administration of public affairs travel to and from foreign countries. The SHMO and STO are responsible for the administration of public affairs travel to the respective regions. The administration of exit and entry for public affairs need to be merged into the new exit and entry administration for all private affairs, to build an effective, systematic and comprehensive system.

Avenues of review: establishment of an administrative review tribunal and judicial reform An independent administrative review tribunal needs to be established, and judicial proceedings needs to be improved to provide effective remedies to violations of RLR. The experiences of the Australian Appeals Tribunal could be a possible modle for China. The relevant detailed analysis and research need to be further done in the future study. It is necessary to reform the working mechanisms of judicial bodies and the management system of their human, financial and material resources; and to gradually separate their judicial and administrative functions.

Further reforms: placing limits of on administrative discretion and decentralisation of 
authority

Additionally, the discretion of the exit and entry administration needs to be limited. This can be achieved by enacting more specific rules and regulations, which will overcome existing ambiguity and flexibility. The inclusion of detailed criteria and procedures can be a priority when drafting the new laws. Secondly, local exit and entry authorities may be vested with more power. This would be achieved by transferring functions from the ministerial and provincial level of administration to the municipal and county levels. This revised structure would allow ministerial and provincial administration to focus on policy formulation, while permitting local administrative bodies to implement policies at "grass roots". Decentralisation would eliminate unnecessary red tape; create an efficient and transparent system and curb corruption. All authorities would be required to obey the law when carrying out their administrative duties and perform their functions strictly within their jurisdiction.

\subsubsection{The reform of related laws and regulations}

RLR policies may be integrated with the laws of nationality, foreign exchange, household registration, tourism, education, labour administration, freedom of information ${ }^{1158}$ and national security, in order to reap the full benefit of emigration, not only for China but for those States to which Chinese people are sent. As such, the reform of related laws and regulations needs to be part of a package of regulatory framework reforms. This subsection addresses the two most important areas related areas for reform: nationality law and foreign exchange law. Recommendations for the other relevant areas are beyond the scope of this research.

\section{Nationality law}

Existing nationality laws need to be reformed in two principle respects: the recognition of

\footnotetext{
1158 According to the Legislative Program of the Standing Committee of Tenth National People's Congress, the Law of Passport, Law of the Freedom of Government Information will be formulated and promulgated in the period between 2003 and 2008. See Zhang, Shuo, "Five Years Legislative Program was Published, Including 76 Bills" (Zhongguo Gongbu Wunian Lifa Guihua, 76 Jian Falv An Bangshang Youming), 18 December 2003, China News Agency, http://news.21cn.com/domestic/guoshi/2003/12/18/1384968.shtml $(19 / 12 / 2003)$
} 
dual nationality; and relaxation of the conditions of naturalization.

The current policy of not recognizing dual nationality need to be reformed to maintain a much more close relationship with overseas Chinese nationals and to encourage more talented nationals who live overseas to return. Given China's low level of economic development, most people prefer to acquire or retain foreign nationality, even under the premise of renounceing the nationality of China. The recognition of dual nationality may reduce this phenomenon. Additionally, integration of an immigrant in a host country facilitates access to the immigrant's country, enriching the culture of the host country, and does not equate to the breaking of cultural ties with the home country. There are few convincing arguments to support the view that the recognition of dual nationality will cause disputes between the countries of nationalities.

A country's system of naturalization plays a key role in the retention of permanent residents and the attraction of aliens. Even though Article 7 of the Law of Nationality 1980 (PRC) stipulates that people who have settled in China may be naturalized upon approval of their applications, there are no related laws specifying who is eligible, when and where an application can be lodge, or how much may be paid. This means that the process of naturalization is almost impossible in practice. It is recommended that an applicant may be eligible for Chinese nationality if the person is:

- A permanent resident of China for three of the preceding five years, including a total of eighteen months in the preceding two and a half years;

- Can speak, listen, read and write Chinese;

- Is of good character;

- Understands the nature of the application;

- Understands the nature of the responsibilities and privileges of Chinese nationality;

- Will be present in China for at least one year of the two years following naturalization. 
Under the new migration system, an eligible person could lodge an application at any county and municipality level exit and entry administration office.

\section{Foreign exchange law}

The reform of foreign exchange law will be beneficial for Chinese people's going abroad. Amendments to existing foreign exchange laws need to be made in following respects.

Effective measures are needed to allow domestic residents to purchase, remit and carry larger sums of foreign exchange when they travel overseas. The complex process of access to foreign exchange should be simplified. A streamlined approval process is needed. The criterion for a maximum amount of foreign exchange needs to be refined. This book, in the absence of the relevant expertise, does not attempt to recommend what the maximum sum may be. In any event, such a calculation is not necessary for the argument raised here.

Moreover, when funds are from a legitimate source, license requirements for individual investors need to be varied to suit registration requirements with a provincial foreign exchange authority. The boldest measure would be to allow domestic institutions and individuals to invest in overseas capital markets or other financial markets. More banks needs to be entitled to provide foreign exchange services. Close attention need be paid to upgrading the quality and uniformity of foreign exchange laws.

\subsubsection{The enhancement of public awareness of RLR}

Implementation of the system so far described is of less value and effect if there is a lack of public awareness of RLR. To date, broad public education of individual liberties has been minimal. Awareness of RLR needs to be promoted in order to give effect to the reforms. Public education can be achieved by (i) publication and distribution in Chinese and other ethnic dialects of the various UN conventions regarding RLR to which China has ratified or acceded; (ii) an increase in the amount of university-based training in relation to RLR; and (iii) using the mass media to broadcast special programmes to 
convey information on matters of RLR protection.

The major obstacle in providing administrative redress for grievances, or implementing public education programmes, is found in the structurally inadequate, poorly funded Chinese institutions, whose purpose it is to fulfil those obligations. Rectifying this requires a concerted and coordinated effort over time. This would heighten public and political responsiveness to the role of human rights in daily living.

\subsubsection{The acceleration of the use of information technology in exit and entry administration}

Acceleration of the use of information technology in exit and entry administration, and the promotion of electronic administration to improve government working efficiency and exercise more effective supervision, is vital. Information networks need to be established by the exit and entry and border check administrations. Then, information networks between the exit and entry administration, household administration, public security, criminal investigation services, and the nationality administration need to be linked. Finally, the scope information networks needs to be extended to the foreign affairs authority, foreign exchange administrative authority, Customs, overseas embassies and consulates, the Courts and Procurators.

\subsection{Conclusions}

This book has identified numerous regulatory gaps and deficiencies, which if left unattended, could seriously undermine the objective of maintaining the confidence of the people of China in RLR, encapsulated in Article 33 Clause 3 of the Constitution of the PRC (Amendment) 2004 and Article 12 Clause 2 of the UDHR. Current regulations have failed by not providing people who want to leave and return to China with statutory safeguards, and not guiding migratory flows in an orderly manner.

The intention of this research is not merely to criticise and expose the deficiencies of RLR in China, but the concern that these problems should be adequately addressed. 
Measures, such as those recommended above, may be devised to address the deficiencies in the regulatory framework governing RLR, especially that governing exit and entry administration. In adopting the recommendations made in this book, the legislature will not only level the playing field for everyone wanting to enter and exit China, but will help to reduce systemic risks and technical barriers imposed by the current system which adversely affect RLR. The legislature may acknowledge that migration policy will need to develop on a day-by-day basis until it becomes an integral part of overall economic and social policy at the regional, national and international levels. This may be closely combined with technological and economic development.

There is still a long way to go before the Chinese authorities protect RLR. A strategy designed to increase public awareness of RLR and secure further governmental protection offers the most promising chance of success. Given continuing resistance to change, however, the process is likely to be tortuous and frustrating. Liberty, like all great, unfinished projects, requires constancy as well as conviction. With concerted and sustained efforts by the Chinese people and the international community, I dare to hope for the day when we will see China recognise and share RLR values adopted by the rest of the world. 


\section{Appendix 1 The Structure of the Chinese State Organisations}

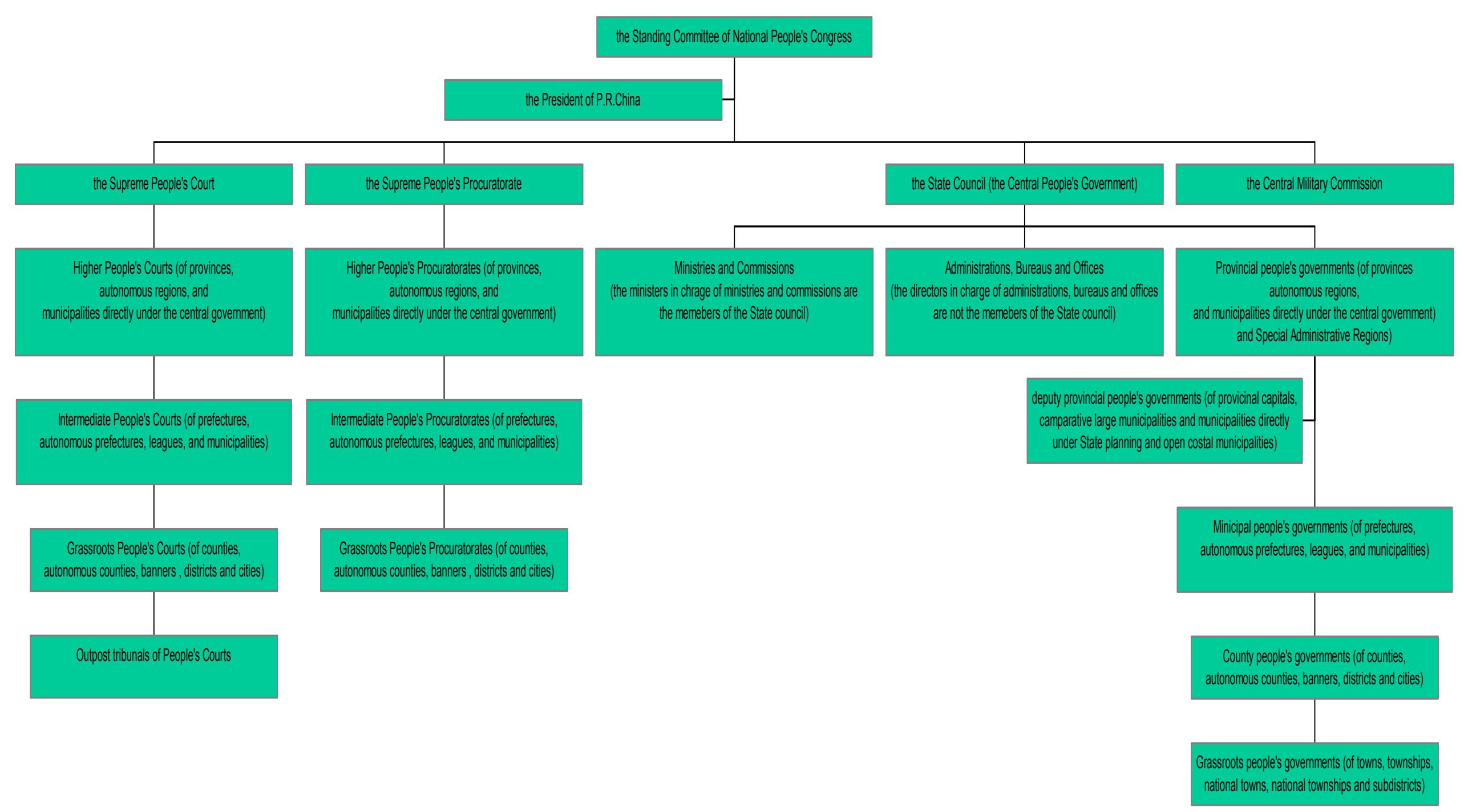




\section{Appendix 2 \\ Merits Review of Administrative Decisions \\ under Chinese Administrative Laws \\ and Administrative Procedure Laws}

\begin{tabular}{|c|c|c|c|}
\hline No. & Remedies & Scope & Sources \\
\hline 1 & $\begin{array}{l}\text { Administrative } \\
\text { procedure }\end{array}$ & $\begin{array}{l}\text { The People's Court shall accept suits brought by } \\
\text { citizens ... against any of the following specific } \\
\text { administrative acts: } \\
\text { (1) an administrative sanction, such as detention, fine, } \\
\text { rescission of license or permit, order to suspend } \\
\text { production of business or confiscation of property, } \\
\text { which one refuses to accept; .... } \\
\text { (4) refusal by an administrative organ to issue a permit } \\
\text { or license, which one considers oneself legally qualified } \\
\text { to apply for, or its failure to respond to the application. }\end{array}$ & $\begin{array}{l}\text { Article } 11 \\
\text { Clause 1 (1) and } \\
\text { (4) of the Law } \\
\text { on } \\
\text { Administrative } \\
\text { Procedure } 1989 \\
\text { (PRC). }\end{array}$ \\
\hline 2 & $\begin{array}{l}\text { Administrative } \\
\text { review }\end{array}$ & $\begin{array}{l}\text { A citizens "can apply to administrative departments for } \\
\text { review if he or she } \\
\text { (1) does not accept a disciplinary warning, fine, the } \\
\text { forfeiture of illegally obtained items, the forfeiture of } \\
\text { illegal treasures, an order suspending business } \\
\text { operations, a temporary suspension or seizure of } \\
\text { permits, or a temporary suspension or seizure of } \\
\text { licenses; .... } \\
\text { (3) does not accept the alteration, termination, or } \\
\text { rescission of a permit, license, certificate of intelligence, } \\
\text { or certificates; .... } \\
\text { (11) there is of the opinion that the administrative } \\
\text { department has infringed their legal rights and interests. }\end{array}$ & $\begin{array}{l}\text { Article } 6 \text { Clause } \\
1 \text { (1), (3) and } \\
\text { (11) of the Law } \\
\text { on } \\
\text { Administrative } \\
\text { Review } 1989 \\
\text { (PRC). }\end{array}$ \\
\hline 3 & Complaint & $\begin{array}{l}\text { Article } 2 \text { Complaints can be made against government } \\
\text { departments of county level or above in relation to: ... } \\
\text { Article } 8 \text { the following matters may be inquired by a } \\
\text { complainant .... } \\
\text { (2) accuse or expose violations of law or negligence by } \\
\text { the staff of administrative authorities; } \\
\text { (3) infringements of the rights or interests of the } \\
\text { complainant; and } \\
\text { (4) other matters. }\end{array}$ & $\begin{array}{l}\text { Articles } 2 \text { and } \\
\text { Article } 8 \text { Clause } \\
1 \text { (2), (3) and (4) } \\
\text { of the Rules on } \\
\text { Compliant } \\
\text { Reporting } 1995 \\
\text { (PRC). }\end{array}$ \\
\hline 4 & $\begin{array}{l}\text { State } \\
\text { compensation }\end{array}$ & $\begin{array}{l}\text { Article } 3 \text { The victim have the right to compensation if } \\
\text { an administrative departments or its functionaries, in } \\
\text { exercising their administrative functions and powers, } \\
\text { commit any of the following acts violating the right of a } \\
\text { citizen: (1) detaining a citizen in violation of the law or } \\
\text { unlawfully taking compulsory administrative measures } \\
\text { in restraint of their personal freedom; .... }\end{array}$ & $\begin{array}{l}\text { Article } 3 \text { Clause } \\
1(1) \text {, and Article } \\
4 \text { Clause } 1 \text { (1) of } \\
\text { the Law of State } \\
\text { Compensation } \\
1994 \text { (PRC). }\end{array}$ \\
\hline
\end{tabular}




\begin{tabular}{|c|c|c|c|}
\hline & & $\begin{array}{l}\text { Article } 4 \ldots \text { [or] commit any of the following acts } \\
\text { violating upon property right: } \\
\text { (1) illegally imposing administrative sanctions such as } \\
\text { fines, revocation of certificates and licenses, ordering } \\
\text { suspension of production and business, or confiscation } \\
\text { of property..... }\end{array}$ & \\
\hline \multirow[t]{3}{*}{5} & \multirow[t]{3}{*}{$\begin{array}{l}\text { Administrative } \\
\text { penalty }\end{array}$} & $\begin{array}{l}\text { Citizens .... against whom a penalty is imposed by } \\
\text { administrative departments shall have the right to state } \\
\text { their case and the right to defend themselves; those who } \\
\text { refuse to accept administrative penalty shall have the } \\
\text { right to apply for administrative review or bring an } \\
\text { administrative lawsuit in accordance with law. }\end{array}$ & $\begin{array}{l}\text { Article } 6 \text { (1) of } \\
\text { the Law of } \\
\text { Administrative } \\
\text { Penalty } 1996 \\
(\mathrm{PRC}) \text {. }\end{array}$ \\
\hline & & $\begin{array}{l}\text { The types of administrative penalty shall include: (1) } \\
\text { disciplinary warning; (2) fine; (3) confiscation of illegal } \\
\text { gains or confiscation of unlawful property or things of } \\
\text { value; (4) ordering for suspension of production or } \\
\text { business; (5) temporary suspension or rescission of } \\
\text { permit or license; (6) administrative detention; and } \\
\text { others as prescribed by laws and administrative rules } \\
\text { and regulations. (7) others as prescribed by laws and } \\
\text { administrative rules and regulations. }\end{array}$ & $\begin{array}{l}\text { Article } 8 \text { of the } \\
\text { Law of } \\
\text { Administrative } \\
\text { Penalty } 1996 \\
\text { (PRC). }\end{array}$ \\
\hline & & $\begin{array}{l}\text { An administrative organ, before deciding on an } \\
\text { administrative penalty that involves ordering for } \\
\text { suspension of production or business, rescission of } \\
\text { business permit or license or imposition of a } \\
\text { comparatively large amount of fine, shall notify the } \\
\text { party that he or she has the right to request a } \\
\text { hearing.... }\end{array}$ & $\begin{array}{l}\text { Article } 42 \text { (1) of } \\
\text { the Law of } \\
\text { Administrative } \\
\text { Penalty } 1996 \\
\text { (PRC). }\end{array}$ \\
\hline 6 & $\begin{array}{l}\text { Administrative } \\
\text { license }\end{array}$ & $\begin{array}{l}\text { Article } 7 \text { Citizens, legal persons or other organizations } \\
\text { shall enjoy the right of making statement and defence in } \\
\text { respect of the implementation of administrative license } \\
\text { by administrative authority and have the right to apply } \\
\text { for administrative review or bring administrative action } \\
\text { according to law. If their lawful rights and interests are } \\
\text { damaged due to the illegal implement of administrative } \\
\text { license by administrative authority, they shall have the } \\
\text { right to claim compensation according to law. }\end{array}$ & $\begin{array}{l}\text { Article } 7 \text { of the } \\
\text { Law on } \\
\text { Administrative } \\
\text { License } 2003 \\
\text { (PRC) }\end{array}$ \\
\hline
\end{tabular}




\section{Appendix 3 Admission Criteria of Chinese Emigration Intermediary Agencies}

Overseas study intermediary agencies

Overseas study intermediary agencies shall not be set up unless the following conditions are satisfied.

(1) It shall be an education institution or education service institution offering service for Chinese citizens with status of legal person;

(2) Its legal representative shall be a Chinese citizen with domestic registered permanent residence;

(3) It shall have staff who are familiar with laws, regulations and policies of this country and other relevant countries on self-funded overseas study intermediary agencies, and possess an educational background of at least junior college. At least 5 personnel with qualifications in foreign languages, law, finance, or secretarial skills must be employed;

(4) It shall have established stable relations with overseas education institutions, and have directly signed valid cooperative agreements with them;

(5) It shall have reserve funds of at least C $¥ 500,000$ (US\$60,386). ${ }^{1}$

Exit and entry intermediary agencies for private purposes

Emigration intermediary agencies for private purpose shall comply with following conditions.

(1) It shall comply with conditions for the establishment of an enterprise with status of legal person;

(2) Its legal representative shall be a Chinese citizen with domestic registered permanent residence and full civil capacity, comply with the relevant provisions on registration and administration of enterprise's legal representatives, have not been subject to criminal punishment for the crime of impairing control of the border (or boundary with a region);

(3) It shall have at least 5 staffs who are familiar with laws, regulations and policies of this country and other relevant countries on entry and exit. The main staff shall possess educational background of junior college or above, and have not been subject to criminal punishment for the crime of impairing control of the border (or the boundary with a region). Personnel in foreign languages, law, and finance with professional qualifications must be employed;

(4) It shall have established regulations and systems that guarantee the normal operation of agency service, and

(5) It shall have established relations with overseas entry and exit service agencies, and have directly signed valid cooperative agreements with them. ${ }^{2}$

(6) It shall have reserve funds of at least reserve funds of C $¥ 500,000$ (US\$60,386). ${ }^{3}$

Overseas employment intermediary agencies

An overseas employment intermediary agency shall fulfil the following conditions:

\footnotetext{
${ }^{1}$ Article 3 of the Rules on the Control of Intermediary Agencies for Self-funded Overseas Study 1999 (PRC), promulgated by the Ministry of Education, the Ministry of Public Security and State Administration of Industry and Commerce on 17 June 1999 and effective at the same day; and Article 2-5 of the Detailed Rules for the Implementation of Rules on the Control of Intermediary Agencies for Self-funded Overseas Study 1999 (PRC), promulgated by the Ministry of Education, the Ministry of Public Security and State Administration of Industry and Commerce on 24 August 1999 and effective at the same day.

${ }^{2}$ Article 6 of the Measures on the Administration of Exit and Entry Intermediary Agencies for Private Affairs 2001 (PRC), jointly promulgated by MPS and State Administration of Industry and Commerce on 17 July 2001 and effective 17 July 2002.

${ }^{3}$ Article 25 of the Measures on the Administration of Exit and Entry Intermediary Agencies for Private Affairs 2001 (PRC), jointly promulgated by the MPS and State Administration of Industry and Commerce on 17 July 2001 and effective 17 July 2002.
} 
(1) It shall meet requirements for the establishment of an incorporated enterprise;

(2) It shall have full-time staff with professional qualifications in law, foreign language, and accounting; and sound working systems for the regulation of staff;

(3) It shall have a reserve fund at least C $¥ 500,000$ (US $\$ 60,386) .{ }^{4}$

Foreign labour and co-operation company

Foreign labour and co-operation companies must comply with Article 7 of the Provisional Measures on the Administration of Foreign Labour and Cooperation 1993 (PRC), which requires that the applicant be State-owned large industrial enterprise, and have made a significant contribution to foreign labour and cooperation. A foreign labour cooperation company needs reserve C $¥ 1$ million (US\$ 120,000) for sending general labourers, and C $¥ 200,000$ (US\$ 240000 ) for sending special kinds of labours. ${ }^{5}$

\section{International travel agencies}

International travel agencies shall not be set up unless the following conditions are satisfied:

(1) There is a sufficient fixed business premises;

(2) It has necessary business facilities;

(3) It has employed at least 4 managers who have been trained and issued qualification certificates by Chinese National Tourism Administration (CNTA), and one certified accountant;

(4) The registered capital and quality-guarantee deposit are not less than $C ¥ 1.5$ million (US\$181,159) and C $¥ 1$ million (US\$120,773). The minimum registered capital required for the Sino-foreign equity joint venture agencies is C $¥ 4$ million (US\$ 483,092). ${ }^{6}$

\section{Overseas training at government expense intermediary agencies}

To establish an overseas training intermediary agency or foreign labour and cooperation company, applicants need to meet the similarly strict conditions, especially with respect to the nature and ownership of the applicants. Overseas training agencies must comply with Article 4 of the Provisional Rules on the Recognition of Overseas Training Qualification of Dispatching Groups and Personals to Other Countries for Training of the Institutions and the Mass Departments 1993 (PRC), which requires that the applicant be an institution, and had been operating as an overseas training agency for at least 3 years.

Sino-foreign joint venture for skilled personnel intermediary agencies

An Operation License of Skilled Personnel Intermediary agency for Sino-foreign jointventure skilled personnel intermediary agencies will be issued provided that:

(1) The Chinese and foreign parties must have independently operated as skilled personnel agencies for at least three years and be of good reputation.

(2) There is a sound management structure and proficient human resources management specialists, including at least 5 professionals with junior college qualifications and skilled personnel agencies service certificates;

\footnotetext{
${ }^{4}$ Article 5 Clause 1 (1) (2) (3) of the Regulations on the Administration for Overseas Employment Intermediary Agencies (Amendment) 2002 (PRC), jointly promulgated by the MLSS, MPS and SAIC on 14 May 2002.

${ }^{5}$ Article 6 Clause 2 of Provisional Measures of the Reserve Funds of Foreign Labour Cooperation 2003 (PRC) (Duiwai Laowu Hezuo Beiyongjing Zaixing Banfa), promulgated by MOC on 21 August 2003.

${ }^{6}$ Article 6, 7, 8 and 27 of the Regulations on the Administrative of Travel Agencies (Amendment) 2001 (PRC) amended pursuant to Travel Agencies Administrative Measures 1996 (PRC), promulgated by the State Council on 11 December 2001 and effective on 1 January 2002; and Article 9, 10, 13 of the Detailed Rules of the Implementation of Regulations on the Administration of Travel Agencies 2003 (PRC) (Lvxingshe Guanli Tiaoli Shishi Xize), promulgated by the CNTA on 10 June 2003.
} 
(3) There is a fixed business venue, sufficient capital and office facilities; There is registered capital of not less than US\$300,000; The share of foreign party is not lower than $25 \%$, and the share of Chinese party is not lower than $51 \%$;

(4) The business has sound articles of association, management system, operational rules and a clearly defined business scope;

(5) The business is entitled to independent civil rights and capable of assuming civil liabilities. ${ }^{7}$

\section{Reason for overly strict admission criteria}

The overly strict admission criteria can be accounted for on the basis of standardising and rectifying the emigration intermediary agencies service market. In 2002, Premier Zhu, Rongji reported "the qualifications of all kinds of market entities need to be carefully examined to properly control market access. $" 8$ The control of market access was regarded as a way of achieving this objective.

\section{Impacts of overly strict admission criteria}

On balance, strict admission criteria, especially in relation to the requirement of minimum reserve funds and staff qualifications, have played a positive role in controlling market access. However, the disadvantages are also obvious.

\footnotetext{
${ }^{7}$ Article 6 Clause 1 (1) to (5) of the Provisional Regulations on the Administration of Sino-Foreign Joint Venture Personnel Intermediary Agency 2003 (PRC) (Zhongwai Hezi Rencai Zhongjie Jigou Guanli Zaixing Guiding), jointly promulgated by the MOP, MOC and SAIC on 4 September 2003.

${ }^{8}$ Zhu, Rongji, Premier of the State Council, Par 3 of Part V of "Report on the Work of the Government (16/03/2002) (English Version)", http://www.fmprc.gov.cn/eng/26804.html (19/07/2003).
} 


\section{Appendix 4}

\section{Functions of Public Security Departments in Relation to Exit and Entry Administration}

\begin{tabular}{|c|c|c|c|}
\hline No. & $\begin{array}{l}\text { Responsible } \\
\text { departments }\end{array}$ & Functions & Sources \\
\hline \multirow[t]{6}{*}{1} & \multirow[t]{6}{*}{$\begin{array}{l}\text { Ministry of } \\
\text { Public Security } \\
\text { (MPS) }\end{array}$} & $\begin{array}{l}\text { Examine and approve } \\
\text { applications for naturalization } \\
\text { and for renunciation or } \\
\text { restoration of Chinese } \\
\text { nationality lodged in China; } \\
\text { issue a certificate to any person } \\
\text { whose application has been } \\
\text { approved. }\end{array}$ & $\begin{array}{l}\text { Article } 17 \text { the Law of Nationality } 1980 \\
\text { (PRC). }\end{array}$ \\
\hline & & $\begin{array}{l}\text { Order alien who have committed } \\
\text { serious offences to leave China } \\
\text { within a time limit or make an } \\
\text { order of deportation. }\end{array}$ & $\begin{array}{l}\text { Article } 30 \text { of the Law on the Control of } \\
\text { Exit and Entry of Citizens } 1985 \text { (PRC). }\end{array}$ \\
\hline & & $\begin{array}{l}\text { Grant Operation Licenses for } \\
\text { Exit and Entry Intermediary } \\
\text { Agency for Private Affairs. }\end{array}$ & $\begin{array}{l}\text { Article 5(2) of the Measures on the } \\
\text { Administrative of Emigration } \\
\text { Intermediary Agency for Private Affairs } \\
2001 \text { (PRC). }\end{array}$ \\
\hline & & $\begin{array}{l}\text { Record License of Overseas } \\
\text { Study Intermediary Agency with } \\
\text { MOE. }\end{array}$ & $\begin{array}{l}\text { Article } 4 \text { the Rules on the Control of } \\
\text { Intermediary Agency for Self-funded } \\
\text { Overseas Study } 1999 \text { (PRC). }\end{array}$ \\
\hline & & $\begin{array}{l}\text { Examine and approve the } \\
\text { applications for permanent } \\
\text { residence of aliens in China. }\end{array}$ & $\begin{array}{l}\text { Article } 5 \text { of the Regulations on } \\
\text { Examination and Approval of } \\
\text { Permanent Residence of Aliens in China } \\
2004 \text { (PRC). }\end{array}$ \\
\hline & & $\begin{array}{l}\text { Change the visa decisions made } \\
\text { by its authorized departments if } \\
\text { necessary. }\end{array}$ & $\begin{array}{l}\text { Articles } 26 \text { (2) of the Law on the } \\
\text { Control of Exit and Entry of Aliens } 1985 \\
(\mathrm{PRC}) .\end{array}$ \\
\hline \multirow[t]{2}{*}{2} & \multirow{2}{*}{$\begin{array}{l}\text { the MPS and its } \\
\text { authorized local } \\
\text { public } \\
\text { security } \\
\text { departments }\end{array}$} & $\begin{array}{l}\text { Handle applications for refugee } \\
\text { status lodged in China. }\end{array}$ & $\begin{array}{l}\text { Articles } 15 \text { and } 25 \text { of the Law on the } \\
\text { Control of Exit and Entry of Aliens } 1985 \\
\text { (PRC). }\end{array}$ \\
\hline & & $\begin{array}{l}\text { Issue or cancel private passports, } \\
\text { or declare such passports invalid. }\end{array}$ & $\begin{array}{l}\text { Articles 12(1) and } 13 \text { of the Law on the } \\
\text { Control of Exit and Entry of Citizens } \\
1985 \text { (PRC). }\end{array}$ \\
\hline 3 & $\begin{array}{l}\text { Agency in the } \\
\text { HKSAR or } \\
\text { MSAR of the } \\
\text { BEEA under the } \\
\text { MPS }\end{array}$ & $\begin{array}{l}\text { Handle applications of Taiwan } \\
\text { Chinese for travel documents } \\
\text { who want to travel to inland } \\
\text { China via HKSAR or MSAR. }\end{array}$ & $\begin{array}{l}\text { Article 13(2) the Measures on the } \\
\text { Control over Chinese Citizens } \\
\text { Travelling to or from the Region of } \\
\text { Taiwan } 1992 \text { (PRC). }\end{array}$ \\
\hline 4 & $\begin{array}{l}\text { Agency of the } \\
\text { BEEA under the }\end{array}$ & $\begin{array}{l}\text { Handle applications from } \\
\text { Taiwan Chinese for travel }\end{array}$ & $\begin{array}{l}\text { Article 13(1) the Measures on the } \\
\text { Control over Chinese Citizens }\end{array}$ \\
\hline
\end{tabular}




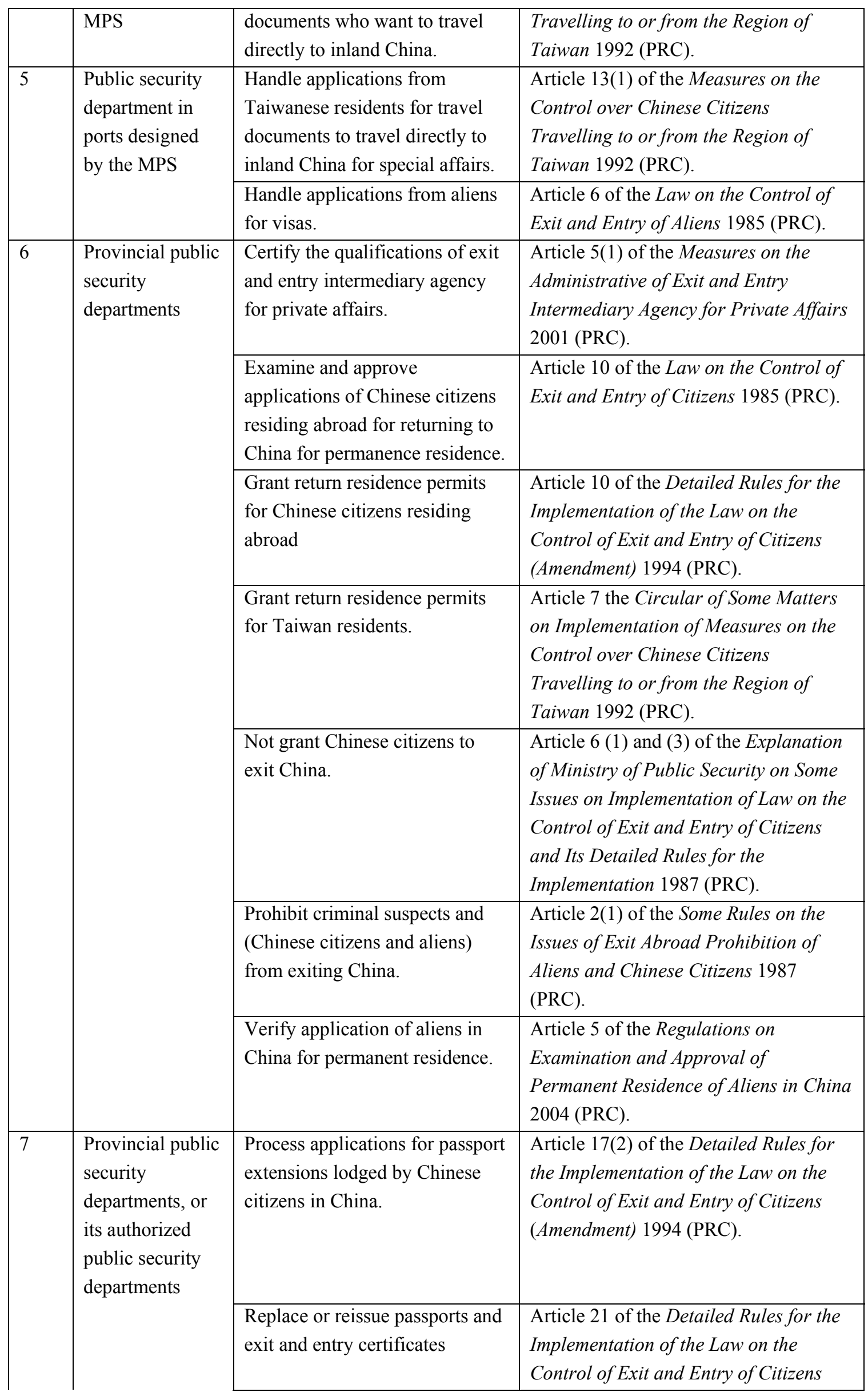




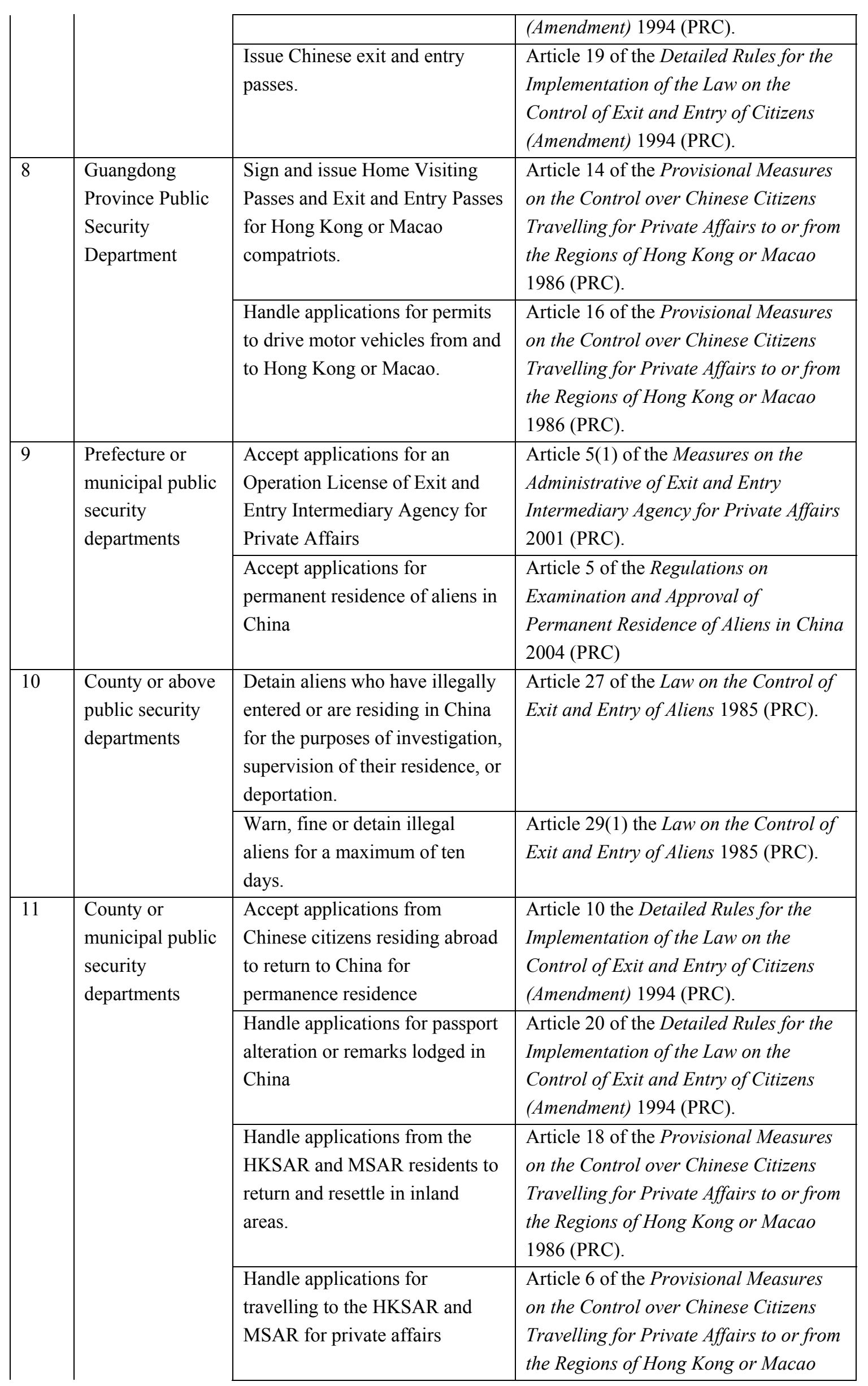




\begin{tabular}{|c|c|c|c|}
\hline & & & 1986 (PRC). \\
\hline & & $\begin{array}{l}\text { Handle applications for } \\
\text { travelling to Taiwan for private } \\
\text { affairs }\end{array}$ & $\begin{array}{l}\text { Article } 6 \text { of the Measures on the } \\
\text { Control over Chinese Citizens } \\
\text { Travelling to or from the Region of } \\
\text { Taiwan } 1992 \text { (PRC). }\end{array}$ \\
\hline & & $\begin{array}{l}\text { Accept applications for Chinese } \\
\text { nationality lodged in China }\end{array}$ & $\begin{array}{l}\text { Article } 15 \text { of the Law of Nationality } \\
1980 \text { (PRC). }\end{array}$ \\
\hline \multirow[t]{3}{*}{12} & \multirow[t]{3}{*}{$\begin{array}{l}\text { Police station or } \\
\text { Residence } \\
\text { Registration } \\
\text { Office in which } \\
\text { they are } \\
\text { registered }\end{array}$} & $\begin{array}{l}\text { Temporary residence registration } \\
\text { of Chinese citizens who are } \\
\text { permanent residents of a foreign } \\
\text { country and who have returned } \\
\text { to China for a short time }\end{array}$ & $\begin{array}{l}\text { Article } 13 \text { of the Detailed Rules for the } \\
\text { Implementation of the Law on the } \\
\text { Control of Exit and Entry of Citizens } \\
\text { (Amendment) } 1994 \text { (PRC). }\end{array}$ \\
\hline & & $\begin{array}{l}\text { Deregistration of the applicants' } \\
\text { household registration before } \\
\text { leaving the country to reside } \\
\text { permanently in a foreign country }\end{array}$ & $\begin{array}{l}\text { Article } 13 \text { of the Detailed Rules for the } \\
\text { Implementation of the Law on the } \\
\text { Control of Exit and Entry of Citizens } \\
\text { (Amendment) } 1994 \text { (PRC). }\end{array}$ \\
\hline & & $\begin{array}{l}\text { Handle the registration of } \\
\text { temporary residents in the } \\
\text { HKSAR or MSAR }\end{array}$ & $\begin{array}{l}\text { Article } 17 \text { of the Provisional Measures } \\
\text { on the Control over Chinese Citizens } \\
\text { Travelling for Private Affairs to or from } \\
\text { the Regions of Hong Kong or Macao } \\
1986 \text { (PRC). }\end{array}$ \\
\hline 13 & $\begin{array}{l}\text { Police station or } \\
\text { Residence } \\
\text { Registration } \\
\text { Office of the } \\
\text { applicants' } \\
\text { original } \\
\text { residence }\end{array}$ & $\begin{array}{l}\text { Residential deregistration for a } \\
\text { short-term absence from the } \\
\text { country and, upon return to } \\
\text { China, resumption of applicants' } \\
\text { regular household registration }\end{array}$ & $\begin{array}{l}\text { Article } 7 \text { of the Detailed Rules for the } \\
\text { Implementation of the Law on the } \\
\text { Control of Exit and Entry of Citizens } \\
\text { (Amendment) } 1994 \text { (PRC). }\end{array}$ \\
\hline \multirow[t]{3}{*}{14} & \multirow[t]{3}{*}{$\begin{array}{l}\text { A public security } \\
\text { department }\end{array}$} & $\begin{array}{l}\text { Give a warning to any person } \\
\text { who, in violation of the } \\
\text { provisions of Law on the Control } \\
\text { of Exit and Entry of Citizens } \\
1985 \text { (PRC), leaves or enters the } \\
\text { country illegally, forges or alters } \\
\text { an exit and entry certificate, uses } \\
\text { another person's certificate as } \\
\text { one's own or transfers one's } \\
\text { certificate or placed them in } \\
\text { detention for not more than } 10 \\
\text { days. }\end{array}$ & $\begin{array}{l}\text { Article } 14 \text { of the Law on the Control of } \\
\text { Exit and Entry of Citizens } 1985 \text { (PRC). }\end{array}$ \\
\hline & & $\begin{array}{l}\text { Sign and issue travel documents } \\
\text { for travel to Taiwan. }\end{array}$ & $\begin{array}{l}\text { Article } 10 \text { of the Measures on the } \\
\text { Control over Chinese Citizens } \\
\text { Travelling to or from the Region of } \\
\text { Taiwan } 1992 \text { (PRC). }\end{array}$ \\
\hline & & $\begin{array}{l}\text { Examine and approve } \\
\text { applications of serving police to } \\
\text { exit. }\end{array}$ & $\begin{array}{l}\text { Article 2(1) of the Explanation of } \\
\text { Ministry of Public Security on Some } \\
\text { Issues on Implementation of Law on the }\end{array}$ \\
\hline
\end{tabular}




\begin{tabular}{|c|c|c|c|}
\hline & & & $\begin{array}{l}\text { Control of Exit and Entry of Citizens } \\
\text { and Its Detailed Rules for the } \\
\text { Implementation } 1987 \text { (PRC). }\end{array}$ \\
\hline 15 & $\begin{array}{l}\text { Public security } \\
\text { departments - } \\
\text { either the } \\
\text { original issuing } \\
\text { department or } \\
\text { department in } \\
\text { which they are } \\
\text { registered }\end{array}$ & $\begin{array}{l}\text { Process applications of Chinese } \\
\text { citizens residing in China for } \\
\text { passport extension. }\end{array}$ & $\begin{array}{l}\text { Article 17(2) of the Detailed Rules for } \\
\text { the Implementation of the Law on the } \\
\text { Control of Exit and Entry of Citizens } \\
\text { (Amendment) } 1994 \text { (PRC). }\end{array}$ \\
\hline \multirow[t]{2}{*}{16} & \multirow[t]{2}{*}{$\begin{array}{l}\text { Public security } \\
\text { departments - } \\
\text { either the } \\
\text { original issuing } \\
\text { department or } \\
\text { higher } \\
\text { department }\end{array}$} & $\begin{array}{l}\text { Revoke or declare invalid } \\
\text { passports and other exit and } \\
\text { entry certificates. }\end{array}$ & $\begin{array}{l}\text { Article } 22 \text { of the Detailed Rules for the } \\
\text { Implementation of the Law on the } \\
\text { Control of Exit and Entry of Citizens } \\
\text { (Amendment) } 1994 \text { (PRC). }\end{array}$ \\
\hline & & $\begin{array}{l}\text { Revoke Home-Visiting Passes } \\
\text { and Exit and Entry Passes for } \\
\text { Hong Kong or Macao } \\
\text { Compatriots. }\end{array}$ & $\begin{array}{l}\text { Article } 25 \text { of the Provisional Measures } \\
\text { on the Control over Chinese Citizens } \\
\text { Travelling for Private Affairs to or from } \\
\text { the Regions of Hong Kong or Macao } \\
1986 \text { (PRC). }\end{array}$ \\
\hline 17 & $\begin{array}{l}\text { Local public } \\
\text { security } \\
\text { departments }\end{array}$ & $\begin{array}{l}\text { Residential registration for } \\
\text { Chinese citizens who are } \\
\text { permanent residents of a foreign } \\
\text { country and have returned to } \\
\text { China for permanent residence } \\
\text { or employment. }\end{array}$ & $\begin{array}{l}\text { Article } 12 \text { of the Detailed Rules for the } \\
\text { Implementation of the Law on the } \\
\text { Control of Exit and Entry of Citizens } \\
\text { (Amendment) } 1994 \text { (PRC). }\end{array}$ \\
\hline \multirow[t]{2}{*}{18} & \multirow[t]{2}{*}{$\begin{array}{l}\text { Higher level } \\
\text { public security } \\
\text { departments }\end{array}$} & $\begin{array}{l}\text { Make the final appellate decision } \\
\text { in relation to detention of } \\
\text { citizens by a public security } \\
\text { department }\end{array}$ & $\begin{array}{l}\text { Article } 15 \text { of the Law on the Control of } \\
\text { Exit and Entry of Citizens } 1985 \text { (PRC). }\end{array}$ \\
\hline & & $\begin{array}{l}\text { Make the final appellate decision } \\
\text { in relation to a fine or detention } \\
\text { of aliens by a public security } \\
\text { department }\end{array}$ & $\begin{array}{l}\text { Article 29(2) of the Law on the Control } \\
\text { of Exit and Entry of Citizens } 1985 \\
\text { (PRC). }\end{array}$ \\
\hline
\end{tabular}




\section{Appendix 5}

\section{Functions of Foreign Affairs Departments in Relation to Exit and Entry Administration}

\begin{tabular}{|c|c|c|c|}
\hline No. & $\begin{array}{l}\text { Responsible } \\
\text { departments }\end{array}$ & Functions & Sources \\
\hline 1 & $\begin{array}{l}\text { Ministry of Foreign } \\
\text { Affairs }\end{array}$ & $\begin{array}{l}\text { Change the visa decisions } \\
\text { made by its authorized } \\
\text { departments if necessary. }\end{array}$ & $\begin{array}{l}\text { Articles } 26 \text { (2) of the Law on the } \\
\text { Control of Exit and Entry of Aliens } \\
1985 \text { (PRC). }\end{array}$ \\
\hline 2 & $\begin{array}{l}\text { MFA and authorized } \\
\text { local foreign affairs } \\
\text { departments in China }\end{array}$ & $\begin{array}{l}\text { Issue, cancel, revoke and } \\
\text { retain public affairs } \\
\text { passports, or declare such } \\
\text { passport invalid. }\end{array}$ & $\begin{array}{l}\text { Articles 12(1) and } 13 \text { of the Law on } \\
\text { the Control of Exit and Entry of } \\
\text { Citizens } 1985 \text { (PRC); } \\
\text { Article } 16 \text { of the Detailed Rules for } \\
\text { the Implementation of the Law on the } \\
\text { Control of Exit and Entry of Citizens } \\
\text { (Amendment) } 1994 \text { (PRC). }\end{array}$ \\
\hline 3 & $\begin{array}{l}\text { Chinese diplomatic } \\
\text { missions and consular } \\
\text { offices }\end{array}$ & $\begin{array}{l}\text { Accept applications for } \\
\text { Chinese nationality lodged } \\
\text { abroad. }\end{array}$ & $\begin{array}{l}\text { Article } 15 \text { the Law of Nationality } \\
1980 \text { (PRC). }\end{array}$ \\
\hline \multirow[t]{6}{*}{4} & \multirow[t]{6}{*}{$\begin{array}{l}\text { Chinese diplomatic } \\
\text { missions, consular } \\
\text { offices or other } \\
\text { agencies located abroad } \\
\text { authorized by MFA }\end{array}$} & $\begin{array}{l}\text { Issue, cancel, revoke, retain } \\
\text { and extend passports and } \\
\text { travel documents, or declare } \\
\text { such documents invalid. }\end{array}$ & $\begin{array}{l}\text { Article 12(2) of the Law on the } \\
\text { Control of Exit and Entry of Citizens } \\
1985 \text { (PRC); } \\
\text { Article } 16 \text { and 17(2) of the Detailed } \\
\text { Rules for the Implementation of the } \\
\text { Law on the Control of Exit and Entry } \\
\text { of Citizens (Amendment) } 1994 \text { (PRC) }\end{array}$ \\
\hline & & $\begin{array}{l}\text { Examine and approve } \\
\text { applications lodged abroad } \\
\text { from Chinese citizens } \\
\text { residing abroad for } \\
\text { returning to China for } \\
\text { permanence residence. }\end{array}$ & $\begin{array}{l}\text { Article } 10 \text { of the Law on the Control } \\
\text { of Exit and Entry of Citizens } 1985 \\
\text { (PRC). }\end{array}$ \\
\hline & & $\begin{array}{l}\text { Issue Chinese travel } \\
\text { permits. }\end{array}$ & $\begin{array}{l}\text { Article } 18 \text { of the Detailed Rules for } \\
\text { the Implementation of the Law on the } \\
\text { Control of Exit and Entry of Citizens } \\
\text { (Amendment) } 1994 \text { (PRC). }\end{array}$ \\
\hline & & $\begin{array}{l}\text { Handle applications lodged } \\
\text { abroad for passport } \\
\text { alterations or remarks. }\end{array}$ & $\begin{array}{l}\text { Article } 20 \text { of the Detailed Rules for } \\
\text { the Implementation of the Law on the } \\
\text { Control of Exit and Entry of Citizens } \\
\text { (Amendment) } 1994 \text { (PRC). }\end{array}$ \\
\hline & & $\begin{array}{l}\text { Replace or reissue passports } \\
\text { or the exit and entry } \\
\text { certificates. }\end{array}$ & $\begin{array}{l}\text { Article } 21 \text { of the Detailed Rules for } \\
\text { the Implementation of the Law on the } \\
\text { Control of Exit and Entry of Citizens } \\
\text { (Amendment) } 1994 \text { (PRC). }\end{array}$ \\
\hline & & Handle applications of & Article 13(3) of the Measures on the \\
\hline
\end{tabular}




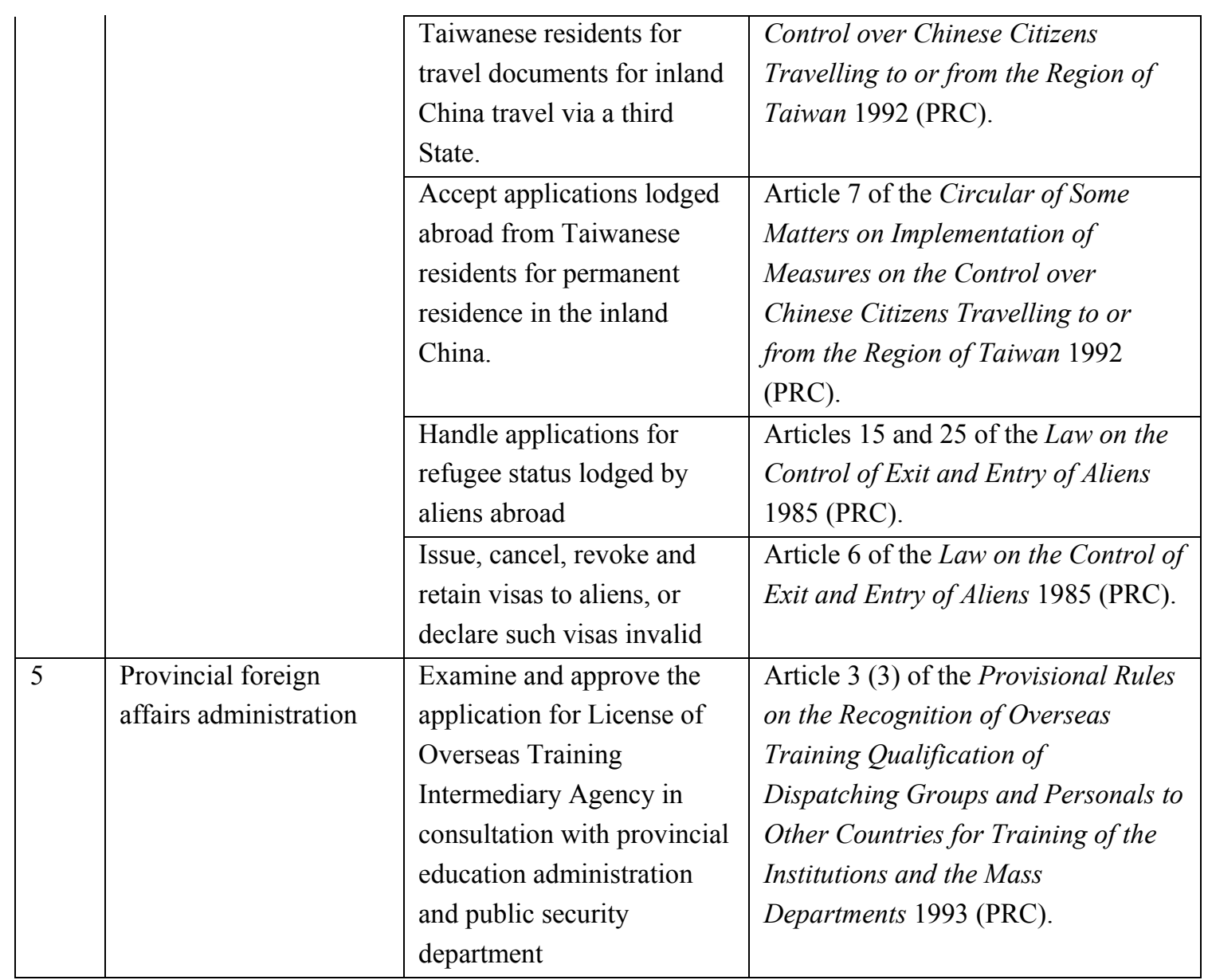




\section{Appendix 6 Functions of Border Security Check and Administration}

\begin{tabular}{|c|c|c|c|}
\hline No. & $\begin{array}{l}\text { Responsible } \\
\text { departments }\end{array}$ & Functions & Sources \\
\hline 1 & $\begin{array}{l}\text { Bureau of Border } \\
\text { Security Check and } \\
\text { Administration under } \\
\text { the MPS }\end{array}$ & $\begin{array}{l}\text { Administer exit and entry } \\
\text { border inspection }\end{array}$ & $\begin{array}{l}\text { Article } 2 \text { of the Regulations of Exit and } \\
\text { Entry Border Inspection } 1995 \text { (PRC). }\end{array}$ \\
\hline \multirow[t]{5}{*}{2} & \multirow[t]{5}{*}{$\begin{array}{l}\text { Border inspection } \\
\text { stations }\end{array}$} & $\begin{array}{l}\text { Take necessary measures to } \\
\text { limit the area of the } \\
\text { activities of aliens who are } \\
\text { denied entry, and are } \\
\text { ordered them to leave China } \\
\text { on the next available means } \\
\text { of transportation. }\end{array}$ & $\begin{array}{l}\text { Article } 15 \text { of the Detailed Rules for the } \\
\text { Implementation of the Law on the } \\
\text { Control of Exit and Entry of Aliens } \\
\text { (Amendment) } 1994 \text { (PRC). }\end{array}$ \\
\hline & & $\begin{array}{l}\text { Exclusive authority to } \\
\text { impose penalties for any } \\
\text { violation of the Regulation } \\
\text { of Inspection of Exit and } \\
\text { Entry Borders Inspection } \\
1995 \text { (PRC). }\end{array}$ & $\begin{array}{l}\text { Article } 31 \text { of the Regulations of Exit and } \\
\text { Entry Border Inspection } 1995 \text { (PRC). }\end{array}$ \\
\hline & & $\begin{array}{l}\text { Refuse Chinese citizens and } \\
\text { aliens entry into or } \\
\text { departure from the country. }\end{array}$ & $\begin{array}{l}\text { Article } 8 \text { of the Regulations of Exit and } \\
\text { Entry Border Inspection } 1995 \text { (PRC); } \\
\text { Article } 15 \text { of the Detailed Rules for the } \\
\text { Implementation of the Law on the } \\
\text { Control of Exit and Entry of Citizens } \\
\text { (Amendment) } 1994 \text { (PRC); Article } 12 \text { of } \\
\text { the Detailed Rules for the } \\
\text { Implementation of the Law on the } \\
\text { Control of Exit and Entry of Aliens } \\
\text { (Amendment) } 1994 \text { (PRC). }\end{array}$ \\
\hline & & $\begin{array}{l}\text { Carry out border inspection } \\
\text { on persons leaving or } \\
\text { entering the country and } \\
\text { their luggage and other } \\
\text { personal belongings; }\end{array}$ & $\begin{array}{l}\text { Article } 14 \text { of the Detailed Rules for the } \\
\text { Implementation of the Law on the } \\
\text { Control of Exit and Entry of Citizens } \\
\text { (Amendment) } 1994 \text { (PRC); Article } 10 \text { of } \\
\text { the Detailed Rules for the } \\
\text { Implementation of the Law on the } \\
\text { Control of Exit and Entry of Aliens } \\
\text { (Amendment) } 1994 \text { (PRC). }\end{array}$ \\
\hline & & $\begin{array}{l}\text { Supervise transportation } \\
\text { leaving or entering the } \\
\text { country; } \\
\text { Guard restricted areas in } \\
\text { ports and terrestrial borders. }\end{array}$ & $\begin{array}{l}\text { Article } 4 \text { of the Regulations of } \\
\text { Inspection of Exit and Entry Borders } \\
1995 \text { (PRC). }\end{array}$ \\
\hline
\end{tabular}




\section{Appendix 7 Functions of Hong Kong and Macao Affairs Offices, Taiwan Affairs Offices and Overseas Chinese Affairs Offices in Relation to Exit and Entry Administration}

\begin{tabular}{|c|c|c|c|}
\hline No. & $\begin{array}{l}\text { Responsible } \\
\text { departments }\end{array}$ & Functions & Sources \\
\hline 1 & $\begin{array}{l}\text { State Council Hong } \\
\text { Kong and Macao } \\
\text { Affairs Office }\end{array}$ & $\begin{array}{l}\text { Provisionally examine and } \\
\text { approve applications of } \\
\text { inland residents for } \\
\text { travelling to Hong Kong } \\
\text { and Macao for public affairs }\end{array}$ & $\begin{array}{l}\text { Article } 4 \text { of the Measures of } \\
\text { Examination and Approval of Sending } \\
\text { Individuals to be Employed in Hong } \\
\text { Kong and Macao for a Long Term } 1991 \\
\text { (PRC). }\end{array}$ \\
\hline 2 & $\begin{array}{l}\text { State Council Taiwan } \\
\text { Affairs Office }\end{array}$ & $\begin{array}{l}\text { Provisionally examine and } \\
\text { approve applications of } \\
\text { inland residents for } \\
\text { travelling to Taiwan for } \\
\text { public affairs }\end{array}$ & $\begin{array}{l}\text { Article } 1 \text { the Circular of Some Matters } \\
\text { on Implementation of Measures on the } \\
\text { Control over Chinese Citizens } \\
\text { Travelling to or from the Region of } \\
\text { Taiwan } 1992 \text { (PRC). }\end{array}$ \\
\hline 3 & $\begin{array}{l}\text { Provincial Taiwan } \\
\text { Affairs Offices or } \\
\text { United Front Work } \\
\text { Departments }\end{array}$ & $\begin{array}{l}\text { Provisionally examine and } \\
\text { approve applications lodged } \\
\text { in China by Taiwanese } \\
\text { residents to enter China for } \\
\text { permanent residence. }\end{array}$ & $\begin{array}{l}\text { Article } 7 \text { the Circular of Some Matters } \\
\text { on Implementation of Measures on the } \\
\text { Control over Chinese Citizens } \\
\text { Travelling to or from the Region of } \\
\text { Taiwan } 1992 \text { (PRC). }\end{array}$ \\
\hline \multirow[t]{2}{*}{4} & \multirow[t]{2}{*}{$\begin{array}{l}\text { Provincial Overseas } \\
\text { Chinese Affairs Offices }\end{array}$} & $\begin{array}{l}\text { Examine and approve } \\
\text { applications of the HKSAR } \\
\text { and MSAR Chinese for } \\
\text { returning and settling in } \\
\text { inland China in consultation } \\
\text { with other departments }\end{array}$ & $\begin{array}{l}\text { Article } 7 \text { of the Explanation of Some } \\
\text { Matters on Implementation of } \\
\text { Provisional Measures on the Control } \\
\text { over Chinese Citizens Travelling for } \\
\text { Private Affairs to or from the Regions } \\
\text { of Hong Kong or Macao } 1987 \text { (PRC). }\end{array}$ \\
\hline & & $\begin{array}{l}\text { Examine and approve } \\
\text { applications from overseas } \\
\text { Chinese for returning and } \\
\text { resettling in China in } \\
\text { consultation with provincial } \\
\text { public security departments }\end{array}$ & $\begin{array}{l}\text { Article } 5 \text { of the Explanation of Ministry } \\
\text { of Public Security on Some Issues on } \\
\text { Implementation of Law on the Control } \\
\text { of Exit and Entry of Citizens and Its } \\
\text { Detailed Rules for the Implementation } \\
1987 \text { (PRC). }\end{array}$ \\
\hline
\end{tabular}




\section{Appendix 8 Functions of Departments Responsible for Emigration Intermediary Agencies}

\begin{tabular}{|c|c|c|c|}
\hline $\begin{array}{l}\text { No } \\
\text {. }\end{array}$ & $\begin{array}{l}\text { Responsible } \\
\text { departments }\end{array}$ & Functions & Sources \\
\hline 1 & $\begin{array}{l}\text { Chinese National } \\
\text { Tourism } \\
\text { Administration }\end{array}$ & $\begin{array}{l}\text { Supervision and } \\
\text { administration of } \\
\text { international travel } \\
\text { agency }\end{array}$ & $\begin{array}{l}\text { Article } 4 \text { of the Regulations on the } \\
\text { Administrative of Travel Agencies } \\
\text { (Amendment) } 2001 \text { (PRC); } \\
\text { Article } 6 \text { of the Detailed Rules of the } \\
\text { Implementation of Regulations on the } \\
\text { Administrative of Travel Agencies } 2003 \\
\text { (PRC). }\end{array}$ \\
\hline 2 & $\begin{array}{l}\text { Ministry of } \\
\text { Commerce (prior } \\
\text { MFTEC) }\end{array}$ & $\begin{array}{l}\text { Examine and approve } \\
\text { applications to engage in } \\
\text { foreign labour and } \\
\text { cooperation }\end{array}$ & $\begin{array}{l}\text { Article } 8 \text { of the Provisional Measures on the } \\
\text { Administrative of Foreign Labour and } \\
\text { Cooperation } 1993 \text { (PRC). }\end{array}$ \\
\hline 3 & $\begin{array}{l}\text { Ministry of } \\
\text { Education }\end{array}$ & $\begin{array}{l}\text { Recognize the operation } \\
\text { qualification of self- } \\
\text { funded overseas study } \\
\text { intermediary agency } \\
\text { service } \\
\text { in consultation with the } \\
\text { MPS }\end{array}$ & $\begin{array}{l}\text { Article } 4 \text { the Rules on the Control of } \\
\text { Intermediary Agencies for Self-funded } \\
\text { Overseas Study } 1999 \text { (PRC). }\end{array}$ \\
\hline 4 & $\begin{array}{l}\text { Ministry of Labour } \\
\text { and Social Security }\end{array}$ & $\begin{array}{l}\text { Recognize the } \\
\text { qualification of overseas } \\
\text { employment intermediary } \\
\text { agency. }\end{array}$ & $\begin{array}{l}\text { Article } 6 \text { of the Regulations on the } \\
\text { Administrative for Overseas Employment } \\
\text { Intermediary Agencies (Amendment) } 2002 \\
\text { (PRC). }\end{array}$ \\
\hline 5 & Ministry of Personnel & $\begin{array}{l}\text { Record Operation License } \\
\text { of Skilled Personnel } \\
\text { Intermediary agency. }\end{array}$ & $\begin{array}{l}\text { Article } 8 \text { of the Provisional Regulations on } \\
\text { the Administrative of Sino-Foreign Joint } \\
\text { Venture Personnel Intermediary Agencies } \\
2003 \text { (PRC). }\end{array}$ \\
\hline 6 & $\begin{array}{l}\text { Provincial commerce } \\
\text { administrations }\end{array}$ & $\begin{array}{l}\text { Manage reserve funds of } \\
\text { foreign labour and } \\
\text { cooperation company. }\end{array}$ & $\begin{array}{l}\text { Article } 4 \text { of the Provisional Measures of the } \\
\text { Reserve Funds of Foreign Labour } \\
\text { Cooperation } 2001 \text { (PRC). }\end{array}$ \\
\hline 7 & $\begin{array}{l}\text { Provincial education } \\
\text { administrations }\end{array}$ & $\begin{array}{l}\text { Accept applications for } \\
\text { the Recognition } \\
\text { Certificate of Operation } \\
\text { Qualification of Self- } \\
\text { funded Overseas Study } \\
\text { Intermediary Agency } \\
\text { Service. }\end{array}$ & $\begin{array}{l}\text { Article } 4 \text { the Rules on the Control of } \\
\text { Intermediary Agencies for Self-funded } \\
\text { Overseas Study } 1999 \text { (PRC). }\end{array}$ \\
\hline 8 & $\begin{array}{l}\text { Provincial labour and } \\
\text { social security } \\
\text { administrations }\end{array}$ & $\begin{array}{l}\text { Provisionally examine } \\
\text { and approve the } \\
\text { applications for the } \\
\text { License of Overseas }\end{array}$ & $\begin{array}{l}\text { Article } 6 \text { of the Regulations on the } \\
\text { Administrative for Overseas Employment } \\
\text { Intermediary Agencies (Amendment) } 2002 \\
\text { (PRC). }\end{array}$ \\
\hline
\end{tabular}




\begin{tabular}{|l|l|l|l|}
\hline & & $\begin{array}{l}\text { Employment Intermediary } \\
\text { Agency, after being } \\
\text { approved by the Public } \\
\text { Security Department }\end{array}$ & \\
\hline 9 & $\begin{array}{l}\text { Provincial personnel } \\
\text { administrations }\end{array}$ & $\begin{array}{l}\text { Examine and approve } \\
\text { applications for the } \\
\text { Operation License of } \\
\text { Skilled Personnel } \\
\text { Intermediary agency. }\end{array}$ & $\begin{array}{l}\text { Article 8 of the Provisional Regulations on } \\
\text { the Administrative of Sino-Foreign Joint } \\
\text { Venture Personnel Intermediary Agencies } \\
2003 \text { (PRC). }\end{array}$ \\
\hline 10 & $\begin{array}{l}\text { State Administration } \\
\text { of Foreign Experts } \\
\text { Affairs }\end{array}$ & $\begin{array}{l}\text { Examine, approve and } \\
\text { grant the License of } \\
\text { Overseas Training } \\
\text { Intermediary agency } \\
\text { (National level) }\end{array}$ & $\begin{array}{l}\text { Article 5(1)(a) of the Provisional Rules on the } \\
\text { Recognition of Overseas Training } \\
\text { Qualification of Dispatching Groups and } \\
\text { Personals to Other Countries for Training of } \\
\text { the Institutions and the Mass Departments } \\
\text { 1993 (PRC). }\end{array}$ \\
\hline
\end{tabular}




\section{Appendix 9 Functions of Other Responsible Governmental Departments in Relation to Exit and Entry Administration}

\begin{tabular}{|c|c|c|c|}
\hline No. & $\begin{array}{l}\text { Responsible } \\
\text { departments }\end{array}$ & Functions & Sources \\
\hline 1 & $\begin{array}{l}\text { Bureau of Harbour } \\
\text { Superintendence or } \\
\text { its authorized harbour } \\
\text { superintendent } \\
\text { departments }\end{array}$ & $\begin{array}{l}\text { Issue, cancel, revoke and } \\
\text { retain seafarer's passport or } \\
\text { declare such passports invalid }\end{array}$ & $\begin{array}{l}\text { Articles 12(1) and } 13 \text { of the Law on the } \\
\text { Control of Exit and Entry of Citizens } \\
1985 \text { (PRC); } \\
\text { Article } 16 \text { of the Detailed Rules for the } \\
\text { Implementation of the Law on the } \\
\text { Control of Exit and Entry of Citizens } \\
\text { (Amendment) } 1994 \text { (PRC). }\end{array}$ \\
\hline 2 & $\begin{array}{l}\text { Labour and personnel } \\
\text { departments }\end{array}$ & $\begin{array}{l}\text { Accept applications of } \\
\text { Chinese citizens who are } \\
\text { permanent residents of foreign } \\
\text { countries who want to return } \\
\text { to China for employment. }\end{array}$ & $\begin{array}{l}\text { Article } 11 \text { of the Detailed Rules for the } \\
\text { Implementation of the Law on the } \\
\text { Control of Exit and Entry of Citizens } \\
\text { (Amendment) } 1994 \text { (PRC). }\end{array}$ \\
\hline 3 & $\begin{array}{l}\text { Ministry of State } \\
\text { Security }\end{array}$ & $\begin{array}{l}\text { Undertake measures to } \\
\text { prevent certain Chinese } \\
\text { citizens and foreign citizens } \\
\text { from exiting China }\end{array}$ & $\begin{array}{l}\text { Article 2(3) of the Some Rules on the } \\
\text { Issues of Exit Abroad Prohibition of } \\
\text { Aliens and Chinese Citizens } 1987 \\
\text { (PRC). }\end{array}$ \\
\hline 4 & $\begin{array}{l}\text { Provincial security } \\
\text { departments }\end{array}$ & $\begin{array}{l}\text { Prohibit criminal suspects } \\
\text { from exiting China }\end{array}$ & $\begin{array}{l}\text { Article 2(1) of the Some Rules on the } \\
\text { Issues of Exit Abroad Prohibition of } \\
\text { Aliens and Chinese Citizens } 1987 \\
\text { (PRC). }\end{array}$ \\
\hline 5 & $\begin{array}{l}\text { State Council Bureau } \\
\text { for Religious Affairs }\end{array}$ & $\begin{array}{l}\text { Provisionally examine and } \\
\text { approve application for } \\
\text { exiting China for pilgrimage }\end{array}$ & $\begin{array}{l}\text { Article 1(1) of the Circular of State } \\
\text { Council Bureau for Religion Affairs, } \\
\text { State Administrative of Foreign } \\
\text { Exchange, Ministry of Foreign Affairs, } \\
\text { Ministry of Public Security, Bank of } \\
\text { China, Customs General Administrative } \\
\text { and Civil Aviation Administrative of } \\
\text { China on Several Rules of Self-support } \\
\text { Pilgrimage Administrative } \\
\text { (Amendment) } 1995 \text { (PRC). }\end{array}$ \\
\hline 6. & $\begin{array}{l}\text { State Administrative } \\
\text { of Foreign Exchange }\end{array}$ & $\begin{array}{l}\text { Control the purchase, } \\
\text { remittance and carrying of } \\
\text { foreign exchange for the } \\
\text { purposes of exiting China for } \\
\text { private and public affairs }\end{array}$ & $\begin{array}{l}\text { Article } 6 \text { of the Provisional Measures } \\
\text { on the Administrative of Foreign } \\
\text { Exchange of Individual Residents in } \\
\text { Inland } 1998 \text { (PRC); } \\
\text { Article } 1 \text { of the Circular of State } \\
\text { Administrative of Foreign Exchange on } \\
\text { Some Matters of Improving the } \\
\text { Administrative of Selling Foreign } \\
\text { Exchange for Public Affairs } 2002 \\
\text { (PRC). }\end{array}$ \\
\hline
\end{tabular}




\section{Appendix 10 Functions of Other Departments and Units in Relation to Exit and Entry Administration}

\begin{tabular}{|c|c|c|c|}
\hline No & $\begin{array}{l}\text { Responsible } \\
\text { departments }\end{array}$ & Functions & Sources \\
\hline 1 & $\begin{array}{l}\text { Chinese Communist } \\
\text { Party }\end{array}$ & $\begin{array}{l}\text { Provisionally examine } \\
\text { and approve applications } \\
\text { for exiting China from } \\
\text { Party members. }\end{array}$ & $\begin{array}{l}\text { Article 2(1) of the Explanation of Ministry } \\
\text { of Public Security on Some Issues on } \\
\text { Implementation of Law on the Control of } \\
\text { Exit and Entry of Citizens and Its Detailed } \\
\text { Rules for the Implementation } 1987 \text { (PRC). }\end{array}$ \\
\hline 2 & $\begin{array}{l}\text { Responsible } \\
\text { departments under } \\
\text { the Central } \\
\text { Committee of CPC, } \\
\text { the State Council and } \\
\text { provincial } \\
\text { administration. }\end{array}$ & $\begin{array}{l}\text { Provisionally examine } \\
\text { and approve the } \\
\text { application of various } \\
\text { professional groups for } \\
\text { exiting China }\end{array}$ & $\begin{array}{l}\text { Article 2(2) of the Explanation of Ministry } \\
\text { of Public Security on Some Issues on } \\
\text { Implementation of Law on the Control of } \\
\text { Exit and Entry of Citizens and Its Detailed } \\
\text { Rules for the Implementation } 1987 \text { (PRC). }\end{array}$ \\
\hline 3 & $\begin{array}{l}\text { Deputy provincial } \\
\text { level or provincial } \\
\text { level governments }\end{array}$ & $\begin{array}{l}\text { Examine, approve and } \\
\text { grant a License of } \\
\text { Overseas Training } \\
\text { Intermediary Agency } \\
\text { (Regional level) }\end{array}$ & $\begin{array}{l}\text { Article } 5 \text { (1) (a) of the Provisional Rules on } \\
\text { Qualifications Recognizance of Government } \\
\text { Sponsored Institutions and Mass } \\
\text { Organizations of Sending Group, Team and } \\
\text { Individuals Abroad for Training } 1993 \\
\text { (PRC). }\end{array}$ \\
\hline 4 & $\begin{array}{l}\text { Guangdong province } \\
\text { government }\end{array}$ & $\begin{array}{l}\text { Provisionally examine } \\
\text { and approve applications } \\
\text { from Guangdong } \\
\text { residents for travelling to } \\
\text { Hong Kong or Macao for } \\
\text { public affairs }\end{array}$ & $\begin{array}{l}\text { Article } 4 \text { of the Measures of Examination } \\
\text { and Approval of Sending Individuals to be } \\
\text { Employed in Hong Kong and Macao for the } \\
\text { Long Term } 1991 \text { (PRC). }\end{array}$ \\
\hline 5 & $\begin{array}{l}\text { Military unit with } \\
\text { which applicant } \\
\text { originally served. }\end{array}$ & $\begin{array}{l}\text { Provisionally examine } \\
\text { and approve applications } \\
\text { for exiting China of } \\
\text { demobilized military } \\
\text { personnel who know } \\
\text { confidential information } \\
\text { and were discharged from } \\
\text { active military services } \\
\text { within } 5 \text { years }\end{array}$ & $\begin{array}{l}\text { Article 2(3) of the Explanation of Ministry } \\
\text { of Public Security on Some Issues on } \\
\text { Implementation of Law on the Control of } \\
\text { Exit and Entry of Citizens and Its Detailed } \\
\text { Rules for the Implementation } 1987 \text { (PRC). }\end{array}$ \\
\hline 6 & $\begin{array}{l}\text { Peoples' Liberation } \\
\text { Army }\end{array}$ & $\begin{array}{l}\text { Provisionally examine } \\
\text { and approve applications } \\
\text { for exiting China from } \\
\text { serving Army personnel }\end{array}$ & $\begin{array}{l}\text { Article 2(1) of the Explanation of Ministry } \\
\text { of Public Security on Some Issues on } \\
\text { Implementation of Law on the Control of } \\
\text { Exit and Entry of Citizens and Its Detailed } \\
\text { Rules for the Implementation } 1987 \text { (PRC). }\end{array}$ \\
\hline 7 & $\begin{array}{l}\text { Courts and the } \\
\text { Procuratorates }\end{array}$ & Withhold passports & $\begin{array}{l}\text { Article } 16 \text { of the Detailed Rules for the } \\
\text { Implementation of the Law on the Control }\end{array}$ \\
\hline
\end{tabular}




\begin{tabular}{|c|c|c|c|}
\hline & & & $\begin{array}{l}\text { of Exit and Entry of Citizens (Amendment) } \\
1994 \text { (PRC). }\end{array}$ \\
\hline 8 & $\begin{array}{l}\text { The host or } \\
\text { employing } \\
\text { organization }\end{array}$ & $\begin{array}{l}\text { Accept applications of } \\
\text { Chinese citizens who are } \\
\text { permanent residents of a } \\
\text { foreign country from } \\
\text { returning to China for } \\
\text { employment }\end{array}$ & $\begin{array}{l}\text { Article } 11 \text { of the Detailed Rules for the } \\
\text { Implementation of the Law on the Control } \\
\text { of Exit and Entry of Citizens (Amendment) } \\
1994 \text { (PRC). }\end{array}$ \\
\hline 9 & $\begin{array}{l}\text { Working units } \\
\text { sending Chinese } \\
\text { citizens abroad for } \\
\text { public affairs }\end{array}$ & $\begin{array}{l}\text { Power to apply to the } \\
\text { MPS or the local foreign } \\
\text { affairs department for an } \\
\text { exit certificate on behalf } \\
\text { of their employees }\end{array}$ & $\begin{array}{l}\text { Article } 6 \text { of the Law on the Control of Exit } \\
\text { and Entry of Citizens } 1985 \text { (PRC). }\end{array}$ \\
\hline 10 & $\begin{array}{l}\text { United Front Work } \\
\text { Department under the } \\
\text { Central Committee of } \\
\text { the PRC. }\end{array}$ & $\begin{array}{l}\text { Provisionally examine } \\
\text { and approve applications } \\
\text { lodged abroad by } \\
\text { Taiwanese residents for } \\
\text { travelling to China for } \\
\text { permanent residence }\end{array}$ & $\begin{array}{l}\text { Article } 7 \text { the Circular of Some Matters on } \\
\text { Implementation of Measures on the Control } \\
\text { over Chinese Citizens Travelling to or from } \\
\text { the Region of Taiwan } 1992 \text { (PRC). }\end{array}$ \\
\hline
\end{tabular}




\section{Appendix 11}

\section{Merits Review of Administrative Decisions Concerned the Imposition of Penalties}

\begin{tabular}{|c|c|c|c|c|}
\hline No. & $\begin{array}{l}\text { Administrati } \\
\text { ve penalties }\end{array}$ & $\begin{array}{l}\text { Sources of } \\
\text { administrative penalties }\end{array}$ & Remedies & Sources of remedies \\
\hline \multirow[t]{4}{*}{1} & \multirow[t]{4}{*}{ Detention } & $\begin{array}{l}\text { Article 29(1) of the Law } \\
\text { on the Control of Exit } \\
\text { and Entry of Aliens } 1985 \\
\text { (PRC). } \\
\text { Article 40, } 41,42 \text { and } 48 \\
\text { of the Detailed Rules of } \\
\text { the Implementation o } \\
\text { Law on the Control of } \\
\text { Exit and Entry of Aliens } \\
\text { (Amendment) } \\
\text { (PRC). }\end{array}$ & $\begin{array}{l}\text { An affected individual } \\
\text { may, within } 15 \text { days of } \\
\text { receiving the notification, } \\
\text { appeal to the public } \\
\text { security department at the } \\
\text { next highest level, which } \\
\text { shall make the final } \\
\text { decision; or institute } \\
\text { proceedings in the local } \\
\text { Court. }\end{array}$ & $\begin{array}{l}\text { Article 29(2) of the } \\
\text { Law on the Control } \\
\text { of Exit and Entry of } \\
\text { Aliens } 1985 \text { (PRC). } \\
\text { Article } 50 \text { of the } \\
\text { Detailed Rules of the } \\
\text { Implementation of } \\
\text { Law on the Control } \\
\text { of Exit and Entry of } \\
\text { Aliens } 1985 \text { (PRC). }\end{array}$ \\
\hline & & $\begin{array}{l}\text { Article } 14 \text { the Law on the } \\
\text { Control of Exit and Entry } \\
\text { of Citizens } 1985 \text { (PRC). } \\
\text { Article 23, } 24 \text { and } 25 \text { of } \\
\text { the Detailed Rules of the } \\
\text { Implementation o Law on } \\
\text { the Control of Exit and } \\
\text { Entry of Citizens } \\
\text { (Amendment) } 1994 \\
\text { (PRC). }\end{array}$ & As above & $\begin{array}{l}\text { Article } 15 \text { of the Law } \\
\text { on the Control of Exit } \\
\text { and Entry of Citizens } \\
1985 \text { (PRC). }\end{array}$ \\
\hline & & $\begin{array}{l}\text { Articles } 33 \text { to } 36 \text { of the } \\
\text { Measures on the Control } \\
\text { over Chinese Citizens } \\
\text { Travelling to or from the } \\
\text { Region of Taiwan } 1992 \\
\text { (PRC). }\end{array}$ & As above & $\begin{array}{l}\text { Article } 39 \text { of the } \\
\text { Measures on the } \\
\text { Control over Chinese } \\
\text { Citizens Travelling to } \\
\text { or from the Region of } \\
\text { Taiwan } 1992 \text { (PRC). }\end{array}$ \\
\hline & & $\begin{array}{l}\text { Articles } 26,27 \text { and } 28 \text { of } \\
\text { the Provisional Measures } \\
\text { on the Control over } \\
\text { Chineser Citizens } \\
\text { Travelling for Private } \\
\text { Affairs to or from the } \\
\text { Regions of Hong Kong or } \\
\text { Macao } 1986(P R C) \text {. }\end{array}$ & N/A & $\mathrm{N} / \mathrm{A}$ \\
\hline 2 & Fine & $\begin{array}{l}\text { Article } 29 \text { of the Law on } \\
\text { the Control of Exit and } \\
\text { Entry of Aliens } 1985 \\
\text { (PRC). } \\
\text { Article } 40 \text { to } 47 \text { of the }\end{array}$ & $\begin{array}{l}\text { An affected individual may } \\
\text { within } 15 \text { days of receiving } \\
\text { the notification, appeal to } \\
\text { the public security } \\
\text { department at the next }\end{array}$ & $\begin{array}{l}\text { Article 29(2) of the } \\
\text { Law on the Control } \\
\text { of Exit and Entry of } \\
\text { Aliens } 1985 \text { (PRC). } \\
\text { Article } 50 \text { of the }\end{array}$ \\
\hline
\end{tabular}




\begin{tabular}{|c|c|c|c|c|}
\hline & & $\begin{array}{l}\text { Detailed Rules of the } \\
\text { Implementation o Law on } \\
\text { the Control of Exit and } \\
\text { Entry of Aliens } \\
\text { (Amendment) } 1994 \\
\text { (PRC). }\end{array}$ & $\begin{array}{l}\text { highest level, which shall } \\
\text { make the final decision; or } \\
\text { institute proceedings in the } \\
\text { Local Court. }\end{array}$ & $\begin{array}{l}\text { Detailed Rules of the } \\
\text { Implementation of } \\
\text { Law on the Control } \\
\text { of Exit and Entry of } \\
\text { Aliens } 1985 \text { (PRC). }\end{array}$ \\
\hline & & $\begin{array}{l}\text { Articles } 33 \text { to } 38 \text { of the } \\
\text { Measures on the Control } \\
\text { over Chinese Citizens } \\
\text { Travelling to or from the } \\
\text { Region of Taiwan } 1992 \\
\text { (PRC). }\end{array}$ & As above & $\begin{array}{l}\text { Article } 39 \text { of the } \\
\text { Measures on the } \\
\text { Control over Chinese } \\
\text { Citizens Travelling to } \\
\text { or from the Region of } \\
\text { Taiwan } 1992 \text { (PRC). }\end{array}$ \\
\hline 3 & $\begin{array}{l}\text { Order to leave } \\
\text { the country } \\
\text { within a } \\
\text { specified } \\
\text { time, or } \\
\text { deportation. }\end{array}$ & $\begin{array}{l}\text { Article } 30 \text { of the Law on } \\
\text { the Control of Exit and } \\
\text { Entry of Aliens } 1985 \\
\text { (PRC). } \\
\text { Article 40,42, 43, 44, } 46 \\
\text { to } 47 \text { of the Detailed } \\
\text { Rules of the } \\
\text { Implementation o Law on } \\
\text { the Control of Exit and } \\
\text { Entry of Aliens } \\
\text { (Amendment) } 1994 \\
\text { (PRC). }\end{array}$ & N/A & $\mathrm{N} / \mathrm{A}$ \\
\hline & & $\begin{array}{l}\text { Article } 40 \text { of the } \\
\text { Measures on the Control } \\
\text { over Chinese Citizens } \\
\text { Travelling to or from the } \\
\text { Region of Taiwan } 1992 \\
\text { (PRC). }\end{array}$ & $\mathrm{N} / \mathrm{A}$ & $\mathrm{N} / \mathrm{A}$ \\
\hline 4 & $\begin{array}{l}\text { Shorten } \\
\text { period of } \\
\text { residence. }\end{array}$ & As above & As above & As above \\
\hline 5 & $\begin{array}{l}\text { Discipli- } \\
\text { nary warning }\end{array}$ & $\begin{array}{l}\text { Articles } 37 \text { and } 38 \text { the } \\
\text { Measures on the Control } \\
\text { over Chinese Citizens } \\
\text { Travelling to or from the } \\
\text { Region of Taiwan } 1992 \\
\text { (PRC). }\end{array}$ & $\begin{array}{l}\text { An affected individual } \\
\text { may, within } 15 \text { days of } \\
\text { receiving the notification, } \\
\text { appeal to the public } \\
\text { security department at the } \\
\text { next highest level, which } \\
\text { shall make the final } \\
\text { decision; or institute } \\
\text { proceedings in the local } \\
\text { Court. }\end{array}$ & $\begin{array}{l}\text { Article } 39 \text { of the } \\
\text { Measures on the } \\
\text { Control over Chinese } \\
\text { Citizens Travelling to } \\
\text { or from the Region of } \\
\text { Taiwan } 1992 \text { (PRC). }\end{array}$ \\
\hline & & $\begin{array}{l}\text { Article } 14 \text { the Law on the } \\
\text { Control of Exit and Entry } \\
\text { of Citizens } 1985 \text { (PRC). } \\
\text { Article } 23 \text { and } 25 \text { of the } \\
\text { Detailed Rules of the }\end{array}$ & $\mathrm{N} / \mathrm{A}$ & $\mathrm{N} / \mathrm{A}$ \\
\hline
\end{tabular}




\begin{tabular}{|c|c|c|c|c|}
\hline & & $\begin{array}{l}\text { Implementation o Law on } \\
\text { the Control of Exit and } \\
\text { Entry of Citizens } \\
\text { (Amendment) } \\
\text { (PRC). }\end{array}$ & & \\
\hline & & $\begin{array}{l}\text { Article } 29 \text { of the Law on } \\
\text { the Control of Exit and } \\
\text { Entry of Aliens } 1985 \\
\text { (PRC). } \\
\text { Article } 42,43,45 \text { and } 46 \\
\text { of the Detailed Rules of } \\
\text { the Implementation o } \\
\text { Law on the Control of } \\
\text { Exit and Entry of Aliens } \\
\text { (Amendment) } 1994 \\
\text { (PRC). }\end{array}$ & N/A & N/A \\
\hline & & $\begin{array}{l}\text { Articles } 26 \text { and } 28 \\
\text { Provisional Measures on } \\
\text { the Control over Chinese } \\
\text { Citizens Travelling for } \\
\text { Private Affairs to or from } \\
\text { the Regions of Hong } \\
\text { Kong or Macao } 1986 \\
\text { (PRC). }\end{array}$ & N/A & $\mathrm{N} / \mathrm{A}$ \\
\hline \multirow[t]{3}{*}{6} & \multirow[t]{3}{*}{$\begin{array}{l}\text { Confiscation } \\
\text { of forged } \\
\text { certificates }\end{array}$} & $\begin{array}{l}\text { Article } 23 \text { of the Detailed } \\
\text { the Rules for the } \\
\text { Implementation of Law } \\
\text { on the Control of Exit } \\
\text { and Entry of Citizens } \\
\text { (Amendment) } 1994 \\
\text { (PRC). }\end{array}$ & $\mathrm{N} / \mathrm{A}$ & $\mathrm{N} / \mathrm{A}$ \\
\hline & & $\begin{array}{l}\text { Article } 47 \text { of the Detailed } \\
\text { the Rules for the } \\
\text { Implementation of Law } \\
\text { on the Control of Exit } \\
\text { and Entry of Aliens } \\
\text { (Amendment) } 1994 \\
\text { (PRC). }\end{array}$ & $\mathrm{N} / \mathrm{A}$ & $\mathrm{N} / \mathrm{A}$ \\
\hline & & $\begin{array}{l}\text { Article } 26 \text { of the } \\
\text { Provisional Measures on } \\
\text { the Control over Chinese } \\
\text { Citizens Travelling for } \\
\text { Private Affairs to or from } \\
\text { the Regions of Hong } \\
\text { Kong or Macao } 1986 \\
\text { (PRC). }\end{array}$ & $\mathrm{N} / \mathrm{A}$ & N/A \\
\hline
\end{tabular}




\section{Appendix 12}

\section{Merits Review of Administrative Decisions Concerned the Processing of Applications for Exit and Entry}

\begin{tabular}{|c|c|c|c|c|}
\hline No. & $\begin{array}{l}\text { Administra- } \\
\text { tive decisions }\end{array}$ & Sources of administrative authority & Remedies & $\begin{array}{l}\text { Sources } \\
\text { remedies }\end{array}$ \\
\hline \multirow[t]{5}{*}{1} & \multirow{5}{*}{$\begin{array}{ll}\text { Refusal to } \\
\text { permit exit } \\
\text { China or } \\
\text { refusal to } \\
\text { issue } \\
\text { passport }\end{array}$} & $\begin{array}{l}\text { Article } 23 \text { of the Law on the Control of Exit } \\
\text { and Entry of Aliens } 1985 \text { (PRC). }\end{array}$ & $\mathrm{N} / \mathrm{A}$ & $\mathrm{N} / \mathrm{A}$ \\
\hline & & $\begin{array}{l}\text { Article } 8 \text { of the Law on the Control of Exit } \\
\text { and Entry of Citizens } 1985 \text { (PRC). }\end{array}$ & $\mathrm{N} / \mathrm{A}$ & $\mathrm{N} / \mathrm{A}$ \\
\hline & & $\begin{array}{l}\text { Article } 12 \text { the Measures on the Control over } \\
\text { Chinese Citizens Travelling to or from the } \\
\text { Region of Taiwan } 1992 \text { (PRC). }\end{array}$ & N/A & $\mathrm{N} / \mathrm{A}$ \\
\hline & & $\begin{array}{l}\text { Article } 13 \text { of the Provisional Measures on the } \\
\text { Control over Chinese Citizens Travelling for } \\
\text { Private Affairs to or from the Regions of Hong } \\
\text { Kong or Macao } 1986 \text { (PRC). }\end{array}$ & $\mathrm{N} / \mathrm{A}$ & $\mathrm{N} / \mathrm{A}$ \\
\hline & & $\begin{array}{l}\text { Article 6(1) of the Operational Norms of } \\
\text { Application, Examination and Approval of } \\
\text { Exiting Abroad and Passport For Private } \\
\text { Affairs of Citizens } 1996 \text { (PRC). }\end{array}$ & $\begin{array}{l}\text { Affected } \\
\text { individuals } \\
\text { have the } \\
\text { right to } \\
\text { query the } \\
\text { decision, } \\
\text { and the } \\
\text { relevant } \\
\text { department } \\
\text { must } \\
\text { respond. }\end{array}$ & $\begin{array}{l}\text { Article 6(2) of the } \\
\text { Operational } \\
\text { Norms } \\
\text { Application, } \\
\text { Examination and } \\
\text { Approval of } \\
\text { Exiting Abroad } \\
\text { and Passport For } \\
\text { Private Affairs of } \\
\text { Citizens } 1996 \\
\text { (PRC). }\end{array}$ \\
\hline 2 & $\begin{array}{l}\text { Failure to } \\
\text { determine an } \\
\text { application } \\
\text { within } \\
\text { prescribed } \\
\text { time }\end{array}$ & $\begin{array}{l}\text { Article 6(1) of the Operational Norms of } \\
\text { Application, Examination and Approval of } \\
\text { Exiting Abroad and Passport For Private } \\
\text { Affairs of Citizens } 1996 \text { (PRC). }\end{array}$ & As above & As above \\
\hline \multirow[t]{4}{*}{3} & \multirow{4}{*}{$\begin{array}{l}\text { Withhold } \\
\text { exiting } \\
\text { China }\end{array}$} & $\begin{array}{l}\text { Article } 24 \text { of the Law on the Control of Exit } \\
\text { and Entry of Aliens } 1985 \text { (PRC). }\end{array}$ & $\mathrm{N} / \mathrm{A}$ & $\mathrm{N} / \mathrm{A}$ \\
\hline & & $\begin{array}{l}\text { Article } 9 \text { the Law on the Control of Exit and } \\
\text { Entry of Citizens } 1985 \text { (PRC). }\end{array}$ & N/A & N/A \\
\hline & & $\begin{array}{l}\text { Article } 24 \text { the Measures on the Control over } \\
\text { Chinese Citizens Travelling to or from the } \\
\text { Region of Taiwan } 1992 \text { (PRC). }\end{array}$ & $\mathrm{N} / \mathrm{A}$ & $\mathrm{N} / \mathrm{A}$ \\
\hline & & $\begin{array}{l}\text { Article } 20 \text { of the Provisional Measures on the } \\
\text { Control over Chinese Citizens Travelling for } \\
\text { Private Affairs to or from the Regions of Hong } \\
\text { Kong or Macao } 1986 \text { (PRC). }\end{array}$ & N/A & N/A \\
\hline
\end{tabular}




\begin{tabular}{|c|c|c|c|c|}
\hline \multirow[t]{2}{*}{4} & \multirow{2}{*}{$\begin{array}{l}\text { Refusal to } \\
\text { permit exit to } \\
\text { the HKSAR, } \\
\text { MSAR or } \\
\text { Taiwan, or } \\
\text { refusal to } \\
\text { issue travel } \\
\text { destinations } \\
\text { documents for } \\
\text { those }\end{array}$} & $\begin{array}{l}\text { Articles 6, 7, } 10 \text { and } 12 \text { of the Measures on } \\
\text { the Control over Chinese Citizens Travelling } \\
\text { to or from the Region of Taiwan } 1992 \text { (PRC). }\end{array}$ & $\mathrm{N} / \mathrm{A}$ & $\mathrm{N} / \mathrm{A}$ \\
\hline & & $\begin{array}{l}\text { Articles } 11 \text { and } 13 \text { of the Provisional } \\
\text { Measures on the Control over Chinese } \\
\text { Citizens Travelling for Private Affairs to or } \\
\text { from the Regions of Hong Kong or Macao } \\
1986 \text { (PRC). }\end{array}$ & N/A & N/A \\
\hline \multirow[t]{3}{*}{5} & \multirow[t]{3}{*}{$\begin{array}{l}\text { Refusal to } \\
\text { permit } \\
\text { Chinese } \\
\text { nationals to } \\
\text { return for } \\
\text { permanent } \\
\text { residence }\end{array}$} & $\begin{array}{l}\text { Article } 10 \text { the Law on the Control of Exit and } \\
\text { Entry of Citizens } 1985 \text { (PRC). } \\
\text { Article } 10 \text { the Detailed Rules of the } \\
\text { Implementation o Law on the Control of Exit } \\
\text { and Entry of Citizens (Amendment) } 1994 \\
\text { (PRC). }\end{array}$ & N/A & N/A \\
\hline & & $\begin{array}{l}\text { Article } 20 \text { the Measures on the Control over } \\
\text { Chinese Citizens Travelling to or from the } \\
\text { Region of Taiwan } 1992 \text { (PRC). }\end{array}$ & N/A & N/A \\
\hline & & $\begin{array}{l}\text { Article } 18 \text { the Provisional Measures on the } \\
\text { Control over Chinese Citizens Travelling for } \\
\text { Private Affairs to or from the Regions of Hong } \\
\text { Kong or Macao } 1986 \text { (PRC). }\end{array}$ & N/A & N/A \\
\hline 6 & $\begin{array}{l}\text { Refusal to } \\
\text { permit } \\
\text { overseas } \\
\text { Chinese to } \\
\text { return for } \\
\text { employment }\end{array}$ & $\begin{array}{l}\text { Article } 11 \text { of the Detailed Rules for the } \\
\text { Implementation of Law on the Control of Exit } \\
\text { and Entry of Citizens (Amendment) } 1994 \\
\text { (PRC). }\end{array}$ & N/A & N/A \\
\hline \multirow[t]{3}{*}{7} & \multirow[t]{3}{*}{$\begin{array}{lr}\text { Refusal to } \\
\text { register a } \\
\text { permanent } \\
\text { household }\end{array}$} & $\begin{array}{l}\text { Article } 11 \text { of the Law on the Control of Exit } \\
\text { and Entry of Citizens } 1985 \text { (PRC). } \\
\text { Article } 12 \text { of the Detailed Rules for the } \\
\text { Implementation of Law on the Control of Exit } \\
\text { and Entry of Citizens (Amendment) } 1994 \\
\text { (PRC). }\end{array}$ & N/A & N/A \\
\hline & & $\begin{array}{l}\text { Article } 20 \text { the Measures on the Control over } \\
\text { Chinese Citizens Travelling to or from the } \\
\text { Region of Taiwan } 1992 \text { (PRC). }\end{array}$ & N/A & N/A \\
\hline & & $\begin{array}{l}\text { Article } 18 \text { the Provisional Measures on the } \\
\text { Control over Chinese Citizens Travelling for } \\
\text { Private Affairs to or from the Regions of Hong } \\
\text { Kong or Macao } 1986 \text { (PRC). }\end{array}$ & N/A & $\mathrm{N} / \mathrm{A}$ \\
\hline \multirow[t]{2}{*}{8} & \multirow{2}{*}{$\begin{array}{l}\text { Refusal to } \\
\text { extend the } \\
\text { term of a } \\
\text { passport or } \\
\text { other travel } \\
\text { documents }\end{array}$} & $\begin{array}{l}\text { Article } 17 \text { of the Detailed Rules for the } \\
\text { Implementation of Law on the Control of Exit } \\
\text { and Entry of Citizens (Amendment) } 1994 \\
\text { (PRC). }\end{array}$ & N/A & $\mathrm{N} / \mathrm{A}$ \\
\hline & & $\begin{array}{l}\text { Article } 22 \text { the Provisional Measures on the } \\
\text { Control over Chinese Citizens Travelling for }\end{array}$ & N/A & N/A \\
\hline
\end{tabular}




\begin{tabular}{|c|c|c|c|c|}
\hline & & $\begin{array}{l}\text { Private Affairs to or from the Regions of Hong } \\
\text { Kong or Macao } 1986 \text { (PRC). }\end{array}$ & & \\
\hline \multirow[t]{3}{*}{9} & \multirow{3}{*}{$\begin{array}{l}\text { Refusal to re- } \\
\text { issue/ } \\
\text { replace a } \\
\text { passport or } \\
\text { other travel } \\
\text { documents }\end{array}$} & $\begin{array}{l}\text { Article } 29 \text { the Measures on the Control over } \\
\text { Chinese Citizens Travelling to or from the } \\
\text { Region of Taiwan } 1992 \text { (PRC). }\end{array}$ & N/A & N/A \\
\hline & & $\begin{array}{l}\text { Article } 24 \text { the Provisional Measures on the } \\
\text { Control over Chinese Citizens Travelling for } \\
\text { Private Affairs to or from the Regions of Hong } \\
\text { Kong or Macao } 1986 \text { (PRC). }\end{array}$ & N/A & N/A \\
\hline & & $\begin{array}{l}\text { Article } 21 \text { of the Detailed Rules for the } \\
\text { Implementation of Law on the Control of Exit } \\
\text { and Entry of Citizens (Amendment) } 1994 \\
\text { (PRC). }\end{array}$ & N/A & N/A \\
\hline \multirow[t]{3}{*}{10} & \multirow[t]{3}{*}{$\begin{array}{l}\text { Revocation } \\
\text { /invalidation } \\
\text { of passports }\end{array}$} & $\begin{array}{l}\text { Articles } 16 \text { and } 22 \text { of the Detailed Rules for } \\
\text { the Implementation of Law on the Control of } \\
\text { Exit and Entry of Citizens (Amendment) } 1994 \\
\text { (PRC). }\end{array}$ & $\mathrm{N} / \mathrm{A}$ & N/A \\
\hline & & $\begin{array}{l}\text { Articles } 31 \text { and } 32 \text { the Measures on the } \\
\text { Control over Chinese Citizens Travelling to or } \\
\text { from the Region of Taiwan } 1992 \text { (PRC). }\end{array}$ & N/A & N/A \\
\hline & & $\begin{array}{l}\text { Article } 25 \text { the Provisional Measures on the } \\
\text { Control over Chinese Citizens Travelling for } \\
\text { Private Affairs to or from the Regions of Hong } \\
\text { Kong or Macao } 1986 \text { (PRC). }\end{array}$ & N/A & N/A \\
\hline
\end{tabular}




\section{Bibliography 1 Bibliography in Chinese}

1. "The Pros and Cons of Young Children Studying Abroad" (Zhaoning Liuxuesheng Xianxiang Taoshi) No. 6 (2001) of Chinese Scholars Abroad (Shengzhou Xueren), www.chisa.edu.cn (April 2003), page 166

2. Bao, Dazhang, The Explanation of Regulations and Proced.ures Governing Exit and Entry in Taiwan (Taiwan Diqu Chujing Rujing Faling Shouxu Xiangjie), Bao Da Zhang, Taibei, China, 1957

3. Bureau of Exit and Entry Administration, the Ministry of Public Security, The Collection of Laws and Regulations Governing Exit and Entry of the PRC (Zhonghua Renmin Gongheguo Churu Jing Guanli Fagui Huibian), the Publishing House of Qunzhong, Beijing, 1987

4. Bureau of Party, Government Foreign Affairs Carders under Department of Personal of Central Committee of Chinese Communist Party, The Collection of Popular Official Documents and Letters, Regulations and Laws Governing Examination and Administration of Exiting Abroad (Chuguojing Shenpi Ji Guanli Gongzuo Changyong Wenjian Fagui Xuanbian), the Publishing House of Dangjian Duwu, internal Publication (Neibu Faxing), Beijing, 1994

5. Cao, Dejin and Xu, Qun, The Reasons of Overstay of Overseas Students and Its Countermeasures (Chuguo Liuxue Renyuan Zhiwai Bugui De Yuanyin Ji Duice), No. 8 (3) (1998) of Journal of the Administration of Hospital of People's Liberation Army (Jiefangjun Yiyuan Guanli Zazhi), pages 256-258

6. Cao. Shuji, The History of Chinese Migration: the Period of the Qing Dynasty and the Public of China (Zhongguo Yimin Shi: Qing Minguo Shiqi), the Publishing House of Fujian Renmin, Fuzhou, China, 1997

7. Cen, Dejian, Research on Problems of Illegal Immigration (Feifa Yimin Xianxiang de Falv Sikao), the Thesis of LLM, The University of People, China, Beijing, 2002

8. Chen, Haoshen (ed.), The Collection of Historical Materials on Overseas Labour Exiting Abroad (Huagong Chuguo Siliao Hvbian), The Publishing House of China, Beijing, 1985

9. Chen, Tieyuan, Overseas Study without intermediary Agencies: the interview to Visa Officer of Foreign Countries in China (Piekai Zhongjie Qu Liuxue: Zhuhua Qianzheng Guan Fangtan), the Publishing House of Writer, Beijing, 2002

10. Chen, Yuetao, The Writing on the Documents of the Exit and Entry Administration of Public Security Organs (Gongan Churujing Guanli Wenshu Xiezuo), Series of the Applicable Writing of Public Security Organs (Gongan Yingyong Xiezuo Congshu), (interior Published within Public Security Organs) (Gongan Jiguan Neibu Faxing), the Publishing House of China University of People's Public Security, Beijing, 1999

11. Committee of Exit and Entry Administration under Chinese Association of Police, (ed.), The Collection of Papers on the Control of Exit and Entry (III) (Churujing Guanli Lunwenxuan (san)), (interior Published within Public Security Organs) (Gongan Jiguan Neibu Faxing), the Publishing House of Qunzhong, Beijing, 2001

12. Committee of Exit and Entry Administration under Chinese Association of Police, (ed.), The Collection of Papers on the Control of Exit and Entry (II), (Churujing Guanli Lunwenxuan (er)), (interior Published within Public Security Organs) (Gongan Jiguan Neibu Faxing), the Publishing House of Qunzhong, Beijing, 1999

13. Dai, Chaowu, Immigration Policy in the USA and Emigration in Asia (Meiguo Yimin Zhengce Yu Yazhou Yimin), the Publishing House of Zhongguo Social Science, Beijing, 1999

14. Department of Exit and Entry Administration, Beijing Public Security Bureau, the Kit of Eixt and Entry (Churujing Xuzhi), the Publishing House of Renshi, Beijing, 2000 
15. Department of Exit and Entry Administration, Jilin Public Security Bureau, (ed.), The Handbook of Exit and Entry Administration (Churu Jing Guanli Zhishi Shouce), the Publishing House of Jilin Renmin, Changchun, 1988

16. Department of Exit and Entry under Ministry of Public Security \& Department of Border Security Checking and Administration, Great Change Over Last 50 years: the Analysis of the Data of Exit and Entry of Individuals (Fenyun Bianhuan Wushi Nian: Cong Churujing Renyuan Tongji Shuju Kan Jianguo Yilai De jubian), No. 22 (1999) of People's Public Security (Renmin Gongan)

17. Department of Legal and Policy Research of the Ministry of Public Security, China, The Collection of Laws and Regulations regarding Public Security: 1950-1979 (Gongan Fagun Huibian:1950-1979), Qunzhong Publishing House, Beijing, 1980

18. Department of Politics under the Ministry of Public Security, Frontier Defence and Exit and Entry Administration, the Series of Basic Textbook of People's Police Operation: (Bianfang Yu Churu Jing Guanli, Renmin Jingcha Gongan Yewu Jichu Jiaochai), examined by Committee of Textbook Editing and Examination of the Ministry of Public Security, the Publishing House of Qunzhong, internal Publication in Public Security Organs (Gongan Jiguan Neibu Faxing), Beijing, 1999

19. Dictionary Department, institute of Linguistics, Chinese Academy of Social Sciences, The Contemporary Chinese Dictionary (Chinese-English edition) (Xiandai Hanyu Cidian), Foreign Language Teaching and Research Press, Beijing, 2002

20. Division of Human Resource, the Ministry of Agriculture, China, The Outline of Examination and Administration of Going Abroad (Chuguojing Renyuan Shencha Guanli Dagang), the Publishing House of Chinese Agriculture, internal Publication (Neibu Faxing), Beijing, 1999

21. Dong, Lihua and Ma, Yong, The Legal Guide of Studying Abroad at One's Own Expense (Zifei Chuguo Liuxue Falv Zhinan), Zhishi Publishing House, Beijing, 2000

22. Du, Chengming, On Migration Freedom (Lun Qianxi Ziyou Quan), Vol.54 No.4 July 2001 Wuhan University Journal (Social Sciences), pages 406-410

23. Du, Minmin, (ed.), The Returning of Overseas Chinese: the Series of Youth Patriotism Education (Qingnian Aiguo Zhuyi Jiaoyu Congshu: Wode Zhongguo Xin: Ji Zuwai He Guiguo Huaqiao), the Publishing House of Jilin Technology and Science, Changchun, China, 1985

24. Duan, Chenrong, The Study on Population Migration (Renkou Qianyi Yanjiu: Yuanli Yu Fangfa), Chongqing Publishing House, Chongqing, China, 1998

25. Duan, Kuang, (Translation), The Living and Legal Guide to Aliens in Japan (Waiguoren Zai Reben de Shenghuo Yu Falv Zhinan), the Publishing House of Shanghai Kexue Puji, Shanghai, 1992

26. Exit and Entry Administration under Jilin Province Public Security Department and Bureau of Border Security Check and Administration under Jilin Province Public Security Department, (ed.), The Kit of Exit, Entry and Frontier Defense (Shiyong Churu Jing Bianfang Zhishi Daquan), the Publishing House of Jilin Wenshi, Changchun, China, 1994

27. Fan, Qiangwei, Human Rights Battle between China and the USA/EU (Lun Woguo Yu Meigou de Renquan Douzheng), the Thesis of Doctor of Science Socialism, Beijing, 2001

28. Fu, Qing, The Guide to Chinese Citizen Exit and Entry (Zhongguo Gongmin Churu Jing Quanshu), The Publishing House of Qunzhong, Beijing, 2000

29. Hao, Jinmin, international Human Rights Law (Guoji Renquan Fa), the Publishing House of Shandong University, Jinan, China, 1993

30. Hao, Zaijing, The Migration, Exit and Entry of Hong Kong (Yingxiong Mowen Chuchu: Xianggang De Yimin Yu Churu Jing), the Publishing House of Renmin Wenxue, Beijing, 1997

31. Hong, Wanping, Dong, Lishan and Yu, Hang, The Guide to Go Abroad for Private Purpose (Yinsi Chujing Zhinan), the Publishing House of Jilin Renmin, Changchun, China, 1992 
32. Hornby, A. S., Oxford Advanced Learner's English-Chinese Dictionary (Niujin Gaoji Yinghan Shuangjie Cidian), $4^{\text {th }}$ edion, The Commercial Press and Oxford University Press, Hong Kong and Beijing, 1997

33. information Office of the State Council of The People's Republic of China, Human Rights in China, 1991, White Paper of Human Rights (English Versions), Beijing, November 1991

34. information Office of the State Council of The People's Republic of China, Human Rights in China, 2000, White Paper of Human Rights (English Versions), Beijing, 2000

35. Information Office of the State Council of The People's Republic of China, "Fifty Years of Progress in China's Human Rights (June 2000) (English Versions)", http://www.fmprc.gov.cn/eng/32282.html $(20 / 05 / 2003)$

36. Jiang, Zemin, the President of the People's Republic of China, "Build a Well-off Society in an AllRound Way and Create a New Situation in Building Socialism with Chinese Characteristics: Report page $16^{\text {th }}$ China Communist Party Congress (8/11/2002) (English Versions)", http://www.fmprc.gov.cn/eng/37815.html (19/07/2003)

37. Jin, Liangjun, (ed.), The Guide to Visa, Exit and Entry in the World (Shijie Geguo Qianzheng Yu Churu Jing Zhinan), the Publishing House of Chinese Gongshang Lianhe, Beijing, 1999

38. Journalist of the Journal of Human Rights, Correct Appliance of the Law and Impartial Trial under the Law: Strengthen the Safeguard of Human Rights in the Realm of Justice in a Down-to-earth Way: the Interview of the Comrade Xiao, Yang, the President of Supreme People's Court (Zunque Shiyong Falv Yifa Gongzheng Caipan Qieshi Jiaqiang Sifa Lingyu De Renquan Baozhang: Fang Zuigao Renming Fayuan Yuanzhang Shouxi Dafaguan Xiao Yang Tongzhi), No. 6 [2002] the Journal of Human Right, page 3-8

39. Lan, Bo, The Questions and Answers to Exit and Entry Administration in China, the Series of Popularizing Legal Knowledge in Minor Nationality Area (Minzu Diqu Puji Falv Zhishi Congshu: Woguo Churu Jing Guanli Wenda), the Publishing House of Minzu, Beijing, 1987

40. Legal System Working Committee, the National People's Congress Standing Committee, China, The Volume of Administration Law, Compilation of Laws, Regulations, Rules and Judicatory Explanation of the PRC (Zhonghua Renmin Gongheguo Falv Xingzhengfagui Guizhang Sifa Jiesi Feilei Huibian Xingzhengfajuan), the Publishing House of Beijing University, Beijing, 1998

41. Li, Changfu, The History of Chinese Colonization (Zhongguo Zhimin Shi), The Publishing House of Shangwu, Shanghai, 1937

42. Li, Changfu, The History of Overseas Chinese in South East Asia (Nanyang Huaqiao Shi), The Publishing House of Shangwu, Shanghai, 1937

43. Li, Debing, The History of Modern Chinese Emigration (Jindai Zhongguo Yimin Shiyao), the Publishing House of Harbing, Harbing, China, 1994

44. Li, Hengmei, (ed.), The Collection of the Papers Regarding Migration History (Yimin Shi Lunji), Qilu Shushe, Qilu Shushe, Jinan, China, 1998

45. Li, Qirong, Migrants and Modern USA (Yimin Yu Jindai Meiguo), the Publishing House of Chinese Huaqiao, Beijing, 1991

46. Li, Shaozhong, Research of Modern Chinese Human Rights Issues (Dangdai Zhongguo Renquan Wenti Yanjiu), the Thesis of Doctor of the History, Hunan Normal University, Changsha, China, 1999

47. Li, Wenhui, Review of the Control of the Exit and Entry: the Collection of Papers on the Control of Exit and Entry of Shanghai Public Security Organs (Churujing Guanli Zongheng: Shanghai Gongan Churujing Guanli Lunwenji), internal publication (Neibu Faxing), the Publishing House of Police education, Beijing, 1998

48. Liang, Maoxin, The Research on Immigration Policy in the USA (Meguo Yimin Zhengce Yanjiu), The Publishing House of Dongbei Normal University, Changchun, China, 1996 
49. Liu, Jixuan and Su, Shi, The History of Chinese Cololizaiton in South East Asia (Zhonghua Minzu Tuozhi Nanyang Shi), Shanghai Shudian, Shanghai, 1937, reprint in 1990

50. Liu, Shengping, Xia, Yong, (ed.), Human Rights and the World (Renquan Yu Shijie), the Publishing House of People's Courts, Beijing, 1996

51. Lu, Jing, The Study on the Freedom of Migration (Lun Qianxi Ziyou), the Thesis of LLM, The University of People, China, Beijing, 2002

52. Mao, Fengping, (ed.), The Explanation of the Law and Regulations Governing Exit and Entry and the Collections of Related Regulations (Chujing Rujing Falv Fagui Sijie Yu Xiangying Fagui Zhaibian), the Publishing House of Jilin Renmin, Changchun, China, 1994

53. Mao, Qixiong, The Encyclopedia of Overseas Chinese and Foreign Chinese: the Volume of Laws, Regulations and Policies (Huaqiao Huaren Baike Quanshu: Falv Tiaoli Zhengce Juan), the Publishing House of Overseas Chinese of China, Beijing, 2000

54. Meng, Peiyuan, "Relationship Between Man and Nature in Traditional Human Rights Concepts of China and West", No. 1 [2003] the Journal of Human Rights, http://www.humanrightschina.org/zt/03111201/200312003129103111.htm (26/02/2004)

55. Mo, Qibo and Zhu, Qiliang, the Handbook of Chinese Citizen's Going Abroad for Private Purpose (Zhongguo Gongmin Yinsi Chuguo Shouce), the Publishing House of Guangxi Renmin, Nanling, China, 1997

56. Mo, Qibo, (ed.), The Administration of Citizen's Exit and Entry (Gongmin Churu Jing Guanli), the Publishing House of Giuangxi Minzu, Nanling, China, 1997

57. Overseas Chinese Affairs Commission, the Republic of China, The Republic of China, Overseas Chinese Affairs Statistics, Taipei, Taiwan, 1994

58. Pan, Ling, The History of Chinese Migration (Yanhuang Zisun - Huaren Yimin Shi), The Publishing House of Sanlian Book Store, Shanghai Branch, Shanghai, 1993

59. Shen, Chen, 'Language and Culture: Two Goals of Foreign Language Teaching in China, Lessons from History and Perspectives for the future', Australia Review of Applied Linguistic 12 / 2, 1989, page 51.

60. Su, Huiyu and Li, Yiran, (ed.), The Guide to Exit and Entry for Private Purpose (Yisi Churu Jing Bidu), The Publishing House of Wenhui, Shanghai, 1998

61. Sun, Longji, The Deep Structure of Chinese Culture, The Publishing House of Guangxi Normal University, Guiling, China, 2004

62. the Ministry of Public Security of the the PRC, The Textbook Control of Country Board and Administration of Exit and Entry (Bianfang Yu Churujing Guanli), the Publishing House of the University of People's Public Security, Beijing, 1999

63. Wan, Zhenshan, (ed.), The General Updated Guide of the Exit and Entry of individuals (Zuixin Renyuan Churu Jing Quanshu), the Publishing House of Renshi, Beijing, 2002

64. Wang, Guoliang and Zhu, Lin, The Administration on Exit and Entry, one of Planning Textbooks of Higher education of People's Police (Renmin Jingcha Gaodeng Jiaoyu Guihua Jiaocha: Churujing Guanlixue), Interior Published within Public Security Organs (Gongan Jiguan Neibu Faxing), the Publishing House of China University of People's Public Security, Beijing, 2002

65. Wen, Xongfei, The History of Overseas Chinese in South East Asia (Nanyang Huaqiao Tongshi), the Publishing House of Shangwu, Shnaghai, 1943

66. Wong, Li, Chinese Migration Legislation and International Norms (Zhongguo Yiming Lifa Yu Guoji Guanli), Vol. 26 No.2 June 1996, Journal of Hangzhou University, pages 25-29

67. Wong, Li, International Immigration Law and the Practices (Guoji Yiminfa Lilun Yu Shijian), the Publishing House of Law, Beijing, China, 2001 
68. Xiang, Dang, The Guide to the Law of Exit and Entry in China and Foreign Countries, (Zhongwai Churujing Falv Zhinan), the Publishing House of China University of People's Public Security, Beijing, 1998

69. Xie, Xiuying, "The Economical Analysis on Overseas Study at Their Own Expense and the trend of Junior Age of the Age of Students" (Zifei Chuguo Liuxue Re Jiqi Dilinghua Qushi De Jingjixue Fengxi), in Vol. 16 No. 1 of Journal of Shanxi Youth Managerial Cadres Institution (Shanxi Qingnian Guanli Ganbu Xueyuan Xuebao), page 24-26.

70. Xu, Jiali, (ed.), The Guide to Going Abroad Consultation (Chuguo Zixun Daquan), the Publishing House of Kexue Puji, Beijing, 1992

71. Xu, Jongqi, The Comparative Study between China and South Korean regarding Aliens Exit and Entry and Legal Status (Waiguoren Churu Jing Jiqi Falv Diwei De Hanzhong Falv Falv Bijiao), the Thesis of LLM, The institute of Foreign Relationship, China, Beijing, 2001

72. Yan, Bei, The Migration of Chinese Population in the New Period (Xin Shiqi Zhongguo Renkou Qianyi), the Publishing House of Hunan Education, Changsha, 1999

73. Yang, Fajing, (ed.), The introduction to Exit Abroad (Chuguo Zhishi Gailan), the Publishing House of Science Popularization, Beijing, 1990

74. Yang, Guozhen, the China's Coastal Society and Emigration Overseas in Ming Dynasty and Qing Dynasty (Mingqing Zhongguo Yanhai Shehui Yu Haiwai Yimin), the Publishing House of Higher Education, Beijing, 1997

75. Yang, Yuguan, United Nations Human Rights Treaty Bodies and the Their Comments (Lianheguo Renquan Gongyue Jigou Yu Jingdian Yaoyi), the Publishing House of China University of People's Public Security, Beijing, 2004

76. Yang, Yuguan, Human Rights Law: Internatonal Convenant on Civil and Political Eights, the Publishing House of China University of People's Public Security, Beijing, 2003

77. Yi, Songgong, "Why the Student in Middles Schools and Higher Educational Institutions Would Like to Go Abroad (Dazhong Xuesheng Weihe Yao Chuguo)", in No. 6 of 1999 Society (Shehui), page 9-11

78. Yin, Xiaohu and Lin, Yan, The Change of the Chinese Legal Stipulations Regarding to the Freedom of Movement and the Thoughts on the Change (Wuoguo Falv Guanyu Qianxi Ziyou Guiding De Bianhua Jiqi Sikao), No. 6 [2001] The Journal of Jurisprudence, page 10-14

79. Yu, Huaying and Gong, Yu, The Legal Study on Exit, Entry and international Trade (Churu Jing Yu Guoji Jingmao Falv Wenti Yanjiu), the Publishing House of Xinan Normal University, Chongqing, China, 1997

80. Yu, Shutong and Wen, Jia (ed.), A New Chinese-English Law Dictionary (Xin Hanying Faxue Cidian), the Publishing House of Law, Beijing, 1998

81. Zeng, peiyan, Report on the Implementation of the 2001 Plan for National Economic and Social Development and on the Draft Plan for National Economic and Social Development (12/03/2002) (English Versions)

82. Zeng, Shaocong, Migration in South East Asia: Migration to Taiwan and Filliping by Sea in Ming Dynasty and Qing Dynasty, the Series of Sea and China (Dongyang Hanglu Yimin: Mingqing Haiyang Yimin Taiwan Yu Feilvbing De Bijiao Yanjiu, Haiyang Yu Zhongguo Congshu), the Publishing House of Jiangxi Gaoxiao, Nanchang, China, 1998

83. Zhang, Fan, (ed.), The Update Guide to the People Going Abroad (Zuixin Chuguo Renyuan Zhinan), the Publishing House of Zejiang Wenyi, Hangzhou, China, 1991

84. Zhang, Feng and Ye, Youshen, Exit and Entry Administration According to Laws and Crackdown of Illegal Migration (Shilun Yifa Guanli Churujing Xingwei Yu Daji Feifa Yimin Huodong), No. 2 (2003) of Journal of Fujian Public Security College (Fujian Gongan Gaodeng Zhuanke Xuexiao Xuebao) pages $36-39$, page 38 
85. Zhang, Xiuming, The Return of Overseas Students Since Reform and Opening-up and Their Place: the Analysis of the Questionnaire Survey of Returned Overseas Students (Gaige Kaifang Yilai Liuxuesheng De Huigui Ji Chujing: Genju Guiguo Liuxusheng Wenjuan DiaoCha De Fenxi), No.2 (1999) of Journal of Research of the History of Overseas Chinese and Foreign Chinese (Huaqiao Huaren Lishi Ynajiu), pages 50-62

86. Zhang, Yonghe, Origin of Rights: a Research Report on the Freedom of Human's Migration (Quanli de Youlai: Renlei Qianyi Ziyou de Yanjiu Baogao), the Publishing House of Jiancha, Beijing, 2001

87. Zhang, Youxue, "An analysis of the Phoenomeon of Carving out of the Chinese Students Who Have Returned from Overseas Study" (Chinese version), No.4 (2001) Chinese Scholars Abroad, page 134, www.chisa.edu.cn $(26 / 04 / 2003)$

88. Zhao, Yufei, Question Why the Application Filed by Law-firm for Exit and Entry Intermediary Agency Shall not be Accepted (Ziyi Yisi Churujing Zhongjie Huodong Guanli Banfa: Yimin Yewu Zenneng Dui Lvshi Shiwusuo Guanshang Damen), No.2 [2002] Chinese Lawer (Zhongguo Lvshi), pages $71-72$

89. Zhu, Guohong, Overseas Chinese: a History Research on international Migration (Zhongguo De Haiwai Yimin - Yixiang Guoji Qianyi De Lishi Yanjiu), the Publishing House of Fudan University, Shanghai, 1994

90. Zou, Ruihan, The Guide of Exit and Entry (Churu Jing Xuzhi), the Publishing House of Lujiang, Xiamen, China, 1990 


\section{Bibliography 2 Bibliography in English}

1. “America Retreats from Human Rights Motion against China", The Times, 16 March 1998, page 13

2. "Bottom line for U.S. and China: no Kowtows on Human Rights", The New York Times, 27 March 1994

3. "Clinton U-turn as He Defends links with China", The Daily Telegraphy, New York, 25 October 1997, page 11

4. "Cook takes on global "evil", The Guardian, 18 July 1997, London, page 5

5. "Facts and Figures on International Migration", Migration Policy Issues, No. 2, March 2003, IOM International Organization for Migration, Geneva, Switzerland, page 1

6. "Human Rights Watch World Report 2003: Asia: China and Tibet", http://nadaily.com/cgi-bin/nphproxyb.cgi/010000A/http/hrw.org/wr2 (5/07/2003)

7. "Manual of Service of The Immigration Office National Police Agency of the Ministry of Interior of the Republic of China 2002", http://www.immigration.gov.tw, (26/11/2003)

8. "Report of Improving Service Quality of The Immigration Office National Police Agency of the Ministry of Interior of the Republic of China 2001", http://www.immigration.gov.tw, (26/11/2003)

9. Akehurst, Michael, A Modern introduction to international Law, $6^{\text {th }}$ edition, Harper Collins Academic, London, 1987 and Routled.ge, New York, 1987

10. Amerasinghe, C. F., Local Remed.ies in international Law, Grotius Publication Ltd., Cambridge, the UK, 1990

11. andreassen, Bard-anders and Swinchart (ed.), Theresa, Human Rights in Developing Countries Yearbook 1992, Nordic Human Rights Publications and the Norwegian institute of Human Rights, Oslo, Norway, 1993

12. andreassen, Bard-anders and Swinehart, Theresa (ed.), Human Rights institutes in Norway, Denmark, the Netherlands, Finland and Swed.en (Compile), Human Right in Developing Countries Yearbook 1990, N. P. Engel, Publisher, Kehl, Strasbourg and Arlington, 1991

13. Aristide Zolberg R., "international Migration in Political Perspective," in Mary M. Kritz, Charles B. Keely, and Silvano M. Tomasi, (ed.)., Global Trends in Migration: Theory and Research in international Population Movements. New York: Centre for Migration Studies, 1980

14. Australian Foreign Affairs and Foreign Trade Ministry, "People's Republic of China: AustraliaChina Bilateral Relationship", http://www.dfat.gov.au/geo/china/cb_bilateral.html (22/10/2003)

15. Australian Foreign Affairs and Foreign Trade Ministry, People's Republic of China: Country Information, http://www.dfat.gov.au/geo/china/cb_background.html (22/10/2003)

16. Australian Human Rights Center, "Human Rights in Taiwan: Issues for the $21^{\text {st }}$ Century," http://www.ahrcentre.org/reports/Human_Rights_in_Taiwan.htm (04/09/2003)

17. Baehr, Peter R. et al (ed.), Human Rights: Chinese and Dutch Perspectives, Kluwer Law international, the Hague, the Netherlands, 1996

18. Baehr, Peter, Hey, Hilde, Smith Jacqueline and Swinehart, Theresa (ed.), Human Right in Developing Countries 1994 Yearbook, N. P. Engel, Publisher, Kehl, Strasbourg and Arlington, 1995

19. Baehr, Peter, Sadiwa, Lalaine and Smith Jacqueline (ed.), Human Right in Developing Countries 1996 Yearbook, Kluwer Law international, the Hague, the Netherlands, 1996

20. Baubock, Rainer, Transnational Citizenship: Membership and Rights in international Migration, ed.ward Elgar, Cheltenham, the UK, 1994

21. Bellagio IV Population Conference Ulvshale Denmark: Working Papers of the Rockefeller Foundation, The Rockefeller Foundation, New York, 1977

22. Bentham, Jeremy, Anarchical Fallacies, Blackstone, Volume 1, p369, 370 
23. Beresford, Melanie and Phong, Dang, Economic Transition in Vietnam: Trade and Aid in the Demise of a Centrally Planned. Economy, Edward Elgar Publishing Ltd., Cheltenham, the UK and Northampton, the USA, 2000

24. Bevan, Vaughan, The Development of British Immigration Law, Croom Helm, Beckenham, the UK, 1986

25. Bhagwati, Jagdish N. and Wilson (ed.), John Douglas, income Taxation and international Mobility, the Massachusetts institute of Technology, Massachusetts, the USA, 1989

26. Biao. Xiang, "Emigration from China: A Sending Country Perspective", International Migration, Volume 41, Number 3 (September 01, 2003), pages 21-48, http://ejournals.ebsco.com/direct.asp?ArticleID=P8PYFRBJLETKMYT3KQ4F $(01 / 10 / 2003)$

27. Blischenko, I. P., vice-president of the Association of Soviet Lawyers, Right to Leave and to Return to one's Country, 1988, pages $1 / 21$

28. ВØ, Bente, Puntervold, Immigration Control, Law and Morality: Visa Policies towards Visitors and Asylum Seekers, an Evaluation of the Norwegian Visa Policies within a Legal and Moral Frame of Reference, Unipub Forlag og Forfatterren, Oslo, 2002

29. Bobbio, N. The Age of Rights, Political Press, Cambridge, the UK, 1995

30. Bossuyt, Marc J., Guide to the "Travaux Preparatoires' of the international Covenant on Civil and Political Rights, Martinus Nijhoff Publishers, Dordrecht, the Netherlands, 1987

31. Bradley, Catherine, What Do We Mean by Human Rights: Freed.om of Movement, Franklin Watts, London, 2002

32. Briggs, Vernon M., Jr, Mass Immigration and the National interest, $2^{\text {nd }}$, M. E. Sharpe, inc., New York, the USA, 1996

33. Brohmer, Jurgen, State Immunity and the Violation of Human Rights, Martinus Nijhoff Publishers, the Hague, the Netherlands 1997

34. Brown, Judith M. \& Foot, Rosemary Migration: The Asian Experience, The Macmillan Press Ltd., London, 1994

35. Brownlie, Ian and Goodwin-Gill, Guy S. (ed.), Basic Documents on Human Rights, $4^{\text {th }}$ edition, Oxford University Press, Oxford, the UK, 2002

36. Brownlie, Ian, Principles of Public international Law, $4^{\text {th }}$ edition, Oxford University Press, Oxford, the UK, 1990

37. Buckland, W. W. and Mcnair, Arnold D., $2^{\text {nd }}$ ed.ion revised. by Lawson, F. H., Roman Law and Common Law: A Comparison in Outline, Cambridge University Press, Cambridge, 1952

38. Buggy, T.P., Chinese Immigration and the Emergence of an Australian Image of China, 1848-1861, the thesis of Master of Arts Macquarie University, 1978

39. Bureau of Democracy, Human Rights and Labor, U.S. Department of State, Vietnam Country Reportss on Human Rights Practices: 2002, Washington D.C., 2003, 26 pages

40. Butler, W. E., Soviet Law ( $2^{\text {nd }}$ edition), Butterworth \& Co. (Publishers) Ltd., London, 1988

41. Caenegem, R. C. Van, Legal History: A European Perspective, the Hambledon Press, London, 1991

42. Campbell, E., \& Whitmore, H., Freedom in Australia, Sydney, 1966

43. Campbell, Persia Crawford, Chinese Coolie Emigration to Countries within the British Empire China Frank Cass and Company Ltd., London, 1923

44. Campbell, Tom D. (ed.), The international Library of Essays in Law and Legal Theory Second Series: Legal Positivism, Dartmouth Publishing Company Ltd., Ashgate Publishing Limited., Aldershot Hants England and Brookfield Vermont, the USA, 1999

45. Cantor, Norman F. and Werthman, Michaels (ed.), The History of Popular Culture to 1815, The Macmillan Company, New York and Collier-Macmillan Ltd., London, 1968

46. Cardozo, Benjamin N., The Growth of the Law, Yale University Press, New Haven, the USA, 1966 
47. Castles, Stephen. and Miller, Mark, The Age of Migration, $3^{\text {rd }}$ edition, Palgarave Macmillan, Basingstoke and New York, the USA, 2003

48. Chalidze, Valery, To Defend These Rights, Random House, New York, 1974 at.98-99

49. Charlesworth, Hilary, McCorquodale, Robert etc (ed.), The Australian Year Book of international Law 2001 Volume 21, the Centre of international and Public Law, Faculty of Law, Australian National University, 2001

50. Chaturved.i, R. G., Philosophy of Law, The institute for Research and Advanced. Studies, Jaipur, india, 1984

51. Chen, Lifu, The Confucian Way: A New and Systematic Study of 'the Four Books', translated. from the Chinese by Liu, Shih Shun, KPI Limited., London, 1986

52. Chin, James K., "Reducing Irregular Migration from China". International Migration, Volume 41, $\begin{array}{llllll}\text { Number } & 3 & \text { (September } & 01, & 2003), & \text { pages }\end{array}$ http://ejournals.ebsco.com/direct.asp?ArticleID=445TEX0XG8PNYXEQH1X5 01/10/2003

53. Choi, C.Y., Chinese Migration and Settlement in Australia, Sydney University Press, 1975

54. Coenelius, Wayne A., Philip L. Martine, and James F. Hollifield, (ed.), Controlling Immigration: A Global Perspective. Stanford, Calif.: Stanford University Press, 1994

55. Commonwealth of Australia, Australia's Third Report under the international Covenant on Civil and Political Rights: March 1987 - December 1995, the Attorney-General's Department Robert Garran Office, Barton, ACT, Australia, 1998

56. Congressional - Executive-Commission on China, "The People's Republic of China", http://www.cecc.gov/pages/virtualAcad/his/prc.php (04/01/2005)

57. Craig, P.P., Administrative Law, (fourth ed.ion), Sweet \& Maxwell Ltd., London, 1999

58. Cranston, Maurice, What are Human Rights?, Taplinger Publishing Co., inc., New York, 1973

59. Crock, Mary and Saul, Ben, Future Seekers: Refugees and the Law in Australia, The Federation Press, Sydney, 2002

60. D"amato, Anthony, Jurisprudence: a Descriptive and Normative Analysis of Law, Martinus Nijhoff Publishers, Dordrecht, the Netherlands, 1984

61. Dalziel, Lianne, Minister of Immigration, New Zealand, Options for Setting Enforceable Standards for Immigration Consultants, 2001

62. David, Rene and Brierley, John E. C., Major Legal System in the World Today: An introduction to the Comparative Study of Law, $3^{\text {rd }}$ edtion, Stevens \& Sons, 1985

63. Davidson, Alastair, "Globalization and Citizenship", ARENA Journal No. 12 1998, pages 83/105

64. Davis, Michael C. (ed.), Human Rights and Chinese Values: Legal, Philosophical, and Political Perspectives, Oxford University Press, New York, 1995 Macquarie University, Australia

65. De, Sous La Direction (ed.), The Limit of Human Rights in Comparative Constitutional Law, Les ed.ion Yvon Blais inc. Canada, 1986

66. Defining Migration Priorities in an Interdependent World, Migration Policy Issues No. 1, March 2003, Migration Policy and Research Programme, International Organization of Migration

67. Delmas-Marty, Mireille (ed.), the European Convention for the Protection of Human Rights: internaitonal Protection Versus National Restrictions, Martinus Nijhoff Publishers, Dordrecht, the Netherlands, 1992

68. Democratic People's Republic of Korea, Second Periodic Report of the Democratic People's Republic of Korea on its Implementation of the International Covenant on Civil and Political Rights $25^{\text {th }}$ December 1999, Human Rights Committee, CCPR/CPRK/2000/2 4 May 2000

69. Dennery, Etienne Asia's Teemin Millions: and Its Problems for the West, Kennikat Press, Port Washington, 1931

70. Department of Justice, Equality and Law Reform, International Comparative Study of Migration Legislation and Practice, The Stationary Office, Dublin, Ireland, 2002, 128 pages 
71. Department of Public Information, the United Nations, "The Universal Declaration of Human Rights: A Magna Carta for All Humanity”, DPI/1937/A—December 1997, http:www.unhchr.ch/udhr/miscinfo/carta.htm (18-05-2003)

72. Dijk, P. van and Hoof, G. J. H. van, Theory and Practice of the European Convention on Human Rights, Kluwer Law and Taxation Publishers, Deventer/Netherlands, 1984

73. Dixon, Martin, Textbook on international Law, Blackstone Press Ltd., London, 1990

74. Drake, Michael (ed.), Population in indusfor Trial Implementationization, Methuen \& Co. Ltd., London, 1969

75. Dukelow, Daphne A. The Dictionary of Canadian Law, A Carswell Publication, Barrie, Ontario, Canada, 1991

76. Edwards, R. Randle, Henkin, Louis and Nathan, andrew J., Human Rights in Contemporary China, Columbia University Press, New York, 1986

77. Eide, Asbjorn and Mubanga-Chipoya, Chama, Conscientious Objection to Military Service: Report prepared. in pursuance of resolutions 14 (XXIV) and 1982/30 of the Sub-Commission on Prevention of Discrimination and Protection of Minorities, the United. Nations, New York, 1985

78. Eide, Asbjorn and Mubanga-Chipoya, Chama, Conscientious Objection to Military Service, report prepared in pursuance of resolutions 14 (XXXIV) and 1982/30 of the Sub-Commission on Prevention of Discrimination and Protection of Minorities, E.85.XIV.1, United Nations, New York, 1985

79. Ermacora, Felix, Nowak, Manfred. and Tretter, Hannes (ed.), international Human Rights: Documents and introductory Notes, Law Books in Europe, Vienna, Austria, 1993

80. ESC Res. 1503, 48 UN ESCOR Supp. (No. 1A) at 89, UN Doc. E/4832/Add.1 (1970)

81. Feinberg, Joel and Gross, Hyman, (ed.), Philosophy of Law, $3^{\text {rd }}$, Wadsworth Publishing Company, Belmont, ththe USA, 1986

82. Fitzgerald, C.P., The Chinese View of their Place in the World, Oxford University Press, Amen House, London, 1964

83. Flemin, John G., The Law of Torts, $6^{\text {th }}$ edtion, The Law Book Co., Sydney, 1983

84. Foldesi, Tamas, "The Right to Move and Its Achilles" Hell, The Right to Asylum", 8 Connel Journal of International Law, Spring 1993, page 289

85. Freed.man, Warren, The Right to Travel: A Right or A Privilege? Work Paper of Sao Paulo Conference on the Law of the World, the World Peace Through Law Centre, Washington, the USA, 1981

86. Freeman, M. D. A., Lloyd's introduction to Jurisprudence, $7^{\text {th }}$ edtion, Sweet \& Maxwell Ltd., London, 2001

87. Friborg, Coran (ed.), Brain Drain Statistics: Empirical Evidence and Guidelines, Report on international Expert Meeting in Stockholm 1973 and Guidelines for Future Studies, Offsetoriginals i Sundt offset, Stockholm, 1975

88. Fried.man, Lawrence M., A History of American Law, Simon and Schuster, New York, 1973

89. Fried.mann, Daniel and Barak-Erez, Daphne (ed.), Human Rights in Private Law, Hart Publishing c/o, Oregon, the USA, 2001

90. Fried.mann, W., Legal Theory, Law Publishers, London, 1944

91. Friedberg, Rachel M. and Hunt, Jennifer, "The Impact of Immigrants on Host Country Wages, Employment and Growth”, Journal of Economical Perspectives, Volume 9, Number 2, Spring 1995, pages $23-44$

92. Gao, M.C.F. and Liu. X. "From Student to Citizen: A Survey of Students from the People"s Republic of China (PRC) in Australia". International Migration, Volume 36, Number 1 (March 1998), pages 27-48, http://ejournals.ebsco.com/direct.asp?ArticleID=ND9C6QUN9G11LWTAQXN0 01/10/2003 
93. Garcia-Amador, F V., Sohm, Louis B. and Baxter, R.R., Recent Codification of the Law of State Responsibility for injuries to Aliens, Oceana Publications, inc., New York, 1974

94. Garner, Bryan A., (ed. in Chief), Black's Law Dictionary, $7^{\text {th }}$ edtion, West Group, St. Paul, Minn., 1999

95. George, Robert P., in Defense of Natural Law, Clarendon Press, London, 1999

96. Ghandhi, P. R., "The Human Rights Committee and Derogation in Public Emergencies", 1989, 32 German Yearbook of International Law 323, pages 326

97. Giese. Karsten, "New Chinese Migration to Germany: Historical Consistencies and New Patterns of Diversification within a Globalized Migration Regime". International Migration, Volume 41,

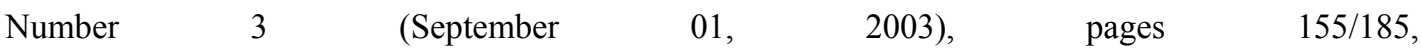
http://ejournals.ebsco.com/direct.asp?ArticleID=KGDYHW2NFRNQFNHXH7A7 (01/10/2003)

98. Glaser, William A., The Brain Drain: Emigration and Return, Findings of a UNITAR Multinational Comparative Survey of Professional Personnel of Developing Countries who Study Abroad, Pergamon Press, London, 1978

99. Globalization Affects Global Immigration, Book Review, Workers Without Frontiers - the Impact of Globalization on international Migration, Stalker, Peter, international Labour Organization, 2000, http://search.chinadaily.com.cn/isearch/

I_textinfo.exe?bdname=cndy_printedition\&listid=10291\&selectword=MIGRATION $<18 / 06 / 2003>$

100.Goodwin-gill, Guy S., international Law and the Movement of Persons Between States, Oxford University Press, Oxford, 1978

101.Guerassimoff. Carine, “The New Chinese Migrants in France”. International Migration, Volume 41, Number 3 (September 01, 2003), pages 135/154,

http://ejournals.ebsco.com/direct.asp?ArticleID=NCLK1QYBQX3W8A7MPW8G (01/10/2003)

102.Guild, Elspeth and Minderhoud, Paul (ed.), Security of Residence and Expulsion: Protection of Aliens in Europe, Kluwar Law internaitonal, the Hague, the Netherlands, 2000

103.Haines, Robin F. Emigration and the Labouring Poor: Australian Recruitment in Britain and Ireland, 1836 - 60, Macmillan Press Ltd, London, 1997

104.Hall, Davis L. and Ames, Roger T, Thinking Through Confucius, State University of New York Press, Albany, the USA, 1987

105.Hannum, Hurst, The right to Leave and Return in international Law and Practice, Martinus Nijhoff Publishers, Dordrecht, the Netherlands, 1987

106.Harding, Alan, A Social History of English Law, Penguin Books Ltd., England, 1966

107.Hart, H. L. A., Essays in Jurisprudence and Philosophy, Clarendon Press, Oxford, 1983

108.Hart, H. L. A., The Concept of Law, Oxford University Press, London, 1961

109.Hastie, W., Outlines of the Science of Jurisprudence: an introduction to the Systematic Study of Law, Gaunt, inc., Holmes Beach, the USA, 2000

110. Healey, Justin (ed.), Human Rights and Civil Riights, Issues in Society, Volume 139, The Spinney Press, independent ed.ucational Publisher, Balmain, Australia, 2000

111.Healey, Kaye, (ed.), Global Migration: Issues for the Nineties, Volume 47, The Spinney Press, Balmain, Australia, 1995

112.Hed.wig Rudolph \& Mirijana Morokvasic, Bridging States and Markets: international migrations in the early 1990s, Berlin, 1993

113.Hegarty, Angela and Leonard, Siobhan (ed.), A Human Rights: An Agenda for the $21^{\text {st }}$ Century, Cavendish Publishing Limited., London, 1999

114.Held, D., McGrew, A., Goldblatt, D., and Perraton, J., Global Transformations: Politics, Economics, and Culture, Polity Press, Cambridge, 1999

115.Held, Political Theory and the Modern State, Oxford, Basil Blackwell, 1989 
116.Henkin, Louis, (ed.), The international Bill of Rights: the Covenant on Civil and Political Rights, Columbia University Press, New York, 1981

117.Henriques, H. S. Q., The Law of Aliens and Naturalization including the Text of the Aliens Act, 1905, Butterworth \& Co., London, 1906

118.Hogg, Quintin, The Brain Drain, CPC Outline Series No. 1, the Conservative Political Centre, London, 1967

119. Hosack, John, on the Rise and Growth of the Law of Nations, as Established. by General Usage and by Treaties, From the Earliest Time to the Treaty of Utrecht, From the Earliest time to the Treaty of Utrecht, Jas. Wade, Covent Garden, the UK, 1882

120.Hugo, Graeme, Rudd, Dianne and Harris, Kevin, Emigration from Australia: Economic Implications, Second report on an ARC SPIRT grant CEDA information Paper No. 77, Adelaide University Australia, 2001

121.Hui, One Jin, Chinese indentured. Labour: Coolies and Colonies in Robin Cohen, The Cambridge Survey of World Migration, Cambridge University Press, Cambridge, 1995

122.Human Rights Committee, Equality of Rights Between Men and Women: General Comment 28: 29/03/2000, ICCPR General comment 28, http://www.unhchr.ch/tbs/doc.nsf/(symbol)/CCPR.C.21.Rev.1.Add.9.+CCPR+comment+28.En?Ope nDocument (30-05-2003)

123. Human Rights Committee, Freedom of Movement (Art. 12): 02/11/99. CCPR/C/21/Rev.1/Add.9, CCPR General comment 27. (General Comment), http://www.unhchr.ch/tbs/doc.nsf/(symbol)/CCPR.C.21.Rev.1.Add.9.+CCPR+comment+27.En?Ope nDocument (30-05-2003)

124.Human Rights Committee, Position of Aliens, General Comment 15/27, 22/07/1986

125.Human Rights in China, Custody and Repatriation Not Welcome at the Party: Behind the "Cleanup" of China's Cities - A Report on Administrative Detention under "Custody and Repatriation, HRIC Arbitrary Detention Series, No. 2, New York, 1999, 63 pages http://iso.hrichina.org:8151/download_repositiory/a/c\&r\%2099.doc (18-05-2003)

126.Human Rights Watch, "Human Rights Watch Report 2001: Vietnam: Human Rights Developments," www.hrw.org/wr2k1/asia/vietnam.html (4/12/2003)

127.Human Rights Watch, "Human Rights Watch World Report 2001: A Human Rights Framework (Introduction)", http://www.hrw.org/wr2k1/intro/intro01.html (25/07/2003)

128. Human Rights Watch, Human Rights Watch World Report 2001: Asia, http://www.hrw.org/wr2k1/asia/index.html (25/07/2003)

129.Human Rights Watch, Human Rights Watch World Report 2002: Asia: China and Tibet, http://nadaily.com/cgi-bin/nph-proxyb.cgi/010000A/http/hrw.org/wr2 (5/07/2003)

130.Human Rights Watch/Asia and Human Rights in China, China: Enforced Exile of Dissidents: Government "Re-entry Blacklist" Revealed", Vol.7 No.1, January 1995

131.Humphrey, John P., Human Rights \& the United. Nations a Great Adventure Transnational Publishers, inc, New York, 1984

132.Hunter, Ian, and Saunders David (ed.), Natural Law and Civil Sovereignty: Moral Right and State Authority in Early Modern Political Thought, Palgrave Macmillan, New York, 2002

133.Ian Brownlie, CBE, QC and Guy S., Goodwin-Gill, Basic Documents on Human Rights, $4^{\text {th }}$ edtion, Oxford University Press, Oxford, the UK, 2000

134.Immigration Office National Police Agency of the Ministry of Interior of Republic of China, "the Manual of Service for the People, Immigration Office" (Ruchujing Guanliju Weiming Fuwu Shouce), September 2002, www.immigraiton.gov.tw (28/11/2003)

135.Immigration Office National Police Agency of the Ministry of Interior of Republic of China, "the Enforcement Plan of Upgrading Service Quality all the Round in 2002" (Neizhengbu Jingzhengshu 
Ruushujing Guanliju Jiushiyi Niandu Quanmian Tisheng Fuwu Pingzhi Zhixing Jihuashu), www.immigraiton.gov.tw $(28 / 11 / 2003)$

136.Ingles, Jose D, Study of Discrimination in Respect of The Right of Everyone to Leave any country, including His Own, and to Return to His Country: Special Repporteur of the Sub-commission on Prevention of Discrimination and Protection of Minorities, United Nations Publication Sales No.: 64. XIV. 2 New York 1963

137.Inter-American Commission on Human Rights, Sixth Report on the Situation of Political Prisoners in Cuba, 1979, O.A.S Doc. No. OEA/Ser. L/V/II 48; doc. 7 at 9 International Migration Review, New York, page 24

138. International Organization for Migration, "the People's Republic of China - Migration in 1999", www.iom.org (18/06/2003)

139. International Organization for Migration, International Migration Report 2002, ST/ESA/SER.A/220, International Organization for Migration, Geneva, Switzerland, 2002, 64 pages

140.International Organization for Migration, International Respect for Migrations' Rights, 2002, International Organization for Migration, Geneva, Switzerland, 2002, 28 pages

141.International Organization for Migration, Myths and Realities of Chinese Irregular Migration, No. 1 of IOM Migration Research Series, International Organization for Migration, Geneva, Switzerland, 2000, 44 pages

142.International Organization for Migration, The Link between Migration and Development in the Least Developed Countries, International Organization for Migration, Geneva, Switzerland, 2001, 14 pages

143. International Organization for Migration, The State of Migration Management in Central America: an Applied Research, Final Report, International Organization for Migration, Geneva, Switzerland, 2002, 89 pages

144.Ired.ale, Robyn, Hawksley, Charles and Castles, Stephen (ed.), Migration in the Asia Pacific: Population, Settlement and Citizenship Issues, ed.ward Elgar Publishing Limited., Cheltenham, the UK and Northampton, the USA, 2003

145.Iredale, Robyn, "The need to Import Skilled Personnel: Factors Favoring and Hindering its International Mobility", International Migration Vol. 37(1) 1999, pages 89/114

146.Iredale. R. "The Need to Import Skilled Personnel: Factors Favouring and Hindering its International Mobility”. International Migration, Volume 37, Number 1 (March 1999), pages 89/123, http://ejournals.ebsco.com/direct.asp?ArticleID=TW74D522315K6EVM8G0K 01/10/2003

147.Irick, Robert L., Ch"ing Policy Toward the Coolie Trade 1847 - 1878, Chinese Materials Centre Asian Library Series No. 18, 1982

148.Isin, Engin F. and Turner, Bryan S. (ed.), Handbook of Citizenship Studies, Sage Publications, London, 2002

149.Issues Paper from the Republic of South Korea, Asia Pacific Migration Research Network, Migration Issues in the Asia Pacific, 11 pages

150.Itoh, Fumio (ed.), China in the Twenty-first Century: Politics, Economy, and Society, United. Nations University Press, Tokyo, Japan, 1997

151.Jagerskiold, S., "Freed.om of Movement" Henkin, L. (ed.), The international Bill of Rights: The Covenant on Civil and Political Rights, Columbia University Press, New York, 1981

152.James F. Hollifield, Migration Theory, Routled.ge, New York, 2000

153.Joseph, Sarah and Sehultz, Jenny et al, The international Covenant on Civil and Political Rights: Cases, Materials, and Commentary, Oxford University Press, New York, 2000

154.Judith M. Brown \& Rosemary Foot, Migration: The Asian Experience, The Macmillan Press Ltd. London, 1994

155.Kao, Charles H. C. (Gao, Xijun), Brain Drain: a Case Study of China, Mei Ya Publications, inc. Taipei, the Republic of China, 1971 
156.Keely, Charles B., Globalization Transforms, Trade-Migration Equation, Blackwell Publishing Ltd. Oxford, 2003

157.Keith, Ronald C. and Lin, Zhiqiu, Law and Justice in China's New Marketplace, Palgrave, New York, 2001

158.Kelsen, Hans, The Communist Theory of Law, Scientia Verlag Aalen, the USA, 1976

159.Kent, Ann, Human Rights in the People's Republic of China, Discussion Paper No.3, 1989-90, Legislative Research Service, the Parliamentary of the Commonwealth of Australia, 1990

160.Kibreab, Gaim, "Citizenship Rights and Repatriation of Refugees", Volume 37, Issue 1, Spring 2003, The

161.Kim, Hyung I, Fundamental Legal Concepts of China and the West: A Comparative Study, Kennikat Press Corp. Port Washington, the USA, 1981

162.Kirkbride, Paul, (ed.), Globalization: The External Pressures, John Wiley \& Sons, Ltd., West Sussex, the UK, 2001

163.Koessler, “"Subject”, "Citizen". "National” and "Permanent Allegiance”“, in Yale Law Journal, 1946/1947, p58-76, page 59

164.Kofman, Eleonore and Youngs, Gillian, (ed.), Globalization: Theory and Practice, Pinter, New York, 1996

165.Kokko, Ari and Sjoholm, Fredrik, Stockholm School of Economics, The Internationalization of Vietnamese

166.Koser, The Return and Reintegration of Rejected Asylum Seekers and Irregular Migrants, No. 4 IOM Migration Research Series, International Organization for Migration, Geneva, Switzerland, 2001, 47 pages

167.Kramer, Matthew H., in Defense of Legal Positivism: Law without Trimmins, Oxford University Press, 1999

168. Krieger, Silke and Trauzettel, Rolf (ed.), Confucianism and the Modernization of China, v. Hase \& Koehler Verlag, Mainz, Eschwege, Germany, 1991

169. Kuttner, S., Gratian and Plato, in: church and Government in the Middle Ages, Essay presented to C. R. Cheney, Cambridge 1976, pages 93/118

170.Laczko. Frank, "Introduction: Understanding Migration between China and Europe". International Migration, Volume 41, Number 3 (September 01, 2003), pages 5/19, http://ejournals.ebsco.com/direct.asp?ArticleID=DKET6U2Y1B0DEAWEA2QK (01/10/2003)

171.Laroque, Pierre, 'Conclusions' in The Future of Migration, the OECD 1990, page27

172.Laroque, Pierre, “Conclusionss' at The Future of Migration, OECD 1986 PP32-33

173.Laroque, Pierre, Conclusionss, The Future of Migration, OECD 1990 p30

174.Lechner, Frank J. and Boli John (ed.), Globalization Reader, Blackwell Publishers, Malden, the USA, 2000

175.Lee, Tahirih V. (ed.), Foreigners in Chinese Law, Garland Publishing, INC., New York and London, 1997

176.Lee, Tahirih V.(ed.), Law, the State and Society in China, Garland Publishing inc., New York, 1997

177.Lee, Tahirih, Law, the State, and Society in China, Garland Publishing, inc., New York, 1997

178.Lester, Lord of Herne Hill QC and Joseph, S., "Obligations of Non-Discrimination" in Harris, D. and Joseph S. (ed.), The international Covenant on Civil and Political Rights and United. Kingdom Law, Clarendon Press, Oxford, 1995

179. Liechtenstein v. Guatemala (Nottebohm Case) Second Phase, Judgement, International Court Journal reports 1955, Rep 4

180.Lockwood, B. Jr., Finn, J. and Jubinsky, G., Working Paper for the Committee of Experts on Limitation Provisions, 7 HRQ 35, 1985. Order public may be used to negate private law contacts "in 
the interest of higher imperatives"; "public order" is not used in the same way in common law jurisdictions.

181.Lowell, B. Lindsay, Skilled Migration abroad or Human Capital Flight?, http://www.migrationinformation.org/Feature/display.cfm?ID=135 (05/06/2003)

182.Lumpur, Kuala, Reality of Labor Migration of Vietnam and Her Policies, Paper presented at a Meeting on the Implications of Changing Patterns of Asian Labor Migration, 1991

183. Macdonald, Ian A. \& Black, Nicholas J, Immigration Law and Practice in the United. Kingdom, $3^{\text {rd }}$ ed., Butterworths, London, 1991

184. Mackerras, Colin, Taneja, Pradeep and Young, Graham, China Since 1978 ( ${ }^{\text {nd }}$ edition), Addison Wesley Longman Australia Pty Ltd, South Melbourne, Australia, 1998

185.MacNair, The Chinese Abroad: Their Position and Protection, Shanghai, 1925

186. Mark Wooden, Robert Holton, Graeme Hugo and Judith Sloan, Australia Immigration: a Survey of the Issues, New York, the Bureau of Immigration Research, 1990

187.Market Information and Analysis Section, Department of Foreign Affairs and Trade, Australia, China: the Fact Sheet, using the latest data from the ABS, the IMF and various international sources, October 2003

188. Marr, David G. and White, Christine P. (ed.), Postwar Vietnam: Dilemmas in Socialist Development, Cornell Southeast Asia Program, New York, 1988

189. Martin, David A., The New Asylum Seekers: Refugee Law in the 1980s: the Ninth Sokol Colloquium on international Law, international Studies in Human Rights Volume 10, Martinus Nijhoff Publishers, Dordrecht, the Netherlands, 1988

190.Martin, Francisco Forrest, Schnably, Stephen J., Slye, Ronald C. etc, international Human Rights Law \& Practice: Cases, Treaties and Materials, Kluwer Law internaitonal, the Hague, the Netherlands, 1997

191.Martin, Philip and Widgren, Jonas, international Migration: Facing the Challenge, Vol. 57 No.1, New York, Population Bulletin: A publication of the Population Reference Bureau, March 2002

192.Martin, Philip and Widgren, Jonas, International Migration: Facing the Challenge, Population Reference Bureau, Wahington D.C., 2002, 39 pages

193.Martin, Philip and Widgren, Jonas, International Migration: Facing the Challenge, Volum 57, No. 1, Population Bulletin, March 2002, the Population Reference Bureau, Washington, USA, 2002, 40 pages

194.McGrew, T. "A Global Society”, in Hall, S., Held D. and McGrew T. (ed.), Modernity and Its Future, Polity Press, Cambridge, 1992

195.McWilliams, P.K., Canadian Criminal Evidence, $3^{\text {rd }}$ edtion, Canada Law Book, Aurora, 1988

196.Meron, Theodor, (ed.), Human Rights in international Law: Legal and Policy Issues, Volume I, Clarendon Press, Oxford, the UK, 1984

197.Meron, Theodor, Human Rights and Humanitarian Norms as Customary Law, Oxford University Press, New York, 1989

198.Meron, Theodor, Human Rights Law-Making in the United. Nations: a Critique of instruments and Process, Clarendon Press, New York, 1986

199. Molony, John, History of Australia, Penguin Books Australia Ltd., Ringwood, Australia, 1987

200.Mozaffari, Mehdi, Globalisation and Civilizations, Routledge Taylor \& Francis Group, London, 2002

201.Ness, Peter Van, Human Rights and Democracy in China: Four Theories on Why the World Should Care, working paper No.167, Peace Research Centre, Research School of Pacific Studies, Canberra, The Australian National University, 1996

202.Neumann, Franz, The Rule of Law: Political Theory and the Legal System in Modern Society, Berg Publishers Ltd, Warwickshire, the UK, 1986 
203.Nguyen, D.T. and Bandara, J.S., Emigration Pressure and Structural Change: Vietnam, A report prepared under UNDP Technical Support Services 1, ILO East Asia Multidisciplinary Advisory Team (ILO/EASMAT) and ILO Regional Office for Asia and the Pacific, Unpublished document issued without formal editing by ILO, Bangkok 1996, 35 pages

204. Nicolet, Alan, The World of the Citizen in Republican Rome, University of California, Berkeley, the USA, 1988

205.Nieto. Gladys, “The Chinese in Spain”. International Migration, Volume 41, Number 3 (September 01, 2003), pages 215/237,

http://ejournals.ebsco.com/direct.asp?ArticleID=DMFMH0U6K7D2Y85AYQXF 01/10/2003

206. Noll. Gregor. "Rejected Asylum Seekers: The Problem of Return". International Migration, Volume 37, Number 1 (March 1999), pages 267/288, http://ejournals.ebsco.com/direct.asp?ArticleID=TCM1DEBBV1G3C1TRHU0G 01/10/2003

207.Nowak, Manfred., U.N. Covenant on Civil and Political Rights: CCPR Commentary, N. P. Engel, Publisher, Kehl am Rhein $\cdot$ Strasbourg $\cdot$ Arlington, 1993

208.Nygh, Peter E and Butt, Peter (General ed.), Butterworths Australian Legal Dictionary, Butterworths Australian

209. Nyíri. Pál, Chinese Migration to Eastern Europe. International Migration, Volume 41, Number 3 (September 01, 2003), pages 239/265, http://ejournals.ebsco.com/direct.asp?ArticleID=F9TLFXE966B5175UB932 (01/10/2003)

210. Orfield, Lester B. and Re, Edward D., Cases and Materials on International Law, Revised Edition, The Bobbs-Merrill Company, Inc., Indianapolis, Kansas City and New York, 1965

211.O'Meara, Patrick, Mehlinger, Howard D. and Krain, Mattew, Globalization and the Challenges of a New Century, indiana University Press, Bloominton, the USA, 2000

212.Panhuys, P. Van, The Roles of Nationality in international Law: An Outline, 1959, A. W. Sythoff, Leyden, Netherlands,

213.Papademetrious, Demetrios, G., Reflections on International Migration and its Future, International Organization for Migration, Geneva, Switzerland, 2002, 58 pages

214.Perry, Elizabeth J. and Selden, Mark (ed.), Chinese Society: Change, Conflict and Resistance, Routledge, London, 2000

215.Plender, Richard, International Migration Law, Revised. $2^{\text {nd }}$ ed., Martinus Nijhoff Publishers Dordrecht, the Netherlands, 1988

216.Pohlenz, Max, Freed.om in Greek Life and Thought, Dordecht, Reidel, 1966

217.Population Division, Department of Economic and Social Affairs, International Migration Report 2002, United Nations Secretariat, 2002, ST/ESA/SER.A/220, United Nations, New York, 2002, 62 pages

218.Population Division, Department of Economic and Social Affairs, United Nations Secretariat, International Migration: Explicit Policies, Uncertain Consequences, UN/POP/MIG/2002/BP/2, New York, 2002, 15 pages

219.Population Division, Department of Economic and Social Affairs, United Nations Secretariat, Measuring International Migration: Many Questions, Few Answers, UN/POP/MIG/2002/BP/1, New York, 2002, 10 pages

220.Population Division, Department of Economic and Social Affairs, United Nations Secretariat, International Migration from Countries with Economies in Transition: 1980-1999, ESA/P/WP.176, New York, 2002, 123 pages

221.Potter, David, Goldblatt, David, Kiloh, Margaret and Lewis, Paul (ed.), Democratization, Blackwell Publishers inc. Malden MA, the USA, 1997

222.Potter, Pitman B., The Chinese Legal System: Globalization and Local Legal Culture, Routled.ge, London and New York, 2001 
223.Powell, Colin L. 'Preface', at "Supporting Human Rights and Democracy: The U.S. Record 20022003", the Bureau of Democracy, Human Rights, and Labor, 2003

http://www.state.gov/g/drl/rls/shrd/2002/21763.htm (05-07-2033)

224.Provost, Rene, State Responsibility in international Law, (ed.), Ashgate Publishing Company, Burlington, the USA, 2002

225.Purcell, Victor, The Chinese in South East Asia, London, 1965

226. Ramcharan, B. G. The Concept and Present Status of the international Protection of Human Rights: Forty Years After the Universal Declaration, Martinus Nijhoff Publishers, Dordrecht, the Netherlands, 1989

227.Read, William, Legal Thinking: Its Limits and Tensions, University of Pennsylvania Press, Philadelphia, the USA, 1986

228. Reid, Karen, A Practitioner's Guide to the European Convention on Human Rights, Sweet \& Maxwell, London, 1998

229.Robertson, A. H., Human Rights in the World: an introduction to the Study of the international Protection of Human Rights, $2^{\text {nd }}$ edtion, Manchester University Press, Manchester, the UK, 1982

230.Robin Cohen, The Cambridge Survey of World Migration, Cambridge University Press, Cambridge, 1995

231. Robin, Cohen, The Cambridge Survey of World Migration, Combridge University Press, Cambridge, 1995

232.Robinson, Nehemiah, The Universal Declaration of Human Rights: Its Origin, Significance, Application, and interpretation, institute of Jewish Affairs, World Jewish Congress, New York, 1958

233. Robinson, Vaughan, Migration and Public Policy, ed.ward Elgar Publishing Limited., Cheltenham, the UK, 1999

234.Roche, Peter, Citizenship in the Western Tradition, University if North Carolina Press, Chapel Hill, the USA, 1992

235.Rosenblum, Victor G., Law as a Political instrument, Random House, inc., New York, 1955

236. Rousseau, Jean-Jacques, The Social Contract, Translated. and introduced. by Cranston, Maurice, Penguin Books Ltd, Harmondsworth, Middlesex, England, 1968

237. Rubenstein, Kim, Australian Citizenship Law in Context, Lawbook Co., Pyrmont, Australia, 2002

238. Ryan. Jan, "Chinese Women as Transnational Migrants: Gender and Class in Global Migration Narratives". International Migration, Volume 40, Number 2 (June 2002), pages 93/116, http://ejournals.ebsco.com/direct.asp?ArticleID=Y68W70EMXGPAGE 1NVEM5DF7 (01/10/2003)

239.Seidman, Ann, Seidman, Robert B. and Payne, Janice (ed.), Legislative Drafting for Market Reform: Some Lessons from China, Macmillan Press Ltd. London, 1997 and St. Martin's Press, inc., New York, 1997

240.Shelton, Dinah, Remed.ies in international Human Rights Law, Oxford University Press, New York, 1999

241. Sherwin-White, A.N. Roman Citizenship, Clarendon Press, Oxford, 1939

242.Shih, Chih-yu, Collective Democracy Political and Legal Reform in China, The Chinese University Press, Hong Kong, 1999

243. Sibley, "The Passport System”, in Journal of the Society of Comparative Legislation (1906), pages 26-33 Skeldon, Ronald, "Migration from China (Contemporary China: The Consequences of Change)", Journal of International Affairs, Wntr 1996 v49 n2, pages 434-455 http://web6.infotrac.galegroup.com/itw/infomark/740/651/37374829w6/purl=rc1_EAI (25/07/2003)

244. Sieghart, Paul, The international Law of Human Rights, Oxford University Press, New York, 1983

245.Sik, Ko Swan and Sang, Chang Hyo (ed.), Nationality and international Law in Asian Perspective, Martinus Nijhoff Publishers, Dordrecht, the Netherlands, 1990

246. Simon Fisher, Agency Law, Butterworths, Sydney, 2000 
247.Simon, Denis Fred. and Kau, Michael, Y. M., Taiwan: Beyond the Economic Miracle, M. E. Sharpe, inc., New York, 1992

248. Skeldon, Ronald, (ed.) Emigration from Hong Kong: Tendencies and Impacts, The Chinese University Press, Hong Kong, 1995

SMEs, draft version: 3 April 2004

249. Sowell, Thomas, Migrations and Cultures: A World View, BasicBooks, A member of the Perseus Books Group, 1996

250.Stahl, Charles, Ball, Rochelle, inglis, Christine and Gutman, Pamela, Global Population Movements and Their Implications for Australia, Australian Government Publishing Service, Canberra, Australia 1993

251.Stalker, Peter, The No-Nonsense Guild to international Migration, New internationalist Publications Ltd, Oxford, the UK, 2001

252.Stein, Peter, Legal Evolution: The Story of an Idea, Cambridge University Press, Cambridge, the UK, 1980

253.Steiner, Henry J. and Alston, Philip (ed.), international Human Rights in Context: Law, Politics, Morals: Text and Materials, $2^{\text {nd }}$ edition, Oxford University Press, New York, 2000

254.Stipp, John L., Dirrim, Allen, W. and Hollister, C. Warren, The Rise and Development of Western Civilization: 1660 to the Present, John Wiley \& Sons, inc., New York, London and Sydney, 1967

255.Stockman, Norman, Understanding Chinese Society, Polity Press in association with Blackwell Publishers Ltd. Malden, the USA, 2000

256.Stokke, Hugo, Suhrke, Astri and Todtersen, Arne (ed.), Human Rights in Developing Countries Yearbook 1997, Kluwer Law international Nordic Human Rights Publications, the Hague, the Netherlands, 1998

257.Submission on Immigration Consulting Industry, The National Citizenship and Immigration Law Section of the Canadian Bar Association, 2002

258. Sun, Wangning, Leaving China: Med.ia, Migration, and Transnational Imagination, Rowman \& Littlefield Publishers, inc. Maryland, the USA, 2001

259. Swales, John M. \& Feak, Christine B., Academic Writing for Graduate Students Essential Tasks and Sklls: A Course for Bonnative Speakers of English, The University of Michigan Press, Michigan, the USA, 1994

260. Swinburne University (ed.) The Collection of Conference Papers, Globalization and Citizenship: An international Conference, Melbourne, 1997

261.Tan, zhimin, "The Discuss on Current Permission System of Entry into Mainland Area of Residents in Taiwan Area" (Taiwan Diqu Renming Jingru Dalu Diqu Xianxing Xukezhi Zhi Tantao) (12 October 1998), www.immigraiton.gov.tw (28/11/2003)

262.Teather, David C. B. and Yee, Herbert S. (ed.), China in Transition, Macmillan Press Ltd. London and St. Martin's Press, inc., New York, 1999

263.Thayer, Carlyle A. and Marr David G. (ed.), Vietnam and the Rule of Law, Department of Political and Social Change, Research School of Pacific Studies, Australian National University, Canberra, 1993

264.The CIA, "The World Factbook: China", 18 December 2003, http://www.cia.gov/cia/publications/factbook/geos/ch.html (2/02/2004)

265.The OECD, Migration and Development: New Partnerships for Co-operation, Head of Publications Service, the OECD, Paris Cedex, France, 1994

266. The OECD, Migration and the Labour Market in Asia: Recent Trends and Policies, the OECD, Paris 2001

267. The OECD, The Changing Course of international Migration,, Head of Publications Service, the OECD, Paris Cedex, France, 1993 
268. The OECD, the Future of Migration, The secretary-general of the OECD, 1986

269.The UNHCR, The Haitian Interdiction Case 1993 Brief Amicus Curiae, 6 IJRL 86 (1994)

270. The United Nations doc. ICCPR/C/79/Add. 55 (1995), para. 16.

271.The United Nations General Assembly, "Report of the World Conferences on Human Rights Vienna, 14-25 June 1993 Report of the Secretary-General”, Distr. General A/CONF.157/24 (Part I), 13 October 1993

272.The United Nations, International Migration Policies and Programs: A World Survey. Sales No. E. 82 XIII. 4

273. The United Nations, Recommendations on Statistics of International Migration. Revision 1, Sales No. E.98.XVII.14, 1998

274. The World Bank, "Vietnam - Poverty Assessment and Strategy", Report No. 13442-VN, World Bank, Washington, D.C. USA, 1995

275.Thunø. Mette, "Channels of Entry and Preferred Destinations: The Circumvention of Denmark by Chinese Immigrants". International Migration, Volume 41, Number 3 (September 01, 2003), pages 99/133, http://ejournals.ebsco.com/direct.asp?ArticleID=3V5R8BJXFJKHYAKM4VRL (01/10/2003)

276. Thunø. Mette, "Channels of Entry and Preferred Destinations: The Circumvention of Denmark by Chinese Immigrants". International Migration, Volume 41, Number 3 (September 01, 2003), pages 99/133, http://ejournals.ebsco.com/direct.asp?ArticleID=PWP5YC699HJ7LL4D0RY3 (01/10/2003)

277.Tomlinson, John, Globalization Culture, Polity Press in association with Blackwell Publishers Ltd., Cambridge, the UK, 1999

278.Torpey, John, The invention of The Passport: Surveillance, Citizenship and the State, Cambridge University Press, Cambridge, the UK, 2000

279.Turack, Daniel C., The Passport in international Law, Lexington Books, D.C. Health and Company, Toronto, Canada, 1972

280.Twining, William, Globalisation and Legal Theory, Northwestern University Press, Evanston, the USA, 2000

281.US Committee for Refugees, "China: World Refugee Survey 2003 Country Reports", http://refugees.org/world/countrypt/easia_pacific/2003/china.cfm (2/02/2004)

282.US Department of State, "China (Including Hong Kong and Macao): Country Reports on Human Rights Practices 2000", http://www.state.gov/g/frl/rls/hrrpt/2000/eap/684.htm (2/02/2004)

283.US Department of State, "China (Including Hong Kong and Macao): Country Reports on Human Rights Practices 2001”, http://www.state.gov/g/frl/rls/hrrpt/2001/eap/8289.htm (2/02/2004)

284.US Department of State, "China (Including Hong Kong and Macao): Country Reports on Human Rights Practices 1999”, http://www.state.gov/g/frl/rls/hrrpt/1999/eap/684.htm (2/02/2004)

285.US Department of State, "China (Including Hong Kong and Macao): Country Reports on Human Rights Practices 2002”, http://www.state.gov/g/frl/rls/hrrpt/2002/eap/684.htm (2/02/2004)

286.US Department of State, "China: Country Reports on Human Rights Practices 1998", http://www.state.gov/www/global/human_rights/1998_hrp_report/china.html (2/02/2004)

287.Vasak, Karel and Liskofsky, Sidney, (ed.), the Right to Leave and Return: Papers and Recommendations of the international Colloquium Held in Uppsala, Swed.en, 19-21 June 1972, The American Jewish Committee, Arbor, the USA, 1976

288. Vaughan Robinson, Migration and Public Policy. ed.ward Elgar Publishing Limited., London, 1999

289.Vietnam Business Forum, Sub-Working Group on Administrative Reform Review of Licenses/Permits and Related Issues, 2002

290. Vietnam, "Ninth Period Report on the Implementation of the International Convention on the Elimination of All Forms of Racial Discrimination", Distr. General CERD/C/357/Add.2, 17 October 2000, http://www.hri.ca.fortherecord2001/documentation/tbodies/cerd-c-357-ad (04/12/2003) 
291.Vietnam, Second Period Report on the Implementation of the International Convention on Civil and Political Rights, Distr. General CCPR/C/VNM/2001/2, 14 May 2001

292.Vinogradoff, Paul, Outlines of Historical Jurisprudence, Volume Two, The Jurisprudence of the Greek City, Oxford University Press, Oxford, the UK, 1922

293. Waddington, Clare, "International Migration Policies in Asia: A Synthesis of ILO and other Literature on Policies Seeking to Manage the Recruitment and Protection of Migrants, and Facilitate Remittances and Their Investment", Paper presented at Regional Conference on Migration, Development and Pro-Poor Policy Choices in Asia 2003, 21 pages, www.livelihoods.org, $(05 / 12 / 2003)$

294. Walters, R. P., A History of the League of Nations, Volume II, Oxford University Press, London, 1952

295.Wang, Gungwu, Don't Leave Home: Migration and The Chinese, Times Academic Press, Singapore, 2001

296.Wang, Sing-wu The Organization of Chinese Emigration 1848-1888 with special reference to Chinese Emigration to Australia, Chinese Materials Centre inc. San Francisco, 1978

297.Wang, Singwu, "the Attitude of the Ch'ing Court Towards Chinese Emigration", Chinese Culture, Vol.IX, No.4, December 1968, pages 62-63

298. Washington: Government Printing Office, Senate Hearings on Soviet Pentecostals Residing in the U.S. Embassy in Moscow, 19 November 1981, ser. J-97-82, at 125

299. Weis, P., Nationality and statelessness in international Law, $2^{\text {nd }}$ revised. ed.ions, Sijthoff \& Noordhodd international Publishers B. V., Alphen aan den Rijn, The Netherlands, 1979

300.Weis, P., Nationality and statelessness in international Law, Stevens \& Sons Limited., London, 1956

301.Wellman, Carl, A Theory of Rights: Persons Under Laws, institutions, and Morals, Rowman \& Allanheld Publishers, Totowa, New Jersey, the USA, 1985

302.Wichberg, Wdgar, "The Chinese as Overseas Migrants in Brown", in Brown, Judith M. \& Foot, Rosemary (ed.), Migration: The Asian Experience, The Macmillan Press Ltd., London, 1994

303.Williams, Paul (ed.), The international Bill of Human Rights, Entwhistle Books, Glen Ellen, the USA, 1981

304.Willis, F. Roy, Western Civilization an Urban Perspective: Volume II from the $17^{\text {th }}$ Century to the Contemporary Age, D. C. Heath and Company, Lexington, the USA, 1973

305.Wolfgang Weidlich and Gunter Haag, interregional Migration: Dynamic Theory and Comparative Analysis, Springer - Verlag, 1988

306.Wong, Alan, Hong Kong: Stronger than Ever at dinner talks at Four Seasons Hotel, Sydney, Thursday 10 July 2003

307.World Population Monitoring 1997: Issues of International Migration and Development, United Nations publication, Sales No. E. 98. XIII. 4

308.Wu, Yuanli et al, Human Rights in the People's Republic of China, Westview Press, Boulder, Colorado, the USA, 1988

309.Xian, Lixian, "The Discussion on Application Procedure of Entry into Mainland Area of Residents in Taiwan Area" (Taiwan Diqu Jingru Dalu Diqu Shengqing Chengxu Zhi Taitao) (14 March 2000), www.immigraiton.gov.tw $(28 / 11 / 2003)$

310. Year Book of International Law Commission 1977 (pt. 2) at 31, UN Doc. A/CN.4/SER.A/1977/Add.1 (Part 2) (1978)

311.Young, Song Ji, "The Invisible Refugees: North Korean Asylum Seekers in China", http://iso.hrichina.org/iso/article.adp?article_id=4248\&subcategory_id=287 (18/05/2003)

312.Zayonchkovskaya, Zhanna, The Russian Federation. In International Migration in Central and Eastern Europe and the Commonwealth of Independent States, UNECE Economic Studies no. 8, UNECE and UNFPA Sales No. GV.E.96.0.22, Geneva and New York 
313.Zhang. Guochu, "Migration of Highly Skilled Chinese to Europe: Trends and Perspective". International Migration, Volume 41, Number 3 (September 01, 2003), pages 73-97, http://ejournals.ebsco.com/direct.asp?ArticleID=CTM27M34E7REQMFE2J8M (01/10/2003)

314.Zhao, Suisheng, China and Democracy: the Prospect for a Democratic China, Routledge, New York, 2000 and London, 2000

315.Zhu, Muzhi, "Some Thoughts on Democracy", No.4 [2002] The Journal of Human Rights, http://www.humanrights-china.org/zt/03111201/200312003129103621.htm (26/02/2004) 